\title{
International Project Catalog of Modular Integrated Utility Systems
}

\section{NBS SPECIAL PUBLICATION \\ 515}

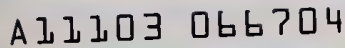

U.S. DEPARTMENT OF COMMERCE/National Bureau of Standards for DEPARTMENT OF HOUSING AND URBAN DEVELOPMENT
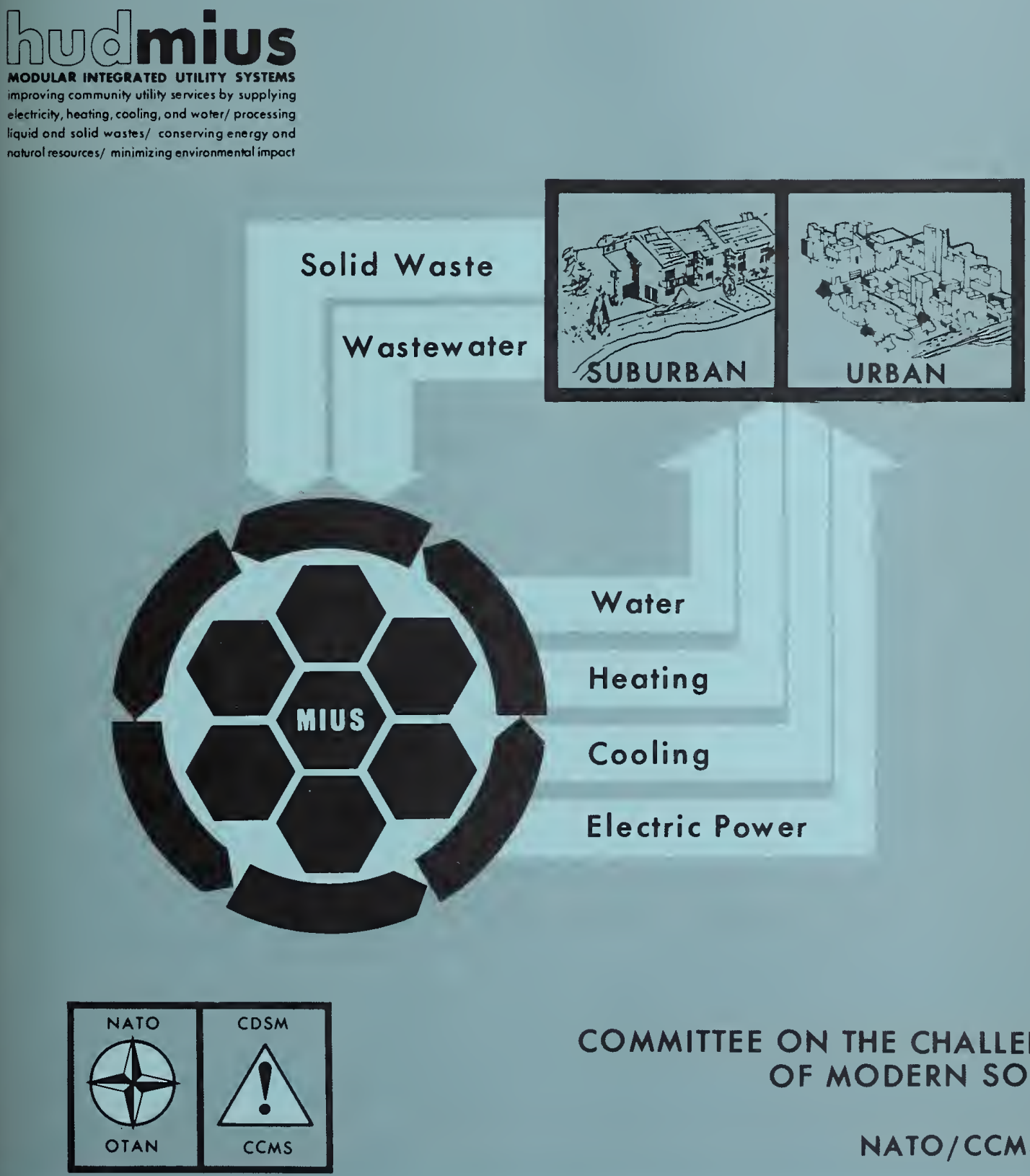

COMMITTEE ON THE CHALLENGES OF MODERN SOCIETY

NATO/CCMS 73 
The National Bureau of Standards' was established by an act of Congress March 3, 1901. The Bureau's overall goal is to strengthen and advance the Nation's science and technology and facilitate their effective application for public benefit. To this end, the Bureau conducts research and provides: (1) a basis for the Nation's physical measurement system, (2) scientific and technological services for industry and government, (3) a technical basis for equity in trade, and (4) technical services to promote public safety. The Bureau's technical work is performed by the National Measurement Laboratory, the National Engineering Laboratory, and the Institute for Computer Sciences and Technology.

THE NATIONAL MEASUREMENT LABORATORY provides the national system of physical and chemical and materials measurement; coordinates the system with measurement systems of other nations and furnishes essential services leading to accurate and uniform physical and chemical measurement throughout the Nation's scientific community, industry, and commerce; conducts materials research leading to improved methods of measurement, standards, and data on the properties of materials needed by industry, commerce, educational institutions, and Government; provides advisory and research services to other Government Agencies; develops, produces, and distributes Standard Reference Materials; and provides calibration services. The Laboratory consists of the following centers:

Absolute Physical Quantities ${ }^{2}$ - Radiation Research - Thermodynamics and Molecular Science - Analytical Chemistry - Materials Science.

THE NATIONAL ENGINEERING LABORATORY provides technology and technical services to users in the public and private sectors to address national needs and to solve national problems in the public interest; conducts research in engineering and applied science in support of objectives in these efforts; builds and maintains competence in the necessary disciplines required to carry out this research and technical service; develops engineering data and measurement capabilities; provides engineering measurement traceability services; develops test methods and proposes engineering standards and code changes; develops and proposes new engineering practices; and develops and improves mechanisms to transfer results of its research to the utlimate user. The Laboratory consists of the following centers:

Applied Mathematics - Electronics and Electrical Engineering ${ }^{2}$ - Mechanical

Engineering and Process Technology ${ }^{2}$ - Building Technology - Fire Research Consumer Product Technology - Field Methods.

THE INSTITUTE FOR COMPUTER SCIENCES AND TECHNOLOGY conducts research and provides scientific and technical services to aid Federal Agencies in the selection, acquisition, application, and use of computer technology to improve effectiveness and economy in Government operations in accordance with Public Law 89-306 (40 U.S.C. 759), relevant Executive Orders, and other directives; carries out this mission by managing the Federal Information Processing Standards Program, developing Federal ADP standards guidelines, and managing Federal participation in ADP voluntary standardization activities; provides scientific and technological advisory services and assistance to Federal Agencies; and provides the technical foundation for computer-related policies of the Federal Government. The Institute consists of the following divisions:

Systems and Software - Computer Systems Engineering - Information Technology.

'Headquarters and Laboratories at Gaithersburg, Maryland, unless otherwise noted; mailing address Washington,D.C. 20234.

'Some divisions within the center are located at Boulder, Colorado, 80303.

The National Bureau of Standards was reorganized, effective April 9, 1978. 


\title{
International Project Catalog of

\begin{abstract}
A Report of the
Committee on the Challenges of Modern Society

Rational Use of Energy Pilot Study

Modular Integrated Utility Systems Project
\end{abstract}

\author{
M. H. Nimmo \\ C. W. Phillips
}

Center for Building Technology

National Engineering Laboratory

National Bureau of Standards

Washington, D. C. 20234

Prepared for:

Division of Energy, Building Technology and Standards

Office of Policy Development and Research

U.S. Department of Housing and Urban Development

Washington, DC 20410

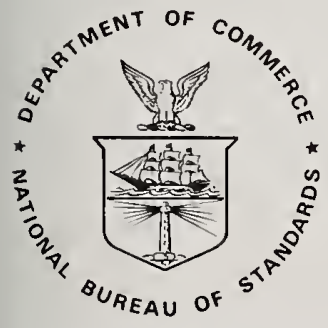

U.S. DEPARTMENT OF COMMERCE, Juanita M. Kreps, Secretary

Dr. Sidney Harman, Under Secretary

Jordan J. Baruch, Assistant Secretary for Science and Technology

NATIONAL BUREAU OF STANDARDS, Ernest Ambler, Director

Issued July 1978 
Library of Congress Catalog Card Number: 78-600056

National Bureau of Standards Special Publication 515

Nat. Bur. Stand. (U.S.), Spec. Publ. 515, 455 pages (July 1978)

CODEN: XNBSAV

U.S. GOVERNMENT PRINTING OFFICE

WASHINGTON: 1978

For sale by the Superintendent of Documents, U.S. Government Printing Office, Washington, D.C. 20402 Stock No. 003-003-01953-4 Price \$6.50

(Add 25 percent additional for other than U.S. mailing). 


\section{FOREWORD}

This International Project Catalog was prepared for the Committee on the Challenges of Modern Society - Rational Use of Energy Pilot Study Modular Integrated Utility System (CCMS-MIUS Project), to identify modular integrated utility system type of projects among participating countries. This product of the committee's work is an outgrowth of strong international concern for improving utility services to communities, reducing energy consumption and improving the environment.

The CCMS-MIUS Project has been piloted by the U.S. under the leadership and sponsorship of the U.S. Department of Housing and Urban Development (HUD) Division of Energy, Building Technology and Standards, Office of Policy Development and Research.

The International Project Catalog is significant in that it provides experts with a means to seek further technical information and data on a particular project in which they are interested. For each project the catalog includes a description of the project, its status, the approach, expected results, some technical data, the principal investigator, and an indication whether or not data is/or will be available.

Another product being prepared by the CCMS-MIUS Project separate from the catalog is a standard methodology for measuring the performance of Modular Integrated Utility Systems (MIUS) type of projects and the reporting and taking of data. This product will aid principal investigators in preparing a final report and other experts where reports are available in evaluating and comparing the performance of systems.

The International Project Catalog has been designed to facilitate the location of projects by country and type of project (e.g., total energy, district heating) and to aid the inclusion of future revisions.

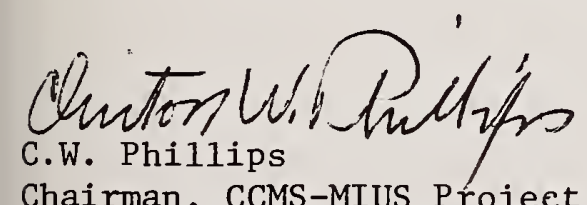

Chairman, CCMS-MIUS Project Committee and NBS/HUD-MIUS Program Manager

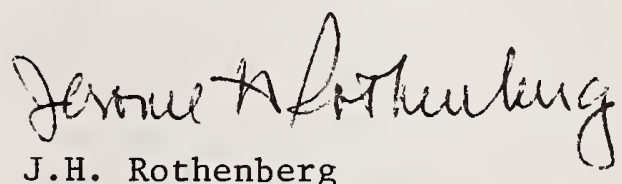

J.H. Rothenberg

Head, U.S. Delegation to CCMS-MIUS Project Committee and HUD-MIUS Program Director 


\section{CONTRIBUTING STAFF}

This Catalog was prepared by the Secretariat of the CCMS-MIUS Project under the direction of the Project's Data Format Committee.

The U.S. was the lead country and the Department of Housing and Urban Development (HUD) served as the lead agency of the CCMS-MIUS Project. HUD sponsored and directed the U.S. participation and effort under the leadership of J.H.Rothenberg, HUD-MIUS Program Director. The National Bureau of Standards in providing technical support to HUD on the HUD-MIUS Program performed the duties of Secretariat and chaired the semi-annual committee meetings. The individuals who contributed to the preparation of this Catalog are hereby acknowledged:

J.H.Rothenberg (HUD) - Head of U.S. Delegation as lead çountry

\section{Secretariat}

Clinton W. Phillips (NBS)-CCMS-MIUS Project Committee Chairman Morris H. Nimmo (NBS) - Editor

Walter Shipp (NBS) - Contributing Editor

Sandra I. Kelley (NBS) - Administrative Aide

Ulesia B. Gray (NBS) - Clerical and Typing

Norma A. Wood (NBS) - Clerical and Typing

Data Format Committee

Canada (K.R.Solvason)

Italy (Dr. Marzio Mangialajo)

Netherlands (J.W.H. Van den Bergh)

United Kingdom (P.J.O'Neill)

United States (C.W.Phillips, Chairman)

Contributing Countries and Their Coordinators

Belgium - J.A.Michel

Canada - K.R. Solvason

Denmark - Prof. E. Bjorn Qvale

Federal Republic of Germany - Dr. Helmut Klein

France - Dr. Tovy Grjebine

Italy - Dr. Marzio Mangialajo

Japan - Kunio Shimizu

Netherlands - J.W.H.Van den Bergh

Sweden - Ulf Renghold

United Kingdom - P. J. O'Neil1

United States - C.W.Phillips

Others Who Contributed to the Catalog through their Committee Participation are:

Austria - P.V.Gilli

Federal Republic of Germany - Dr. Ulrich Plantikow

France - Michel Simon

Netherlands - J.A.Knobbout

U.S.CCMS Coordinator - F.A.Harris 
PART I INTRODUCTION

Page

Abstract . . . . . . . . . . . . . . . . . 1

1.1 Purpose . . . . . . . . . . . . . . . . . 2

1.2 Scope . . . . . . . . . . . . . . . . . . 2

1.3 History and Description of CCMS . . . . . . . . . . . 3

1. 4 CCMS-MIUS Project. . . . . . . . . . . . . . . 3

1.4.1 Origin and Objectives . . . . . . . . . . . 3

1.4.2 Description of the MIUS Concept . . . . . . . . 5

1.4.3 Definition of "MIUS Type of Project" . . . . . . 6

1.5 Participating Countries . . . . . . . . . . . . . 9

1.6 Organization of Catalog and How to Use the Catalog . . . 9

1.6 .1 Contents . . . . . . . . . . . . . . . . 9

1.6.2 Description of Identification Number and Code . . 10

1.6.3 How to Use the Catalog . . . . . . . . . . . 12

1.7 Three Level Reporting System . . . . . . . . . . . . 13

1.8 Project Summary Form . . . . . . . . . . . . . . 14

1.8.1 Description . . . . . . . . . . . . . . 14

1.8.2 Instructions for Completing the Form . . . . . . . 14

1.9 How to Obtain Additional Copies . . . . . . . . . . . 18

' PART II LIST OF PROJECTS BY COUNTRY • • • • • • • • • • • . 19

PART III PROJECT DESCRIPTIONS . • • • • • • • • • • • . 31

Section 1 Modular Integrated Utility Systems (MIUS). . . 31

2 Total E'nergy Systems . . . . . . . . . . 41

3 Integrated Utility Systems . . . . . . . . 125

4 District Heating . . . . . . . . . . 267

5 Utility Systems . . . . . . . . . . 303

6 Component/Equipment . . . . . . . . . 395 
I-I Identification Number C'ode . . . . . . 10

2-1 Projects Reported from Belgium ........ 19

2-2 Projects Reported from Canada......... . 19

2-3 Projects Reported from Denmark......... 19

2-4 Projects Reported from Finland . . . . . . 20

2-5 Projects Reported from France......... 20

2-6 Projects Reported from Germany ........ 20

2-7 Projects Reported from Italy ........ . 21

2-8 Projects Reported from Japan ......... . 22

2-9 Projects Reported from Netherlands ...... 22

2-10 Projects Reported from Sweden ......... 25

2-11 Projects Reported from United Kingdom . . . . . 25

2-12 Projects Reported from United States . . . . . 26 
International Project Catalog of Modular Integrated Utility Systems

M.H. Nimmo

C.W. Phillips

The International Project Catalog prepared for the Committee on the Challenges of Modern Society-Rational Use of Energy Pilot Study Modular Integrated Utility Systems (CCMS-MIUS Project) is a compilation of project descriptions on more than 200 Modular Integrated Utility Systems (MIUS) type of projects being conducted in the participating countries. Each project description includes a description of each project, its status, the approach, expected results, some technical data, the principal investigator, an indication whether or not data is/or will be available and other miscellaneous project information. The catalog is useful to the experts in identifying the various projects being conducted and seeking further technical information on those particular projects in which they are interested:

The catalog is the first of a three level reporting system to report on MIUS type of projects. The second and third level reporting systems, which are expected to be improved and completed in future activities under another international organization, will provide information and guidelines for reporting progress and supplying data. The catalog consists of three parts: an Introduction, list of Projects by Country, and Project Descriptions, one for each project reported.

Keywords: Catalog, CCMS-MIUS Project Catalog, International Project Catalog, Project Catalog, Project Summary Forms, Reporting System. 


\subsection{PURPOSE}

This International Project Catalog has been designed to provide summary descriptions of Modular Integrated Utility System (MIUS) type of projects* being conducted by countries participating in the Committee on the Challenges of Modern Society (CCMS), Rational Use of Energy Pilot Study, Modular Integrated Utility System (MIUS) Project hereafter referred to as the CCMS-MIUS Project.

The International Project Catalog has been prepared by the CCMS-MIUS Project under the direction of its Data Format Committee to assist users in identifying MIUS type of projects and assessing the objectives, progress and significance of each project. The catalog also provides at a glance a sampling of the state of the art in MIUS type of projects and integrated utility system technology and research and thus provides a base for the exchange of information and data resulting from research.

The catalog is a collection of Project Summary Forms assembled on the projects reported. Each form covers one project and provides a description of the project,its status, the approach, expected results, some technical data and other miscellaneous project information. It further indicates whether analytical data and more comprehensive information is or will be available and from whom it may be obtained.

There are many energy saving and energy efficient MIUS type of projects either planned, in progress or in operation. Some are operating successfully and efficiently while others are marginal or disappointing. Thus an organized and standard method of measuring performance in order that MIUS type of projects can be compared with each other is essential if the danger of someone replicating a less than desirable project is to be reduced and shortcomings identified and corrected. Since information and analyses of MIUS type of projects are to be shared among participating countries, the need for a standard method for measuring the performance of a project is even greater. The CCMS-MIUS Project recognizing this need also worked toward the preparation of a standard methodology for measuring performance. It is included in the project's report to the Fall CCMS Plenary, October 18-19, 1977.

\subsection{SCOPE}

The International Project Catalog includes MIUS type of projects submitted by all participating NATO and Non-NATO countries. Every effort was made to be as comprehensive as possible in view of the information available at the time.

* Refer to paragraph 1.4 .3 for a definition of"MIUS type of projects." 
Each Project Summary Form submitted as a candidate for the Catalog was considered on the basis of whether the project is a MIUS type of project, its significance to MIUS technology, and the expected availability of information and data resulting from the project. Project Summary Forms were accepted on projects that are planned, in progress or completed. Although there was no time limit on projects submitted, those projects that were completed for more than two years were examined more carefully and included primarily on the basis of their significance. Paragraph 1.4.3 Definition of "MIUS Type of Project" is the criteria that was used for selecting Project Summary Forms for inclusion in the c atalog. Future selections for any subsequent update of the catalog will also follow tile same cxiteria.

Twenty-six countries (15 NATO and 11 Non-NATO) were invited to participate in the CCMS-MIUS Projects and provide inputs to the catalog. Fifteen countries participated in the CCMS-MIUS Project by having attended and participated in the semi-annual meetings and/or by having provided Project Summary Forms.

\subsection{HISTORY AND DESCRIPTION OF CCMS}

The Committee on the Challenges of Modern Society (CCMS) is a committee of the North Atlantic Treaty Organization (NATO) created by the member countries on the occasion of the twentieth anniversary of the Alliance in 1969.

CCMS was established and directed to examine how to improve, in every practical way, the exchange of views and experience among the NATO countries in the task of creating a better environment for their societies ... and to consider specific problems of the human environment with the deliberate objective of stimulating action by member governments.

The basis of CCMS and its work program is to promote an effective and continuing exchange of information, technology and experience in order to pool the world's expertise and expand the base of knowledge, and to create the best possible environment for all nations. Participation is open to Non-NATO countries.

The CCMS is flexible and action oriented and differs from most international organizations in that it operates by a "pilot study" method where countries with the most expertise and interest agree to take the lead role (pilot), finance the project ard see that action ensues.

\subsection{CCMS-MIUS PROJECT}

\subsubsection{Origin and Objectives}

The CCMS-MIUS Project is one among severa]. projects that comprise the pilot study program, Rational Use of Energy. The project was crganized as a result of strong mutual international concern over the need to improve methods for providing improved utility services to communities. 
The MIUS concept of integrating the services into a single plant is the major thrust and distinguishing characteristic of the project. This project was approved at the NATO CCMS Ministers Level Meeting in Turin, Italy, May 1974 with the establishment of the pilot study, Rational Use of Energy. This pilot study began from an ad hoc committee established to investigate the feasibility of establishing such a pilot study and the Chairman's report on the U.S. proposal for a pilot study on "Energy Conservation and Meetings of Experts on Energy Conservation in Buildings and Industry". The object of this pilot study was to identify and transfer energy conservation technology among the participating countries.

The pilot study, Rational Use of Energy and its sub-project, the CCMSMIUS Project, are both piloted by the United States. The U.S. Department of Housing and Urban Development (HUD) was assigned the lead agency role responsibility for the CCMS-MIUS Project due to its pursuance of the MIUS concept through its HUD-MIUS Program and its experience with the Total Energy Demonstration at Jersey City, N.J.

The CCMS-MIUS Project had its first meeting in Brussels at NATO headquarters, April 10-11, 1975. It was an organization meeting in which the various needs in the transfer of Modular Integrated Utility Systems information were identified and tasks to help satisfy these needs begun.

At present the CCMS has eleven pilot studies underway. They are as follows :

\section{STUDY}

1. Advanced Wastewater Treatment

2. Disposal of Hazardous Wastes

3. Solar Energy

4. Geothermal Energy

5. Rational Use of Energy

- Climatic Conditions and Test Reference Year

c Electric Utility Load Management

- International Industrial Data Base

- Modular Integrated Utility Systems

\section{PILOT}

U.K.

FRG

U.S.

U.S.

Denmark

U.S.

U.S. \& Italy

U.S.

FRG

U.S.

Canada

Frarice

U.S.

U.S. 
The following pilot studies have been completed.

1. Environment and Regional Planning

2. Disaster Assistance

3. Road Safety

4. Air Pollution

5. Inland Water Pollution

6. Coastal Water Pollution

7. Advanced Health Care

8. Urban Transportation

\subsubsection{Description of the MIUS Concept}

The Modular Integrated Utility System Concept brings together subsystems that together provide improved means for furnishing essential services for residential communities.

The MIUS "recycles energy" by providing an option to package into one processing plant ali of the six utility services necessary for community development.

- electricity

- space heating and water heating

- air conditioning

- solid waste processing

- wastewater treatment

- residential water purification

Conventional methods of generating electricity convert about $35 \%$ of the energy input to electrical output. The remaining $65 \%$ is vented to the atmosphere or flowing water in a manner that optimizes the electrical conversion process. MIUS theoretically can recover better than half of this rejected energy and use it for space heating, air conditioning, water heating and to improve wastewater treatment efficiencv. An additional 5-10\% fuel savings can be made by recycling solid waste for its energy content.

In addition to saving energy, MIUS minimizes the environmental impact of utility systems.

The overall objectives of the MIUS concept are to:

- Provide utility services in an improved manner with advantages in total cost, decreased environmental impact and increased efficiency in the utilization of natural resources;

- Provide utility service capacity at a pace equal to the rate of growth of the new development;

- Make land available for development in areas that are not being serviced by conventional utility. 


\subsubsection{Definition of "MIUS Type of Project"}

The following criteria was used to select projects for the catalog. It will be used also for any further revisions.

Although the MIUS concept generally connotes or is thought of as the integration of six utility services, it is accepted as two or more integrated utility services. However, for classification purposes in this catalog, a MIUS will be thought of as having five or six utility services.

A "MIUS type of project", a term used throughout this catalog, means a broad range of utility/energy systems which are related to, similar to, part of a MIUS, or may include a MIUS. A "MIUS type of project" is one that involves a utility system/subsystem that is, or has the potential to be, integrated with one or more utility system(s)/subsystem(s) to produce those utility services more efficiently and economically than would be possible with independent (non-integrated) systems.

"Integrated" refers to use of a combined plant to furnish more than one utility service with a total system approach, whereby some resource requirements of one utility would be met by utilizing the effluent of another.

\section{Project}

What constitutes a project? A project acceptable for inclusion in the International Project Catalog should be hardware oriented. A project may even be a study, such as a feasibility study, if it has major national significance, or if it is one that could lead to the construction of an actual system or a study which shows that an application is not feasible.

An acceptable hardware system may be a research-oriented laboratory or pilot plant investigation, or it may be a demonstration or commercial facility which is serving actual community utility loads. A laboratory investigation would most likely be one for equipment or subsystem development, a pilot plant would be one for experimentation with future plants or system development in mind, a demonstration facility would be one constructed specifically to prove feasibility of an actual reallife plant by acquisition and evaluation of data. A commercial facility serving an actual community or industry is highly desirable as a CCMSMIUS project if basic operating data is available for evaluating periormance. 
What do we mean by Modular? Modular can have several meanings when applied to an integrated utility system. Some ideas that were helpful in determining a CCMS-MIUS type of project are as follows:

1. Modular may connote a small community size plant serving a small community or part of a community. Thus, the modular system is part of the overall infrastructure. It could be a small facility serving a shopping center, a school, a hospital, an apartment complex or a combination of these.

2. Modular may connote a small community size plant with the potential to grow in increments as the community grows. Thus the added increment could be considered a module.

3. Modular may represent the structure of the integrated utility system itself, since an integrated utility system would consist of subsystems. Thus a subsystem could be considered a module.

\section{MIUS Type of Projects}

The following definitions and guidelines of MIUS type of projects were used in considering projects for the Catalog.

1. MIUS - An integrated utility system where all utility subsystems are integrated to provide utility services better, more economically and with less fuel consumption than conventional systems. A MIUS provides power, space heating/cooling, domestic hot water, solid waste processing, wastewater treatment and provisions for potable water. A MIUS recovers rejected heat from power generation and refuse incineration, and reduces undesirable discharges to the environment. It is recognized that a MIUS, no matter how well designed and operated, can not achieve maximum overall efficiency all of the time. All rejected heat that is reclaimable is unlikely to be needed 100 percent of the time, e.g. very little, if any, space heating/cooling may be needea during mild temperatures.

2. Total Energy System (TE) - An integrated utility system that provides power, space heating/cooling and domestic hot water. It recovers rejected heat from power generation.

3. Integrated Utility System (IUS) (other than a complete MIUS or Total Energy) - Two or more utility subsystems which are integrated. Examples are: use of renovated wastewater for use in power plant cooling towers, solid waste processing with incineration and wastewater treatment, and wastewater trea.tment with water renovation or reuse. A MIUS and a Total Energy System are special cases of an Integrated Utility System.

4. District Heating (DH)-A system by which heat is supn1-ied to buildings in an urban area through insulated pipelines from one or more heat 
sources situated external to the buildings. Any district heating system that has the potential or is to be integrated with another utility subsystem (refuse incineration or power generation, to provide better services at less cost) should be included.

5. Utility System - A system that furnishes a single utility service. A utility subsystem that is being improved or developed for integration with another utility system or one that is being improved to exhance the integration process should be considered. This would include, for example an improved method of recovering heat during power generation.

6. Component/Equipment - A component or piece of equipment that is being improved or developed specifically for the purpose of improving the integrated utility system/subsystem, or the integration process. For example: Thermal Storage Systems, boilers, heat pumps, heat exchangers, etc. Note: A project to improve a component or piece of equipment such as a boiler or heat pump, with no specific objective related to integrated systems should not be considered a project for the catalog.

\section{$\underline{\text { Scale }}$}

Although modular in "MIUS" has sometimes been interpreted as being limited to small scale plants, this is not correct. For the purpose of identifying projects all size plants which followed the type of projects listed above were considered.

\section{Status}

The status of a project was not a critical factor in the acceptance of a project for the catalog. Projects that were in the planning stage, on-going, or completed were accepted. A project was not considered complete until the final report had been published or released and data evaluated.

\section{Availability of Data}

A pilot plant, demonstration facility or commercial system should be one in which good quality data that will be useful in analyzing plant performance is being acquired and is readily accessible. The more data available the better, however, operational data such as that produced by a commercial system was adequate in choosing candidates for the project catalog. 
NATO and Non-NATO countries are participating in the COMS-MIUS Project.

Those NATO and Non-NATO countries that have participated in the CCMSMIUS Project by either sending Project Summary Forms for inclusion in the International Project Catalog or by participating in the CCMS-MIUS Project meeting are as follows: Austria, Belgium, Canada, Denmark, Finland, France, Federal Republic of Germany, Italy, Japan, the Netherlands, New Zealand, Spain, Sweden, the United Kingdom and the United States.

All countries that have particular interest in MIUS type of projects by virtue of their work, are encouraged to participate in any future activities. Any future work will be under the auspices of another International Organization when one has been acquired, as the CCMSMIUS Project concluded its activities at its last meeting July 12-14, 1977, after a two year period.

$\frac{1.6 \text { ORGANIZATION OF CATALOG AND }}{\text { HOW TO USE THE CATALOG }}$

\section{6 .1 Contents}

The catalog is divided into three parts, Introduction, List of Projects by Country, and Project Descriptions. Part I, Introduction, includes the purpose of the catalog and its intended use; the scope of the catalog's coverage; the history and description of the CCMS-MIUS Project, the MIUS concept and a definition of a MIUS type of project; the countries participating in the CCMS-MIUS Project, the Catalog's organization and how to use the catalog; a discussion of the three level reporting system; a description of the Project Summary Form, and how one may obtain additional copies of the catalog. Part II, List of Projects by Country, includes a table for each country reporting MIUS type of projects. Each table lists each MIUS type of project indentified or reported for that particular country. There may be projects listed which do not have a completed Project Summary Form. If a completed Project Summary Form is provided in Part III, the Identification Number will be given. Part III, the Project Description is a compilation of Project Summary Forms, one for each project reported, and is divided into 6 sections, one:; for each type of project. They are MIUS, Total Energy Systems, Integrated Utility Systems (IUS - for purpose of the catalog an IUS is defined as two or more integrated utility systems other than MIUS and Total Energy), District Heating, Utility Systems (a single system), and Component/Equipment.

Each project is assigned an identification number which can be useful in locating a project. It can assist in quickly identifying the type of project, the project's location, the fuel used, ownership, and the country in which the project is located. Refer to paragraph 1.6.3., How to Use the Catalog. 


\subsubsection{Description of Identification \\ Number and Code}

Part III, Project Descriptions, of the Catalog has been organized according to the identification number, an eight digit code, as shown in Table $1-1$. This listing is by no means inclusive. As more projects are included, in any future revision, categories wit1 be added, as necessary. In some cases the combination of some areas mor be necessary.

Table 1-1 Identification

Number Code

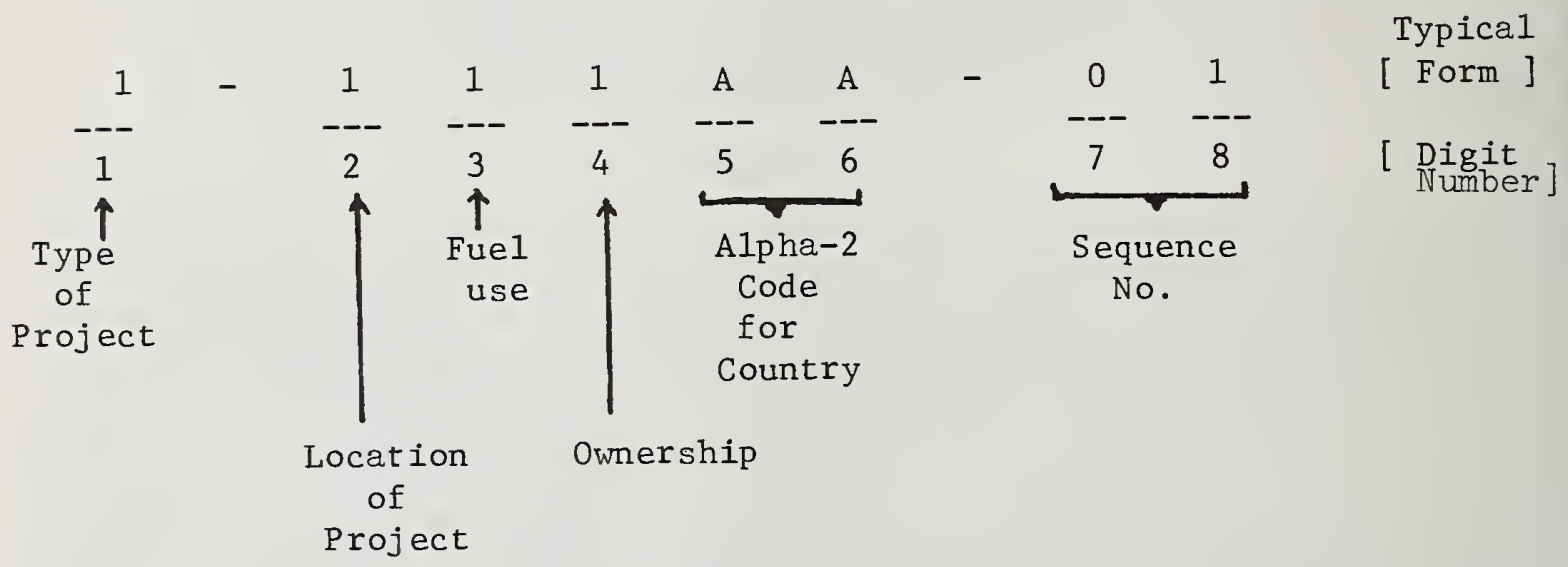

In the case of fuel use there are systems that are multi-fueled. If more than one fuel category is needed to identify the fuels used, indicate more than one category by using a period (.) to represent "and". For example: categories 1 "and"2 may be represented by "1.2". Thus the identification number might be 1-21.21AA-09. If three categories are needed use "1.2.3". The identification number woul.d then be 1-21.2.31AA-09. 
Table 1-1 Identification Number Code (cont.)

The First digit--Type of Project

1. MIUS

2. Total Energy System

3. Integrated Utility System (IUS)

4. District Heating

5. Utility System (a single

6. Component/Equipment

The Second digit -- Location of Project

1. Community (Residential/Commercial)

6. Utility

7. Military Base

8. Small Utility

3. School

4. Hospital

5. Industrial/Commercial

9. Hotel/Motel

0 . Other

The Third digit -- Fuel Used

1. Fuel Oil (distillate, residual or

6. $\mathrm{Coal}+\mathrm{RDF}$ crude)

2. Natural Gas

7. Fuel Oil + Natural Gas

8. Solar Assist

3. Refuse Derived Fuel (RDF)

9. Nuclear

4. Synthetic Gas

0. Other

5. Coal

The Fourth digit -- Ownership

1. Public

2. Private

3. Cooperative

4. Public and Private

The fifth and six digit -- The country where the Project is located, using the Alpha-2 Code, of ISO Standard 3166-1974 and American National Standard $739.27-1976$.

Those countries which reported MIUS type of projects and their Alpha-2 codes are as follows:

$\begin{array}{llll}\text { Belgium } & - \text { BE } & \text { Italy } & - \text { IE } \\ \text { Canada } & - \text { CA } & \text { Japan } & - \text { JP } \\ \text { Denmark } & \text { - DK } & \text { Netherlands } & - \text { NL } \\ \text { Finland } & - \text { FI } & \text { Sweden } & - \text { SE } \\ \text { France } & - \text { FR } & \text { United Kingdom } & - \text { GB } \\ \text { Germany } & - \text { DE } & \text { United States } & - \text { US }\end{array}$

The seventh and eighth digits form the Sequence Number. 
As an example, 1-222US-12 would be a MIUS located in the U.S. in a shopping center using natural gas and privately owned. The last two digits indicate that it is the 12 th entry in the MIUS category of projects.

\subsubsection{How to Use the Catalog}

The catalog has been designed in order that a particular project can be easily located on the basis of country, type of project by country, type of project, project descriptions (e.g. location, fuel used, ownership, etc.). The first step in using this Catalog is to become familar with its organization (e.g. Parts, Sections, etc.) and the various aids such as Table of Contents, Tables 2-1 through Table 2-12, and the Identification Number. Study the identification number and learn the code for each digit. Refer to Paragraph 1.6.2.

The Table of Contents identif'ies the type of projects (e.g. total energy, district heating) by their Section Number in Part III; Tables 2-1 through 2-12 in Part II identify all projects in a particular country; by using the first digit of the identification, a further breakdown by the type of project for a particular country can be located; and by using the identification number alone a project may be identified easily and in many cases located on the basis of country, type of project, location (e.g. community, utility) fuel used and type of ownership (e.g. public, private).

\section{Examples :}

Question: Locate all Total Energy Projects in the U.S.

Procedure: Go to Table 2-12, locate all projects whose identification number begins with a 2 (corresponds to total energy systems) observe sequence numbers. They are numbers 2--07, --18,--19,--21, --25,--27, --38, $--39,--40$. (Note the 2nd through the 5th digit in this case are not used. Only the first digit which identifies the type of project and the last two digits which identify the sequence within the type of project category are used.)

Question: Locate all oil fired total energy systems.

Procedure: Go to Section 2 for all total energy systems; check each identification number and note that the third digit is a 1. They are numbers 2--04, --05, --06, $-07,--16,--17,--18,--21,--27,--28,--38$.

Question: Locate all privately owned total energy systems in the Netherlands.

Procedure: Go to Table $2-9$ and identify all total energy projects. They are 2-01, 08, 09, 10-12, 14, 15, 17, 22-24, 30-37, 41. Go to Section 2, check the projects identified above, and observe those projects that have PRIVATE checked in box 11, Type of Project. They are 2-11, 12, $14,15,17,30-34,37$ and 41 . 
The International Project Catalog was designed as the first of a three level reporting system, Phase I, to report data on MIUS type of projects. The catalog is comprised of Project Summary Forms assembled together with appropriate tables of contents. This first phase is designed to be all inclusive without identifying successful or marginal bereficial systems, but to make certain that all possible systems are covered. The information contained on these forms is a broad overview of what the system is supposed to accomplish rather than a detailed analysis. The Project Summary Form developed by the CCMS-MIUS Project Data Format Committee will in general, tell where a project is located and who is responsible for its development and what generally is to be expected. Enough general information is included to allow a quick assessment of its merits and whether or not more information would be desirable. If in fact more information is necessary in order to determine whether this system would serve a given set of needs as perceived by the decision maker than he would requesi. Phase II.

The second level reporting system, Phase II, is the "Project Progress/ Evaluation Report". It was designed and partially developed by the CCMS-MIUS Project Data Format Committee and is intended to serve as an executive summary, i.e. it provides much more detail than Phase I. Obviously not all systems reported in Phase I are appropriate for the second level reporting system, Phase II.

If an expert desires more information than is provided in the Project Summary Form, he may contact the principal investigator or sponsoring organization to obtain the Project Progress/Evaluation Report if one is available. The report may not follow the same outline provided in the report form, but generally it will provide the information requested as appropriate for the particular project. The availability or future availability of a Project Progress/Evaluation Report may be indicated by whether the "Exchange of data" box (12) on the Project Summary Form has been checked "Yes or No". Not al1 projects, of course, will have a Project Progress/Evaluation Report if the "Exchange of data" box is checked "Yes".

From the Project Progress/Evaluation Report one willibe able to make valid comparisons of similar projects to determine which one is best suited for a given set of conditions. The format is also such that problems and how they were overcome can be assessed and comparisons made. Many times similar projects in different locations have varying degrees of success, and it becomes quite difficult to determine what the critical factors are. Phase II should eliminate this variance or at least reduce its magnitude.

Although the Project Progress/Evaluation Report was designed and partially developed by the CCMS-MIUS Project its future development and use, if any, will be done under the auspices of another International Organization when one has been acquired as the CCMS-MIUS Project has concluded its activitics. 
The third level reporting system, Phase III, and final Phase is the "Standard Methodology for Measuring the performance of MIUS Type of Projects". It was developed by the CCMS-MIUS Project Measurement Technology Committee. This methodology is a standard methodology which is a guide for documenting the measurement of performance and taking of and reporting of data resulting from testing and demonstration of MIUS type of projects. It is the complete analysis of the system in such fashion that every conceivable constraint is considered and all critical points are identified. With this report a project can be successfully duplicated in another location. The standard methodology is included in the CCMS-MIUS Project report to the CCMS Plenary.

These forms have one common goal in mind and that is to carry the project manager from an ideal to a successful project in a logical sequential fashion using the inverted pyramid approach, eventually narrowing down to the one concept that fits all the needs of a particular area.

\subsection{PROJECT SUMMARY FORM}

\subsubsection{Description}

The Project Summary Form is two pages (front and back) and serves as a vehicle for providing summary descriptions of MIUS type of projects. The Project Summary Form is intended to assist experts in determining if a project is of interest to him and in accessing the objectives, progress and significance of each project.

Each CCMS-MIUS Project participant was asked to prepare a Project Summary Form for all MIUS type of projects with which he is associated or knowledgeable whether or not project data will be available for sharing with other experts.

The completed Project Summary Forms then were forwarded to the Secretariat who processed, printed, and bound the forms to compose this International Project Catalog. The catalog will be disseminated to CCMS-MIUS Project participants. It will also be made available to others on a single copy basis upon request.

\subsubsection{Instruction for Completing the Form}

The following instructions were used to guide the CCMS-MIUS Project participants in the completion of Project Summary Forms, and are included as follows to help the catalog user better understand the content of each Project Summary Form by knowing the criteria under which the Project Summary Forms were prepared. 
When completing a form, one should endeavor to provide all of the information requested, in order to give as complete a description of the project as possible. Information also should be limited to the space provided where possible, to minimize the task of the Secretariat in collecting and cataloging the material. If there is insufficient room on the front page to include the "Purpose of Project" and "Status and Results" use the continuation boxes on the reverse side.

Detail instruction for completing each box are provided below to guide those preparing the form. Abbreviated instructions are included in each box, as appropriate, adjacent to the headings.

1. TITLE OF PROJECT. Enter official title of CCMS-MIUS type of project A CCMS-MIUS type of project is one that can be or has the potential to be integrated into a utility system that will increase plant efficiency or as a minimum provide an economical and beneficial utility service better than that which separate non-integrated utility systems can provide. (Also refer to paragraph 1.4.3 for the definition of a MIUS type of project.) If this project has subordinate projects, prepare Project Summary Forms for those that are appropriate for the catalog. Include those projects which are planned, ongoing, or have been completed.

3. PERFORMING ORGANIZATION. Enter name and complete mailing address of organization performing research. For example:

\author{
Center for Building Technology \\ National Bureau of Standards \\ U.S. Department of Commerce \\ Washington, D. C. 20234
}

4. FRINCIPAL INVESTIGATOR. Enter name, title of principal investigator (person directly responsible for project); also provide complete mailing address if different from the performing organization.

5. SUPPORTING ORGANIZATION. Enter name and address of organization providing financial support for this project if different from the performing organization. Also provide name and title of person to contact who has responsibility for the project. Also enter name of the owner of the utility or facility, if appropriate.

6. DURATION OF INVESTIGATION. Enter month and year investigation, began or is expected to begin, and the expected completion date, month and year. If investigation has been completed, include data investigation was completed. 
7. ESTIMATED FUNDING AND MANPOWER. In order to describe the size of the project, please provide monies allocated per period of time, and estimated number of man years for same period of time. Use dollars (\$) for English version, and Francs for French version. For example:

\section{$\$ 1,000,000$ for three years, 27 man years}

8. PURPOSE OF PROJECT. Describe purpose of investigation using a brief narrative. Include objectives, motivations, approach, plans, and expected results. Also include any appropriate milestones with expected completion dates. Use the reverse side if necessary.

9. STATUS AND RESULTS. Describe briefly status of project and results of the investigation (findings to date). Also indicate whether the project is plarned, in-progress or completed by checking $(\checkmark)$ the applicable box. Use the reverse side if more space is needed for the narrative.

10. UTILITY SERVICES. Denote which utility services are being investigated by checking the appropriate boxes.

11. TYPE OF PROJECT. Denote whether this project is government-sponsored, private or cooperative (government and private) by checking the appropriate box.

12. EXCHANGE OF DATA. Denote whether this project will result in data that can be shared with other CCMS-MIUS Project participants by checking $(\sqrt{ })$ the appropriate box.

13. TECHNICAL DATA. Provide the requested technical data as appropriate. This data, depending upon the status of the project, may be design data as well as measured or calculated values as a result of testing or operation. The type of data requested in this box is appropriate for a demonstration facility, an operating plant, or a system that may ultimately become part of an integrated system. If your project can more appropriately be represented by other types of technical data or if there are other technical data which you consider important, please include. Use the unused space in this box or one of the continuation boxes below. Identify this additional data by using the box number and title.

Project location - This is the location of the plant or system being demonstrated or operated. Also include the expected site of a plant or system to be constructed. 
13. TECHNICAL DATA (Continued). Degree-days - Include both the heating degree-days during the winter and the cooling degreedays or hours during the summer. Also define the base for both heating and cooling degree-days or cooling hours. For example, in the U.S. heating degree-days are equal to the mean daily dry-bulb temperature below $65^{\circ} \mathrm{F}$ for each calendar day on which such deficiency or excess occurs and are accumulated for each day. The amount of cooling required is frequently determined in the U.S. by using the number of cooling hours the dry-bulb temperature is above $80^{\circ} \mathrm{F}\left(26.7^{\circ} \mathrm{C}\right)$ for the year (normally during the 3-4 months summer period). However, the amount of cooling required is also determined by using the number of cooling degree-days. This is equal to the mean daily dry-bulb temperature above $65^{\circ} \mathrm{F}$ for each calendar day on which such excess temperature occurs and are accumulated for each day.

Plant Load Capacity - Include the maximum load that the plant can produce or is designed to produce on a continuous basis for each utility service as indicated.

Heat to Power Ratio (average) - Provide the average heat to power ratio. Indicate whether it is the expected ratio or that calculated from measured values. Use consistent units of measure such as megawatts.

Energy Source - Indicate the primary energy source, such as coal, gas, or oil, etc. Also list any secondary source such as solid waste (RDF) or solar energy.

Expected Payback Period - Denote the expected payback period of the plant in utilities services as compared with a conventional system. Consider overcost of operation and maintenance if any, capital investment, interest and depreciation. Consider any other influencing factors, such as taxes, environmental penalties, etc.

Type and Size of User - Characterize the users by describing the size of the community being served. Use number of units and floor area for residential and commercial users as indicated in the box and thermal load and power load for industry.

14. OTHER RELATED PROJECTS. Enter title of other projects being conducted in your country or organization which are related to this project. If this project is a large effort with sub-. ordinate projects which have been or will be included in the catalog also, enter the title of the subordinate projects. If this project is part of a larger effort enter title of the larger (total) effort as well as the other subordinate projects for which Project Summary Forms have or will be prepared. 
14. OTHER RELATED PROJECTS (Continuea)). Identify the larger effort by preceding title with "(LP"); identify the subordinate projects by preceding title with "(SF)". Use the reverse side if necessary.

\subsection{HOW TO OBTAIN ADDITIONAL COPIES}

Additional paper copies are available from the U.S. Government Printing Office, Superintendent of Documents, Washington, D. C. 20402, etc. Microfiche may be purchased from the National Technical Information Service, Springfield, Virginia, 22151. 
PART II LIST OF PROJECTS BY

TABLE 2- 1 Projects Reported from BELGIUM

\begin{tabular}{|c|c|c|c|}
\hline No. & Project Title & $\begin{array}{l}\text { Identification } \\
\text { No. }\end{array}$ & $\begin{array}{l}\text { Page } \\
\text { No. }\end{array}$ \\
\hline 1 & TOTAL ENERGY PLANT FOR HOTEL CREST & $2-922 \mathrm{BE}-42$ & 137 \\
\hline 2 & TREATMENT OF MUNICIPAL SLUDGE BY USE OF RESIDUAL HEAT & $3-832 \mathrm{BE}-69$ & 277 \\
\hline 3 & $\begin{array}{l}\text { HEATING OF DWELLINGS BY HEAT PUMP USING DIRECTLY COLLECTED - } \\
\text { OR STORED SOLAR ENERGY }\end{array}$ & $5-182 B E-11$ & 343 \\
\hline 4 & $\begin{array}{l}\text { RATIONAL USE OF ENERGY CASE-STUDY ON GREENHOUSES, DEVELOPMENT } \\
\text { OF COMPUTER CODE AND DESIGN OF REGULATION DEVICE }\end{array}$ & $5-582 \mathrm{BE}-18$ & 357 \\
\hline 5 & MISCELLANEOUS SCK/CEN ACTIVITIES REIATED TO MIUS & $5-832 B E-46$ & 413 \\
\hline 6 & $\mathrm{H}_{2}$ - PRODUCTION BY WATER ELECTROLYSIS & $6-802 B E-23$ & 461 \\
\hline 7 & ELECTRODES FOR FUEL CELLS & $6-802 B E-24$ & 463 \\
\hline 8 & $\begin{array}{l}\text { STUDY AND DEVELOPMENT OF NEW ALIOYS SHOWING THE SHAPE MEMORY } \\
\text { EFFECT, AND THEIR APPLICATIONS, i.a. IN A "METAL ENGINE" } \\
\text { OR "SOLID STATE ENG INE" }\end{array}$ & $6-802 B E-25$ & 465 \\
\hline
\end{tabular}

TABLE 2-2 Projects Reported from CANADA

\begin{tabular}{|c|c|c|c|}
\hline No. & \multicolumn{1}{|c|}{ Project Title } & $\begin{array}{c}\text { Identification } \\
\text { No. }\end{array}$ & $\begin{array}{c}\text { Page } \\
\text { No. }\end{array}$ \\
\hline 1 & $\begin{array}{c}\text { IMPROVEMENT OF ENERGY UTILIZATION IN CANADA -- URBAN } \\
\text { USE SECTOR }\end{array}$ & $3-601 \mathrm{CA}-22$ & 183 \\
2 & CANWEL (CANADIAN WATER ENERGY LOOP) & $3-831 \mathrm{CA}-64$ & 267 \\
3 & OTTAWA MASTER PLAN STUDY & $3-831 \mathrm{CA}-65$ & 269 \\
4 & DISTRICT ENERGY SYSTEM ANALYSIS (DESA) & $4-601$ CA-13 & 309 \\
\hline
\end{tabular}

TABLE 2-3 Projects Reported from DENMARK

\begin{tabular}{|l|c|c|c|}
\hline No. & \multicolumn{1}{|c|}{ Project Title } & $\begin{array}{c}\text { Identification } \\
\text { No. }\end{array}$ & $\begin{array}{c}\text { Page } \\
\text { No. }\end{array}$ \\
\hline 1. & $\begin{array}{l}\text { POWER AND HEAT PRODUCTION FORM A COMBINED DIESEL RANKINE } \\
\text { POWER PLANT } \\
\text { TOTAL ENERGY SYSTEM FOR A GREENHOUSE }\end{array}$ & $2-111 \mathrm{DK}-04$ & 61 \\
\hline
\end{tabular}


TABLE 2-4 Projects Reported from FINLAND

\begin{tabular}{|l|l|c|c|}
\hline No. & \multicolumn{1}{|c|}{ Project Title } & $\begin{array}{c}\text { Identification } \\
\text { No. }\end{array}$ & $\begin{array}{c}\text { Page } \\
\text { No. }\end{array}$ \\
\hline 1. & MERTANIEMI POWER PLANT (FINLAND) & $3-611$ FI-27 & 193 \\
\hline
\end{tabular}

TABLE 2-5 Projects Reported from FRANCE

\begin{tabular}{|c|c|c|c|}
\hline No. & Project Title & $\begin{array}{l}\text { Identification } \\
\text { No. }\end{array}$ & $\begin{array}{l}\text { Page } \\
\text { No. }\end{array}$ \\
\hline 1. & DISTRICT FROM NUCLEAR POWER PLANTS - STUDY & $3-691 F R-56$ & 251 \\
\hline 2. & ENERGY SAVINGS & $5-102 F R-03$ & 327 \\
\hline 3. & $\begin{array}{l}\text { SOLAR HEATING INSTALLATION FOR TECHNIP BUILDINGS IN SAINT- } \\
\text { NAZAIRE (FRANCE) }\end{array}$ & $5-102 \mathrm{FR}-04$ & 329 \\
\hline 4. & THERMAL STORAGE OF ENERGY & $6-601 F R--14$ & 443 \\
\hline
\end{tabular}

TABLE 2-6 Projects Reported from GERMANY

\begin{tabular}{|c|c|c|c|}
\hline No. & Project Title & $\begin{array}{l}\text { Identification } \\
\text { No. }\end{array}$ & $\begin{array}{l}\text { Page } \\
\text { No. }\end{array}$ \\
\hline 1. & BLOCK HEAT-POWER STATION & $2-123 D E-13$ & 79 \\
\hline 2. & $\begin{array}{l}\text { MODEL COMMUNITY WITH NOVEL ENERGY AND HEATING SYSTEMS } \\
(\text { ET/5109) }\end{array}$ & $3-101 D E-03$ & 145 \\
\hline 3. & USES OF LONG-DISTANCE HEAT IN POWER STATIONS & $3-601 D E-23$ & 185 \\
\hline 4. & $\begin{array}{l}\text { OVERALL STUDY ON THE POSSIBILITIES OF LONG-DISTANCE HEAT } \\
\text { SUPPLY FROM HEATING POWER STATIONS IN THE FRG. (ET 5072) }\end{array}$ & $3-691 D E-50$ & 239 \\
\hline 5. & $\begin{array}{l}\text { PROJECT STUDY ON LONG-DISTANCE HEAT SUPPLY FROM HEATING } \\
\text { POWER STATIONS IN THE MANNHEIM-LUDWIGSHAFEN-HEIDELBERG } \\
\text { AREA (ET 5073) }\end{array}$ & $3-691 D E-51$ & 241 \\
\hline 6. & $\begin{array}{l}\text { PLANNING AND DESIGN WORK FOR DEMONSTRATING INTERCONNECTION } \\
\text { NETWORKS FOR LONG-DISTANCE HEAT SUPPLY IN THE OBERHAUSEN } \\
\text { AREA (ET 5074) }\end{array}$ & $3-691 D E-52$ & 243 \\
\hline 7. & $\begin{array}{l}\text { STUDY OF THE LONG-DISTANCE HEAT-SUPPLY SYSTEM IN THE KOBLENZ- } \\
\text { BONN-BAD GODESBERG-KOLN AREA (ET 5075) }\end{array}$ & $3-691 D E-53$ & 245 \\
\hline 8. & $\begin{array}{l}\text { PROJECT STUDY FOR THE CONURBATION OF BERLIN TO ASCERTAIN } \\
\text { THE POSSIBILITIES OF SAVING ENERGY AND SUBSTITUTING NUCLEAR } \\
\text { ENERGY FOR FOSSIL FUELS (ET 5076) }\end{array}$ & $3-691 D E-54$ & 247 \\
\hline
\end{tabular}


TABLE 2-6 Projects Reported from GERMANY

\begin{tabular}{|c|c|c|c|}
\hline No. & Project Title & $\begin{array}{c}\text { Identification } \\
\text { No. }\end{array}$ & $\begin{array}{l}\text { Page } \\
\text { No. }\end{array}$ \\
\hline 9. & AGROTHERM & $3-691 \mathrm{DE}-55$ & 249 \\
\hline 10 & DISTRICT HEAT SUPPLY SYSTEM INGOLDSTADT (ET 5147A) & $4-651 D E-16$ & 315 \\
\hline 11. & $\begin{array}{l}\text { INSTALLATION OF A HEAT-PUMP PLANT FOR THE PRODUCTION OF HEAT } \\
\text { AND WARM WATER FOR RESIDENTIAL BUILDINGS (ET 5804) }\end{array}$ & $5-101 \mathrm{DE}-01$ & 323 \\
\hline 12. & SYSTEM STUDY "ELECTRIC BULK POWER TRANSMISSION & $5-103 \mathrm{DE}-07$ & 335 \\
\hline 13. & PROGRAM STUDY "HEAT DISPERSION" (ET 5004) & $5-601 D E-19$ & 359 \\
\hline 14. & $\begin{array}{l}\text { FUEL CONSERVATION IN (CONVENTIONAL) HOT WATER HEATING SYSTEMS } \\
\text { BY GAS-OPERATED HEAT PUMPS (ET 5164A THRU ET 5167A) }\end{array}$ & $5-821 \mathrm{DE}-40$ & 401 \\
\hline 15. & GASIFICATION OF MUNICIPAL AND INDUSTRIAL WASTE (ET 1040) & $5-82.41 \mathrm{DE}-41$ & 403 \\
\hline 16. & $\begin{array}{l}\text { STUDY CONCERNING SEASONAL THERMAL STORAGE DEVICES FOR LOW } \\
\text { TEMPERATURES (ET 4048) }\end{array}$ & $6-601 D E-10$ & 435 \\
\hline 17. & $\begin{array}{l}\text { "LONG DISTANCE HEAT TRANSPORT LINE SAAR" LONG DISTANCE HEAT } \\
\text { SUPPLY OF THE CITY VOLKLINGEN (ET 4137A) }\end{array}$ & $6-601 D E-11$ & 437 \\
\hline 18. & LONG-DISTANCE HEAT RAIL RUHR: MIDDLE SECTION (ET 4145) & $6-601 \mathrm{DE}-12$ & 439 \\
\hline 19. & $\begin{array}{l}\text { STUDY OF ENERGY STORAGES IN SYSTEMS OF HEAT-POWER COUPLING } \\
\text { (ET 41.97A) }\end{array}$ & $6-601 D E-13$ & 441 \\
\hline 20. & $\begin{array}{l}\text { LARGE HEAT STORAGE UNIT WITH A HEAT CAPACITY OF } 1500 \text { GCAL, } \\
\text { IN THE KFA, JUELICH (ET 4139A) }\end{array}$ & $6-601 D E-22$ & 459 \\
\hline
\end{tabular}

TABLE 2- 7 Projects Reported from ITALY

\begin{tabular}{|c|c|c|c|}
\hline No. & Project Titie & $\begin{array}{l}\text { Identification } \\
\text { No. }\end{array}$ & $\begin{array}{l}\text { Page } \\
\text { No. }\end{array}$ \\
\hline 1. & SAN POLO RESIDENTIAL DISTRICT & $2-101 \mathrm{IE}-03$ & 59 \\
\hline 2. & CENTRALE TERMOELETTRICA QUARTIERE COMASIIJA & $2-111$ IE-05 & 63 \\
\hline 3. & TOTAL ENERGY HOSPITAL (BRESCIA) & $2-401 I E-20$ & 93 \\
\hline 4 . & $\begin{array}{l}\text { TOTAL ENERGY DIEESEL POWERED HEAT PUNP FOR AIR CONDITIONING } \\
\text { OF BUILDINGS }\end{array}$ & $2-512$ IE -28 & 109 \\
\hline 5. & TOTAL ENERGY MODULE (TOTEM) & $2-522$ IE-29 & 111 \\
\hline 6. & $\begin{array}{l}\text { SYSTEN FOR SUPPLYING UTILITY SERVICES TO A MULTI-FAMILY } \\
\text { LOW RISE BUILDING }\end{array}$ & $3-122 \mathrm{IE}-06$ & 151 \\
\hline 7. & CENTRALE THERMOELECTTRICA DI VAREDO & $3-572 I E-20$ & 179 \\
\hline
\end{tabular}


TABLE 2-7 Projects Reported from ITALY

\begin{tabular}{|c|c|c|c|}
\hline No. & Project Title & $\begin{array}{l}\text { Identification } \\
\text { No. }\end{array}$ & $\begin{array}{l}\text { Page } \\
\text { No. }\end{array}$ \\
\hline 8 . & $\begin{array}{l}\text { MILANO OLGETTINA - ELECTRICITY AND HEAT COMBINED PRODUCTION } \\
\text { BY SOLID WASTE INCINERATION }\end{array}$ & $3-631 I E-30$ & 199 \\
\hline 9. & $\begin{array}{l}\text { MILANO ZAIIA - ELECTRICITY AND HEAT COMBINED PRODUCTION BY } \\
\text { SOLID WASTE INCINERATION }\end{array}$ & $3-631 \mathrm{IE}-31$ & 201 \\
\hline 10 & MONCALIERI POWER PLANT (HEAT RECOVERY) & $3-671 I E-49$ & 237 \\
\hline 11. & $\begin{array}{l}\text { DISTRICT HEATING IN BRESCIA (TELERISCALDAMENTO DELLA } \\
\text { CITTA DI BRESCIA) }\end{array}$ & $4-111 \mathrm{IE}-03$ & 289 \\
\hline 12. & BIOGAS PLANT FOR PIG SLURRY TREATMENT - REGGIO EMILIA & 5-543IE-17 & 355 \\
\hline
\end{tabular}

TABLE 2- 8 Projects Reported from JAPAN

\begin{tabular}{|c|c|c|c|}
\hline No. & Project Title & $\begin{array}{c}\text { Identification } \\
\text { No. }\end{array}$ & $\begin{array}{l}\text { Page } \\
\text { No. }\end{array}$ \\
\hline 1. & OHTEMACHI OFFICE AREA D.H.C. PLANT & $3-123 J P-11$ & 161 \\
\hline 2. & KATAYAMAZU SPA DISTRICT DH PLANT & $4-113 J P-06$ & 295 \\
\hline 3. & BANNAGURO HOUSING ESTATE DH PLANT & $4-113 J P-07$ & 297 \\
\hline 4. & SENBOKU NEW TOWN TOGA AREA CENTER (DHC PLANT) & $4-122 J P-09$ & 301 \\
\hline 5. & TOMAKOMAI CITY BUSINESS AREA DH PLANT & $4-122 J P-10$ & 303 \\
\hline 6. & $\begin{array}{l}\text { 2ND MORINOMIYA HOUSING ESTATE OF JAPAN HOUSING CORPORATION } \\
\text { DHC PLANT }\end{array}$ & $4-122 J P-11$ & 305 \\
\hline 7. & CHIBA KAIHIN NEW TOWN (KEMIGAWA AREA) PLANT & $4-123 J P-12$ & 307 \\
\hline
\end{tabular}

TABLE 2- 9 Projects Reported from NETHERLANDS

\begin{tabular}{|c|l|c|c|}
\hline No. & \multicolumn{1}{|c|}{ Project Title } & $\begin{array}{c}\text { Identification } \\
\text { No. }\end{array}$ & $\begin{array}{c}\text { Page } \\
\text { No. }\end{array}$ \\
\hline 1. & TOTAL ENERGY/HEAT PUMP SYSTEMS & $2-021 \mathrm{NL}-01$ & 55 \\
2. & TOTAL-ENERGY PLANT "SWIMMING POOL" 'T KEERPUNT AMSTELVEEN & $2-121 \mathrm{NL}-08$ & 69 \\
3. & TOTAL-ENERGY PLANT FOR SWIMMING POOL & $2-121 \mathrm{NL}-09$ & 71 \\
4. & TOTAL-ENERGY-PLANT FOR SWIMMING POOL & $2-121 \mathrm{NL}-10$ & 73 \\
5. & TOTAL-ENERGY PLANT (LP) CENTRAAL BEHEER, INSURANCE COMPANY & $2-122 \mathrm{NL}-11$ & 75 \\
\hline
\end{tabular}


TABLE 2- 9 Projects Reported from NETHERLANDS

\begin{tabular}{|c|c|c|c|}
\hline No. & Project Title & $\begin{array}{c}\text { Identification } \\
\text { No. }\end{array}$ & $\begin{array}{l}\text { Page } \\
\text { No. }\end{array}$ \\
\hline 6 . & TOTAL ENERGY PLANT VICTORIA VESTA & $2-122 N L-12$ & 77 \\
\hline 7. & TOTAL ENERGY PLANT FOR DEPARTMENT STORE $V \&$ D & $2-222 \mathrm{NL}-14$ & 81 \\
\hline 8. & TOTAL ENERGY PROJECT IN HOUSE FOR MENTAL DEFECTIVES & $2-22.42 N L-15$ & 83 \\
\hline 9. & TOTAL ENERGY PLANT VRIJE UNIVERSITEIT & $2-312 N L-17$ & 87 \\
\hline 10. & TOTAL ENERGY PLANT HET NIEUWE SPITTAAL HOSPITAL & $2-420 \mathrm{NL}-22$ & 97 \\
\hline 11. & TOTAL ENERGY PLANT FOR LUKAS HOSPITAL & $2-421 N L-23$ & 99 \\
\hline 12 . & TOTAL ENERGY PLANT ST. ANNA HOSPITAL & $2-422 \mathrm{NL}-24$ & 101 \\
\hline 13. & $\begin{array}{l}\text { TOTAL ENERGY PLANT FOR CHICKEN SLAUGHTER-HOUSE "FRIKI", } \\
\text { OOSTERWOLDE }\end{array}$ & $2-522 \mathrm{NL}-30$ & 113 \\
\hline 14. & TOTAL ENERGY PROJECT FOR ALUMINUM FACTORY & $2-522 \mathrm{NL}-31$ & 115 \\
\hline 15. & TOTAL ENERGY PLANT FOR GREENHOUSE BOOTS & $2-522 N L-32$ & 117 \\
\hline 16. & TOTAL ENERGY FOR NURSEY GARDENS & $2-522 \mathrm{NL}-33$ & 119 \\
\hline 17. & TOTAL ENERGY PLANT LILY CULTIVATING COMPANY & $2-522 \mathrm{NL}-34$ & 121 \\
\hline 18. & TOTAL ENERGY PLANT FOR GREENHOUSE & $2-522 N L-35$ & 123 \\
\hline 19. & TOTAL ENERGY PLANT "FACTORY NEW HOLLAND" & $2-523 N L-36$ & 125 \\
\hline 20. & TOTAL ENERGY PLANT FOR INDUSTRIAL APPLICATION EMINENT & $2-572 N L-37$ & 127 \\
\hline 21. & $\begin{array}{l}\text { IMPROVEMENT OF ENERGY GENERATION PLANTS BY USING TOTAL } \\
\text { ENERGY SYSTEMS }\end{array}$ & $2-822 N L-4 I$ & 135 \\
\hline 22. & UTILIZATION OF HEAT, GENERATED BY COMBUSTION OF WASTE & 3-031NL-02 & 143 \\
\hline 23. & LOCAL HEATING FOR TOWNS TO BE BUILT (IN PLANNING) & $3-101 N L-04$ & 147 \\
\hline 24. & $\begin{array}{l}\text { IMPROVING THE EFFICIENCY OF THE COMBINED STEAM/POWER } \\
\text { GENERATING SYSTEM }\end{array}$ & $3-502 \mathrm{NL}-15$ & 169 \\
\hline 25. & $\begin{array}{l}\text { TECHNOLOGICAL AND ECONOMICAI OPTIMIZATION OF ELECTRIC POWER } \\
\text { STATIONS AND HEAT/POWER GENERATING PLANTS }\end{array}$ & $3-600 N L-21$ & 181 \\
\hline 26. & COMBINED HEAT AND POWER PRODUCTION FOR DISTRICT HEATING & $3-601 N L-26$ & 191 \\
\hline 27. & TOTAL ENERGY PLANT FOR SEWAGE TREATMENT 'SCRAVENZANDE & $3-821 N L-59$ & 257 \\
\hline 28. & TOTAL ENERGY PLANT FOR SEWAGE TREATMENT HILVERSUM & $3-821 N L-50$ & 259 \\
\hline 29. & TOTAL ENERGY PLANT FOR SEWAGE TREATMENT RWZI-NEIUGRAAF & $3-821 N L-61$ & 261 \\
\hline 30. & TOTAL ENERGY PLANT FOR SEWAGE TREATMENT - NIJMEGEN & $3-821 N L-62$ & 263 \\
\hline 31. & TOTAL ENERGY - PLANT FOR SEWAGE TREATMENT - RAALTE & $3-821 N L-63$ & 265 \\
\hline
\end{tabular}


TABLE 2-9 Projects Reported from NETHERLANDS

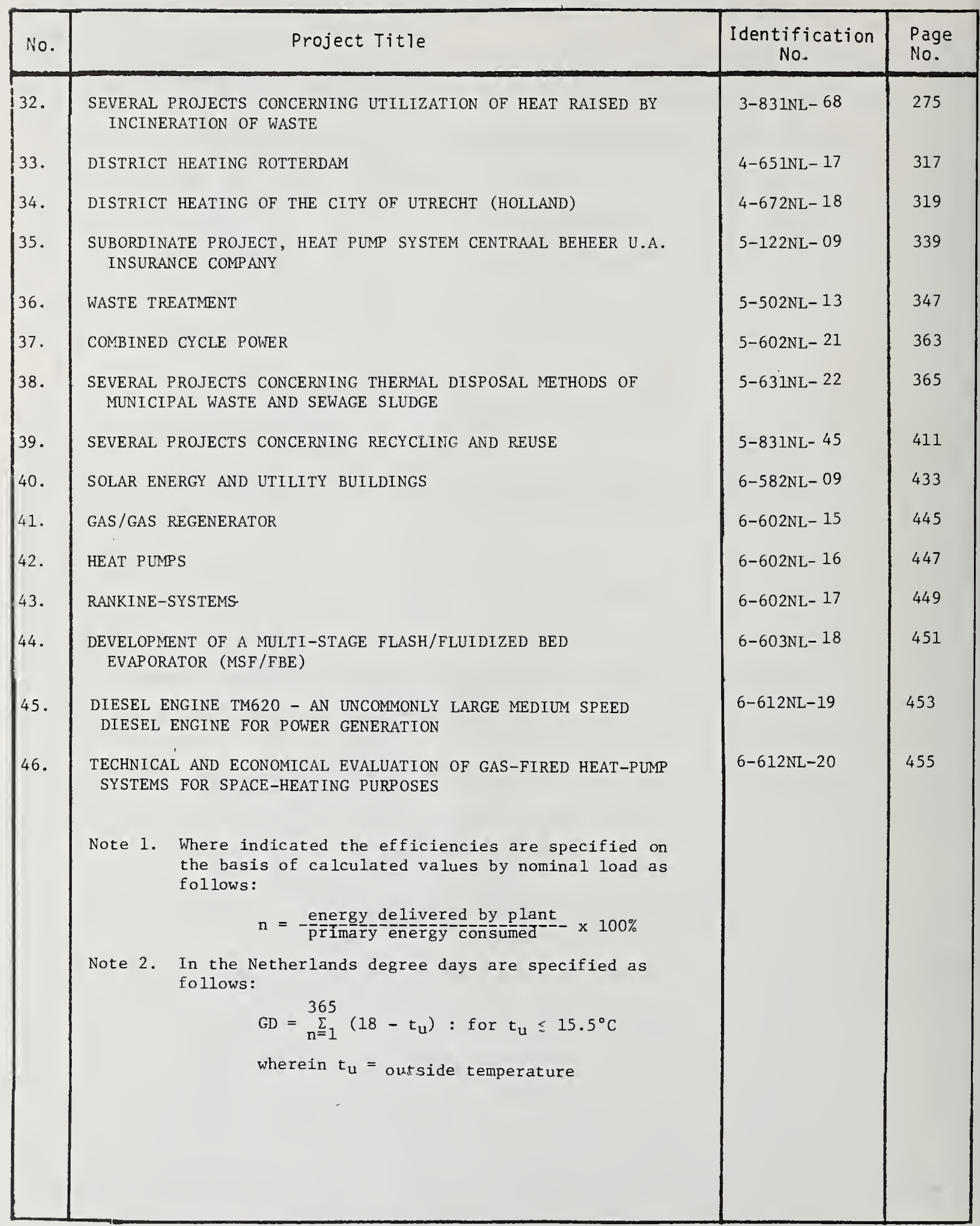


TABLE 2-10 Projects Reported from SWEDEN

\begin{tabular}{|c|c|c|c|}
\hline No. & Project Title & $\begin{array}{l}\text { Identification } \\
\text { No. }\end{array}$ & $\begin{array}{l}\text { Page } \\
\text { No. }\end{array}$ \\
\hline 1. & TOTAL ENERGY DIESEL PLANT & $2-111 \mathrm{SE}-06$ & 65 \\
\hline 2. & $\begin{array}{l}\text { MINI-NUCLEAR PLANTS FOR DOMESTIC HEATING AND HOT WATER } \\
\text { SUPPLY }\end{array}$ & 3-191SE-13 & 165 \\
\hline 3. & LOCAL ENERGY PLANTS FOR DOMESTIC FUELS & $3-601 S E-24$ & 187 \\
\hline 4. & DISTRICT HEATING SYSTEM ENKOPING & 4-101SE-01 & 285 \\
\hline 5. & VASTERAS DISTRICT HEATING POWER STATION (8OMW ELEC.) & $4-111 \mathrm{SE}-04$ & 291 \\
\hline 6. & THE VARTA POWER STATION & 4-111SE-05 & 293 \\
\hline 7. & VASTERAS DISTRICT HEATING POWER STATION ( $400 \& 500 M W$ ELEC.) & $4-114 \mathrm{SE}-08$ & 299 \\
\hline 8. & WASTE HEAT UTILIZATION IN FORSETRY & $5-501 S E-12$ & 345 \\
\hline
\end{tabular}

TABLE 2-11 Projects Reported from UNITED KINGDOM

\begin{tabular}{|c|c|c|c|}
\hline No. & Project Title & $\begin{array}{l}\text { Identification } \\
\text { No. }\end{array}$ & $\begin{array}{l}\text { Page } \\
\text { No. }\end{array}$ \\
\hline 1. & TOTAL ENERGY USAGE IN HOUSES IN THE BRETTON DISTRICT (887) & $2-101 G B-02$ & 57 \\
\hline 2. & MEDICAL AREA TOTAL ENERGY PLANT, INC & $2-311 \mathrm{~GB}-16$ & 85 \\
\hline 3. & LEEDS GENERAL INFIRMARY GENERATOR STATION COMPLEX & $3-471 G B-14$ & 167 \\
\hline 4. & ATHENS PAPER MILL-ATHENS & $3-512 \mathrm{~GB}-16$ & 171 \\
\hline 5. & WASTE HEAT RECOVERY SCHEME FROM SITE GENERATING PLANT & $3-512 \mathrm{~GB}-17$ & 173 \\
\hline 6. & PROCESS STEAM SUPPLIES TO BRITISH CELANESE CO., LTD. & $3-51.53 \mathrm{~GB}-19$ & 177 \\
\hline 7. & WASTEWATER TREATMENT & $3-61.41 G B-28$ & 195 \\
\hline 8. & DISTRICT HEATING FEASIBILITY STUDY (939) & $4-102 G B-02$ & 287 \\
\hline 9. & PERFORMANCE OF DISTRICT HEATING SCHEMES (907) & $4-602 G B-15$ & 313 \\
\hline 10. & $\begin{array}{l}\text { INCREASING LUNER CAPACITY BY MEANS OF DRAG REDUCING POLYMER } \\
(955)\end{array}$ & $5-102 \mathrm{~GB}-05$ & 331 \\
\hline 11. & ALTERNATIVE SOURCES OF ENERGY FOR BUILDINGS (922) & $5-102 G B-06$ & 333 \\
\hline 12. & $\begin{array}{l}\text { EFFECT OF LOAD AND FLOW VARIABILITY ON SEWAGE WORKS PERFORM- } \\
\text { ANCE ( } 975)\end{array}$ & $5-802 G B-38$ & 397 \\
\hline 13. & ENERGY CONSERVATION VIA THE CN HEAT GENERATOR (891) & $6-002 \mathrm{~GB}-01$ & 417 \\
\hline
\end{tabular}


TABLE 2-11 Projects Reported from UNITED KINGDOM

\begin{tabular}{|l|l|c|c|}
\hline Ho. & \multicolumn{1}{|c|}{ Project Title } & $\begin{array}{c}\text { Identification } \\
\text { No. }\end{array}$ & $\begin{array}{c}\text { Page } \\
\text { No. }\end{array}$ \\
\hline 14. & $\begin{array}{l}\text { TOTAL HEAT SYSTEMS - STIRLING ENGINE AND OTHER PRIME MOVERS } \\
\text { FOR USE AS HEAT PUMPS AND CIRCULATORS (925) }\end{array}$ & $6-002 \mathrm{~GB}-02$ & 419 \\
15. & UTILIZATION OF LOW GRADE HEAT ENERGY (936) & $6-002 \mathrm{~GB}-03$ & 421 \\
16. & HEAT PUMPS (885) & $6-101 \mathrm{~GB}-04$ & 423 \\
17. & $\begin{array}{l}\text { APPLICATIONS OF HEAT PUMPS, HEAT PIPES AND SIMILAR DEVICES } \\
\text { FOR HEAT RECOVERY AND ENERGY CONSERVATION (908) }\end{array}$ & $6-102 \mathrm{~GB}-06$ & 427 \\
\hline
\end{tabular}

TABLE 2-12 Projects Reported from UNITED STATES

\begin{tabular}{|c|c|c|c|}
\hline No. & Project Title & $\begin{array}{l}\text { Identification } \\
\text { No. }\end{array}$ & $\begin{array}{l}\text { Page } \\
\text { No. }\end{array}$ \\
\hline 1. & $\begin{array}{l}\text { MIST (MODULAR INTEGRATED UTILITY SYSTEM - INTEGRATION AND } \\
\text { SUBSYSTEM TEST) FACILITY }\end{array}$ & $1-011$ US-01 & 43 \\
\hline 2. & GRID-CONNECTED INTEGRATED COMMUNITY ENERGY SYSTEM (ICES) & 1-101US-02 & 45 \\
\hline 3. & MIUS DEMONSTRATION & $1-111 U S-03$ & 47 \\
\hline 4. & MIUS DEMONSTRATION EVALUATION & $1-111 U S-04$ & 49 \\
\hline 5. & INTEGRATED UTILITY SYSTEMS & $1-363 \mathrm{US}-05$ & 51 \\
\hline 6. & $\begin{array}{l}\text { MODULAR INTEGRATED UTILITIES SYSTEM - TOTAL ENERGY DATA } \\
\text { MEASUREMENT SYSTEM }\end{array}$ & 2-111US-07 & 67 \\
\hline 7. & TOTAL ENERGY PLANT & $2-312 U S-18$ & 89 \\
\hline 8. & $\begin{array}{l}\text { WILKES-BARRE AREA VOCATIONAL-TECHNICAL SCHOOL TOTAL ENERGY } \\
\text { PLANT }\end{array}$ & $2-321$ US -19 & 91 \\
\hline 9. & WILFORD HALL USAF MEDICAL CENTER & $2-411 U S-21$ & 95 \\
\hline 10. & SIOUX VALLEY HOSPITAL TOTAL ENERGY PLANT & $2-422 U S-25$ & 103 \\
\hline 11 & CENTRAL ENERGY PLANT - WALT DISNEY WORLD & $2-512 U S-27$ & 107 \\
\hline 12 . & LINDEN GENERATING STATION & $2-612 U S-38$ & 129 \\
\hline 13. & CONSTRUCT TOTAL ENERGY POWER PLANT (COMPLETED APRIL 1970) & $2-721$ US -39 & 131 \\
\hline 14. & NAVAL TRAINING CENTER GENERATING PLANT & $2-772 \mathrm{US}-40$ & 133 \\
\hline 15. & $\begin{array}{l}\text { ENVIRONMENTAL, ECONOMIC, AND CONSERVATION ASPECTS OF INTE- } \\
\text { GRATED ENERGY USE APPLICATIONS }\end{array}$ & 3-001US-01 & 141 \\
\hline 16. & $\begin{array}{l}\text { INTEGRATED COMMUNITY ENERGY SYSTEMS (ICES) SYSTEMS } \\
\text { ENGINEERING }\end{array}$ & $3-101$ US -05 & 149 \\
\hline 17. & DEVELOPMENT OF TESTING OF A VAPOR COMPRESSION SYSTEM & $3-103 \mathrm{US}-07$ & 153 \\
\hline
\end{tabular}


TABLE 2-12 Projects Reported from UNITED STATES

\begin{tabular}{|c|c|c|c|}
\hline No. & Project Title & $\begin{array}{l}\text { Identification } \\
\text { No. }\end{array}$ & $\begin{array}{l}\text { Page } \\
\text { No. }\end{array}$ \\
\hline 18. & ALASKA VILLAGE DEMONSTRATION PROJECT, WAINWRIGHT, ALASKA & $3-111$ US-08 & 155 \\
\hline 19. & ALASKA VILLAGE DEMONSTRATION PROJECT, EMMONAK FACILITY & 3-111US-09 & 157 \\
\hline 20. & $\begin{array}{l}\text { ALASKA VILLAGE DEMONSTRATION PROJECT, A THIRD FACILITY FOR } \\
\text { SMALL INTERIOR VILLAGE }\end{array}$ & $3-111$ US -10 & 159 \\
\hline 21. & CODISPOSAL \& COORDINATED MATERIALS RECOVERY & $3-133 \mathrm{US}-13$ & 165 \\
\hline 22. & CAT JOLIET PLANT "F" & 3-512US-19 & 177 \\
\hline 23. & $\begin{array}{l}\text { DEMONSTRATION OF COMBINED DISPOSAL OF SEWAGE SLUDGE AND } \\
\text { SOLID WASTE IN PUROX OXYGEN REFUSE CONVERTER }\end{array}$ & $3-601$ US -25 & 189 \\
\hline 24 . & ONONDAGA COUNTY RESOURCE RECOVERY PROJECT & $3-631$ US -29 & 197 \\
\hline 25. & N.W.5 8 STREET RESOURCE RECOVERY FACILITY & $3-631 U S-32$ & 203 \\
\hline 26. & $\begin{array}{l}\text { CITY OF BALTIMORE - SOLID WASTE DISPOSAL AND RESOURCE RE- } \\
\text { COVERY PLANT (PYROLYSIS PLANT) }\end{array}$ & $3-631$ US -33 & 205 \\
\hline 27. & HARRISBURG REFUSE INCINERATOR & $3-631$ Us -34 & 207 \\
\hline 28. & HARRISBURG INCINERATOR & $3-631$ US -35 & 209 \\
\hline 29. & MILWAUKEE RESOURCE RECOVERY FACILITY & $3-632 U S-36$ & 211 \\
\hline 30. & $\begin{array}{l}\text { NASHVILLE THERMAL TRANSFER CORPORATION, A MASS SOLID WASTE } \\
\text { FIRED CENTRAL HEATING AND COOLING FACILITY }\end{array}$ & $3-632$ US -37 & 213 \\
\hline 31. & $\begin{array}{l}\text { TOWN OF HEMPSTEAD SOLID WASTE MANAGEMENT \& RESOURCE RE- } \\
\text { COVERY FACILITY }\end{array}$ & $3-633$ US -38 & 215 \\
\hline 32. & MEMPHIS LIGHT, GAS \& WATER DIVISION; ENERGY RECOVERY SYSTEM & $3-633$ US -39 & 217 \\
\hline 33. & RESOURCE RECOVERY SYSTEM & $3-633$ US -40 & 219 \\
\hline 34 . & GREATER BRIDGEPORT RESOURCES RECOVERY STEAM & $3-633 \mathrm{US}-41$ & 221 \\
\hline 35. & MSD RESOURCE RECOVERY PROGRAM & $3-633 U S-42$ & 223 \\
\hline 36. & CO-INCINERATION OF SEWAGE FLUDGE WITH REFUSE AND/OR COAL & $3-661 U S-43$ & 225 \\
\hline 37. & $\begin{array}{l}\text { ENVIRONMENTAL EFFECT OF UTILIZING SOLID WASTE AS A SUPPLE- } \\
\text { MENTARY POWER-PLANT FUEL }\end{array}$ & $3-661$ Us -44 & 227 \\
\hline 38. & $\begin{array}{l}\text { ST. LOUIS WASTE CO-FIRING WITH COAL PROJECT: EQUIPMENT, } \\
\text { FACILITIES AND ENVIRONMENTAL EVALUATION OF MERAMAC POWER } \\
\text { PLANT }\end{array}$ & $3-661$ Us -45 & 229 \\
\hline 39. & HMDC RESOURCE RECOVERY FACILITY & $3-661$ US -46 & 231 \\
\hline 40. & EVALUATION OF AMES SOLID WASTE RESOURCES & $3-661 U S-47$ & 233 \\
\hline
\end{tabular}


TABLE 2-12 Projects Reported from UNITED STATES

\begin{tabular}{|c|c|c|c|}
\hline No. & Project Title & $\begin{array}{l}\text { Identification } \\
\text { No. }\end{array}$ & $\begin{array}{l}\text { Page } \\
\text { No. }\end{array}$ \\
\hline 41. & $\begin{array}{l}\text { CHICAGO SOUTHWEST SUPPLEMENTARY FUEL PROCESSING FACILITIES } \\
\text { AND COMMONWEALTH EDISON CRAWFORD POWER PLANT }\end{array}$ & $3-663 \mathrm{US}-48$ & 235 \\
\hline 42. & PRODUCTION OF POTABLE WATER FROM WASTEWATER & $3-801$ US -57 & 253 \\
\hline 43. & $\begin{array}{l}\text { EVALUATION OF FULL SCALE. WASTEWATER REFUSE SYSTEM FOR } \\
\text { DOMESTIC GROUNDWATER REPLEN ISHMENT }\end{array}$ & $3-803$ US -58 & 255 \\
\hline 44. & WASTE-AS-FUELS PROGRAM & $3-831$ US -66 & 271 \\
\hline 45. & $\begin{array}{l}\text { PLANT-SCALE STUDY OF COMBINED INCINERATION OF SEWAGE SLUDGE } \\
\text { WITH COAL \& SOLID WASTE }\end{array}$ & $3-831$ US -67 & 273 \\
\hline 46. & $\begin{array}{l}\text { ROTARY KILN GASIFICATION OF SEWAGE SLUDGE SOLID WASTE } \\
\text { MIXTURE }\end{array}$ & 3-832US-70 & 279 \\
\hline 47. & $\begin{array}{l}\text { FEASIBILITY OF COMBINED INCINERATION OF SEWAGE SLUDGE WITH } \\
\text { SOLID WASTES }\end{array}$ & $3-832 \mathrm{US}-71$ & 281 \\
\hline 48. & STUDY ON DISTRICT HEATING FOR RETROFIT OF POWER PLANTS & $4-601$ US -14 & 311 \\
\hline 49. & EXTRACTION OF HEAT FROM RIVER BY HEAT, PUMP - ESSLINGEN & 5-101US-02 & 325 \\
\hline 50. & A SNOW MELTER FOR A DOMESTIC WATER SUPPLY & $5-112 \mathrm{US}-08$ & 337 \\
\hline 51. & $\begin{array}{l}\text { TECHNICAL ASSESSMENT OF AIR POILUTION CONTROL FOR SO } \mathrm{S}_{\mathrm{X}} \text {, NO} \mathrm{N}_{\mathrm{X}} \text {, } \\
\text { AND OTHER AIR EMISSIONS AT THE BALTIMORE DEMONSTRATION GAS } \\
\text { PYROLYSIS FACILITY }\end{array}$ & $5-131$ US -10 & 341 \\
\hline 52. & $\begin{array}{l}\text { STEAM EXPORT SYSTEM AT THE CHICAGO NORTHWEST SOLID WASTE DIS- } \\
\text { POSAL }\end{array}$ & $5-531$ US -14 & 349 \\
\hline 53. & FIRING DENSIFIED REFUSE DERIVED FUEL IN A STOKER BOILER & $5-533 U S-15$ & 351 \\
\hline 54. & $\begin{array}{l}\text { PREPARATION OF DENSIFIED REFUSE DERIVED FUEL FOR STOKER } \\
\text { BOILERS }\end{array}$ & $5-533$ US -16 & 353 \\
\hline 55. & HARRISBURG ADVANCED WASTEWATER TREATMENT FACILITY & $5-601 U S-20$ & 361 \\
\hline 56. & RECYCLE ENERGY SYSTEM & $5-631 \mathrm{US}-23$ & 367 \\
\hline 57. & $\begin{array}{l}\text { TECHNICAL AND ECONOMIC EVALUATION OF THE EPA RESOURCE } \\
\text { RECOVERY DEMONSTRATION FACILITY IN SAN DIEGO, CALIFORNIA }\end{array}$ & $\begin{array}{c}5-631 \mathrm{US}-24 \\
-\end{array}$ & 369 \\
\hline 58. & ENVIRONMENTAL ASSESSMENT OF WASTE-TO-ENERGY & $5-631$ US -25 & 371 \\
\hline 59. & $\begin{array}{l}\text { AIR POLLUTION CONTROL TECHNOLOGY DEVELOPMENT FOR WASTE-AS- } \\
\text { FUEL PROCESSES }\end{array}$ & $5-631$ US -26 & 373 \\
\hline 60. & CONVERSION OF SOLID WASTE TO POLYMER GASOLINE & $5-631$ US -27 & 375 \\
\hline 61. & PILOT SCALE PYROLYTIC CONVERSION OF MIXED WASTE TO FUEL & $5-631$ US -28 & 377 \\
\hline
\end{tabular}


TABLE 2-12 Projects Reported from UNITED STATES

\begin{tabular}{|c|c|c|c|}
\hline No. & Project Title & $\begin{array}{l}\text { ldentification } \\
\text { No. }\end{array}$ & $\begin{array}{l}\text { Page } \\
\text { No. }\end{array}$ \\
\hline 62. & PUROX SYSTEM & $5-633$ US -29 & 379 \\
\hline 63. & $\begin{array}{l}\text { CITY OF FRANKLIN SOLID WASTE DISPOSAL AND RESOURCE RECOVERY } \\
\text { FACILITY }\end{array}$ & $5-633$ US -30 & 381 \\
\hline 64. & PALMER SOLID WASTE RESOURCE RECOVERY PROJECT & $5-661$ US -31 & 383 \\
\hline 65. & $\begin{array}{l}\text { EVALUATION OF AMES' WASTE PROCESS - AN ENERGY RECOVERY } \\
\text { SYSTEM }\end{array}$ & $5-661$ US -32 & 385 \\
\hline 66 . & $\begin{array}{l}\text { PREPARATION, USE AND COST OF } d-R D F \text { AS A SUPPLEMENTARY FUEL } \\
\text { IN STOKER FIRED BOILERS }\end{array}$ & $5-661$ US -33 & 387 \\
\hline 67 . & $\begin{array}{l}\text { EFFECTS OF BURNING DENSIFIED FORMS OF MUNICIPAL SOLID WASTES } \\
\text { DERIVED FUELS IN INDUSTRIAL, UTILITY AND INSTITUTIONAL } \\
\text { STOKER-FIRED BOILERS }\end{array}$ & $5-661$ US -34 & 389 \\
\hline 68. & WOOD WASTE AS A POWER PLANT FUEL IN THE OZARKS & $5-661 U S-35$ & 391 \\
\hline 69. & SALVAGE FUEL BOILER PLANT & $5-731$ US-36 & 393 \\
\hline 70 . & $\begin{array}{l}\text { INSTRUMENTATION OF SEWAGE SLUDGE PROCESSING OPERATIONS IN- } \\
\text { CLUDING ANAEROBIC DIGESTION \& VACUUM FILTRATION }\end{array}$ & $5-801 \mathrm{US}-37$ & 395 \\
\hline 71. & $\begin{array}{l}\text { INVESTIGATE HEAT TREATMENT OF SLUDGE \& PROCESSING OF } \\
\text { SUPERNATANT TO REDUCE BOD \& COD }\end{array}$ & $5-802 U S-39$ & 399 \\
\hline 72. & $\begin{array}{l}\text { CONCEPTUAL DESIGN \& COST ESTIMATION FOR HEATING AN ANAERO- } \\
\text { BIC DIGESTER BY SOLAR ENERGY }\end{array}$ & $5-831$ US -42 & 405 \\
\hline 73. & $\begin{array}{l}\text { EVALUATE COST OF HEAT TREATMENT OF SLUDGE INCLUDING COST OF } \\
\text { TREATING SIDE STREAMS }\end{array}$ & $5-831$ US -43 & 407 \\
\hline 74 . & EVALUATION OF WASTE-TO-ENERGY PROCESSES & $5-831$ US -44 & 409 \\
\hline 75. & SOLAR HEAT SYSTEM FOR INDOOR SWIMMING FACILITY & $6-101$ US -05 & 425 \\
\hline 76. & $\begin{array}{l}\text { COAL FUELED, FLUIDIZED-BED GAS TURBINE UNIT FOR MIUS } \\
\text { APPLICATIONS }\end{array}$ & $6-151$ US -07 & 429 \\
\hline 77. & RESOURCE RECOVERY - MONTGOMERY COUNTY, OHIO & $6-532$ US -08 & 431 \\
\hline 78. & HARRISBURG STEAM MAIN & $6-631$ US -21 & 457 \\
\hline 79. & $\begin{array}{l}\text { STUDY OF MODIFICATIONS REQUIRED TO CONVERT A MULTIPLE HEARTH } \\
\text { INCINERATOR TO PYROLYTIC OPERATION }\end{array}$ & $6-833$ US -26 & 467 \\
\hline 80 . & OPTIMIZATION OF ACTIVATION OF SOLID WASTES & 6-833US- 27 & 469 \\
\hline
\end{tabular}



PART III PROJECT DESCRIPTIONS

\begin{tabular}{|c|c|}
\hline $\begin{array}{l}\text { NBS-1075 } \\
(2-77)\end{array}$ & $\begin{array}{l}\text { U.S. DEPARTMENT OF COMMERCE } \\
\text { NATIONAL BUREAU OF STANDARDS }\end{array}$ \\
\hline
\end{tabular}

PROJECT SUMMARY FORM

1. Title of Project (Official Title)

MIST (Modular Integrated Utility System) (Integration and Subsystem Test) Facility

3. Performing Organization (Complete Mailing Address)

National Aeronautics and Space Administration

Lyndon B. Johnson Space Center

Houston, Texas 77058 U.S.A.

ATTN : Code EZ

Willie S. Beckhman tion identification No

(Secretarıa Use Only)

$$
\text { 1-011US-01 }
$$

2 Date (Form Completed)

\section{$11 / 10 / 76$}

4 Principal Investigator (Name and Complete Mailing Address)

National Aeronautics and Space Administra-

Lyndon B. Johnson Space Center

Houston, Texas 77058 U.S.A.

ATTN: Code EZ

5. Supporting Organization (Complete Mailing Address and Name of 6 . Duration of Investıgation (Beginning and ending/ Contact)

J.H.Rothenberg, Program Manager

HUD/MIUS Program

Dept. of Housing and urban Development

Office of Policy Development and Research

4517 th St. S.W., Rm. 8158

Washington, D.C. 20410 U.S.A.

8. Purpose of Project (Objectives, Motivations, Approach, Plans and Expected Results)

$$
5 / 74 \text { to present }
$$

7. Estimated Funding and Manpower (Monies and Manyears)

$$
\$ 1,150,000
$$

To provide a test facility which will be capable of:

a. Evaluation of various MIUS subsystems and system design issues.

b. Providing data for verification of software used in analysis and design.

c. Providing a test bed for development and evaluation of future subsystem concepts.

\section{Status and Results}

1. ASME Publication 74-ENAS-44 - The MIST Laboratory: A Testbed for the MIUS Program.

2. Results reported in JSC NASA TMX 58187 (pub1ished Jecember 1976).

This project is: $\square$ planned $\square$ in-progress $\square$ completed

Use Box No. 16 if additional space is needed

10. Utility Services

electrical power

space heating

wastewater treatment

space cooling

solid waste processing

potable water

Use Box No 15 if additional space is needed

8 potable hot water

12. Exchange of data 


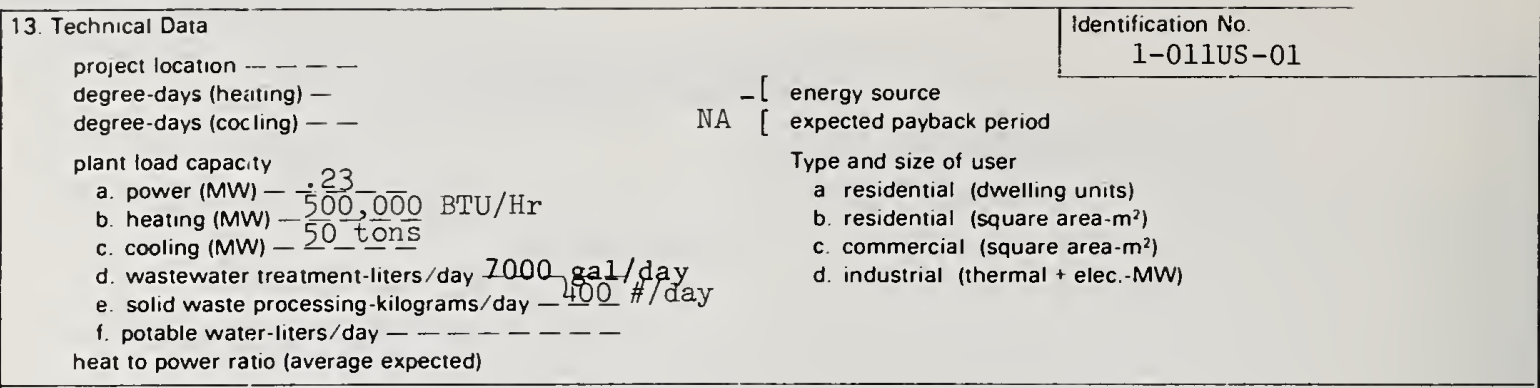

14. Other Related Projects (Tit/es)

HUD/MIUS Demonstration Project

(1-111US-03)

15. Additional space for Purpose of Project 


\begin{tabular}{|c|c|c|}
\hline \multicolumn{2}{|c|}{$\begin{array}{l}\text { NBS-1075 } \\
(2.77) \\
\text { PROJECT SUMMARTMRY FORM OF COMMERCE } \\
\text { NATIONAI. BUREAU OF STANDARDS }\end{array}$} & $\begin{array}{l}\text { Identification No. } \\
\text { (Secretariat Use Only) }\end{array}$ \\
\hline \multicolumn{2}{|c|}{$\begin{array}{l}\text { 1. Title of Project (Officral Title) } \\
\text { Grid-Connected Integrated Community Energy Systems (GC-ICES) }\end{array}$} & $\begin{array}{r}\text { 2. Date (Form Completed) } \\
\text { November, } 1977\end{array}$ \\
\hline $\begin{array}{l}\text { 3. Performing Organization (Complete Mailing Address) } \\
\text { Engineering Division } \\
\text { Argonne National Laboratory } \\
9700 \text { S. Cass Avenue } \\
\text { Argonne, Illinois } 60439 \\
\text { U.S.A. }\end{array}$ & \multicolumn{2}{|c|}{$\begin{array}{l}4 \text { Principal Investigator (Name and Complete Mailing Address) } \\
\text { J. Pascual } \\
\text { Engineering Division } \\
\text { Argonne National Laboratory } \\
9700 \text { S. Cass Avenue } \\
\text { Argonne, Illinois } 60439 \\
\text { U.S.A. }\end{array}$} \\
\hline $\begin{array}{l}\text { 5. Supporting Organization /Complete Mailing Address and Name of } \\
\text { Contact) } \\
\text { John Rodousakis } \\
\text { Community Systems Branch } \\
\text { U.S. Department of Energy } \\
\text { Washington, D.C. } 20545 \\
\text { U.S.A. }\end{array}$ & $\begin{array}{l}\text { 6. Duration of Investigatic } \\
\text { Jan. -May, } 1976 \\
\text { May 1976-May } 198 \\
\text { 7. Estimated Funding and } \\
\text { Approx. \$5 milli }\end{array}$ & $\begin{array}{l}\text { on (Beginning and ending) } \\
\text { Phase I } \\
81 \text { Other Phases } \\
\text { Manpower (Monies and Manyears) } \\
\text { ion }\end{array}$ \\
\hline \multicolumn{3}{|c|}{$\begin{array}{l}\text { 8. Purpose of Project (Dbjectives, Motivations, Approach, Plans and Expected Results) } \\
\text { Objectives: } \\
\text { to design, construct, and operate a G-C ICES in a manner that is: } \\
\text { (a) conserving of energy and scarce fuels, (b) economically viable, } \\
\text { and (c) feasible from an institutional prospective. } \\
\text { Motivations: to enhance the rate of commercialization } \\
\text { to develop a system, based on available technologies, which operates } \\
\text { continuously at the highest possible en rgy efficiency by relying on } \\
\text { the local grid to act as an electrical "fly wheel", and to build a } \\
\text { demonstration project and monitor the results. } \\
\text { to enter various phases of the demonstration project, detailed feasibility } \\
\text { analysis, preliminary design, construction and operation with reasonable } \\
\text { assurance of attaining an economically viable, energy conserving system. } \\
\text { Expected Results: Utilization of the optimum of the energy produced by an ICES system } \\
\text { based on community demand. }\end{array}$} \\
\hline \multicolumn{3}{|r|}{ Use Box No. 15 if additional space is $r$} \\
\hline \multirow{2}{*}{\multicolumn{3}{|c|}{$\begin{array}{l}\text { 9. Status and Results } \\
\text { Phase I completed. } \\
\text { Phase II contracts awarded and in progress }\end{array}$}} \\
\hline & & \\
\hline \multicolumn{2}{|l|}{ This project is: $\square$ planned $[$ in-progress $\square$ completed } & This project is: $\square$ planned $[$ in-progress $\square$ completed \\
\hline \multicolumn{3}{|l|}{ 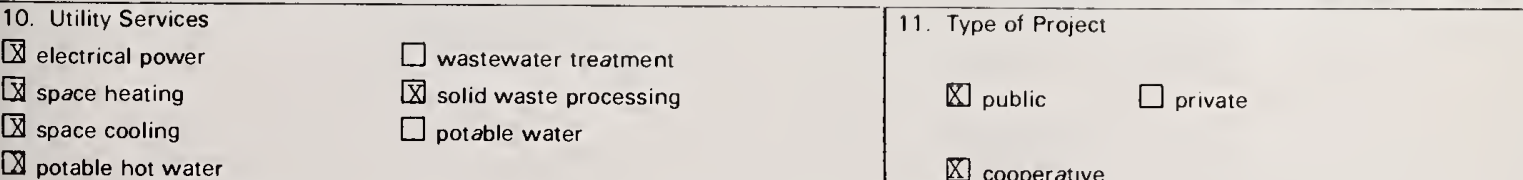 } \\
\hline 12. Exchange of data & & \\
\hline
\end{tabular}


13. Technical Data

project location ......-

degree-days (heaıtıng) -

degree-days (cocling\} - -

plant load capacity

a. power $(\mathrm{MW})-\ldots$

b. heating $(M W) \ldots \ldots$

c. cooling $(\mathrm{MW})-$

d. wastewater treatment-liters/day $-\ldots-\ldots$

e. solid waste processing-kilogramis/day - - -

f. potable water-liters/day $-\ldots-\ldots-\ldots$ heat to power ratio (average expected)

14. Other Related Projects (Tilles)

Grid-Connected Integrated Community Energy Systems (ICES) Systems Engineering (3-101US-05)

15. Additional space for Purpose of Project
Identification No

1-I01US-02

energy source

expected payback period

Type and size of user

a. residential (dwelling units)

b residential (square area $-\mathrm{m}^{2}$ )

c commercial (square area- $\mathrm{m}^{2}$ )

d industrial (thermal + elec - MW)

16 Additional space for Status and Results 


\section{PROJECT SUMMARY FORM}

1 Title of Project (Official Tit/e)

\section{IIIUS Demonstration}

\section{Performing Organization (Complete Malling Address)}

Interstate Land Development Corporation 336 Post office Road

St. Charles, Maryland 20601

U.S.A.

\section{Supporting Organization /Complete Mailing Address and Name of Contact)}

Jerome H. Rothenberg, Director, HUD-iiIUS Prp

Division of Energy Bldg. Technology and

Standards

Office of Policy Development and Research 4517 th St., S.W., Room 8158

8. Purpose of Project iobjectives. Motivations. Approach, Plans and Expected Results)

The purpose of the iIUS Demonstration, Phase II of the HUD-MIUS Program is to actualize the MIUS concept by constructing, instrumenting and evaluating a MIUS in a residential community. The demonstration will serve as a means to evaluate the actual technical performance of an integrated system serving a line load. The evaluation will result in the collection of data that will assist investors, developers, utilities, etc. in appraising the concept. In addition to evaluating the technical performance and economics of the MIUS concept, the demonstration will also provide a means to evaluate its environmental impact and assess the institutional factors that may become barriers to future MIUS's.

The MIUS 1s a system that brings together several subsystems into a master system that serves the utility needs of a community and performs the combined functions as well as or better than a conventional system with the potential for lower cost to the consumet.

The MIUS recovers more than half of the waste heat from power generation and recycles it to help provide space heating/covling, water heating, and wastewater treatment Another 5-10 percent fuel savings is possible by recycling solid waste for its energy content.

Use Box No. 15 if additional space is needed

9. Status and Results

A grant for the MIUS design was awarded in April 1976 to Interstate Land Development Inc. (ILD). The MIUS demonstration will be constructed in a New Community near Washington, D.C. starting in 1977. It w111 provide utilities for 700 dwelling units 18,580 square meters for commercial shopping space and other space as we11 as a 8360 square meter school. Gamze, Korobkin and Caloger will design the MIUS. NBS will evaluate the design, instrument the system, collect data, evaluate system performance, and identify and evaluate institutional barriers.

This project is: $\square$ planned $\square$ in-progress $\square$ completed

$\begin{array}{ll}\text { 10. Utility Services } & \\ \text { a electrical power } & \\ \square \text { space heatırig } & \square \text { potablewater water } \\ \text { s space cooling } & \\ \square \text { potable hot water } & \end{array}$

Use Box No. 16 if additional space is needed

12. Exchange of data 


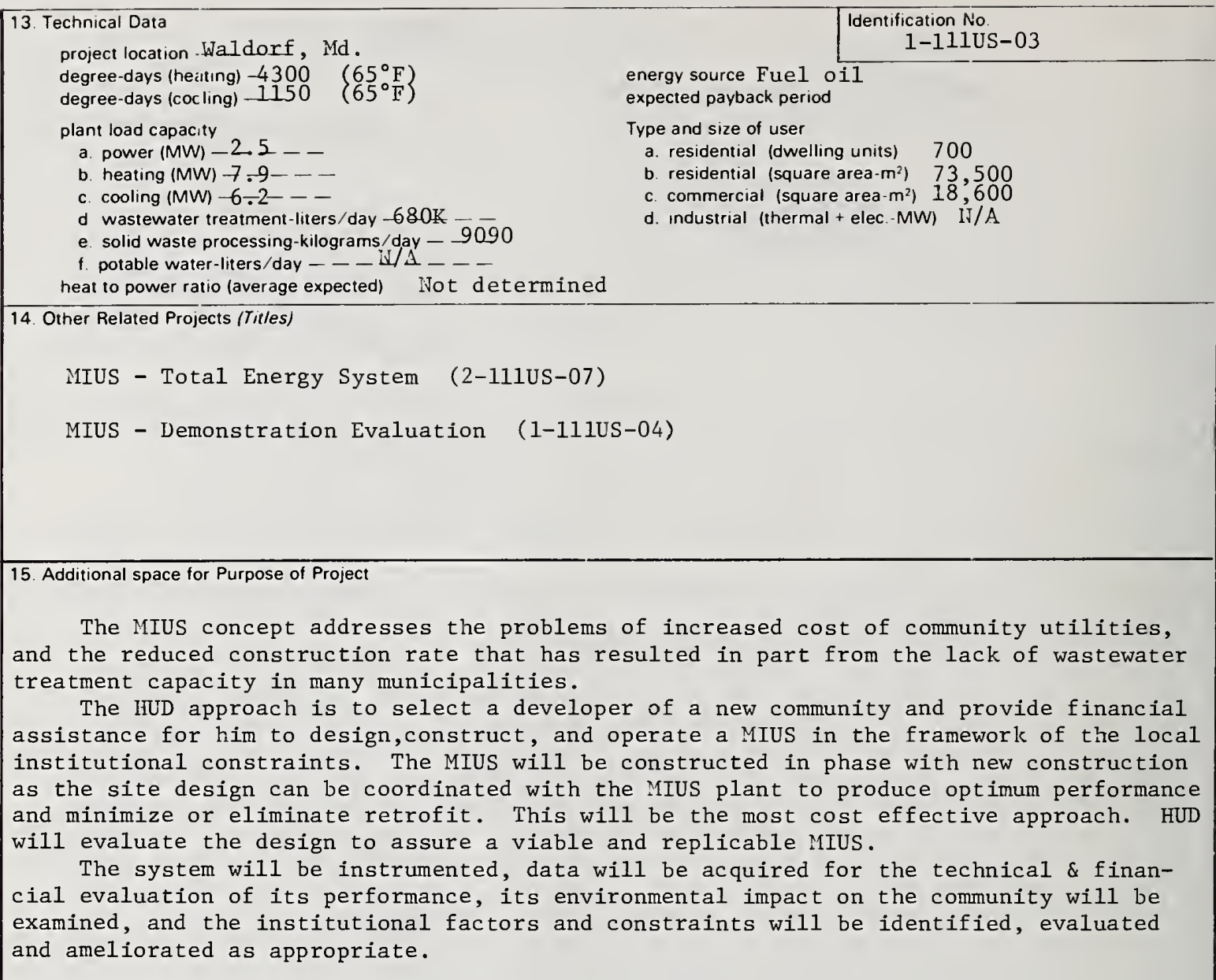

16. Additional space for Status and Results

The demonstration is in the preliminary design phase with various system configurations now under investigation for economic viability. The design concept under consideration is a grid connected site where power production is independent of site electrical demand, but exceeds internal plant demand and the demand of the commercial space. Excess power is sold to the local electric utility at wholesale rates which must be comparable to alternative utility options. Inergy purchased by the MIUS from the local electric utility would be billed by the local electric utility at cost plus $0.1 c / \mathrm{KWH}$.

Note: Sufficient funds are not available at the date of this publication to initiate construction of the MIUS. Preparation of a final report on the design has been completed by the developer. 


\section{PROJECT SUMMARY FORM}

$$
\text { 1-111US-04 }
$$

1. Title of Project (Official Title)

2 Date (Form Completed)

\section{MIUS Demonstration Evaluation}

Sep tember 30, 1977

\section{Performing Organization (Complete Mailing Address)}

Office of Housing and Building Technology Center for Building Technology

National Bureau of Standards

Department of Commerce

Washington, D.C. 20234

U.S.A.
5. Supporting Organization /Complete Mailing Address and Name of Contact) Dept. of Housing and Urban Development

Division of Energy Building Technology and Standards

Office of Policy Development and Research

4517 th St. S.W., Room 8158

Washington, D.C. 20410 U.S.A.

Jerome H. Rothenberg, Director, HUD-MIUS Prokram

8. Purpose of Project (Objectives, Motivations. Approach. Plans and Expected Results)

This demonstration is intended to actualize the Modular Integrated Utility System (MIUS) concept and to obtain sufficient data to permit investors to appraise the cost effectiveness and risks of the concept. The key objectives are: 1) collection and analysis of data on the financial performance of the MIUS; 2) a chronicle and evaluation of institutional impediments to implementation of the MIUS; 3 ) collection and analysis of data on the technical performance of the MIUS compared to available alternatives; 4) analysis of site utility demand characteristics; and 5) an analysis of the environmental effects of MIUS discharges.

The MIUS concept addresses the increased cost of community utilities. The increased cost and unavailability of utilities are in part responsible for halving the percentage of middle-income families who own their own homes. The MIUS concept of integrating the facilities for providing electricity, space heating, space cooling, domestic water heat-i ing, solid waste processing, and wastewater treatment has a potential to reduce the life-cycle of these utilities while reducing fuel energy consumption by up to $50 \%$. For this latter reason, MIUS has a potential for inclusion in the national energy conservatiфn program.

9. Status and Results

NBS worked with HUD to define the nature of the demonstration, its objectives, and the statement of work under which the site developer would operate. NBS prepared a specification defining the performance levels expected of the MIUS. Review of the developer's design concept was initiated following award of the HuD contract in April 1976. NBS has monitored the developer's interaction with regulatory authorities and has prepared a format for the collection of cost data. The MIUS design concept has been prepared and the initial buildings to be served have been identified. Preliminary design definition of equipment has been completed and reviewed by NBS. A financial This project is: $\square$ planned $\mathbb{X}$ in-progress $\square$ completed

10. Utility Services

国 electrical power

space heating

i space cooling

: potable hot water

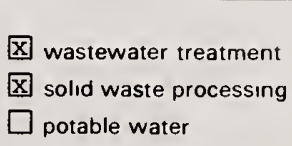

Use Box No. 16 if additional space is needed

12. Exchange of data

Will data be available from this project that will be shared with others?

Ex Yes No 


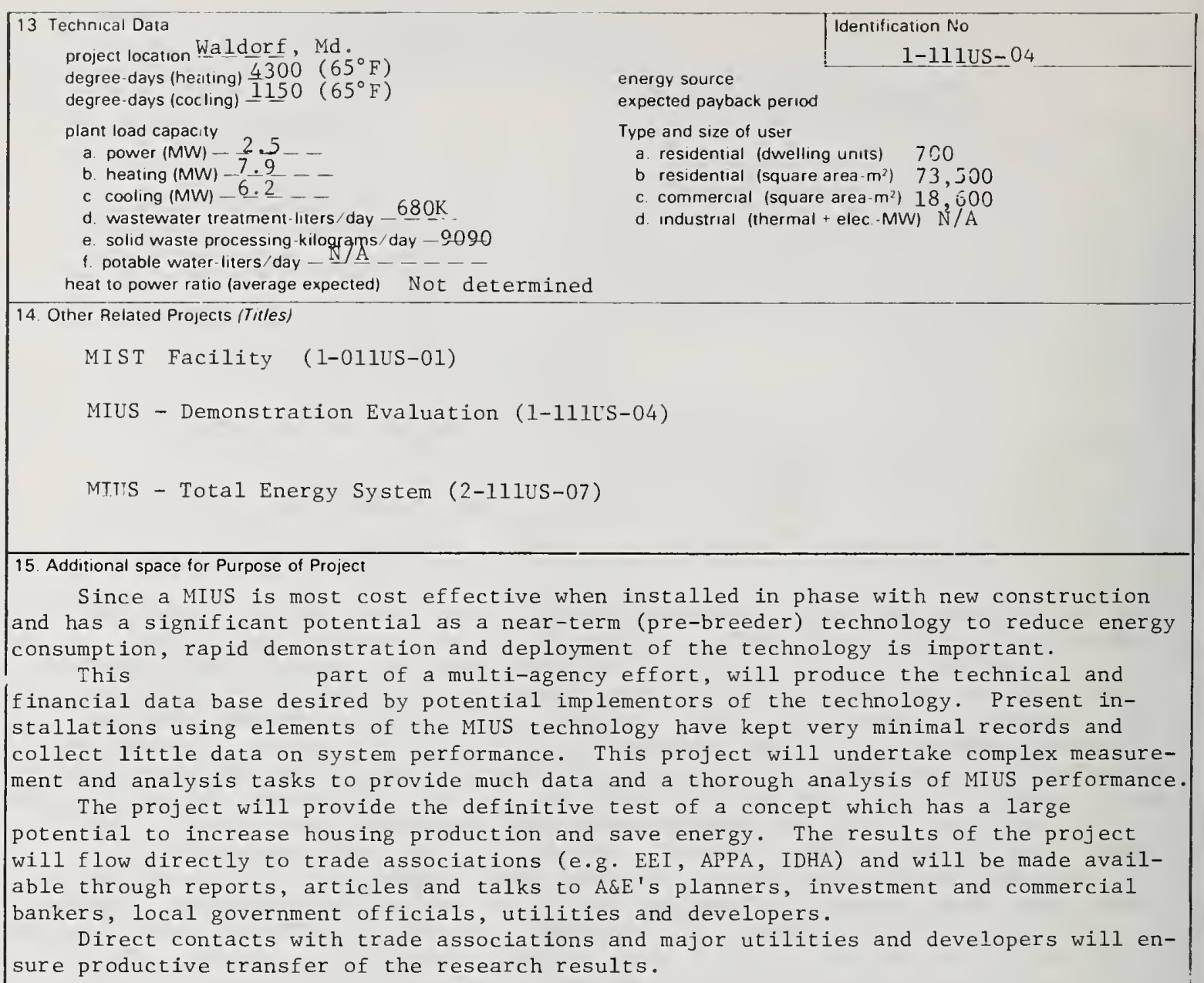

EEI - Edison Electric Institute

APPA - American Public Power Association

IDHA - International District Heating Association

16. Additional space for Status and Results

feasibility analysis has been prepared. Preliminary discussions have been held with most regulatory authorities. Many buildings on the site are completed and are entering the construction phase. Financing and/or tenants are being sought for the remaining buildings. Sufficient funds are not presently available to initiate construction of the MIUS. Preparation of a final report by the developer is now in progress.

Two papers which discuss the MIUS Demonstration have been published:

Rothenberg, Jerome H., The Modular Integrated Utility Systems (MIUS) Program, Proceedings of the XI IECEC Conference, September 1976.

Schaefgen, John R., Integrating Community Utilities for Resource Conservation, Proceedings of the Third National Conference on Complete Water Reuse, June 1976. 


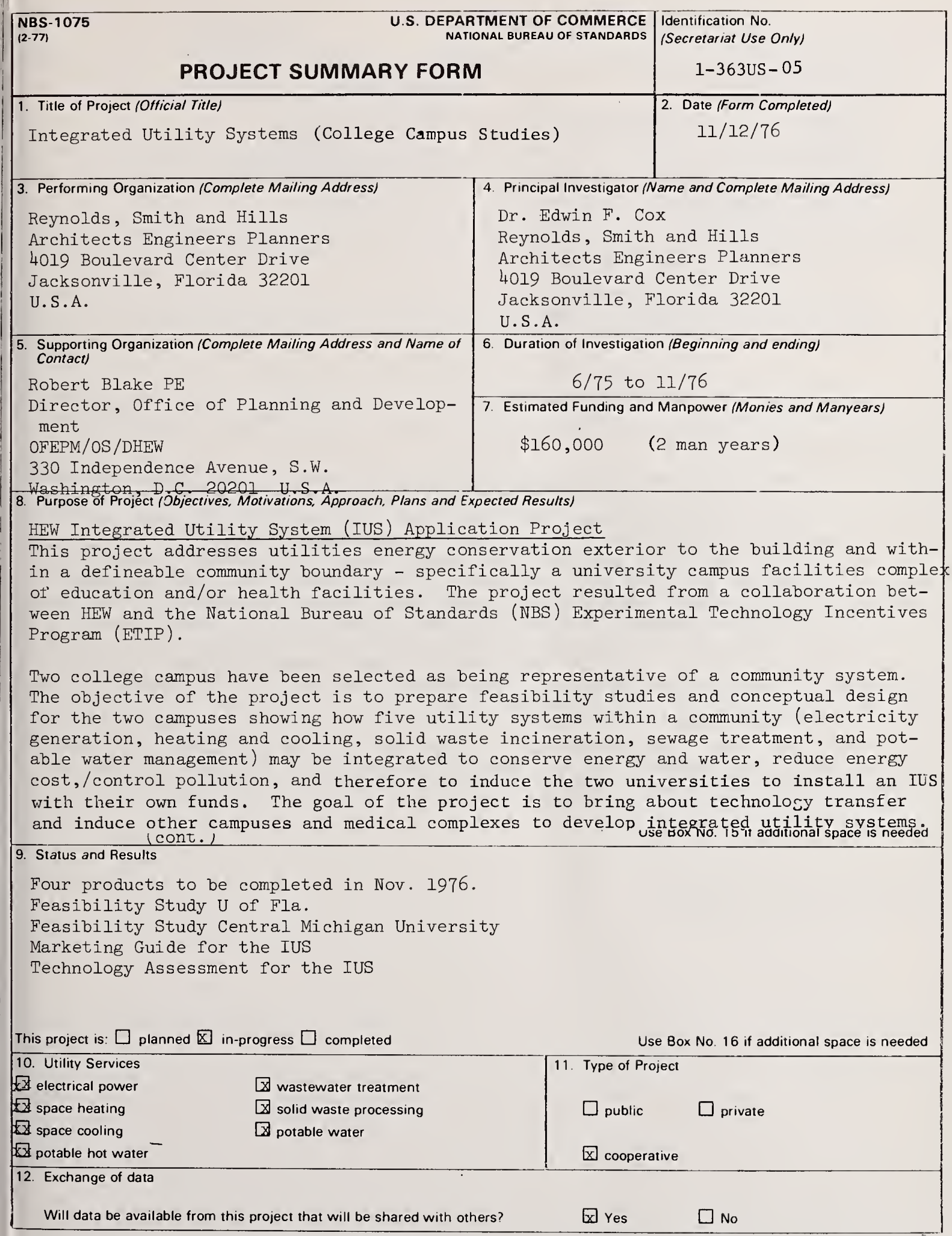




\section{Technical Data}

project location -. - - -

degree-days (heating) -

degree-days (cocling) - -

plant load capacity

a. power $(\mathrm{MW})----$

b. heating $(\mathrm{MW})-\ldots$

c. cooling (MW) ----

d. wastewater treatment-liters/day - - - -

e. solid waste processing-kilograms/day - - -

f. potable water-liters/day $-\ldots-\ldots---$ heat to power ratıo (average expected) 8 to $10,000 \mathrm{Btu} / \mathrm{KWH}$

14 Other Related Projects (Titles)

HUD-MIUS - Jerome H. Rothenberg

ERLA-ICES - Steve Cavros

HEW-Campus Community IUS - Max Novinsky

\section{Identification No \\ 1-363US -05 \\ energy source - coal, OIl, wood chips,solid waste expected payback period 5 years}

Type and size of user

a. residential (dwelling units)

b. residential (square area $-\mathrm{m}^{2}$ )

c. commercial (square area- $\mathrm{m}^{2}$ )

d. Industrial (thermal +elec-MW) Environment

\section{Additional space for Purpose of Project}

Phase one of the project was completed in 1976. Reports entitled "Integrated Utility System (IUS) - Feasibility and Conceptual Design" have been delivered to the University of Florida at Gainesville and Central Michigan University and Mount Pleasant. The reports recommended ( 1 ) installation of on site electric power generating capacity (2) utilization of the accessory heat for heating, air conditioning, and hot water service, (3) incineration of university and town solid waste, and (4), use of liquid effluent for plant process water and irrigation. The economic indicators, in the case of the University of Flordia are $44 \%$ annual energy cost savings as compared to the present costs projected to 1981, the year of IUS start up. The IUS investment cost is estimated at $\$ 19.5$ million. The interest rate of return on the investment is $23 \%$ per year, the discounted total savings to investment ratio is 3.4 , and the payback time is less than 5 years.

Phase two of the project is the design and installation of the two IUS plants. Both Universities have accepted the report recommendations and plan to secure investment capital and initiate design in 1977 and complete construction in 1981. 


\begin{tabular}{|c|c|c|c|}
\hline \multicolumn{3}{|c|}{$\begin{array}{l}\text { NBS-1075 } \\
(2 \cdot 77)\end{array}$} & $\begin{array}{l}\text { Identification No } \\
\text { (Secretariat Use On/y) } \\
2-021 \mathrm{NL}-01 \\
\text { 2. Date (Form Completed) } \\
3-15-77\end{array}$ \\
\hline & $\begin{array}{l}\text { Purpose of Project } \text { Dbjectives. Motivations. Approach, Plans and } \\
\text { Evaluation of energy systems based on } \\
\text { tions and heat pumps for space-heating ap } \\
\text { the applicability of each of the energy-s } \\
\text { creates an electricity demand which impro } \\
\text { TE-installation. The TE-installation pro } \\
\text { heat pump economics. A preliminary study } \\
\text { of various system configurations with spe } \\
\text { centralized and decentralized TE-installa } \\
\text { Continuation of the project features } \\
\text { procedure and to initiation of experiment } \\
\text { previous evaluation. } \\
\text { Present work is carried out in cooper } \\
\text { envisaged with national gas and electrici }\end{array}$ & $\begin{array}{l}\text { pected Results) } \\
\text { the combination o } \\
\text { lications. The c } \\
\text { ving component sy } \\
\text { es the energy-uti } \\
\text { luces cheap electr } \\
\text { is aimed at evalu } \\
\text { ial reference to } \\
\text { ions. } \\
\text { he development of } \\
\text { I work as indicat } \\
\text { tion with CTI-TNO } \\
\text { y companies, tech }\end{array}$ & $\begin{array}{l}\text { f total energy (TE) installa } \\
\text { ombined system improves } \\
\text { stems. The heat pump } \\
\text { lization efficiency of the } \\
\text { icity which improves the } \\
\text { ating the applicability } \\
\text { the comparison between } \\
\text { a system-optimalization } \\
\text { ed by the results of the } \\
\text { Future cooperation is } \\
\text { nical universities and }\end{array}$ \\
\hline
\end{tabular}

Use Box No. 15 if additional space is needed

9. Status and Results

\begin{tabular}{|c|c|c|c|}
\hline This project is: $\square$ planned $\square$ in-progress $\square$ completed & Use Bo & No. 16 if ad & itional space is needed \\
\hline 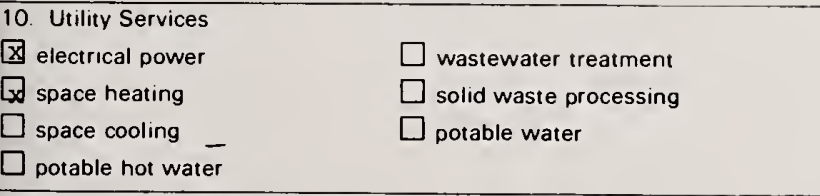 & $\begin{array}{l}\text { 11. Type of Project } \\
\square \text { public } \\
\square \text { cooperative }\end{array}$ & $\square$ private & \\
\hline $\begin{array}{l}\text { 12. Exchange of data } \\
\text { Will data be available from this project that will be shared with others? }\end{array}$ & $\square$ Yes & $\square$ No & Unknown \\
\hline
\end{tabular}


13. Technical Data

project location - - - -

degree-days (heatıng) -

degree-days (cocling) - -

plant load capacity

a. power (MW) ----

b. heating (MW) - $-\ldots$

c. cooling (MW) $---\ldots$

d. wastewater treatment-liters/day - - - -

e. solid waste processing-kilograms/day - - -

f. potable water-liters/day ------heat to power ratio (average expected)

14. Other Related Projects (Tit/es) dentification No

2-021NL-01

energy source

expected payback period

Type and size of user

a. residential (dwelting unıts)

b. residential (square area- $m^{2}$ )

c. commercial (square area- $\mathrm{m}^{2}$ )

d. industrial (thermal + elec.-MW)

15. Additional space for Purpose of Project

16. Additional space for Status and Results 


\begin{tabular}{|c|c|c|}
\hline $\begin{array}{r}\text { U.S. DEPA } \\
\text { PROJECT SUMMARY FORI }\end{array}$ & $\begin{array}{l}\text { TMENT OF COMMERCE } \\
\text { ONAL BUREAU OF STANDARDS } \\
\mathbf{1}\end{array}$ & $\begin{array}{l}\text { Identification No. } \\
\text { (Secretariat Use Only) } \\
2-101 \mathrm{~GB}-02\end{array}$ \\
\hline $\begin{array}{l}\text { 1. Title of Project (Official Title) } \\
\text { Total Energy Usage in Houses in the Brett }\end{array}$ & District $(887)$ & $\begin{array}{l}\text { 2. Date (Form Completed) } \\
\qquad 3 / 15 / 77\end{array}$ \\
\hline $\begin{array}{l}\text { 3. Performing Organization (Complete Mailing Address) } \\
\text { Building Research Establishment } \\
\text { Eucknells Lane } \\
\text { Garston, Watford Herts WD2 7JR } \\
\text { Enfland }\end{array}$ & $\begin{array}{l}4 \text { Principal Investigator } / \\
\text { R.S.J. Leacl } \\
\text { R.G. Courtn } \\
\text { E.W. Spink }\end{array}$ & $\begin{array}{l}\text { Jame and Complete Mailing Address) } \\
\text { ey }\end{array}$ \\
\hline $\begin{array}{l}\text { 5. Supporting Organization (Complete Mailing Address and Name of } \\
\text { Contact) } \\
\text { Department of the Environment } \\
2 \text { Marsham St. } \\
\text { London SWIP } 3 \mathrm{~EB} \\
\text { England }\end{array}$ & $\begin{array}{l}\text { 6. Duration of Investigatic } \\
\qquad 9 / 74 \text { to } \\
\text { 7. Estimated Funding and } \\
22,576\end{array}$ & $\begin{array}{l}\text { (Beginning and ending) } \\
\text { Manpower (Monies and Manyears) }\end{array}$ \\
\hline
\end{tabular}

The following will be measured by a meter: Cold water service inlet; inlet to hot water storage tank; district heating return line from radiator systems; and between flow and return service of district heating system, cooling and other electrical loads will be distinguished. To provide information for a field study into total energy consumption.

electrical power

国 space heating

$\square$ space cooling

$\square$ potable hot water

12. Exchange of data

$\square$ wastewater treatment

$\square$ solid waste processıng

$\square$ potable water

Will data be available from this project that will be shared with others?
Use Box No 16 if additional space is needed

11 Type of Project

public $\square$ private

cooperatıve

$\square$ Yes

No 


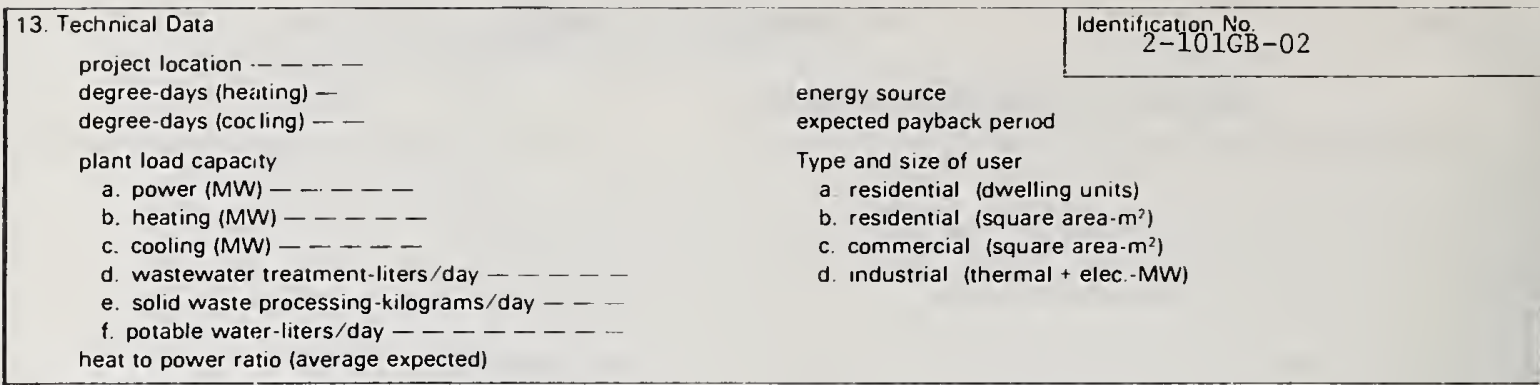

14. Other Related Projects (Titles)

15. Additional space for Purpose of Project

16. Additional space for Status and Results 


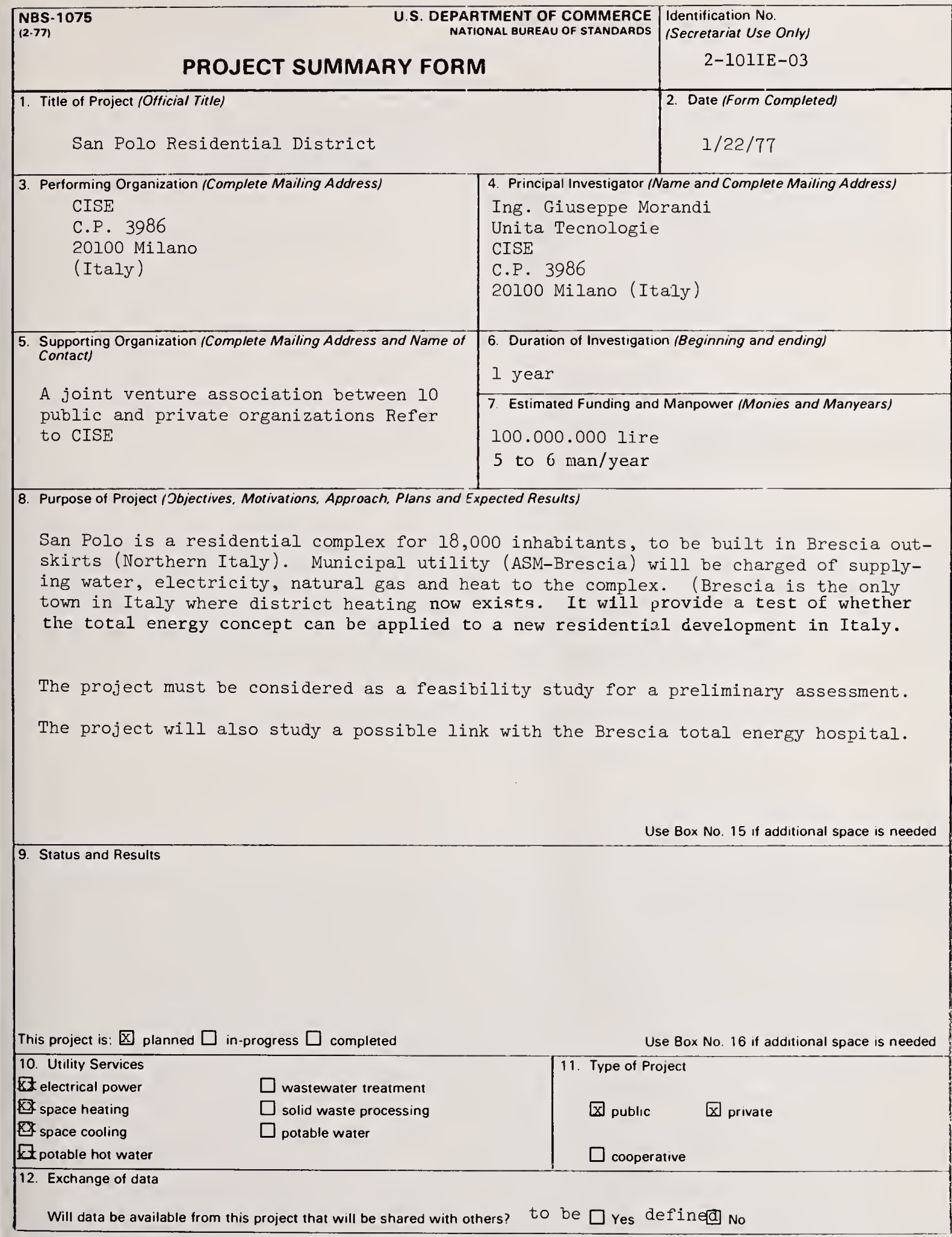




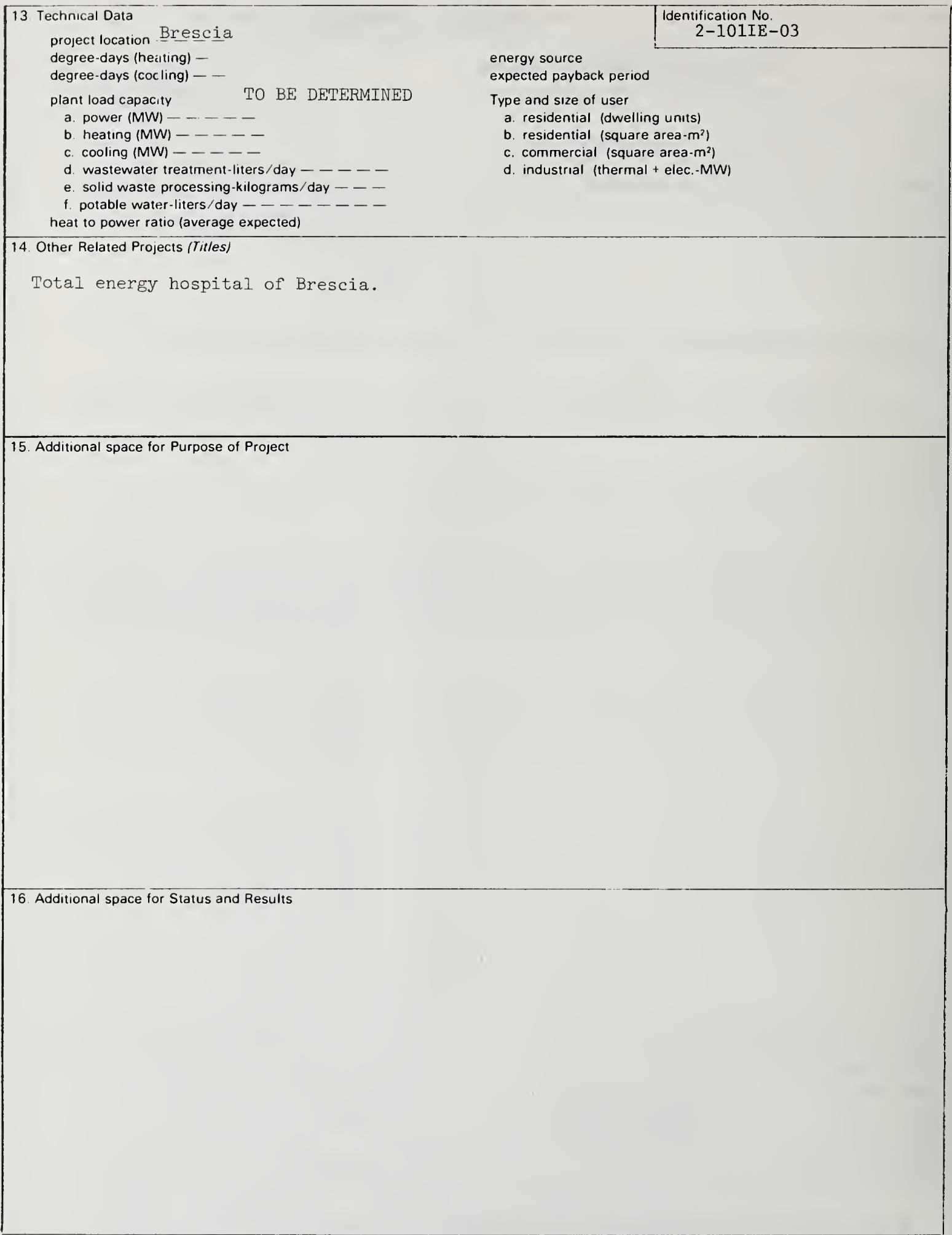




\begin{tabular}{|c|c|c|}
\hline \multicolumn{2}{|l|}{$\left[\begin{array}{l}\text { NBS-1075 } \\
(2-77)\end{array}\right.$} & \multirow{2}{*}{\begin{tabular}{|c}
$\begin{array}{r}\text { identification No } \\
\text { (Secretariat Use Only) } \\
2-1110 \mathrm{~K}-04\end{array}$ \\
2 Date (Form Completed) \\
$11 / 24 / 76$
\end{tabular}} \\
\hline $\begin{array}{l}\text { 1. Title of Project (Official Title) } \\
\text { Power and Heat Production form a Combined } \\
\text { Power Plant }\end{array}$ & Diesel Rankine & \\
\hline $\begin{array}{l}3 \text { Performing Organization (Complete Mailing Address) } \\
\text { Laboratory for Energetics } \\
\text { Technical University of Denmark } \\
\text { Bldg. } 403 \\
\text { DK-2800 Lyngby Denmark }\end{array}$ & $\begin{array}{l}4 \text { Principal Investigator } \\
\text { Qvale, E.B., P } \\
\text { Laboratory for } \\
\text { Technical Univ } \\
\text { Bldg. } 403 \\
\text { DK-2800 Lyngby }\end{array}$ & $\begin{array}{l}\text { Vame and Complete Mailing Address) } \\
\text { ofessor } \\
\text { Energetics } \\
\text { ersity of Denmark } \\
\text { Denmark }\end{array}$ \\
\hline $\begin{array}{l}\text { 5. Supporting Organization (Complete Mailing Address and Name of } \\
\text { Contact) } \\
\text { The Council of Technology }\end{array}$ & $\begin{array}{l}\text { 6. Duration of Investigati } \\
4 / 75 \text { to } 2 / 7 \\
\text { 7. Estimated Funding anc } \\
160,000 \mathrm{Dkr} \text { (ap) } \\
\text { for half a year }\end{array}$ & $\begin{array}{l}\text { on (Beginning and ending) } \\
\text { Manpower (Monies and Manyears) } \\
\text {. } \$ 27,500) \\
\text { 1.2. Manyears }\end{array}$ \\
\hline \multicolumn{3}{|c|}{$\begin{array}{l}\text { 8. Purpose of Project (jbjectives, Motivations. Approach, Plans and Expected Results) } \\
\text { The purpose of this investigation has been to evaluate the problems concerning the } \\
\text { contruction and operation of a plant for the combined production of electricity and } \\
\text { district heating using diesel engines and steam turbines. The goal has been to develop } \\
\text { a preliminary design for a competitive } 82 \text { MW (electric) plant for a medium-size Danish } \\
\text { town based on up-to-date technical information and to establish the basis for compari- } \\
\text { son between this type of power plant and the conventional steam power plant. The work } \\
\text { has consisted of collection and evaluation of the most recent information concerning } \\
\text { technical, economic, and environmental aspects of these plants. }\end{array}$} \\
\hline
\end{tabular}

Use Box No. 15 if additional space is needed

\section{Status and Results}

A first design of a combined Diesel-Rankine Power and Heat Plant for the city of Herning in Denmark has been completed. The plant consists of 6 medium-speed diesel engines with separate generators and one steam turbine. Steam for the steam cycle is produced in a common exhaust gas boiler. Total power output $82.6 \mathrm{MW}$. The heat production is $69.7 \mathrm{MW}$, of which $37.3 \mathrm{MW}$ comes from the steam condenser and $32.4 \mathrm{MW}$ from the diesel engines (water coolers, oil coolers, and coolers for air from turbochargers). If the same power and heat were going to be generated in a conventional This project is: $\square$ planned $\square$ in-progress $\square$ completed (continued) 10. Utility Services A t electrical power Q space heatıng $\square$ space cooling $\square$ wastewater treatment $\square$ solid waste processing $\square$ potable water Use Box No. 16 if additional space is needed $\square$ potable hot water 1. Type of Project

$\square$ public $\square$ private 12. Exchange of data 


\begin{tabular}{|c|c|}
\hline $\begin{array}{l}\text { 13. Technical Data } \\
\text { project location -Herning, Demark }\end{array}$ & $\begin{array}{r}\text { Identification No. } \\
2-111 \mathrm{DK}-04\end{array}$ \\
\hline $\begin{array}{l}\text { degree-days (heating) }- \\
\text { degree-days (cocling) }--\end{array}$ & $\begin{array}{l}\text { energy source Heavy fuel oil } \\
\text { expected payback period }\end{array}$ \\
\hline $\begin{array}{l}\text { plant load capacity } 82.6 \mathrm{MW} \\
\text { a. power (MW) }-82.7 \mathrm{MW} \\
\text { b. heating (MW) } 69.7 \mathrm{MW} \\
\text { c. cooling (MW) }----- \\
\text { d. wastewater treatment-liters/day }----- \\
\text { e. solid waste processing-kilograms/day }--- \\
\text { f. potable water-liters/day }---\overline{84} \\
\text { heat to power ratio (average expected) }\end{array}$ & $\begin{array}{l}\text { Type and size of user } \\
\text { a. residential (dwelling units) } \\
\text { b. residential (square area- } \mathrm{m}^{2} \text { ) } \\
\text { c. commercial (square area- } \mathrm{m}^{2} \text { ) } \\
\text { d. industrial (thermal + elec. }-\mathrm{MW} \text { ) }\end{array}$ \\
\hline
\end{tabular}

14. Other Related Projects (Titles)

15. Additional space for Purpose of Project

16 Additional space for Status and Results

power plant (efficiency 0.40) and district heating plant (efficiency 0.85) the consumption of primary energy would be 57.5 percent higher. The political, economic and technical aspects of the combined generation in a Diesel-Rankine Power and Heat Plant, and the problems of integrating this type into the present district-heating and electric networks have been studied. Information collected for users of diesel engines and from the manufacturers indicate that there should be no irrevocable operational problems and that the reliability of the diesel engines is very high. The present value of the accumulated surplus for this plant during the period in question (20 years) will amount to 1.3 times the intial cost of the plant. Further information see paper F69296, 11 Intersociety Energy Conversion Engineering Conference. 


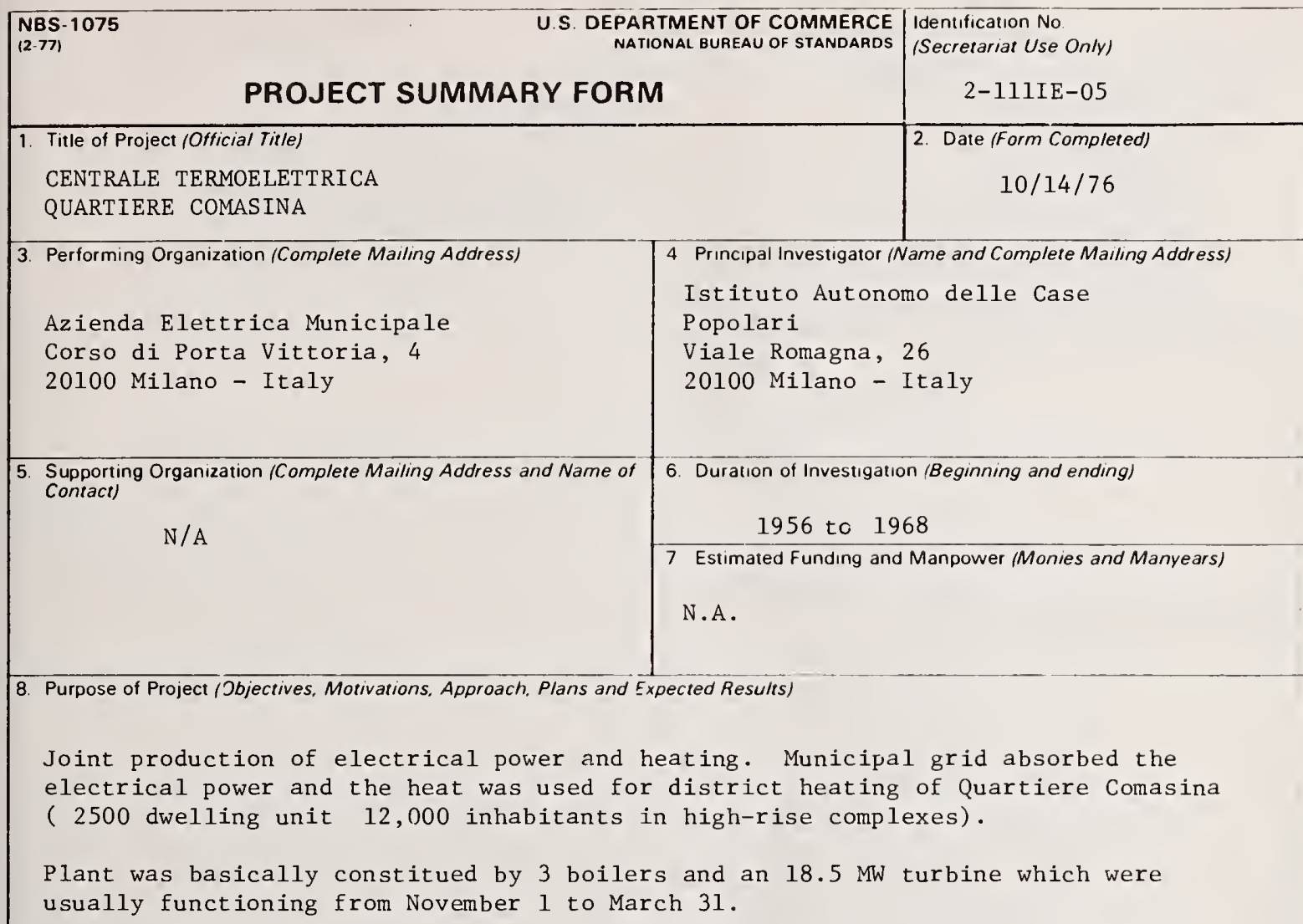

Building started in 1956 and power production in 1958. The plant was dismantled in 1968 for economical reasons.

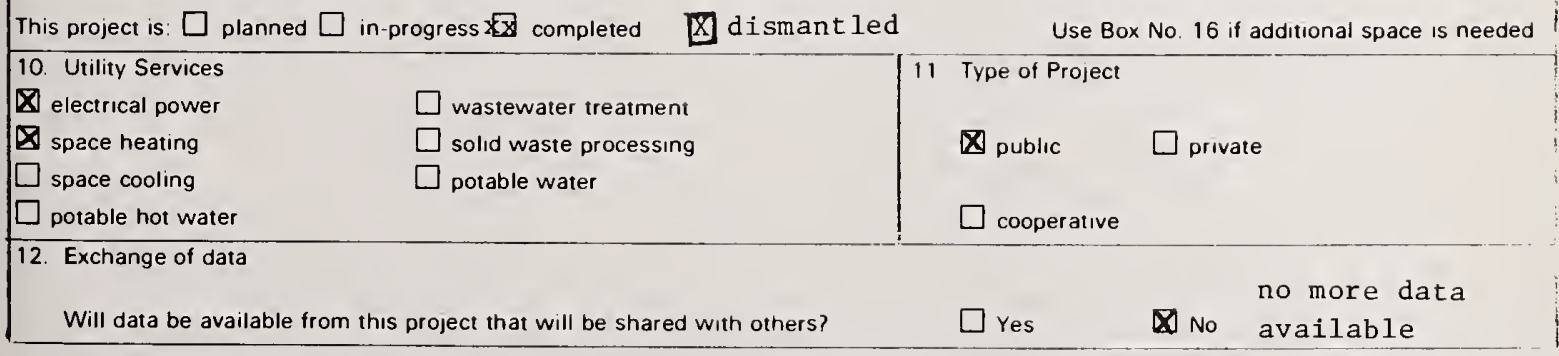




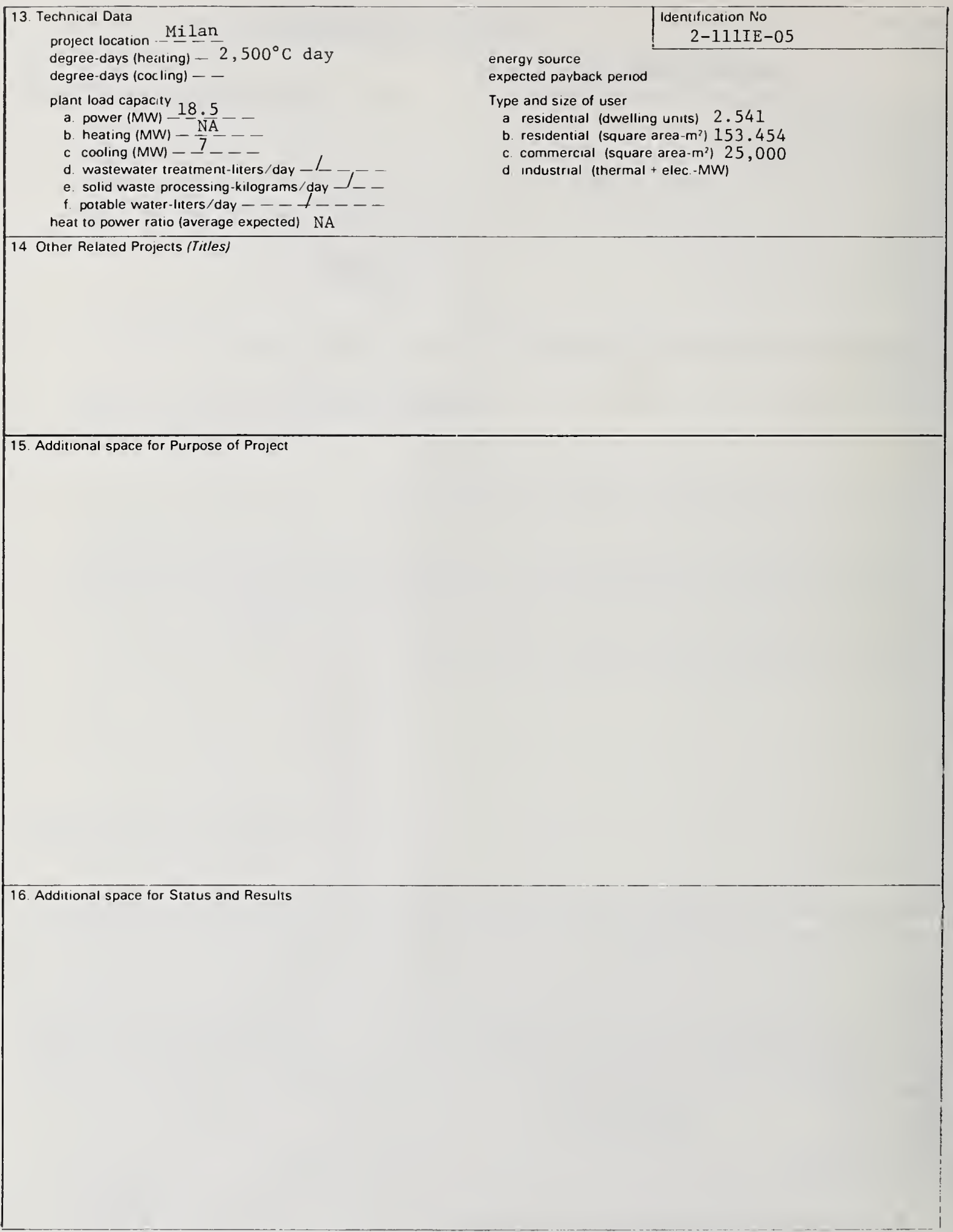




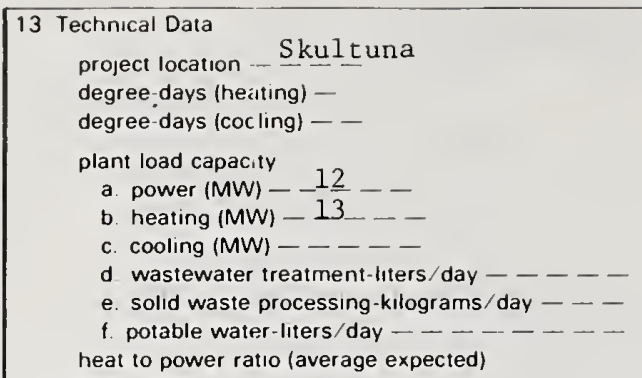

urce

expected payback period

Type and size of user

a residential (dwelling units) 4000 inh

b. residential (square area $-\mathrm{m}^{2}$ ) $6 \mathrm{MW}$ heat

c. commercial (square area- $\mathrm{m}^{2}$ )

d industrial (thermal + elec.-MW)

14. Other Related Projects (Titles)

16. Additional space for Status and Results 
NBS-1075

U.S. DEPARTMENT OF COMMERCE NATIONAL BUREAU OF STANDARDS

Identification No. (Secretariat Use On/y)

(2.77)

\section{PROJECT SUMMARY FORM}

1. Title of Project (Official Title)

2-111US-07

2. Date (Form Completed)

May 5, 1977

Modular Integrated Utility System - Total Energy

3. Performing Organization (Complete Mailing Address)

Gamze, Korobkin and Caloger

205 w. Wacker Drive

Chicago, Illinois 60606

U.S.A.

4. Principal Investigator (Name and Complete Mailing Address)

Maurice G. Gamze

Gamze, Korobkin and. Caloger

Chicago, I11. 60606 U.S.A.

Clinton W. Phillips

National Bureau of Standards

Washington, D. C. 20234 , U.S.A.

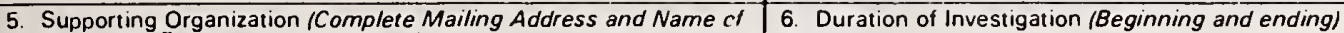

Contact) Jerome H. Rothenberg, Dir.HUD-MIUS Program

Department of Housing \& Urban Development

Division of Energy Building Technology \&

Standards

Office of Policy Development \& Research

451 th St. SW Room 8158

Washington, D. C. 20410 , U.S.A.

Total Program 1970-1978

7. Estimated Funding and Manpower (Monies and Manyears)

\section{$\$ \overline{5}, 000,000$}

8. Purpose of Project (Jbjectives. Motivations. Approach. Plans and Expected Results) The purpose of the Total Energy Demonstration at Jersey City, N.J. is for the first time in the United States to evaluate the economy, efficiency, \& reliability of total energy systems as compared to conventional utility plants. Although total energy plants have been around for some time in the U.S. most have been constructed for industry and commercial application. Accurate data on the performance and reliability of the existing plants have not been collected and made available particularly in a residential community. The information gathered in this evaluation also will provide valuable spin-off knowledge for the MIUS concept. HUD's involvement stems from its reponsibility for improving the cost of housing in the Nation's communities.

The distinguishing characteristic of a total energy system is its generation of electricity locally with the recovery and reuse of waste heat for space heating, water heaking and space cooling. It was predicted that a total energy syst.em would reduce the fuel normally required to supply all of the sites energy requirement by one-third \& the annual cost of operation \& maintenance by $25 \%$ as compared with a conventional system. Additiont ally a total energy system can be expanded as needed to serve a growing development.

ally a total energy system can be expanded as needed to serve Use Box No. is if additional space is needed

9. Status and Results The plant was designed \& is being operated by the engineering firm of Gamze-Korobkin-Caloger, Inc., Chicago, Il1. The plant was put into operation January, 1974. The plant has $5 \mathrm{~V}-12$ Caterpillar D398TA diesels driving $600 \mathrm{kw}$ generators each: No more than 3 engines are required to maintain full load. There are two 3,9MW boilers capable of supplying all of the thermal energy required for the site without using heat recovery. Two $1.9 \mathrm{MW}$ absorption chillers supply the cooling needs.

The instrumentation was designed \& installed by NBS. The collection of data from the

TE Data Acquisition System has been underway since May, 1975.

The first performance report, the most important near-term milestone, was released

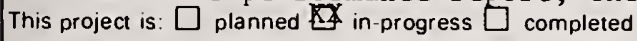

\begin{tabular}{ll}
\hline 10. Utility Services & $\square$ wastewater treatment \\
$\bigotimes$ electrical power & $\square$ solid waste processing \\
$\square$ space heatıng & $\square$ potable water
\end{tabular}
Use Box No. 16 if additional space is needed

国 potable hot water 11. Type of Project

Q

12. Exchange of data cooperative

Will data be available from this project that will be shared with others?

EY Yes No 
project location - Jersey City, N.J. USA

degree-days (heiting) -4811

degree-days (cocling) -400

energy source

Fuel Oil No. 2

expected payback period To be determined

plant load capacity

a power (MW) -2.4

b. heating (MW) $7.6 \ldots$

c. cooling (MW) $-3-8--$

d. wastewater treatment-liters/day - NA - -

e. solid waste processing-kilogrags/day NA

Type and size of user

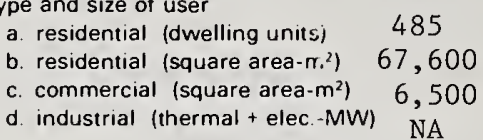

f. potable water-liters/day - _

heat to power ratio (average expected) Annual BLR output + Eng. Recov/Gross $\mathrm{KW}=24$

14. Other Related Projects (Titles)

MTUS Demonstration ( $1-111$ US-03)

MIUS Demonstration Evaluation (1-111US-04)

15. Additional space for Purpose of Project

The total energy plant which serves the Summit Plaza Apartments provides power, space heating/cooling, and hot water for 485 apartments, a school, 6,500 sq. meters of commercial space and a swimming pool.

The objective was to design and construct a plant, utilizing existing technology, at an innovative housing project being constructed by HUD under the Operation BREAKTHROUGH Program. After construction the objective was to install, operate and maintain an instrumentation and acquisition system and to collect, reduce and analyze data, prepare evaluations of component and system performance and monitor plant operations/retrofit/ maintenance activities as related to plant performance.

16. Additional space for Status and Results

in May, 1977 analyzing the plants performance from November,1975 to 0ctober, 1976. pata will be collected through December 1977 and a final report will be released in nid-1978.

In addition to performance reports a report on the design of the plant and the design and operation of the instrumentation and Data Acquisition System will be published. 


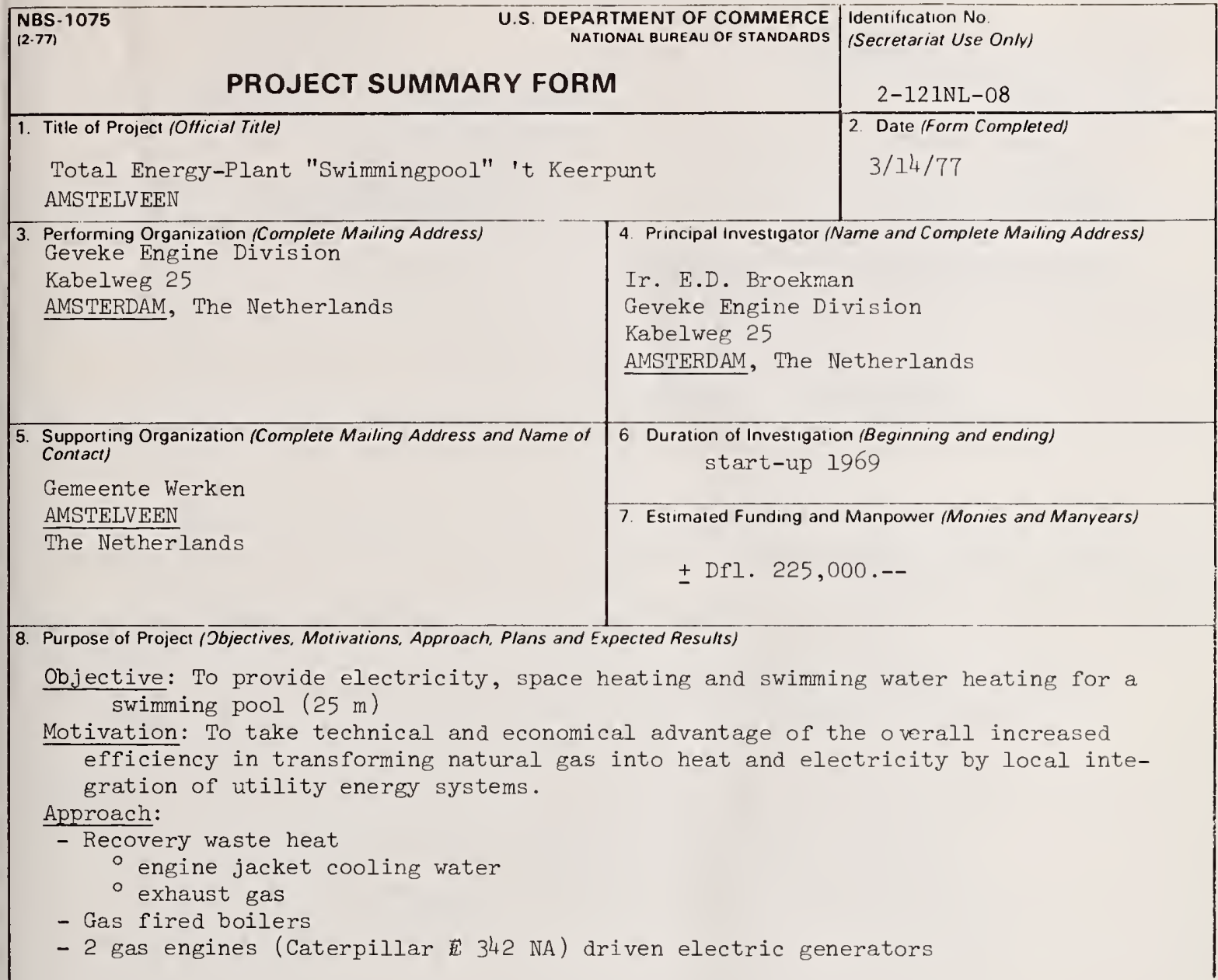

Use Box No. 15 if additional space is needed

9. Status and Results

Plant put in operation summer 1969

Electricity production $1 \times 10^{6} \mathrm{kWh}$ per year

- efficiency TE-plant

- efficiency electr. supply 28\%

- efficiency heat supply jacket cooling 30\%

- efficiency heat supply exhaust gas $12 \%$

Refer to Note 2, Table 2-9.

This project is: $\square$ planned $\square$ in-progress completed

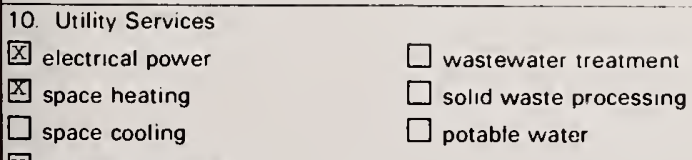

Use Box No 16 if additional space is needed

$\mathrm{X}$ potable hot water

12. Exchange of data

Will data be available from this project that will be shared with others?

XXes

No

Contact 4 


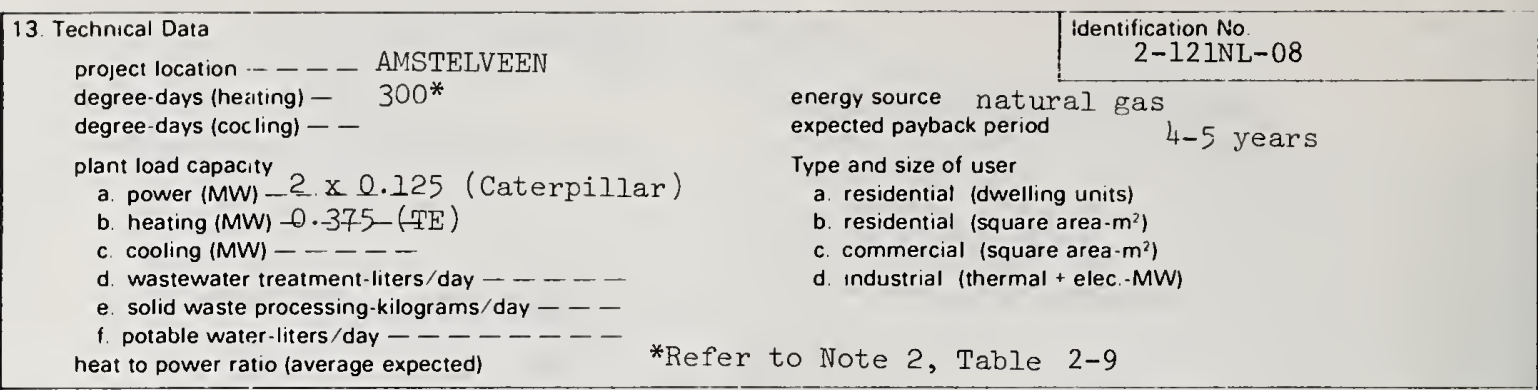

14. Other Related Projects (Titles)

Swimming Pool: Bussum, Leidschendam, Rotterdam, Nijmegen The Netherlands

15. Additional space for Purpose of Project

16. Additional space for Status and Results 


\begin{tabular}{|c|c|c|}
\hline \multicolumn{2}{|l|}{ PROJECT SUMMARY FORM } & \multirow{2}{*}{\begin{tabular}{|c}
$\begin{array}{c}\text { Identification No. } \\
\text { (Secretariat Use On/y) } \\
2-121 \mathrm{NL}-09\end{array}$ \\
2 Date (Form Completed) \\
$3 / 14 / 77$
\end{tabular}} \\
\hline $\begin{array}{l}\text { 1. Title of Project (Official Titte) } \\
\text { Total Energy Plant for Swimming Pool }\end{array}$ & & \\
\hline $\begin{array}{l}\text { 3. Performing Organization (Complete Mailing Address) } \\
\text { N/A }\end{array}$ & $\begin{array}{l}4 \text { Principal Investıgator } / \\
\text { Gemeentelijke Di } \\
\text { Recreatie } \\
\text { Afd. Zuembaden } \\
\text { M.A. Versloot } \\
\text { Weena } 760 \\
\text { ROTTERDAM, The N }\end{array}$ & $\begin{array}{l}\text { Vame and Complete Mailing Äddress) } \\
\text { enst voor Sport en } \\
\text { vetherlands }\end{array}$ \\
\hline $\begin{array}{l}\text { 5. Supporting Organization (Complete Mailing Address and Name of } \\
\text { Contact) }\end{array}$ & \begin{tabular}{|} 
6. Duration of Investigatio \\
$\mathrm{N} / \mathrm{A}$ \\
7. Estımated Funding and \\
$f 350,000$
\end{tabular} & On (Beginning and ending) \\
\hline $\begin{array}{l}\text { 8. Purpose of Project /Objectives, Motivations, Approach, Plans and } \\
\text { Objective: To provide electricity, space } \\
\text { Motivation: To take technical and economi } \\
\text { efficiency in transforming natural ga } \\
\text { integration of utility energy systems } \\
\text { Approach: } \\
\text { - Installation of } 3 \text { Caterpillar type G } 35 \\
\text { - Recovery of waste heat by series connec } \\
\text { o heat exchanger with separate engin } \\
\text { - exhaust gas heat exchanger } \\
\text { - Gas fired boiler for temporarily limite } \\
\text { space during component breakdown } \\
\text { - No grid connection }\end{array}$ & $\begin{array}{l}\text { xpected Results } \\
\text { al advantage of } t \\
\text { into heat and el } \\
\text { NA gas driven en } \\
\text { ion of } \\
\text { jacket cooling } \\
\text { additional suppl }\end{array}$ & $\begin{array}{l}\text { ng water heating } \\
\text { he overall increased } \\
\text { ectricity by local } \\
\text { gine electric generators } \\
\text { ater loops } \\
\text { y of heat or as }\end{array}$ \\
\hline
\end{tabular}

The plant operates basically as an independent energy supply unit

Use Box No. 15 if additional space is needed

9. Status and Results

The plant is in operation.

Results of 1975 indicate that the net cost of electricity produced corrected for pool heating is $10.8 \mathrm{ct} / \mathrm{kWh}$ compared to $10 \mathrm{ct} / \mathrm{kWh}$ from the municipal grid.

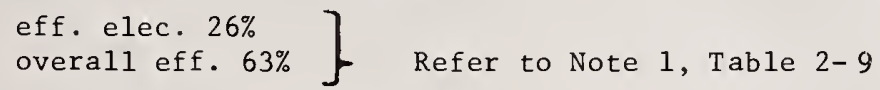

This project is: $\square$ planned $\square$ in-progress $\square$ completed

\begin{tabular}{|c|c|c|c|}
\hline \multicolumn{2}{|l|}{ 10. Utility Services } & \multirow{2}{*}{\multicolumn{2}{|c|}{ 11. Type of Project }} \\
\hline$凶$ electrical power & $\square$ wastewater treatment & & \\
\hline space heating & $\square$ solid waste processing & $x \geq$ public & $\square$ private \\
\hline$\square$ space cooling & $\square$ potable water & & \\
\hline$\square$ potable hot water & [x] pool water heating & $\square$ cooperative & \\
\hline
\end{tabular}

12. Exchange of data 


\section{Technical Data}

project location - - - - -

degree-days (heating) -

degree-days (cocling) - -

plant load capacity $140 \mathrm{~kW} / \mathrm{unit}$
a power (MW) - - - - -
b. heatıng (MW) - $-\ldots$
c. cooling $(\mathrm{MW})-\ldots-\ldots$
d wastewater treatment-liters/day _ _ _ _
e. solid waste processing-kilograms/day - - -
f. potable water-liters/day $---\ldots-\ldots$
heat to power ratio (average expected)

14. Other Related Projects (Titles) energy source

expected payback period

Type and size of user

a. residential (dwelling units)

b. residential (square area- $\mathrm{m}^{2}$ )

c. commercial (square area- $\mathrm{m}^{2}$ )

d. Industrial (thermal + elec.-MW)

15. Additional space for Purpose of Project 


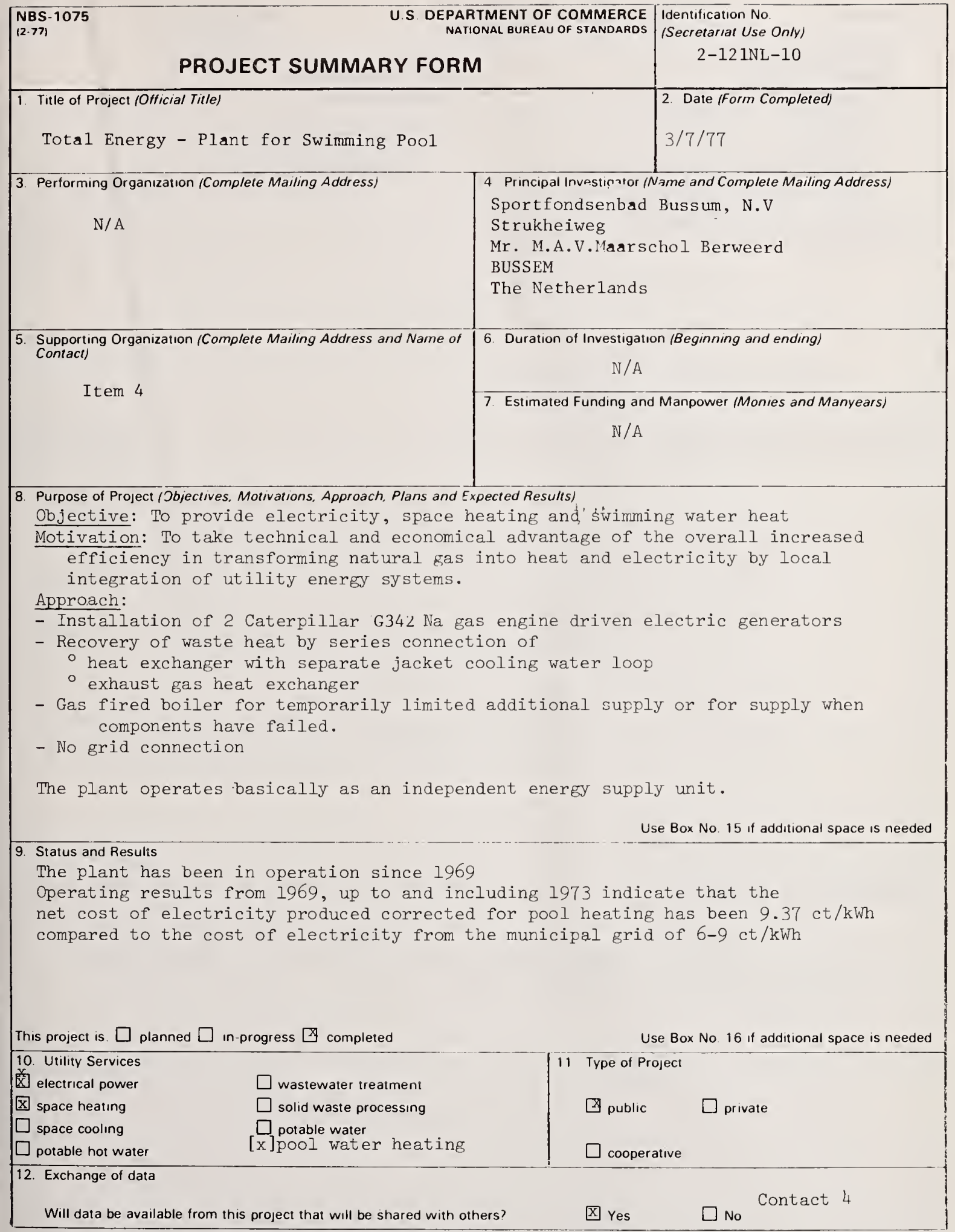


13 Technical Data

project location

degree-days (cocling) -

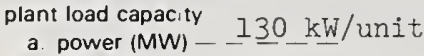

b. heating $(\mathrm{MW})-\ldots-\ldots$

c. cooling (MW) - - - -

d. wastewater treatment-liters/day $-\ldots-\ldots$

e. solid waste processing-kilograms/day $-\ldots$

$f$ potable water-liters/day ------heat to power ratio (average expected)
14. Other Related Projects (Titles)

energy source
expected payback period
Type and size of user
a. residential (dwelling units)
b. residential (square area- $\mathrm{m}^{2}$ )
c. commercial (square area- $\mathrm{m}^{2}$ )
d. industrial (thermal + elec. $\mathrm{MW}$ )

15. Additional space for Purpose of Project

16. Additional space for Status and Results

The net cost is based on the total cost for production minus cost of gas supply which would be required for separate heating 


NBS-1075 U.S. DEPARTMENT OF COMMERCE
$(2-77)$

PROJECT SUMMARY FORM

1. Title of Project (Official Title)

Tota1 Energy-P1ant (LP)

Centraal Beheer, Insurance Company

3. Performing Organization (Complete Mailing Address)

Ir. A. Verhoef

DYNAF B.V.

Kwakelkade 29, P.0.Box 54

ALKMAAR, The Netherlands

Van Heugten B.V.
Identification No

(Secretariat Use Only)

2-122NL-11
2. Date (Form Completed)

$1 / 20 / 77$

4 Principal Investigator (Name and Complete Mailing Address)

Ir. P.H.H.Leijendekkers

Raadgevend Technics Adviesbureau

St. Annastraat 143-147

NIJMEGEN

5. Supporting Organization /Complete Mailing Address and Name of

Mr. L. L. Bosdijk

c/o Centraal Beheer U.A.

P.0.Box 700

APELDOORN

The Netherlands

Duration of Investigation (Beginning and ending)

August 1971 til1 November 1972

7. Estimated Funding and Manpower (Monies and Manyears)

$\$ 6,000,000$ for one and a half year

8. Purpose of Project (Objectives, Motivations, Approach, Plans and Expected Results)

Objective: To provide electricity and space-heat and cooling etc. for office building and computer centre.

Motivation: To take technical and economical advantage of the increase of overall efficiency in transforming natural gas into heat, electricity, etc. by local integration of systems.

Approach: Installation of 3 gas (Waukesha F-352l-GSl, 1000 rpm) driven electric generators (A.V.Kaick), $450 \mathrm{kVA}$ each of which one is spare

- recovery of waste heat - engine jacket cooling water)

- exhaust gas ) ebullient cooling

- installation of 3 gas fired boilers ( $15 \mathrm{psi}, 1200 \mathrm{kgf} / \mathrm{hr}$ steam)

- installation of 1 absorption cooling engine

- grid connection for additional electricity supply, and the possibility to take over the complete supply in case of emergency

Use Box No 15 if addıtıonal space is needed

9. Status and Results

The plant has been in operation since 1972

Results 1976 are

$\begin{array}{lll}\text { - efficiency TE-plant } & 68.14 & \text { ] } \\ \text { - efficiency electr. suppl. } & 26.1 \% \\ \text { - efficiency heat suppl. } & 42.04 \%\end{array}$ J Refer to Note 1, Table 2-9

This project is: $\square$ planned $\square$ in-progress $\square$ completed

Use Box No. 16 if additional space is needed

10. Utility Services

冈 electrical power

space heating

$凶$ space cooling

\% potable hot water

12. Exchange of data wastewater treatment

$\square$ solid waste processing

$\square$ potable water

Will data be available from this project that will be shared with others?

4 Yes

No

11 Type of Project

$\square$ public $\quad$ private

cooperative 


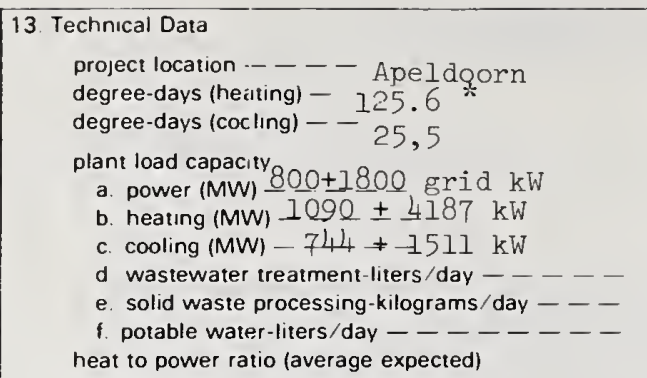

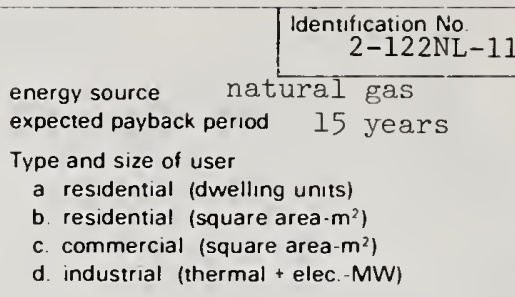

*Refer to Note 2, Table 2-9

\section{Other Related Projects (Titles)}

SP - Heat Pump System

See 5-122NL-09

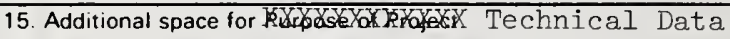

- days, heating, temp. under $15^{\circ} \mathrm{C}$

- days, cooling, temp. above $23^{\circ} \mathrm{C}$

Plant load capacity:

a: Usually the power supply is $800 \mathrm{~kW}$ from total-energy plant and $250 \mathrm{~kW}$ from grid in case of breakdown of TE-plant grid supply up to $1800 \mathrm{~kW}$ is possible.

b. Steam capacity TE-plant $1090 \mathrm{kw}$, additional capacity gas fired boilers is $4187 \mathrm{~kW}$ (sufficient for complete take-over in case of breakdown). waste heat is normally used for heating and cooling (absorption system).

c. Absorption cooling engine $744 \mathrm{~kW}$, additional centr. compr. engine $1511 \mathrm{~kW}$, (also sufficient for complete take over by breakdown TE-plant, electr. supply via grid)

Type and size of user:

office building for 1050 people, square area $23.323 \mathrm{~m}^{2}$, including a computer centre.

16. Additional space for Status and Results

Reports of economical and technical results are available in Dutch language Contact: "Beheer en Onderhoud"

Misset

P.O. Box 4

DOETINCHEM

Remark: Efficiencies based on lower heating value 


\begin{tabular}{|c|c|c|}
\hline \multicolumn{2}{|c|}{$\begin{array}{l}\text { U.S. DEPARTMENT OF COMMERCE } \\
\text { NATIONAL BUREAU OF STANDARDS }\end{array}$} & $\begin{array}{l}\text { Identification No. } \\
\text { (Secretariat Use On/y) } \\
2-122 \mathrm{NL}-12 \\
\text { 2. Date (Form Completed) } \\
3 / 7 / 77\end{array}$ \\
\hline $\begin{array}{l}\text { 8. Purpose of Project /Objectives, Motivations, Approach. Plans and } \\
\text { Objective: To provide electricity and spa } \\
\text { Motivation: To take technical and economic } \\
\text { efficiency in transforming natural gas int } \\
\text { of utility energy systems. } \\
\text { Approach: } 3 \text { gas engine driven (Caterpilla } \\
\text { of which one is spare. } \\
\text { - recovery of waste heat from } \\
\text { o engine jacket cooling water } \\
\text { o engine exhaust gas } \\
\text { - I ahsorption rooler } \\
\text { - } 2 \text { gas fired boilers for additional heat }\end{array}$ & $\begin{array}{l}\text { pected Results) } \\
\text { heating and coo } \\
\text { heat and electri } \\
\text { G } \mathrm{TA} \text { ) electri } \\
\text { upply }\end{array}$ & $\begin{array}{l}\text { ling for office building } \\
\text { le overall increased } \\
\text { icity by local integration } \\
\text { ic generators (V.Kaick) }\end{array}$ \\
\hline
\end{tabular}

Use Box No. 15 if addıtional space is needed

9. Status and Results

The plant has been in operation since 1973

Data from 1975:

- Total efficiency of TE-plant

$69.02 \%$

- Efficiency electr. supply

$25.47 \%$

- Efficiency heat supply

$33.55 \%$

]

JRefer to Note 1, Table 2-9. Efficiencies

$\mathrm{J}$ are based on total energy delivered and consumed over a full year.

This project is: $\square$ planned $\square$ in-progress $\square$ completed

\begin{tabular}{ll}
\hline 10. Utility Services & $\square$ wastewater treatment \\
$\square$ electrical power & $\square$ solid waste processing \\
$\square$ space heating & $\square$ potable water \\
$\square$ space cooling &
\end{tabular}

Use Box No. 16 if additional space is needed

$\square$ potable hot water

cooperative

12. Exchange of data

Will data be available from this project that will be shared with others?

Q Yes

No

See 9 


\section{Technical Data}

project location -- - - -

degree-days (heatıng) -

EDE

degree-days (coclıng) - -

plant load capacity $540 \mathrm{~kW} /$ unit

b. power (MW) $-75 \underline{0}, \underline{000} \mathrm{kcal} / \mathrm{h}$ unit

c. cooling (MW) $-1,500,000 \mathrm{kcal} / \mathrm{h}$

d. wastewater treatment-liters/day _ . _ . -

e. solid waste processing-kilograms/day - - -

$f$ potable water-liters/day $--\ldots----$

heat to power ratio (average expected)

14 Other Related Projects (Tit/es) dentification $\mathrm{No}$

$2-122 \mathrm{NL}-12$

energv source natural gas

expected payback period

Type and size of user

a. residential (dwelling units)

b. residential (square area- $\mathrm{m}^{2}$ )

c. commercial (square area- $\mathrm{m}^{2}$ )

d. industrial (thermal + elec - MW)

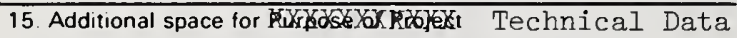

e. Bruto volume buildings: $79000 \mathrm{~m}^{3}$

f. Wall Surface : $6000 \mathrm{~m}^{2}$

g. Window surface : $18000 \mathrm{~m}^{2}$

h. Number of levels : 5

16. Additional space for Status and Results

- Overall efficiency TE-plant + gas fired boilers $71.91 \%$

- Load factor 0.373

- Average load 41.13 (of max. power of one engine)

Remark: Efficiencies based on lower heating values

Technical and economical information is published in

Beheer en onderhoud

MISSET

Postbus 4, Yselkade 32

DOETINCHEM 


$\begin{aligned} & \text { NBS-1075 } \\ & (2.77)\end{aligned}$
U.S. DEPARTMENT OF COMMERCE
NATIONAL BUREAU OF STANDARD

PROJECT SUMMARY FORM

1. Title of Project (Official Title)

Block Heat-Power Station

3. Performing Organization (Complete Mailing Address)

Heidenheimer Heizkraftwerks GmbH

Postfach 1860

7920 Heidenheim/Benz

Federal Republic of Germany

Identification No.

$$
12 / 21 / 76
$$

2. Energietechnik GmbH*)

*) S. Beiblatt
(Secretariat Use On/V)

$$
2-123 \mathrm{DE}-13
$$

2. Date (Form Completed)

4. Principal Investigator (Name and Complete Mailing Address)

1. Stadtwerke Heidenheim $\mathbf{A G}^{*}$ )

3. Forschungsstelle fur Energiewirtschaft*D

* See box 15, reverse side, for complete

6. Duration of investigation (Beginning and ending)

1975 to 1978

Bundeministerium fur Forschung

und Technologie

Stresemannstrasse 10

5300 Bonn-Bad Godesberg

Federal Republic of Germany

8. Purpose of Project (Objectives, Motivations, Approach, Plans and Expected Results)

Establishment of an experimental station to demonstrate the feasibility of coupling power and heat production in block heating power stations and to relate numerical values to primary energy conservation

Energy balances for daily and yearly full load and part load operation will be plotted.

Power \& heat consumption and cost values will be determined, and the idle time and operational safety of all aggregate parts will be investigated. The cost of maintenance and the possibilities for automating the system will be investigated. The standardization of new communities (300-400 units) as it effects a block heating power station will be examined.

Use Box No. 15 if additional space is needed

9. Status and Results

The testing phase has been completed and the evaluation phase has begun.

This project is: $\square$ planned $\mathrm{X}$ in-progress $\square$ completed

Use Box No. 16 if additional space is needed

10. Utility Services

kz electrical power

还 space heating

wastewater treatment

$\square$ solid waste processing

$\square$ space cooling

$\square$ potable water

$\square$ potable hot water

12. Exchange of data

Will data be available from this project that will be shared with others?

ख Yes

No 
13. Technical Data project location 느므믈 Heidenheim/Br. Iglauerstr. 66 degree-days (heâting) degree-days (cocling) - energy source Erdgas Identification No. plant load capacity
a. power (MW) - 0,8 MVA
b. heating $(\mathrm{MW})-1 . \underline{\mathrm{MW}}$
c. cooling (MW) $--\ldots-$
d. wastewater treatment-liters/day $-\ldots-\ldots$
e. solid waste processing-kilograms/day _ _ -
f. potable water-liters/day - $-\ldots-\ldots$ heat to power ratio (average expected)

14. Other Related Projects (Titles

15. Additional space for Purpose of Project

\author{
Stadtwerke Heidenheim AG \\ Postfach 1869 \\ 7920 Heidenheim/Brenz \\ Federal Republic of Germany \\ Energietechnik $\mathrm{GmbH}$ \\ Postfach 5424 \\ 4307 Kettwig \\ Federal Republic of Germany \\ Forschungsstelle fur Energiewirtschaft \\ Am Blutenanger 71 \\ 8000 Munchen 50 \\ Federal Republic of Germany
}
ype and size of user
a. residential (dwelling units) 283
b. residential (square area-m²) 16760
c. commercial (square area- $\mathrm{m}^{2}$ )
d. Industrial (thermal + elec.-MW) 


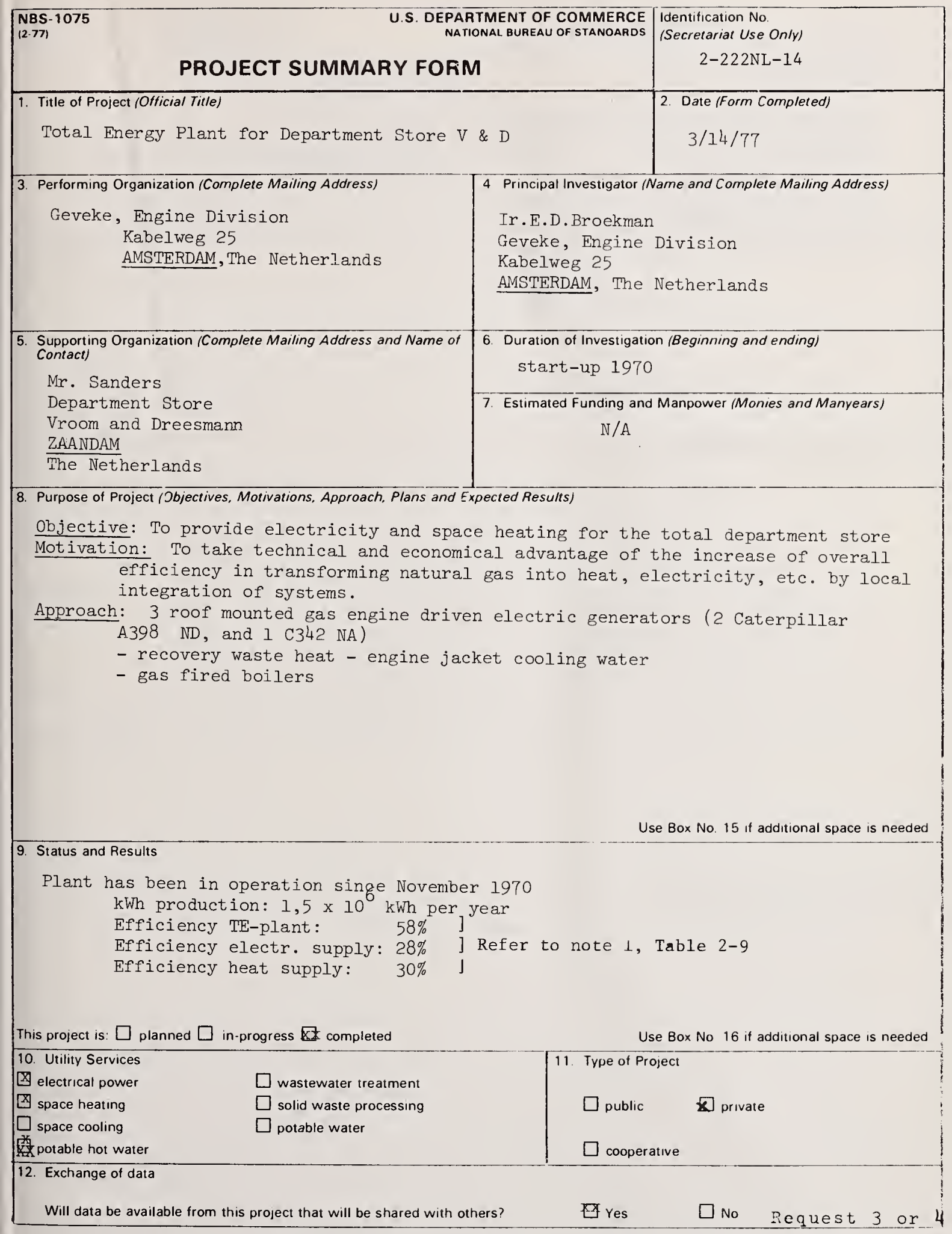




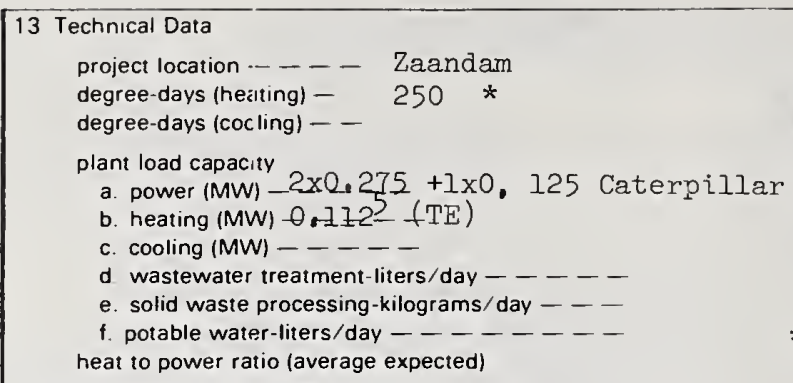

energy source Natural gas expected payback period $5-8$ years

Type and size of user
a. residential (dwelling units)
b. residential (square area- $\mathrm{m}^{2}$ )
c. commercial (square area- $\mathrm{m}^{2}$ )
d. industrial (thermal + elec.-MW)

14. Other Related Projects (Titles)

15. Additional space for Purpose of Project

16. Additional space for Status and Results

Remark: Efficiencies based on lower heating value 


NBS-1075 U.S. DEPARTMENT OF COMMERCE
NATIONAL BUREAU OF STANDARDS

PROJECT SUMMARY FORM

1. Title of Project (Official Title)

Total Energy Project in house for mental defectives
Identification No

(Secretariat Use Only)

$2-22.42 \mathrm{NL}-15$

2. Date (Form Completed)

\section{$3 / 14 / 77$}

3. Performing Organization (Complete Mailing Address)

Landré Ruhaak Motoren B.V.

Industrieweg 30, P.0.B 63

Vianen

The Netherlands

5. Supporting Organization (Complete Mailing Address and Name of Contact)

Ver. Johannes Stichting

Hooge Burch, Spoorlaan 19

Zwammerdam

The Netherlands

Attn: Mr. Ir. P. Haanappel (pr. Supervisor)

4. Principal Investigator (Name and Complere Mailing Address)

B.V.Ontwerp - en Adviesbureau

R. Veenhuizen

Jan van Nassaulaan 104

The Hague

The Netherlands

6. Duration of Investigation (Beginning and ending)

$$
12 / 71 \text { to } 10 / 74
$$

7. Estimated Funding and Manpower (Monies and Manyears)

Df1. $750,000 .=10$ man years

\section{Purpose of Project (Dbjectives, Motivations, Approach, Plans and Expected Results)}

Objectives: To transfer natural gas into electricity and fuel

Motivation: Electricity supply in peak hours and night time, to supply heat for central heating of buildings. Also used as standby units.

Approach: Two gen. set units of 300 KVA each, supply electricity for peak-shaving purpose. The recovered heat will be transferred ty a heat exchanger to by a central heating system at $90^{\circ} \mathrm{C}$. The shortage of heat will be supplied by a conventional boiler. The standby use will be obtained by autom. supplying LPG gas in case of failure of public services.

Plans: To reduce extra cost of peak hour supply of electricity and to generate cheap heat for heating purposes.

Exp. results: Lower costs of electricity and heating. Price details not available.

Use Box No. 15 if additional space is needed

9. Status and Results

Installation is now in continuous service

Results not yet available

This project is: $\square$ planned $\square$ in-progress $\square$ completed

Use Box No. 16 if additional space is needed

10. Utility Services

X electrical power

space heating

wastewater treatment

$\square$ space cooling

$\square$ solid waste processing

$\square$ potable water

$\square$ potable hot water

12. Exchange of data

11. Type of Project

$\square$ public $\quad$ private

cooperative 


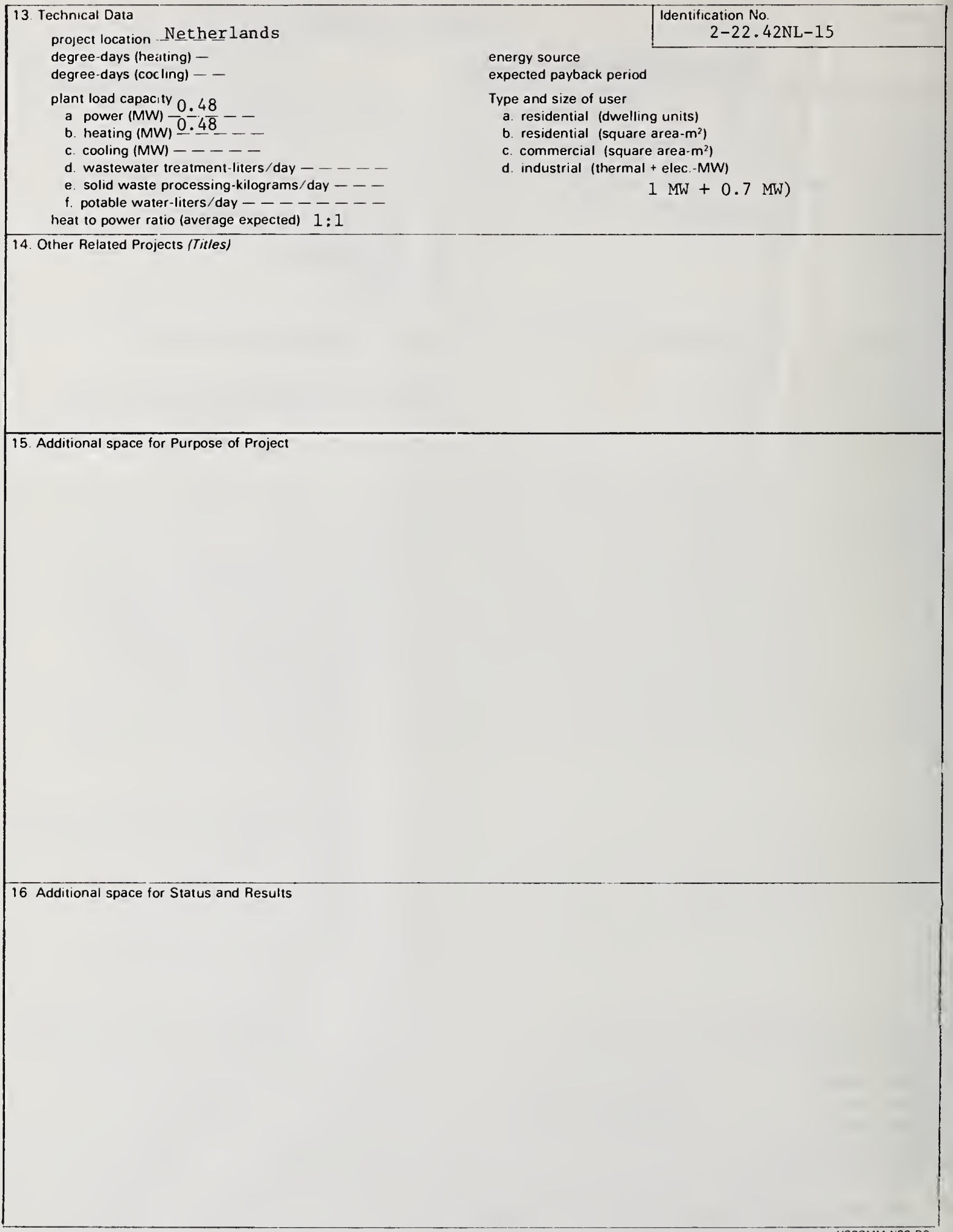




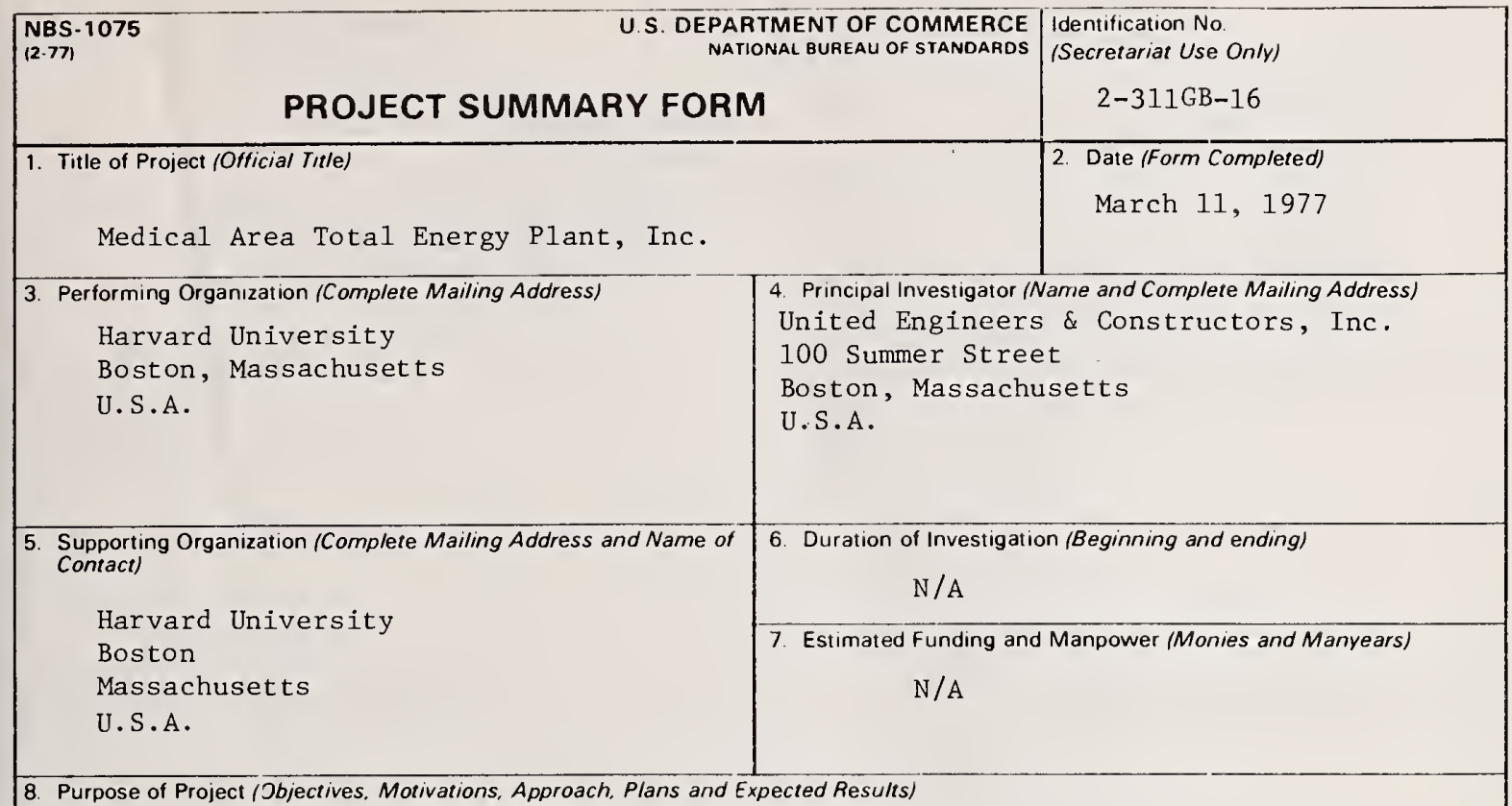

Total Energy Plant to supply electrical and heating services to the Harvard University Hospital complex.

9. Status and Results

Project is in final planning stages with construction commenced and a considerable amount of equipment already purchased.

This project is: $\square$ planned $\square$ in-progress $\square$ completed Use Box No. 16 if additional space is needed 10. Utility Services electrical power space heating space cooling $\square$ potable hot water

12. Exchange of data 


\begin{tabular}{|c|c|}
\hline \multirow{2}{*}{$\begin{array}{l}\text { 13. Technical Data } \\
\text { project location } \\
\text { degree-days (heitting) - } \\
\text { degree-days (cocling) }\end{array}$} & $\begin{array}{r}\text { Identification No. } \\
2-311 \text { UK-15 }\end{array}$ \\
\hline & $\begin{array}{l}\text { energy source fuel oil } \\
\text { expected payback period }\end{array}$ \\
\hline $\begin{array}{l}\text { plant load capacity } \\
\text { a. power (MW) } \\
\text { b. heating (MW) }-40 \\
\text { c. cooling (MW) }- \\
\text { d. wastewater treatment-liters/day }-10- \\
\text { e. solid waste processing-kilograms/day }-- \\
\text { f. potable water-liters/day }---- \\
\text { heat to power ratio (average expected) }\end{array}$ & $\begin{array}{l}\text { Type and size of user } \\
\text { a residential (dwelling units) } \\
\text { b. residential (square area- } \mathrm{m}^{2} \text { ) } \\
\text { c. commercial (square area- } \mathrm{m}^{2} \text { ) } \\
\text { d. Industrial (thermal + elec. }-\mathrm{MW} \text { ) }\end{array}$ \\
\hline
\end{tabular}

14. Other Related Projects (Titles)

15. Additional space for Purpose of Project

16. Additional space for Status and Results

Information supplied by:

Mioleri Blackstone, Ltd. (Diesel Engine Manufacturer)

Hazel Grove

Stockport, Chesline SK75AH

United Kingdom 


\begin{tabular}{|c|c|c|}
\hline \multicolumn{2}{|l|}{ PROJECT SUMMARY FORM } & \begin{tabular}{|} 
Identification No \\
(Secretariat Use On/y) \\
$2-312 \mathrm{NL}-17$
\end{tabular} \\
\hline $\begin{array}{l}\text { 1. Title of Project (Official Title) } \\
\text { Total Energy Plant } \\
\text { Vrije Universiteit }\end{array}$ & & $\begin{array}{l}\text { 2. Date (Form Completed) } \\
3 / 7 / 77\end{array}$ \\
\hline $\begin{array}{l}\text { 3. Performing Organization (Complete Malling Address) } \\
\text { Mr. Van Tuyl } \\
\text { Croon Company } \\
\text { Schiemond } 22 \\
\text { ROTTERDAM } \\
\text { The Netherlands }\end{array}$ & $\begin{array}{l}4 \text { Principal Investigator in } \\
\text { Ir. W. Jongendi } \\
\text { N.V.Nederlandse } \\
\text { Planning and Re } \\
\text { GRONINGEN, The }\end{array}$ & $\begin{array}{l}\text { Vame and Complete Mailing Address) } \\
\text { jk } \\
\text { Gasunie } \\
\text { search Departtient } \\
\text { Netherlands }\end{array}$ \\
\hline $\begin{array}{l}\text { 5. Supporting Organization /Complete Mailing Address and Name of } \\
\text { Contact) } \\
\text { Ir. L. van der Meer } \\
\text { Vrije Universiteit } \\
\text { De Boelelaan } 1105 \\
\text { AMSTERDAM, The Netherlands }\end{array}$ & $\begin{array}{r}\text { 6. Duration of Investigatio } \\
\text { N/A }\end{array}$ & $\begin{array}{l}\text { on (Beginning and ending) } \\
\text { Manpower (Monies and Manyears) }\end{array}$ \\
\hline $\begin{array}{l}\text { 8. Purpose of Project (Objectives, Motivations, Approach, Plans and } \\
\text { Objective: To provide electricity and spac } \\
\text { Motivation: The increased overall efficien } \\
\text { natural fuel into heat and electricity } \\
\text { Approach: installation of } 6 \text { (Ruston Paxman } \\
\text { generators. Normally natural gas with } \\
\text { provided with turbo boosters ( } \mathrm{CO}, \mathrm{CO}_{2} \text {, } \\
\text { - recovery of waste heat from exhaust } \\
\text { generator cooling water is released } \\
\text { - grid connection for additional elect }\end{array}$ & $\begin{array}{l}\text { hected Results) } \\
\text { heating for the } \\
\text { by and economical } \\
\text { dual-fuel engine } \\
80 \% \text { diesel oil is } \\
\mathrm{O}_{2}, \mathrm{CH}_{4} \mathrm{NO}_{\mathrm{x}} \text { cont } \\
\text { gas. Engine cooli } \\
\text { the atmosphere } \\
\text { ricity supply. }\end{array}$ & $\begin{array}{l}\text { university complex. } \\
\text { advantages in transforming } \\
\text { ed systems. } \\
\text { driven (Smit) electric } \\
\text { used. The engines are } \\
\text { ent) } \\
\text { ng jacket water and } \\
\text { presently. }\end{array}$ \\
\hline
\end{tabular}

Use Box No 15 if additional space is needed

9. Status and Results

The plant is in operation for some years.

Presently extensive test are done to determine accurately the energy balance as well as the quality of combustion gases being released to the atmosphere.

The tests indicate that:

- The TE-plant efficiency is 53\% $\}$ Refer to Note 1, Table 2-9. The efficiency was measured during a certain period at different loads \& did not appear to change. By improving the exhaust gas heat exchanger \& using the heat from the lub cil \& jacket cooling water the efficienфy This project is: $\square$ planned $\square$ in-progress $\square$ completed could be improved by 14 yse Box No. 16 if additional space is needed

10. Utility Services

ख Xelectrical power

XX.

$\square$ wastewater treatment
$\square$ solıd waste processing

$\square$ potable water

public 7 private

potable hot water

cooperative

2. Exchange of data 


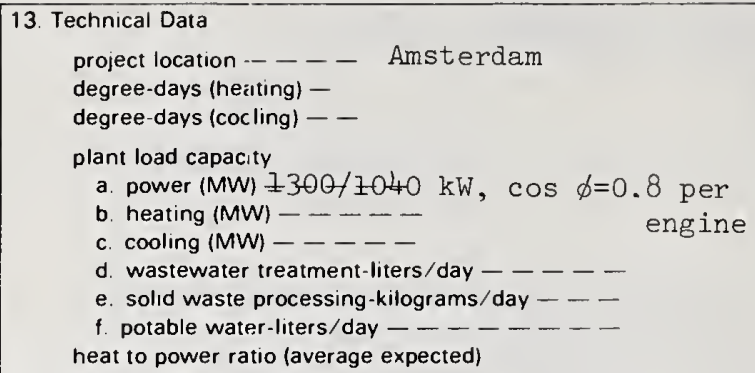

14. Other Related Projects (Titles)

15. Additional space for Purpose of Project

16. Additional space for Status and Results

The TE-plant efficiency could be increased to $71 \%$ by

- increasing the exhaust gas cooler $\pm 4 \%$

- recovery of waste heat engine jacket cooling water presently released to the atmosphere $14 \%$

Remark: The efficiencies are based on the lower heating value 


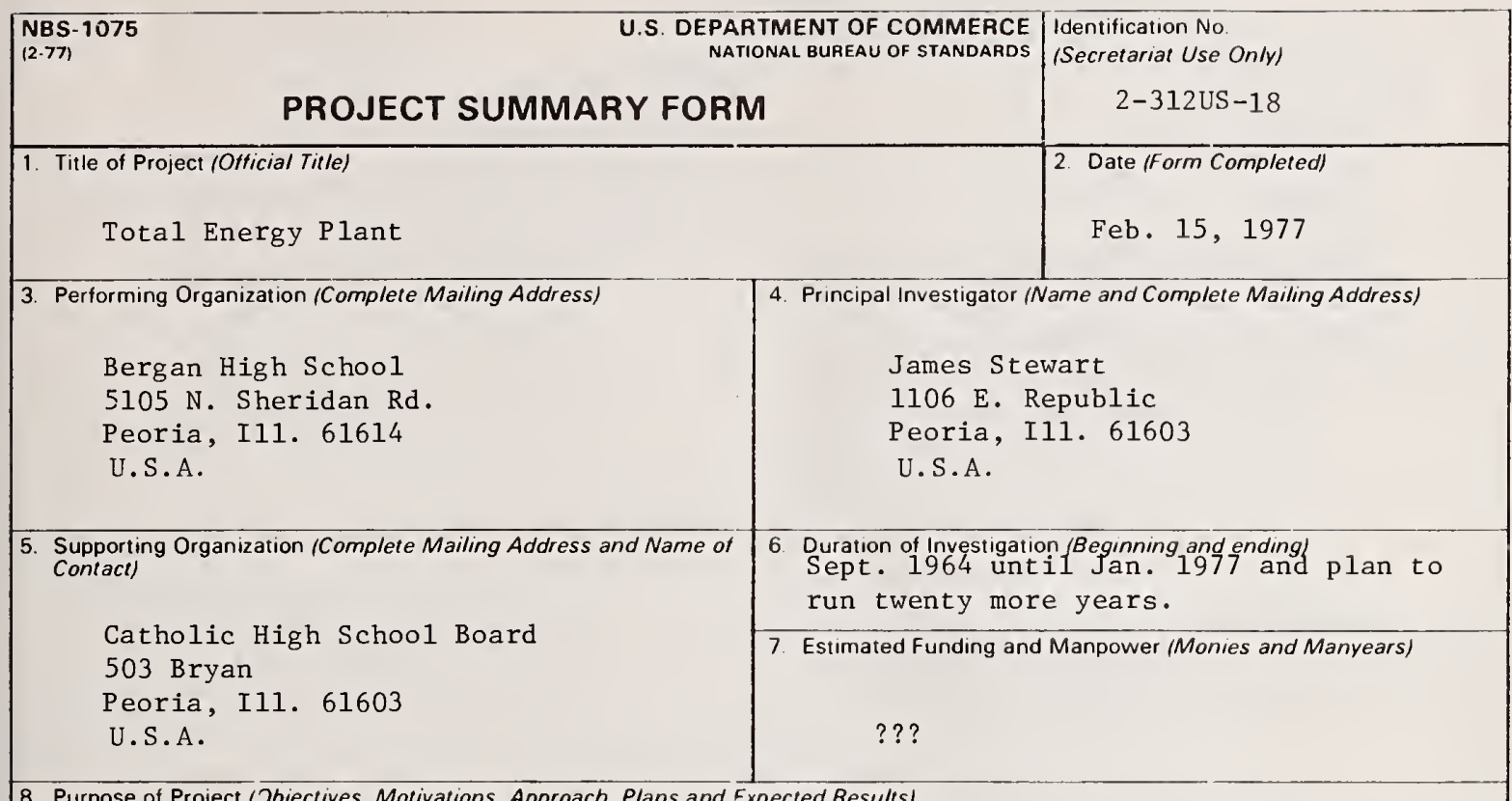

8. Purpose of Project (Jbjectives, Motivations, Approach, Plans and Expected Results)

To provide a home for the Christian Brothers teaching at Bergan. Also to provide a high school of $129,000 \mathrm{sq}$. ft. floor space, that is well insulated with airconditioning in the summer and in the winter heat the building using hot water and forced air. Fresh air from roof ducts via air handling units. All windows to the outside can not be opened.

Caterpillar engine 1400 R.P.M. $450 \mathrm{hp} 16 \mathrm{cy}$. diesel electric generator set at 400-480-3p. With transformer operating. The electric set for best resulted is out put $300 \mathrm{am}$. Ps 440-480-3p. This will heat the building and give electricity. We use 1 engine for 20 degrees and above and 2 engines for 20 degrees and below to 25 below zero like we have had this winter.

Use Box No. 15 if additional space is needed

9. Status and Results

The school has operated for over fourteen year with minimal problems.

This project is: $\square$ planned $\square$ in-progress completed

\begin{tabular}{ll}
\hline 10. Utility Services & \\
$\square$ electrical power & $\square$ wastewater treatment \\
$\square$ space heating & $\square$ solid waste processing \\
$\square$ space cooling & $\square$ potable water
\end{tabular}

Use Box No. 16 if additional space is needed

[X] potable hot water

12. Exchange of data

Will data be available from this project that will be shared with others?

XX Yes No 
13. Technical Data

project location

degree-days (heating) -

degree-days (cocling) - -

plant load capacity

a. power (MW) - - - - -

b. heating (MW) $\ldots \ldots$

c. cooling (MW)

d wastewater treatment-liters/day - - - -

e. solıd waste processing-kilograms/day _- -

f. potable water-liters/day $-\ldots-\ldots-\ldots$ heat to power ratio (average expected)

14. Other Related Projects (Titles)
Identification No

2-312US- 18

energy source

expected payback period

Type and size of user

a. residential (dwelling units)

b. residential (square area $-\mathrm{m}^{2}$ )

c. commercial (square area- $\mathrm{m}^{2}$ )

d. Industrial (thermal + elec.-MW)

15. Additional space for Purpose of Project

16. Additional space for Status and Results 


\begin{tabular}{|c|c|c|}
\hline \multicolumn{2}{|l|}{$\begin{array}{l}\text { NBS-1075 } \\
(2-77)\end{array}$} & $\begin{array}{l}\text { Identification No } \\
\text { (Secretariat Use On(y) } \\
2-321 \text { US - } 19\end{array}$ \\
\hline $\begin{array}{l}\text { 1. Title of Project (Official Title) } \\
\text { Wilkes-Barre Area Vocationa1-Technical S } \\
\text { Total Energy Plant }\end{array}$ & 1001 & $\begin{array}{l}\text { 2. Date (Form Completed) } \\
2-3-77\end{array}$ \\
\hline $\begin{array}{l}\text { 3. Performing Organization (Complete Mailing Address) } \\
\text { Robert F. Jones, Director, Voc. Ed. } \\
\text { Wilkes-Barre Area Voc.-Tech School } \\
\text { P.O. Box } 1699 \text {, North End Station } \\
\text { Wilkes-Barre, Pennsylvania } 18705 \\
\text { U.S.A. }\end{array}$ & $\begin{array}{l}\text { 4. Principal Investigator } \mathrm{N} \\
\text { Robert F. Jones } \\
\text { Wilkes-Barre Ar } \\
\text { P.O. Box 1699, } \\
\text { Wilkes-Barre, P } \\
\text { U.S.A. }\end{array}$ & $\begin{array}{l}\text { Vame and Complete Mailing Address) } \\
\text { Director, Voc. Ed. } \\
\text { ea Voc.-Tech School } \\
\text { North End Station } \\
\text { ennsylvania } 18705\end{array}$ \\
\hline $\begin{array}{l}\text { 5. Supporting Organization (Complete Mailing Address and Name of } \\
\text { Contact) } \\
\text { Joint Operating Committee } \\
\text { Wilkes-Barre Area Voc-Tech School } \\
\text { P.O. Box } 1699 \text {, North End Station } \\
\text { Wilkes-Barre, Pennsylvania } 18705 \\
\text { U.S.A. }\end{array}$ & $\begin{array}{l}\text { 6. Duration of Investigatio } \\
\text { Unknown } \\
\text { 7. Estimated Funding and } \\
\$ 8,350,000 \text { for } \\
\$ 800,000 \text { for }\end{array}$ & $\begin{array}{l}\text { Manpower (Monies and Manyears) } \\
25 \text { years } \\
6 \text { years }\end{array}$ \\
\hline
\end{tabular}

8. Purpose of Project (Jbjectives, Motivations. Approach, Plans and Expected Results)

To provide all of the electricity (except for emergency corridor lighting) and all heat for a Vocational High School. The system also air-conditions all of the classrooms, the administrative officies, the cafeteria and kitchen and most of the shopts.

Five engines fueled by propane (LPG) or natural gas from a pipeline turn generators that make electricity. Hot water passed through the engine jackets is further heated by the engine exhaust in a heat recovery unit. Steam from the separator unit is used to heat water for cooking, sinks, and showers; to heat water to a higher temperature for building heat, and during warm weather, to provide energy for chilling water for air conditioning.

A computer monitors the overall operation of the entire T.E. System. It also monitors operational functions at 252 points in the power room and throughout the school building.

Use Box No. 15 if additional space is needed

9. Status and Results

Initial structure completed in September 1972

Expansion completed in September 1975

This project is: $\square$ planned $\square$ in-progress $\square$ completed

区electrical power

space heating

$\triangle$ space cooling

$\nabla$ potable hot water

$\begin{array}{ll} & {[] \text { wastewater treatment }} \\ & {[] \text { solid waste processing }} \\ & \vdots] \text { potable water }\end{array}$

[] wastewater treatment

T. solid waste processing

12. Exchange of data

Will data be available from this project that will be shared with others?

$\square$ Yes

$\nabla$ No 


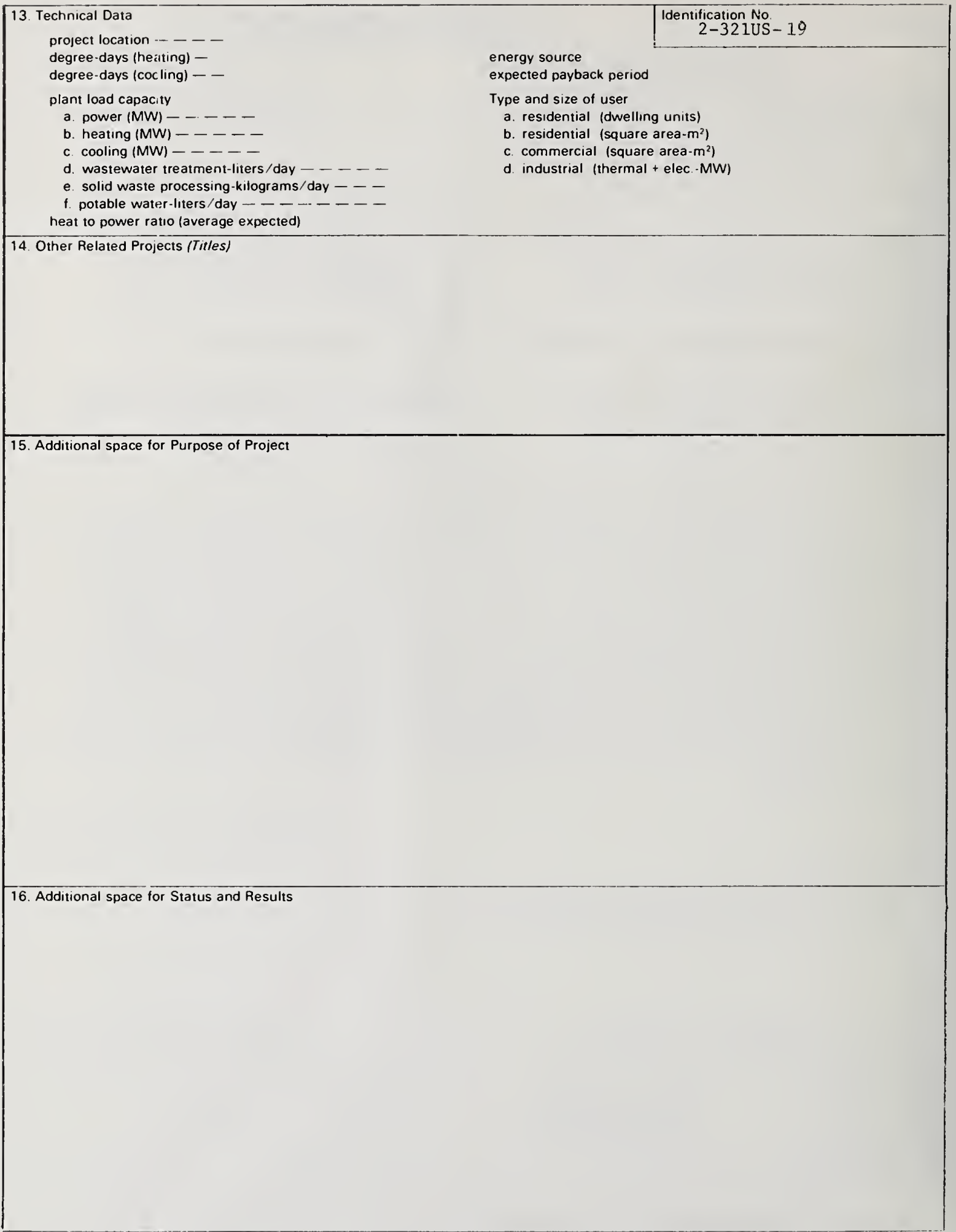


Use Box No 15 if additional space is needed

$$
\begin{array}{|l}
\hline 1 \\
\hline \\
\hline \\
\hline 1 \\
\hline
\end{array}
$$

\begin{tabular}{|c|c|c|}
\hline \multicolumn{2}{|c|}{$\begin{array}{l}\text { U.S. DEPARTMENT OF COMMERCE } \\
\text { NATIONAL BUREAU OF STANDARDS }\end{array}$} & $\begin{array}{l}\text { Identification No } \\
\text { (Secretariat Use Only) } \\
2-401 \mathrm{IE}-20\end{array}$ \\
\hline $\begin{array}{l}\text { 1. Title of Project (Official Title) } \\
\text { Total Energy Hospital (Brescia) }\end{array}$ & & $\begin{array}{l}\text { 2. Date (Form Completed) } \\
\qquad 1 / 22 / 77\end{array}$ \\
\hline $\begin{array}{l}\text { 3. Performing Organization (Complete Mailing Address) } \\
\text { CISE } \\
\text { C.P. } 3986 \\
20100 \text { Milano } \\
\text { (Italy) }\end{array}$ & \multicolumn{2}{|l|}{$\begin{array}{l}\text { Ing. Giuseppe M } \\
\text { Unita Tecnologi } \\
\text { CISE, C.P. } 3986 \\
20100 \text { Milano (It }\end{array}$} \\
\hline $\begin{array}{l}\text { 5. Supporting Organization (Complete Mailing Address and Name of } \\
\text { Contacl) } \\
\text { Progetto finalizzato "Energetica" } \\
\text { del Consiglio Nazionale delle Ri- } \\
\text { cerche - Via Morgagni, 30/E, Roma } \\
\text { ing. Publio Fedi }\end{array}$ & $\begin{array}{l}\text { 6. Duration of Investigatic } \\
\text { N/A } \\
\text { 7. Estimated Funding and } \\
10.000 .000 \text { lire } \\
1 \text { man year }\end{array}$ & Manpower (Monies and Manyears) \\
\hline
\end{tabular}

8. Purpose of Project (Jbjectives, Motivations, Approach, Plans and Expected Results)

The project, very interesting because of the induced energy and money savings, must be considered as a feasibility study for the application of the total energy concepts to a hospital.

The project will be referred to a medium size hospital ( 400 beds) under construction in Brescia, very close to the future residential district (San Polo) that will be the object of a similar feasibility study.

9. Status and Results

Work has just started with input data collection

This project is: $\square$ planned $\square$ in-progress $\square$ completed $\square$ wastewater treatment

$\square$ solid waste processing

$\square$ potable water

space cooling

potable hot water

Exchange of data

Will data be available from this project that will be shared with others?

\section{E}

NBS-1075 U.S. DEPARTMENT OF COMMERCE
NATIONAL BUREAU OF STANDAADS 


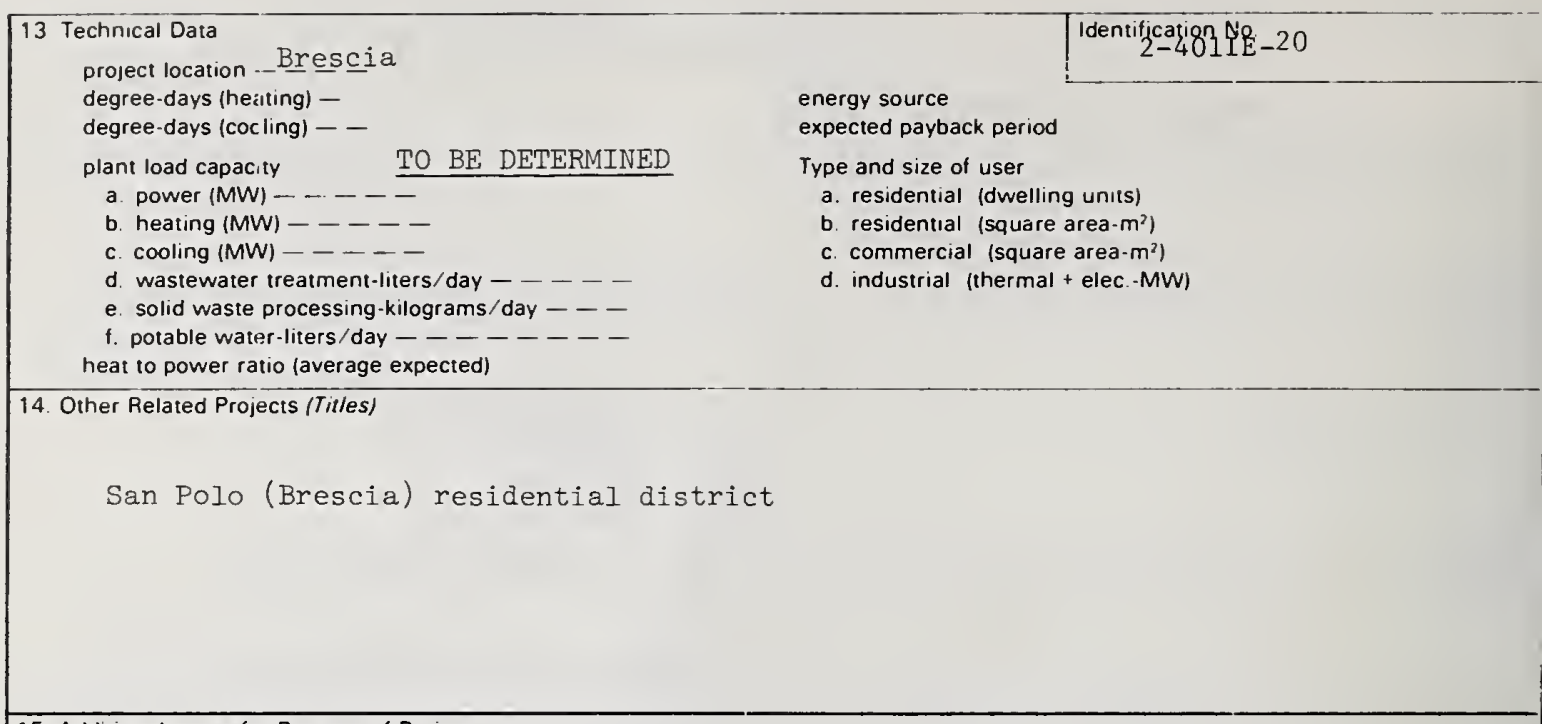

15. Additional space for Purpose of Project

16. Additional space for Status and Results 


NBS-1075 U.S. DEPARTMENT OF COMMERCE
NATIONAL BUREAU OF STANDARDS
(2.77)

PROJECT SUMMARY FORM

1. Title of Project (Official Tit/e)

Wilford Hall USAF Medical Center

3. Performing Organization (Complete Mailing Address)

HQ USAF/PREE

Bolling AFB

Washington, D.C. 20332

U.S.A.

5. Supporting Organization (Complete Mailing Address and Name of Contact)

HQ USAF/PREE

Bolling AFB

Washington, D.C. 20332

U.S.A.

8. Purpose of Project ( Objectives, Motivations, Approach, Plans and Expected Results,

To produce electric power for a large medical center and utilize waste heat from the diesel engines for heating and cooling the complex. Project has an estimated annual requirement of $72,655 \times 10^{6} \mathrm{Btu}$ for heating, $38,696 \times 10^{6}$ Btu for cooling, $57,080 \times 10^{6} \mathrm{Btu}$ for processes, and $24,883,530 \mathrm{KWH}$ for electricity. Project has an estimated payout period of 5 years. Current plan is to install two 1495-ton electrically driven-chillers, two 905-ton absorption chillers and five 2000-KW Diesel-driven generators. The final design may modify the number and size of units.

Use Box No. 15 if additional space is needed

9. Status and Results

Study is complete. Project is under design. Construction contract award scheduled for summer of 1977 . 


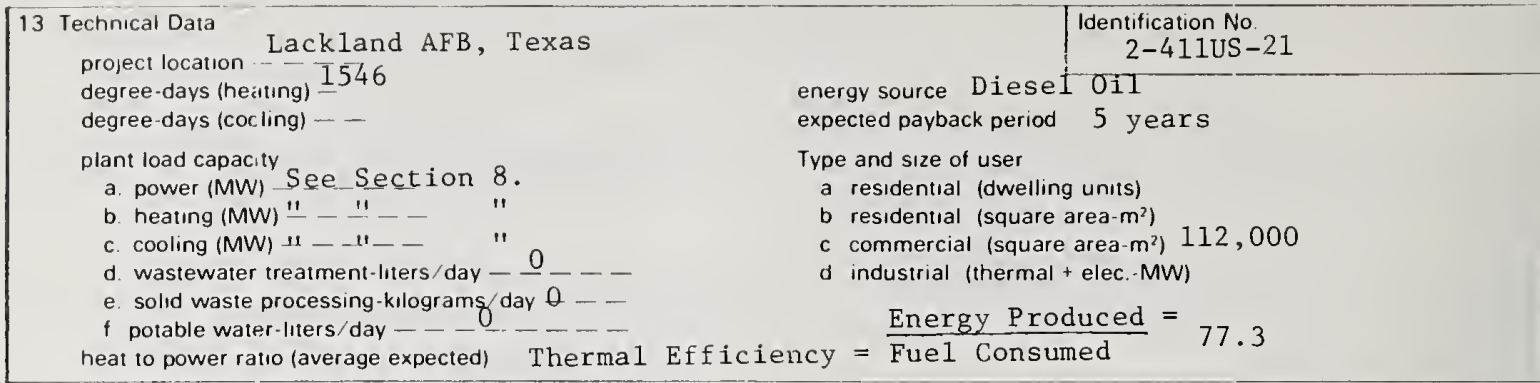

14 Other Related Projects (Titles)

15 Additional space for Purpose of Project

16. Additional space for Status and Results 


\begin{tabular}{|c|c|c|c|}
\hline \multicolumn{3}{|c|}{$\begin{array}{l}\text { NBS-1075 } \\
|2.77|\end{array}$} & $\begin{array}{l}\text { Identification No } \\
\text { (Secretariat Use On/y) } \\
2-420 \text { NL- } 22 \\
\text { 2. Date (Form Completed) } \\
3 / 14 / 77\end{array}$ \\
\hline & $\begin{array}{l}\text { Purpose of Project (Objectives, Motivations. Approach. Plans and } \\
\text { Objective: To provide electricity and S } \\
\text { Motivation: Obtaining technical and econc } \\
\text { gas at higher efficiency into heat and } \\
\text { systems. } \\
\text { Approach: } \\
\text { - Instgllation of } 3 \text { gas engine (Waukesha- } \\
\text { l200 rpm, } 735 \mathrm{kVA} \text {, of which one is sf } \\
\text { - Recovery of waste heat } \\
\text { o engine jacket cooling water ) ebu } \\
\text { o exhaust gas } \\
\text { - Gas fired boilers } \\
\text { - Absorption cooler } \\
\text {-Grid Connection }\end{array}$ & $\begin{array}{l}\text { xpected Results) } \\
\text { ace heating for a } \\
\text { mical advantage bj } \\
\text { electricity by } 10 \\
\text { I } 5108 \text { ) driven el } \\
\text { are } \\
\text { 11ient } \\
\text { i, } 1500 \mathrm{~kg} / \mathrm{hr} \text { ste }\end{array}$ & $\begin{array}{l}\text { hospital. } \\
\text { y transforming natural } \\
\text { cal integration of utility } \\
\text { ectric generators (V.Kaich) } \\
\text { am/unit }\end{array}$ \\
\hline
\end{tabular}

Use Box No. 15 it additional space is needed

9. Status and Results
The plant has been in operation since August 1974. Results extrapolated from data obtained for the period January-October 1975.

- efficiency TE-plant

- efficiency electr. supply

$70.3 \%$ 」

- efficiency heat supply

$21.8 \%$ ] Refer to Note 1, Table 2-9

$48.5 \%$

This project is: $\square$ planned $\square$ in-progress completed Use Box No 16 if additional space is needed \begin{tabular}{l}
10 \\
$x$ \\
$x$ \\
$\square$ \\
\hline 12 \\
\hline
\end{tabular}

Utility Services

electrical power

wastewater treatment

space heating

$\square$ solıd waste processing

space coolıng

$\square$ potable water

11. Type of Project

public $\square$ private

potable hot water

2. Exchange of data

Will data be available from this project that will be shared with others?

Yes

No

Request 3 and 4 
13. Technical Data

project location -.. - - ZUTPHEN

degree-days (heáting) -

degree-days (cocling) - -

plant load capacity

a. power (MW) $980 \mathrm{~kW} \pm 100 \mathrm{~kW}$ grid

b. heating (MW)

c. cooling (MW) $-\ldots-\ldots$

d. wastewater treatment-liters/day $-\ldots-\ldots$

e. solid waste processing-kilograms/day _ _ _.

f. potable water-liters/day - _ - _ - - -

heat to power ratio (average expected)
Identificatign No

$-420 N \mathrm{~L}-22$

energy source natural gas expected payback period

9.17 years

Type and size of user
a. residential (dwelling units)
b. residential (square area- $\mathrm{m}^{2}$ )
c. commercial (square area- $\mathrm{m}^{2}$ )
d. industrial (thermal + elec.-MW)
e. hospital: 450 beds

14. Other Related Projects (Titles)

15. Additional space for Purpose of Project

16. Additional space for Status and Results

Total cost of investment TE-plant (including connection cost etc. project financing, and design cost) Dfl. 1,894,997.

Remark: Efficiencies based on lower heating values 


\begin{tabular}{|c|c|c|}
\hline \multicolumn{2}{|l|}{ PROJECT SUMMARY FORM } & \multirow{2}{*}{\begin{tabular}{|l}
$\begin{array}{l}\text { Identification No. } \\
\text { (Secretariat Use Only) } \\
2-421 \mathrm{NL}-23\end{array}$ \\
$\begin{array}{c}\text { Date (Form Completed) } \\
3 / 14 / 77\end{array}$
\end{tabular}} \\
\hline $\begin{array}{l}\text { 1. Title of Project (Official Title) } \\
\text { Total Energy Plant for LUKAS Hospital }\end{array}$ & & \\
\hline $\begin{array}{l}\text { 3. Performing Organization (Complete Mailing Address) } \\
\text { Ir. B. Verhoef } \\
\text { DYNAF } \\
\text { Kwakelkade } 29, \text { P.O.Box } 54 \\
\text { ALKMAAR, The Netherlands }\end{array}$ & $\begin{array}{l}4 \text { Principal Investigator } / \\
\text { Ir. P.H.H.Leije } \\
\text { Raadgevend Tech } \\
\text { Van Heugten B.V } \\
\text { St. Annastraat } \\
\text { NIJMEGEN, The }\end{array}$ & $\begin{array}{l}\text { Lame and Complete Mailing Address) } \\
\text { ndekkers, Mr. Liebeek } \\
\text { nics Advies Bureau } \\
\text { i43-147 } \\
\text { Jetherlands }\end{array}$ \\
\hline $\begin{array}{l}\text { 5. Supporting Organization (Complete Mailing Address and Name of } \\
\text { Contact) } \\
\text { Mr. Schaa fsma } \\
\text { LUKAS Hospital } \\
\text { Albert Schweitzerlaan } 31 \\
\text { APELDOORN, The Netherlands }\end{array}$ & $\begin{array}{l}\text { 6. Duration of Investigatic } \\
\text { January } 1972- \\
\text { 7. Estimated Funding anc } \\
\text { Df } 1.2,200,000\end{array}$ & $\begin{array}{l}\text { (Beginning and ending) } \\
\text { September } 1973 \\
\text { Manpower (Monies and Manyears) } \\
--\end{array}$ \\
\hline $\begin{array}{l}\text { 8. Purpose of Project (Jbjectives, Motivations. Approach Plans and } \\
\text { Objective: To provide electricity, spact } \\
\text { Motivation: To take technical and econom } \\
\text { efficiency in transforming natur } \\
\text { local integration of systems. } \\
\text { Approach: } \\
\text { - Installation of } 3 \text { gas engine drive } \\
\text { - Recovery of waste heat } \\
\text { o engine jacket cooling water } \\
\text { o exhaust gas } \\
\text { - Gas fired boilers } \\
\text { - Grid connection for additional el } \\
\text { - Absorption coolers }\end{array}$ & $\begin{array}{l}\text { heating Results } \\
\text { cal advantage of } t \\
\text { gas into heat, } \\
\text { n electric generat } \\
\text { ctricity supply }\end{array}$ & $\begin{array}{l}\text { ng for a hospital. } \\
\text { he increase of overall } \\
\text { lectricity, etc. by } \\
\text { ors }\end{array}$ \\
\hline
\end{tabular}

Use Box No. 15 if additional space is needed

9. Status and Results

The plant has been in operation since 1974

Results (1975)

- efficiency TE-plant $74.4 \%$

- efficiency electr. supply $28.8 \%$ ]Kefer to Note 1, Table 2-9

- efficiency heat supply $45.6 \%$

This project is: $\square$ planned $\square$ in-progress $\square$ completed

10. Utility Services

space cooling

electrical power

space heating

x potable hot water

12. Exchange of data

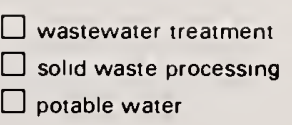

$\square$ wastewater treatment

$\square$ potable water

Will data be available from this project that will be shared with others?
Use Box No. 16 if additional space is needed

11. Type of Project

$\square$ public $\square$ private

cooperative

$\square$ Yes

No

Request 4 
13. Technical Data

project location.

Apeldoorn

degree-days (heating) -

degree-days (cocling) - -

plant load capacity

a. power (MW) $1400 \mathrm{~kW}+100 \mathrm{Grid}$

b. heatıng (MW) - $\ldots$

c. cooling (MW) - - - -

d. wastewater treatment-liters/day _ _ _ -

e. solid waste processing-kilograms/day - - -

f. potable water-liters/day -------heat to pr er ratio (average expected)

14. Other Related Projects (Tit/es)

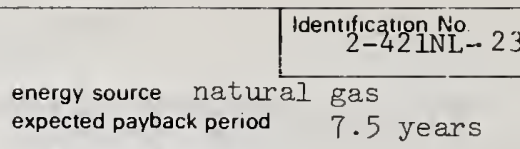

Type and size of user

a residential (dwelling units)

b. residential (square area- $\mathrm{m}^{2}$ )

c. commercial (square area- $\mathrm{m}^{2}$ )

d. industrial (thermal + elec. $M W$ )

e. hospital - 500 beds

15. Additional space for Purpose of Project

16. Additional space for Status and Results

Cost of investment (connection, instrumentation, tools, project financing design cost) Df1. 2,202,400.

Payback period on basis of net savings 7.42 years.

Remark: Efficiencies based on lower heating values. 
Identification No.

(Secretariat Use On/y)

2-4 22NL-24

PROJECT SUMMARY FORM

1. Title of Project (Official Tit/e)

2. Date (Form Completed)

Total Energy Plant

St. Anna Hospital

$3 / 14 / 77$

3. Performing Organization (Complete Mailing Address)

Ir. A. Verhoef

DYNAF B.V.

Kwakelkade 29, P.0. Box 54

ALIMAAR

The Netherlands

(2)

\section{Supporting Organization (Complete Mailing Address and Name of Contact)}

C.Th. M. Dalessi

St. Anna Hospital

GELDROP

The Netherlands
4. Principal Investigator (Name and Complete Mailing Address)

Ir. P.H.H.Leijendekkers

Raadgevend Technish

Van Heugten B.V.

St. Annastraat $143-147$

NIJMEGEN

The Netherlands

6. Duration of Investigation (Beginning and ending)

August 1969 - July 1971

7. Estimated Funding and Manpower (Monies and Manyears)

approx. Dfl. 1,300,000 --

\section{Purpose of Project (Jbjectives, Motivations, Approach, Plans and Expected Results)}

Objective: To provide electricity and space heating for a hospital

Motivation: To take technical and economical advantage of the increase of overall efficiency in transforming natural gas into heat, electricity, etc. by local integration of systems.

Approach:

- Installation of 3 gas engine driven electric generators of which one is spare

- Recovery from waste heat

- engine jacket cooling water

- exhaust gas

-Gas fired boilers

- Grid Connection for additional electricity supply

Use Box No. 15 if additional space is needed

\section{Status and Results}

The plant has been in successful operation since 1972

Data from 1975

- efficiency TE-plant $71.98 \%$

- efficiency electr. supply $27.18 \%$

- efficiency heat supply $44.80 \%$

]Refer to Note 1, Table 2-9.

IEfficiencies are based on total energy delivered and consumed over a full year.

This project is: $\square$ planned $\square$ in-progress 6 completed

\section{Utility Services}

space heaing

space heating

space cooling

potable hot water $\square$ wastewater treatment

$\square$ solid waste processing

$\square$ potable water
Use Box No. 16 if additional space is needed

Will data be available from this project that will be shared with others?

G. Yes

No 
13 Technical Data

project location - - - - Geldrop

degree-days (heatung) -

degree-days (coclıng) - -

plant load capacity

a power (MW) - 1080_kW

b. heating (MW) $-\cdots$

c. cooling (MW) - - -

d wastewater treatment-hiters/day _ - - -

e. solid waste processing-kilograms/day $-\ldots$

f. potable water-liters/day ------heat to power ratio (average expected)

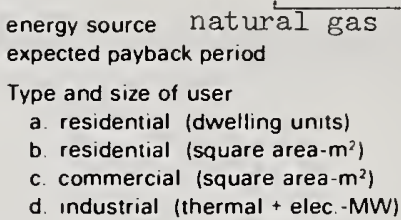

Type and size of user

a. residential (dwelling units)

b. residential (square area- $\mathrm{m}^{2}$ )

c. commercial (square area- $\mathrm{m}^{2}$ )

d. Industrial (thermal + elec. $-\mathrm{MW}$ )

14. Other Related Projecis (Tules)

15. Additional space for Purpose of Project

16. Additional space for Status and Results

- Total efficiency TE-plant + gas fired boilers $78.64 \%$

- Load factor 0.566

- Average load 47\% (of power of one engine)

Reports of technical and economical data are available in Dutch language

Contact: "Beheer en Onderhouri"

MISSET

P.O.BOX 4

DOETINCHEM

Remark: Efficiencies based on lower heating value- 


$\begin{aligned} & \text { NBS-1075 } \\ & (2-77)\end{aligned}$
U.S. DEPARTMENT OF COMMERCE
NATIONAL BUREAU OF STANDAROS

PROJECT SUMMARY FORM

1. Title of Project (Official Title)

Sioux Valley Hospital Total Energy Plant

3. Performing Organization (Complete Mailing Address)

Sioux Valley Hospital

1100 S. Euclid

Sioux Falls, SD 57105

U.S.A.
Identification No

(Secretariat Use Only)

$$
\text { 2-422Us-25 }
$$

2. Date (Form Completed)

$2-2-77$

\section{Supporting Organization /Complete Mailing Address and Name of} Contact)

Sioux Valley Hospital

1100 S. Euclid

Sioux Falls, SD 57105 U.S.A.

Gary Rothenbuehler

Purpose of Project (Jbjectives, Motivations. Approach, Plans and Expected Results)

To provide the most economical, reliable and pollution free source of power, heating and air conditioning for our hospital.

Commenced operation in April 1971 and all of our objectives have been fulfilled.

Original thought of Total Energy was conceived after we realized that we would have to have had two generators for emergency power anyway, so we installed three with the intention of the plant paying itself off in ten years.

Use Box No. 15 if additional space is needed

9. Status and Results

We are currently in full operation but due to critical shortage of natural gas and the rising prices we find it is not economically feasible to continue in our current status. By 1980 we will be back into a steam and refrigeration plant with back up electrical systems for outages. We will again be purchasing our electricity.

This project is: $\square$ planned $\square$ in-progress $\square$ completed

potable hot water

2. Exchange of data

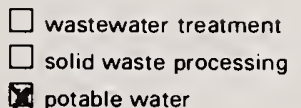

$\square$ solid waste processing

potable water

Will data be available from this project that will be shared with others?

Use Box No. 16 if additional space is needed

11. Type of Project

$\square$ public $\quad$ private

cooperative
Gary Rothenbuehler

Total Energy Plant Foreman

Sioux Falls, SD 57105

U.S.A. 


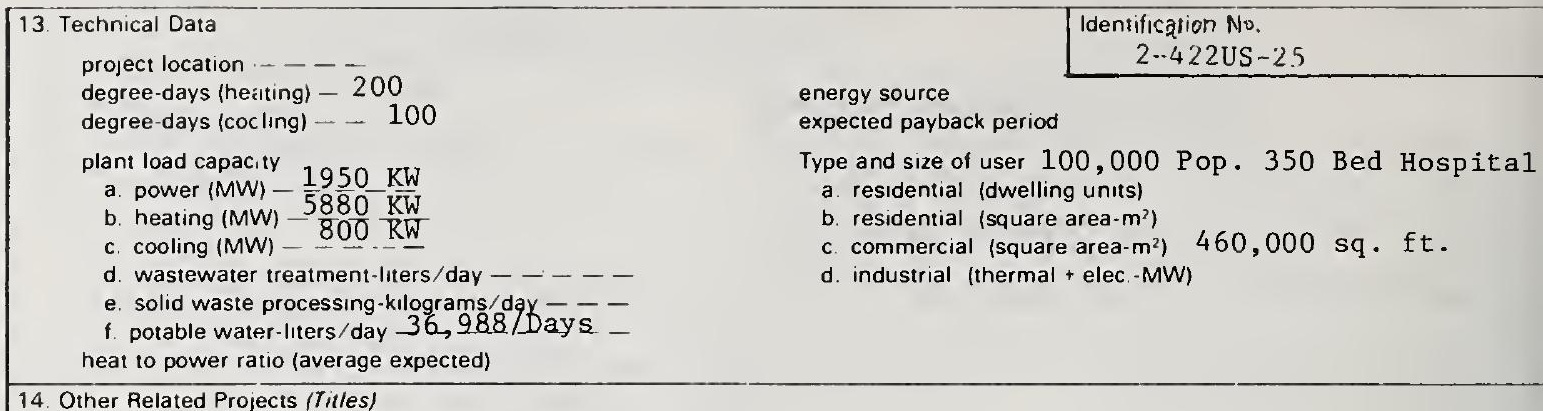

15. Additional space for Purpose of Project

16. Additional space for Status and Results 


$\begin{array}{lr}\begin{array}{l}\text { NBS-1075 } \\ (2.77)\end{array} & \text { U.S. DEPARTMENT OF COMMERCE } \\ \text { NATIONAL BUREAU OF STANDARDS }\end{array}$

PROJECT SUMMARY FORM

1. Title of Project (Otficial Title)

Total Energy System for a Greenhouse

3. Performing Organization (Complete Mailing Address)

Technical University of Denmark

Copenhagen, Denmark
Identification No

(Secretariat Use Only)
5. Supporting Organization (Complete Mailing Address and Name of
Contact)

Denmark
6 Duration of Investigation (Beginning and ending)

$$
10 / 76 \text { to } 9 / 77
$$

7 Estımated Funding and Manpower (Monies and Manyears)

NA

8. Purpose of Project (Jbjectives. Motivations. Approach. Plans and Expected Results)

A number of greenhouse crops can be raised advantageously entirely or partially with the use of a artifical lighting, which means that they will be able to be grown in a highly insulated greenhouse. The electric energy for the lighting fixtures is produced by local diesel generators, heat loss from the fixtures and the diesel motors in utilized for the heating of the entire greenhouse.

The purpose of the project is to work out an up-to-date outline of the project. If it is shown that the project is economic with respect to energy and/or money, a detailed project will be worked out that will then try to be realized.

Use Box No. 15 if additional space is needed

9. Status and Results

This project is: $\square$ planned $\square$ in-progress $\square$ completed

10. Utility Services

electrical power

A. space heating

$\square$ space cooling

$\square$ potable hot water

12. Exchange of data

Will data be available from this project that will be shared with others? $\square$ wastewater treatment

$\square$ solıd waste processing

$\square$ potable water

Use Box No. 16 if additional space is needed

11. Type of Project

$\triangle$ public $\square$ private

cooperative

$$
2-511 \mathrm{DK}-26
$$

Date (Form Completed)

$$
3-15-77
$$

Technical University of Denmark Copenhagen, Denmark 


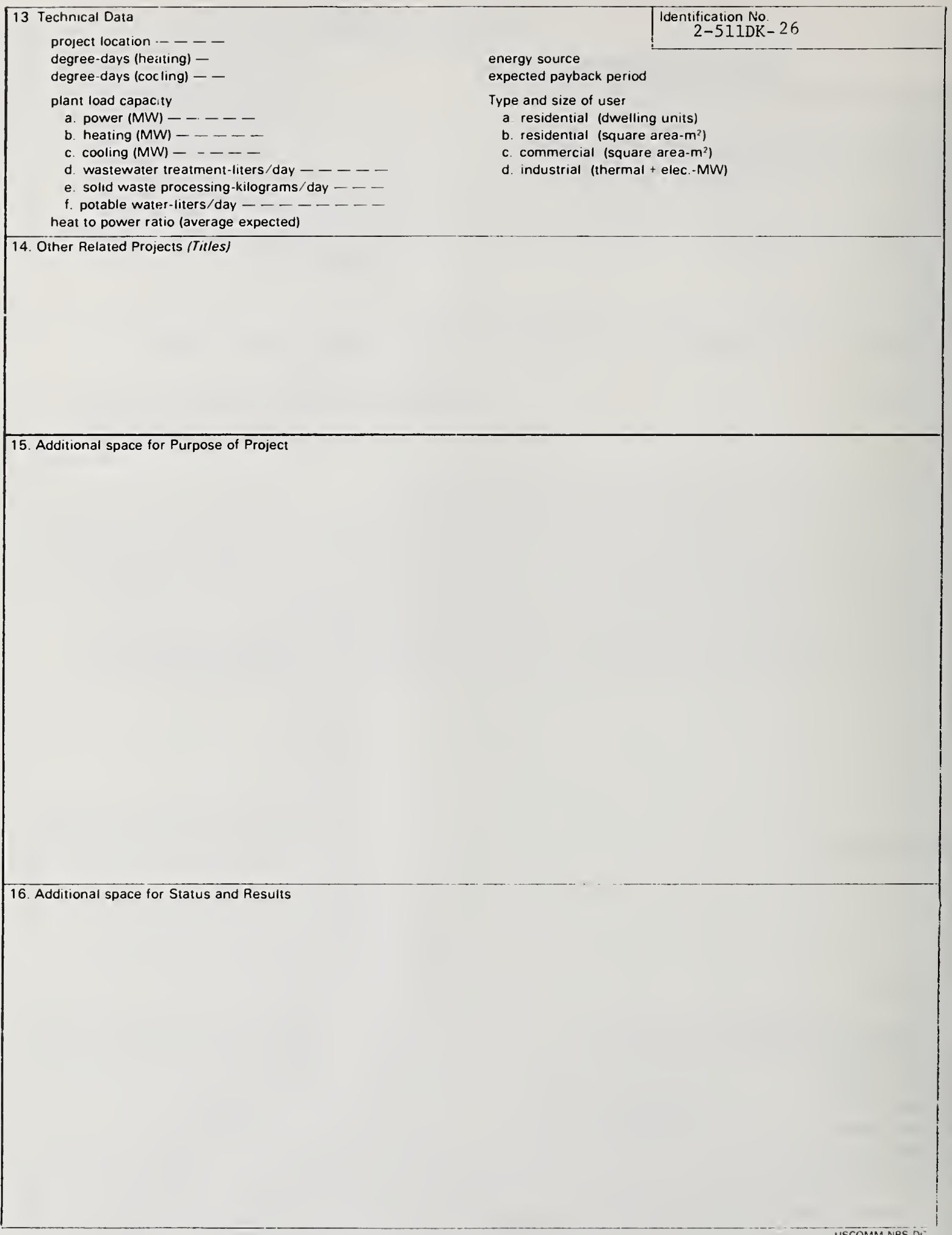




\begin{tabular}{|c|c|c|}
\hline \multicolumn{2}{|l|}{\begin{tabular}{|l|} 
NBS-1075 \\
$(2-77)$
\end{tabular}} & \\
\hline \multicolumn{2}{|l|}{$\begin{array}{l}\text { 1. Title of Project (Official Title) } \\
\text { Central Energy Plant - Walt Disney World }\end{array}$} & \\
\hline $\begin{array}{l}\text { 3. Performing Organization (Complete Mailing Address) } \\
\text { Reedy Creek Utilities Co., Inc. } \\
\text { P.O. Box } 40 \\
\text { Lake Buena Vista, Florida } 32830 \\
\text { U.S.A. }\end{array}$ & \multicolumn{2}{|c|}{$\begin{array}{l}\text { Earl Shaw } \\
\text { Manger, Energy Systems } \\
\text { Reedy Creek Utilities Co., Inc. } \\
\text { P.0. Box } 40 \\
\text { Lake Buena Vista, Florida } 32830 \text {, U.S.A. }\end{array}$} \\
\hline $\begin{array}{l}\text { 5. Supporting Organization (Complete Mailing Address and Name of } \\
\text { Contact) } \\
\text { N/A }\end{array}$ & \multicolumn{2}{|c|}{\begin{tabular}{|l} 
6. Duration of Investigation (Beginning and ending) \\
Cont inuing operat ional data for \\
on-line facility
\end{tabular}} \\
\hline \multicolumn{3}{|c|}{$\begin{array}{l}\text { 8. Purpose of Project (Objectives, Motivations. Approach. Plans and Expected Results) } \\
\text { Plant was constructed as a fully functional, advanced energy plant employing two } \\
\text { jet engines to generate power and recovering waste heat in high temperature hot } \\
\text { water (HTHW) boilers. } \\
\text { HTHW is partially used in absorption chillers to generate chilled water (CW) for } \\
\text { air conditioning. } \\
\text { An integrated underground distribution network distributes from the Central Energy } \\
\text { Plant, electrical power at } 12 \mathrm{KV} \text {, HTHW at } 400^{\circ} \text {, and CW at } 42^{\circ} \text { throughout the } 1200 \\
\text { acre developed area. HTHW is also pumped throughout the complex to supply all } \\
\text { heating needs such as spece heating, domestic hot water at hotels, cooking, reheat } \\
\text { for air conditioning etc. Chilled water is produced at the plant and pump through- } \\
\text { out the area to provide all cooling and air conditioning requirements. }\end{array}$} \\
\hline \multicolumn{3}{|c|}{$\begin{array}{l}\text { 9. Status and Results } \\
\text { The plant has been on line and operational for five and one-half years, and has been } \\
\text { a success. The versatility of using turbines, generators, boilers, absoprtion and an } \\
\text { advanced total energy system. } \\
\text { In times of national or regional fuel and power shortages, the complex has eased } \\
\text { the burden locally by utilizing our own fuel storage and generating capacity to its } \\
\text { maximum extent. Direct cut backs have been exercised to reduce utility loads during } \\
\text { emergencies by having complete control at one central energy palnt. } \\
\text { This project is: } \square \text { planned } \square \text { in-progress } \ \text { completed } \\
\text { Use Box No. } 16 \text { if additional space is needed }\end{array}$} \\
\hline \multicolumn{3}{|l|}{$\begin{array}{l}\text { 10. Utitity Services } \\
\text { electrical power } \\
\text { space heating } \\
\square_{\text {space cooling }} \\
\square \text { potable hot water } \\
\end{array}$} \\
\hline 12. Exchange of data & & \\
\hline
\end{tabular}




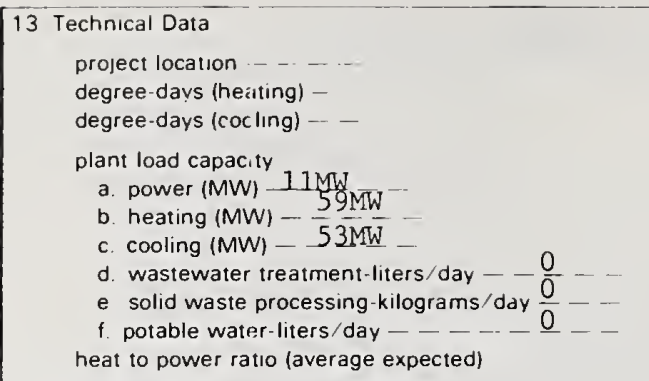

14. Other Related Projects (Tit/es)

Central Energy Plant Solar office Addition - a solar energy prototype office building with 3800 square feet of horizontal parabolic collectors serving as the roof. This is part of Walt Disney Production's Experimental Prototype Community of Tomorrow program. 


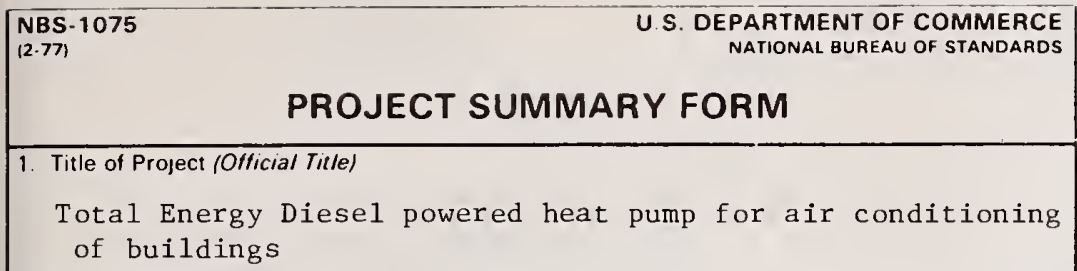

Identification No

(Secretariat Use On/y)

2-512IE-28

2. Date (Form Completed)

$11 / 15 / 76$

3. Performing Organization (Complete Mailing Address)

4 Prıncıpal Investıgator (Name and Complete Mailing Address)

FIAT - C.R.F.

Strada del Drosso, 145

10135 Torino

Italy 5. Supporting Organization (Complete Mailing Address and Name of
Contact)

Consiglio Nazionale delle Ricerche - CNR Progetto Finalizzato Energia - Cap. IX Piazzale delle Scienze, 7 - Roma Italy Prof. M. Silvestri

Ing. Armando Campanile

FIAT - C.R.F.

Strada del Drosso, 145

10135 Tor ino

Italy

6 Duration of Investıgation (Beginning and ending)

March 1976 - Dec. 1980

7. Estımated Funding and Manpower (Monies and Manyears)

Italian Liras 445 millions

6 man-years

8. Purpose of Project (Jbjectives, Motivations, Approach, Plans and Expected Results)

Construction and comparative operation of a pilot plant powered by a Diesel engine with an output of about $50 \mathrm{HP}$, for a peak heat requirement of about $140,000 \mathrm{kcal} / \mathrm{h}$ for winter heating (outdoor temperature of $-10{ }^{\circ} \mathrm{C}$ ) and of about half the above figure for summer cooling (this on account of the smaller heat differential required).

The novelty, with respect to the conventional heat pumps (electrically driven) is represented by the fact that the power is supplied by a thermal engine which allows the possibility of recovering the exhaust gas and coolant heat which would otherwise be lost.

The program develops through the following main phases : preliminary studies, study and design of the system, construction tests.

The final product is a running system for evaluating:

Use Box No. 15 i! additıonal space is needed

9. Status and Results

- Study and project of the system: completed

- Construction: is underway

This project is: $\square$ planned $\Omega$ in-progress $\square$ completed

Use Box No. 16 if additional space is needed 10. Utılity Services electrical power 国 space heating $\square$ space cooling $\square$ potable hot water wastewater treatment solid waste processing potable water 12. Exchange of data 


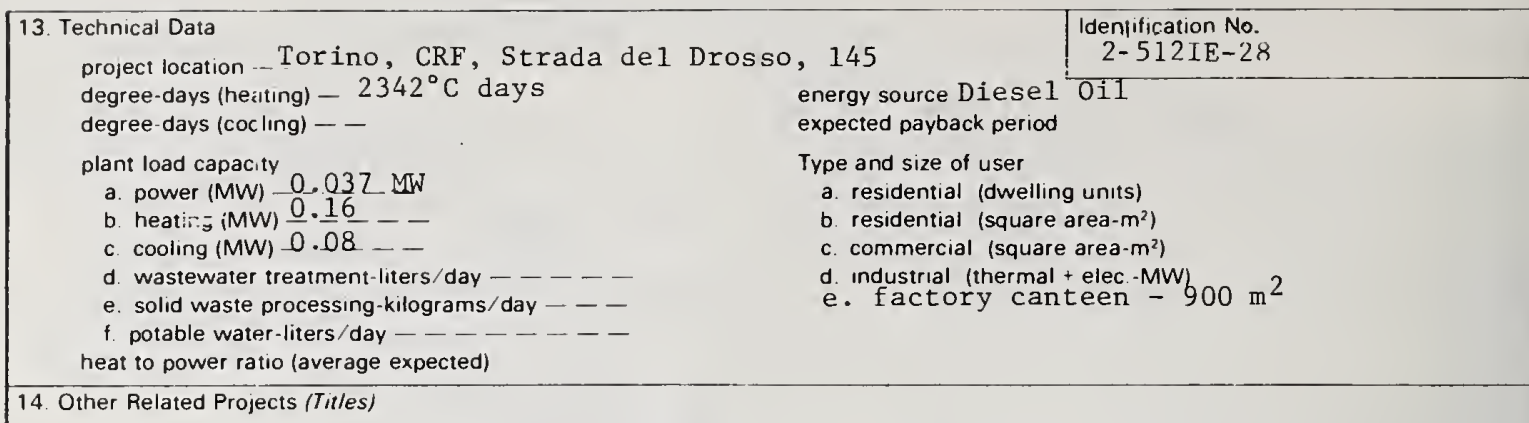

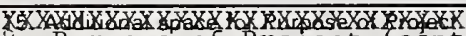

8. Purpose of Project (cont.)

- Operation of the system for a full season with critical processing of the experimental results obtained and comparison with the conventional system.

- The defrosting problem.
}

16. Additional space for Status and Results 


\begin{tabular}{|c|c|c|}
\hline $\begin{array}{r}\text { U.S. DEPA } \\
\text { PROJECT SUMMARY FORI }\end{array}$ & $\begin{array}{l}\text { TMENT OF COMMERCE } \\
\text { ONAL BUREAU OF STANDARDS }\end{array}$ & $\begin{array}{l}\text { Identification No. } \\
\text { (Secretariat Use On(y) } \\
2-522 \text { IE-29 }\end{array}$ \\
\hline $\begin{array}{l}\text { 1. Title of Project (Official Tit/e) } \\
\text { TOTAL ENERGY MODULE (TOTEM) }\end{array}$ & & $\begin{array}{c}2 \text { Date (Form Completed) } \\
11 / 15 / 76\end{array}$ \\
\hline $\begin{array}{l}\text { 3. Performing Organization (Complete Mailing Address) } \\
\text { FIAT - Centro Ricerche } \\
\text { U.R. Apparati Propulsivi } \\
\text { Strada del Drosso, } 145 \text { - Torino } \\
\text { Italy }\end{array}$ & $\begin{array}{l}4 \text { Principal Investıgator } \\
\text { Ing. A. Campan } \\
\text { C.R.F. } \\
\text { Strada del Dro } \\
\text { Italy }\end{array}$ & $\begin{array}{l}\text { Iame and Complete Mailing Address) } \\
\text { ile } \\
\text { sso, } 145 \text { - Torino }\end{array}$ \\
\hline $\begin{array}{l}\text { 5. Supporting Organization (Complete Mailing Address and Name of } \\
\text { Contact) } \\
\text { FIAT - Gruppo Auto } \\
\text { C. so G. Agnelli, } 200 \text { - Torino (Italy) } \\
\text { Dr. Dal Bo }\end{array}$ & $\begin{array}{l}\text { 6. Duration of Investigatı } \\
\text { Jan. } 1976-\mathrm{N} \\
700.000 \$ 5 \mathrm{~m}\end{array}$ & $\begin{array}{l}\text { (Beginning and ending) } \\
\text { Manpower (Monies and Manyears) } \\
\text { an years }\end{array}$ \\
\hline
\end{tabular}

8. Purpose of Project (Objectives, Motivations, Approach, Plans and Expected Results)

OBJECTIVE: To demonstrate technical and economic advantages of providing heat and electricity in small integrated groups

MOTIVATION: To increase efficiency in transforming natural gas in to heat and electricity

APPROACH : The "Total Energy" Group provides electricity by mean of an I.C. otto motor coupled with an a syncronous electric generator of $15 \mathrm{kw}$ power, at a constant speed of $3000 \mathrm{R} / \mathrm{M}$. 3 heat exchangers utilized heat of the cooling system and of the exhaust gases to heat water.

PLANS : Design and construct some prototypes of "Total Energy" groups.

Use Box No. 15 if additional space is needed

9. Status and Results

First prototype under preliminary tests other prototypes are under construction.

This project is: $\square$ planned $[$ in-progress $\square$ completed

\begin{tabular}{|l|l|}
\hline 10. Utility Services & 11 Type of Project \\
$\square$ electrical power & $\square$ wastewater treatment \\
$\square$ spece heatıng & $\square$ solid waste processing \\
$\square$ space cooling & $\square$ potable water \\
$\square$ potable hot water & $\square$ public \\
\hline
\end{tabular}

12. Exchange of data

Will data be available from this project that will be shared with others?

Yes

[X] No AT PRESENT 


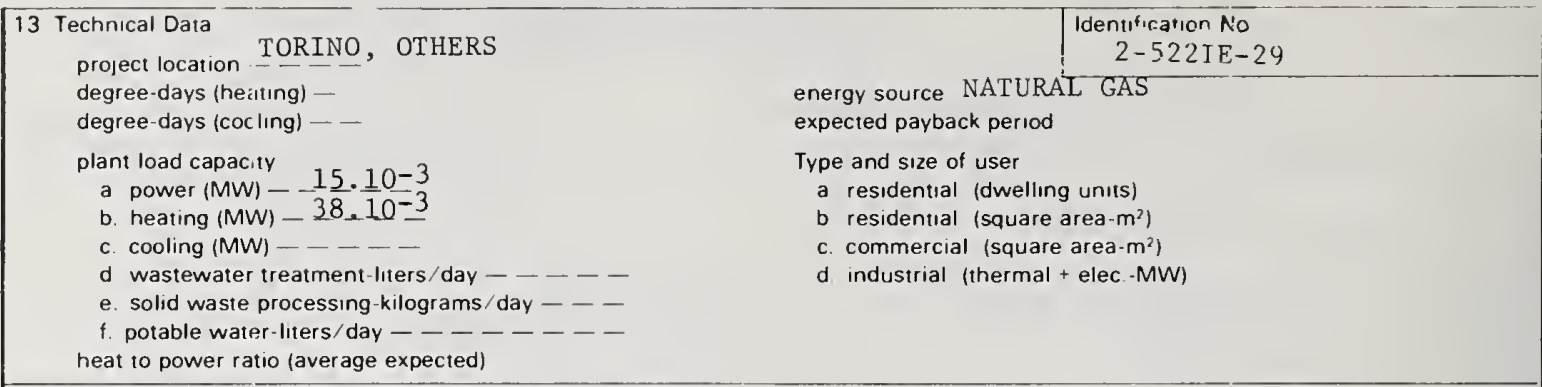

14. Other Related Projects (Tit/es)

Also see Project Summary Forms 3-122IE-06.

15. Additional space for Purpose of Project

16. Additional space for Status and Results 


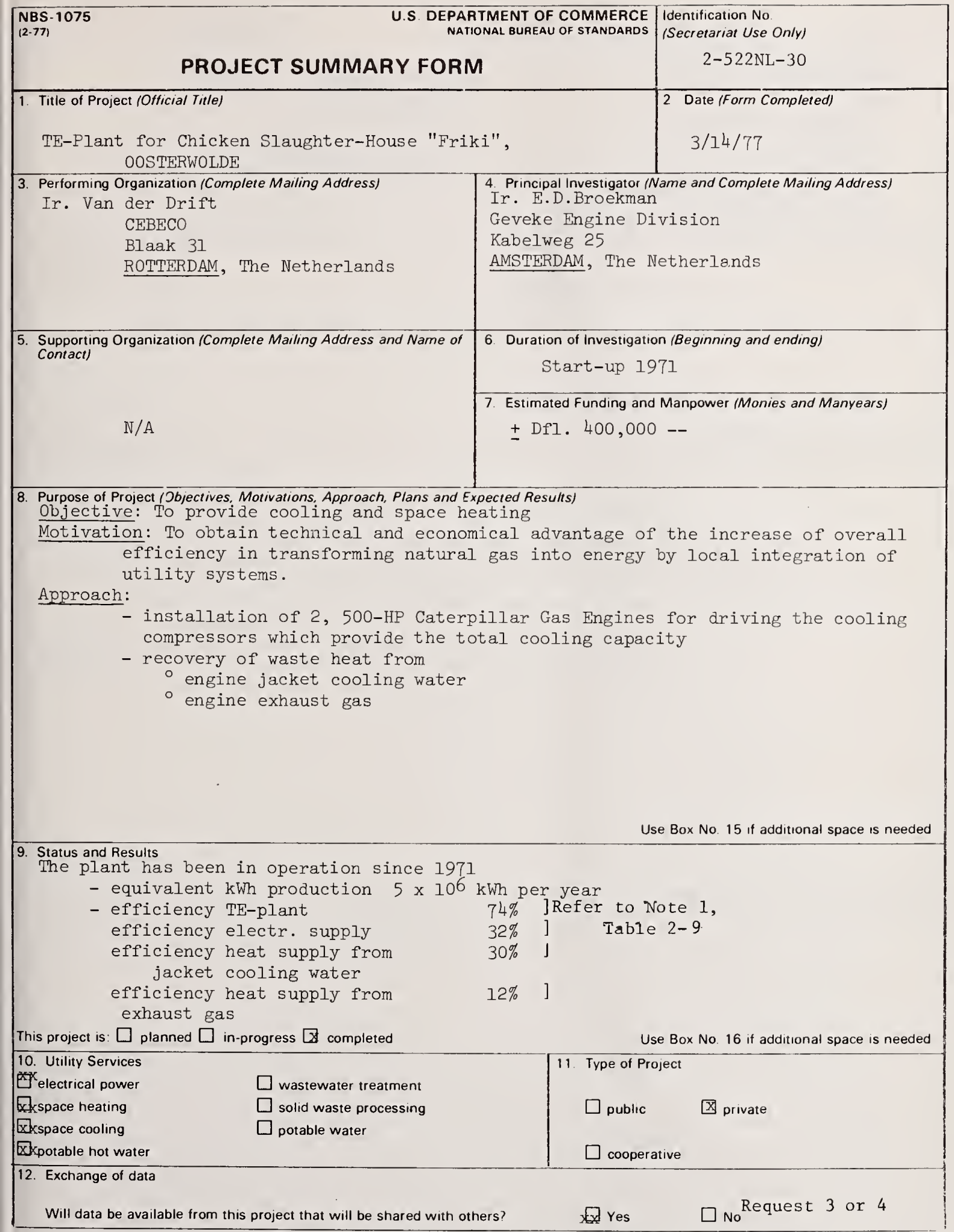




\begin{tabular}{|c|c|}
\hline 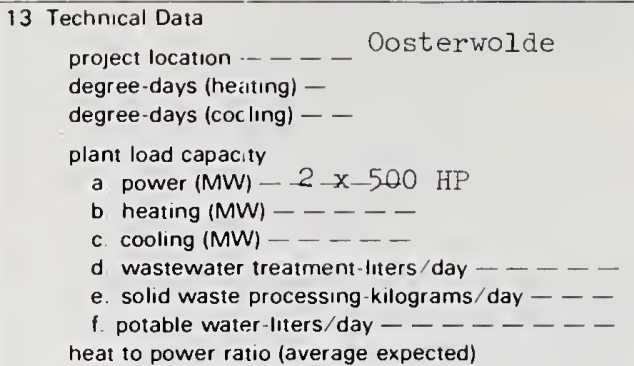 & 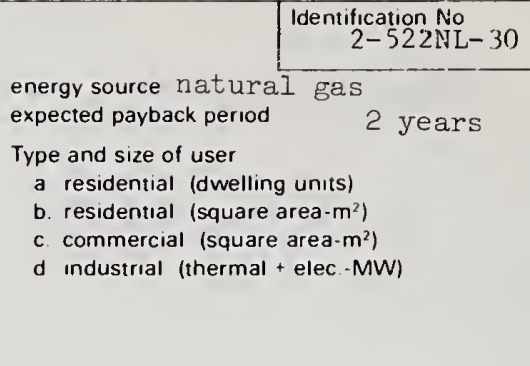 \\
\hline
\end{tabular}

14. Other Related Projects (Titles)

15. Additional space for Purpose of Project

16. Additional space for Status and Results

Remark: Efficiencies are based on lower heating value 
$\begin{aligned} & \text { NBS-1075 } \\ & (2-77)\end{aligned}$
U.S. DEPARTMENT OF COMMERCE
NATIDNAL BUREAU OF STANDARDS

PROJECT SUMMARY FORM

1. Title of Project (Officia/ Tit/e)

Total Energy Project for Aluminium Factory
4. Principal Investigator (Name and Complete Mailing Address) Mr. G.S.Bongers

Landre Ruhaak Motoren B.V.

Industrieweg

Vianen

The Netherlands

6. Duration of Investigation (Beginning and ending)

$$
2 / 76 \text { to } 11 / 76
$$

7. Estimated Funding and Manpower (Monies and Manyears)

Dfl. 500,000. -.3 man year

Kijckerweg 107

De Lier

The Netherlands

attn. Mr. J.J. Zitman

8. Purpose of Project (Jbjectives, Motivations, Approach, Plans and Expected Results)

Objectives: to transfer natural gas into electricity and heat

Motivation: electr. supply, heating factory, pre-heating bars in furnace

Approach: One natural gas engine direct coupled with alternator $800 \mathrm{kVA}$ to generate electricity, cooling water heat at $80^{\circ} \mathrm{C}$ is transferred to factory by a heat-exchanger and radiators. Exhaust gases of $625^{\circ} \mathrm{C}$ are conducted in the furnace

Plans: To generate cheaper power at lower costs of energy.

Exp. results: Heating savings approx. Dfl. 35.000. = per year

Electric cost savings Dfl. 125.000. = per year

Use Box No. 15 if additional space is needed

9. Status and Results

Installation is continuous in service for 144 hours per week.

The factory can be heated in wintertime at an average temp. of $18^{\circ} \mathrm{C}$

The bars are preheated up to $320^{\circ} \mathrm{C}$

In summer the cooling water heat will be rejected.

This project is: $\square$ planned $\square$ in-progress $\square$ completed

$$
\begin{array}{|l}
\hline 10 \\
\text { ख } \\
\text { ख } \\
\square \\
\square \\
\hline 12 \\
\hline
\end{array}
$$

Services

space cooling

potable hot water

2. Exchange of data

Will data be available from this project that will be shared with others?

$\square$ wastewater treatment

$\square$ solid waste processing

$\square$ potable water
Use Box No. 16 if additional space is needed 11. Type of Project

$\square$ public private

cooperative
Secretariat Use Only

$2-522 \mathrm{NL}-31$

$3 / 11 / 77$ 


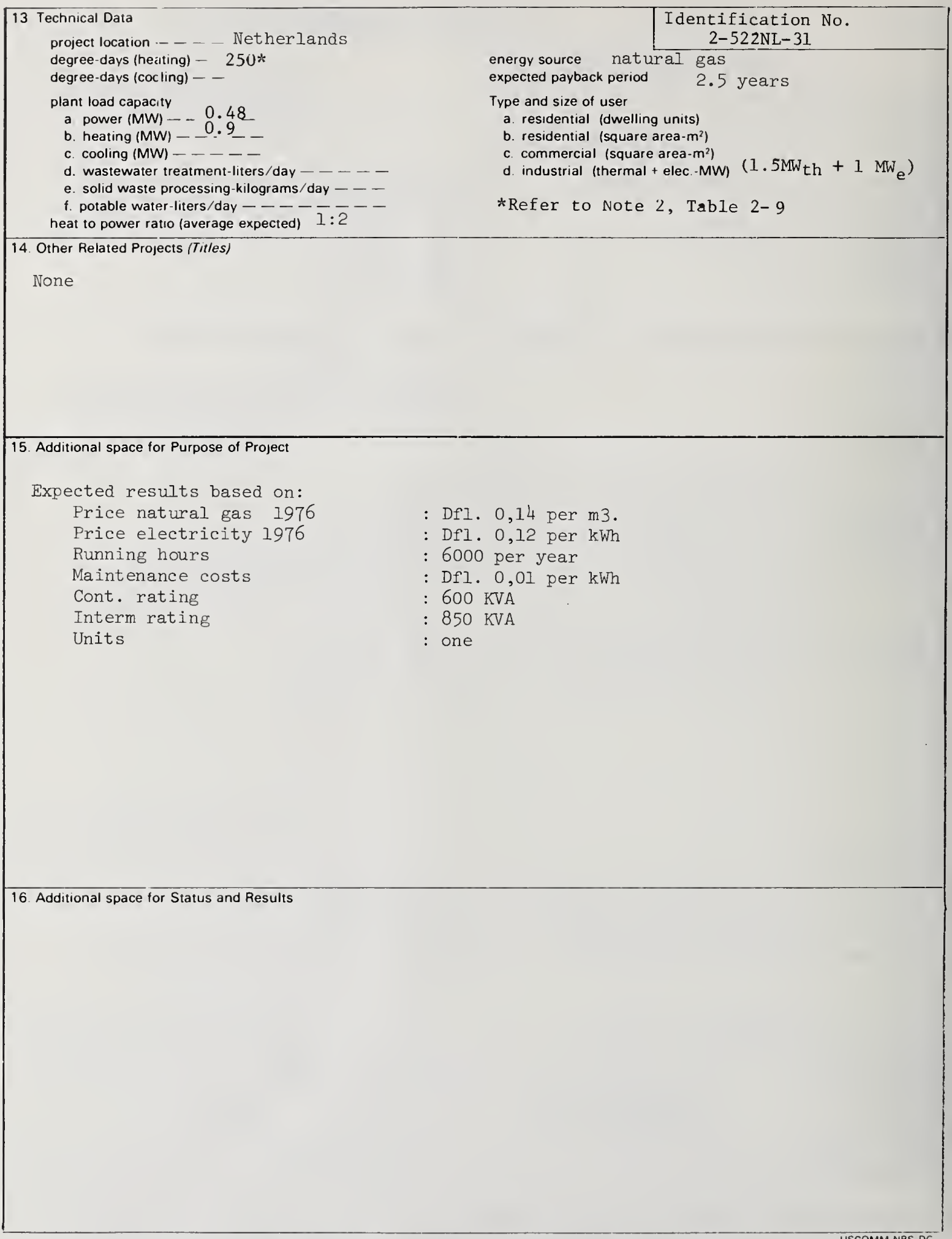




\begin{tabular}{|c|c|c|}
\hline \multicolumn{2}{|l|}{ PROJECT SUMMARY FOF } & $\begin{array}{l}\text { Identification No } \\
\text { (Secretariat Use Only) } \\
2-522 \text { NL-32 }\end{array}$ \\
\hline \multicolumn{2}{|l|}{$\begin{array}{l}\text { 1. Title of Project (Official Title) } \\
\text { Total Energy Plant for Greenhouse Boots }\end{array}$} & $\begin{array}{l}\text { 2. Date (Form Completed) } \\
3 / 14 / 77\end{array}$ \\
\hline $\begin{array}{l}\text { 3. Performing Organization (Complete Mailing Address) } \\
\text { DYNAF B.V. } \\
\text { Kwakelkade } 29, \text { P.O. Box } 54 \\
\text { ALKMAAR, The Netherlands }\end{array}$ & \multicolumn{2}{|c|}{ 4. Principal Investigator /Name and Complete Mailing Ac } \\
\hline $\begin{array}{l}\text { 5. Supporting Organization (Complete Mailing Address and Name of } \\
\text { Contact) } \\
\text { Mr. Boots } \\
\text { Fa. Boots-Greenhouse } \\
\text { Rustenburgerweg } \\
\text { HEER HUGOWAARD, The Netherlands }\end{array}$ & \multicolumn{2}{|c|}{ 6. Duration of Investigation (Beginning and ending) } \\
\hline \multicolumn{3}{|c|}{$\begin{array}{l}\text { 8. Purpose of Project (Objectives, Motivations, Approach, Plans and Expected Results) } \\
\text { Objective: To provide electricity for crop illumination and greenhouse heating } \\
\text { Motivation: To obtain economic advantage from the increased efficiency in transforming } \\
\text { natural gas into electricity and heat by local integration of systems } \\
\text { Approach: } \\
\text { - I gas engine (Waukesha F } 817 \mathrm{GA} \text { ) driven electric generator } 155 \mathrm{pk} \text { ( } \mathrm{HP} \text { ), } 110 \mathrm{kVA} \\
\text { - Recovery of heat from } \\
\text { o engine jacket cooling water } \\
\text { o exhaust gas } \\
\text { - Additional boilers } \\
\text { - Operating of the plant as energy island } \\
\text { - Feeding the recovered heat into the existing central heating system }\end{array}$} \\
\hline
\end{tabular}

Use Box No. 15 if additional space is needed

This project is: $\square$ planned $\square$ in-progress $\square x$ completed

Use Box No 16 if additional space is needed

$$
\begin{array}{|l}
\hline 10 \\
\square \\
\square \\
\square \\
\hline 12 \\
\hline
\end{array}
$$

- Feeding the recovered heat into the existing central heating system

9. Status and Results

The plant has been in operation since November 1976

Supportin

Fa. Boots-Greenhouse

Rustenburgerweg

DYNAF B.V.

2. Box 54

The plant has been in operation since November 1976 


\begin{tabular}{|l|l|}
\hline 13 Technical Data & Identification No \\
project location - \\
degree-days (heating) - \\
degree-days (cocling) -
\end{tabular}

14. Other Related Projects (Titles)

15. Additional space for Purpose of Project

16. Additional space for Status and Results 


\begin{tabular}{|c|c|c|c|}
\hline \multicolumn{3}{|c|}{\begin{tabular}{|l|} 
NBS-1075 \\
$(2-77)$
\end{tabular}} & \begin{tabular}{|l} 
Identification No. \\
(Secretariat Use Only) \\
$2-522 \mathrm{NL}-33$
\end{tabular} \\
\hline \multicolumn{3}{|c|}{$\begin{array}{l}\text { 1. Title of Project /Official Title) } \\
\text { Total Energy for Nursery Gardens }\end{array}$} & $\begin{array}{l}\text { 2. Date (Form Completed) } \\
3 / 14 / 77\end{array}$ \\
\hline \multicolumn{2}{|r|}{$\begin{array}{l}\text { Performing Organization (Complete Mailing Address) } \\
\text { Techn. Handelsonderneming } \\
\text { J. de Ruiter } \\
\text { Vinkenweg } 72 \\
\text { Rijnsburg } \\
\text { The Netherlands }\end{array}$} & \multicolumn{2}{|c|}{$\begin{array}{l}4 \text { Principal Investigator (Name and Complete Mailing Address) } \\
\text { Landré Ruhaak Motoren, B.V. } \\
\text { Industrieweg } 30, \text { P.O.B. } 63 \\
\text { Vianen } \\
\text { The Netherlands }\end{array}$} \\
\hline \multicolumn{2}{|r|}{$\begin{array}{l}\text { 5. Supporting Organization (Complete Mailing Address and Name of } \\
\text { Contact) } \\
\text { P.A. van Paridon } \\
\text { Rijnsburgerweg } \\
\text { Voorhout } \\
\text { The Netherlands }\end{array}$} & \multicolumn{2}{|c|}{$\begin{array}{l}\text { 6. Duration of Investigation (Beginning and ending) } \\
6 / 75 \text { to } 10 / 75 \\
\text { 7. Estimated Funding and Manpower (Monies and Manyears) } \\
\text { Dfl. } 100,000 .=.2 \text { man years }\end{array}$} \\
\hline \multicolumn{4}{|c|}{$\begin{array}{l}\text { 8. Purpose of Project (Pbjectives, Motivations, Approach, Plans and Expected Results } \\
\text { Objective: To transfer natural gas into electricity and heat } \\
\text { Motivation: Electricity for lighting flowers and heating greenhouses. } \\
\text { Approach: One generator set of } 100 \mathrm{KVA} \text { provides electricity for the bulbs and } \\
\text { the motor provides by means of a heat exchanger heat of } 90^{\circ} \mathrm{C} \text { to } \\
\text { reduce costs of heating by a conventional boiler. } \\
\text { Plans: To reduce lighting and heating costs and to extend the periods of producing } \\
\text { flowers per year. } \\
\text { Exp. results: Heating savings approx. Dfl. } 4,870 .=\text { per year } \\
\text { Electr. savings approx. Dfl.16.500. = per year }\end{array}$} \\
\hline
\end{tabular}

Use Box No. 15 if additional space is needed

9. Status and Results

Installation is continuous in service during 3 months per year in winter time.

Till $0^{\circ} \mathrm{C}$ ambient temp. the installation provides enough heat fon the greenhouse without the use of the stand-by boiler.

This project is: $\square$ planned $\square$ in-progress $\square$ completed

Use Box No. 16 if additional space is needed

10. Utility Services

electrical power

space heating

wastewater treatment

$\square$ space cooling

$\square$ solid waste processing

$\square$ potable water

11. Type of Project

$\square$ potable hot water

$\square$ public $\quad$ 呕 private

12. Exchange of data

EX Yes

No 
13 Technical Data

project location

degree-days (heating) -

degree-days (cocling) - -

plant load capacity

a power $(\mathrm{MW})--80 \mathrm{~kW}$

b. heating (MW) $-8 \theta \mathrm{kW}$

c. cooling (MW) - $\ldots \ldots$

d. wastewater treatment-liters/day $-\ldots-\ldots$

e. solıd waste processing-kilograms/day - - -

f. potable water-liters/day $--\ldots--\ldots$

heat to power ratio (average expected)

14. Other Related Projects (Tit/es)

iotal energy for two other nursery gardens already completed.

There is a potential of approximately 150 gardens. dentifiration N'n

$2-522 \mathrm{NL}-33$

energy source natural gas

expected payback period

5 years

Type and size of user

a. residential (dwelling units)

b. residential (square area- $\mathrm{m}^{2}$ )

c. commercial (square area- $\mathrm{m}^{2}$ )

d. industrial (thermal + elec. MW)

15. Additional space for Purpose of Project

16. Additional space for Status and Results 


\begin{tabular}{|c|c|c|}
\hline \multicolumn{2}{|l|}{$\begin{array}{l}\text { NBS- } 1075 \\
(2.77)\end{array}$} & \multirow{2}{*}{\begin{tabular}{|l}
$\begin{array}{l}\text { Identification No. } \\
\text { (Secretariat Use Only) } \\
2-522 \mathrm{NL}-34\end{array}$ \\
$\begin{array}{l}\text { 2. Date (Form Completed) } \\
3 / 14 / 77\end{array}$
\end{tabular}} \\
\hline \multicolumn{2}{|l|}{$\begin{array}{l}\text { 1. Title of Project (Officia/ Title) } \\
\text { TE-Plant } \\
\text { Lily Cultivating Company }\end{array}$} & \\
\hline $\begin{array}{l}\text { Performing Organızation (Complete Mailing Address) } \\
\text { Geveke Engine Division } \\
\text { Kabelweg } 25 \\
\text { AMSTERDAM, The Netherlands }\end{array}$ & \multicolumn{2}{|c|}{$\begin{array}{l}4 \text { Principal Investigator (Name and Complete Mailing Address) } \\
\text { Ir. E.D.Broekman } \\
\text { Geveke Engi ne Division } \\
\text { Kabelweg 25 } \\
\text { AMSTERDAM, The Netherlands }\end{array}$} \\
\hline $\begin{array}{l}\text { 5. Supporting Organization (Complete Malling Address and Name of } \\
\text { Contact) } \\
\text { Mr. Dekker } \\
\text { Company Dekker } \\
\text { HENSBROEK, The Netherlands }\end{array}$ & $\begin{array}{l}\text { 6. Duration of Investigatio } \\
\text { Start-up } 1975 \\
\text { 7. Estimated Funding and } \\
\quad+\text { Dfl. 200,0 } \\
\text { - }\end{array}$ & $\begin{array}{l}\text { Manpower (Monies and Manyears) } \\
\text { Mo. -- }\end{array}$ \\
\hline \multicolumn{3}{|c|}{$\begin{array}{l}\text { 8. Purpose of Project (Jbjectives, Motivations, Approach. Plans and Expected Results) } \\
\text { objective: To provide electricity and space heating for a greenhouse during } \\
\text { approx. } 6 \text { months a year. } \\
\text { Motivation: To obtain economic advantage from the increased efficiency in transforming } \\
\text { natural gas into electricity and heat by local integration of systems. } \\
\text { Approach: } 1 \text { gas engine (Caterpillar G } 398 \mathrm{TM} \text { ) driven electric generator. } \\
\text { - Recovery of waste heat from } \\
\text { o engine jacket cooling water } \\
\text { o exhaust gas } \\
\text { o lub. oil cooling } \\
\text { radiation losses }\end{array}$} \\
\hline
\end{tabular}

Use Box No 15 if additional space is needed

9. Status and Results

The plant has been in operation since 1975

- equivalent $\mathrm{kWh}$ production $2.6 \times 10^{6} \mathrm{kWh}$ per year

- efficiency TE-plant

- efficiency heat supply from jacket cooling water + lub. oil cooler

- efficiency heat supply from exhaust gas 15\% ]

- efficiency heat supply from radiation losses 10\% J

This project is: $\square$ planned $\square$ in-progress $\square$ completed

Use Box No 16 if additional space is needed 10. Utility Services

$凶$ electrical power

space heating

wastewater treatment

$\square$ space cooling

$\square$ solid waste processing

$\square$ potable water

$85 \%$ JRefer to Note 1 , $30 \%$ ] Table 2-9

$\square$ potable hot water

11 Type of Project

12. Exchange of data

Will data be available from this project that will be shared with others?

Y Yes

Request 4 


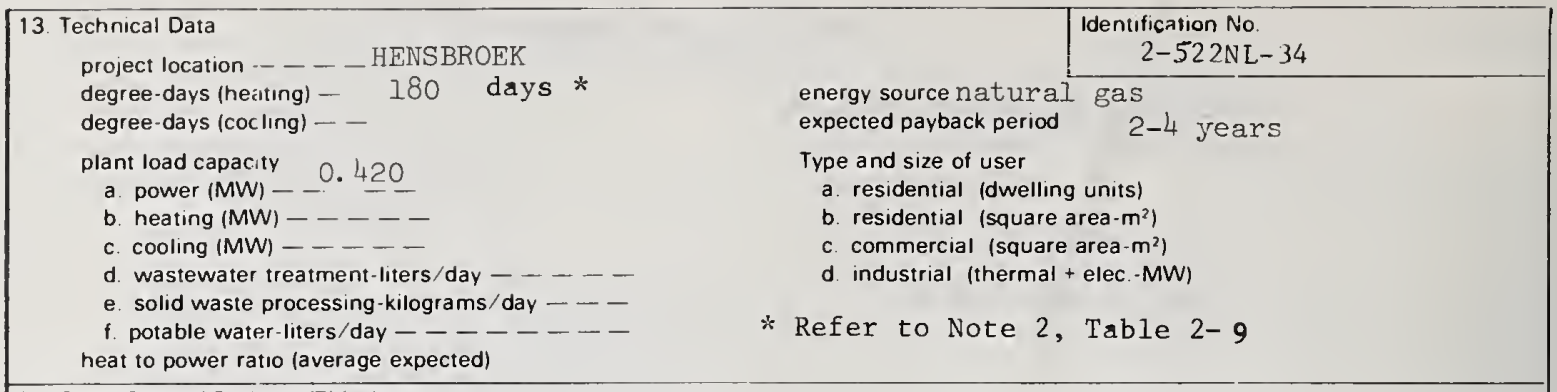

14 Other Related Projects (Titles)

15. Additional space for Purpose of Project

16. Additional space for Status and Results 


\begin{tabular}{|c|c|c|}
\hline \multicolumn{2}{|l|}{$\begin{array}{l}\text { NBS-1075 } \\
(2-77)\end{array}$} & \multirow{2}{*}{$\begin{array}{l}\begin{array}{l}\text { Identification No. } \\
\text { (Secretariat Use Only) } \\
2-522 \text { NL-35 }\end{array} \\
\text { 2. Date (Form Completed) } \\
3 / 14 / 77\end{array}$} \\
\hline $\begin{array}{l}\text { 1. Title of Project (Official Title) } \\
\text { Total Energy Plant for Greenhouse }\end{array}$ & & \\
\hline $\begin{array}{l}\text { 3. Performing Organization (Complete Mailing Address) } \\
\text { Ir. A.Verhoef } \\
\text { DYNAF B.V. } \\
\text { Kwakelkade 29, P.0. Box } 54 \\
\text { ALKMAAR, The Netherlands }\end{array}$ & $\begin{array}{l}4 \text { Principal Investigator } \\
\text { Mr. Van Tuyl } \\
\text { Croon and Comp } \\
\text { Schiemond 22. } \\
\text { ROTTERDAM, THF }\end{array}$ & $\begin{array}{l}\text { Vame and Complete Mailing Address) } \\
\text { + DYNAF } \\
\text { Netherlands }\end{array}$ \\
\hline $\begin{array}{l}\text { 5. Supporting Organization (Complete Mailing Address and Name of } \\
\text { Contact) } \\
\text { Mr. Smit } \\
\text { Openbare Nuts Bedrijven } \\
\text { Boomgaardlaan } 12 \\
\text { SCHIPLUIDEN, The Netherlands }\end{array}$ & $\begin{array}{r}\text { 6. Duration of Investigatic } \\
\mathrm{N} / \mathrm{A} \\
\begin{array}{r}\text { 7. Estımated Funding and } \\
\text { Dfl. } 136,40\end{array}\end{array}$ & $\begin{array}{l}\text { Manpower (Monies and Manyears) } \\
\text { O. -- }\end{array}$ \\
\hline $\begin{array}{l}\text { 8. Purpose of Project / Objectives, Motivations, Approach, Plans and } \\
\text { Objective: To provide electricity for cro } \\
\text { Motivation: By local production of electr } \\
\text { local grid, increase of main grid ca } \\
\text { heat could be used efficiently for g } \\
\text { Approach: } \\
\text { - I gas engine (Waukesha F } 1197 \mathrm{C} 4,240 \mathrm{p} \\
\text { - Recovery of waste heat, which is fed in } \\
\text { o from engine jacket cooling water } \\
\text { o from exhaust gases } \\
\text { o from lub. oil cooler } \\
\text { - Parallel operation to the local public } \\
\text { main grid }\end{array}$ & $\begin{array}{l}\text { illumination and } \\
\text { city and supply o } \\
\text { acity could be pr } \\
\text { cenhouse heating } \\
\text { (HP) driven elec } \\
\text { the heating sys } \\
\text { grid without powe }\end{array}$ & $\begin{array}{l}\text { greenhouse heating } \\
\text { f electricity to the } \\
\text { evented while waste } \\
\text { tric generator } \\
\text { tem of the greenhouse } \\
\text { feedback to the }\end{array}$ \\
\hline
\end{tabular}

Use Box No. 15 if additional space is needed

\section{Status and Results}

The plant has been in operation since January 1977

Measurements are made to determine in service efficiencies.

This project is: $\square$ planned $\square$ in-progress $\square$ completed

(10.

11. Type of Project
$\square$ public $\square$ private
$\square$ cooperative


13 Technical Data

project location -.....

degree-days (heáting) -

degree-days (cocling) - -

plant load capacıty

a power $(\mathrm{MW})--0.2$

b. heating (MW) - $\underline{0}: \underline{2} \underline{8}$

c. cooling (MW) - - - -

d wastewater treatment-liters/day - - - -

e. solıd waste processing-kilograms/day - -

f. potable water-liters/day _ _ _ _ - - -

heat to power ratio (average expected)

\section{CHIPLUIDEN}

15. Additional space for Purpose of Project

16. Additional space for Status and Results

\author{
energy source natural gas \\ expected payback period \\ Type and size of user \\ a residentıal (dwelling units) \\ b. residential (square area- $m^{2}$ ) \\ c. commercial (square area- $\mathrm{m}^{2}$ ) \\ d industrial (thermal + elec. MW)
}

Identification No.

$2-522 \mathrm{NL}-35$

CCMS Ratıonal Use of Energy PIlot Study, CCMS-MIUS Project, 92076 
$\begin{aligned} & \text { NBS-1075 } \\ & (2-77)\end{aligned}$
U.S. DEPARTMENT OF COMMERCE
NATIONAL BUREAU Or STANDARDS

PROJECT SUMMARY FORM

1. Title of Project (Official Tit/e)

Total Energy Plant

"Factory New Holland"

3. Performing Organization (Complete Mailing Address)

Geveke Engine Division

Kabelweg 25

AMSTERDAM, The Netherlands

Ir. E.D.Broekman

Kabelweg 25
Identification No.

(Secretariat Use On/y)

$$
2-523 N L-36
$$

2. Date (Form Comp/eted)

$3 / 14 / 77$

Principal Investigator (Name and Complete Mailing Address)

Geveke Engine Division

AMSTERDAM, The Netherlands

6. Duration of Investigation (Beginning and ending)

Start-up 1968

Nederlandse Melkunie

WOERDEN

The Netherlands

7. Estimated Funding and Manpower (Monies and Manyears) $\mathrm{N} / \mathrm{A}$

8. Purpose of Project (Jbjectives, Motivations, Approach, Plans and Expected Results)

Objective: To provide electricity and dishwater heating for the factory

Motivation: To take technical and economical advantage of the overall increased

efficiency in transformirg natural gas into heat and electricity by local

integration of utility energy systems.

Approach: 2 gas driven engines (Caterpillar) coupled to one electric generator

- recovery waste heat

engine jacket cooling water

- grid connection

Use Box No. 15 if additional space is needed

9. Status and Results

Plant has been in operation since Mid-summer 1968

Equivalent $\mathrm{kWh}$ production: $1.2 \times 10^{6} \mathrm{kWh}$ per year

- Efficiency TE-plant : $58 \%$ ]

- Efficiency electr. supply : 28\% ] Refer to Note 1, Table 2-9

- Efficiency heat supply : $30 \%$

This project is: $\square$ planned $\square$ in-progress $\square$ completed Use Box No 16 if additional space is needed

$$
\text { 品 }
$$
10. Utility Services

$[$ electrical power

space heating

space cooling

首 potable hot water

12. Exchange of data

$\square$ wastewater treatment

$\square$ solid waste processing

$\square$ potable water

11. Type of Project

$\square$ public $\square$ private

cooperative

Will data be available from this project that will be shared with others?

Yes

$\square$ No

Request 3 
13. Technical Data

project location .....- Woerden

degree-days (heattıng) -

degree-days (cocling) - -

plant load capacity

a. power $(M W)-C .3-$

b. heating $(\mathrm{MW})-\ldots$

c. cooling (MW) -----

d. wastewater treatment-liters/day _ _ - -

e. solid waste processing-kılograms/day - - -

f. potable water-liters/day $-\ldots-\ldots-\ldots$

heat to power ratio (average expected)

14. Other Related Projects (Tit/es)

Ir. Van Houten (Dir.), Mr. De Groot

Potato-Mill Factory "Twee Provincien"

ETADSKANAAI,

The Netherlands

15. Addizional space for Purpose of Project dentsfication No

$2-523 N L-36$

energy source natural gas expected payback period $3-5$ years

Type and size of user

a residential (dwelling units)

b. residential (square area- $m^{2}$ )

c. commercial (square area- $\mathbf{m}^{2}$ )

d. industrial (thermal + elec.-MW)

16. Additional space for Status and Results

Remark: Efficiencies based on lower heating value 


\begin{tabular}{|c|c|c|}
\hline \multicolumn{2}{|c|}{$\begin{array}{l}\text { NBS-1075 } \\
\begin{array}{l}\text { U.S. DEPARTMENT OF COMMERCE } \\
\text { NATIONAL BUREAU OF STANDARDS }\end{array} \\
\text { PROJECT SUMMARY FORM }\end{array}$} & {$\left[\begin{array}{c}\text { Identification No. } \\
\text { (Secretariat Use On(y) } \\
2-572 \mathrm{NL}-37\end{array}\right.$} \\
\hline $\begin{array}{l}\text { 1. Title of Project /Official Title) } \\
\text { Total Energy plant for Industrial Applice } \\
\text { EMINENT }\end{array}$ & tion & $\begin{array}{l}\text { 2. Date (Form Completed) } \\
3 / 14 / 77\end{array}$ \\
\hline $\begin{array}{l}\text { 3. Performing Organization (Complete Mailing Address) } \\
\text { DYNAF, B.V. } \\
\text { Kwakelkade 29, P.O. Box } 54 \\
\text { ALKMAAR, The Netherlands }\end{array}$ & $\begin{array}{l}4 \text { Principal Investigator } / \\
\text { Ir. A.Verhoef } \\
\text { DYNAF B.V. } \\
\text { Kwakelkade 29, } \\
\text { ALKMAAR, The N }\end{array}$ & $\begin{array}{l}\text { lame and Complete Mailing Address) } \\
\text { P.O.Box } 54 \\
\text { therlands }\end{array}$ \\
\hline $\begin{array}{l}\text { 5. Supporting Organization (Complete Mailing Address and Name of } \\
\text { Contact) } \\
\text { Mr. K. L.Vreeken } \\
\text { B.V. Eminent } \\
\text { Dronenhceck 1, P.O. Box } 25 \\
\text { BODEGRAVEN } \\
\text { The Netherlands }\end{array}$ & \begin{tabular}{|l|} 
6. Duration of Investigati \\
N/A \\
$\begin{array}{c}\text { 7. Estimated Funding an } \\
\text { N/A }\end{array}$
\end{tabular} & $\begin{array}{l}\text { In (Beginning and ending) } \\
\text { Manpower (Monies and Manyears) }\end{array}$ \\
\hline 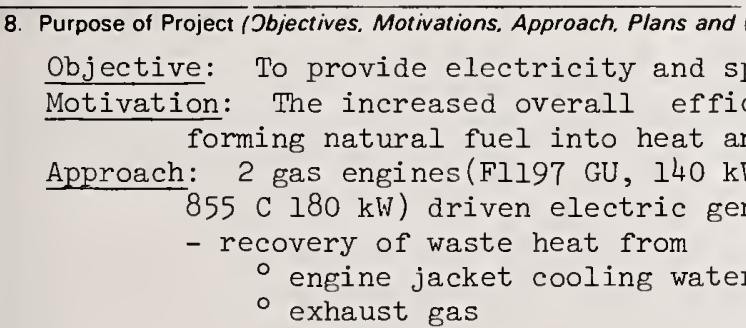 & $\begin{array}{l}\text { pected Results } \\
\text { ace heating for f } \\
\text { iency and economi } \\
\text { d electricity by } \\
\text { ) and } 1 \text { diesel en } \\
\text { erators. } \\
\text { hot water }\end{array}$ & $\begin{array}{l}\text { ctory and office building. } \\
\text { ocal advantages in trans- } \\
\text { ocalegrated systems. } \\
\text { ine (Cummens type NT- }\end{array}$ \\
\hline
\end{tabular}

Use Box No. 15 if additional space is needed

9. Status and Results

Order for erection of the plant has been given. According to design calculations the efficiencies are:

- efficiency TE-plant 75\% ] Refer to Note 1, Table 2-9

- efficiency electricity gen. $26 \%$

- efficiency heat generation 49\% ]

Remark: Efficiencies are based on lower heating values

This project is: $\square$ planned $\square$ in-progress $\square$ completed

Use Box No. 16 if additional space is needed

\begin{tabular}{ll}
\hline 10. Utility Services & $\square$ wastewater treatment \\
$\square$ electrical power & $\square$ solid waste processing \\
$\square$ space heating & $\square$ potable water \\
$\square$ potable hot water &
\end{tabular}

12. Exchange of data

Will data be available from this project that will be shared with others?

Q Yes

Request 4 
13. Technical Data

project location - - - -

degree-days (heating) -

degree-days (cocling) - -

plant load capacity

a. power (MW) $-14.0 \mathrm{~kW} /$ unit

b. heating $(\mathrm{MW})-\ldots-$

c. cooling (MW) _... -

d. wastewater treatment-liters/day _ - - -

e. solid waste processing-kilograms/day --

f. potable water-liters/day ------heat to power ratio (average expected)

14. Other Related Projects (Titles)

\begin{tabular}{l|l} 
energy source \\
expected payback period
\end{tabular}$\quad \begin{gathered}\begin{array}{c}\text { identification No. } \\
2-572 \mathrm{NL}-37\end{array} \\
\text { natural gas }\end{gathered}$

Type and size of user

a. residential (dwelling units)

b. residential (square area- $\mathrm{m}^{2}$ )

c. commercial (square area- $m^{2}$ )

d. industrial (thermal + elec.-MW)

15. Additional space for Purpose of Project

16. Additional space for Status and Results 
13. Technical Data

Linden, N.J.

degree-days (heating) -

degree-days (cocling) - -

plant load capacity
a. power $(\mathrm{MW})$ - (maximum 511
b. heating (MW) (maximum 580
c. cooling (MW) $--\ldots-\ldots$
d. wastewater treatment-liters/day - 20.4 x_106
e. solid waste processing-kilograms/day - -
f. potable water-liters/day _ _ _ _ _ - heat to power ratio (average expected)

14. Other Related Projects (Titles)

energy source Heavy $\mathrm{Oi} 1$
expected payback period
Type and size of user
a. residential (dwelling units)
b. residential (square area- $\mathrm{m}^{2}$ )
c. commercial (square area- $\mathrm{m}^{2}$ )
d. industrial (thermal + elec. $-\mathrm{MW}$ )

ification No

$-612 U S-38$

15. Additional space for Purpose of Project

16. Additional space for Status and Results

Article: Large Scale Exchange of Extraction Steam for Residual Fuel at the Linden Generating Station, Proceedings of the American Power Conference, Volume XVIII - 1956, Illinois Institute of Technology, 3300 S Federal, Chicago Illinois 60616 . 


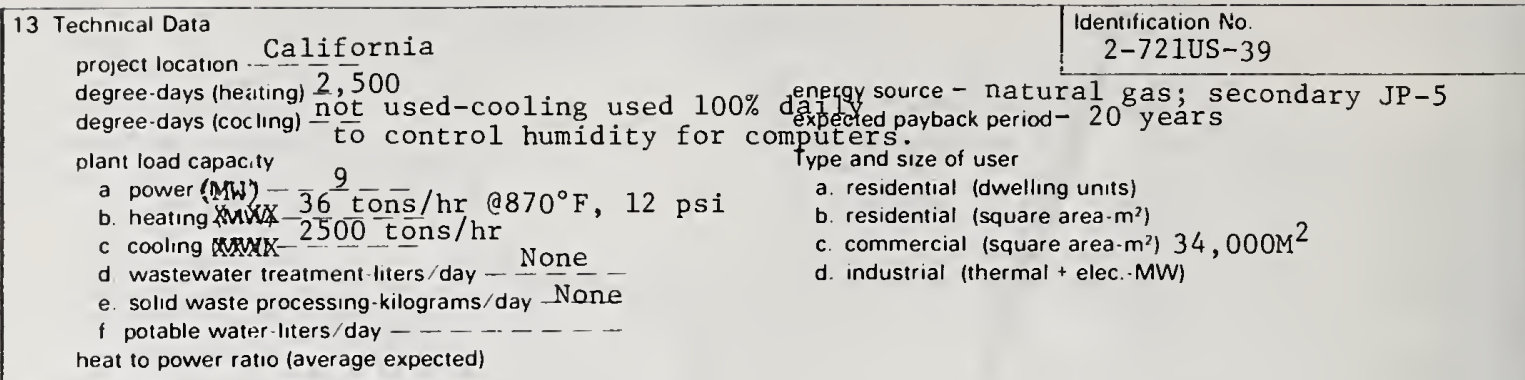

14 Other Related Projects (Titles)

None

15. Additional space for Purpose of Project

16. Additional space for Status and Results 


\begin{tabular}{|l}
$\begin{array}{l}\text { NBS-1075 } \\
(2-77)\end{array}$ \\
U.S. DEPARTMENT OF COMMERCE \\
NATIONAL BUREAU OF STANDARDS
\end{tabular}

PROJECT SUMMARY FORM

1. Title of Project (Otficial Tit/e)

Naval Training Center Generating Plant

3. Performing Organization (Complete Mailing Address)

Applied Energy, Inc.

P.0. Box 909

San Diego, California 92112

U.S.A.

\section{Supporting Organization (Complete Mailing Address and Name of Contact)}

NOT APPLICABLE identification No

(Secretariat Use Only)

2-772US- 40
2. Date (Form Completed)

$11 / 76$
4 Principal Investigator (Name and Complete Mailing Address)

Robert C. Eckely, General Manager

Applied Energy, Inc.

P.0. Box 909

San Diego, California 92112

U.S.A.

Commercial Plant - began operation in 1971

7. Estimated Funding and Manpower (Monies and Manyears)

\section{NOT APPLICABLE}

8. Purpose of Project (Objectives, Motivations, Approach. Plans and Expected Results)

Construct and operate a commercial gas turbine heat power plant at the Naval Training Center in San Diego, California to serve the Naval Training Center and Marine Corps Recruitment Depot. Steam is supplied to these facilities \& electricity is supplied to the San Diego Gas \& Electric Co. System (Applied Energy, Inc. is a wholly-owned subsidiary of SDG\&E).

\section{Status and Results}

The gas turbine heat recovery plant has been operated since 1971 on a basis of steam production economics. This depends on fuel (natural gas or distillate oil) cost \& availability for the gas turbine and separate auxiliary boiler.

This project is: $\square$ planned $\mathrm{Q}$ in-progress $\square$ completed

Ex electrical power

space heating

$\square$ space cooling

$\square$ potable hot water

Use Box No. 16 if additional space is needed

2. Exchange of data 


\begin{tabular}{|c|c|}
\hline \multirow{2}{*}{$\begin{array}{l}\text { 13. Technical Data } \\
\text { project locatıon - San Diego } \\
\text { degree-days (heätıng) _ } \\
\text { degree-days (coclıng) _ - }\end{array}$} & $\begin{array}{l}\text { identification No } \\
2-772 \mathrm{US}-40\end{array}$ \\
\hline & $\begin{array}{l}\text { energy source Natural Gas \& Distillate Oil } \\
\text { expected payback period }\end{array}$ \\
\hline 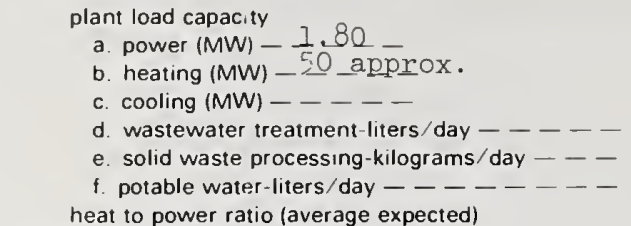 & $\begin{array}{l}\text { Type and size of user } \\
\text { a. residential (dwelling units) } \\
\text { b. residential (square area }-\mathrm{m}^{2} \text { ) } \\
\text { c. commercial (square area- } \mathrm{m}^{2} \text { ) } \\
\text { d. industrial (thermal }+ \text { elec. }-\mathrm{MW} \text { ) }\end{array}$ \\
\hline
\end{tabular}

14. Oiher Related Projects (Tit/es)

Other gas turbine heat recovery power plants operated by AEI and interconnected with

the PSE\&G system: 32nd Street Generating Station

North Island Generating Station

15. Additional space for Purpose of Project

16. Additional space for Status and Results 
NBS-1075

(2-77)
U.S. DEPARTMENT OF COMMERCE NATIONALL BUREAU OF STANDARDS

\section{PROJECT SUMMARY FORM}

1. Title of Project (Official Tit/e)

Improvement of Energy Generation Plants by Using Total Energy Systems

3. Performing Organization (Complete Mailing Address)

RIJN Schelde Verolme N.V.

OOSTMAASLAAN 5965

Rotterdam, Netherlands
4 Principal Investigator (Name and Complete Mailing Address)

P. Croockewit

OOSTMAASLAAN 5965

Rotterdam, Nether lands
5. Supporting Organization (Complete Mailing Address and Name of Contact)

Netherlands

RIJN Schelde Verolme N.W.

OOSTMAASLAAN 5965

Rotterdam, Nether lands dentification No

(Secretariat Use Only)

$2-822 \mathrm{NL}-41$

2. Date (Form Completed)

$3 / 15 / 77$

8. Purpose of Project (Objectives, Motivations, Approach, Plans and Expected Results)

Objectives: a) Combined cycle installation engineering

b) Total energy systems

c) Off gas energy recovery systems

6. Duration of Investigation (Beginning and ending)

$$
7 / 74 \text { to } 6 / 75
$$

7. Estimated Funding and Manpower (Monies and Manyears)

\section{Unknown}

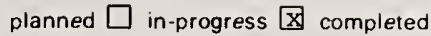

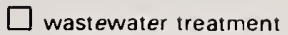

$\square$ solid waste processing

$\square$ potable water 11. Type of Project

$\square$ public $\quad$ private

cooperative

potable hot water

Yes

$\square$ No

[x] unknown 
13 Technical Data

project location

degree-days (heatıng) -

degree-days (coclıng) - -

plant load capacity

a power (MW) - - - -

b. heatıng $(\mathrm{MW})-\ldots-\cdots$

c. cooling (MW) - - - -

d. wastewater treatment-liters/day - - - -

e. solid waste processıng-kilograms/day - - -

f. potable water-liters/day $-\ldots-\ldots---$ heat to power ratio (average expected)

14. Other Related Projects (Tit/es)
Identification No

$2-822 \mathrm{NL}-41$

energy source

expected payback perıod

Type and size of user

a residentıal (dwelling units)

b residentıal (square area $\cdot \mathrm{m}^{2}$ )

c. commercial (square area- $\mathrm{m}^{2}$ )

d industrial (thermal + elec. MW)

15. Additional space for Purpose of Project

16. Additional space for Status and Results 
NBS-1075 U.S. DEPARTMENT OF COMMERCE
(2-77)

PROJECT SUMMARY FORM

1. Title of Project (Official Tit/e)

Total Energy Plant for Hotel CREST
Identification No

(Secretariat Use Only)

$2-922 \mathrm{BE}-42$

2. Date (Form Completed)

$3 / 14 / 77$

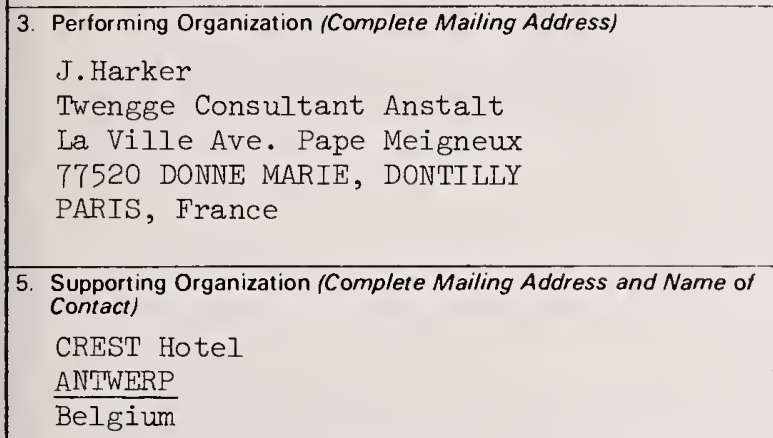

3. Performing Organization (Complete Mailing Address)

J. Harker

Twengge Consultant Anstalt

La Ville Ave. Pape Meigneux

77520 DONNE MARIE, DONTILLY

PARIS, France 5. Supporting Organization (Complete Mailing Address and Name of
Contact)

CREST Hotel

ANTWERP

Belgium

4. Principal Investigator (Name and Complete Mailing Address)

Ir. A. Verhoef

DYNAF B.V.

Kwakelkade 29, P.0. Box 54

ALKMAAR, The Netherlands

6. Duration of Investigation (Beginning and ending)

N/A

7. Estimated Funding and Manpower (Monies and Manyears)

Dfl. 1,400,000.-- 2.5 man years

8. Purpose of Project (Jbjectives, Motivations, Approach, Plans and Expected Results)

Objective: To provide electricity, space heating and cooling

Motivation: To take technical and economical advantage of the increase of overall efficiency in transforming natural gas into heat, electricity etc. by local

integration of systems

Approach:

- 3 gas engine (Waukesha F 352l-G) driven electric alternator (UNELEC 450 kWA)

- Recovery of waste heat from

o engine jacket cooling water

- exhaust gases

- 1 absorption cooler

Use Box No. 15 if additional space is needed

9. Status and Results

The plant has been in operation since August 1973

Start-up test showed good agreement with calculated values

planned $\square$ in-progress $\square$ completed

Use Box No. 16 if additional space is needed 10. Utility Services

$\mathrm{X}$ electrical power

space heating

space cooling

potable hot water

2. Exchange of data

Will data be available from this project that will be shared with others? $\square$ wastewater treatment

$\square$ solid waste processing

$\square$ potable water

public private

cooperative

res

No

Request 5 
13 Technical Data

project location -. - .. ANTWERP

degree-days (heatting) -

degree-days (coclıng) - -

plant load capacity

a power (MW) - $750 \mathrm{~kW}$

b heatıng (MW) - . . . .

c cooling ( $\mathrm{MW}$ ) - $-\ldots$

d. wastewater treatment-liters/day _.....

e. solıd waste processıng-kılograms/day _ _ -

f. potable water-liters/day $-\ldots \ldots \ldots$

heat to power ratıo (average expected)

14. Other Related Projects (Titles)

15. Additıonal space for Purpose of Project

16. Additional space for Status and Results

energy source naturaI gas

expected payback perıod

Type and size of user

a residentıal (dwellıng unıts)

b. residential (square area- $m^{2}$ )

c. commercial (square area- $\mathrm{m}^{2}$ )

d Industrial (thermal + elec -MW)

4. Other Related Projects (Thles) 


\begin{tabular}{|c|c|c|}
\hline \multicolumn{2}{|c|}{$\begin{array}{l}\begin{array}{l}\text { NBS-1075 } \\
(2.77)\end{array} \\
\text { P.S. DEPARTMENT OF COMMERCE } \\
\text { NATIONAL BUREAU OF STANDARDS } \\
\text { PROJECT SUMMARY FORM }\end{array}$} & \multirow{2}{*}{$\begin{array}{l}\begin{array}{l}\text { Identification No. } \\
\text { (Secretariat Use On/y) } \\
3-001 U S-01\end{array} \\
\text { 2. Date (Form Completed) }\end{array}$} \\
\hline $\begin{array}{l}\text { 1. Title of Project (Official Title) } \\
\text { Environmental, Economic, and Conservation } \\
\text { grated Energy use Applications }\end{array}$ & pects of Inte- & \\
\hline $\begin{array}{l}\text { 3. Performing Organization (Complete Mailing Address) } \\
\text { Georgia Institute of Technology } \\
225 \text { North Avenue NW } \\
\text { Atlanta, Georgia } 30332 \\
\text { U.S.A. }\end{array}$ & $\begin{array}{l}4 \text { Princinal lnvestigator }(N \\
\text { Dr. Neil B. HI } \\
\text { Georgia Insti } \\
225 \text { North Aver } \\
\text { Atlanta, Geor } \\
\text { U.S.A. }\end{array}$ & $\begin{array}{l}\text { ame and Complete Mailing Address) } \\
\text { tsen } \\
\text { tute of Technology } \\
\text { nue NW } \\
\text { gia } 30332\end{array}$ \\
\hline $\begin{array}{l}\text { 5. Supporting Organization (Complete Mailing Address and Name of } \\
\text { Contact) } \\
\text { Dr. C.C. Lee } \\
\text { U.S.EPA, PTCB, IERL } \\
\text { Cincinnati, Ohio } 45268 \\
\text { U.S.A. }\end{array}$ & $\begin{array}{l}\text { 6. Duration of investigation } \\
4 / 76 \text { to } 1 / 78 \\
\text { 7. Estimated funding and } \\
\$ 120,000\end{array}$ & $\begin{array}{l}\text { I (Beginning and ending) } \\
\text { Manpower (Monies and Manyears) }\end{array}$ \\
\hline $\begin{array}{l}\text { 8. Purpose of Project } / \text { bijectives, Motivations, Approach plans and } \\
\text { The purpose of } \\
\text { economic and technical feasibility of alter } \\
\text { assess various integrated energy system cor } \\
\text { utility and industrial needs, to identify } \\
\text { trial processes to thermal outputs of power } \\
\text { final concepts selected for their potential } \\
\text { ments, and to make recommendations about fu } \\
\text { activities based on the project results. } \\
\text { This research study will follow a phase- } \\
\text { Five phases have been identified and are li } \\
\text { Phase 1: Project management; } \\
\text { Phase 2: Environmental, economic and te } \\
\text { Phase 3: Methodology development and fi } \\
\text { Phase 4: Concept analysis and evaluatic } \\
\text { Phase 5: Conclusion and Recommendation. }\end{array}$ & $\begin{array}{l}\text { xpected Resu/ts } \\
\text { up-to-date analyse } \\
\text { rnatives for supply } \\
\text { ncepts for supplyir } \\
\text { the technical feas } \\
\text { r plants, to analy? } \\
\text { l for future envirc } \\
\text { uture environmenta. } \\
\text {-oriented program } \\
\text { isted below: } \\
\text { echnological overvi } \\
\text { inal concept select } \\
\text { on; }\end{array}$ & $\begin{array}{l}\text { s of the environmental, } \\
\text { ying total energy needs, to } \\
\text { ng multipurpose energy for } \\
\text { ibility of matching indus- } \\
\text { ze extensively several } \\
\text { onmentally sound develop- } \\
\text { I research and development } \\
\text { to achieve its objectives. } \\
\text { iew and preliminary concept } \\
\text { tion; }\end{array}$ \\
\hline
\end{tabular}

9. Status and Results

Title of Project /Otficial Title)

Environmental, Economic, and Conservation Aspects of Inte-

Princinal Investigator (Name and Complete Mailing Address) Dr. Neil B. Hilsen

Georgia Institute of Technology

225 North Avenue NW

Atlanta, Georgia 30332

U.S.A.

Duration of Investigation (Beginning and ending)

$4 / 76$ to $1 / 78$

Dr. C.C.Lee

U.S.EPA, PTCB, IERL

Cincinnati, Ohio 45268

U.S.A.

Use Box No 15 if additional space is needed

his project is: $\square$ planned $\square$ in-progress $\square$ completed Use Box No. 16 if additional space is needed

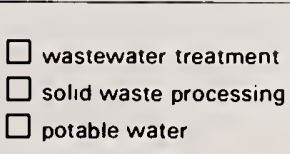
11 Type of Project
public $\square$ private space heating space cooling ? potable hot water cooperative 


\section{Technical Data}

project location ........

degree-days (heatıng) -

degree-days (cocling) - -

plant load capacity

a power (MW) - ... . . .

b. heatıng (MW) - - - -

c. cooling (MW) - - - -

d. wastewater treatment-liters/day _ _- - - -

e. solid waste processing-kilograms/day --

f. potable water-liters/day $--\ldots-\ldots-\ldots$

heat to power ratio (average expected)

14. Other Related Projects (Titles)

15. Additional space for Purpose of Project

energy source

expected payback period

Type and size of user

a. residential (dwelling units)

b. residential (square area $-m^{2}$ )

c. commercial (square area- $m^{2}$ )

d. Industrial (thermal + elec.-MW)

16. Additional space for Status and Results 
NBS-1075

(2-77)
U.S. DEPARTMENT OF COMMERCE Identification No

NATIONAL BUREAU OF STANOARDS (Secretariat Use On/y)

\section{PROJECT SUMMARY FORM}

$$
\text { 3-031NL-02 }
$$

2. Date (Form Completed)

$6 / 10 / 77$

Several projects concerning utilization of heat raised by incineration of waste.

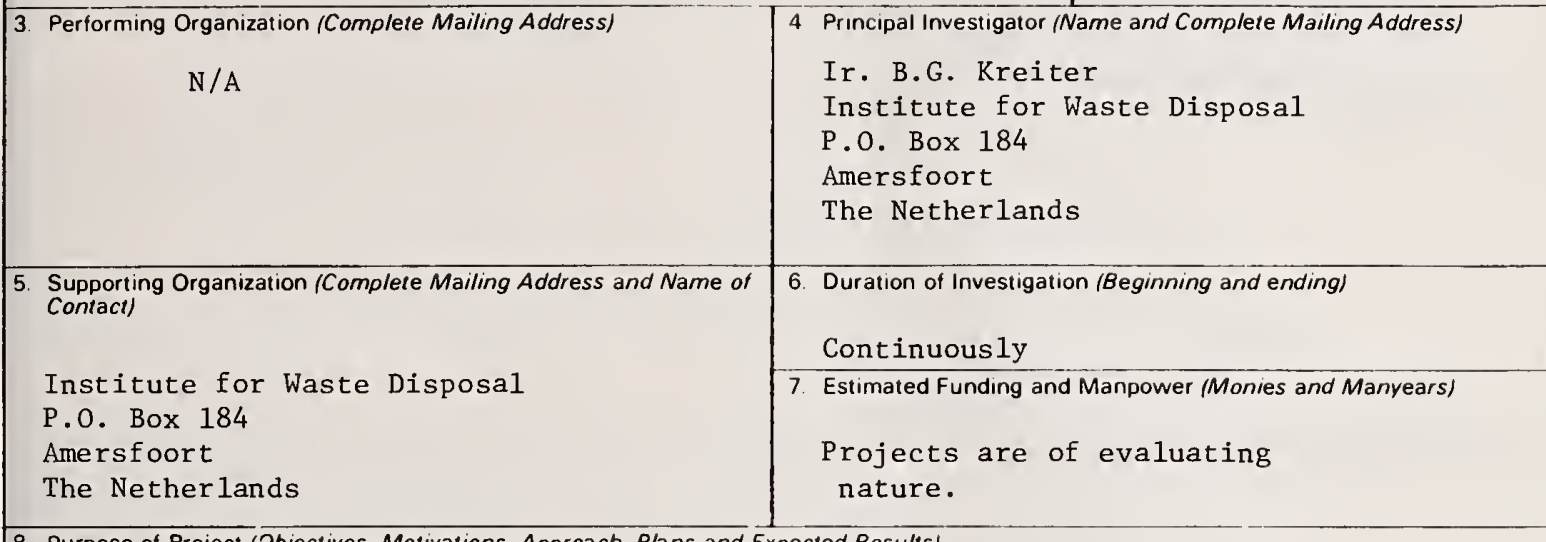

8. Purpose of Project (Jbjectives, Motivations, Approach, Plans and Expected Results)

Generation of electric power is a wel1-known method of utilization of incinerationheat.

The low efficiency, however, is a reason to investigate alternatives.

Running projects are: - district heating (in cooperation with a national committee)

- water evaporation

- firing of the light combustible waste fraction in powerstation boilers. 
13 Technical Data

project location

energy source

degree-days (heiting) -

expected payback period

degree-days (cocling) -

plant load capacity
a. power (MW) $-\ldots--$
b. heating (MW) - - - -
c. cooling $(\mathrm{MW}) \ldots \ldots$
d wastewater treatment-liters/day - $-\ldots$
e. solid waste processing-kilograms/day - - -
f. potable water-liters/day _ _ _ . . _ - heat to power ratio (average expected)
Type and size of user
a. residential (dwellıng units)
b. residential (square area $-\mathrm{m}^{2}$ )
c. commercial (square area $-\mathrm{m}^{2}$ )
d. Industral (thermal + elec.-MW)

14. Other Related Projects (Tilles)

15. Additional space for Purpose of Project

16. Additional space for Status and Results 
$\begin{array}{|lr|}\begin{array}{l}\text { NBS-1075 } \\ (2-77)\end{array} & \text { U.S. DEPARTMENT OF COMMERCE } \\ \text { NATIONAL BUREAU OF STANDARDS }\end{array}$

PROJECT SUMMARY FORM

1. Title of Project (Official Tit/e)

Model Community with novel energy and heating systems (ET 5109)
3. Performing Organization (Complete Mailing Address)

D. - Ing. Arne Strassberger

Beethovenstr. 33

53 Bonn-Beue1 1

Federal Republic of Germany
5. Supporting Organization /Complete Mailing Address and Name of Contact)

PLE/KFA Juelich

Dr. Plantikow

Postfach 1913

D-517 Juelich

Federal Republic of Germany
Identification No

(Secretariat Use On/y)

3-101DE-03

2. Date (Form Completed)

Jan. 6, 1975

8. Purpose of Project (Objectives, Motivations, Approach, Plans and Expected Resu/ts)

- Energy saving buildings based on sensible planning,

- Saving energy through integrated energy supplies,

- Heating rooms with energy produced during the summer,

- Utilization of diverse heat sources.

This project is: $\square$ planned $\square$ in-progress $\square$ completed 10. Utility Services

\section{wer} ectical power space heating $\square$ space coolıng $\square$ potable hot water 12. Exchange of data Use Box No. 16 if additional space is needed

$$
\text { 4,206-\$ US (11077.--DM) }
$$




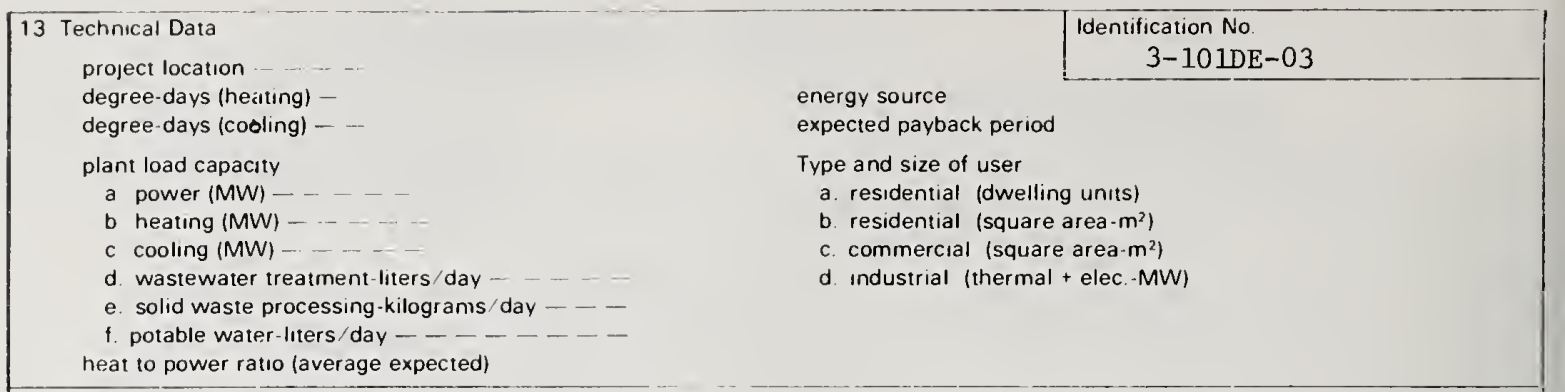

14 Other Related Projects (Titles)

15 Additional space for Purpose of Project

16. Additional space for Status and Results

This study is available from BMFT (See box 5) 
$\begin{aligned} & \text { NBS-1075 } \\ & (2-77)\end{aligned}$
U.S. DEPARTMENT OF COMMERCE
NATIONAL BUREAU OF STANDARDS

\section{PROJECT SUMMARY FORM}

1. Title of Project (Official Title)

Local Heating for Towns to be Built (In planning)
Identification No

(Secretariat Use Only)

$3-101 \mathrm{NL}-04$

2. Date (Form Completed)

$3 / 15 / 77$

3. Performing Organization (Complete Mailing Address)

1. Delft Univ. of Technology

2. Technischi Hogeschoal Delft, The Netherlands

3. Centrum voor Technische Milienkunde
4 Principal Investigator (Name and Complete Mailing Address) G.S.Jonker Delft Univ. of Technology Center for Environmental Science Technology Delft, The Netherlands

6. Duration of Investigation (Beginning and ending)

NA

7. Estimated Funding and Manpower (Monies and Manyears) NA

2. Technischi Hogeschoal, Delft, The Netherlands

8. Purpose of Project (Objectives, Motivations, Approach, Plans and Expected Results)

Methods for (local) heating will be studied concerning towns to be built (Almere, North quarter of Breda and the quarter Holy of the town Vlaardingen) as well as environmental aspects. Also will be regarded: a) incineration of refuse; b) efficient utilization of power stations and their capacity (MW); c) utilization of solar energy for space heating; d) use of water heat, tec.

The utilization of partly solar energy and partly waste heat is of substantial importance for the physical planning of the town concerned. What is acceptable from the point of view of civil engineering will be studied.

Use Box No. 15 if additional space is needed

9. Status and Results

This project is: $\square$ planned $\square$ in-progress $\square$ completed Use Box No. 16 if additional space is needed

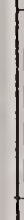

(10.

5. Supporting Organization /Complete Mailing Address and Name of Contact)

Delft University of Technology

Delft, The Netherlands 
13. Technical Data

project location - - - -

degree-days (heating) -

degree-days (coclıng) - -

plant load capacity
a. power (MW)
b. heating (MW) ----
c. cooling (MW) - - - -
d. wastewater treatment-liters/day _ _ _ -
e. solid waste processing-kılograms/day _ - -
f. potable water-liters/day $--\ldots----$
heat to power ratıo (average expected)

14. Other Related Projects (Titles) energy source expected payback period

Type and size of user

a residential (dwelling units)

b. residential (square area- $\mathrm{m}^{2}$ )

c. commercial (square area- $\mathrm{m}^{2}$ )

d Industrial (thermal + elec.-MW)

15. Additıonal space for Purpose of Project

16. Additional space for Status and Results 
Identification No.

(Secretariat Use On/y)

\section{PROJECT SUMMARY FORM}

1. Title of Project /Official Tit/e)

$$
\text { 3-101US-05 }
$$

2. Date (Form Completed)

Integrated Community Energy Systems (ICES) Systems Engineering

Nov. 1977

3. Performing Organization (Complete Mailing Address)

Energy \& Environmental Systems Division Argonne National Laboratory

9700 S. Cass Avenue

Argonne, I11inois 60439

U.S.A.
4 Principal Invesigator (Name and Complete Mailing Address)

John Roberts

EES Division

Argonne National Laboratory

9700 S. Cass Avenue

Argonne, Illinois 60439

U.S.A.

6. Duration of Investigation (Beginning and ending)

Started January 1976 - Ongoing

7. Estimated Funding and Manpower (Monies and Manyears)

Approx. \$1 million/yr.

5. Supporting Organization /Complete Mailing Address and Name of Contact)

John Rodousakis

Community Systems Branch

U.S. Department of Energy

20 Massachusetts Avenue, N.W.

Washington, D.C. 20545

U.S.A.

8. Purpose of Project (Objectives, Motivations, Approach, Plans and Expected Results)

Objectives: (1) to develop basic data and methods for evaluation and design of ICES.

(2) to identify and conduct preliminary engineering and economic evaluation and intercomparisons of numerous ICES concepts, leading to an ICES Systems Guide.

(3) to conduct detailed engineering evaluations of advanced ICES concepts.

(4) to perform tests of components and subsystems for integration into ICES

(5) to provide engineering support to ICES demonstrations, especially in th申 feasibility, design, and evaluation phases.

Motivations: to conserve energy and scarce fuels through new methods of satisfying the energy needs of American communities.

Plans: (1) to develop a sound data base for the performance and cost of components and subsystems.

(2) to develop and validate methods for design of central plants, distribution systems and end-use equipment.

(3) to evaluate and catalog the more promising ICES concepts for ready acce\$s by consulting engineers and planners.

9. Status and Results

Use Box No. 15 if additional space is needed

Periodic reports on technology evaluation of subsystems. Computerized programs, simulation and optimization under development.

[X] wastewater treatment

X] solid waste processing

X potable water
1. Type of Project

XXpublic $\quad \square$ private

cooperatıve 
13. Technical Data

project location ..... - -

degree-days (heating) -

degree-days (cocling) - -

plant load capacity

a. power (MW) - - - -

b heatıng (MW) - - - -

c. cooling (MW) - - - -

d wastewater treatment-liters/day _ ... _ -

e. solid waste processıng kilograms/day _ - -

f. potable water-lıters/day - - _ - - - -

heat to power ratio (average expected)

14. Other Related Projects (Titles)

Grid-connected Integrated Community Energy System (ICES) (1-101US-02) energy source

expected payback period

Type and size of user

a residential (dwellıng unıts)

b. residential (square area- $\mathrm{m}^{2}$ )

c commercial (square area- $\mathrm{m}^{2}$ )

d Industrial (thermal + elec-MW)

15. Additional space for Purpose of Project

Approach: to take ICES Systems Engineering from conceptual design to future commercialization through: (1) Technology Evaluations which provide performance and cost data for conceptual designs; (2) Design \& Method Manuals which provide useroriented computer codes to simulate and optimize the various program elements; (3) Systems Development which integrates the various Systems Engineering technical areas into a systems synthesis and development effort; (4) Evaluation of Advanced ICES which assesses the potential and economic viability of ICES programs and demonstrations and analyze successes and failures; and (5) ICES Test Facility which provides laboratory-tested engineering data for implementing successful DOE demonstration programs that will lead to future commercialization

Estimated Results: to realize the goal of successful conservation in the provision of energy to a community. 


$\begin{aligned} & \text { NBS-1075 } \\ & (2-77)\end{aligned}$
U.S. DEPARTMENT OF COMMERCE
NATIONAL GUREAU OF STANDARDS

\section{PROJECT SUMMARY FORM}

1. Title of Project (Official Title)

System for supplying utility services to a multi-family low rise building

3. Performing Organization (Complete Mailing Address)

FIAT - Centro Ricerche

U.R. - Apparati Propulsivi

Strada del Drosso, 145 - Torino

Italy

\section{Supporting Organization (Complete Mailing Address and Name of} Contact)

FIAT - Gruppo Auto

C. so G. Agnelli, 200 - Torino - Italy

Dr. Dal Bo

Ing. A. Campanile

C.R.F.

Italy

$1 / 76$ to $5 / 77$
Identification $\mathrm{No}$

(Secretariat Use Only)

2. Date (Form Completed)

$3-7-77$

$3-7-77$

4. Principal Investigator (Name and Complete Mailing Address)

Strada del Drosso, 145 - Torino

6. Duration of Investigation (Beginning and ending)

7. Estimated Funding and Manpower (Monies and Manyears)

$\$ 200,0002$ man years

8. Purpose of Project (Jbjectives, Motivations, Approach. Plans and Expected Results)

The objective is "in situ" testing of performances of a small group generating heat and electricity for housing services. The group named TOTEM has been developed by FIAT and is described under a different Project Summary Form. The research is motivated by the need of increasing the efficiency in the utilization of fuel resources.

The experiment here described consists of 3 TOTEM groups which operate in parallel among them and with an integrating boiler. The system provides heat and electricity to a four-stored 16 apartments building located in TORINO - via Spotorno 40. The base thermal load is supposed to be supplied by the three TOTEM Groups.

Use Box No. 15 if additional space is needed

9. Status and Results

Installation of the plant completed

Operation being started

This project is: $\square$ planned $\mathrm{X}$ in-progress $\square$ completed Use Box No. 16 if additional space is needed 10. Unily Services electrical power

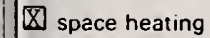
$\square$ space cooling 四 potable hot water 12. Exchange of data wastewater treatment $\square$ solid waste processing $\square$ potable water Will data be available from this project that will be shared with others?

[X] Yes No 


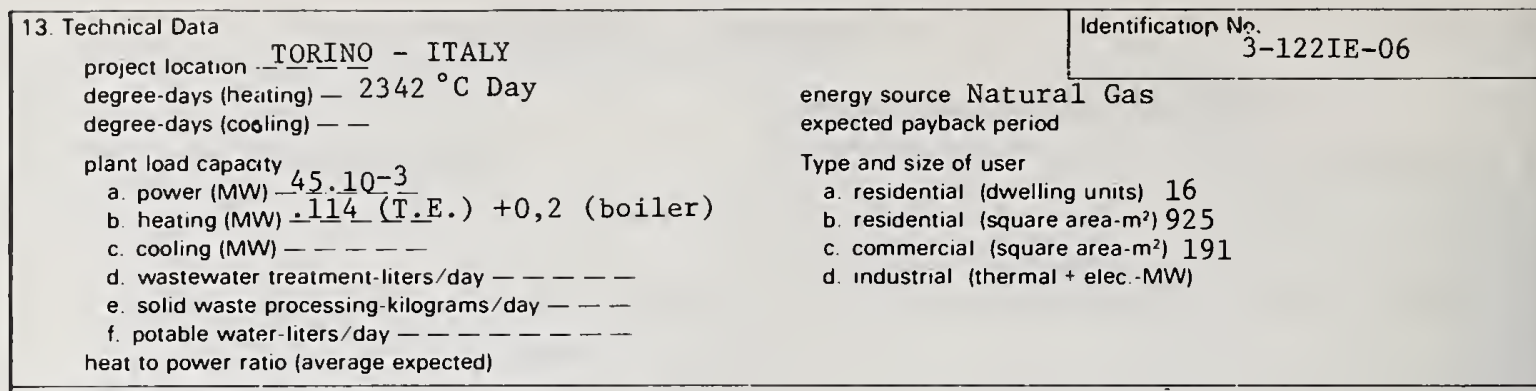

14. Other Related Projects (Tit/es)

Also see Project Summary Form 2-522IE-29.

15. Additional space for Purpose of Project

16. Additional space for Status and Results 
project location - - - -

degree-days (heating) -

degree-days (cocling) - -

plant load capacity
a. power (MW) - - - -
b. heating (MW) $-\ldots-\ldots$
c. cooling (MW) ----
d. wastewater treatment-liters/day _ _ _ -
e. solid waste processing-kilograms/day - - -
f. potable water-liters/day $-\ldots-\ldots-\ldots-$ heat to power ratio (average expected)

14. Other Related Projects (Titles)

15. Additional space for Purpose of Project

energy source

expected payback period

Type and size of user
a. residential (dwelling units)
b. residential (square area- $\mathrm{m}^{2}$ )
c. commercial (square area- $m^{2}$ )
d. industrial (thermal + elec.-MW)

16. Additional space for Status and Results 


$\begin{array}{lr}\begin{array}{l}\text { NBS-1075 } \\ (2-77)\end{array} & \text { U.S. DEPARTMENT OF COMMERCE } \\ \text { NATIONAL BUREAU OF STANDARDS }\end{array}$

PROJECT SUMMARY FORM

1. Title of Project (Official Title)

Alaska Village Demonstration Project, Wainwright, Alaska
Identification No.

(Secretariat Use Only)
3-111US-08

2. Date (Form Completed)

$$
11 / 23 / 76
$$

3. Performing Organization (Complete Mailing Address)

Arctic Environmental Research Station College, Alaska 99701

U.S.A.
4. Principal Investigator (Name and Complete Mailing Address)

Bertold Puchtler

Arctic Environmental Research Station

College, Alaska 99701

U.S.A.

6. Duration of Investigation (Beginning and ending)

$$
10 / 70 \text { to } 12 / 77
$$

7. Estimated Funding and Manpower (Monies and Manyears)

12 man years $\$ 2,000,000$

ATTN: Bert Puchtler

Also See Box 15

8. Purpose of Project (Objectives, Motivalions, Approach, Plans and Expected Results)

PURPOSE: To demonstrate methods for providing safe water supply, waste dispcsal and improving enviornmental health conditions in Alaskan villages.

APPROACH: Provide a central facility to serve each village involved. Such facility to include potable water treatment, waster water treatment, showers, saunas and laundry facilities. Also incoporating vehicular pickup and delivery system for wastewater and potable water. Employ an energy conservative approach to minimize operating costs with future use of waste heat from power generation.

Use Box No. 15 if additional space is needed

9. Status and Results

Interim report is available

This project is: $\square$ planned $[$ in-progress $\square$ completed Use Box No. 16 if additional space is needed

10. Utility Services

两electrical power

国 space heatıng

$\square$ space cooling

Qxpotable hot water

12. Exchange of data

wastewater treatment

Q solid waste processing

potable water of Project

図 public $\square$ private

cooperatıve 
13. Technical Data $70^{\circ} 38.21$

project location $160^{\circ} 0 \mathrm{I}^{\circ} .8 \mathrm{~W}$

degree-days (heating) 19,000 below $65^{\circ} \mathrm{F}$

degree-days (cocting) - -

plant load capacity

a. power (MW) $-\frac{0}{4} \cdot \frac{0}{2}=-10=3$

c. cooling (MW) - - - -

d. wastewater treatment-liters/day $-20 \times 10^{3}$

e. solid waste processing-kilograms/day $\frac{2}{20 \times}{ }^{3}$

f. potable water-liters/day - - - 20x $^{-10}{ }^{3}$

heat to power ratio (average expected)

14. Other Related Projects (Tit/es)

(SP) Alaska Village Demonstration Project, Ermonak, Alaska

(LP) Village Safe Water Program - State of Alaska, Department of Environmental Conservation

Wainwright Secondary School Complex - North Slope Borough, Alaska

15. Additional space for Purpose of Project

Department of Housing and Urban Development

Division of Energy, Building Technology and Standards

Office of Policy Development Research

Washington, D.C. 20410 U.S.A.

Jerome $H$. Rothenberg, Director, HUD/MIUS Program Manager 
(2.77)
NBS-1075

U.S. DEPARTMENT OF COMMERCE Identification No.

NATIONAL BUREAU OF STANDARDS

\section{PROJECT SUMMARY FORM}

1. Title of Project (OHficial Tit/e)

Alaska Village Demonstration Project, Emmonak Facility
(Secretariat Use On/y)

$$
\text { 3-111US-09 }
$$

2. Date (Form Completed)

$11 / 24 / 76$

\begin{tabular}{|l|l|l|}
\hline 3. Performing Organization (Complete Mailing Address) & 4. Principal Investigator (Name and Complete Mailing Address)
\end{tabular}

U.S. Environmental Protection Agency Arctic Environmental Research Station College, Alaska

U.S.A.
Bert Puchtler, Head

Alaska Village Demonstration Project Arctic Environmental Research Station College, Alaska 99701 U.S.A.

6. Duration of Investigation (Beginning and ending)

$$
1971 \text { - } 1978
$$

7. Estimated Funding and Manpower (Monies and Manyears)

$$
\$ 1,000,00030 \text { man years }
$$

U.S. Environmental Protection Agency Arctic Environmental Research Station College, Alaska U.S.A.

8. Purpose of Project (Objectives, Motivations, Approach, Plans and Expected Resu/ts)

Primary central village utility facility for water, waste, bathing \& laundry purposes. However, since costs in remote Alaska are high and processes are energy intensive, the several processes were interfaced, and heat needs were exchanged with waste heat sources as a supplement to primary heat source. Results were only partially successful due to lack of simple system of controling the interfaces.

The project has been in operation while facility has been under completion. Considerable process modification has been done to reduce operating costs and improve reliability of the several processes.

This project is: $\square$ planned $[$ in-progress $\square$ completed Use Box No. 16 if additional space is needed

Utility Services

$\square$ electrical power

$\otimes$ space heating

$\square$ space cooling

potable hot water

wastewater treatment

[.] solid waste processing

potable water

12. Exchange of data

Public laundry Public bathing

11. Type of Project

$\square$ public $\square$ private

Will data be available from this project that will be shared with others?

Yes

No 
13 Technical Data Tmmonak, Alaska project location (Bearing Sea Coast) degree-days (heiting) 1 4, 000

degree-days (cocling)

ing) - -

energy source

expected payback period

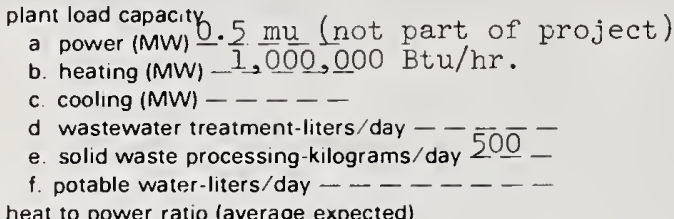

heat to power ratio (average expected)

Type and size of user

a. residential (dwelling units) 80

b. residential (square area- $\mathrm{m}^{2}$ ) 500

c. commercial (square area- $\mathrm{m}^{2}$ )

d. Industrial (thermal + elec.-MW)

14. Other Related Projects (Titles)

15. Additional space for Purpose of Project

16. Additional space for Status and Results 


\begin{tabular}{|c|c|c|}
\hline \multicolumn{2}{|c|}{ 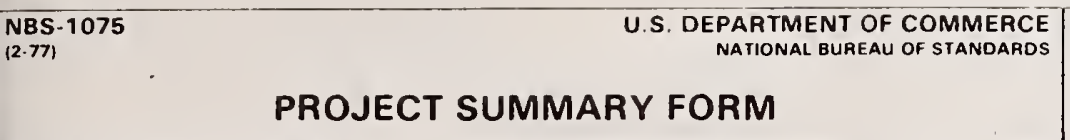 } & $\begin{array}{r}\text { (dentification No. } \\
\text { (Secretariat Use On/y) } \\
3-111 \text { US-10 }\end{array}$ \\
\hline $\begin{array}{l}\text { 1. Title of Prolect (Official Title) } \\
\text { Alaska Village Demonstration Project, A Thi } \\
\text { Small Interior Village }\end{array}$ & a Facility for & 2. Date (Form Completed) \\
\hline $\begin{array}{l}3 \text { Performing Organization /Complete Mailing Address) } \\
\text { U.S. Environmental Protection Agency } \\
\text { Arctic Environmental Research Station } \\
\text { College, Alaska } 99701 \\
\text { U.S.A. }\end{array}$ & \multicolumn{2}{|c|}{$\begin{array}{l}\text { Principal Investigator (Name and Complete Malling Address) } \\
\text { M.A.Mitchell, Head. } \\
\text { Alaska Village Demonstration Projects } \\
\text { Arctic Environmental Research Station } \\
\text { College, Alaska } 99701 \\
\text { U.S.A. }\end{array}$} \\
\hline $\begin{array}{l}\text { 5. Supporting Organization (Complete Mailing Address and Name of } \\
\text { Contact) } \\
\text { U.S. Environmental Protection Agency } \\
\text { Arctic Environmental Research Station } \\
\text { College, Alaska } 99701 \\
\text { U.S.A. }\end{array}$ & 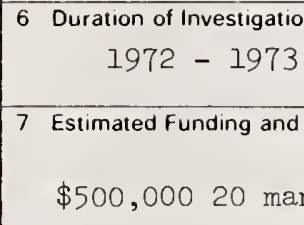 & On (Beginning and ending) \\
\hline $\begin{array}{l}\text { 8. Purpose of Project } \text { Objectives. Motivations, Approach, Plans anc } \\
\text { This third facility was to be a refinemen } \\
\text { AVDP. It was to provide potable water, } \\
\text { power \& heat source for a small 100-200 p } \\
\text { would have been a totally integrated syst } \\
\text { fuel savings, improved health, fire safet }\end{array}$ & $\begin{array}{l}\text { cted Results) } \\
\text { the first tr } \\
\text { disposal, be }\end{array}$ & $\begin{array}{l}\text { acility designs under th } \\
\text { ng, laundry, central } \\
\text { interior Alaska. It } \\
\text { increased efficiency, }\end{array}$ \\
\hline
\end{tabular}

Use Box No 15 if additional space is needed

9. Status and Results

The facility design was $90 \%$ complete when funding was withdrawn. The design A\&E still holds the work and could proceed with adequate program resources.

This project is planned $\square$ in-progress $\square$ completed

10. Utility Services

electrical power

space heatıng

wastewater treatment

[0 space cooling

$\square$ potable hot water

$\mathrm{X}$ solid waste processing

$\left[\frac{\mathrm{X}}{\mathrm{X}}\right]^{\text {potable water }}$ community \& bath laundry

2. Exchange of data

Will data be available from this project that will be shared with others?

Y Yes

Use Box No. 16 if additional space is needed

$\left[\begin{array}{ll}11 \text { Type of Project } \\ \square \text { public } \square \text { private } \\ \square \text { cooperative }\end{array}\right.$

cooperative

-

$\square$ No If carried out! 


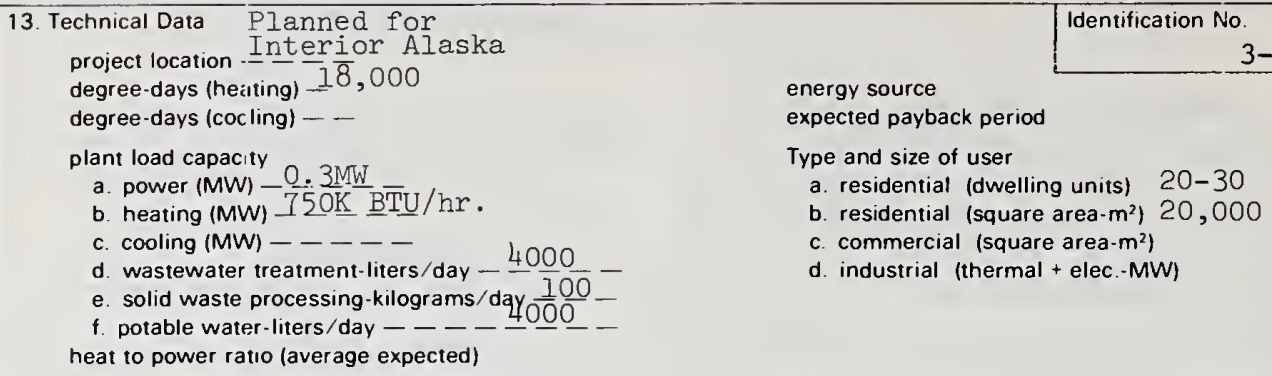

energy source expected payback period

Type and size of user

a. residential (dwelling units) 20-30

b. residential (square area- $\mathrm{m}^{2}$ ) 20,000

c. commercial (square area- $\mathrm{m}^{2}$ )

d. industrial (thermal + elec. MW)

14. Other Related Projects (Tirles)

15. Additional space for Purpose of Project 


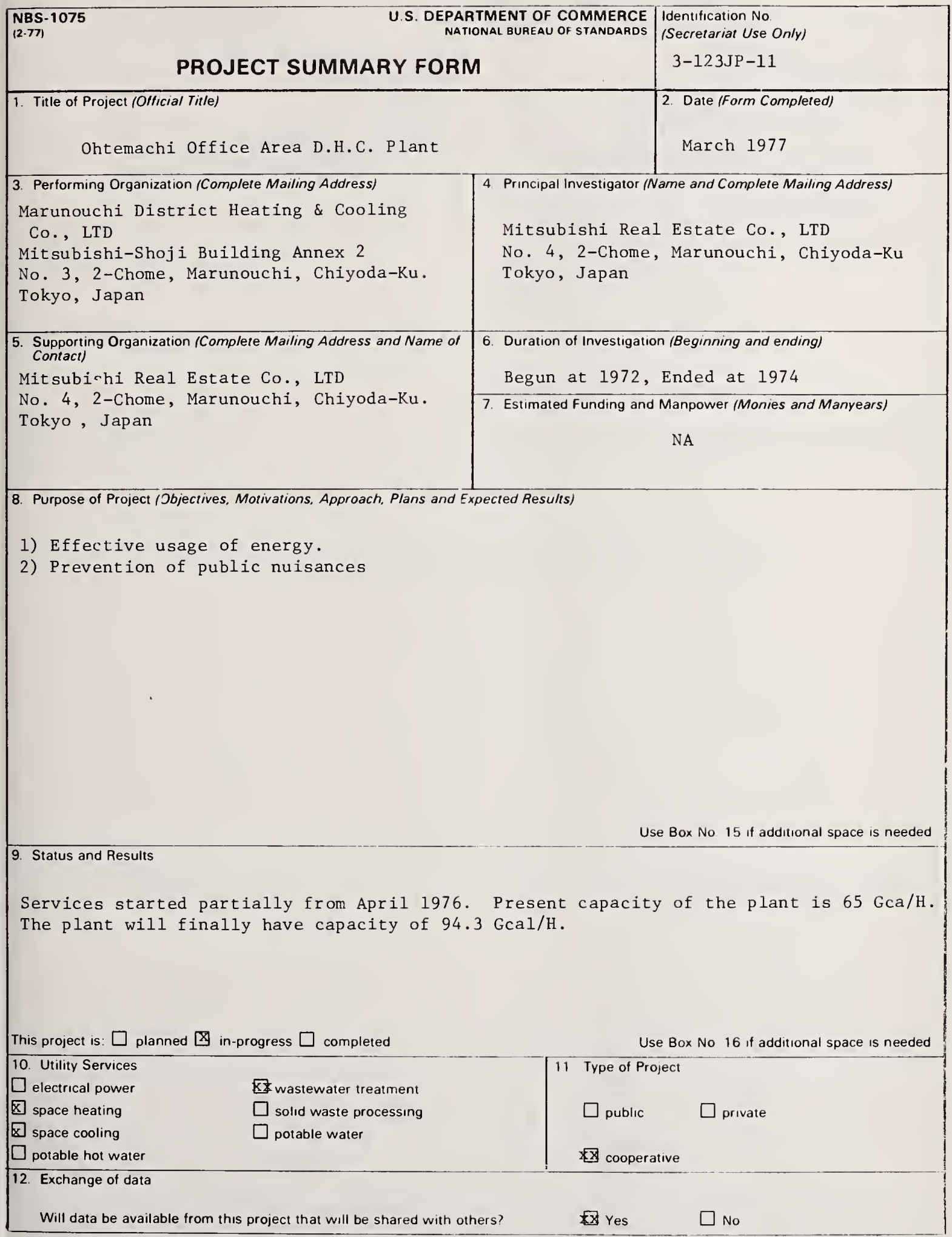




\section{Technical Data}

project location - Tokyo, J apan

degree-days (heatıng) 1,956

degree-days (cocling) -..

plant load capacity

a. power $(\mathrm{MW})-15$ (present)

b. heating (MW) $-\frac{34}{5}-(40 \mathrm{Gcal} / \mathrm{H})$ (present)

c. cooling (MW) - 56 ( $65 \mathrm{Gca} 1 / \mathrm{H})$ (present)

d. wastewater treatment day $-5,000$

e. solid waste processing-kilograms/day _ -

f. potable water-liters/day $--\ldots-\ldots$

heat to power ratio (average expected)

14. Other Related Projects (Titles)

\section{Identification No \\ 3-123JP-11 \\ energy source City Gas \\ expected payback period not known}

Type and size of user
a. residentıal (dwelling units)
b. residential (square area- $\mathrm{m}^{2}$ )
c. commercial (square area- $\mathrm{m}^{2}$ ) ],650,00
d industrial (thermal + elec-MW) (final)

15. Additional space for Purpose of Project

16. Additional space for Status and Results 


\begin{tabular}{|c|c|c|}
\hline \multicolumn{2}{|l|}{$\begin{array}{l}\text { NBS-1075 } \\
(2-77)\end{array}$} & $\begin{array}{l}\text { Identification No. } \\
\text { (Secretariat Use On/y) } \\
3-133 \text { US }-12\end{array}$ \\
\hline $\begin{array}{l}\text { 1. Title of Project (Official Title) } \\
\text { Codisposal \& Coordinated Materials Recove }\end{array}$ & & $\begin{array}{l}\text { 2. Date (Form Completed) } \\
\qquad 11 / 23 / 76\end{array}$ \\
\hline $\begin{array}{l}\text { 3. Performing Organization (Complete Mailing Address) } \\
\text { Brown and Caldwe } 11 \text { Consulting Engrs } \\
1501 \mathrm{~N} \text {. Broadway } \\
\text { Walnut Creek, CA } 94596 \\
\text { U.S.A. }\end{array}$ & $\begin{array}{l}\text { 4. Principal Investigator } N \\
\text { Dr. Richard S } \\
\text { Brown and Cal } \\
1501 \text { N. Broad } \\
\text { Walnut Creek, } \\
\text { U.S.A. }\end{array}$ & $\begin{array}{l}\text { Vame and Complete Mailing Address) } \\
\text { tone } \\
\text { ldwe } 11 \text { Consulting Engr. } \\
\text { Away } \\
\text { CA } 94596\end{array}$ \\
\hline $\begin{array}{l}\text { 5. Supporting Organization (Complete Mailing Address and Name of } \\
\text { Contact) } \\
\text { F.L. Evans } \\
\text { U.S. EPA, OR\&D, MERL, WRD } \\
\text { Cincinnati, Ohio } 45268 \\
\text { U.S.A. }\end{array}$ & $\begin{array}{l}\text { 6. Duration of Investigatio } \\
\text { 7. Estimated Funding and } \\
\$ 90,000\end{array}$ & $\begin{array}{l}\text { on (Beginning and ending) } \\
\text { Manpower (Monies and Manyears) }\end{array}$ \\
\hline
\end{tabular}

8. Purpose of Project (Objectives, Motivations, Approach, Plans and Expected Results)

Identification of situations where co-disposal or coordinated materials recovery or recycling of waste residuals is economically and technically justified.

9. Status and Results

Not yet started

wastewater treatment

kit solid waste processing

$\square$ potable water

space heating

space cooling

X potable hot water

12. Exchange of data

Will data be available from this project that will be shared with others?
Yes

$\square$ No 
13 Technical Data

project location - . - .

degree-days (heasting) -

degree-days (cocling) - -

plant load capacity
a. power (MW) - ... - -
b. heating (MW) - - - -
c. cooling (MW) - - -
d. wastewater treatment-liters/day - $\ldots$
e. solid waste processing-kilograms/day - - -
f. potable water-liters/day $-\ldots \ldots \ldots \ldots$
heat to power ratio (average expected)

14 Other Related Projects (Tit/es)
Identification No

$$
\text { 3-133US- } 12
$$

energy source

expected payback period

Type and size of user
a residentıal (dwellıng units)
b. residential (square area- $m^{2}$ )
c. commercial (square area- $\mathrm{m}^{2}$ )
d industrial (thermal + elec.-MW)

15. Additional space for Purpose of Project

16. Additional space for Status and Results 


\begin{tabular}{|c|c|c|}
\hline \multicolumn{2}{|l|}{ PROJECT SUMMARY FORM } & \multirow{2}{*}{\begin{tabular}{|c|}
$\begin{array}{c}\text { Identification No } \\
\text { (Secretariat Use On/y) } \\
3-191 \mathrm{SE}-13\end{array}$ \\
$\begin{array}{c}\text { 2. Date (Form Completed) } \\
3 / 15 / 77\end{array}$
\end{tabular}} \\
\hline $\begin{array}{l}\text { 1. Title of Project (Official Title) } \\
\text { Mini-Nuclear Plants for Domestic Heating } \\
\text { Supply }\end{array}$ & nd Hot Water & \\
\hline $\begin{array}{l}\text { 3. Performing Organization (Complete Malling Address) } \\
\text { 1. ASEA-ATOM } \\
\text { 2. AB Atomenergic, Sweden } \\
\text { 3. Finnatum (Finish Company) } \\
\text { 4. Finnish State Technological Research } \\
\text { Center }\end{array}$ & 4. Principal Investigator /N & Vame and Complete Mailing Address) \\
\hline $\begin{array}{l}\text { 5. Supporting Organization (Complete Mailing Address and Name of } \\
\text { Contact) } \\
\text { Sweden } \\
\text { (Government Grant) }\end{array}$ & \begin{tabular}{|} 
6. Duration of Investigatio \\
$1976-19$ \\
7. Estimated Funding and \\
9 million
\end{tabular} & $\begin{array}{l}\text { on (Beginning and ending) } \\
\frac{77}{\text { Manpower (Monies and Manyears) }} \\
\text { S kr. }\end{array}$ \\
\hline $\begin{array}{l}\text { 8. Purpose of Project (Jbjectives, Motivations, Approach. Plans and } \\
\text { This project is a nuclear heating plat } \\
\text { heat for Urban Area with a popluation bet } \\
\text { project is based on an idea by Erik Svenk } \\
\text { Fuel Supply Company (SKBF). } \\
\text { Based on experiences to date, a nucle } \\
\text { to be competitive compared with oil-fired } \\
\text { if such a plant is not as profitable as a } \\
\text { The plant now being studied by ASEA-A } \\
\text { which is about one-fifth of a modern Swed } \\
\text { reactor vessel is heated to just over } 100 \\
\text { The project is considered safe and suitab } \\
\text { reduce Sweden's dependence on oil of }\end{array}$ & $\begin{array}{l}\text { to to be placed in } \\
\text { een } 50,000 \text { and } 10 \\
\text { Managing Direct } \\
\text { hower plant for } \\
\text { home heaters or d } \\
\text { combined power an } \\
\text { OM has a thermal } \\
\text { sh nuclear power } \\
\text { C, thus there is } \\
\text { e for urban siting }\end{array}$ & $\begin{array}{l}\text { a rock Chamber to generate } \\
0,000 \text { inhabitants. The } \\
\text { or of the Swedish Nuclear } \\
\text { production of heat appears } \\
\text { istrict heating plants even } \\
\text { d district heating plant. } \\
\text { capacity of } 100-300 \mathrm{MW} \\
\text { plant. The water in the } \\
\text { no problem of over-pressure. } \\
\text { g. The main purpose is to } \\
\text { domestic heating }\end{array}$ \\
\hline
\end{tabular}

9. Status and Results

A complete report is expected in the fall of 1977.

$$
\begin{array}{|l}
\hline 1 \\
\hline \mathbf{Z} \\
\hline \\
\hline \\
\hline \\
\hline 1 \\
\hline
\end{array}
$$

Mini-Nuclear Plants for Domestic Heating and Hot Water 4. Principal Investigator (Name and Complete Mailing Address)

1. ASEA-ATOM

B Atomenergic, Sweden

. Finnatum (Finish Company)

Finnish State Technological Research
Center

Supporting Organization (Complete Mailing Address and Name of

weden

$1976-1977$

9 million Skr 
13. Technical Data

project location

degree-days (heating) -

degree-days (coclıng) _-

plant load capacity

a. power (MW) - - - -

i. heating (MW) $-\ldots$

c. cooling (MW) - - -

d. wastewater treatment-liters/day $-\ldots-\ldots$

e. solid waste processing-kilograms/day - - -

f. potable water-liters/day $-\ldots-\ldots-\ldots$

heat to power ratio (average expected)
Identification No.

3-191SE- 13

energy source

expected payback period

Type and size of user

a. residential (dwelling units)

b. residential (square area- $\mathrm{m}^{2}$ )

c. commercial (square area- $\mathrm{m}^{2}$ )

d. industrial (thermal + elec. MW)

14. Other Related Projects (Tit/es)

15. Additional space for Purpose of Project

16. Additional space for Status and Results 


$\begin{aligned} & \text { NBS-1075 } \\ & (2-77)\end{aligned}$
U.S. DEPARTMENT OF COMMERCE
NATIONAL BUREAU OF STANDARDS

PROJECT SUMMARY FORM

1. Title of Project (Official Title)

Leeds General Infirmary Generator Station Complex

3. Performing Organization (Complete Mailing Address)

Leeds Area Health Authority (Teaching)

Western District

Generator Station Complex

Leeds General Infirmary, Leeds 1

U.K.

5. Supporting Organization (Complete Mailing Address and Name of Contact)

As Above

\section{$\mathrm{N} / \mathrm{A}$}

8. Purpose of Project (Jbjectives, Motivations, Approach, Plans and Expected Results)

To provide service supplies of electricity, steam, hot water, chilled water compressed air for 1600 bed general hospital.

Use Box No 15 if additional space is needed

9. Status and Results

Commissioned and now in initial operation phase.

This project is: $\square$ planned $\square$ in-progress completed

10. Utility Services

electrical power

space heatıng

space cooling

potable hot water

Use Box No 16 if additional space is needed

12. Exchange of data

$\square$ wastewater treatment

solid waste processing

$\square$ potable water dentification No

(Secretariat Use On/y)

$3-471 \mathrm{~GB}-14$

2. Date (Form Completed)

March 19, 1977
4 Principal Investigator (Name and Complete Mailing Address)

Superintendent

Leeds General Infirmary, Leeds 1

$\mathrm{U} . \mathrm{K}$.
Station Commissioned January 1977

. Estimated Funding and Manpower (Monies and Manvears)
11. Type of Project

public $\square$ private

cooperative 


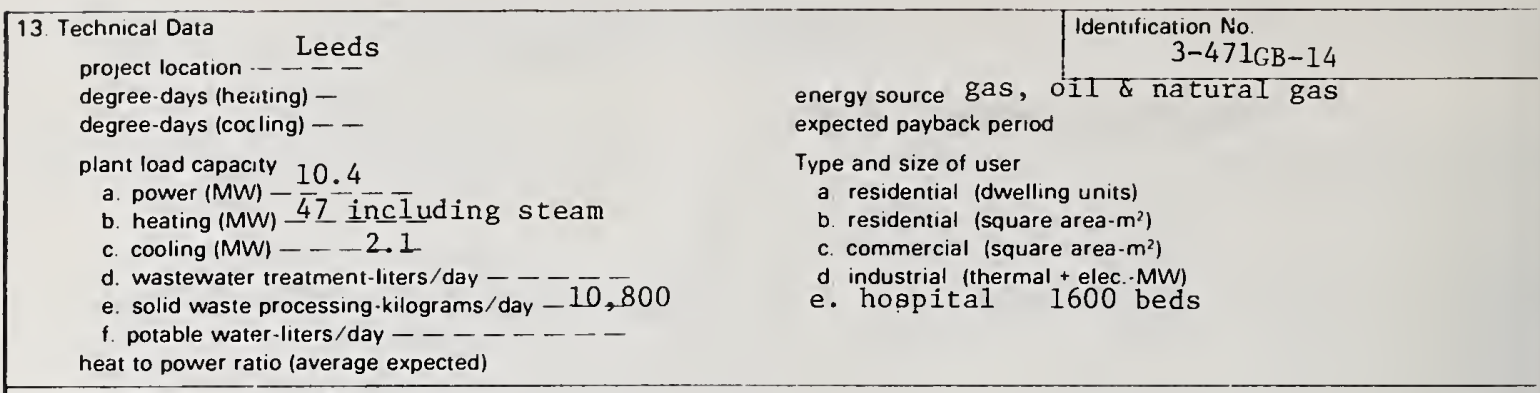

14. Other Related Projects (Titles)

15. Additional space for Purpose of Project

16. Additional space for Status and Results 


\begin{tabular}{|c|c|c|}
\hline $\begin{array}{r}\text { U.S. DEPA } \\
\text { NA } \\
\text { PROJECT SUMMARY FOR }\end{array}$ & $\begin{array}{l}\text { RTMENT OF COMMERCE } \\
\text { IONAL GUAEAU OF STANDARDS } \\
\text { V }\end{array}$ & $\begin{array}{l}\text { Identification No. } \\
\text { (Secretariat Use Only) } \\
3-502 \mathrm{NL}-15\end{array}$ \\
\hline $\begin{array}{l}\text { Generat ing Sy stem } \\
\text { AKzorming Organization (Complete Mailing Address) } \\
\text { Arnhem, The Nether lands }\end{array}$ & \multicolumn{2}{|c|}{$\begin{array}{l}\text { 4. Principal Investigator (Name and Complete Mailing Address) } \\
\text { G.K. Dorling } \\
\text { AKZON. V. } \\
\text { Arnhem, The Netherlands }\end{array}$} \\
\hline \multirow[t]{2}{*}{$\begin{array}{l}\text { 5. Supporting Organization (Complete Mailing Address and Name of } \\
\text { Cortact) }\end{array}$} & \multicolumn{2}{|c|}{$\begin{array}{l}\text { 6. Duration of Investigation (Beginning and ending) } \\
\text { NA }\end{array}$} \\
\hline & \multicolumn{2}{|c|}{$\begin{array}{l}\text { 7. Estimated Funding and Manpower (Monies and Manyears) } \\
\text { NA }\end{array}$} \\
\hline
\end{tabular}

AKZO, as an important consumer of energy, has acquired detailed information about combined steam/power generating systems.

The project is to be regarded as a continuous study to improve the energy conversion efficiency within an industrial economic framework.

Use Box No. 15 if additional space is needed

9. Status and Results

$x$ electrical power

$\otimes$ space heating

$\square$ space cooling

$\otimes$ potable hot water

12. Exchange of data

planned $\square$ in-progress $\square$ completed

Use Box No. 16 if additional space is needed

wastewater treatment

$\square$ solid waste processing

$\square$ potable water

11. Type of Project

$\square$ public $\square$ private

cooperative

Will data be available from this project that will be shared with others?

Yes

No $[\mathrm{x}]$ unknown 
13 Technical Data

project location - - - -

degree-days (heating) -

degree-days (cocling) - -

plant load capacıty

a. power (MW) - - - -

b. heating (MW) $-\ldots$

c. cooling (MW) - - - -

d wastewater treatment-liters/day _ - _ -

e. solid waste processing-kilograms/day - - -

f. potable water-liters/ojay $-\ldots-\ldots-\ldots$ heat to power ratio (average expected)

14 Other Related Projects (Tit/es) energy source expected payback period

Type and size of user

a. residential (dwelling units)

b. residential (square area- $\mathrm{m}^{2}$ )

c. commercial (square area- $\mathrm{m}^{2}$ )

d. industrial (thermal + elec. MW)

15. Additional space for Purpose of Project

16. Additional space for Status and Results 


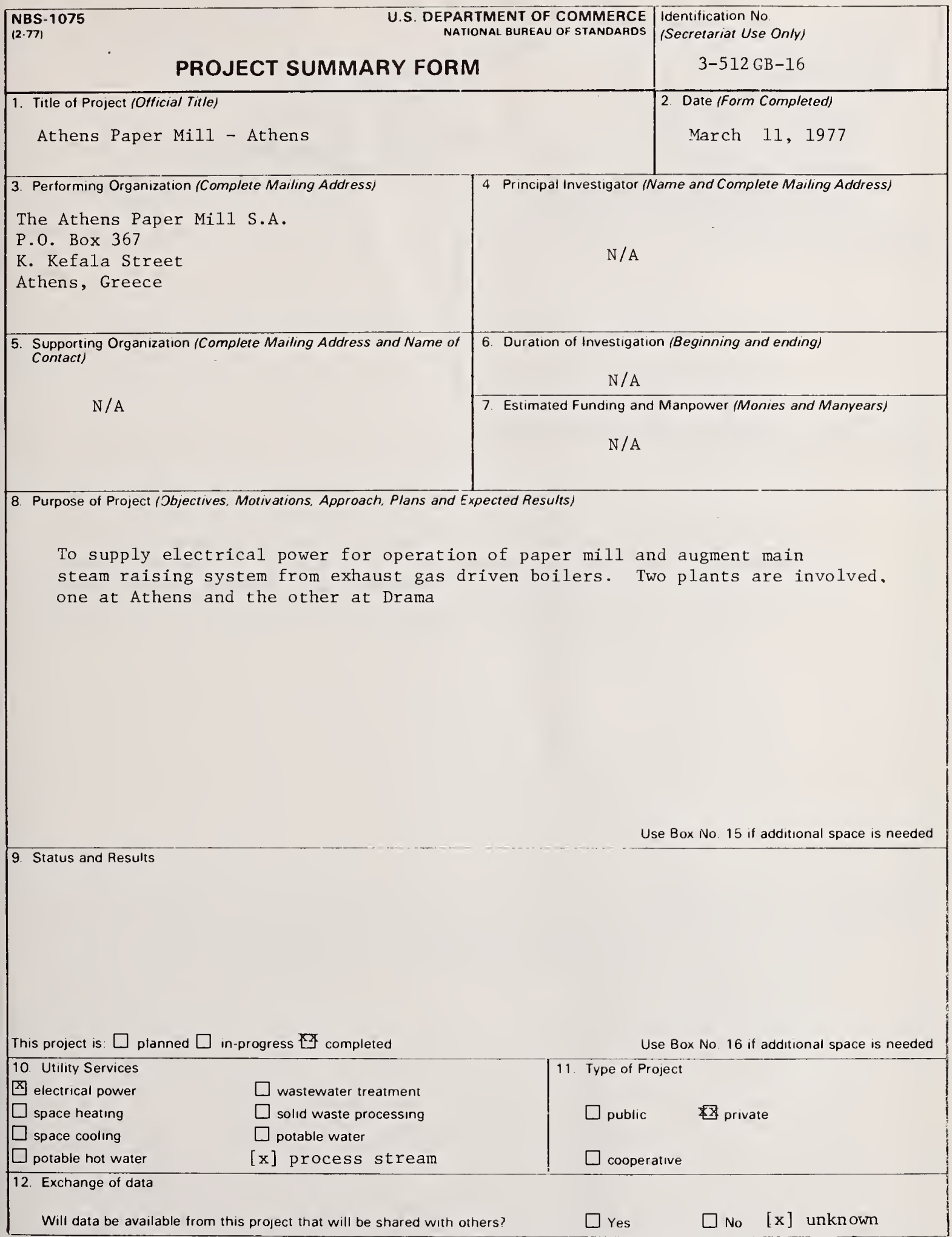




\begin{tabular}{|c|c|}
\hline $\begin{array}{l}13 \text { Technical Data } \\
\text { project location }-\ldots--\end{array}$ & $\begin{array}{r}\text { Identification No } \\
3-512 \mathrm{~GB}-16\end{array}$ \\
\hline $\begin{array}{l}\text { degree-days (heating) - } \\
\text { degree-days (cocling) }--\end{array}$ & $\begin{array}{l}\text { energy source fuel oil } \\
\text { expected payback period }\end{array}$ \\
\hline
\end{tabular}

14. Other Related Projects (Titles)

15. Additional space for Purpose of Project

16. Additional space for Status and Results

Information supplied by diesel engine supplier. Contract:

Mioleir Blackstone Ltd.

Haze1 Grove

Stockport, Chesline SK75AH

United Kingdom 


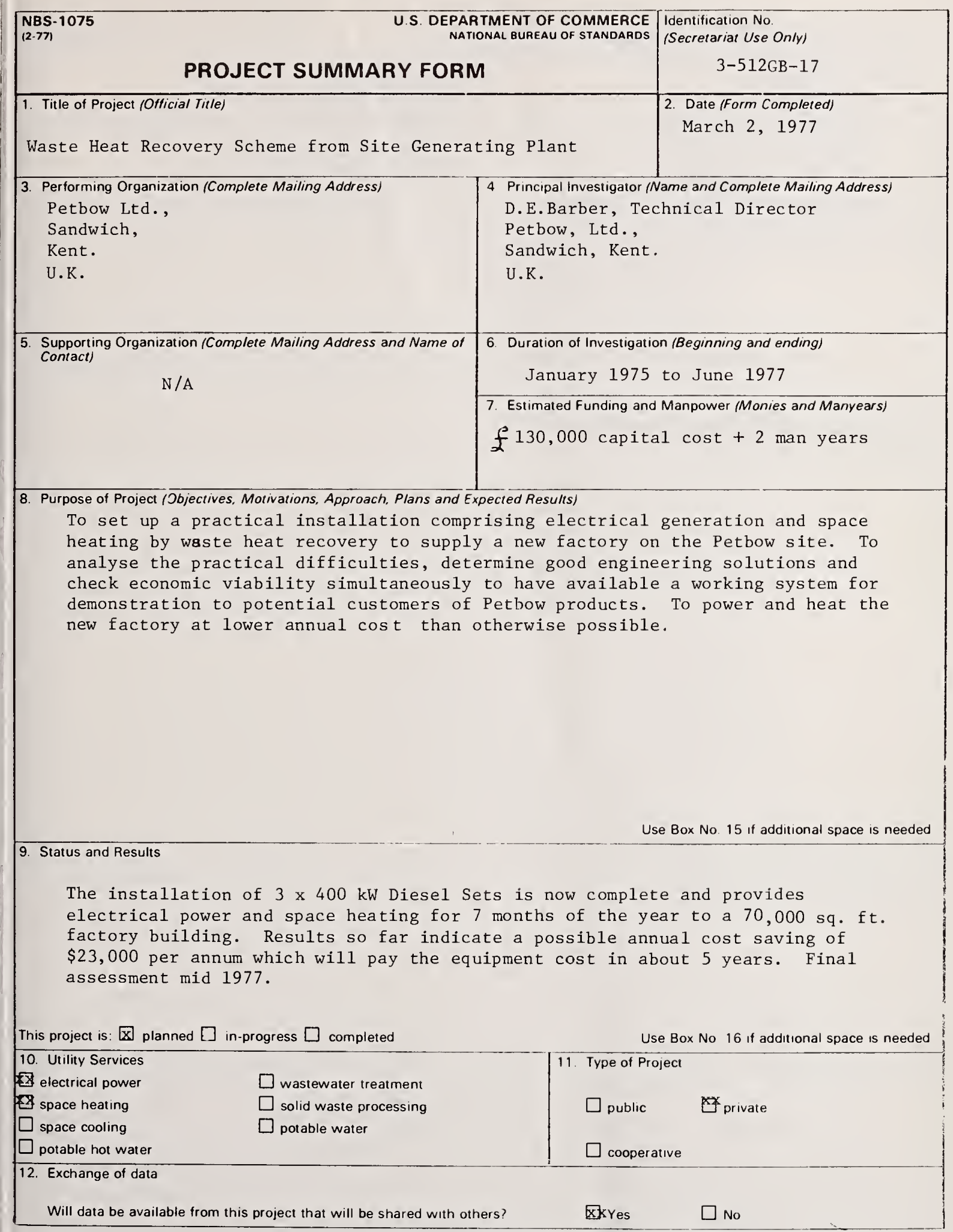




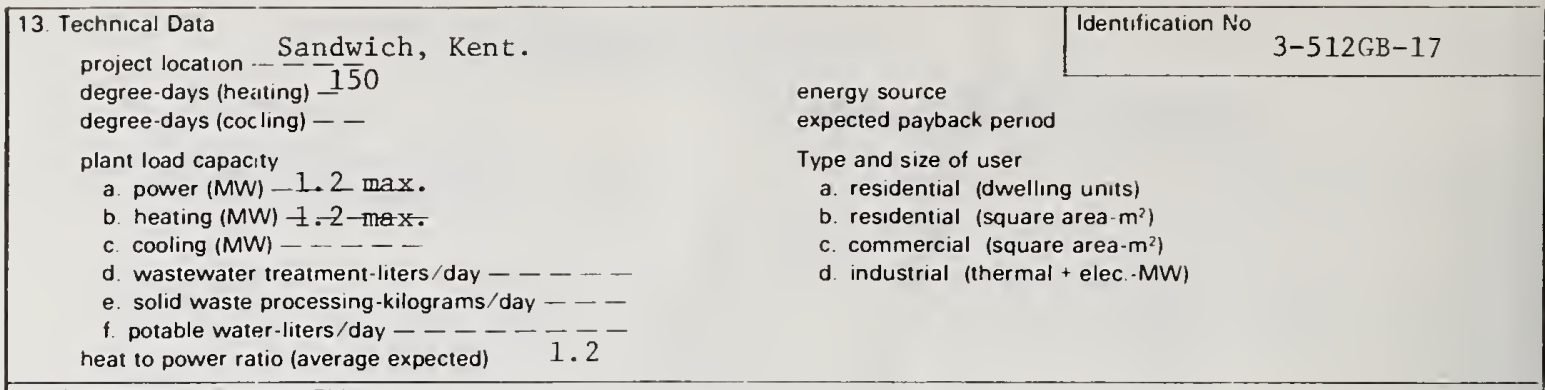

14. Other Related Projects (Titles)

15. Additional space for Purpose of Project

16. Additional space for Status and Results 


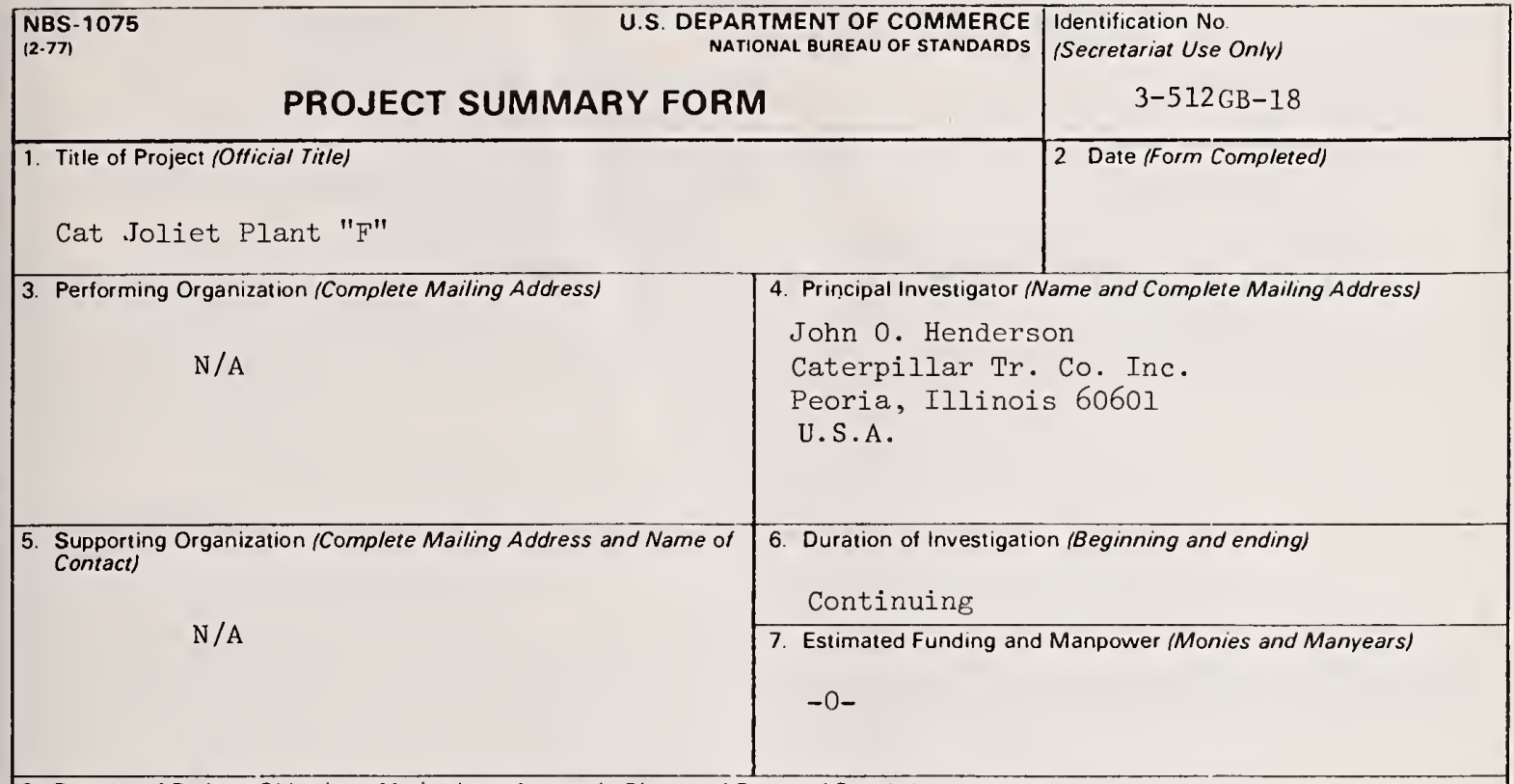

8. Purpose of Project (Jbjectives, Motivations. Approach, Plans and Expected Resu/ts)

Economical - Reliable Production of required utilities for production of Hydraulic Components under closely controlled environmental conditions using numerically tape controlled machinery.

Use Box No. 15 if additional space is needed

9. Status and Results

- Excellent -

This project is: $\square$ planned $\square$ in-progress $\square$ completed Use Box No. 16 if additional space is needed

$\begin{array}{ll}10 . \text { Utility Services } & {[\text { wastewater treatment }} \\ \square] \text { electrical power } & {[\text { solid waste processing }} \\ \square] \text { space heating } & {[\text { potable water }} \\ {[] \text { space cooling }} & \end{array}$

12. Exchange of data

Will data be available from this project that will be shared with others?

$\triangle$ Yes No 


\section{Technical Data}

project location -... -

degree-days (heating) -

degree-days (cocling) - -

plant load capacity

a. power (MW) - _ - -

b. heating $(\mathrm{MW})----$

c. cooling (MW) - - -

d. wastewater treatment-liters/day $--\ldots$

e. solid waste processing-kilograms/day - - -

f. potable water-liters/day _ _ _ _ _ _ -

heat to power ratio (average expected)

14. Other Related Projects (Tit/es)
Identification No.

$3-512 \mathrm{~GB}-18$

energy source

expected payback period

Type and size of user

a. residential (dwelling units)

b. residential (square area- $\mathrm{m}^{2}$ )

c. commercial (square area- $\mathrm{m}^{2}$ )

d. industrial (thermal + elec.-MW)

15. Additional space for Purpose of Project

16. Additional space for Status and Results 


\begin{tabular}{|c|c|c|}
\hline \multicolumn{2}{|c|}{\begin{tabular}{|rr}
$\begin{array}{l}\text { NBS-1075 } \\
(2.77)\end{array}$ & U.S. DEPARTMENT OF COMMERCE \\
NATIONAL GUREAU OF STANDARDS \\
& PROJECT SUMMARY FORM
\end{tabular}} & $\begin{array}{l}\text { Identification No } \\
\text { (Secretariat Use On/v) } \\
3-51.53 \mathrm{~GB}-19\end{array}$ \\
\hline $\begin{array}{l}\text { 1. Title of Project (Official Title) } \\
\text { Process Steam Supplies to British Celan }\end{array}$ & ese Co., Ltd. & $\begin{array}{l}\text { 2. Date (Form Completed) } \\
\text { March 16, } 1977\end{array}$ \\
\hline $\begin{array}{l}3 \text { Performing Organization (Complete Mailing Address) } \\
\text { Midlands Region Headquarters } \\
\text { Central Electricity Generating Board } \\
\text { Haslucks Green Road } \\
\text { Shirley, Solihull. } \\
\text { U.K. }\end{array}$ & $\begin{array}{l}4 \text { Principal Investigator } 1 \text { } \\
\text { Director of Resc } \\
\text { Midlands Region } \\
\text { Central Electric } \\
\text { Haslucks Green } \\
\text { Shirley, Solihul } \\
\text { U.K. }\end{array}$ & $\begin{array}{l}\text { Name and Complete Mailing Address) } \\
\text { ource Planning } \\
\text { Headquarters } \\
\text { city Generating Board } \\
\text { Road } \\
11\end{array}$ \\
\hline $\begin{array}{l}\text { 5. Supporting Organization (Complete Mailing Address and Name of } \\
\text { Contact) } \\
\text { Director of Resource Planning } \\
\text { Midlands Region Headquarters } \\
\text { Central Electricity Generation Board } \\
\text { Haslucks Green Road } \\
\text { Shirley, Solihull } \\
\text { U.K. }\end{array}$ & $\begin{array}{l}\text { 6. Duration of Investigatio } \\
\text { April } 1974 \text {, stil } \\
\text { 7. Estimated Funding and } \\
\$ 10 \mathrm{M}-\$ 17 \mathrm{M} \text { over } \\
\text { depending on met }\end{array}$ & $\begin{array}{l}\text { on (Beginning and ending) } \\
11 \text { in progress } \\
\text { Manpower (Monies and Manyears) } \\
3 \text { or } 4 \text { years respectively } \\
\text { thod of firing adopted }\end{array}$ \\
\hline
\end{tabular}

8. Purpose of Project (Objectives, Motivations, Approach, Plans and Expected Results)

To provide an additional supply of steam for process use by British Celanese increasing by approx. $60 \%$ the existing supply which has been in operation since 1960. This additional supply is via a back-pressure turbine the electrical output from which is supplied directly to the National Grid system.

9. Status and Results

Negotiations as to type of fuel, quantity of steam supply and price of steam supplied are not concluded.

This project is: $\quad$ planned $\square$ in-progress $\square$ completed Use Box No 16 if additional space is needed 10. Utility Services Q7 electrical power $\square$ space heatıng $\square$ space cooling $\square$ potable hot water

$\square$ wastewater treatment
$\square$ solıd waste processıng
$\square$ porable water
$x$ process




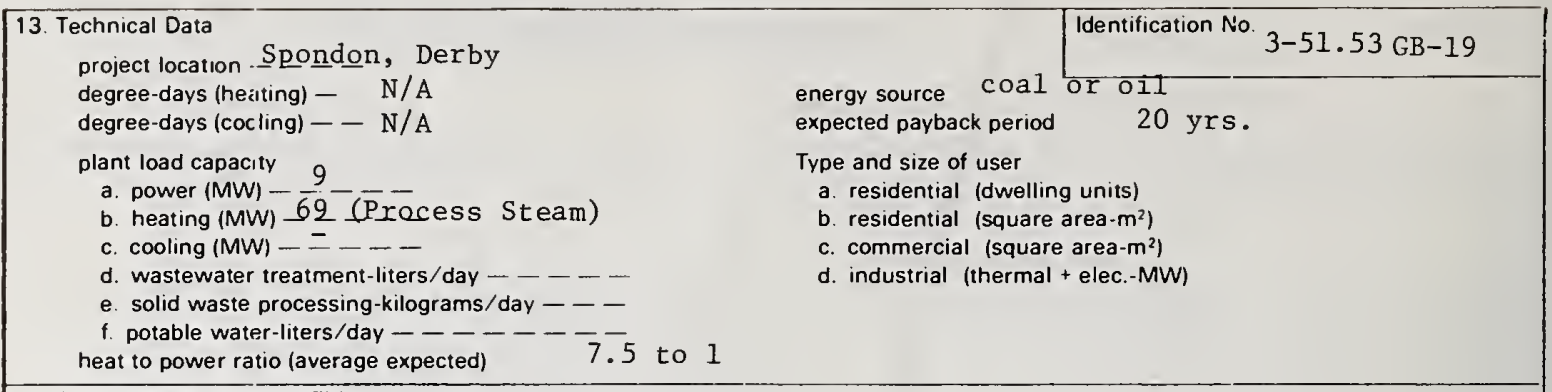

14. Other Related Projects (Titles)

none

15. Additional space for Purpose of Project

16. Additional space for Status and Results 
(2.77)
NBS-1075

U.S. DEPARTMENT OF COMMERCE

NATIONAL TUREAU OF STANDARDS

\section{PROJECT SUMMARY FOFM}

1. Title of Project (Official Tit/e)

Centrale Thermoelecttrica di Varedo

3. Performing Organization (Complete Mailing Address) SNIA-VISCOSA

Via Montebello, 18

20121 Milano (Italy) Supporting
Contact)

8. Purpose of Project (Jbjectives, Motivations, Approach, Plans and Expected Resu/ts)

(2) $\mathrm{N} / \mathrm{A}$ N/A
Identification No.

(Secretariat Use On/y)

3-572IE-20
2. Date (Form Completed)

$$
1 / 7 / 77
$$

\footnotetext{
$$
\mathrm{N} / \mathrm{A}
$$

N/A

Maximum electric power: $44 \mathrm{MW}$

Condensation electric power: $30 \mathrm{MW}$

Steam pressure: $181 \mathrm{~kg} / \mathrm{cm}^{2}$

Steam temperature: $535^{\circ} \mathrm{C}$
}

6. Duration of Investigation (Beginning and ending)

7. Estimated Funding and Manpower (Monies and Manyears)

Since 1971 SNIA VISCOSA has a combined power plant producing electric power and heat for its industrial plants of Varedo.

Use Box No 15 if additional space is needed
1971

$8000 \mathrm{~h}$

Annual utilization

Fuel

Max. Steam flow rate

Process heat max. steam flow rate

Max. elect. power output

$\begin{array}{cc}8000 \mathrm{~h} & 8300 \mathrm{~h} \\ \text { Oil } 80 \%-\mathrm{NG} 20 \% & 0 i 120 \%-\mathrm{NG} 80 \% \\ 152 \text { tons } / \mathrm{h} & 138 \text { tons } / \mathrm{h} \\ 78 \text { tons } / \mathrm{h} & 76 \text { tons } / \mathrm{h} \\ 33.2 \mathrm{MW} & 29 \mathrm{MW}\end{array}$

Use Box No. 16 if additional space is needed planned $\square$ in-progress $\uplus^{3}$ completed

wastewater treatment

$\square$ solıd waste processing

$\square$ potable water

$\mathrm{X}$ Industrial heat
Project

public 团 private

cooperative potable hot water

Exchange of data

Will data be available from this project that will be shared with others?

[X] Yes

$\square$ No

No




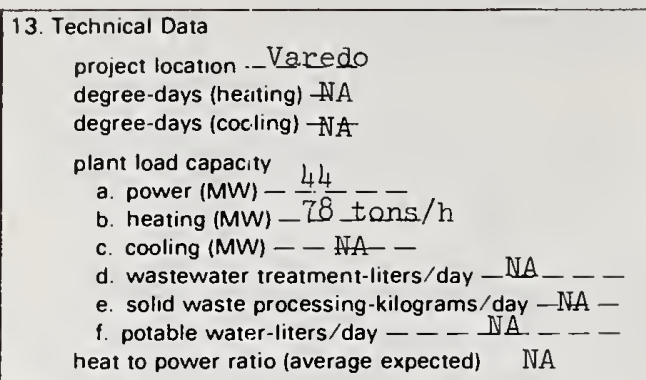

Identification No.
$3-5$ T2IE-20

Type and size of user
a residential (dwelling units)
b. residential (square area- $m^{2}$ )
c. commercial (square area- $\mathrm{m}^{2}$ )
NA
d. industrial (thermal + elec.-MW)

14. Other Related Projects (Titles)

15. Additional space for Purpose of Project

16. Additional space for Status and Results 


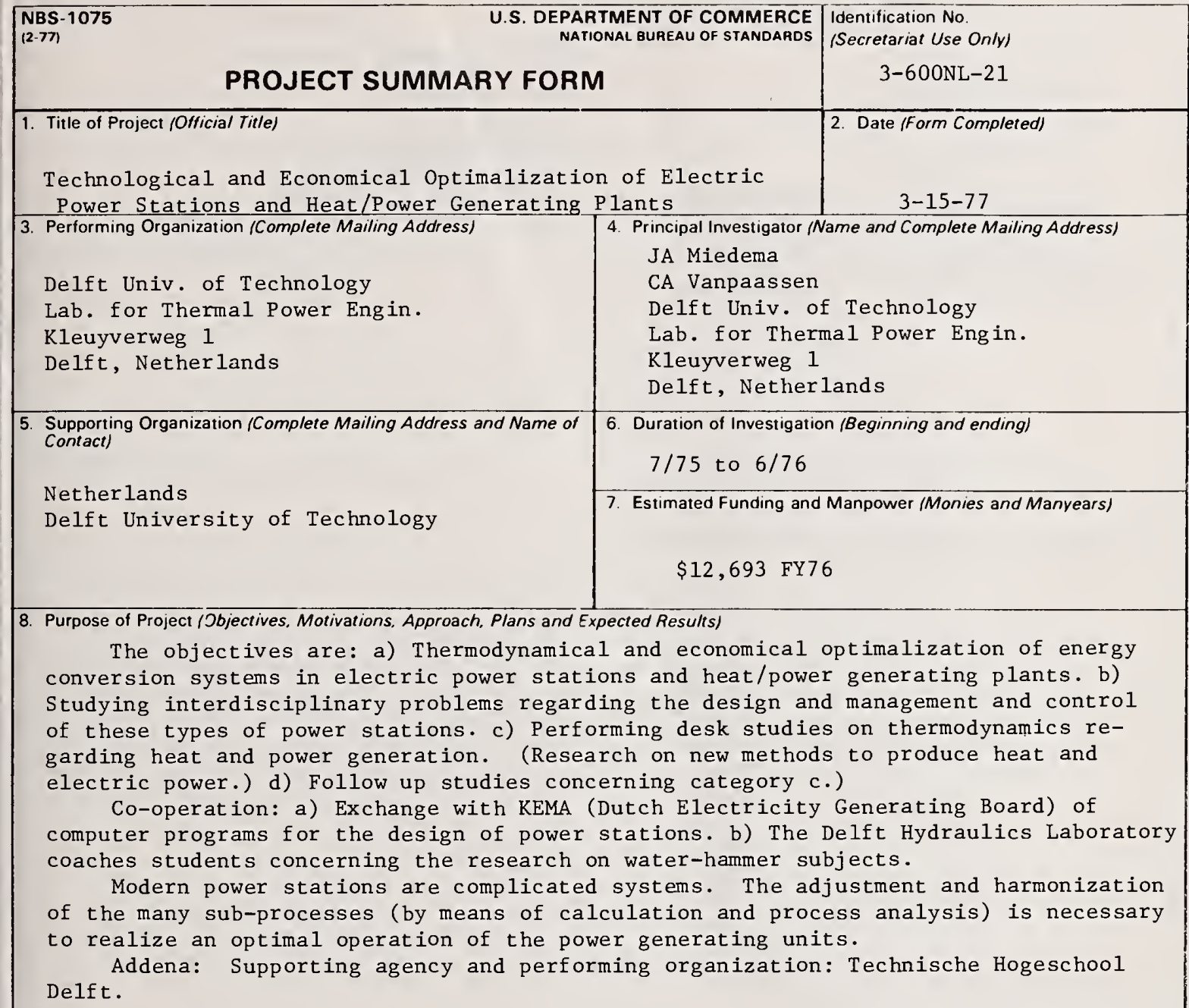

Use Box No. 15 if additional space is needed

9. Status and Results

This project is: $\square$ planned $\square$ in-progress $\square$ completed 
13. Technical Data

project location - - - -

degree-days (heating) -

degree-days (cocling) - -

plant load capacity
a power (MW) -
b. heating (MW) - . -
c. cooling (MW) $-\ldots$
d. wastewater treatment-liters/day _ - -
e. Solid waste processing-kilograms/day _ - -
f. potable water-liters/day $-\ldots-\ldots-\ldots$
heat to power ratio (average expected)

14. Other Related Projects (Titles)
Identification No.

3-600NL-2I

energy source

expected payback period

Type and size of user

a. residential (dwelling units)

b. residential (square area- $m^{2}$ )

c. commercial (square area- $\mathrm{m}^{2}$ )

d. industrial (thermal + elec.-MW)

15. Additional space for Purpose of Project

16. Additional space for Status and Results 


\begin{tabular}{|c|c|c|}
\hline \multicolumn{2}{|l|}{$\begin{array}{l}\text { NBS-1075 } \\
(2-77)\end{array}$} & $\begin{array}{l}\text { Identification No } \\
\text { (Secretariat Use Only) } \\
3-601 \mathrm{CA}-22\end{array}$ \\
\hline \multicolumn{2}{|c|}{$\begin{array}{l}\text { 1. Title of Project (Official Title) } \\
\text { Improvement of Energy Utilization in Canada -- Urban use } \\
\text { Sector }\end{array}$} & 2. Date (Form Completed) \\
\hline \multicolumn{3}{|c|}{\begin{tabular}{l|r} 
3. Performing Organization (Complete Mailing Address) & 4. Principal Investigator (Na \\
Carleton University & Prof. JT Rogers \\
Colonel by Dr., KIS 5B6 & D. Moizer \\
Ottawa, Ontario, Canada & DA Millar \\
& G. Paquet \\
TB Hedley
\end{tabular}} \\
\hline $\begin{array}{l}\text { 5. Supporting Organization (Complete Mailing Address and Name of } \\
\text { Contact) }\end{array}$ & \multicolumn{2}{|c|}{$\begin{array}{l}\text { 6. Duration of Investigation (Beginning and ending) } \\
\qquad 4 / 76 \text { to } 3 / 77 \\
\text { 7. Estimated Funding and Manpower (Monies and Manyears) } \\
\$ 18,850 \text { FY76 }\end{array}$} \\
\hline \multicolumn{3}{|c|}{$\begin{array}{l}\text { 8. Purpose of Project (Jbjectives, Motivations. Approach. Plans and Expected Results) } \\
\text { The work to date has covered the following topics: Application of CANDU reactors } \\
\text { to dual-purpose use. Utilization of low-grade heat in Canadian industry. Survey of } \\
\text { present district heating systems throughout the world. Survey of utilization of energy } \\
\text { for residential and commercial purposes in Canada. Development of methods of } \\
\text { optimization of dual-purpose power plants and other energy devices. Study of thermal } \\
\text { energy storage systems for dual-purpose power plants. Development of notes on } \\
\text { electrical energy conversion. } \\
\text { Use Box No. } 15 \text { if additional space is needed }\end{array}$} \\
\hline \multirow{2}{*}{\multicolumn{3}{|c|}{$\begin{array}{l}\text { 9. Status and Results } \\
\text { Results have been reported in ERG Reports } 74-3,75-4 \text { and in internal technical memos. } \\
\text { This project is: } \square \text { planned } \square \text { in-progress } \square \text { completed }\end{array}$}} \\
\hline & & \\
\hline \multicolumn{3}{|c|}{ 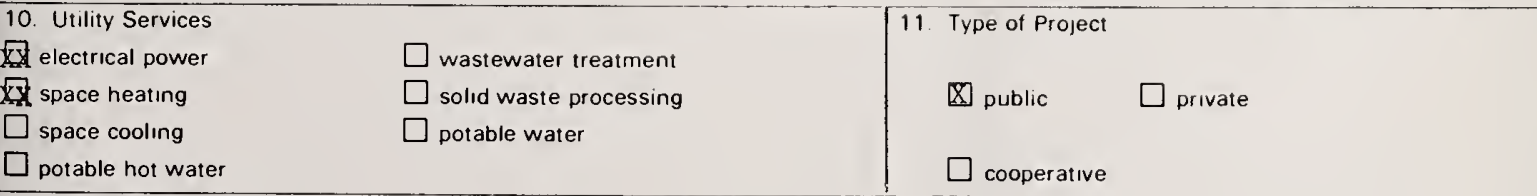 } \\
\hline 12. Exchange of data & & \\
\hline
\end{tabular}


13. Technical Data

Identification No

project location -- - - -

degree-days (heating) -

energy source

degree-days (cocling) - -

expected payback period

plant load capacity

a. power (MW) - - _ -

b. heating (MW) $--\ldots$

c. cooling (MW) - - - -

d. wastewater treatment-liters/day _ _ _ _ -

e. solid waste processing-kilograms/day _ -

f. potable water-liters/day -------heat to power ratio (average expected)

14. Other Related Projects (Titles)

15. Additional space for Purpose of Project

16. Additional space for Status and Results

ype and size of user

a. residential (dwelling units)

b. residential (square area- $\mathrm{m}^{2}$ )

c. commercial (square area- $\mathrm{m}^{2}$ )

d. industrial (thermal + elec.-MW) 
\begin{tabular}{lr}
\hline $\begin{array}{l}\text { NBS-1075 } \\
(2-77)\end{array}$ & U.S. DEPARTMENT OF COMMERCE \\
NATIONAL BUREAU OF STANDARDS
\end{tabular}

PROJECT SUMMARY FORM

1. Title of Project (Otficial Title)

Uses of long-distance heat in power stations
Identification No

(Secretariat Use Only)

2. Date (Form Completed)

Sept. 30, 1975

3. Performing Organization (Complete Mailing Address)

Dip1.-Ing.R. Schwedler

Beratender Ingenieur VDI

Furstenrieder STr. 35

8000 Munchen 21

Federal Republic of Germany
5. Supporting Organization (Complete Mailing Address and Name of Contact)

PLE/KFA-Juelich

Postfach 1913

Dr. Plantikow

D-517 Juelich

Federal Republic of Germany
4. Principal Investigator (Name and Complete Mailing Address)

Rolf Schwedler

address see 3

8. Purpose of Project (Objectives, Motivations, Approach, Plans and Expected Results)

It is the aim of this project, proceeding from the state of the art technology and existing experiences, to test the possibilities of utilizing waste heat from thermal electric stations, and to compile forthcoming sollutions. Through this project, it should become evident which of these possibilities for utilization would be worthy of an introduction, and therfore profit by an intensified further development .

7. Estimated Funding and Manpower (Monies and Manyears)

$$
\text { 15,966. - SUS }
$$

1. Type of Project

$$
\text { 国 public } \square \text { private }
$$

cooperative

图 Yes

No 
degree-days (heating) -

degree-days (cocling) -

plant load capacity

a. power $(\mathrm{MW})--\ldots$

b. heating ( $M W)----$

c. cooling (MW) -----

d. wastewater treatment-liters/day - _ - - -

e. solid waste processing-kilograms/day ---

f. potable water-liters/day $--\ldots--\ldots$ heat to power ratio (average expected)

14. Other Related Projects (Titles) energy source

expected payback period

Type and size of user

a. residential (dwelling units)

b. residential (square area- $\mathrm{m}^{2}$ )

c. commercial (square area- $\mathrm{m}^{2}$ )

d. Industrial (thermal + elec-MW)

15. Additional space for Purpose of Project

16. Additional space for Status and Results 


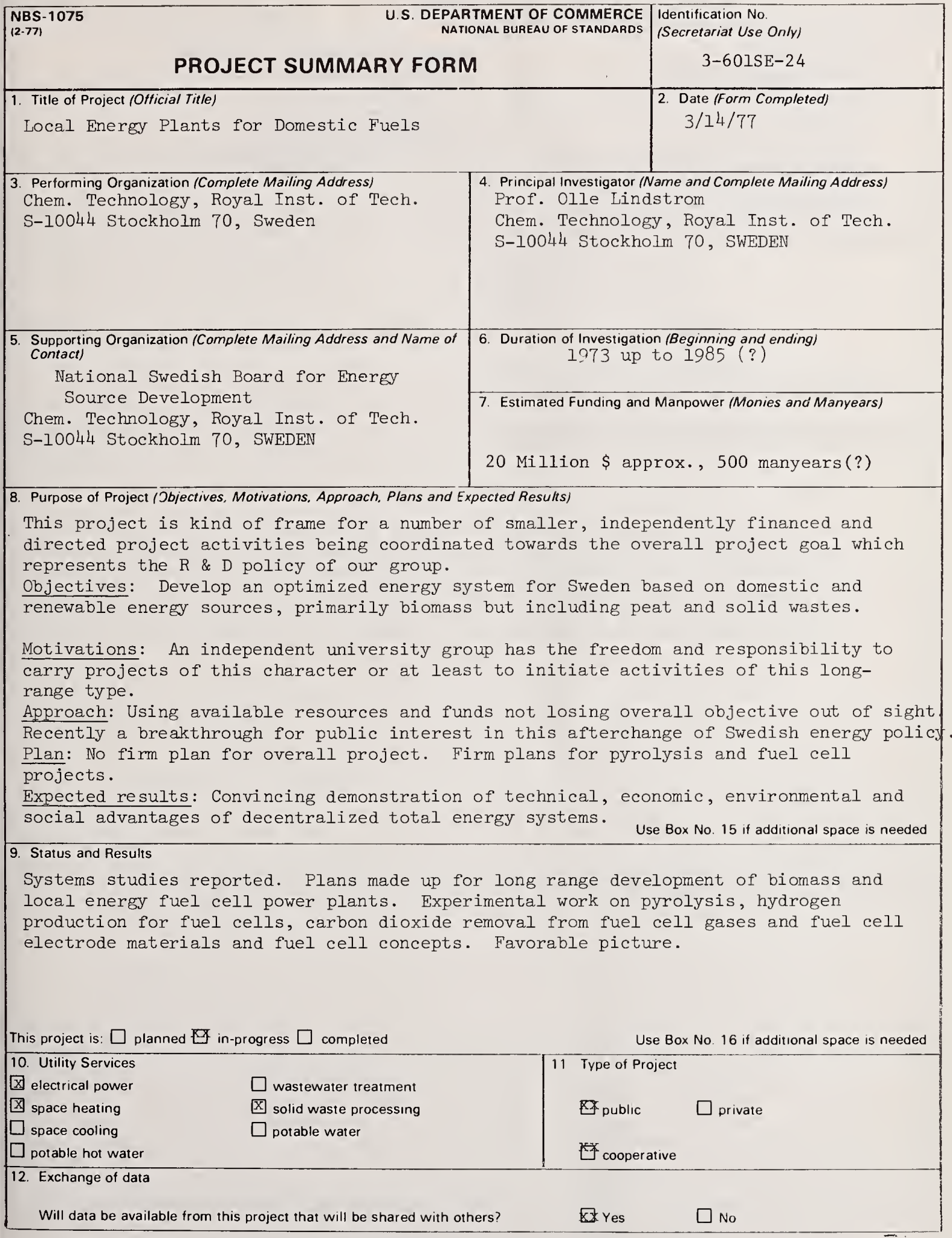


13. Technical Data

project location - - - -

degree-days (heating) -

degree-days (coclıng) -

plant load capacity

a. power (MW) - - - 5

b. heating (MW) -----10

c. cooling (MW) $-\ldots-\ldots$

d. wastewater treatment-liters/day - - - - -

f. potable water-liters/day $-\ldots-\ldots$

10,000

energy source
expected payback perıod
Type and size of user
a. residential (dwelling units)
b. residential (square area- $\mathrm{m}^{2}$ )
c. commercial (square area- $\mathrm{m}^{2}$ )
d. Industrial (thermal + elec $-\mathrm{MW}$ )

heat to power ratio (average expected)

14. Other Related Projects (Titles)

15. Additional space for Purpose of Project

16. Additional space for Status and Results 


\begin{tabular}{|c|c|c|}
\hline \multicolumn{2}{|l|}{ PROJECT SUMMARY FORM } & $\begin{array}{r}\text { Identification } \\
\text { ISecretariat } \\
3-t\end{array}$ \\
\hline \multicolumn{2}{|c|}{$\begin{array}{l}\text { 1. Title of Project (Olficial Title) } \\
\text { Demonstration of Combined Disposal of Sewage Sludge and } \\
\text { Solid Waste in Purox Oxygen Refuse Converter }\end{array}$} & 2. Date (Form Completed) \\
\hline $\begin{array}{l}\text { 3. Performing Organization (Complete Mailing Address) } \\
\text { The Sanitary Board of the City of South } \\
\text { Charleston, West Virginia } \\
\text { City Hall, 4th Avenue \& D Street } \\
\text { South Charleston, W.Va. } 25303 \\
\text { U.S.A. }\end{array}$ & \multicolumn{2}{|c|}{$\begin{array}{l}\text { 4. Principal Investigator (Name and Complete Mailing Address) } \\
\text { Mr. William J. Plank, P.E. } \\
\text { Project Manager, Union Cabride (Linde Div.) } \\
\text { P.O. Box } 44 \\
\text { Tonawanda, N.Y. } 14150 \\
\text { U.S.A. }\end{array}$} \\
\hline $\begin{array}{l}\text { Supporting Organization (Complete Mailing Address and Name of } \\
\text { Contact) }\end{array}$ & $\begin{array}{r}\text { 6. Duration of Investigatic } \\
7 / 75\end{array}$ & $\begin{array}{l}\text { on (Beginning and ending) } \\
\text { to } 9 / 77\end{array}$ \\
\hline $\begin{array}{l}\text { Union Carbide Corp. } \\
\text { Mr. W.J.Plan } \\
\text { P.O. Box } 44 \\
\text { Tonawanda, N.Y. } \\
14150 \text { U.S.A. }\end{array}$ & $\begin{array}{l}\text { 7. Estimated Funding and } \\
\$ 443,150 \text { (total } \\
\$ 332,000 \text { (EPA) }\end{array}$ & lanpower (Monies and Manyears) \\
\hline
\end{tabular}

8. Purpose of Project (Objectives, Motivations, Approach, Plans and Expected Results)

The objectives of this grant are to confirm and demonstrate the technical and economic feasibility of disposing of sewage sludge in combination with municipal refuse in the Union Carbide Purox System, and to establish the environmental effects of this means of disposal. The project will be carried out a Union Carbide Corporations full scale test facility in South Charleston, West Virginia. An intermediate quality level gas is a product of the system and is suitable for power generation

\section{Status and Results}

Project grant just beginning - supplemental funding for grant approved 9/30/76

This project is: $\square$ planned $\mathbb{Z}$ in-progress $\square$ completed Use Box No. 16 if additional space is needed 
13. Technical Data

project location

degree-days (heiting

degree-days (cocling) - -

plant load capacity

a. power $(\mathrm{MW})-\ldots$

b heating (MW) ----

c. cooling (MW) $-\ldots-\ldots$

d. wastewater treatment-liters/day - - - -

e. solid waste processing-kilograms/day - - -

f. potable water-liters/day ------heat to power ratio (average expected)
Identification No

3-601US-25

energy source

expected payback period

Type and size of user

a. residential (dwelling units)

b. residential (square area- $m^{2}$ )

c. commercial (square area- $\mathrm{m}^{2}$ )

d. industrial (thermal + elec.-MW)

14. Other Related Projects (Titles)

15. Additional space for Purpose of Project

16. Additional space for Status and Results 


\begin{tabular}{|c|c|c|}
\hline \multicolumn{2}{|c|}{$\begin{array}{|lr|}\begin{array}{l}\text { NBS-1075 } \\
(2-77)\end{array} & \text { U.S. DEPARTMENT OF COMMERCE } \\
\text { NATIONAL BUREAU OF STANDARDS } \\
\text { PROJECT SUMMARY FORM }\end{array}$} & $\begin{array}{l}\text { Identification No } \\
\text { (Secretariat Use On/y) } \\
3-601 \text { NL-26 }\end{array}$ \\
\hline \multicolumn{2}{|c|}{$\begin{array}{l}\text { 1. Title of Project (Official Title) } \\
\text { Combined Heat and Power Production for District Heating } \\
\text { purposes }\end{array}$} & $\begin{array}{r}\text { 2. Date (Form Completed) } \\
6 / 8 / 77\end{array}$ \\
\hline $\begin{array}{l}\text { 3. Performing Organization (Complete Mailing Address) } \\
\text { Lab. for Thermal Power Engineering } \\
\text { Delft Univ. of Technology } \\
\text { Rotterdamseweg 139A } \\
\text { Delft } \\
\text { Netherlands }\end{array}$ & \multicolumn{2}{|c|}{$\begin{array}{l}4 \text { Principal Investigator (Name and Complete Mailing Address) } \\
\text { Ir. J.A. Miedema } \\
\text { Lab. for Therma } 1 \text { Power Engineering } \\
\text { Delft Univ. of Technology } \\
\text { Rot terdamseweg 139A } \\
\text { Delft } \\
\text { Netherlands }\end{array}$} \\
\hline $\begin{array}{l}\text { 5. Supporting Organization (Complete Mailing Address and Name of } \\
\text { Contact) } \\
\text { Delft Univ. of Technology } \\
\text { Netherlands }\end{array}$ & \multicolumn{2}{|c|}{$\begin{array}{l}\text { 6. Duration of Investigation (Beginning and ending) } \\
7 / 75 \text { to } 7 / 79 \\
\text { 7. Estimated Funding and Manpower (Monies and Manyears) } \\
\begin{array}{l}\$ 130,000 \text { not included personal costs } \\
7 \text { man years }\end{array}\end{array}$} \\
\hline
\end{tabular}

The objectives are: a) Thermodynamical and economical optimalization of energy conversion systems in combined heat and power generating plants. b) Studies with respect to the integration of heat storage possibilities in district heating systems where combine heat and power production is applied. Special attention will be given to heat storage possibilities in heat distribution networks. c) Investigation to the impact of a heat/ power station to be built for a district-heating scheme on existing power stations, in especially with respect to fuel conservation aspects.

\section{Motivations}

1. Modern/heat power stations are complicated systems. The adjustment and harmonization of the many sub-processes (by means of calculations and process analysis is to realize an optimal operation of the power generating units.

2. In the near future special attention will be given to the introduction of district heating in the Netherlands. Especially the studies b) Use Box No. 15 if additional space is needed 9. Status and Results

Two computer programs have been developed in order to be able to study the points $8 a^{\circ}$ and $8 \mathrm{c}$. Some corrections will be still necessary and parameter analysis will be performed in the near future.

A limited study has been performed with respect to point $8 \mathrm{~b}$. Special attention will be given to heat storage possibilities in heat distribution networks.

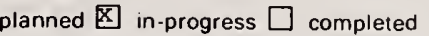

Use Box No 16 if additional space is needed 
13. Technical Data

project location -. - -

degree-days (heatting) -

degree-days (cocling) - -

plant load capacity

a. power $(\mathrm{MW})--\ldots$

b. heating (MW) ----

c. cooling (MW) ----

d. wastewater treatment-liters/day -----

e. solid waste processing-kilograms/day $-\ldots$

f. potable water-liters/day -------heat to power ratio (average expected)

14. Other Related Projects (Titles)
Identification No

3-601NL- 26

energy source

expected payback period

Type and size of user

a. residential (dwelling units)

b. residential (square area- $m^{2}$ )

c. commercial (square area- $\mathrm{m}^{2}$ )

d. industrial (thermal + elec.-MW)

15. Additional space for Purpose of Project

and c) have been set up for this purposes.

Approach

All studies will be restricted to desk studies and the development of some computer programs.

\section{Co-operation}

1. Exchange with KEMA (I)utch Electricity Generating Board) of computer programs for the optimalization of heat/power stations.

2. Exchange with TPD-TNO (Technical, Physical Research Institute) of know-how with respect to heat storage and heat storage systems.

\section{Expected Results}

An insight in the possibilities for district heating in the Netherlands and its contribution to fuel conservation.

\section{Addena}

Supporting agency and performing organization:

Technical University of Delft.

16. Additional space for Status and Results 
NBS-1075

(2-77)
U.S. DEPARTMENT OF COMMERCE NATIONAL BUREAU OF STANDARDS

\section{PROJECT SUMMARY FORM}

1. Title of Project (Official Title)

\section{MERTANIEMI POWER PLANT (FINLAND)}

3. Rerforming Organizatior (Complete Mailing Address) Lappeenrannan Lampovoima Uy LappeenrantaFinland

-FIAT Termomeccanica-nucleare e Turbogas

S.p.A(FIAT TTG SpA)via Cuneo, 20 Torino Italy

-AHLSTROM-Finland

-TRANSELEKTRO/GANZ -Hungary

5. Supporting Organization (Complete Mailing Address and Name of Contact)

N.A.

7. Estimated Funding
N.A.

6. Duration of Investigation (Beginning and ending) N.A.

8. Purpose of Project (Objectives, Motivations, Approach, Plans and Expected Results)

\section{ELECTRIC ENERGY PRODUCTION AND DISTRICT HEATING}

Use Box No. 15 if additional space is needed

9. Status and Results

planned $\square$ in-progress $\square$ completed

$$
\begin{array}{|l}
\hline 10 \\
\hline \\
\square \\
\square \\
\hline 12 \\
\hline 12 \\
\hline
\end{array}
$$


13 Technical Data

project location

degree-days (heiting) -

degree-days (cocling) -

plant load capacity

a. power (MW) - 170 about

b. heating (MW) $-\ldots$

c cooling (MW) - _ . -

d. wastewater treatment-liters/day - - - -

e. solid waste processing-kilograms/day _ -

f. potable water-liters/day - - - - - -

heat to power ratio (average expected)

14 Other Related Projects (Tit/es)

15. Additional space for Purpose of Project
Identification No.

$3-611$ F $T-27$

energy source

expected payback period

Type and size of user
a residential (dwelling units)
b. residentıal (square area- $\mathrm{m}^{2}$ )
c. commercial (square area- $\mathrm{m}^{2}$ )
d Industrial (thermal + elec.-NW)

16. Additional space for Status and Results 


\begin{tabular}{|c|c|c|}
\hline \multicolumn{2}{|c|}{$\begin{array}{l}\begin{array}{l}\text { NBS-1075 } \\
(2.77)\end{array} \\
\text { PROJECT SUMMARY FORARTMENT OF COMMERCE } \\
\text { NATIONAL BUREAU OF STANOARDS }\end{array}$} & $\begin{array}{l}\text { Identification No. } \\
\text { (Secretariat Use Only) } \\
3-61.41 \mathrm{~GB}-28\end{array}$ \\
\hline $\begin{array}{l}\text { 1. Title of Project (Official Title) } \\
\text { Wastewater Treatment }\end{array}$ & & $\begin{array}{l}\text { 2. Date (Form Completed) } \\
\text { March } 1977\end{array}$ \\
\hline $\begin{array}{l}\text { 3. Performing Organization (Complete Mailing Address) } \\
\text { Metropolitan Public Health Division } \\
\text { Thames Water Authority } \\
\text { Broadway Buildings } \\
\text { 50-64 Broadway SW1H ODB } \\
\text { U.K. }\end{array}$ & $\begin{array}{l}\text { 4. Principal Investigator } \mathrm{N} \\
\text { Mr. L.H. Thompson, } \\
\text { WPC } \\
\text { Divisional Manage } \\
\text { Metropolitan Publ } \\
\text { Thames Water Auth } \\
50-64 \text { Broadway SW }\end{array}$ & $\begin{array}{l}\text { Vame and Complete Mailing Address) } \\
\text { CEng FICE FIPHE FInst. } \\
\text { ic Health Division } \\
\text { ority, Broadway Buildings } \\
\text { JiH ODB, U.K. }\end{array}$ \\
\hline $\begin{array}{l}\text { 5. Supporting Organization (Complete Mailing Address and Name ct } \\
\text { Contact) } \\
\text { Mr. E. C. Reed DFC, Director of Operations } \\
\text { New River Head } \\
\text { Rosebery Avenue } \\
\text { EC1R } 4 \text { TP. } \\
\text { U.K. }\end{array}$ & $\begin{array}{l}\text { 6. Duration of Investigatio } \\
\text { On going operat } \\
\text { 7. Estimated Funding and } \\
\text { On going inbuil }\end{array}$ & $\begin{array}{l}\text { Ional activity } \\
\text { Manpower (Monies and Manyears) } \\
\text { t works operation }\end{array}$ \\
\hline
\end{tabular}

8. Purpose of Project (Objectives, Motivations, Approach, Plans and Expected Results)

Sewage gas is burnt in dual fuel engines for power on a works. Heat is received from the engine jackets and exhaust gas to heat sludge to obtain sewage gas.

The amount of gas, power requirements and heat load do not always correlate Sometimes bought in energy is required; other types heat must be dumped.

9. Status and Results

To reduce the amount of bought-in energy by utilizing natural resources.

This project is: $\square$ planned $\square$ in-progress $\square$ completed

$\square$ wastewater treatment

wastewater treatment

$\square$ potable water
Use Box No. 16 if additional space is needed

11 Type of Project

public $\square$ private

cooperative

\footnotetext{
Will data be available trom this project that will be shared with others?
}

Yes $\square$ No 
project location -- - -

degree-days (heating) -

degree-days (cocling) - -

plant load capacity
a. power (MW) - - - -
b. heating (MW) ----
c. cooling (MW) - - -
d. wastewater treatment-liters/day $-\ldots-\ldots$
e. solid waste processing-kilograms/day - -
f. potable water-liters/day $--\ldots-\ldots$
heat to power ratio (average expected)

14. Other Related Projects (Tirles)

All major cities with advanced plant are behaving similarly. energy source

expected payback period

Type and size of user
a. residential (dwelling units)
b. residential (square area $-\mathrm{m}^{2}$ )
c. commercial (square area- $m^{2}$ )
d. industrial (thermal + elec.-MW)

15. Additional space for Purpose of Project

16. Additional space for Status and Results 


\begin{tabular}{|c|c|c|}
\hline \multicolumn{2}{|c|}{$\begin{array}{l}\begin{array}{l}\text { NBS-1075 } \\
(2-77)\end{array} \\
\text { P.S. DEPARTMENT OF COMMERCE } \\
\text { NATIONAL BUREAU OF STANDARDS } \\
\text { PROJECT SUMMARY FORM }\end{array}$} & $\begin{array}{l}\text { Identification No } \\
\text { (Secretariat Use On/y) } \\
3-631 \text { US }-29\end{array}$ \\
\hline $\begin{array}{l}\text { 1. Title of Project (Official Title) } \\
\text { Onondaga County Resource Recovery Project }\end{array}$ & & $\begin{array}{l}\text { 2. Date (Form Completed) } \\
\text { February 3, } 1977\end{array}$ \\
\hline $\begin{array}{l}\text { 3. Performing Organization (Complete Mailing Address) } \\
\text { County of Onondaga } \\
14 \text { th Floor Civic Center } \\
421 \text { Montgomery Street } \\
\text { Syracuse, New York } 13201 \\
\text { U.S.A. }\end{array}$ & $\begin{array}{l}\text { 4. Principal Investigator } / N \\
\text { Carrier Corporat } \\
\text { Energy Systems D } \\
\text { Carrier Tower } \\
\text { Syracuse, New Yo } \\
\text { U.S.A. }\end{array}$ & $\begin{array}{l}\text { Name and Complete Mailing Address) } \\
\text { tion } \\
\text { Division } \\
\text { ork } 13201\end{array}$ \\
\hline $\begin{array}{l}\text { 5. Supporting Organization (Complete Mailing Address and Name of } \\
\text { Contact) }\end{array}$ & \begin{tabular}{|} 
6. Duration of Investigatio \\
N/A \\
7. Estimated Funding and \\
N/A
\end{tabular} & $\begin{array}{l}\text { on (Beginning and ending) } \\
\text { d Manpower (Monies and Manyears) }\end{array}$ \\
\hline
\end{tabular}
(1)

Use solid waste produced in county as fuel for heating and cooling hospitals, housing developments, university buildings and government buildings through existing distribution system.

\section{Status and Results}

Project planning complete. Bids submitted on major equipment. 


\begin{tabular}{|c|c|c|}
\hline $\begin{array}{l}13 \text { Technical Data } \\
\text { project location }--\ldots \ldots\end{array}$ & Identification No. & $3-631 U S-29$ \\
\hline $\begin{array}{l}\text { degree-days (heating) - } \\
\text { degree-days (cocling) - - }\end{array}$ & $\begin{array}{l}\text { energy source } \\
\text { expected payback period }\end{array}$ & \\
\hline 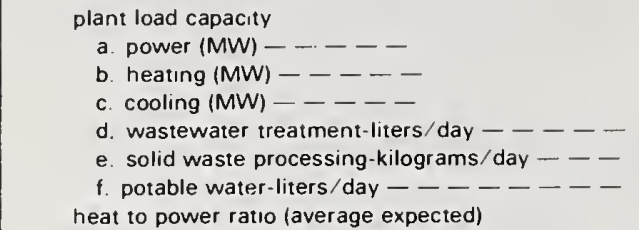 & $\begin{array}{l}\text { Type and stze of user } \\
\text { a. residential (dwelling units) } \\
\text { b. residential (square area- } \mathrm{m}^{2} \text { ) } \\
\text { c. commercial (square area- } \mathrm{m}^{2} \text { ) } \\
\text { d industrial (thermal + elec. }-\mathrm{MW} \text { ) }\end{array}$ & \\
\hline
\end{tabular}

14. Other Related Projects (Tinles)

15. Additional space for Purpose of Project

16. Additional space for Status and Results 


\section{PROJECT SUMMARY FORM}

1. Title of Project (Official Title)

$$
\text { 3-63IIE- } 30
$$

2. Date (Form Completed)

MILANO OLGETTINA - Electricity and heat combined production by solid waste incineration

3. Performing Organization (Complete Mailing Address)

AZIENDA ELETTRICA MUNICIPALE

C.so di Porta Vittoria, 4

20100 -- MILANO (Italy)

5. Supporting Organization /Complete Mailing Address and Name of Contact)

$\mathrm{N} / \mathrm{A}$
4. Principal Investigator (Name and Complete Mailing Address)

$$
\mathrm{N} / \mathrm{A}
$$

6. Duration of Investigation (Beginning and ending)

Investigation started in February 1977

7. Estimated Funding and Manpower (Monies and Manyears) $\$ 2,000,000$ for 25 years

\section{Purpose of Project (Jbjectives, Motivations, Approach, Plans and Expected Results)}

The purpose of the project is the heat recovery for space heating, from a thermoelectric plant using solid waste as primary fuel. The steam is bleeded, according to the users request before the low pressure stage of a turbine and used to produce heat.

Use Box No. 15 if additional space is needed

\section{Status and Results}

The preliminary consideration of feasibility and convenience started in February 1977.

Utility Services

electrical power

space heating

space cooling

potable hot water

Exchange of data

Will data be available from this project that will be shared with others? wastewater treatment

Dolid waste processing

$\square$ potable water
目 publıc $\square$ private
11. Type of Project
$\square$ public
$\square$ cooperatıve

11. Type of Project
$\square$ public
$\square$ cooperatıve

团 Yes
No 


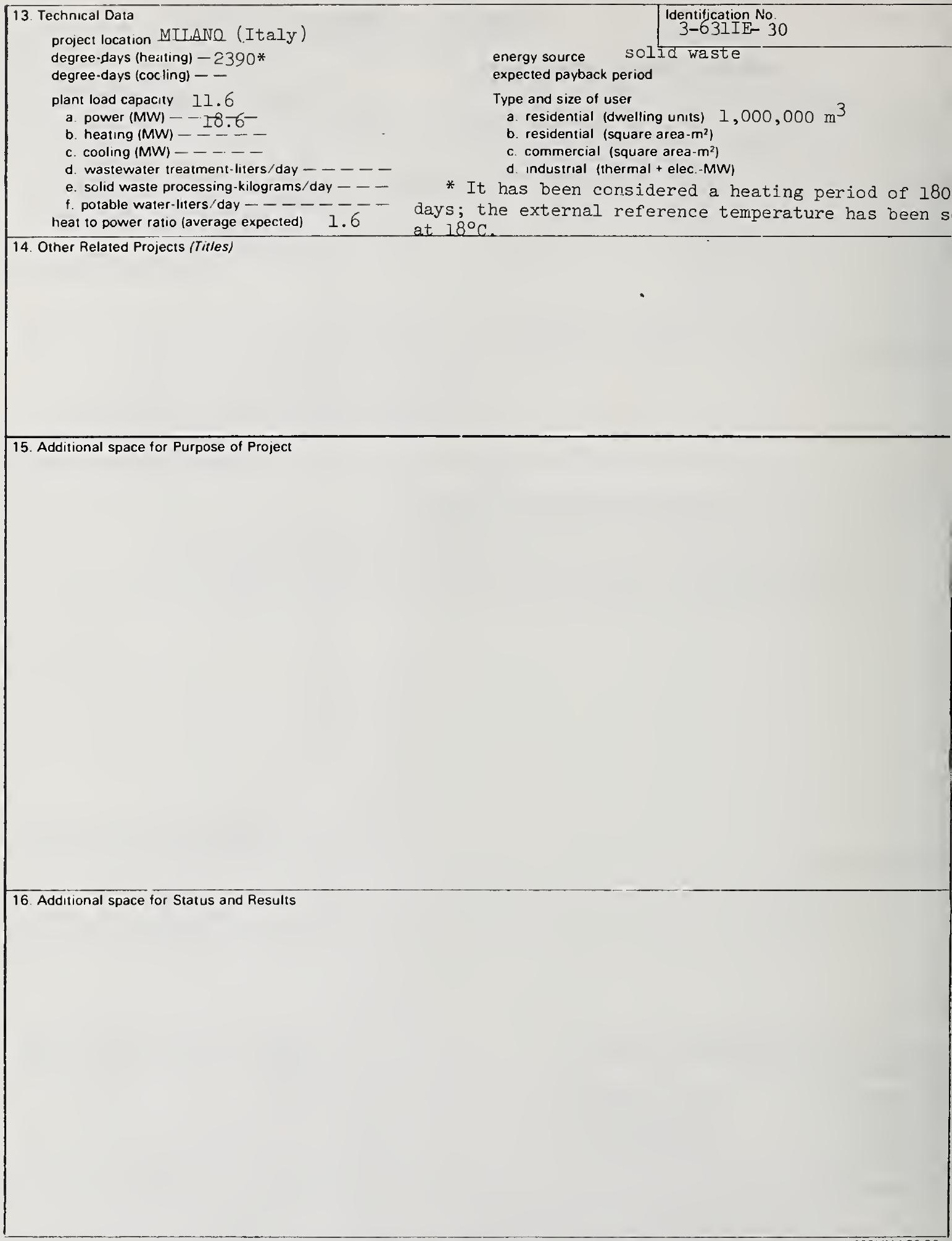




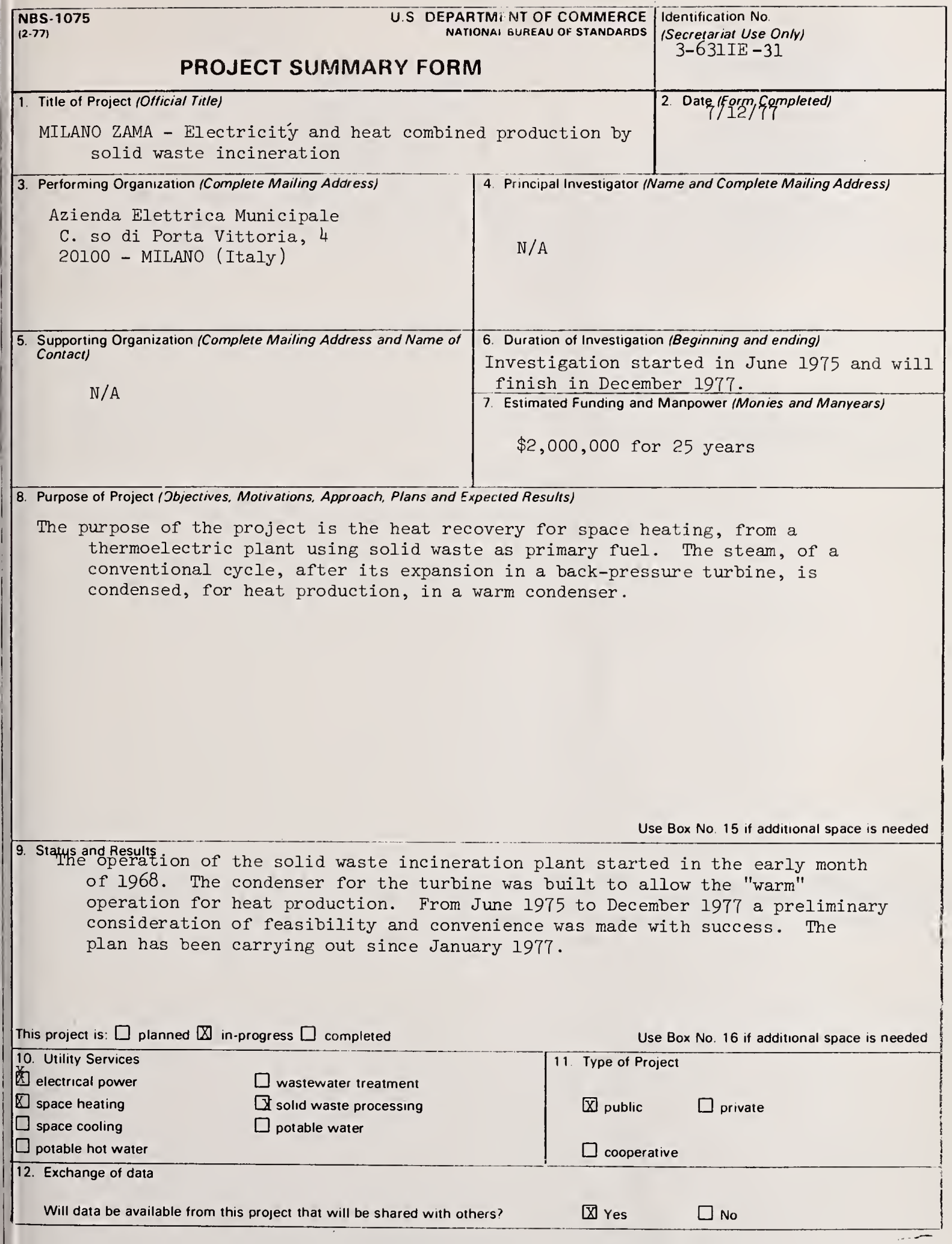




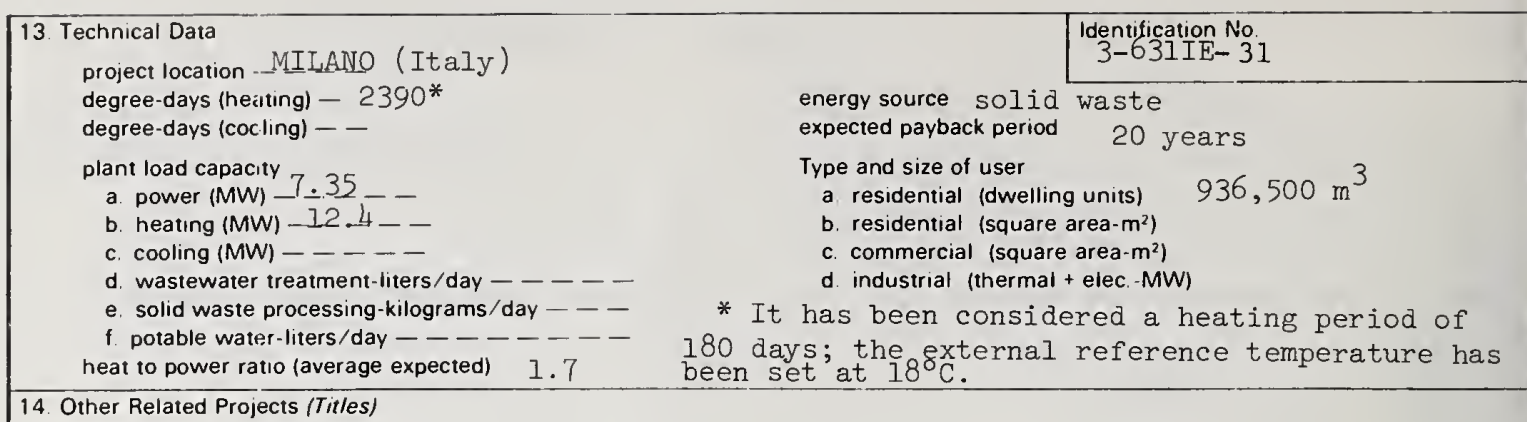

15. Additional space for Purpose of Project

16. Additional space for Status and Results 


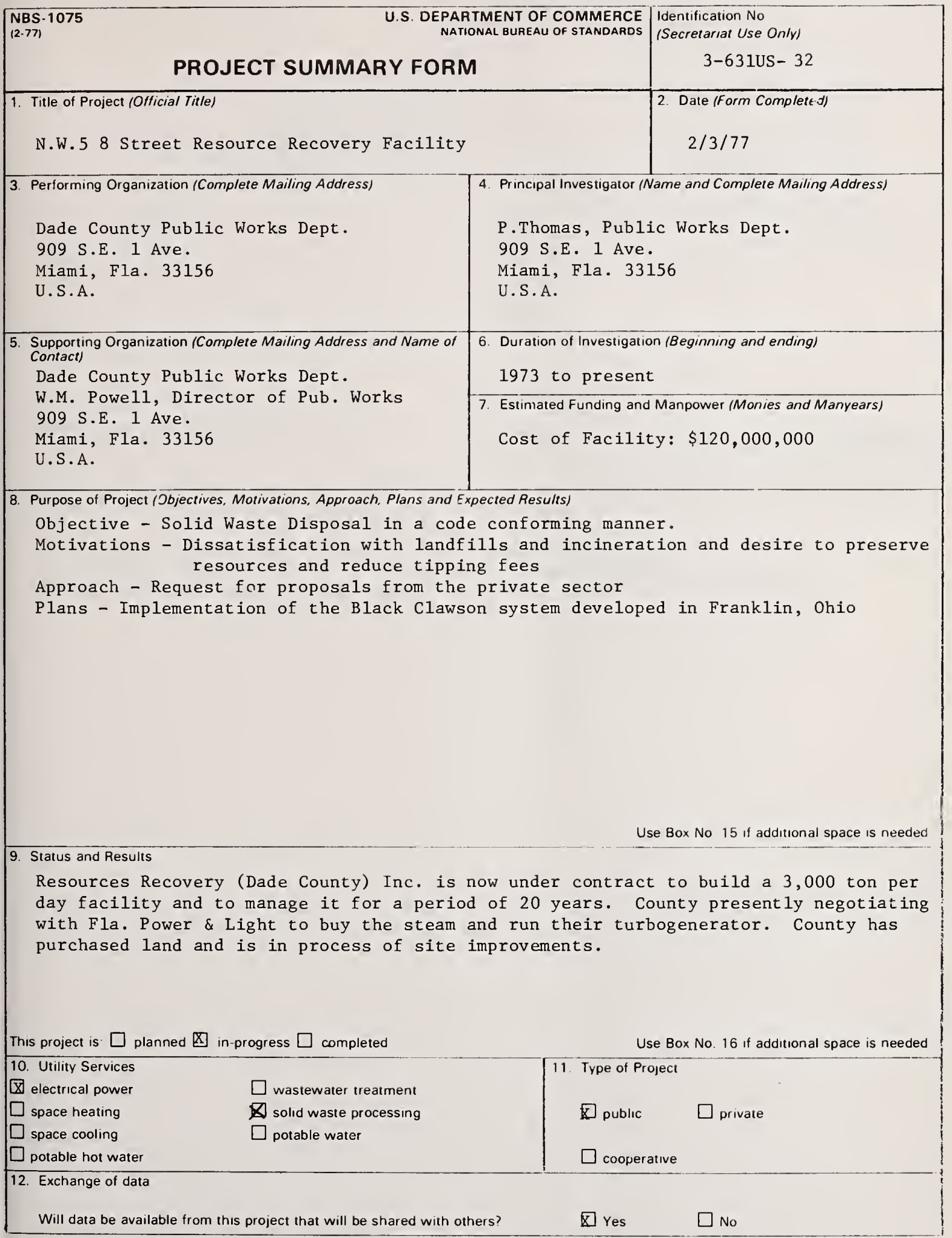


13. Technical Data

project location._N.W. 97 Ave., Miami, Fla.

degree-days (heating) -

degree-days (cocling) - -

plant load capacity

a. power (MW) - - - - -

b. heating (MW) - - - -

c. cooling (MW) -----

d. wastewater treatment-liters/day - $-\ldots$

e. Solid waste processing-kilograms/day - - -

f. potable water-liters/day $--\ldots---$

heat to power ratio (average expected)

14. Other Related Projects (Titles)

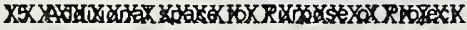

13. Technical Data (cont.)

For further Info contact Mr. Dean Kolhepp

Resources Recovery (Dade County) Inc.

Douglas Entrance

Coral Gables, Fla.

energy source

expected payback period

Type and size of user

a. residential (dwelling units)

b. residential (square area- $\mathrm{m}^{2}$ )

c. commercial (square area- $\mathrm{m}^{2}$ )

d. industrial (thermal + elec-MW) 


\begin{tabular}{|c|c|c|}
\hline \multicolumn{2}{|l|}{ PROJECT SUMMARY FORM } & \begin{tabular}{|} 
Identification No. \\
(Secretariat Use On/y) \\
$3-631$ US- 33
\end{tabular} \\
\hline \multicolumn{2}{|c|}{$\begin{array}{l}\text { 1. Title of Project (Official Title) } \\
\text { City of Baltimore - Solid Waste Disposal and Resource } \\
\text { Recovery Plant (Pyrolysis Plant) }\end{array}$} & $\begin{array}{l}\text { 2. Date (Form Completed) } \\
1 / 31 / 77\end{array}$ \\
\hline $\begin{array}{l}\text { 3. Performing Organization (Complete Mailing Address) } \\
\text { City of Baltimore } \\
\text { Dept. of Public Works } \\
\text { Municipal Bldg. } \\
\text { Baltimore, Md. } \\
\text { U.S.A. }\end{array}$ & \multicolumn{2}{|c|}{$\begin{array}{l}\text { 4. Principal Investigator (Name and Complete Mailing Address) } \\
\text { Carl S. Weinberger, } \\
\text { Plant Manager } \\
\text { 1801 Annapolis Road } \\
\text { Baltimore, Maryland } 21230 \\
\text { U.S.A. }\end{array}$} \\
\hline \multirow[t]{2}{*}{$\begin{array}{l}\text { 5. Supporting Organization (Complete Mailing Address and Name of } \\
\text { Contact) }\end{array}$} & \multicolumn{2}{|c|}{$\begin{array}{l}\text { 6. Duration of Investigation (Beginning and ending) } \\
\text { January } 1976 \text { (Start) }\end{array}$} \\
\hline & \multicolumn{2}{|c|}{$\begin{array}{l}\text { 7. Estimated Funding and Manpower (Monies and Manyears) } \\
\$ 21,000,000 \text { Capital Invest. } \\
\$-2,000,000 \text { Operating Exp. per year }\end{array}$} \\
\hline
\end{tabular}

8. Purpose of Project (Jbjectives, Motivations, Approach, Plans and Expected Results)

The purpose of this project was to use Pyrolysis as a means of converting 1000 tons/ day of Municipal Solid Waste into recoverable energy, metal, and glass. The purpose was also to investigate a new means of waste disposal for municipal refuse.

\section{(Cont.)}

Plant start up was Jan. 1975. To date, process and mechnical problems have limited operations severly. No final determination has been made as to whether the system is an acceptable method for the City of Baltimore as a means of disposal.

This project is: $\square$ planned $\square$ in-progress $\square$ completed Use Box No. 16 if additional space is needed Utility Services $\square$ electrical power Dpace heating $\square$ space cooling $\square$ potable hot water 12. Exchange of data 
13. Technical Data

project location $-\rightarrow--$

degree-days (heatting) -

degree-days (cocling) - -

plant load capacity

a. power (MW) $-\overline{2} \overline{00}, \underline{0} \overline{0} \underline{0}$ \#S team $/ \mathrm{Hr}$

c cooling (MW) -

d. wastewater treatment-liters/day ----

e. solid waste processing-kilograms/day -1000 ton/day

f. potable water-liturs/day $-\ldots-\ldots-\ldots$ heat to power ratio (average expected)

14. Other Related Projects (Tit/es)

LP - Baltimore Municipal Solid Waste Program

SP - Pyrolysis Plant energy source

expected payback period

Type and size of user

a. residential (dwelling units)

b. residential (square area- $\mathbf{m}^{2}$ )

c. commercial (square area- $\mathrm{m}^{2}$ )

d. industrial (thermal + elec-MW)

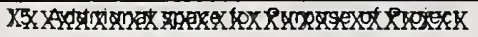

8. Purpose of Project (Cont.)

For complete information, contact:

Mr. David Sussman

Resource Recovery Office

Solid Waste Management

Environmental Protection Agency

Washington, D.C.

U.S.A.

Phone No. 202-755-9140

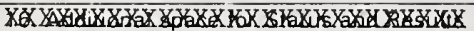

9. Status and Results (Cont.)

Project status is currently operational, however, evaluation and economic study of plant operation is not complete so as to determine wehther project will be a success. Determination should be completed within the next 6 months to 1 year. 
NBS-1075 U.S. DEPARTMENT OF COMMERCE
$(2.77)$

PROJECT SUMMARY FORM

1. Title of Project /Otficia/ Title)

Harrisburg Refuse Incinerator

3 Performing Organization (Complete Mailing Address)

\section{Engineer}

Gannett Fleming, Corddry and

Carpenter, Inc.

P.O. Box 1963

Harrisburg, Pennsylvania 17105

U.S.A.

5. Supporting Organization (Complete Mailing Address and Name of Contact)

Mr. Louis Einhorn

Public Works Director

City of Harrisburg

423 Walnut Street

Harrisburg, Pennsylvania 17101

U.S.A.

8. Purpose of Project (Jbjectives. Motivations. Approach, Plans and Expected Resu/ts)

The Harrisburg Refuse Incinerator was constructed in order to dispose of most of the solid waste from the metropolitan area. The incinerator is of waterwall construction and produces steam as a secondary function of the process. A portion of the steam produced is used for auxiliary in-plant uses. Present plans call for another portion of the steam to be used for the dewatering of sludge from the City's wastewater treatment facility, while the remainder of the excess steam will be supplied to a local utility for supplementary use in the City's district heating system. entification No 3-631US-34

2. Date (Form Comp/eted)

January 21,1977
Project Engineer

Paul W. Bricker
4 Principal Investigator (Name and Complete Mailing Address)

6. Duration of Investigation (Beginning and ending)

December 1969 to April 1973

7. Estimated Funding and Manpower (Monies and Manyears)

$\$ 8,271,155$ (construction cost)

The construction was completed in 1973 and is currently operating on an around the clock basis.

This project is $\square$ planned $\square$ in-progress $\bigotimes \mathbb{\text { completed }}$

Use Box No. 16 if additional space is needed

10. Utility Services electrical power wastewater treatment space heatıng space heating space coolıng potable hot water

[

$\square$ potable water

12. Exchange of data 


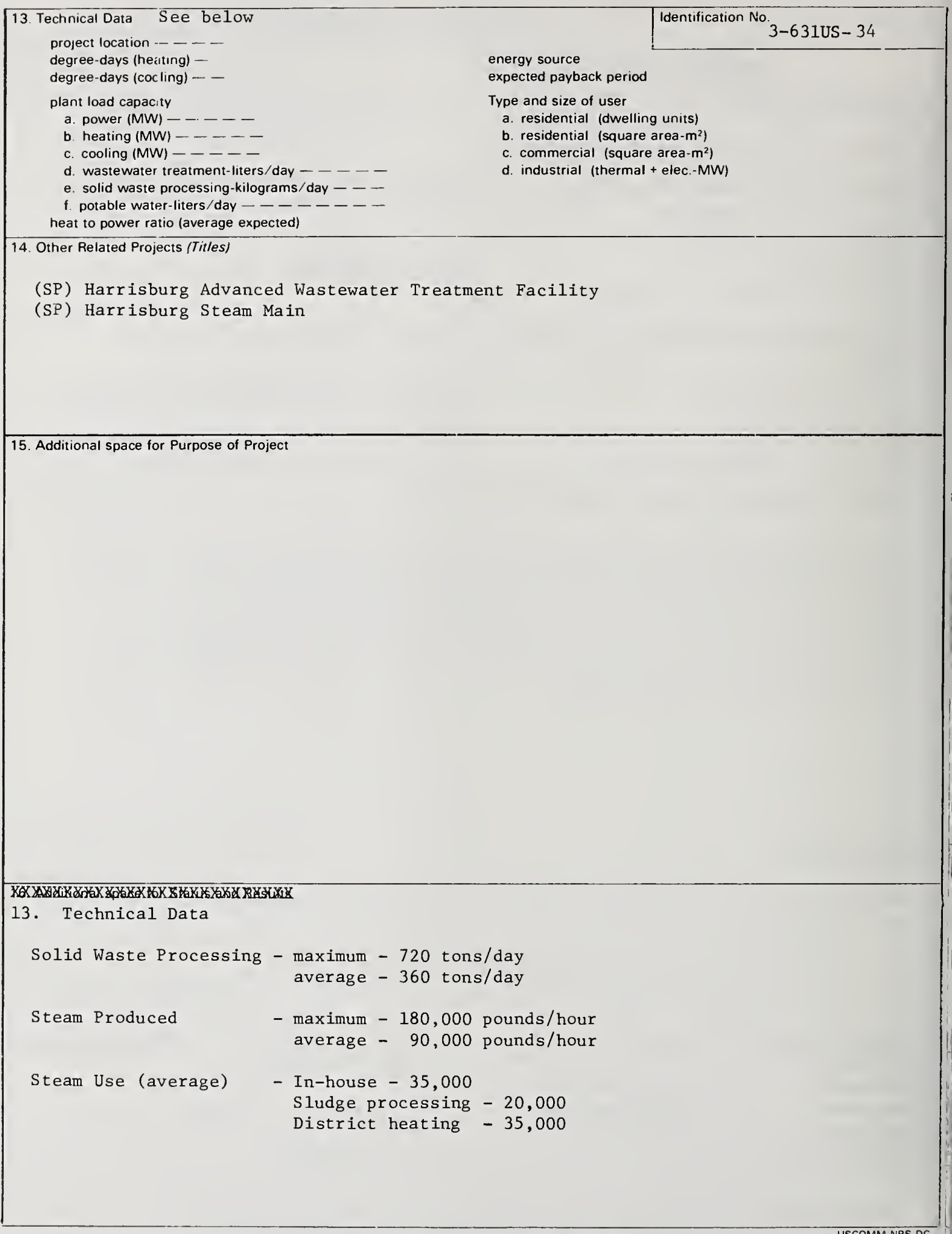




\begin{tabular}{|c|c|c|c|}
\hline \multicolumn{3}{|c|}{\begin{tabular}{|l} 
NBS-1075 \\
$(2.77)$
\end{tabular}} & \begin{tabular}{|c} 
Identification No \\
(Secretariat Use Only) \\
$3-631$ US -35
\end{tabular} \\
\hline \multicolumn{3}{|c|}{ 1. Title of Project (Officral Title) } & $\begin{array}{l}\text { 2. Date (Form Completed) } \\
\text { November } 29,1976\end{array}$ \\
\hline & $\begin{array}{l}\text { Performing Organization (Complete Mailing Address) } \\
\text { UOP, Inc. } \\
10 \text { UOP, Inc. } \\
\text { Des Plaines, I11. } 60016 \\
\text { U.S.A. }\end{array}$ & \multicolumn{2}{|c|}{$\begin{array}{l}\text { 4. Principal Investigator (Name and Complete Mailing Address) } \\
\text { Georg Stabenow } \\
\text { Registered Professional Engineer } \\
\text { Consultant to UOP, Inc. } \\
603 \text { Ann Street, P.O. Box } 508 \\
\text { Stroudsburg, Pa. } 18360 \\
\text { U.S.A. }\end{array}$} \\
\hline \multicolumn{2}{|r|}{$\begin{array}{l}\text { 5. Supporting Organization (Complete Mailing Address and Name of } \\
\text { Contact) } \\
\text { City of Harrisburg } \\
\text { Walnut \& Aberdeen Streets } \\
\text { Harrisburg, Pa. } 17104 \\
\text { U.S.A. }\end{array}$} & \multicolumn{2}{|c|}{$\begin{array}{l}\text { 6. Duration of Investugation (Beginning and ending) } \\
2 \text { yrs for design and construction } \\
\text { 7. Estımated Funding and Manpower (Monies and Manyears) } \\
\quad \$ 3,600,000\end{array}$} \\
\hline \multicolumn{4}{|c|}{$\begin{array}{l}\text { Purpose of Project (Dbjectives, Motivations. Approach, Plans and Expected Results) } \\
\text { To utilize steam generated at existing Harrisburg, Pa. incinerator, (presently } \\
\text { all steam generated is being condensed) for City of Harrisburg District Heating } \\
\text { System Located approximately } 2 \text { miles }(3.22 \mathrm{Km}) \text { from incinerator plant and requires } \\
\text { complete pipeline installation. }\end{array}$} \\
\hline
\end{tabular}

Use Box No 15 if additional space is needed

9. Status and Results

Planning stage, but requires acceleration to reduce fuel oil consumption at existing district heating plant located in downtown Harrisburg.

This project is: $\mathbb{Q}$ planned $\square$ in-progress $\square$ completed

Use Box No 16 if additional space is needed

$$
\text { 泟 }
$$

10. Utility Services

$\square$ electrical power

D space heating

wastewater treatment

space cooling

$\triangle$ solid waste processing

$\square$ potable hot water

$\square$ potable water

1. Type of Project

$\$$ public

$\square$ private

12. Exchange of data

cooperative

Will data be available from this project that will be shared with others?

XX Yes

No 
13. Technical Data

project location _.Harris isburg, $\mathrm{Pa}$.

degree-days (heatting) -

degree-days (cocling) - -

plant load capacity

a power (MW) $-75--$

$\mathrm{x}$ b. heating $(\mathrm{MW})-15$

c. cooling (MW) - - - -

d. wastewater treatment-liters/day $\underline{X} \ldots$

e. solid waste processing-kilograms/day _ -

$f$ potable water-liters/day - _ _ - _ - heat to power ratio (average expected)

14. Oiher Related Projects (Titles)

Resource Recovery from Residue

Ferrous Metal

energy source

expected payback period

Type and size of user

a. residential (dwelling units)

b. residential (square area- $m^{2}$ )

c. commercial (square area- $\mathrm{m}^{2}$ )

d. industrial (thermal + elec - MW)

$655,000 \mathrm{Kg} / \mathrm{d}=720 \mathrm{sh}$. tpd

$7.0 \mathrm{Kg}$ steam per $\mathrm{KW}$

Non-Ferrous Metal, Glass etc.

15. Additional space for Purpose of Project

To maximize energy recovery from existing solid waste incineration plant for utilization in heat consuming plants and to minimize fuel oil consumption for same.

16. Additional space for Status and Results

The Harrisburg Incinerator Plant is presently in full operation, but the energy quantity recovered at a rate of $220,000 \mathrm{Lbs} / \mathrm{H}$ steam at $275 \mathrm{psig}$ and $460^{\circ} \mathrm{F}=100,000$ $\mathrm{Kg} / \mathrm{H}$ at $1892 \mathrm{kPa}$ and $238^{\circ} \mathrm{C}$ is presently wasted in an air colled condensing system. 
NBS-1075

(2-77)
U.S DEPARTMENT OF COMMERCE NATIONAL BUREAU OF STANDAROS
Identification No.

(Secretariat Use Only)
PROJECT SUMMARY FORM

1. Title of Project (Official Tit/e)

Milwaukee Resource Recovery Facility

$$
3-632 U S-36
$$

2. Date (Form Completed)

February 11, 1977

3. Performing Organization (Complete Mailing Address)

4. Principal Investigator (Name and Complete Mailing Address)

Americology Division

American Can Company

American Lane

Greenwich, CT 06830

U.S.A.

5. Supporting Organization /Complete Mailing Address and Name of Contact)

Contract with City of Milwaukee

Contact: Mr. H.A. Goetsch

Commissioner of Public Works

Municipal Bldg. - m. 516

Milwaukee, Wis. 53202

U.S.A.

Mr. L.C. Bielicki

Vice President \& General Manager

(Same as 3)

8. Purpose of Project (Objectives, Motivations, Approach, Plans and Expected Resu/ts)

Objective - To provide disposal service for the City of Milwaukee's entrie municipal refuse collection and recover and recycle approximately $80 \%$ of the refuse processed.

Motivation - To establish a profitable community service business.

Approach - Refuse extraction "dry" process based on size reduction (milling, air classification (separation by size and mass), magnetic and electro magnetic separation and screening and water elutriation. (see attachment)

Results - Processing of over 250,000 tons per year of Milwaukee's garbage with recovery of a shredded fuel, ferrous, non-ferrous (aluminum paper, and glass aggregate products.

Use Box No. 15 if additional space is needed

9. Status and Results

Plant construction has been completed in both the resource recovery facility and the fuel receiving and storage facility at Wisconsin Electric's Oak Creek power generating plant. Both facilities are currently in start-up operations processing municipal refuse. A one-year refuse derived fuel firing demonstration program will begin this spring at Oak Creek power plant. Full commercial operation of the Milwaukee facilities is anticipated by April-May of this year (See Attached press release)

planned $\square$ in-progress $\square$ completed

Use Box No. 16 if additional space is needed electrical power $\square$ space heating space cooling 1 potable hot water 2. Exchange of data Through publication/presentation Will data be available from this project that will be shared with others? Yes No 


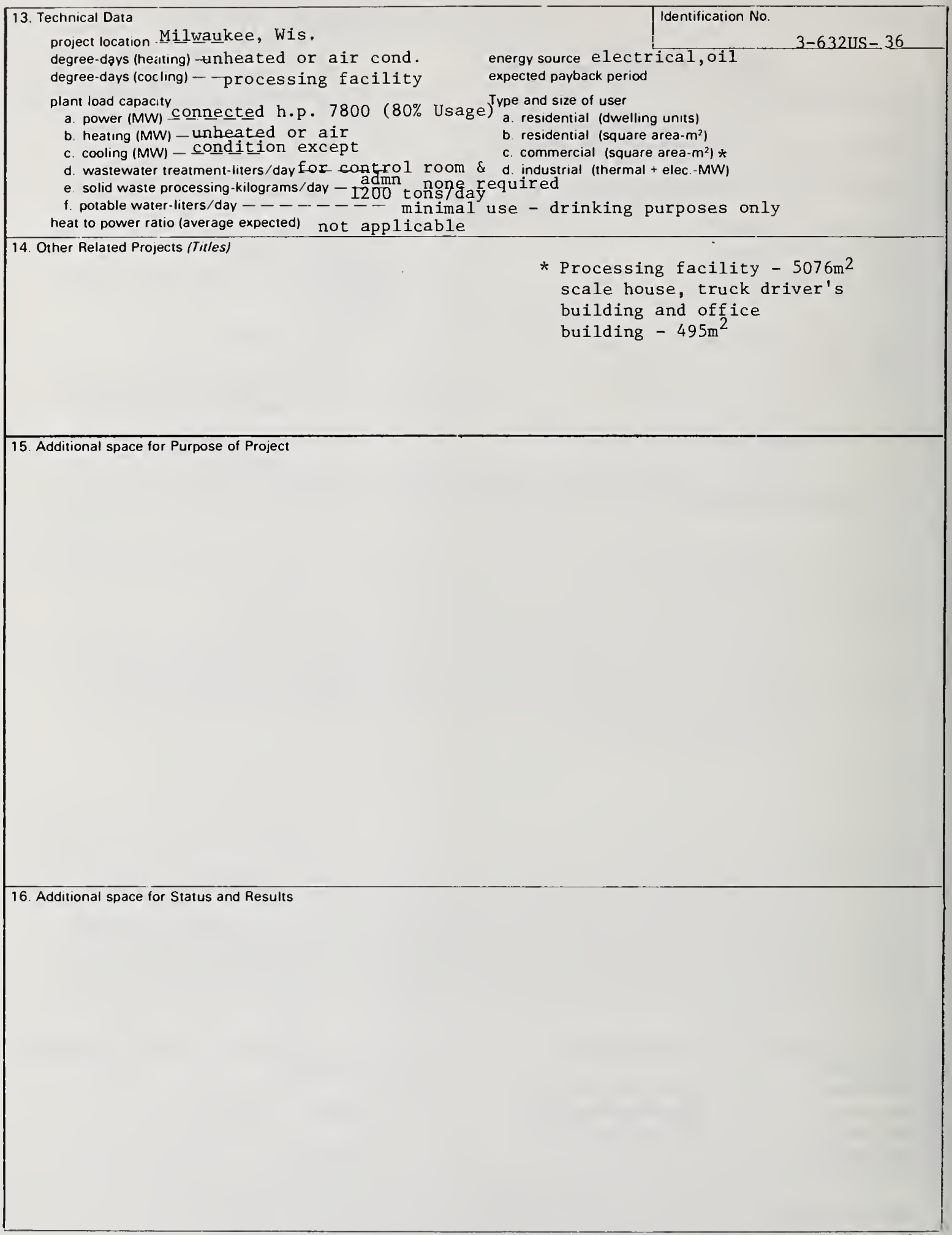


U.S. DEPARTMENT OF COMMERCE Identification No.

PROJECT SUMMARY FORM

1. Title of Project (Official Title)

3-632US- 37

Nashville Thermal Transfer Corporation, A mass solid waste fired central heating and cooling facility.

December 9, 1976

3. Performing Organization (Complete Mailing Address)

Nashville Thermal Transfer Corp.

110 First Avenue South

Nashville, Tennessee 37201

U.S.A.
4. Principal investigator (Name and Complete Mailing Address)

B. A. McDermott

110 First Avenue, South

Nashville, Tennessee 37201

U.S.A.
5. Supporting Organization (Complete Mailing Address and Name of Confact) Nashville Thermal Transfer is a private non profit Tenn. corporation finance by the sale of Revenue Bonds. Title to the physical assets of the corp. is held in escrow to be transferred to the city of Nashville in the year 2002 . 6. Duration of Investigation (Beginning and ending)
Construction began June 1972 . This project d is a continuing effort in the domestic technological development of heat recovery

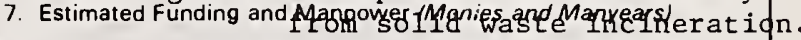
Initial capitalization was $\$ 16.5$ Million. Additional requirement is $\$ 8.0$ Million in $19 / 6$ for some completion. Man years do not apply to

8. Purpose of Project (Objectives, Motivations, Approach, Plans and Expected Results) this facility.

1. Provide low cost district heating and cooling for center city buildings.

2. Recover energy in all combustible solid waste not recycled for other purposes.

3. Partially eliminate the need for sanitary landfill.

4. Substantially reduce the cost of solid waste disposal.

5. Improve water and air quality in urban Nashville by meeting solid waste disposal, water pollution, and air emission standards with a central plant that incorporates effective environmental control equipment.

6. Provide for major ferrous metal recycling from incinerator residue.

7. Create and operate a solid waste fueled central heating and cooling plant project that has a favorable economic and environmental impact on the community.

* Privately financed. This project functions as a quasi-public corporation. The eleven member Board of Directors is made up of city and state officals, with two members from the business community, it therefore cooperates quite closely with those governmental bodies. Use Box No. 15 if additional space is needed

9. Status and Results The results and status as related to the objectives listed in item $B$ are:

1. Reliable district heating and cooling are being provided using solid waste as the primary fuel, presently at the rate of about $75 \%$. However present delivered prices for steam and chilled water are in some cases higher than the equivalent prices for steam and chilled water are in some cases higher than the equivalent energy charge from local utilities. Comparing the cost of purchased energy services from thermal to the total annual owning and operating cost of in building provided service brings the comparison more in line.

This project is: $\square$ planned $\square$ in-progress $\square$ completed
10. Utility Services

$\square$ electrical power

space heating

[X] space cooling

$\square$ potable hot water
Use Box No. 16 if additional space is needed

11. Type of Project

public private

cooperative

12. Exchange of data 
project location.110 First Ave South, Nashville, Tennessee

Identification No.

degree-days (heating) - 3696 Annual

degree-days (cocling) - 1694 Annual

energy source Solid Waste with oil and gas standpy

plant load capacity

a. power $(\mathrm{MW})-\ldots--\mathrm{NA}$

b. heating (MW) ---- See below expected payback period Revenue bonds mature in June 2002. The project should be self supporting

Yype and size of user $5-10$ (dwelling units)

cooling $(\mathrm{MW})$ -

d. wastewater treatment-liters/day - - - - N

e. solid waste processing-kilograms/day - - -

f. potable water-liters/day ------- NA

heat to power ratıo (average expected)

b. residential (square area- $\mathrm{m}^{2}$ )

c. commercial (square area- $\mathrm{m}^{2}$ )

654,545

d. industrial (thermal + elec.-MW)

NA

See below

14. Other Related Projects (Titles) Following are similar projects which are technologically related but separate efforts:

- Harrisburg, Pennsylvania Municipal Incinerator

- Chicago, I1linois Northwest Incinerator

- Saugus, Mi ssachusetts (Wheelabor-Frye)

15. Additional space for Purpose of Project Examples:

13. Degree Day Base $-65^{\circ}-$ Daily max. Temp $=55^{\circ}$

Daily Max. Temp $=92^{\circ}$

Daily Min. Temp $=31^{\circ}$

Daily Max. Temp $=66^{\circ}$

Average Temp $=43^{\circ}$

Average Temp $=79^{\circ}$

Base $56^{\circ}-43^{\circ}=22$

Heating degree days

Base $65^{\circ}-79^{\circ}=14$ cooling degree days.

13b. Heating capacity $=218,000$ pounds per hour (two incinerator boilers)

c. Cooling capacity $=14,000$ tons (two centrifugal chillers)

Heat to power ratio expressed in pounds of steam equals .7. From one pound of solid waste we produce 3.5 pounds of steam. Boilers are $70 \%$ efficient.

Type \& Size of Users

Thermal serves thirty downtown Nashville buildings with a total connected load of 171,300 pounds per hour steam and 8,625 tons of cooling. This represents approximately 3 million square feet of buildings space, of which roughly $90 \%$ is Commercial office and $10 \%$ is Hotel.

16. Additional space for Status and Results

2. Energy is being recovered from solid waste in an efficient manner.

3. Refuse is being reduced $90 \%$ in volume and $75 \%$ in weight, eliminating a portion of the landfill operation.

4. Metropolitan Government's cost of solid waste disposal has been reduced.

5. The Plant is now meeting Federal, State, and Local Air, Water and Solid Waste Disposal Quality Standards. Total emissions from Thermal are less than if Thermal's Customersi were privately and individually heated and cooled.

6. This objective has not been achieved or attempted.

7. This objective has been partially attained in improvement to the enivornmental and in economic benefit to the City. The stablization of service rates as compared to the escalation if comparable utility costs will provide similar economic benefits to service users over the life of the project. 


\begin{tabular}{|c|c|}
\hline $\begin{array}{l}\text { NBS-1075 } \\
(2.77)\end{array}$ & $\begin{array}{l}\text { U.S. DEPARTMENT OF COMMERCE } \\
\text { NATIONAL BUREAU OF STANDARDS }\end{array}$ \\
\hline
\end{tabular}

PROJECT SUMMARY FORM

1. Title of Project (Otficial Title)

Town of Hempstead Solid Waste Managenent \& Resource Recovery Facility

3. Performing Organization (Complete Mailing Address)

Town of Hempstead

Department of Sanitation

1600 Merrick Road

Merrick, N.Y. 11566

U.S.A.

William J . Landman

Town of Hempstead

(Address as in \#3) 5. Supporting Organization (Complete Mailing Address and Name of
Contact) dentification No

(Secretariat Use On/y)

3-633US-38

2. Date (Form Completed)

December 2, 1976

4. Prıncipal Investıgator (Name and Complete Mailing Address)

Commissioner of Sanitation

6. Duration of Investigation (Beginning and ending)

1974 through 1978

7. Estimated Funding and Manpower (Monies and Manyears)

$\$ 73,000,000.00$

Manyears Unavailable

8. Purpose of Project (Jbjectives, Motivations, Approach, Plans and Expected Results,

To provide for the residents of the Town of Hempstead, New York (population 850,000) a Solid Waste Management \& Resource Recovery Facility having a capacity of no less than 2,000 tons per day. The facility will be capable of recovering from the solid waste stream, allmetals, ferrous and non-ferrous, glass, and other saleable product, and to utilize the paper and cellulosic material as a fuel for the on-site generation of electrical power (up to $40 \mathrm{mw} / \mathrm{h}$ ) to be purchased by public utility. The project is an interface with public energy (the Department of Sanitation and private enterprise, Black Clawson Inc.), with the entire project funded by private industry without tax base support of local government, for a contractual period of 20 years. The Department Sanitation, the only customer permitted to utilize the facility, will pay a prescribed tipping fee for services to be rendered over the life term of the contract, and share as a credit up to $40 \%$ of the gross sales of recovered resources and electrical energy produced for sale to the public utility.

Use Box No 15 if additional space is needed

\section{Status and Results}

Project currently (December 1976) under construction; $20 \%$ completed and on schedule. Estimated operational on line June 1978.

This project is: $\square$ planned $\square$ in-progress $\square$ completed Use Box No. 16 if additional space is needed

\begin{tabular}{ll}
\hline 10. Utility Services & $\square$ wastewater treatment \\
$\square$ electrical power & $\square$ solid waste processing \\
$\square$ space heatıng & $\square$ potable water \\
$\square$ space cooling & \\
$\square$ potable hot water &
\end{tabular}

12. Exchange of data 
13. Technical Data

project location -- - -

degree-days (heatting) -

energy source

degree-days (cocling) - -

expected payback period

plant load capacity

a. power (MW) - - - -

b. heating (MW) ----

c. cooling (MW) ----

d. wastewater treatment-liters/day _ _ _ .

e. solid waste processing-kilograms/day - - -

f. Dotable water-liters/day - - - - - -

hea. .o power ratio (average expected)

14. Other Related Projects (Titles)

15. Additional space for Purpose of Project

16. Additional space for Status and Results

a. residential (dwelling units)

b. residential (square area- $\mathrm{m}^{2}$ )

c. commercial (square area- $\mathrm{m}^{2}$ )

d. industrial (thermal + elec.-MW) 


\begin{tabular}{|c|c|c|}
\hline \multicolumn{2}{|l|}{$\begin{array}{l}\text { NBS-1075 } \\
(2-77)\end{array}$} & $\begin{array}{r}\text { Identification No. } \\
\text { (Secretariat Use On/y) } \\
3-633 \mathrm{US}-39\end{array}$ \\
\hline $\begin{array}{l}\text { 5. Supporting Organization (Complete Mailing Address and Name of } \\
\text { Contact) } \\
\text { Same as } 3\end{array}$ & $\begin{array}{c}\text { 6. Duration of Investigati } \\
\text { Nov. } 1973 \text { to SE } \\
\text { 7. Estimated Funding anc } \\
\text { N/A }\end{array}$ & $\begin{array}{l}\text { ion (Beginning and ending) } \\
\text { ept. } 1977 \\
\text { d Manpower (Monies and Manyears) }\end{array}$ \\
\hline $\begin{array}{l}\text { 8. Purpose of Project / } \text { Dbjectives, Motivations, Approach, Plans and } \\
\text { The project's purpose is to effectively u } \\
\text { waste to heat and cool some of the commun } \\
\text { buildings and supply process steam to ind } \\
\text { primary motivation for the project is to } \\
\text { resulting from its loss of natural gas fo } \\
\text { installation of a large central energy co } \\
\text { to connect the new central plant to all }\end{array}$ & $\begin{array}{l}\text { pected Resu/ts) } \\
\text { ilize the energy } \\
\text { ity's hospitals ar } \\
\text { lstrial manufactur } \\
\text { te able to offset } \\
\text { boiler fuel. } \\
\text { lversion plant anc } \\
\text { the buildings tc }\end{array}$ & $\begin{array}{l}\text { in the community's solid } \\
\text { nd commercial office } \\
\text { ring facilities. The } \\
\text { the effect on the community } \\
\text { he project involves the } \\
\text { d a distribution system } \\
\text { o be served. } \\
\text { Jse Box No. } 15 \text { if additional space is needed }\end{array}$ \\
\hline $\begin{array}{l}\text { 9. Status and Results } \\
\text { The preliminary economic and technical fe } \\
\text { Building owners to be served from the pla } \\
\text { support the project. It has received pol } \\
\text { Majyor which authorized the current activ } \\
\text { equipment bidding. }\end{array}$ & $\begin{array}{l}\text { asibility study h } \\
\text { it have committed } \\
\text { itical support fro } \\
\text { ity - Preliminary }\end{array}$ & $\begin{array}{l}\text { as been completed. } \\
\text { themselves to financially } \\
\text { om the City Council and } \\
\text { engineering and major }\end{array}$ \\
\hline $\begin{array}{l}\square \text { wastewater treatment } \\
\square \text { solid waste processing } \\
\square \text { potable water } \\
{[\mathrm{x}] \text { process steam }}\end{array}$ & $\begin{array}{l}\text { 11. Type of } \mathrm{Pr} \\
\square \text { public } \\
\nabla \text { cooper }\end{array}$ & $\begin{array}{l}\text { roject } \\
\text { rative }\end{array}$ \\
\hline Will data be available from this project that will be shared wit & $\square$ Yes & [x] Unknown \\
\hline
\end{tabular}




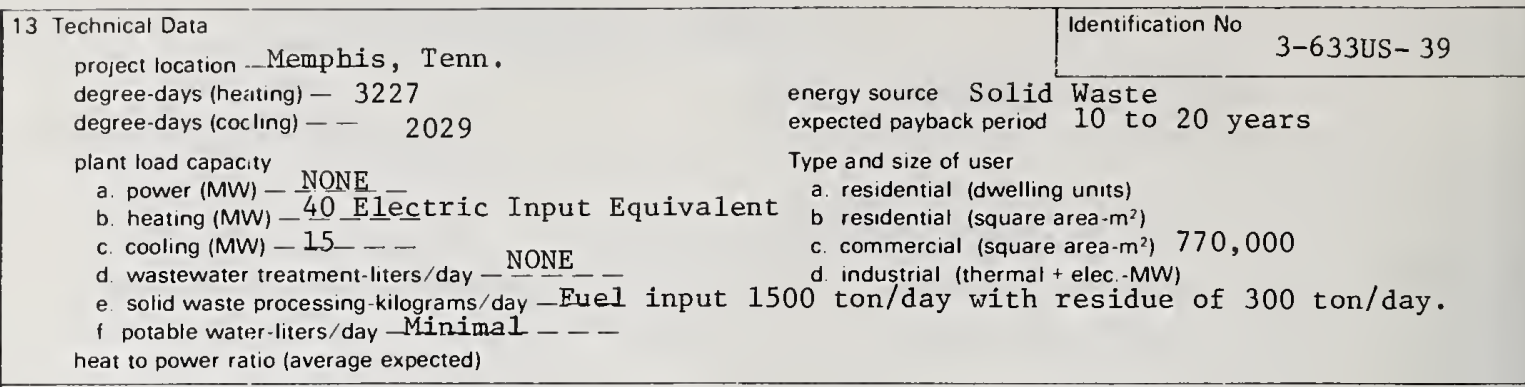

14 Other Related Projects (Titles)

15. Additional space for Purpose of Project

16. Additional space for Status and Results 
NBS- 1075

U.S. DEPARTMENT OF COMMERCE

NATIONAL BUREAU OF STANDARDS

Identification No.

(Secretariat Use Only)

PROJECT SUMMARY FORM

1 Title of Project (Orficial Title)

Resource Recovery System

3-633Us -40

2. Date (Form Completed)

February 16, 1977

3. Performing Organization (Complete Mailing Address)

City of Detroit

Environmental Protection \& Maint. Dept.

513 City - County Building

Detroit, Michigan 48226

U.S.A.

5. Supporting Organization (Complete Mailing Address and Name of Contact)

6. Duration of Investigation (Beginning and ending)

May 1975 to September 1977

7. Estıniated Funding and Manpower (Monies and Manyears)

Consultants $\$ 260,0009 / 76$ to $9 / 77$

City Committee \& Support - 15 persons

8. Purpose of Project (Jbjectives, Motivations, Approach, Plans and Expected Results)

The City of Detroit solicited proposals from private industry to provide the service of disposing of residential, commercial, (1ight) and other solid wastes; to provide steam for electric generation and/or district heating; and to recover recyclable materials. This is to be accomplished at a reasonable cost to the City, while preserving or improving the quality of the environment.

Use Box No. 15 if additional space is needed

9. Status and Results

The City of Detroit is currently in the process of selecting the system-contractor finalist ( 1 of 2 ), selecting energy customer ( 1 of 2 ) and designating system site (1 of 2).

Selection process should be completed on or about $4 / 11 / 77$ and appropriate contracts negotiated and executed on or about $8 / 1 / 77$.

This project is: 8 planned $\square$ in-progress $\square$ completed

\begin{tabular}{|l|c|c|}
\hline 10. Utility Services & $11 \quad$ Type of Project \\
$\square$ electrical power & $\square$ wastewater treatment \\
$\square$ space heating & $\square$ solid waste processing & $\square$ public \\
$\square$ space cooling & $\square$ potable water \\
$\square$ potable hot water & $\square$ cooperative \\
\hline 12 . Exchange of data &
\end{tabular}

Will data be available from this project that will be shared with others?

Y Yes $\square$ No 
13. Technical Data Not specified at this time; particulars will be Identification No. project location -_developed and identified on or about $8 / 1 / 77$ degree-days (heatting) degree-days (cocling) - energy source municipal solid waste (only) plant load capacity
a. power (MW) - - - - -
b. heating (MW) - - - -
c. cooling (MW) - - - -
d. wastewater treatment-liters/day - - - -
e. solid waste processıng-kilograms/day - - -
f. potable water-liters/day - - - - - - - heat to power ratio (average expected)

14. Other Related Projects (Titles)

\section{expected payback period}

Type and size of user
a. residential (dwelling units)
b. residential (square area $-m^{2}$ )
c. commercial (square area- $\mathrm{m}^{2}$ )

3,000 tons per day

15. Additional space for Purpose of Project

16. Additional space for Status and Results 


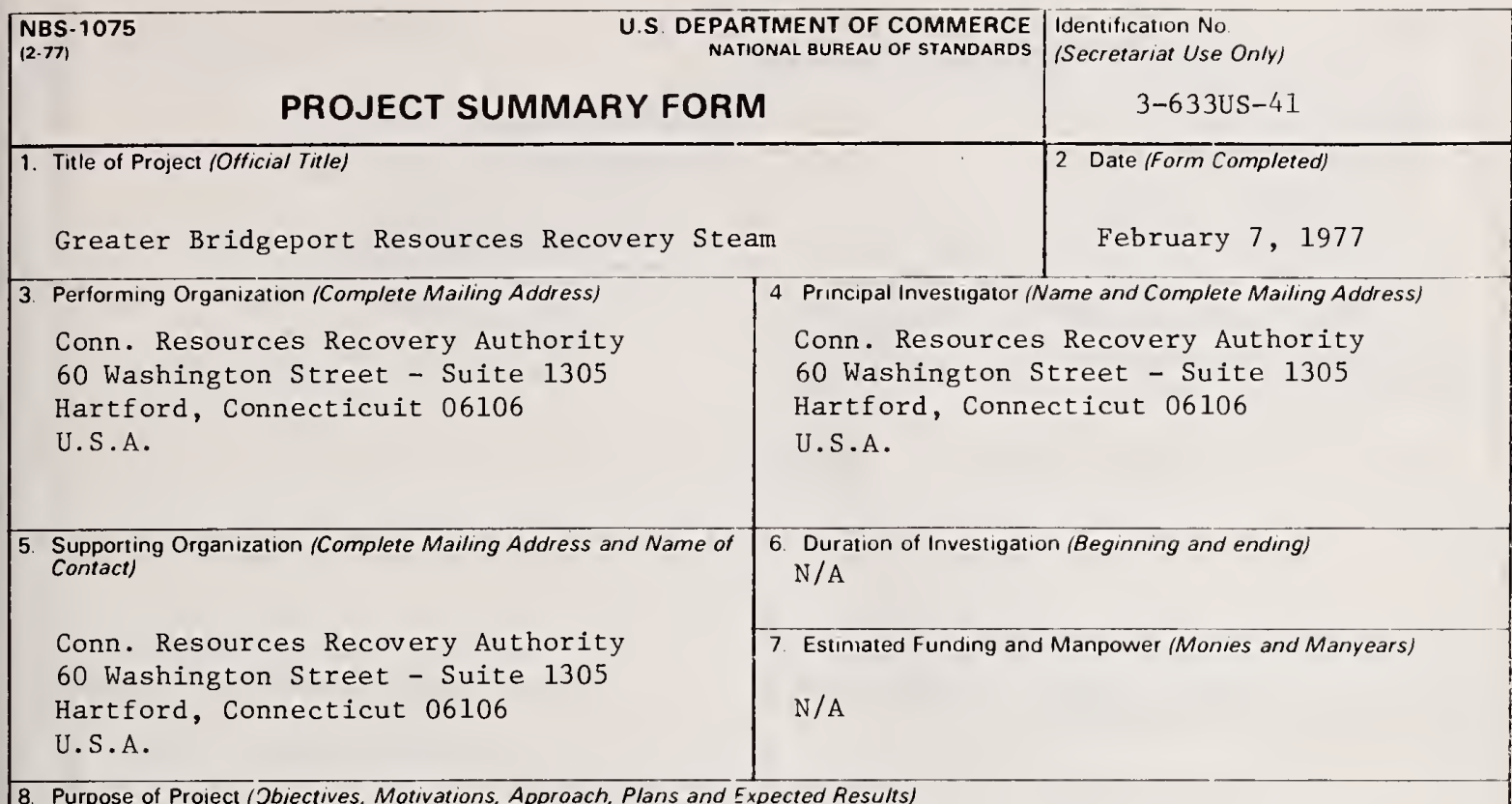

8. Purpose of Project (Objectives, Motivations, Approach. Plans and Expected Results)

Conversion of solid waste stream generated by nine municipalities to a refuse derived fuel to be burned in conjunction with fuel oil at United Illuminating Power Plant in Bridgeport, Connecticut

$$
\begin{aligned}
& 10 \\
& \square \\
& \square \\
& \hline
\end{aligned}
$$
Utility Services Q electrical power $\square$ space heating $\square$ space cooling $\square$ potable hot water $\square$ wastewater treatment [X] solid waste processing $\square$ potable water 2. Exchange of data
$\square$ public
private

[X] cooperative 
13. Technical Data

project location Bridgeport, CT

Identification No

degree-days (heätıng) -

degree-days (cocling) - -

plant load capacity
a. power (MW) -
b. heating (MW) -----
c. cooling (MW) $-\ldots$
d. wastewater treatment-liters/day $-\mathrm{n} / \mathrm{a}--$
e. solid waste processing-kilograms/day 1,6 . $\mathrm{mm}$
f. potable water-liters/day - n Ia
heat to power ratio (average expected)

14. Other Related Projects (Titles)

(L.P.) Conn. Statewide Solid Waste Management Plan

15. Additional space for Purpose of Project

energy source

expected payback period

Type and size of user

a. residential (dwelling units)

b residential (square area- $\mathrm{m}^{2}$ )

c. commercial (square area- $\mathrm{m}^{2}$ )

d. industrial (thermal + elec.-MW)

\section{$3-633$ US -41}

16. Additional space for Status and Results 


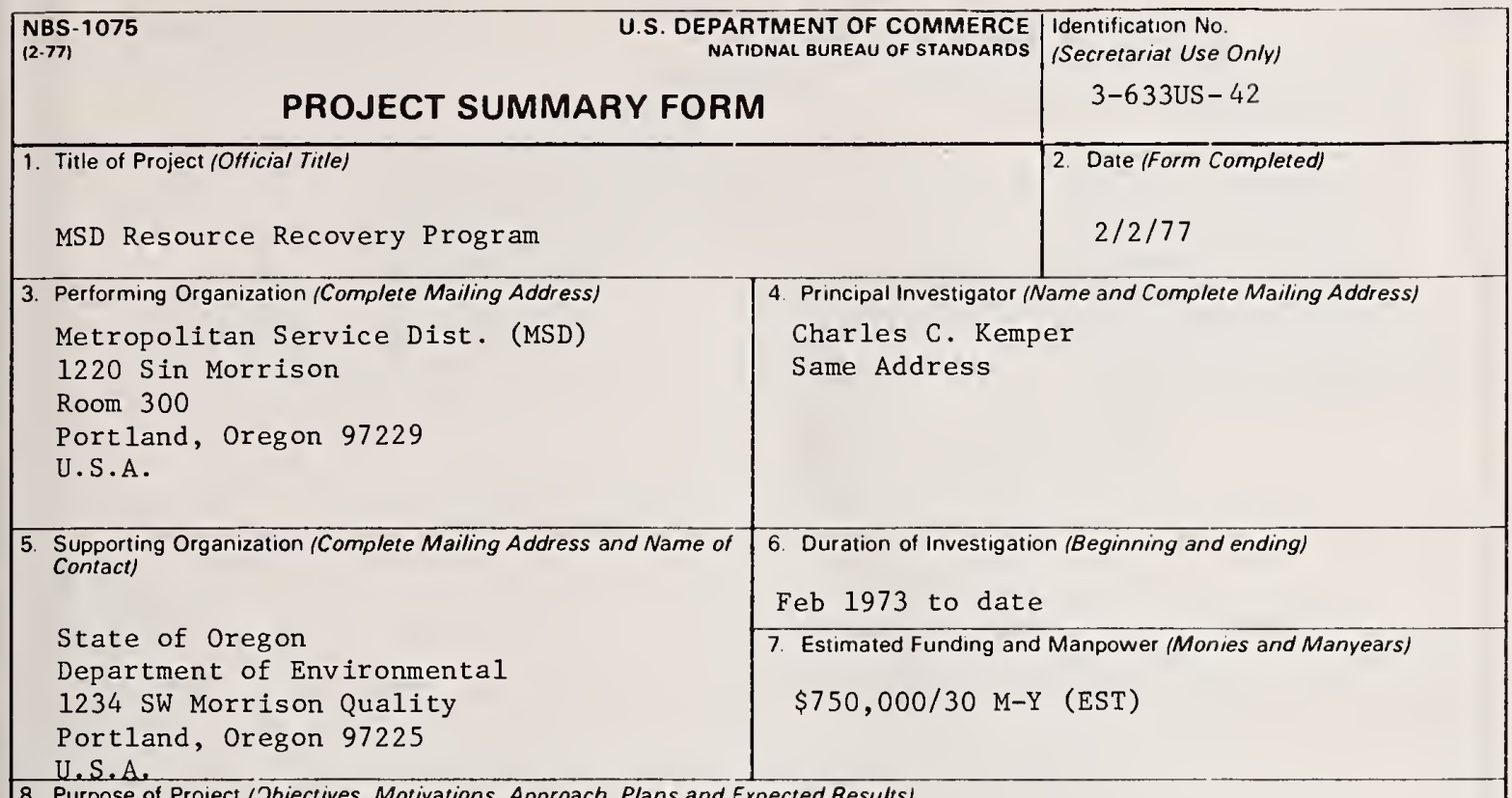

8. Purpose of Project (Jbjectives, Motivations, Approach. Plans and Expected Results)

To reduce dependancy on landfilling solid waste in the Portland Oregon Metropolitan Area. To devevelop a viable alternative solid waste disposal method.

To re cover and reuse maximum of materials in solid waste stream.

To provide for an environmentally sound solid waste disposal system.

Use Box No. 15 if additional space is needed

9. Status and Results

Markets Developed - Preparing for Implementation

This project is: $\square$ planned $\square$ in-progress $\square$ completed

\begin{tabular}{|ll|ll}
\hline 10. Utility Services & 11 Type of Project \\
$\square$ electrical power & $\square$ wastewater treatment & $\square$ public \\
$\square$ space heating & $\square$ solid waste processing & \\
$\square$ space cooling & $\square$ potable water \\
$\square$ potable hot water & $X$ Steam Generation & $\square$ cooperative \\
\hline 12 Exchange of
\end{tabular}

12. Exchange of data

Will data be available from this project that will be shared with others?

Q] Yes

$\square$ No 
13. Technical Data

project location ..Port 1and, Oregon

degree-days (heatting) -

degree-days (cocling) - -

plant load capacity

a. power (MW) - . . -

b. heating $(M W)----$

c. cooling $(\mathrm{MW})----$

d. wastewater treatment-liters/day - - - -

e. solid waste processing-kilograms/day $-2000 \mathrm{~T} / \mathrm{day}$

f. potable water-liters/day -------heat to power ratio (average expected) energy source

expected payback period

Type and size of user

a. residential (dwelling units)

b. residential (square area- $\mathrm{m}^{2}$ )

c. commercial (square area- $\mathrm{m}^{2}$ )

d. industrial (thermal + elec.-MW)

14. Other Related Projects (Titles)

15. Additional space for Purpose of Project

16. Additional space for Status and Results 


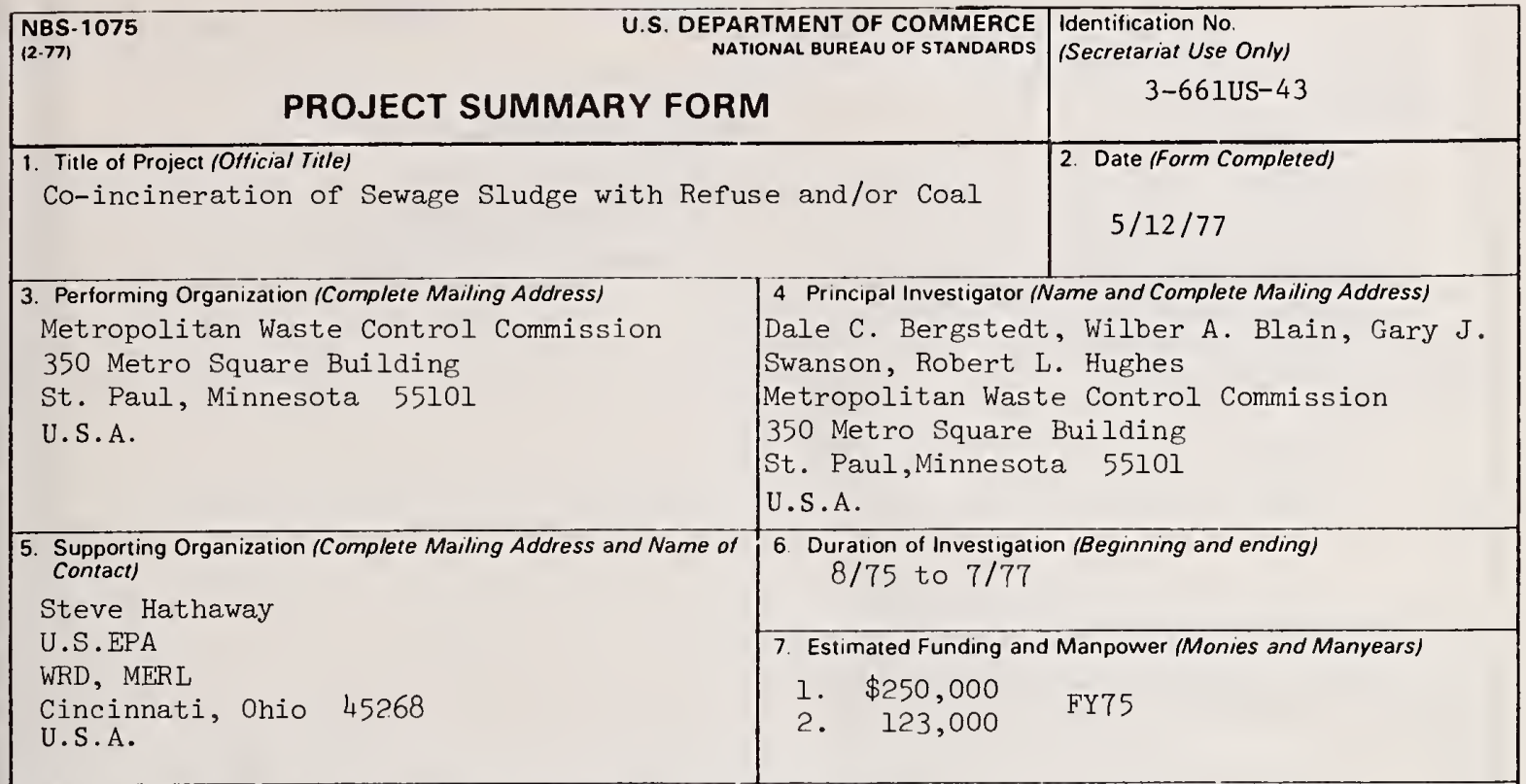

8. Purpose of Project (Jbjectives, Motivations, Approach, Plans and Expected Results)

Purpose of the project is to evaluate the operational worth and environmental aspects, if any, of adding combustible solid matter to wastewater plant sludges and filter cakes as offsets to part or all of the fuels conventionally used in sludge incineration practice. Impending shortages of natural gas and fuel oil create the sense of urgency in this work. Low-sulfur coal and combustible solid wastes will be utilized as admix materials in various test sequences. Wastes to be tried include shredded combustibles from refuse, in pelletized and loose form, wood chips from urban tree-trimming, shredded tires, and industrial combustible wastes. A full-scale multiple hearth furnace in a modern wastewater treatment plant will be used. Applicability to other incinerators of the 200-plus total in United States' communities will be assessed. Assay of stack gases, after scrubbing, will include relevant chemical properties of public health significance. Scrubber drainage and ash will also be assayed.

Use Box No. 15 if additional space is needed

9. Status and Results

Many modifications to the existing, large-scale, multiple hearth sludge incinerator have been accomplishment; these will enable the test sequences to be carried out.

This project is: $\square$ planned $\square$ in-progress $\square$ completed Use Box No. 16 if additional space is needed

\begin{tabular}{ll}
\hline 10. Utility Services & $\square$ wastewater treatment \\
$\square$ electrical power & $\square$ solid waste processing \\
$\square$ space heating & $\square$ potable water \\
$\square$ space cooling &
\end{tabular}




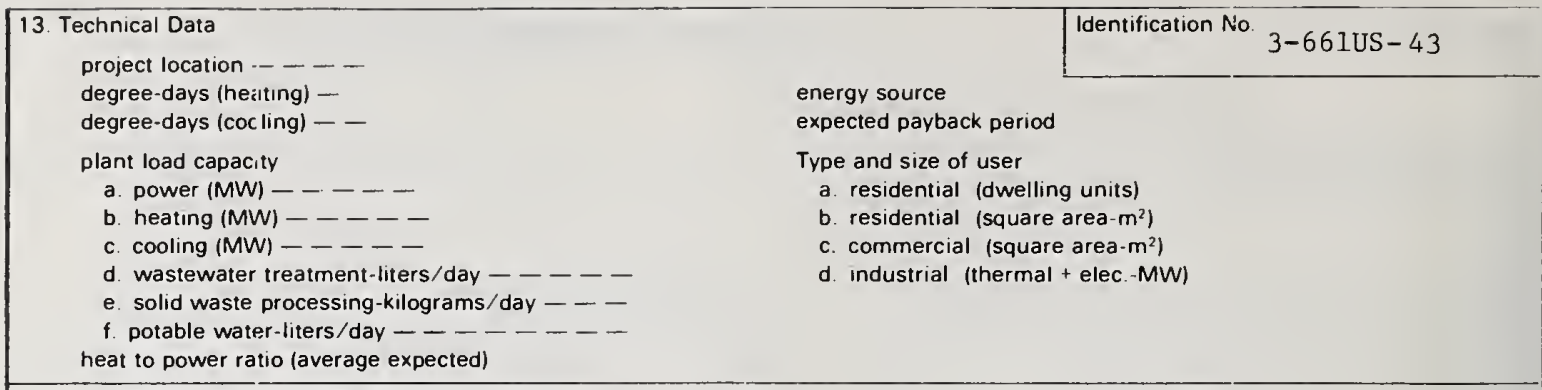

14. Other Related Projects (Tit/es)

15. Additional space for Purpose of Project 
NBS-1075

$(2.77)$

\section{U.S. DEPARTMENT OF COMMERCE}

NATIONAL BUREAU OF STANDARDS

PROJECT SUMMARY FORM

1. Title of Project (Otficial Title)

Environmental Effect of Utilizing Solid Waste as a Supplementary Power-Plant Fuel

3. Performing Organization (Complete Mailing Address)

Battelle Columbus Laboratories

505 King Avenue

Columbus, Ohio 43201

U.S.A.
4 Principal Investigator (Name and Complete Mailing Address) Dale A.Vaughan, Materials Science Dept.

W. K. Boyd Corrosion Research Section

H.H.Krause, Atmospheric Sciences Section R.B.Engdahl, Fuels and Combustion Systems Section

5. Supporting Organization (Complete Mailing Address and Name of Contact)

R. Olexsey

U.S.EPA

ORD, IERL

Cincinnati, Ohio 45268

U.S.A.

6.

Duration of Investigation (Beginning and ending) $6 / 74$ to $6 / 77$

7. Estimated Funding and Manpower (Monies and Manyears) $\$ 120,000$ FY74

190,000 FY75

193,000 FY76

8. Purpose of Project (Objectives, Motivations. Approach. Plans and Expected Results)

The objective of this project is to investigate the benefits to the environment resulting from the utilization of solid waste as a supplementary fuel in existing coal-fired plants.

The approach is to evaluate the gaseous and particulate emission plus the corrosiveness of combustion products as a function of refuse-coal ratio and as a function of sulfur content of the coal. Experiments will be conducted in an operating power station through cooperation of the City of Columbus, Ohio.

Furnace and stack gas and particulate samples will be collected throughout the periods that corrosion probes are inserted at several locations in the heat recovery passes. These probes will be examined for corrosion attack and deposit composition for various gas and metal temperatures to provide guidance in future utilization of solid waste as a supplementary fuel.

Use Box No. 15 if additional space is needed

\section{Status and Results}

Short-duration ( 8 hour) corrosion tests have been completed, as have modifications to the boiler to enable longer duration corrosion testing. 


\begin{tabular}{|c|c|}
\hline 13. Technical Data & $\begin{array}{l}\text { Identification No. } \\
\text { 3-661US-44 }\end{array}$ \\
\hline $\begin{array}{l}\text { project location } \\
\text { degree-days (heatting) }- \\
\text { degree-days (cocling) }-\end{array}$ & $\begin{array}{l}\text { energy source } \\
\text { expected payback period }\end{array}$ \\
\hline 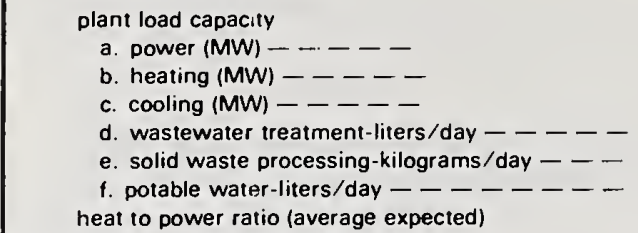 & $\begin{array}{l}\text { Type and size of user } \\
\text { a. residential (dwelling units) } \\
\text { b. residential (square area- } \mathrm{m}^{2} \text { ) } \\
\text { c. commercial (square area- } \mathrm{m}^{2} \text { ) } \\
\text { d. industrial (thermal + elec. }-\mathrm{MW} \text { ) }\end{array}$ \\
\hline 14. Other Related Projects (Tit/es) & \\
\hline
\end{tabular}

15. Additional space for Purpose of Project 


\section{PROJECT SUMMARY FORM}

1. Title of Project (Official Title)

St. Louis Waste Co-firing with Coal Project: Equipment, Facilities and Environmental Evaluation of Meramce Power Plant

3. Performing Organization (Complete Mailing Address)

Midwest Research Institute 425 Volker Boulevard

Kansas City, Missouri 64110 U.S.A.

$$
\text { 3-661US-45 }
$$

2. Date (Form Completed)

$$
5 / 12 / 77
$$

5. Supporting Organization (Complete Mailing Address and Name of Contact)
C. Wiles
U.S.EPA
ORD, MERL
Cincinnati, Ohio 45268
U.S.A.

4. Principal Investigator (Name and Complete Mailing Address)

P.G.Gorman, L.J.Shannon, M.P.Schrag, D. E. Fiscus

Midwest Research Institute

425 Volker Boulevard

Kansas City, Missouri 64110

U.S.A.

6. Duration of Investigation (Beginning and ending)

$$
6 / 68-9 / 77
$$

7. Estimated Funding and Manpower (Monies and Manyears)

$$
\begin{array}{r}
\$ 300,000 \text { FY75 } \\
242,000 \text { FY76 }
\end{array}
$$

8. Purpose of Project (Objectives, Motivations, Approach, Plans and Expected Resu/ts)

As part of an EPA demonstration grant, the City of St. Louis has been processing municipal solid waste and the Union Electric Utility has been firing it as an auxiliary fuel at the Meremac Power Plant. The feasibility of the concept has been demonstrated but more data of a substantive nature is being sought from the program. This procurement is to provide services to fully test and evaluate the refuse preparation and firing processes.

Specifically, this project provides for tests to determine the effects of firing refuse and coal on gases and particulates emitted from a $120 \mathrm{MW}$ tangentially-fired utility boiler. Tests will be made to investigate the mechanisms which cause a loss in ESP performance. Water pollution tests will be conducted and the emission of potentially hazardous pollutants will be investigated. Testing and engineering analyses will be performed to technically and economically evaluate the refuse preparation and firing processes. Requirements for design of emission control devices will be established and process or equipment modifications necessary to reduce process cost and to increase energy or material recovery will be determined.

Use Box No. 15 if additional space is needed

9. Status and Results

Detailed emission characterization has essentially been completed, as have tests of a mobile baghouse for dust and particulate removal from the refuse preparation plant.

This project is: $\square$ planned $\square$ in-progress completed Use Box No. 16 if additional space is needed wastewater treatment $\square$ solid waste processing $\square$ potable water Project

$\begin{array}{ll}\square \text { electrical power } & \square \text { wastewater treatment } \\ \square \text { space heating } & \square \text { solid waste processing } \\ \square \text { space cooling } & \square \text { potable water }\end{array}$

t

11. Type of Project
$\square$ public $\square$ private
$\square$ cooperative

12. Exchange of data 
13. Technical Data

project location -- - -

degree-days (heating) -

degree-days (cocling) - -

plant load capacity

a. power (MW) $--\cdots$

b. heating $(\mathrm{MW})----$

c. cooling (MW) - - -

d wastewater treatment-liters/day - _ _ -

e. solid waste processing-kilograms/day - - -

f. potable water-liters/day $-\ldots-\ldots-\ldots$ heat to power ratio (average expected) energy source

expected payback period

Type and size of user

a. residential (dwelling units)

b. residential (square area- $\mathrm{m}^{2}$ )

c. commercial (square area- $\mathrm{m}^{2}$ )

d. industrial (thermal + elec.-MW)

14. Other Related Projects (Titles)

15. Additional space for Purpose of Project

16. Additional space for Status and Results 


\section{PROJECT SUMMARY FORM}

1 Title of Project (Officıal Tit/e)

HMDC Resource Recovery Facility

$$
\text { 3-661US- } 46
$$

2. Date (Form Completed)

$2-2-77$
3. Performing Organization (Complete Mailing Address)

Hackensack Meadowlands Development Commission

1099 Wall Street West

Lyndhurst, New Jersey 07071 U.S.A.

(Agency of the State of New Jersey)
5. Supporting Organization (Complete Mailing Address and Name of Contact)

Financial Support Provided by HMDC through Revenue Bonds
4 Principal Investigator (Name and Complete Mailing Address)

George D. Cascino, P.E., P.P.

Chief Engineer
6. Duration of Investigation (Beginning and ending)

$2 / 76-11 / 79$

7. Estımated Fundıng and Manpower (Monies and Manyears)

$\$ 21,400,000$ for two years, manpower unknown at this time.

8. Purpose of Project (Dbjectives, Motivations, Approach. Plans and Expected Results)

HMDC will be concstructing a 2500 ton (short)/day solid waste processing facility to service \& process solid wastes from Bergen County, N.J. which has a population of 911,480 ( 1970 Census) and a surface area of $618.36 \mathrm{Km}^{2}$. This processing plant will shred, air classify \& separate the incoming solid waste into four components: ferrous metals, aluminum, refuse-derived fuel (RDF) \& an inert residue (glass, dirt, etc.).

Of these components, the largest fraction by weight, is the RDF which is approximately 1300 tons (short)/day, dry. This component which is composed of light organice materials less than $6.35 \mathrm{~mm}$ in size will be marketed to an electric generating station located in the City of Jersey City, Hudson County, New Jersey, by an existing railroad line between the HMDC Resource Recovery Facility and this electric generating station.

(Continued on second page)

Use Box No. 15 if additional space is needed

9. Status and Results

Preliminary design of the proposed facility was completed on February $18,1976$. The HMDC is currently in the process of obtaining various permits from regulatory agencies On the advise of financial counsel, HMDC applied to the N.J. Board of Public Utilities for a Solid Waste Franchise on August 11, 1976. Upon receipt of this franchise, revenue bonds will be issued to finance the cost of construction. Resolution of this matter is expected in the second half of 1977.

This project is: $\square$ planned $\square$ in-progress $\square$ completed

10. Utılity Services

electrical power

$\square$ space heating

$\square$ space coolıng

$\square$ potable hot water

12. Exchange of data
Use Box No. 16 if additional space is needed wastewater treatment

solid waste processing

$\square$ potable water

Will data be available from this project that will be shared with others?

Y.7. Yes No 


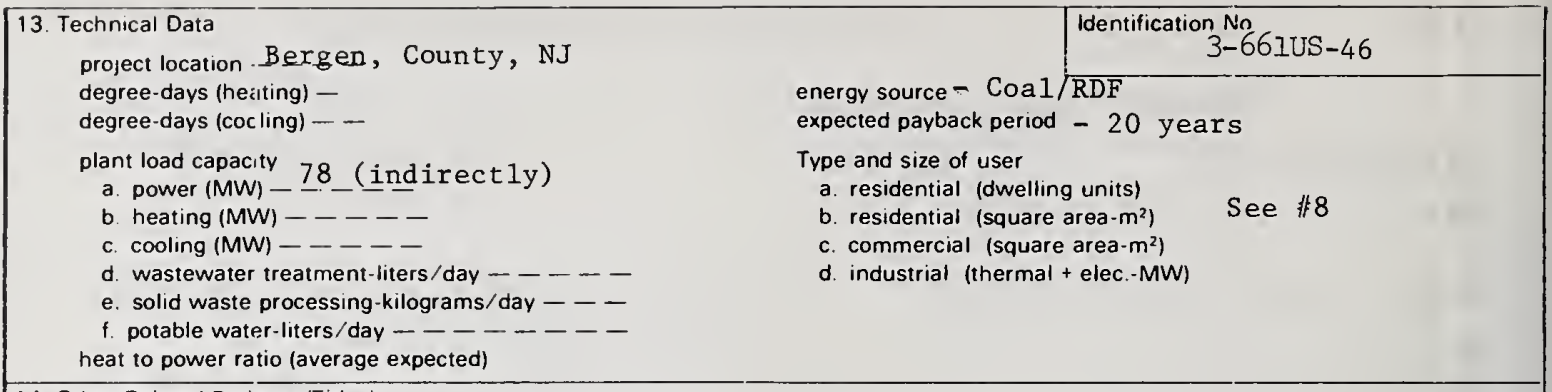

14. Other Related Projects (Tit/es)

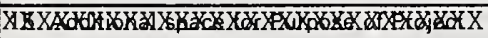

8. Purpose of Project (Cont.)

This generating station which is known as Hudson 1 作 currently uses coal to provide the energy required to generate its average daily load of $434 \mathrm{MWe}$ for its service area which includes al1 12 municipalities of Hudson County. RDF from the HMDC facility would replace $4520 \times 10^{6} \mathrm{Kca} 1 /$ Day of energy, provided by coal, approximately $18 \%$ of Hudson 非's tota1 daily energy input. Based upon the draft contract between HMDC and the utility, this RDF has a current value of $\$ 5.75 / 10^{6} \mathrm{Kca} 1$, approximately $28 \% 1$ ess than

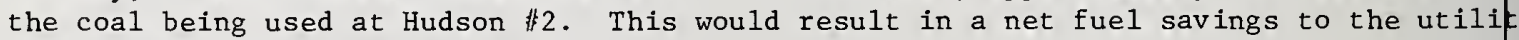
of 3.6 million dollars per year. 


\begin{tabular}{|c|c|c|}
\hline \multicolumn{2}{|l|}{$\begin{array}{l}\text { NBS-107 } \\
(2.77)\end{array}$} & $\begin{array}{l}\text { Identification No. } \\
\text { (Secretariat Use On/y) } \\
3-66 \text { IUS }-47\end{array}$ \\
\hline $\begin{array}{l}\text { 1. Title of Project (Official Title) } \\
\text { Evaluation of Ames Solid Waste Resources }\end{array}$ & 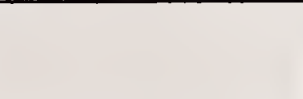 & $\begin{array}{l}\text { 2. Date (Form Completed) } \\
\text { December 9, } 1976\end{array}$ \\
\hline $\begin{array}{l}\text { 3. Performing Organization (Complete Mailing Address) } \\
\text { Engineering Research Institute, Iowa } \\
\text { State Univ., Ames, Iowa } 50010 \text { and } \\
\text { Midwest Research Institute } \\
425 \text { Volker Blvd. } \\
\text { Kansas City, Missouri } 64110 \\
\text { U.S.A. }\end{array}$ & $\begin{array}{l}\text { 4. Principal Investigator / } \\
\text { Mr. A1 Joensen } \\
\text { Engineering Depa } \\
\text { Iowa, State Univ } \\
\text { Ames, Iowa } 50010 \\
\text { U.S.A. }\end{array}$ & $\begin{array}{l}\text { Name and Complete Mailing Address) } \\
\text { rtment } \\
\text { ersity }\end{array}$ \\
\hline $\begin{array}{l}\text { 5. Supporting Organization (Complete Mailing Address and Name of } \\
\text { Contact) } \\
\text { Solid \& Hazardous Waste Research } \\
\text { Municipal Environmental Research Lab. } \\
\text { EPA } \\
26 \text { W. St. Claire St. } \\
\text { Cincinnati, Ohio } 45268 \text {, U.S.A. }\end{array}$ & $\begin{array}{l}\text { 6. Duration of Investigatic } \\
\text { February 5, } 19 \\
\text { 7. Estimated Funding and } \\
\$ 464,841\end{array}$ & $\begin{array}{l}\text { on (Beginning and ending) } \\
76 \text { to February 4, } 1977 \\
\text { d Manpower (Monies and Manyears) }\end{array}$ \\
\hline $\begin{array}{l}\text { 8. Purpose of Project /Objectives, Motivations, Approach. Plans anc } \\
\text { This is the first year of a three-year pr } \\
\text { environmental, economic and technical asp } \\
\text { recovery system. This system is producin } \\
\text { in a coal-fired steam generator and is pr } \\
\text { gram has the following princiapl objectiv } \\
\text { evaluation of facilities and equipment, i } \\
\text { the processing plant and associated power } \\
\text { fuel and by-product materials produced by } \\
\text { impact of firing MSW as a supplemental fu } \\
\text { and solids effects. Laboratory analysis } \\
\text { conducting by E.R.D.A., Ames Laboratory, }\end{array}$ & $\begin{array}{l}\text { pected Results) } \\
\text { ram to conduct an } \\
\text { ts of a full-scal } \\
\text { refused derived f } \\
\text { iding for valuabl } \\
\text { : (1) technical, } \\
\text { ividually and as } \\
\text { lantoperations; ( } \\
\text { he system; ( } 3 \text { ) de } \\
\text { in the utility b } \\
\text { d measurement ins }\end{array}$ & $\begin{array}{l}\text { in-depth evaluation of the } \\
\text { e on-line solid waste } \\
\text { uel to supplement firing } \\
\text { e metal recovery. The pro- } \\
\text { economic and environmental } \\
\text { a system, including both } \\
\text { (2) characterize the refuse } \\
\text { etermine the environmental } \\
\text { oiler including air, water } \\
\text { trumentation is being } \\
\text { ity. }\end{array}$ \\
\hline
\end{tabular}

Use Box No. 15 if additional space is neeoed

\section{Status and Results}

Project in progress and results will be published in 1977

This project is: $\square$ planned in-progress $\square$ completed

$$
\text { 更 }
$$
译 electrical power $\square$ space heatıng $\square$ space coolıng $\square$ potable hot water 12. Exchange of data

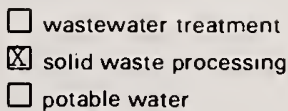

potable water 11 Type of Project

public

private

cooperative 


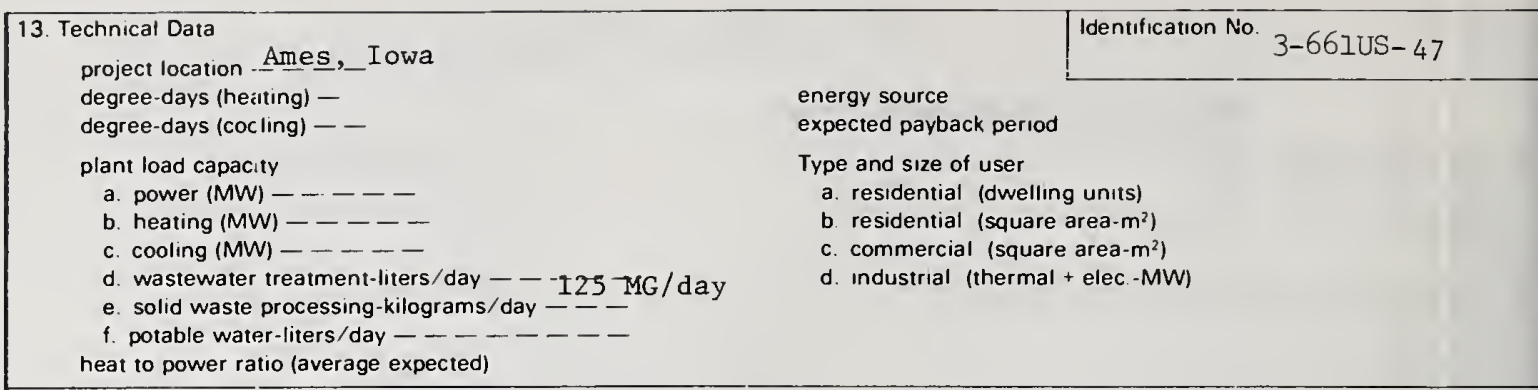

14. Other Related Projects (Titles)

15. Additional space for Purpose of Project

16. Additional space for Status and Results 


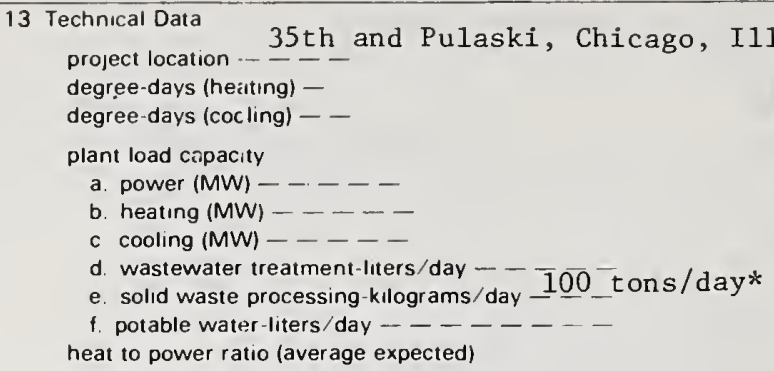

Resource Recovery of Ferrous Metals by Magnetic Separation.

15. Additional space for Purpose of Project energy source expected payback period

Type and size of user

a. residential (dwelling units)

b. residential (square area- $-m^{2}$ )

c. commercial (square area- $\mathrm{m}^{2}$ )

d. Industrial (thermal + elec.-MW)

*500 tons/day processed waste is used as fuel in combination with fuel. 


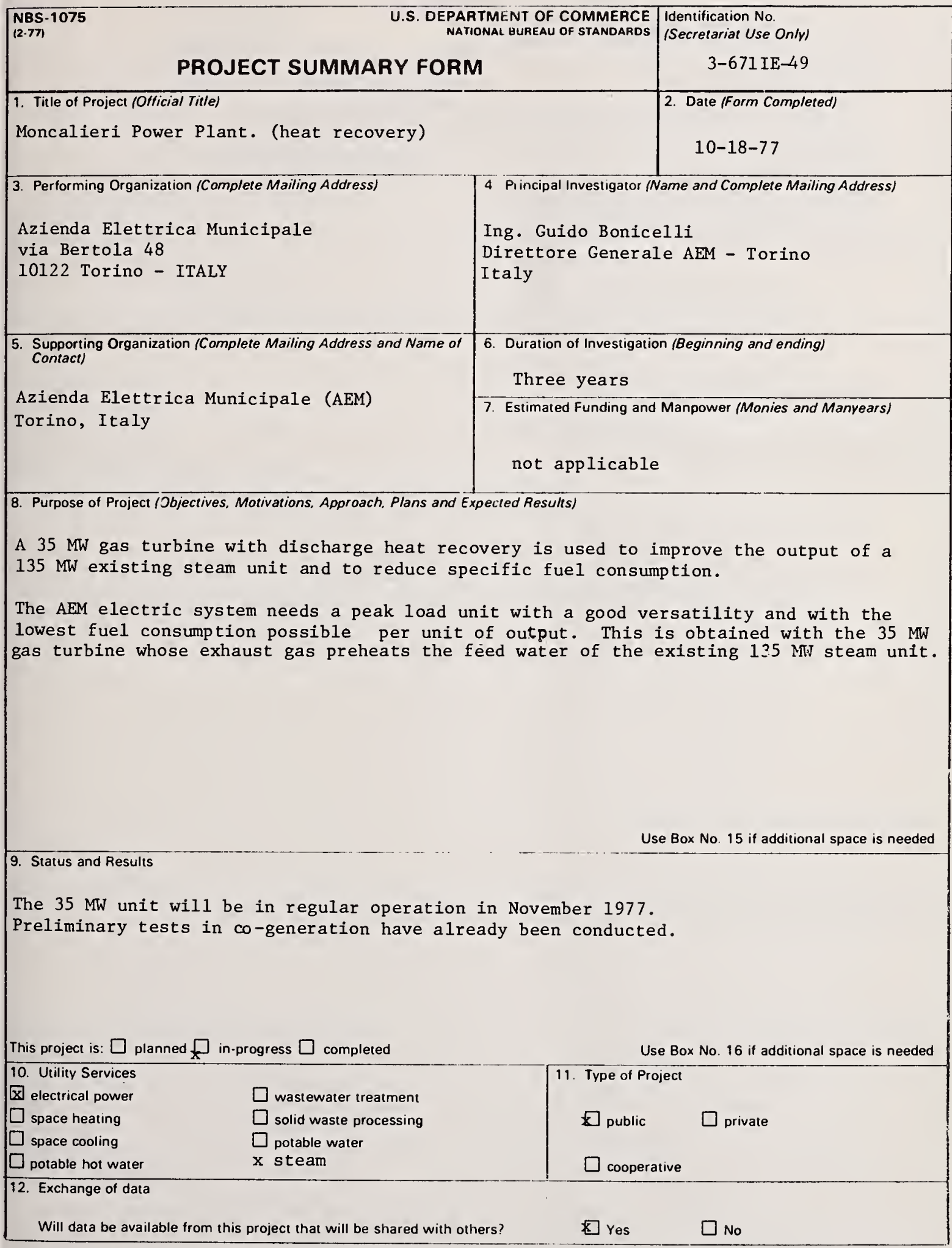




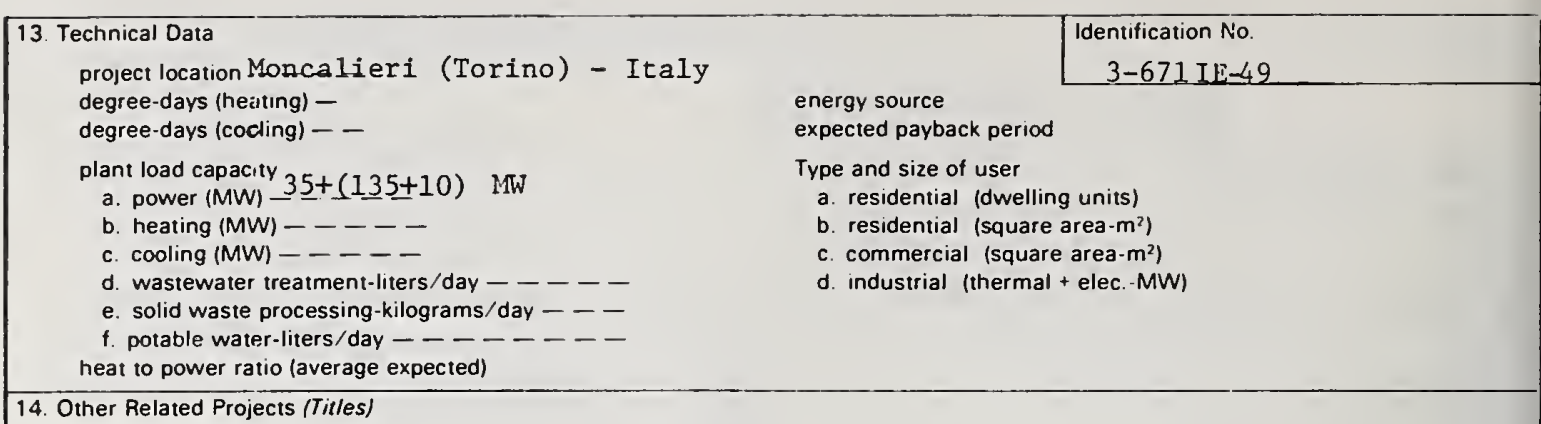

14. Other Related Projects (Titles)

15. Additional space for Purpose of Project

16. Additional space for Status and Results 
U.S. DEPARTMENT OF COMMERCE NATIONAL BUREAU OF STANDAROS

PROJECT SUMMARY FORM

Overall study on the possibilities of long-distance heat supply from heating power stations in the FRG (ET 5072)
Identification No

(Secretariat Use On/y)

3-691DE- 50
2. Date (Form Completed)

Aug. 31, 1976

3. Performing Organization (Complete Mailing Address)

Arbeitsgemeinschaft Fernwarme

e.V. (AGFW)

Kennedyallee 89

D-6000 Frankfurt/Main 70

Federal Republic of Germany

4. Principal Investigator (Name and Complete Mailing Address)

Dipl.-Ing.F.' Neuffer

Arbeitsgemeinschaft Fernwarme

e.V. (AGFW)

Kennedyallee 89

D-6000 Frankfurt/Main 70

Federal Republic of Germany

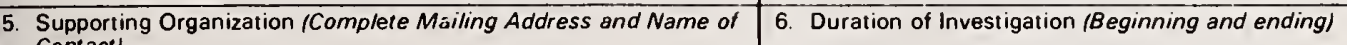
Contact)

PLE/KFA Juelich

Sept. 1, 1974 - Aug. 31, 1976

Dr. Plantikow

Postfach 1913

7. Estimated Funding and Manpower (Monies and Manyears)

$1,062,146 .-\$$ US

D-517 Juelich

Federal Republic of Germany

8. Purpose of Project (Objectives, Motivations, Approach, Plans and Expected Resu/ts)

Estimate of the saving in fossil fuels which can be achieved on a short-term and medium-term basis in the Federal Republic by means of long-distance heating from heating power stations, in particular of the nuclear type, and statement of the ecological and politico-economic advantages obtained thereby, as well as the necessary measures and investments.

9. Status and Results

This project is: $\square$ planned $\square$ in-progress $\square$ completed

16

$$
\text { ( }
$$

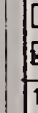




\section{Technical Data}

project location -

degree-days (heatting) -

degree-days (cocling) - -

plant load capacity

a. power $(\mathrm{MW})-\ldots$

b. heating (MW) ----

c. cooling (MW) $-\ldots--$

d. wastewater treatment-liters/day $-\ldots$

e. solid waste processing-kilograms/day _ _ -

f. potable water-liters/day _ _ _ - _ -

heat to power ratio (average expected)

14. Other Related Projects (Titles)

The overall study uses the results obtained in the four planning studies ET 5073,

ET 5074, ET 5075, ET 5076 and extrapolates them to the whole Federa1 Republic.

15. Additional space for Purpose of Project

16. Additional space for Status and Results

The study is available from AGFW (See Box 4). 
Identification No

(Secretariat Use On/y)

3-691DE- 51

\section{PROJECT SUMMARY FORM}

1. Title of Project (Otficial Title)

Project study on long-distance heat supply from heating power stations in the Mannheim-Ludwigshafen Heidelberg area (ET 5073)

3. Performing Organization (Complete Mailing Address)

$\mathrm{KA}-\mathrm{Planung} \mathrm{GmbH}$

Im Breitspiel 7

D-6900 Heidelberg

Federa1 Republic of Germany

2. Date (Form Completed)

Feb. 28, 1976

4 Principal Investigator (Name and Complete Mailing Address)

Dip1.-Ing.Blattner

$\mathrm{KA}-\mathrm{Pl}$ lanung $\mathrm{GmbH}$

Im Breitspie1 7

D-6900 Heidelberg

Federa1 Republic of Germany

5. Supporting Organization (Complete Mailing Address and Name of

6. Duration of Investigation (Beginning and ending)

Contact)

PLE/KFA Juelich

Dr. Plantikow

Postfach 1913

D-517 Juelich

Federal Republic of Germany

Sept. 1, 1974 - Feb. 28, 1976

7. Estimated Funding and Manpower (Monies and Manyears)

$742,307 .-\$$ U.S.

8. Purpose of Project (Objectives, Motivations, Approach, Plans and Expected Resu/ts)

The study of the Mannheim-Ludwigshafen-Heidelberg area is one out of four regional studies which serve as model investigations of long-distance heating systems in tegions with different structures. The choice of this area, besides being highly industrialized, is also based on its particular structure consisting of different clusters. Several nuclear power stations, either under construction of being planned are situated in the periphery surrounding this region. The aim of this study is to find out to which extent it is possible to fulfill the long-distance heating demand of the industry by the nuclear power stations. To this purpose, an economically optimum design of a long-distance heating network is to be developed based on an accurately determined heat requirement. The existing long-distance heating network will form an integral part of the projected planning.

Use Box No. 15 if additional space is needed

9. Status and Results

The chief task was to $f$ ind out and analyse the heat requirements of different groups of consumers and to forecast the economic development up to 1990 . The result shows that in the Mannheim-Ludwigshafen-Heidelberg area a connected 1oad of approx. 2800 $\mathrm{MJ} / \mathrm{s}$ for room heating purposes and about $980 \mathrm{MJ} / \mathrm{s}$ for industrial requirements (i.e. $37 \%$ and $60 \%$ resp. of the total heat demand) can be supplied by a nuclear district heating power station. $40 \%$ of the industrial heat requirements can be met by hot water and $60 \%$ in form of steam. A comprehensive concept of a regional district heating system has been established. Moreover all necessary installations for the generaThis project is: $\square$ planned $\square$ in-progress a completed Use Box No. 16 if additional space is needed

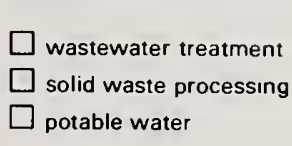

potable water
11. Type of Project

$\square$ public $\square$ private

区 cooperatıve 
13 Technical Data

project location

degree-days (hesting) -

degree-days (cocling) - -

energy source

expected payback period

plant load capacity

a. power $(\mathrm{MW})-\ldots$

b. heating (MW) - $\ldots$

Type and size of user

c cooling (MW) - $\ldots$

a. residential (dwelling units)

b residential (square area- $\mathrm{m}^{2}$ )

c. commercial (square area- $\mathrm{m}^{2}$ )

d. wastewater treatment-liters/day _ _ - -

d industrial (thermal + elec.-MW)

e. solid waste processing-kilograms/day _ _ -

f. potable water-liters/day $-\ldots-\ldots-\ldots$

heat to power ratio (average expected)

14. Other Related Projects (Titles)

This study is to be viewed as being interested with four other studies, ET 5074, ET 5075, ET 5076, and with general study ET 5072 on long-distance heating.

15. Additional space for Purpose of Project

16. Additional space for Status and Results

tion and distribution systems into account. All calculations for predetermining the investment costs were based on this design. Profitability studies and evaluation covering the ecological effects were made in 1976. From an estimated total investment of 1000 million DM for heat generation, transport and distribution, it became obvious that the costs for supplying heating water to individual consumers lie within reasonable limits, whereas the costs for supplying steam to industrial enterprises approach to margin of profitability which is mainly due to the already existing private energy generation facilities in industry.

The study is available from AGFW (See Box 4). 
Identification No

(Secretariat Use Only)

\section{PROJECT SUMIMARY FORM}

1. Title of Project (Otficral Tit/e)

Planning and design work for demonstrating interconnection 2. Date (Form Completed) networks for long-distance heat supply in the Oberhausen area (ET 5074)

3. Performing Organization (Complete Mailing Address)

Energieversorgung Oberhausen (EVO)

Postfach $400420 / 40$ und 60

D-42 Oberhausen

Federal Republic of Germany

Feb. 28, 1976

5. Supporting Organization (Complete Marling Address and Name of Contact)

PLE/KFA Juelich

Dr. Plantikow

Postfach 1913

D-517 Juelich

Federal Republic of Germany

4 Principal Investigator (Name and Complete Mailing Address)

Dip1.-Ing.G.Deuster

address see 3

8. Purpose of Project (Objectives, Motivations, Approach, Plans and Expected Results)

The objective of this design study is to investigate the demand and the supply of long-distance heating for the area of the western Ruhf district. This area, which incorporates the cities of Oberhausen, Muhlheim, and Dinslaken is densely populated and industrialized. This study is to be considered in conjunction with four further studies which will yield information on the long-distance heating demand in model areas of different structure. A subject of this study, in particular, will also be the tiein of a high temperature reactor at a later date. The existing network will be included in the design. The four regional studies will then provide the basis for the 5 th study which will cover the demand for long-distance heating in the Federal Republic.

Use Box No. 15 if additional space is needed

9. Status and Results

The results of the study for the design of an integrated energy supply system within the area of Oberhausen/Western Ruhr district have shown thit the potential for a large district heating system exists in the area investigated. When existing district heat networks expand independently in the next ten years, then high connection costs can be expected. This makes the incorporation of heat from a large, nearby, power station significant. However, the study has shown that the utilization of waste heat form large power stations has its price; with the desired decrease in thermal emission

This project is: $\square$ planned $\square$ in-progress $\square$ completed

Use Box No. 16 if additional space is needed

10. Utility Services

区 electrical power

space heating

$\square$ wastewater treatment

$\square$ space cooling

$\square$ solıd waste processing

$\square$ potable water

Project

[x] potable hot water

11 Type of Project
$\square$ public $\square$ private
$\square$ cooperative

12. Exchange of data 


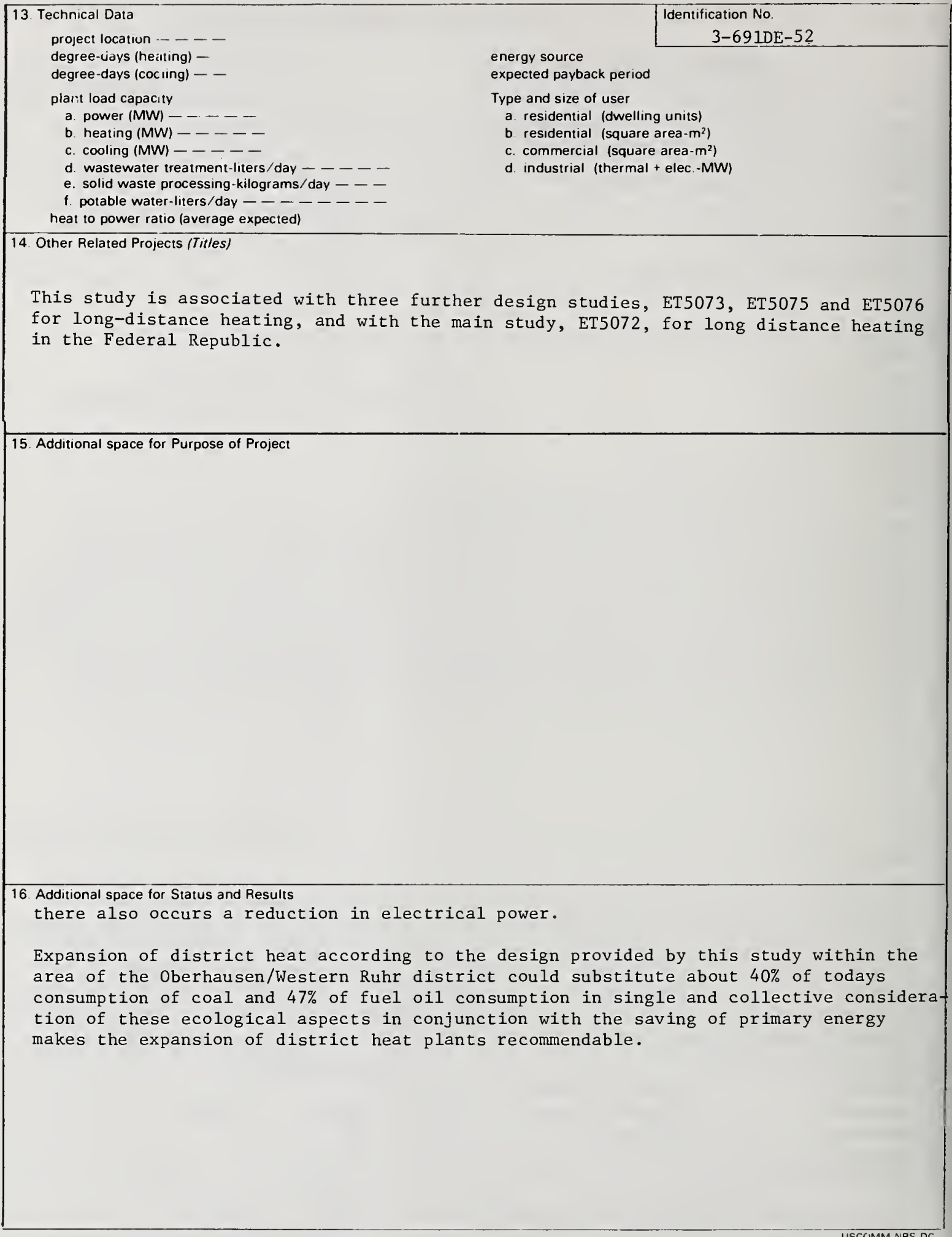


NBS-1075

(2.77)
U.S. DEPARTMENT OF COMMERCE

NATIONAL BUREAU OF STANOARDS
Identification No

(Secretariat Use On/y)

\section{PROJECT SUMMARY FORM}

1. Title of Project (Official Title)

Study of the long-distance heat-supply system in the

Koblenz-Bonn-Bad Godesberg-Koln area (ET5075)
3. Performing Organization (Complete Mailing Address)

Wibera $A G$

Achenbachstr. 43

Postfach 8640

D-4000 Dusseldorf 1

Federa1 Republic of Germany
4 Principal Investigator (Name and Complete Mailing Address) Dip 1.-Ing.E.Orth

Wibera AG

Achenbachstr . 43

Postfach $86 \quad 40$

D-4000 Dusseldorf 1

Federal Republic of Germany

6 Duration of Investigation (Beginning and ending)

Sept. 1, 1974 - Feb. 28, 1976

7. Estimated Funding and Manpower (Monies and Manyears)

$787,815 .-\$$ U.S.

D-5170 Juelich

Federal Republic of Germany

8. Purpose of Project (Objectives, Motivations, Approach, Plans and Expected Resu/ts)

In the study, the demand for long-distance heating of the Koln/Bonn/Bad Godesberg/

Koblenz region is to be investigated on the assumption that the nuclear power station now under construction in Muhlheim-Karlich near Koblenz may also be used for the longdistance heating supply. The essential question is whether it is economical to transport thermal energy over a large distance and through a region with low heat requirements in order to utilize it later on for heat supply in congested areas. This study is one of four regional studies in which certain selected regions of different structure are investigated as to their demand for district heating. These four studies are the basis for the investigations of the heat requirements in the German Federa1 Republic. 
b heatıng (MW) - - - -

c. cooling (MW) - - - -

d. wastewater treatment-liters/day - _ - -

e. Solid waste processing-kılograms/day --

f. potable water-liters/day $-\ldots-\ldots$ heat to power ratio (average expected)

14. Other Related Projects (Titles)

Type and size of user

a residential (dwelling units)

b. residential (square area- $\mathrm{m}^{2}$ )

c. commercial (square area- $\mathrm{m}^{2}$ )

d industrial (thermal + elec-MW)

16. Additional space for Status and Results

The study is available from WIBERA (See box 4) 
Identification No

(Secretariat Use Only)

\section{PROJECT SUMMARY FORM}

1. Title of Project (Officia/ Tit/e)

Project study for the conurbation of Berlin to ascertain the possibilities of saving energy and substituting nuclear energy for fossil fuels. (ET 5076)

3. Performing Organization (Complete Mailing Address)

Energieanlagen Berlin GMBH

Lutzowplatz 11-13

D-1000 Berlin 30

Federa1 Republic of Germany

$$
\text { 3-691DE- } 54
$$

2. Date (Form Completed)

March 31, 1976

\section{Supporting Organization (Complete Mailing Address and Name of Contact) \\ PLE/KFA Juelich \\ Dr. Plantikow \\ Postfach 1913 \\ D-5170 Juelich \\ Federal Republic of Germany}

4. Principal Investigator (Name and Complete Mailing Address) Ing.grad.P.Schade

Energieanlagen Berlin GmbH

Lutzowp latz 11-13

D-1000 Berlin 30

Federal Republic of Germany

8. Purpose of Project (Objectives, Motivations, Approach, Plans and Expected Results)

The project study Berlin forms part of an overall study prepared by the Arbeitsgemeinschaft Fernwarme e.v. (district heat association). This study is conducted to ascertain the existing heat requirement potential to be covered by district heat. The section concerning Berlin deals with the particular situation (insularity) of this town. Investigations are to refer to possibilities of extending the Berlin town heating system by an optimal utilization of waste heat emitted from a nuclear power plant, in conjunction with a description of the economic aspects involved. For this purpose, an exact specification of the heat density and heat requirement must be established. The study will also comprise the aspects of energy conservation and improve air quality in densely populated areas in connection with the use of district heat.

Use Box No. 15 if additional space is needed

9. Status and Results

The project was completed on $5 / 31 / 76$

.

This project is: $\square$ planned $\square$ in-progress completed Use Box No. 16 if additional space is needed

Oct. 1, 1974 - March 31, 1976

1, 117,684. $-\$$ U.S. 
project location -- - - -

degree-days (heatting) -

energy source

degree-days (coclıng) - -

expected payback period

plant load capacity

a. power $(M W)-\cdots--$

Type and size of user

b. heating (MW) -----

a. residential (dwelling units)

c. cooling (MW) -----

b. residential (square area- $m^{2}$ )

c. commercial (square area- $m^{2}$ )

d. wastewater treatment-liters/day -----

d. industrial (thermal + elec.-MW)

e. Solid waste processing-kilograms/day - -

f. potable water-liters/day $---\ldots---$

heat to power ratio (average expected)

14. Other Related Projects (Titles)

The project study must be seen in connection with three other: project studies, ET5073, ET5074, ET5075, and the results will be used in the district heating study, ET5072 for the Federal Republic of Germany.

15. Additional space for Purpose of Project

16. Additional space for Status and Results

The study has been completed and is available from EAB Berlin (See box 4). 
1. Title of Project (Official Tit/e) AGROTHERM

3. Performing Organization (Complete Mailing Address)

August Thyssen-Hutte AG

Kaiser Wilhelm Str. 100

D-41 Duisburg-Hamborn

Federal Republic of Germany
4. Principal Investigator (Name and Complete Mailing Address)

Dir. Herbert Luckow

address see 3

\section{Supporting Organization (Complete Mailing Address and Name of} Contact)

PLE/KFA Juelich

Dr. Plantikow

Postfach 1913

D-517 Juelich

Federal Republic of Germany

6. Duration of Investigation (Beginning and ending)

Jan. 15, 1975 - Dec. 31, 1978

7. Estimated Funding and Manpower (Monies and Manyears)

4.7 Million \$ U.S.

\section{Purpose of Project (Jbjectives. Motivations, Approach. Plans and Expected Resu/ts)}

In an ecologically beneficial way Agrotherm is meant to dissipate the waste heat from power plants by means of a pipeline system buried in the ground. The result thereot will be:

- greater independance for the selection of the location of power plants.

- improved efficiency of power plants as compared with necessarily required dry cooling towers

- increased productivity in agriculture and possible cultivation of plants previously not cultivated here.

\section{Status and Results}

The pilot installation in Neurath was set in operation on May 3, 1976 those at

Auweiler and Riswick on June 25/26, 1976, and the one in Gundremmingen not until November 10, 1976 because of a close-down of the power plant.

The experience gathered so far in the building for this installation confirms that with today's state of technology:

(Continued)

This project is: $\square$ planned $\square$ in-progress $\square$ completed

Use Box No. 16 if additional space is needed

$$
\begin{aligned}
& 10 \\
& 6 \\
& \square \\
& \square \\
& \square \\
& \hline 12
\end{aligned}
$$




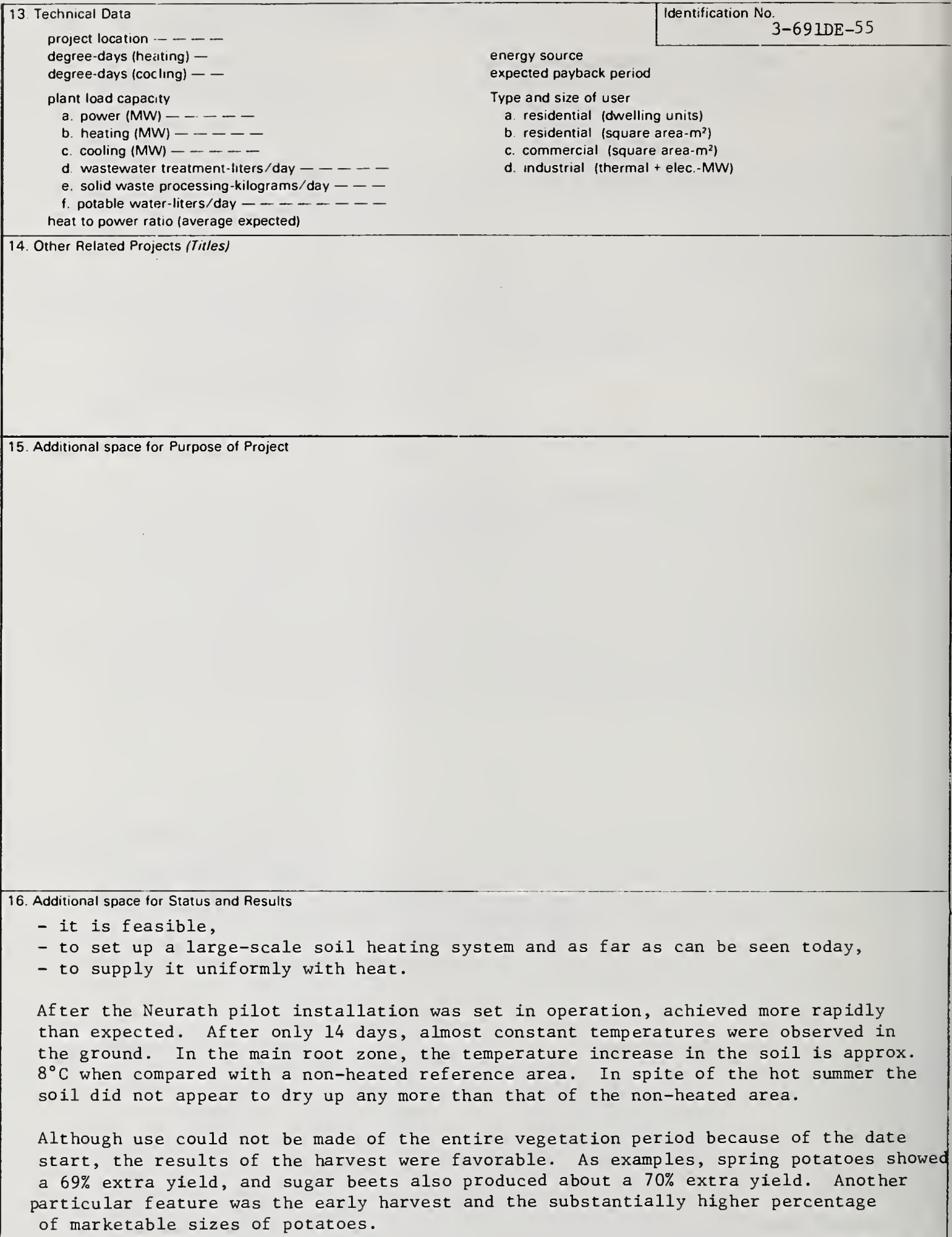




\begin{tabular}{lr}
\hline NBS-1075 \\
(2.77)
\end{tabular}

PROJECT SUMMAFY FORM

1. Title of Project (Otficial Title)
Identification No

(Secretariat Use On/y)

2. Date (Form Completed)

\section{$1 / 20 / 77$}

3. Performing Organization (Complete Mailing Address)

4. Principal Investigator (Name and Complete Mailing Address)

TECHNIP

232, Avenue Napoleon Bonaparte

92500 - Rueil-Malmaison

France

5. Supporting Organization (Complete Mailing Address and Name of Contact)

French environment Quality of Life Ministry

J.M. Bourguet, Manager

TECHNIP Power Division

TECHNIP

232, Avenue Napoleon Bonaparte

92500 - Rueil-Malmaison France

6. Duration of Investıgation (Beginning and ending)

\section{7 months}

7. Estimated Funding and Manpower (Monies and Manyears)

7000 hours

8. Purpose of Project (Objectives, Motivations, Approach, Plans and Expected Resu/ts)

Simultaneous production of heat and electrical power from nuclear plants, in 1985,

for 3 typical sites: - Lyon ( 1.087 .384 people)

- Nantes/Saint-Nazaire (634.153 people)

- Colmar/Mulhouse (302.160 people)

Statistical study about heat consumption at temperatures lower than $100^{\circ} \mathrm{C}$.

Economical study about production, transport and distribution

Pollution reduction.

Use Box No. 15 if additional space is needed

9. Status and Results

This project is: $\square$ planned $\square$ in-progress $\square$ completed 10. Utility Services

electrical power

团 space heating

$\square$ space cooling

$\square$ potable hot water

12. Exchange of data

Will data be available from this project that will be shared with others?

$\square$ wastewater treatment

$\square$ solid waste processing

$\square$ potable water

Use Box No. 16 if additional space is needed

11. Type of Project

[.] public

private

cooperative

$\otimes$ Yes

No 


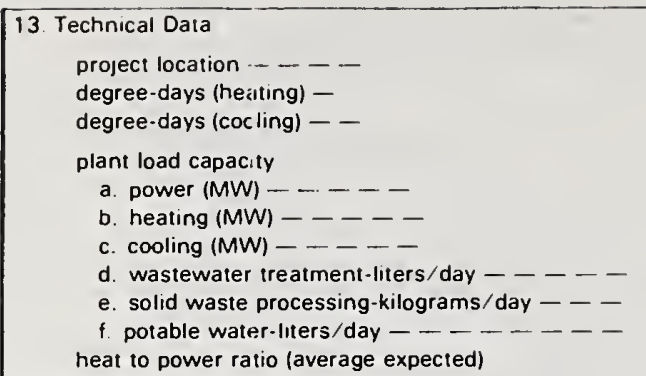

14. Other Related Projects (Tritles)

15. Additional space for Purpose of Project

16. Additional space for Status and Results 
NBS-1075

U.S. DEPARTMENT OF COMMERCE

NATIONAL BUREAU OF STANDARDS

Identification No

(Secretariat Use Only)

PROJECT SUMMARY FORM

1. Title of Project (Otficial Tit/e) 3-801US-57

2. Date (Form Completed)

Production of Potable Water from Wastewater $11 / 23 / 76$

3. Performing Organization (Complete Mailing Address)

4. Principal Investigator (Name and Complete Mailing Address)

U.S. EPA - OR\&D, MERL, WRD

Cincinnati, Ohio 45268

U.S.A.

Howard P. Warner

U.S. EPA-DC Pilot Plant

Washington, D.C. 20032 , U.S.A.

Mailing Address (see box 5)

5. Supporting Organization /Complete Mailing Address and Name of Contact)

6. Duration of Investigation (Beginning and ending)

Dr. Irwin J. Kugelman

U.S. EPA

OR\&D, MERL, WRD

Cincinnati, Ohio 45268

U.S.A.

$$
10 / 74 \text { to } 6 / 77
$$

7. Estimated Funding and Manpower (Monies and Manyears)

$\$ 500,00010$ man years

8. Purpose of Project (Jbjectives, Motivations, Approach, Plans and Expected Results)

Raw domestic wastewater is being treated by 6 processes in series in a $200 \mathrm{~m} / \mathrm{d}$ pilot plant to determine if potable quality water can be consistently achieved. Analyse for all drinking water quality standards are being conducted as well as for trace organics, haloforms, and specific pathogens.

Use Box No. 15 if additıonal space is needed

9. Status and Results

Experimental work complete $10 / 76$ - Final report $6 / 77$

Preliminary data evaluation - finished $\mathrm{H}_{2} \mathrm{O}$ meets all drinking water quality standards.

This project is: $\square$ planned $\square$ in-progress $\square$ completed Use Box No. 16 if additional space is needed

$$
\begin{aligned}
& \text { Th } \\
& \hline 10 \\
& \hline 12 \\
& \hline 8 \\
& \hline 12 \\
& \hline
\end{aligned}
$$




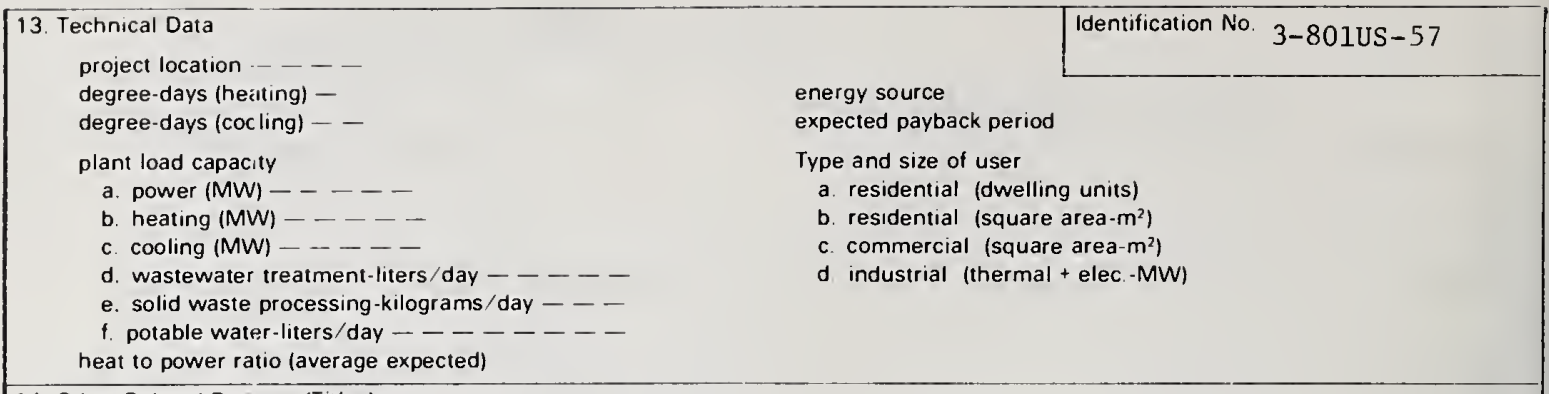

14. Other Related Projects (Titles)

15. Additional space for Purpose of Project

16. Additional space for Status and Results 


\begin{tabular}{|c|c|c|}
\hline \multicolumn{2}{|l|}{ PROJECT SUMMARY FORM } & $\begin{array}{l}\text { Identification No. } \\
\text { (Secretariat Use On/v) } \\
3-803 \text { US - } 58\end{array}$ \\
\hline $\begin{array}{l}\text { 1. Title of Project (Official Title) } \\
\text { Evaluation of Full Scale Wastewater Reuse } \\
\text { Domestic Groundwater Replenishment }\end{array}$ & System for & $\begin{array}{c}2 \text { Date (Form Completed) } \\
11 / 23 / 76\end{array}$ \\
\hline $\begin{array}{l}\text { 3. Performing Organization (Complete Mailing Address) } \\
\text { Orange County Water District } \\
\text { P.0. Box } 8300 \\
\text { Fountain Valley, California } 92708 \\
\text { U.S.A. }\end{array}$ & $\begin{array}{l}4 \text { Principal Investigator } 1 \mathrm{~A} \\
\text { David Argo } \\
\text { Orarge Count } \\
\text { P.O. Box } 830 \\
\text { Fountain Val } \\
\text { U.S.A. }\end{array}$ & $\begin{array}{l}\text { lame and Complete Mailing Address) } \\
\text { Water District } \\
\text { ley, California } 92708\end{array}$ \\
\hline $\begin{array}{l}\text { 5. Supporting Organization (Complete Mailing Address and Name of } \\
\text { Contact) } \\
\text { John English } \\
\text { U.S. EPA, MERL, WRD } \\
\text { Cincinnati, Ohil } 45268 \\
\text { U.S.A. }\end{array}$ & $\begin{array}{l}\text { 6. Duration of Investigatio } \\
1 / 76 \text { to } 6 / 79 \\
\text { 7. Estimated Funding and } \\
\$ 486,000 \text { EPA s. }\end{array}$ & $\begin{array}{l}\text { in (Begınning and ending) } \\
\text { Manpower (Monies and Manvears) } \\
\text { hare } \$ 95,000\end{array}$ \\
\hline $\begin{array}{l}\text { 8. Purpose of Project (Jbjectives, Motivations, Approach, Plans and } \\
\text { The objectives of this study are to evalu } \\
\text { (1) the reliability and effluent variabi } \\
\text { ment (AWT) system producing a water } \\
\text { water replenishment and prevention } \\
\text { (2) the quality of the effluent with reg } \\
\text { monitoring of trace materials (chemi } \\
\text { Particular emphasis will be placed or } \\
\text { mass spectrophotometric procedures. }\end{array}$ & $\begin{array}{l}\text { ected Results) } \\
\text { on a full plan } \\
\text { roaching potable } \\
\text { eawater intrusio } \\
\text { to the identifi } \\
\text {, physical and b } \\
\text { he characterizat. }\end{array}$ & $\begin{array}{l}\text { t-scale basis: } \\
\text { vanced wastewater treat- } \\
\text { quality for use in ground- } \\
\text {, and } \\
\text { cation, measurement, and } \\
\text { iological) and residues. } \\
\text { ion chromatographic/ }\end{array}$ \\
\hline
\end{tabular}

Use Box No. 15 if additional space is needed

9. Status and Results

Treatment plant operation generally successful. Injection of wastewater started 10/76. Analytical work just beginning.

This project is: $\square$ planned in -progress $\square$ completed Use Box No. 16 if additional space is needed

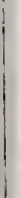

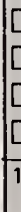

Q7 wastewater treatment

$\square$ solid waste processing

Ex potable water

$\square$ space cooling

$\square$ potable hot water

12. Exchange of data

Will data be available from this project that will be shared with others?

Yes No 


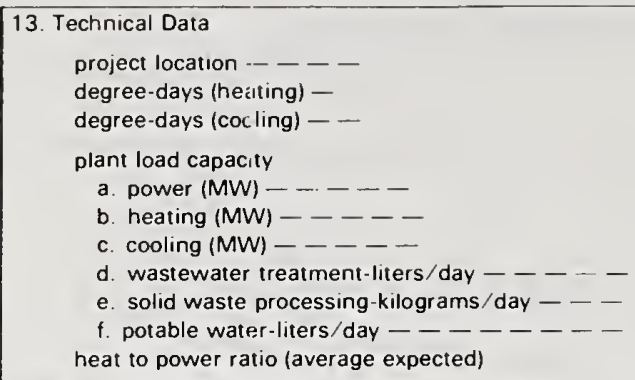

14. Other Related Projects (Tit/es)

15. Additional space for Purpose of Project

16. Additional space for Status and Results 
NBS-1075

(2-77)
U.S DEPARTMENT OF COMMERCE NATIONAL BUREAU OF STANDARDS
Identification No

(Secretariat Use Only)

\section{PROJECT SUMMARY FORM}

1. Title of Project (Official Title)

Total Energy Plant for Sewage Treatment 'sGRAVENZANDE 3-821NL-59

2 Date (Form Completed)

$$
3 / 14 / 77
$$

3. Performing Organization (Complete Mailing Address)

Raadgevend Technics Adviesbureau Van Heugten B.V.

St. Annastraat 143-147

NIJMEGEN, The Netherlands
4 Principal Investigator (Name and Complete Mailing Address)

Ir. P.H.H.Leijendekkers

Raadgevend Technics Adviesbureau

Van Heugten B.V.

St. Annastraat 143-147

NIJMEGEN, The Netherlands

6. Duration of Investıgatıon (Beginning and ending)

$$
\mathrm{N} / \mathrm{A}
$$

7. Estimated Funding and Manpower (Monies and Manyears)

土 Dfl. I,200,000

8. Purpose of Project / Objectives, Motivations, Approach, Plans and Expected Results

Objective: To provide an effective way on sewage treatment before release

Motivation: To use the gas released by sludge fermentation on a most efficient way for sewage treatment.

\section{Approach:}

- 3 gas engine driven electric generators of which one is spare

- Heat recovery from jacket cooling water primarily for sludge heating

(ebulient cooling)

- Compressors and pumps electrically driven

- Grid connection ( $\max$. capacity $8 \mathrm{~kW}$ )

- Plant can be switched over automatically from sewage gas to natural gas

Use Box No. 15 if additional space is needed

\section{Status and Results}

The plant is not yet in operation

The sewage gas delivers approx. $60 \%$ of the primary energy consumption of the engines. 
13. Technical Data

$$
\text { project location - }
$$

degree-days (heating) -

degree-days (cocling) - -

plant load capacity

a power (MWH+ $2 \mathrm{Q} \mathrm{kW}$

b. heatıng (MW) -

c. cooling (MW) $--\ldots$

d. wastewater treatment-liters/day _ _ _ -

e. solid waste processıng-kılograms/day $-\ldots$

f. potable water-liters/day -------heat to power ratio (average expected)

14. Other Related Projects (Titles)

\section{S'GRAVENZANDE}

energy source sewage gas +
expected payback period
Type and size of user
a residential (dwelling units)
b residential (square area- $\mathrm{m}^{2}$ )
c. commercial (square area- $\mathrm{m}^{2}$ )
d industrial (thermal $+\mathrm{elec}-\mathrm{MW}$ )




\begin{tabular}{|c|c|c|}
\hline \multicolumn{2}{|c|}{$\begin{array}{l}\text { U.S. DEPARTMENT OF COMMERCE } \\
\text { NATIONAL BUREAL OF STANDARDS } \\
\text { PROJECT SUMMARY FORM }\end{array}$} & $\begin{array}{l}\text { Identification No. } \\
\text { (Secretariat Use Only) } \\
3-82 \text { INL- } 60\end{array}$ \\
\hline \multicolumn{2}{|l|}{$\begin{array}{l}\text { 1. Title of Project (Official Title) } \\
\text { Total Energy-plant for Sewage Treatment } \\
\text { HILVERSUM }\end{array}$} & $\begin{array}{l}\text { 2. Date (Form Completed) } \\
3 / 14 / 77\end{array}$ \\
\hline $\begin{array}{l}\text { 3. Performing Organization (Complete Mailing Address) } \\
\text { DYNAF.B.V. } \\
\text { Kwakelkade 29, P. O. Box } 54 \\
\text { ALKMAAR, The Nether lands }\end{array}$ & \multicolumn{2}{|c|}{$\begin{array}{l}\text { 4. Principal Investigator (Name and Complete Mailing Address) } \\
\text { Mr. Zuurbier } \\
\text { DYNAF B.V. } \\
\text { Kwakelkade 29, P.0. Box } 54 \\
\text { ALKMAAR, The Netherlands }\end{array}$} \\
\hline $\begin{array}{l}\text { 5. Supporting Organization (Complete Mailing Address and Name of } \\
\text { Contact) } \\
\text { Mr. Hageman } \\
\text { Waterschap "Amstel en Gooiland" } \\
\text { HILVERSUM } \\
\text { The Netherlands }\end{array}$ & \multicolumn{2}{|c|}{$\begin{array}{l}\text { 6. Duration of Investigation (Beginning and ending) } \\
\text { N/A } \\
\begin{array}{l}\text { 7. Estimated Funding and Manpower (Monies and Manyears) } \\
\text { For the TE-plant } \pm \\
2 \text { man years }\end{array} \\
\begin{array}{l}2 \text { man } 1,900,000 .-- \\
\end{array}\end{array}$} \\
\hline \multicolumn{3}{|c|}{$\begin{array}{l}\text { Porpose fi. Project (Objectives. Motivations, Approach. Plans and Expected Results) } \\
\text { Motivation: To provide an effective way of sewage treatment before release } \\
\text { way for sewage treatment. } \\
\text { Approach: } \\
\text { - } 3 \text { gas engine (Waukesha VRG-3lo) driven electric generators (UNELEC, } 450 \mathrm{kVA} \text { ) } \\
\text { - Electric driven pumps and compressors } \\
\text { - Recovery of heat from engine jacket, primarily for sludge heating } \\
\text { - The plant is switched over automatically from sewage gas to natural gas in } \\
\text { case of shortage. }\end{array}$} \\
\hline
\end{tabular}

Use Box No. 15 if additional space is needed

9. Status and Results

The plant has been in operation since November 1974 with good experience

The plant operates conforming design calculations energy basis

$60 \%$ of the fuel required for plant operation is delivered by sludge fermentation.

This project is: $\square$ planned $\square$ in-progress $\square$ completed

Use Box No. 16 if additional space is needed 


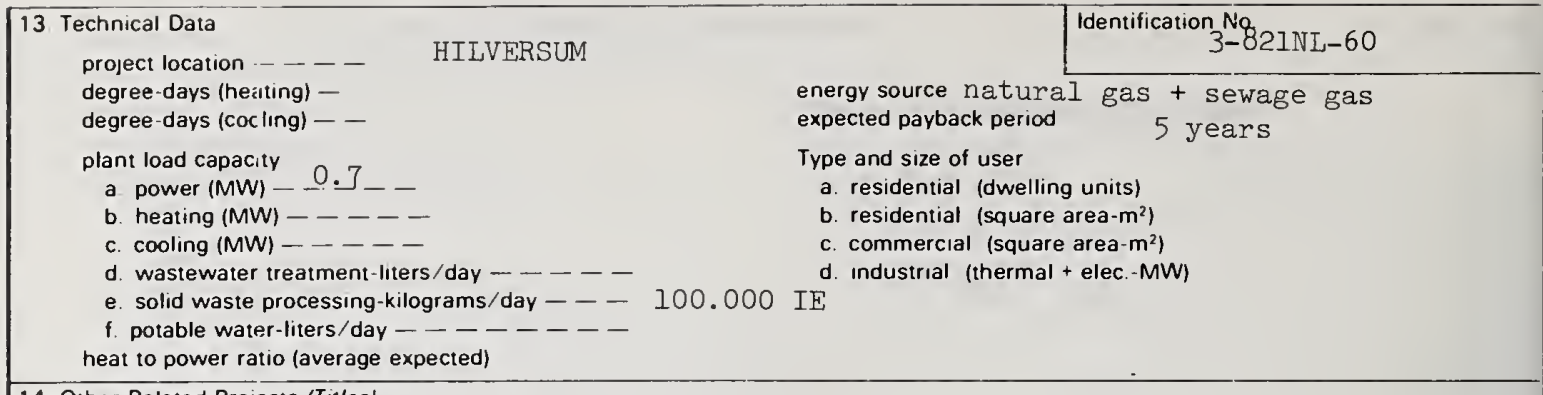

14. Other Related Projects (Titles)

15. Additional space for Purpose of Project

16. Additional space for Status and Results

Remark: IE Inhabilant equivalent 


\begin{tabular}{|l|l|}
\hline \multicolumn{1}{|c|}{ PBS-1075 } \\
(2.77)
\end{tabular}

Use Box No. 15 if additional space is needed

9. Status and Results

The plant has been in operation since August 1976

About $60 \%$ of the gas required for plant operation is delivered by sludge

fermentation

This project is: $\square$ planned $\square$ in-progress $\bigotimes$ completed

Use Box No. 16 if additional space is needed

10. Utility Services

X electrical power

$\square$ space heating

planned $\square$ in-progress $\triangle$ completed

11 Type of Project

$\square$ space cooling

$\square$ potable hot water

$\square$ wastewater treatment

$\square$ solid waste processing

$\square$ potable water

$x$ sludge heating

$\nabla$ public $\square$ private

cooperative

12. Exchange of data

Will data be available from this project that will be shared with others?

X Yes

No

Request 5 
13. Technical Data

project location - - - - NIEUWGRAAF

degree-days (heáting) -

degree-days (cocling) - -

plant load capacity

a. power $(\mathrm{MW})-0.6$

b. heating (MW) ----

c. cooling $\langle\mathrm{MW}\rangle----$

d. wastewater treatment-liters/day _ - _ - -

e. solid waste processing-kilograms/day - - -

f. potable water-liters/day -------heat to power ratio (average expected)

14. Other Related Projects (Titles)

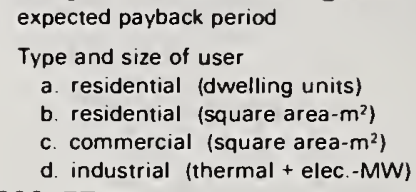
expected payback period

Type and size of user

a. residential (dwelling units)

b. residential (square area- $\mathrm{m}^{2}$ )

c. commercial (square area- $\mathrm{m}^{2}$ )

d. industrial (thermal + elec.-MW)

Identification $\mathrm{N}$

3-82INL-61

energy source natural gas + sewage gas

300, 000 IE

15. Additional space for Purpose of Project

16. Additional space for Status and Results

Remark: IE = Inhabilant Equivalent 


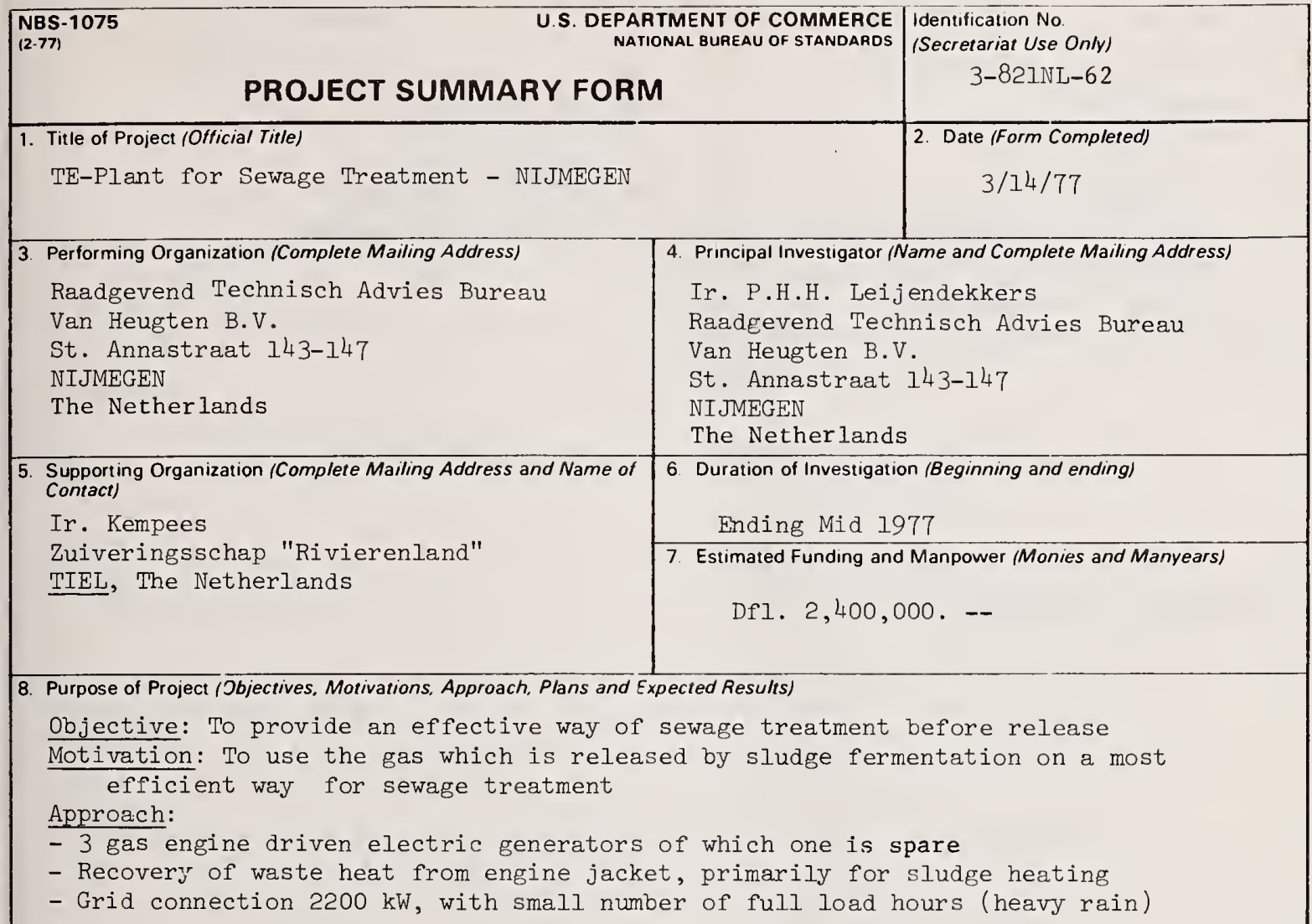

Use Box No. 15 if additional space is needed

\section{Status and Results}

The plant is presently in design

TE-plant delivering $6.8 \times 10^{6} \mathrm{kWh} / \mathrm{a}$

TE-plant consuming sewage gas energy consumption is approx. $60 \%$ of total

Grid connection delivering $2.5 \times 106 \mathrm{kWh} / \mathrm{a}$

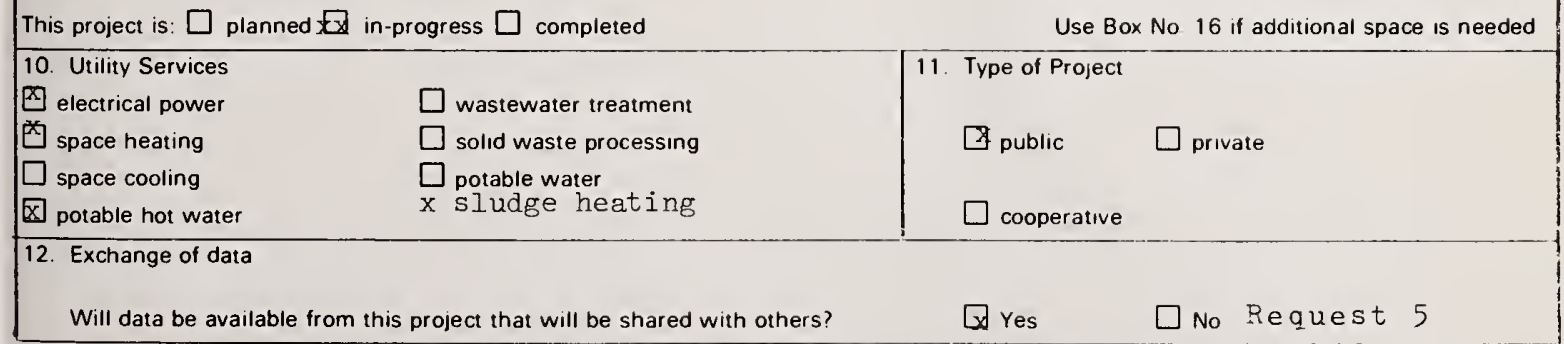




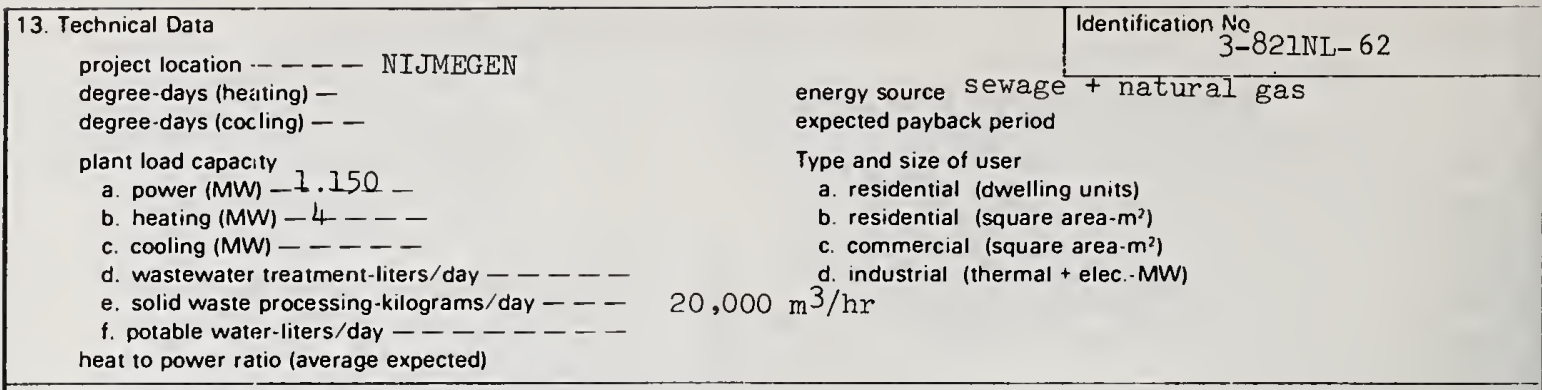

14. Other Related Projects (Titles)

15. Additional space for Purpose of Project

16. Additional space for Status and Results 
Identification No

(Secretariat Use On/y)

3-821NL- 63

\section{PROJECT SUMMARY FORM}

1. Title of Project (Official Title)

2. Date (Form Completed)

Total Energy - Plant for Sewage Treatment - RAALTE

$3 / 14 / 77$

3. Performing Organization (Comp/ere Mailing Address)

Mr. Van Holst Pelikaan

Ingenieurs Bureau

Dwars Hedrik Verhey

Laan 1914

AMERSFOORT, The Netherlands

4. Principal Investigator (Name and Complefe Mailing Address) Mr. Zuurbier

DYNAF B.V.

Kwakelkade 29, P.0. Box 54

ALKMAAR, The Netherlands

5. Supporting Organization (Complete Mailing Address and Name of Contact)

$\mathrm{Mr}$. Horning

Z.W.O

ZWOLLE

The Netherlands

6. Duration of Investigation (Beginning and ending)

$$
\mathrm{N} / \mathrm{A}
$$

7. Estimated Funding and Manpower (Monies and Manyears)

For TE-Plant \pm Dfl. 400,000.--

8. Purpose of Project (Jbjectives, Motivations, Approach, Plans and Expected Results)

Objective: To provide an effective way of sewage treatment before release

Motivation: To use the gas released by sludge fermentation on a most efficient

way for sewage treatment

Approach:

- 3 gas engine (Waukesha VRG-310) driven air compressors (Aerzener GMB 15.10)

- Heat recovery from engine jacket primarily for sludge heating

- Grid connection for electricity supply for driving pumps

- The plant is switched over automatically from sewage gas to natural gas in case of shortage

Use Box No. 15 if additional space is needed

9. Status and Results

The plant will be taken into operation March 1977

About $60 \%$ of the primary engine fuel is delivered by sewage gas

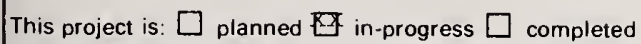

\begin{tabular}{ll}
\hline 10. Utility Services & \\
⿴囗十 Mechanical power & $\square$ wastewater treatment \\
$\square$ space heating & $\square$ solid waste processing \\
$\square$ space cooling & $\square$ potable water \\
$\square$ potable hot water & $\mathrm{x}$ sludge heating
\end{tabular}

Use Box No. 16 if additional space is needed

12. Exchange of data

Will data be available from this project that will be shared with others?

X Yes

No Request 5 


\begin{tabular}{|c|c|}
\hline $\begin{array}{l}\text { 13. Technical Data } \\
\text { project location -__ _ RALPE }\end{array}$ & $\begin{array}{l}\text { Identification No. } \\
\qquad 3-821 N L-63\end{array}$ \\
\hline $\begin{array}{l}\text { degree-days (heiting) - } \\
\text { degree-days (cocling) - }\end{array}$ & $\begin{array}{l}\text { energy source sewage gas + natural gas } \\
\text { expected payback period }\end{array}$ \\
\hline $\begin{array}{l}\text { plant load capacity } \\
\text { a. power (MW) } 75 \text { BHI / unit } \\
\text { b. heating (MW) }--- \\
\text { c. cooling (MW) }---- \\
\text { d. wastewater treatment-liters/day }-\ldots--- \\
\text { e. solid waste processing-kilograms/day }--- \\
\text { f. potable water-liters/day }------ \\
\text { heat to power ratio (average expected) }\end{array}$ & $\begin{array}{l}\text { Type and size of user } \\
\text { a. residential (dwelling units) } \\
\text { b. residential (square area- } \mathrm{m}^{2} \text { ) } \\
\text { c. commercial (square area- } \mathrm{m}^{2} \text { ) } \\
\text { d. industrial (thermal + elec.-MW) }\end{array}$ \\
\hline
\end{tabular}

14. Other Related Projects (Tit/es)

15. Additional space for Purpose of Project 
NBS-1075

(2.77)
U.S DEPARTMENT OF COMMERCE Identification No.

NATIONAI UUREAU OF STANDARDS

(Secretarlat Use On/y)
PROJECT SUMMARY FORM

1. Title of Project (Official Tit/e)

CANWEL (Canadian Water Energy Loop)
3-831CA- 64

2. Date (Form Completed)

August 12, 1977
3 Performing Organization (Complete Mailing Address)

Centra1 Mortgage and Housing Corporation

Ottawa, Ontario

Canada
4 Principal Investigator (Name and Complete Mailing Address)

David Yuille

Project Coordinator

CMHC National office

Ottawa, Ontario

K1A OP7

Canada

6. Duration of Investigation (Beginning and ending)

$$
1972 \text { - } 1979
$$

Ontario Research Foundation

Mississauga, Ontario

Canada
7. Estımated Funding and Manpower (Monies and Manyears)

To date $\$ 5$ million + to completion

$\$ 1$ million (M/Y - ?)

8. Purpose of Project (Jbjectives, Motivations, Approach, Plans and Expected Resu/ts)

1. To develop simple, reliable, high perfornance sewage treatment system producing effluent equating municipal raw water quality.

2. To purify effluent from 1. above, to drinking water quality.

3. To develop efficient automatic system for incineration of solid waste with high-rate energy recovery.

4. To integrate these developments into a partially closed loop system.

\section{Status and Results}

1. Prototype plants serving 500 people now in operation or under construction. Results, so far, are conforming to expectations.

This project is $\square$ planned $\mathbb{X}$ in-progress $\square$ completed

\section{Utility Services}

$\square$ electrical power

$\square$ space heatıng

$\square$ space cooling

potable hot water

12. Exchange of data

$\checkmark$ potable water
Use Box No. 16 if additional space is needed

wastewater treatment

solid waste processing
Project

$\bigotimes$ public $\square$ private

cooperatıve 


\begin{tabular}{|c|c|}
\hline $\begin{array}{l}13 \text { Technical Data } \\
\text { project location } \ldots . . \ldots\end{array}$ & $\begin{array}{l}\text { Identification } \mathrm{No}_{\mathrm{o}} \\
3-831 \mathrm{CA}-64\end{array}$ \\
\hline $\begin{array}{l}\text { project location - } \\
\text { degree-days (heatting) - } \\
\text { degree-days (cocling) - - }\end{array}$ & $\begin{array}{l}\text { energy source } \\
\text { expected payback period }\end{array}$ \\
\hline 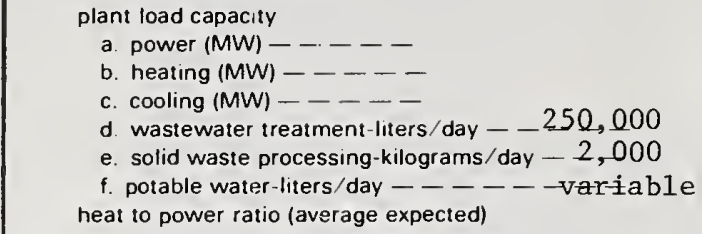 & $\begin{array}{l}\text { Type and size of user } \\
\text { a. residential (dwelling units) } \\
\text { b. residential (square area- } \mathrm{m}^{2} \text { ) variable } \\
\text { c. commercial (square area-m } \mathrm{m}^{2} \text { ) } \\
\text { d. Industrial (thermal + elec.-MW) }\end{array}$ \\
\hline 14. Other Related Projects (Titles) & \\
\hline $\begin{array}{l}\text { 5. Additional space for Purpose of Project } \\
\text { The purpose of the project is to devel } \\
\text { no burden on the environment and conse } \\
\text { water to a re-usable condition and the } \\
\text { necessary activity in the urbanized so } \\
\text { those facilities exists today wherever } \\
\text { environment is overloaded with contami } \\
\text { energy and to shift the demand from no } \\
\text { sources. These developments are direc } \\
\text { size projects. }\end{array}$ & $\begin{array}{l}\text { ew waste management technology that places } \\
\text { water and energy. The renovation of waste } \\
\text { overy of energy from solid waste will be a } \\
\text { y of the } 21 \text { st century. The need for } \\
\text { ter is in limited supply or where the } \\
\text { s. There is a universal need to conserve } \\
\text { newable oil and gas to alternative energy } \\
\text { initially at serving small and intermediate }\end{array}$ \\
\hline
\end{tabular}

16. Additional space for Status and Results

The project has moved successfully through several stages: - concept development, pilot plants, optimization and integration studies, experimental demonstration, and prototype plants. At all stages, performance has been successfully held in line with required criteria. The prospects for success are excellent. Project does not appear to have serious competition. Patents are being applied for in 8 countries. 


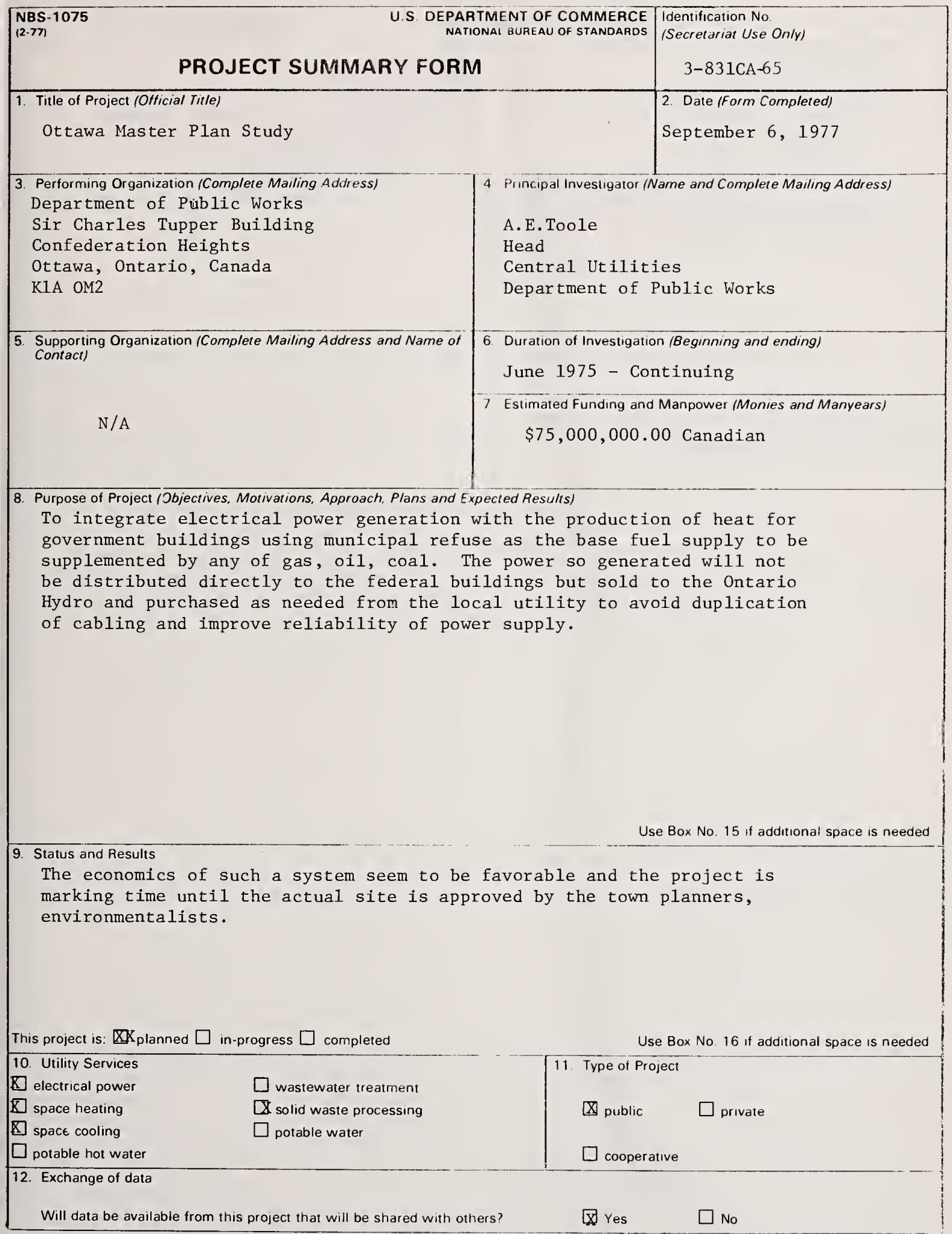




\section{Technical Data}

project location -- - - -

degree-days (heaıting) -

degree-days (cocling) - -

plant load capacity

a power (MW) - $20-30$

b. heating $(\mathrm{MW})--300-$

c. cooling $(\mathrm{MW})--15 \theta-$

d. wastewater treatment-liters/day - - - -

e. solid waste processing-kilograms/day $--1,000,000$

f. potable water-liters/day $--\ldots-1--$

heat to power ratio (average expected) not determined

14. Other Related Projects (Titles)
Identification No

3-831CA- 65

energy source expected payback period

Type and size of user

a. residential (dwelling units) poss. 100,000

b residential (square area- $\mathrm{m}^{2}$ )

c. commercial (square area- $\mathrm{m}^{2}$ )

$2,000,000$

d. Industrial (thermal + elec.-MW)

15. Additional space for Purpose of Project

16. Additional space for Status and Results 


\begin{tabular}{|c|c|c|}
\hline \multicolumn{2}{|c|}{$\begin{array}{l}\text { U.S. DEPARTMENT OF COMMERCE } \\
\text { NATIONAL GUREAU DF STANDAROS } \\
\text { PROJECT SUMMARY FORM }\end{array}$} & $\begin{array}{l}\text { Identification No } \\
\text { (Secretarıat Use On/v) } \\
3-831 \text { US- } 66\end{array}$ \\
\hline $\begin{array}{l}\text { 1. Title of Project (Official Title) } \\
\text { Waste-as-Fuels Program }\end{array}$ & & $\begin{array}{l}\text { 2. Date (Form Completed) } \\
11 / 24 / 76\end{array}$ \\
\hline $\begin{array}{l}\text { 3. Performing Organization (Complete Mailing Address) } \\
\qquad N / A\end{array}$ & \multicolumn{2}{|c|}{ 4. Principal Investigator (Name and Complete Mailing Address) } \\
\hline $\begin{array}{l}\text { 5. Supporting Organization (Complete Mailing Address and Name of } \\
\text { Contact) } \\
\text { U.S.Environmental Protection Agency } \\
\text { Office of Research and Development } \\
\text { Office of Energy, Mining \& Industry } \\
\text { Washington, D-C. } 20460 \\
\text { ATTN: David Berg }\end{array}$ & \multicolumn{2}{|c|}{$\begin{array}{l}\text { 6. Duration of Investigation (Beginning and ending) } \\
\qquad \mathrm{N} / \mathrm{A} \\
\text { 7. Estimated Funding and Manpower (Monies and Manyears) } \\
\text { N/A }\end{array}$} \\
\hline
\end{tabular}

8. Purpose of Project (Jbjectives, Motivations, Approach, Plans and Expected Results)

Research and development activities supporting the technical, environmental, and economic investigations of the use of wastes as fuels including: preparation of fuels and feedstocks; co-incineration of sewage sludge using municipal refuse as and production of solid, liquid, and gaseous fuels by pyrolysis. For project details refer to:

1. EPA Wastes As Fuels Research, Development, and Demonstration Program Plan April 1975 


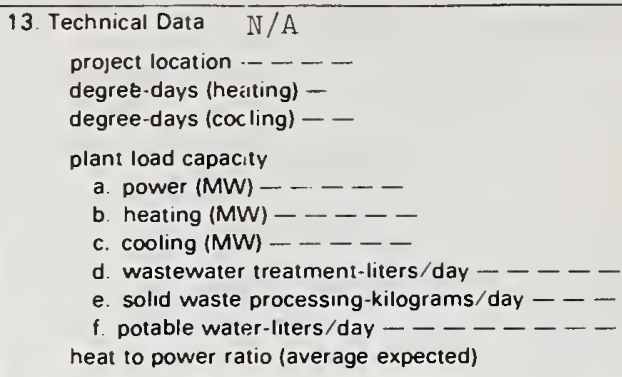

14. Other Related Projects (Tit/es)

$$
\mathrm{N} / \mathrm{A}
$$

15. Additional space for Purpose of Project

\section{energy source}

expected payback period

Type and size of user
a residential (dwelling units)
b. residential (square area- $\mathrm{m}^{2}$ )
c. commercial (square area- $\mathrm{m}^{2}$ )
d. industrial (thermal + elec.-MW) 
NBS-1075

US. DEPARTMENT OF COMMERCE Identification No

NATIONAL BUREAU OF STANDARDS

(Secretariat Use On/y)

PROJECT SUMMARY FORM

3-83IUS-67

1. Title of Project (Official Title)

2. Date (Form Completed)

Plant-Scale study of Combined Incineration of Sewage Sludge with Coal \& Solid Waste

$5 / 12 / 77$

3. Performing Organization (Complete Mailing Address) $\quad$ 4. Principal Investigator (Name and Complete Mailing Address)

Metropolitan Waste Control Commission

Twin Cities Area

350 Metro Square Bldg.

7 th \& Robert St.

St. Paul, MN 35101

Dale C. Bergstedt

Metropolitan Waste Control Commission

Twin Cities Area

350 Metro Square Bldg.

7 th \& Robert St.

St. Paul, MN 35101 5. Supporting Organization (Complete Mailing Address and Name of
Contact)

6. Duration of Investigation (Beginning and ending)

Steven W. Hathaway

U.S. EPA, MERL, WRD

$8 / 1 / 76$ to $7 / 31 / 77$

Cincinnati, $\mathrm{OH} 45268$

7. Estimated Funding and Manpower (Monies and Manyears)

$\$ 371,021$

8. Purpose of Project (Objectives, Motivations, Approach, Plans and Expected Results)

The objective of this project is to evaluate the operational feasibility and environmental aspects of adding combustible solid matter to wastewater treatment plant sludges and filter cakes, as off-sets to part or all the auxiliary fuels used in conventional sludge incineration practice. Low sulfur coal and combustible solid wastes will be utilized as ad mix materials. The tests will take place at the Commission's Seneca 6 TPD.

Use Box No 15 if additional space is needed

\section{Status and Results}

Project has successfully demonstrated the use of coal as a supplemental fuel. Further work plans to automate system and to evaluate solids wastes as well as coal.

This project is: $\square$ planned $\square$ in-progress $\square$ completed Use Box No. 16 if additional space is needed

\begin{tabular}{ll}
\hline 10. Utility Services & \\
$\square$ electrical power & \\
$\square$ space heating & $\square$ solid waste processing \\
$\square$ space cooling & $\square$ potable water \\
$\square$ potable hot water &
\end{tabular}

12. Exchange of data 
13. Technical Data

project location :- - -

degree-days (heatting) -

degree-days (cocling) - -

plant load capacity

a power (MW) - . - -

b. heating (MW) ----

c. cooling (MW) $-\ldots--$

d. wastewater treatment-liters/day - - - -

e. solid waste processing-kilograms/day $-\ldots$

f. potable water-liters/day -------

heat to power ratio (average expected)
Identification No

$3-831 U S-67$

energy source

expected payback period

Type and size of user

a. residential (dwelling units)

b. residential (square area- $m^{2}$ )

c. commercial (square area- $-\mathrm{m}^{2}$ )

d. industrial (thermal + elec.-MW)

14. Other Related Projects (Titles)

15. Additional space for Purpose of Project

16. Additional space for Status and Results 
NBS-1075

(2.77)
U.S. DEPARTMENT OF COMMERCE Identification No.

NATIONAL BUREAU OF STANDARDS

(Secretariat Use Only) 3-831NL- 68

\section{PROJECT SUMMARY FORM}

1. Title of Project /Official Title/

Several projects concerning utilization of heat raised by incineration of waste

3. Performing Organization (Complete Mailing Address)

$$
\mathrm{N} / \mathrm{A}
$$

5. Supporting Organization (Complete Mailing Address and Name of Contact)

Institute for Waste Disposal

P.O. Box 184

Amersfoort

The Netherlands

4. Principal Investigator (Name and Complete Mailing Address) Ir. B.G. Kreiter

Institute for Waste Disposal P.O. Box 184

Amersfoort

The Netherlands

2 Date (Form Completed) $7 / 13 / 77$

6. Duration of Investigation (Beginning and ending) Continuously

7. Estimated Funding and Manpower (Monies and Manyears) Projects are of evaluating nature

8. Purpose of Project (Jbjectives, Motivations, Approach, Plans and Expected Results)

Generation of electric power is a well-known method of utilization of incineration-heat.

The low efficiency, however, is a reason to investigate alternatives.

Running projects are: - district heating (in cooperation with a national committee)

- water evaporation

- firing of the light combustible waste fraction in power-station boilers.

Use Box No. 15 if additional space is needed

9. Status and Results

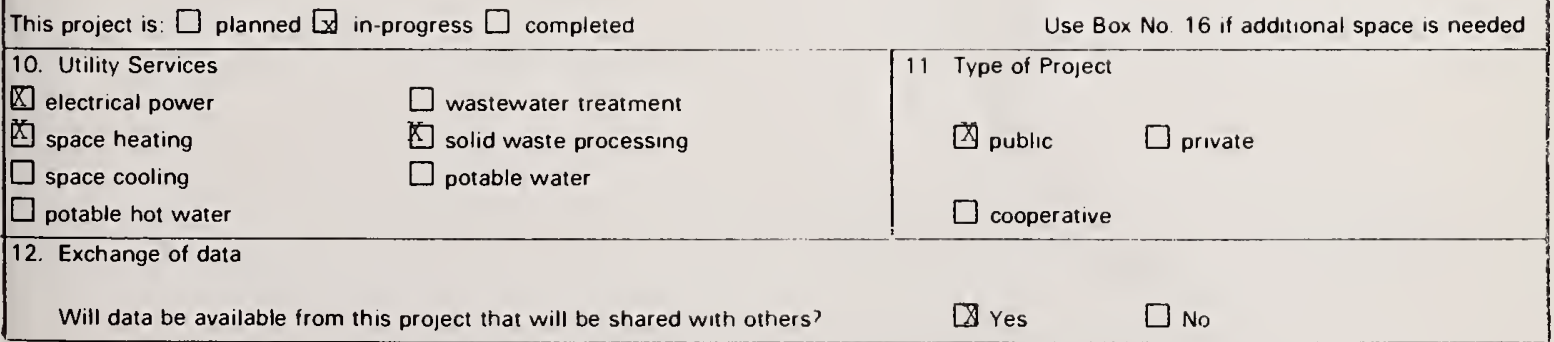




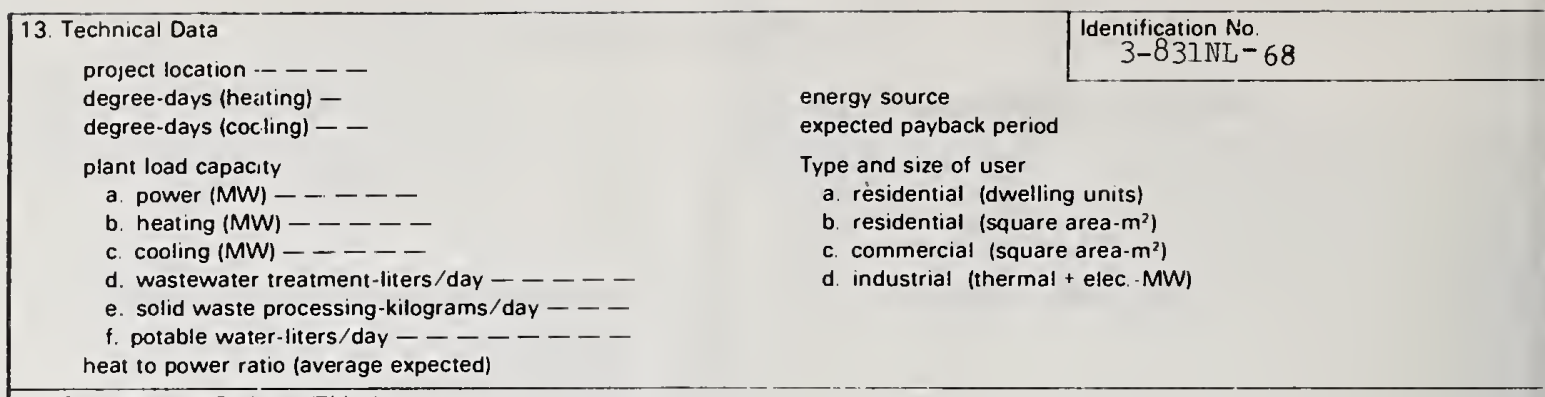

14. Other Related Projects (Titles)

15. Additional space for Purpose of Project

16. Additional space for Status and Results 
NBS-1075

$|2-77|$
U.S. DEPARTMENT OF COMMERCE

NATIONAL BUREAU OF STANDARDS

\section{PROJECT SUMMARY FORM}

1. Title of Project (Official Title)

Treatment of municipal sludge by use of residual heat from refuse incineration

3. Performing Organization (Complete Mailing Address) SCK/CEN

Boeretang 200

B-2400 MOL

Belgium
4. Principal Investigator (Name and Complete Mailing Address) F. DECAMPS

$\mathrm{SCK} / \mathrm{CEN}$

Avenue E. Plaskylaan 144

B-1040 Brussel/Bruxelles

Belgiun

6. Duration of Investigation (Beginning and ending)

$1 / 1 / 78-7 / 1 / 79$

7. Estimated Funding and Manpower (Monies and Manyears) $\$ 700,000$

$2.5 \mathrm{man} / \mathrm{year}$

8. Purpose of Project (Jbjectives. Motivations. Approach, Plans and Expected Results)

- Construction and experimental runs of prototype sludge dryer (size: 10,000 sq. in h)

- Use of heat of existing small incinerators ( $3-6$ ton $\mathrm{h}^{-1}$ )

- Since experimental data on indirect arying are available at SCK/CEN, a prototype will be built without further laboratory work.

Use Box No. 15 if additional space is needed

9. Status and Results

Program proposal submitted to EEC

This project is: planned $\square$ in-progress $\square$ completed

$\square$ electrical power

$\square$ space heating

$\square$ space cooling

$\square$ potable hot water

12. Exchange of data
E wastewater treatment

[x solid waste processing

$\square$ potable water
Use Box No. 16 if additional space is needed 11. Type of Project

$\square$ public $\quad$ private

cooperative 
13. Technical Data

project location -- - - -

degree-days (heatting) -

degree-days (cocling) - -

plant load capacity

a power $(M W)-\cdots--$

b. heatıng $(\mathrm{MW})-\ldots$

c. cooling (MW) - . - -

d. Wastewater treatment-liters/day $-\ldots-50,000$

e. solid waste processing-kilograms/day

f. potable water-liters/day - expected)

14 Other Related Projects (Titles)

Nuclear sludge treatment at SCK/CEN

energy source

dentification No.

3-832BE- 69

expected payback period

Type and size of user

a. residential (dwelling units)

b. residential (square area- $m^{2}$ )

c. commercial (square area- $\mathrm{m}^{2}$ )

d. industrial (thermal + elec.-MW)

15. Additional space for Purpose of Project

16. Additional space for Status and Results 
NBS-1075

(2-77)
U.S. DEPARTMENT OF COMMERCE NATIONAL BUREAU OF STANDARDS

\section{PROJECT SUMMARY FORM}

cial $T ı / e$

Rotary Kiln Gasification of Sewage Sludge Solid Waste Mixture

3. Performing Organization (Complete Mailing Address)

Wright-Malta Corp. Malta Test Station Ballston Spa, N.Y. 12020 U.S.A.

5. Supporting Organization /Complete Mailing Address and Name of Contact)

Steven W. Hathaway U.S. EPA, MERL, WRD Cincinnati, Ohio 45268 U.S.A.
4. Principal Investigator (Name and Complete Mailing Address)

John Coffman

Wright-Malta Corp.

Malta Test Station

Ballston Spa, N.Y. 12020

U.S.A.

6. Duration of Investigation (Beginning and ending)

$$
10 / 24 / 75 \text { to } 11 / 24 / 76
$$

7 Estimated Funding and Manpower (Monies and Manyears)

$$
\$ 53,820
$$

8. Purpose of Project (Jbjectives, Motivations, Approach, Plans and Expected Results)

This research will test the thesis that a mixture of raw solid waste and liquid sewage sludge can be converted clearly into fuel gas, primarily by steam, at temperatures below $1000^{\circ} \mathrm{F}$, in a pressurized, externally heated rotary kiln.

Experimental will determine the influence of these parameters: proportions of liquid to solid waste, types of waste and sludge, size speed of rotation, and fullness of minikiln. The effluent gases will be analyzed and mass balances obtained.

Use Box No. 15 if additional space is needed

9. Status and Results

Near completion. Statistically designed experiment expected to give reliable results. Numerous mechanical problems. Results show detailed chemical reactions and influence of parameters. Project has successfully confirmed chemistry continuous operation of a pressurized rotary kiln has not been attempted, is the critical operating parameter and is very difficult to achieve.

This project is: $\square$ planned $\square$ in-progress $\square$ completed Use Box No. 16 if additıonal space is needed

$$
\text { 6 }
$$

10. Utility Services

electrical power

$\square$ space heatıng

$\square$ space cooling

$\square$ potable hot water

$\square]$ wastewater treatment
$\square$ potable water
11 Type of Project

$\square$ public $\quad$ private

12. Exchange of data

Will data be available from this project that will be shared with others?

X Yes

No 
13. Technical Data

project location

degree-days (cocling) - -

plant load capacity

a. power $(\mathrm{MW})-\ldots$

b. heating $(\mathrm{MW})-\ldots-$

c. cooling $(\mathrm{MW})----$

d. wastewater treatment-liters/day - - - -

e. solid waste processing-kilograms/day - - -

f. potable water-liters/day $-\ldots-\ldots-\ldots$

heat to power ratio (average expected)

14. Other Related Projects (Titles)

15. Additional space for Purpose of Project

16. Additional space for Status and Results

energy source

expected payback period

Type and size of user

a. residential (dwelling units)

b. residential (square area- $m^{2}$ )

c. commercial (square area- $m^{2}$ )

d. industrial (thermal + elec.-MW) 


\section{NBS-1075 \\ (2.77) \\ U.S. DEPARTMENT OF COMMERCE \\ NATIONAL BUREAU OF STANDARDS}

Identification No

(Secretariat Use On/y)

\section{PROJECT SUMMARY FORM}

1. Title of Project (Official Title)

Feasibility of Combined Incineration of Sewage Sludge with Solid Wastes

3. Performing Organization (Complete Mailing Address)

Roy F. Weston Inc.

Weston Way

Westchester, Pa 19380

U.S.A.

5. Supporting Organization (Complete Mailing Address and Name of Contact)

J.B. Farrell

U.S. EPA, OR\&D, MERL, WRD

Cincinnati, Ohio 45268

U.S.A.

4. Principal Investıgator (Name and Complete Mailing Address)

Walter R. Niessen

Roy $F$. Weston Inc.

Weston Way

Westchester, Pa 19380

U.S.A.

6 Duration of Investigation (Beginning and ending)

$$
6 / 4 / 74 \text { to } 9 / 30 / 75
$$

7. Estimated Funding and Manpower (Monies and Manyears)

$$
\$ 72,280
$$

8. Purpose of Project (Jbjectives, Motivations, Approach, Plans and Expected Results)

The objective of this contract is to survey the available technology for incineration of sewage sludge with solid waste and assess the feasibility of each alternative approach. A literature survey, site visits, and contacts with practicing facilities will serve as the basis for determining the technology and economic merit of each technique. Engineering design and economic analysis of 4 selected techniques will be performed for 1,10 , and $100 \mathrm{mgd}$ sewage treatment plants.

9. Status and Results

Project complete

Final report in preparation

This project is: planned $\square$ in-progress $\mathrm{Q}$ completed Use Box No. 16 if additional space is needed

$\square$ space heating

$\square$ space cooling

$\square$ potable hot water

Dolid waste processing

$\square$ potable water

11 Type of Project

$\square$ public $\quad x$ private

12. Exchange of data

cooperative

Will data be available from this project that will be shared with others?

Yes

$\square$ No 


\begin{tabular}{|c|c|c|c|}
\hline $\begin{array}{l}\text { 13. Technical Data } \\
\text { project location }-\ldots \ldots\end{array}$ & & Identification No. & 3-832US-71 \\
\hline $\begin{array}{l}\text { degree-days (heating) }- \\
\text { degree-days (cocling) }-\end{array}$ & \multicolumn{3}{|l|}{$\begin{array}{l}\text { energy source } \\
\text { expected payback period }\end{array}$} \\
\hline 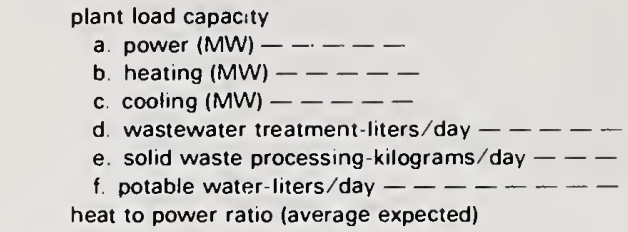 & \multicolumn{3}{|c|}{$\begin{array}{l}\text { Type and size of user } \\
\text { a residential (dwelling units) } \\
\text { b. residential (square area- } \mathrm{m}^{2} \text { ) } \\
\text { c. commercial (square area- } \mathrm{m}^{2} \text { ) } \\
\text { d industrial (thermal + elec }-\mathrm{MW} \text { ) }\end{array}$} \\
\hline
\end{tabular}

14. Other Related Projects (Titles)

15. Additional space for Purpose of Project

16. Additional space for Status and Results 


\begin{tabular}{|c|c|c|}
\hline \multicolumn{2}{|l|}{ PROJECT SUMMARY FORM } & \multirow{2}{*}{\begin{tabular}{|c|}
$\begin{array}{c}\text { Identification No. } \\
\text { (Secretariat Use On/y) } \\
4-101 \text { SE-OI }\end{array}$ \\
$\begin{array}{c}\text { 2. Date (Form Completed) } \\
5 / 23 / 77\end{array}$
\end{tabular}} \\
\hline $\begin{array}{l}\text { 1. Title of Project (Official Title) } \\
\text { Di strict Heating System Enkoping }\end{array}$ & & \\
\hline 3. Performing Organization (Complete Mailing Address) & $\begin{array}{l}4 \text { Principal Investigator }(\mathrm{N} \\
\text { H. Osterberg Ma } \\
\text { Enkoping Distri } \\
\text { Enkoping } \\
\text { Sweden }\end{array}$ & $\begin{array}{l}\text { Vame and Complete Mailing Address) } \\
\text { ct Dir. } \\
\text { ct Heating } \mathrm{CO} \text {. }\end{array}$ \\
\hline $\begin{array}{l}\text { 5. Supporting Organization (Complete Mailing Address and Name of } \\
\text { Contact) }\end{array}$ & $\begin{array}{l}\text { 6. Duration of Investigatio } \\
\text { N/A } \\
\text { 7. Estimated Funding and } \\
\text { N/A }\end{array}$ & $\begin{array}{l}\text { on (Beginning and ending) } \\
\text { Manpower (Monies and Manyears) }\end{array}$ \\
\hline $\begin{array}{l}\text { 8. Purpose of Project (Jbjectives, Motivations. Approach Plans and } \\
\text { The purpose of the project is to provide } \\
\text { the possibility of applying fluidized bed } \\
\text { solid, liquid and gaseous fuels in series } \\
\text { reduce air pollution in a most economical } \\
\text { treated and sewage gas will be feed to th } \\
\text { A standard hot water district heating boi } \\
\text { water in series with the fluidized combus } \\
\text { fluidized combustor is introduced to the } \\
\text { designed for outlet gas temperature } 160^{\circ} \mathrm{C} \\
\text { Particles carried over from the fluidized } \\
\text { through the boiler are collected in hoppe }\end{array}$ & $\begin{array}{l}\text { xpected Results) } \\
\text { electricity, space } \\
\text { leurners utilizin } \\
\text { with existing boi. } \\
\text { way. The sewage } \\
\text { burner. } \\
\text { ler }\left(190 / 140^{\circ} \mathrm{C}\right) \text { is } \\
\text { gor. Combustion p } \\
\text { gas-tight membrane } \\
\text { combustor and rej }\end{array}$ & $\begin{array}{l}\text { heating and to demonstrate } \\
\text { g direct combustion of } \\
\text { lers. This technique will } \\
\text { of Enkoping will also be } \\
\text { modified for recirculating } \\
\text { roducts generated in the } \\
\text { wall water tube boiler } \\
\text { ected during the gas path } \\
\text { to silos. }\end{array}$ \\
\hline
\end{tabular}

Use Box No. 15 if additional space is needed

9. Status and Results

The first commercial multi-fuel fluidized combustion hot water district heating boiler will be operating late 1977 for demonstration 1978-1980 using a wide range of fuels. Selected fuels for demonstration in 1978 are coal, peat, wood and high sulfur residual fuel oil. Within ten years more than 50 multi-fuel fluidized combustion hot water district heating boilers are expected to be operating in Sweden.

This project is: $\square$ planned $\mathbf{Q}$ in-progress completed

Use Box No 16 if additional space is needed 10. Utility Services

国 electrical power

space heating

$\square$ space cooling

$\square$ potable hot water

$\square$ wastewater treatment
$\square$ solid waste processing
$\square$ potable water

12. Exchange of data

11. Type of Project

冈 public $\square$ private

cooperatıve 


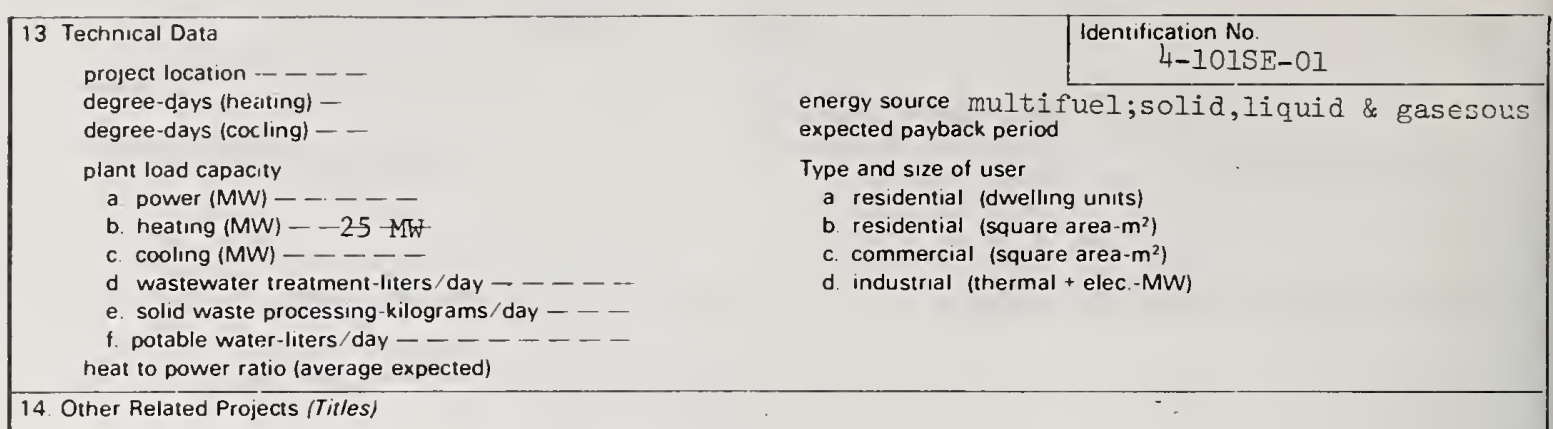

15. Additional space for Purpose of Project

16. Additional space for Status and Results 


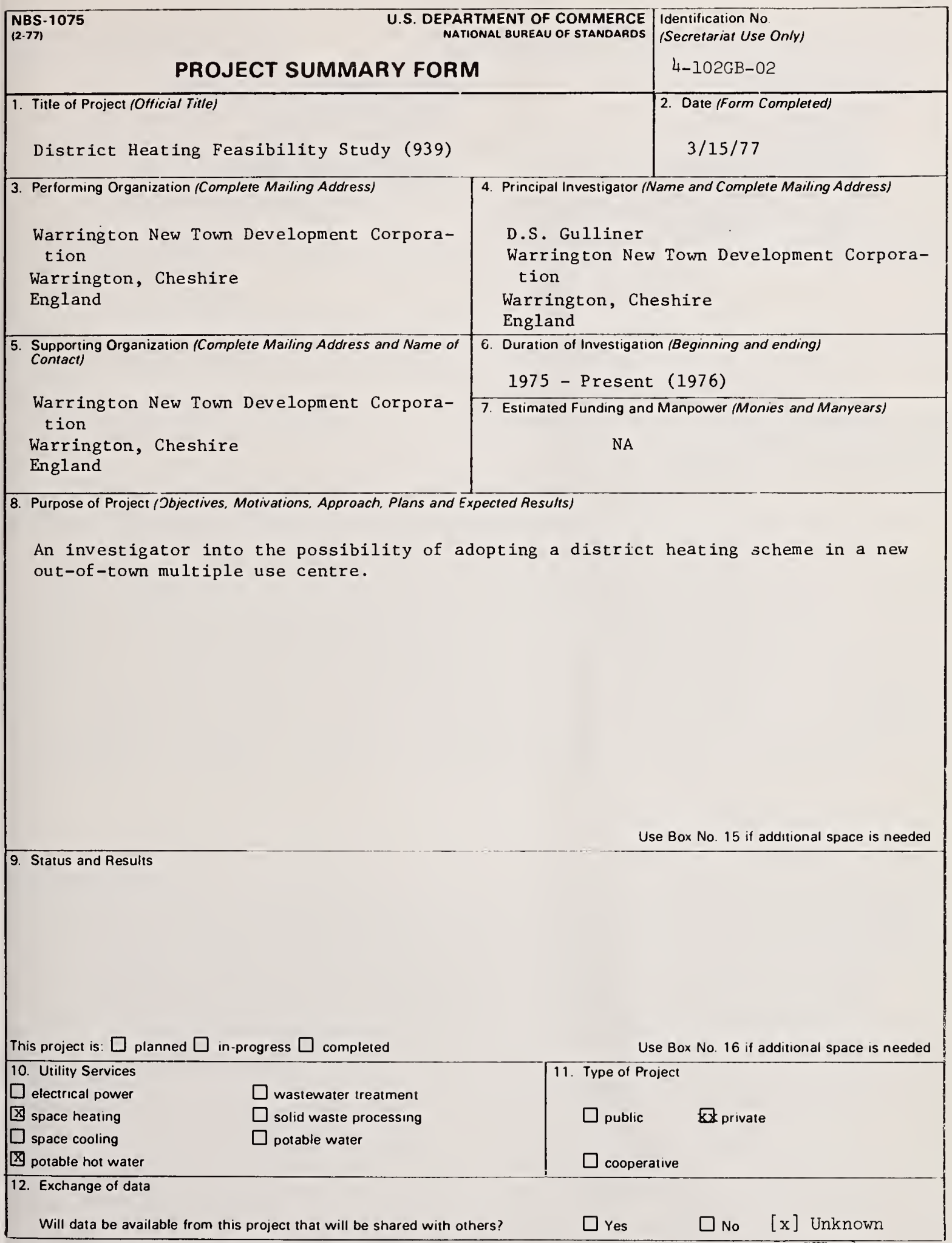


13. Technical Data

project location

degree-days (heäıting) -

degree-days (cocling) - -

plant load capacity

a. power $(\mathrm{MW})--\cdots$

b. heating (MW) $-\ldots-\cdots$

c. cooling (MW) $--\ldots$

d. wastewater treatment-liters/day $-\ldots-\ldots$

e. solid waste processing-kilograms/day - -

f. potable water-liters/day -------

heat to power ratio (average expected)

14. Other Related Projects (Titles)
Identification No

$4-102 \mathrm{~GB}-02$

energy source

expected payback period

Type and size of user

a. residential (dwelling units)

b. residential (square area- $\mathrm{m}^{2}$ )

c. commercial (square area- $\mathrm{m}^{2}$ )

d. industrial (thermal + elec.-MW)

15. Additional space for Purpose of Project

16. Additional space for Status and Results 


\begin{tabular}{|c|c|c|}
\hline \multicolumn{2}{|l|}{$\begin{array}{l}\text { NBS-1075 } \\
(2-77)\end{array}$} & $\begin{array}{l}\text { Identification No. } \\
\text { (Secretariat Use Only) } \\
\quad 4-111 \mathrm{IE}-03\end{array}$ \\
\hline \multicolumn{2}{|l|}{$\begin{array}{l}\text { 1. Title of Project (Official Title) } \\
\text { DISTRICT HEATING IN BRESCIA } \\
\text { (Teleriscaldamento della citta di Brescia) }\end{array}$} & 2 Date (Form Completed) \\
\hline $\begin{array}{l}\text { 3. Performing Organization (Complete Mailing Address) } \\
\text { Azienda Servizi Municipalizzati } \\
\text { Sezione Energetica } \\
\text { Via Lamarmora, } 230 \\
\text { 25100 Brescia (Italy) }\end{array}$ & \multicolumn{2}{|c|}{$\begin{array}{l}\text { 4. Principal Investigator (Name and Complete Mailing Address) } \\
\text { Dip. Eng. Renzo Capra } \\
\text { c/o ASM } \\
\text { Via Lamarmora, } 230 \\
25100 \text { Brescia (Italy) }\end{array}$} \\
\hline $\begin{array}{l}\text { 5. Supporting Organization /Complete Mailing Address and Name of } \\
\text { Contact) } \\
\text { INSTITUTO MOBILIARE ITALIANO }\end{array}$ & \begin{tabular}{|l}
6 Duration of Investigatic \\
Investigation \\
ended in Jan.
\end{tabular} & $\begin{array}{l}\text { on (Beginning and ending) } \\
\text { started in Dec. } 71 \text { and } \\
73-\text { Revised in } 1975 \\
\text { Manpower Monies and Manyears) }\end{array}$ \\
\hline \multicolumn{3}{|c|}{$\begin{array}{l}\text { 8. Purpose of Project /Dbjectives, Motivations, Approach, Plans and Expected Results) } \\
\text { The purpose of the project is to face the energy demands in consideration of the con- } \\
\text { tinuous increase of the fuel costs. The project forsees the electricity and heat com- } \\
\text { bined production with an exploitation rate of the fuel energy contents, about twice the } \\
\text { rate achievable in a single thermolectric plant. In a combined production plant, the } \\
\text { steam, after its expansion in a back-pressure turbine, is bleeded and condensed for } \\
\text { the heat production for the district heating network. The district heating network } \\
\text { operates, as they say, as "warm condenser". The advantages of the combined production } \\
\text { are: considerable saving of fuel, better efficiency of the fuel combustion employing } \\
\text { large boilers always under control, considerable pollution reduction as it is possible } \\
\text { to use flue-gas depuration systems. Great advantages for the users: no fuel problems, } \\
\text { cleanliness, no upkeep, security of the system and continuous heat and hot water } \\
\text { service. }\end{array}$} \\
\hline
\end{tabular}

Use Box No. 15 if additional space is needed

9. Status and Results

After the feasibility study carried out by the "Energi-consult" of Stockholm in 1972, on the 22nd of Jan. 1973 the preliminary project for the first stage of the plant and of the district heating network was approved and worked out by the Board of Management of the Azienda. Up to now a network section of about $16.5 \mathrm{~km}$ has been laid and 3 boilers (total capacity $85 \mathrm{Gcal} / \mathrm{h}$ ) installed. A combined plant (energy-heat) of $30 \mathrm{MW}$ and $77 \mathrm{Gcal} / \mathrm{h}$ is under construction, and it will be put into service on July 1978. The project development forcast are as stated in point 8 .

This project is: $\square$ planned $\square$ in-progress $\square$ completed

Use Box No. 16 if additional space is needed

10. Utility Services

[R] electrical power

[0] space heating

$\square$ space cooling

potable hot water

1 Type of Project

国 public $\square$ private

12. Exchange of data

Will data be available from this project that will be shared with others?

Yes

No 


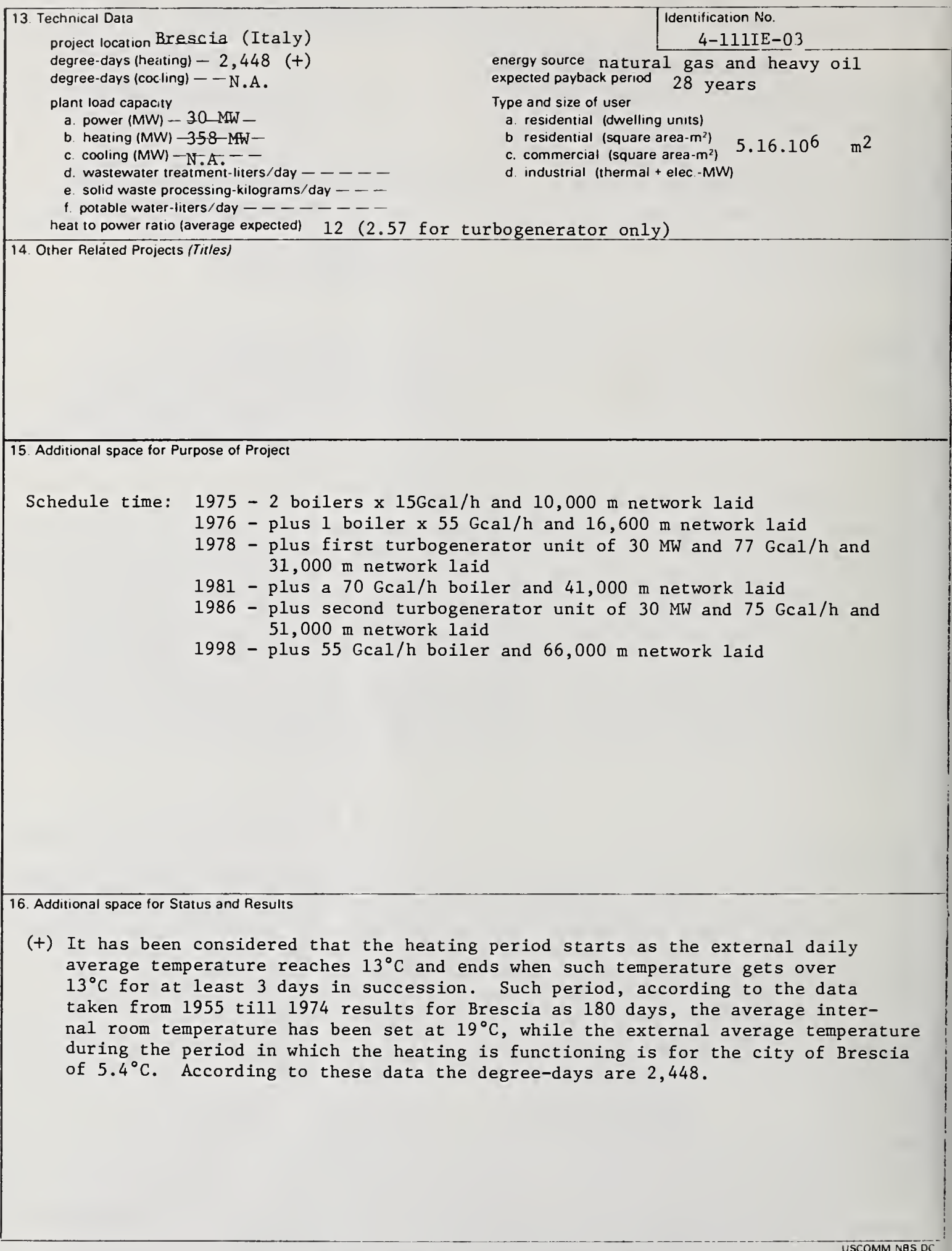




\begin{tabular}{|c|c|c|}
\hline \multicolumn{2}{|l|}{$\begin{array}{l}\text { NBS-1075 } \\
(2-77)\end{array}$} & $\begin{array}{l}\text { Identification No } \\
\text { (Secretariat Use On/y) } \\
4-111 \text { SE-04 }\end{array}$ \\
\hline $\begin{array}{l}\text { 1. Title of Project /Official Tit/e) } \\
\text { Vasteras District Heating Power Station ( } 8\end{array}$ & 30MW electric) & $\begin{array}{l}\text { 2. Date (Form Completed) } \\
5 / 23 / 77\end{array}$ \\
\hline $\begin{array}{l}\text { 3. Performing Organization (Complete Mailing Address) } \\
\text { Vasteras Study Kraftuaeme } \\
\text { Werk Aktiebolag } \\
\text { Vasteras } \\
\text { Sweden }\end{array}$ & $\begin{array}{l}4 \text { Principal Investigator } / \\
\text { L. Metzler Man } \\
\text { Public Works } \\
\text { Vasteras City } \\
\text { Sweden }\end{array}$ & $\begin{array}{l}\text { Vame and Complete Mailing Address) } \\
\text { Direct or } \\
\text { epartment } \\
\text { Council }\end{array}$ \\
\hline $\begin{array}{lr}\text { 5. Supporting Organization (Complete Mailing Address and Name of } \\
\text { Contact) Krangede Aktiebolag } & 29 \% \\
\text { Stora Kopparbergs Bergslags Aktiebolag } 27 . \\
\text { Vasteras Stads Kraftvarmeverk } & 17.5 \% \\
\quad \text { Aktiebolag } & 15 \% \\
\text { Gullspangs Kraftaktiebolag } & \\
\text { Aktiebolaget Bergslagens Gemensamma } & \\
\text { Kraftforvaltming } & 11 \%\end{array}$ & \begin{tabular}{|cc}
6 & Duration of Investigati \\
$5 \%$ & N/A \\
7. & Estimated Funding anc \\
N/A
\end{tabular} & $\begin{array}{l}\text { In (Beginning and ending) } \\
\text { Manpower (Monies and Manyears) }\end{array}$ \\
\hline
\end{tabular}

8. Purpose of Project (Jbjectives, Motivations, Approach, Plans and Expected Results)

The purpose of the project originally was to sell heat as well as electricity.

It also helps to reduce energy consumption.

9. Status and Results

The plant has been successfully in operation for many years.

(See blocks 15 and 16 on reverse side for technical data.)

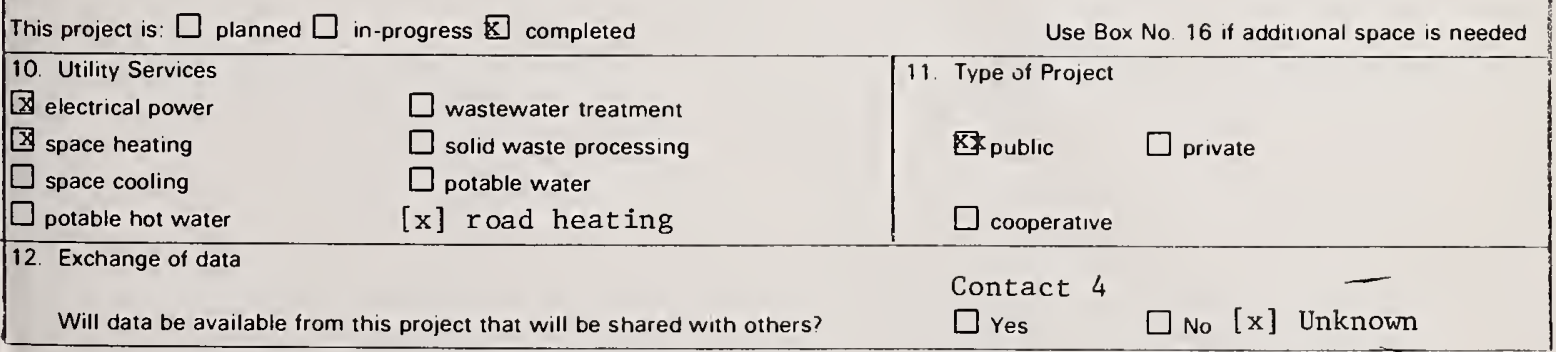




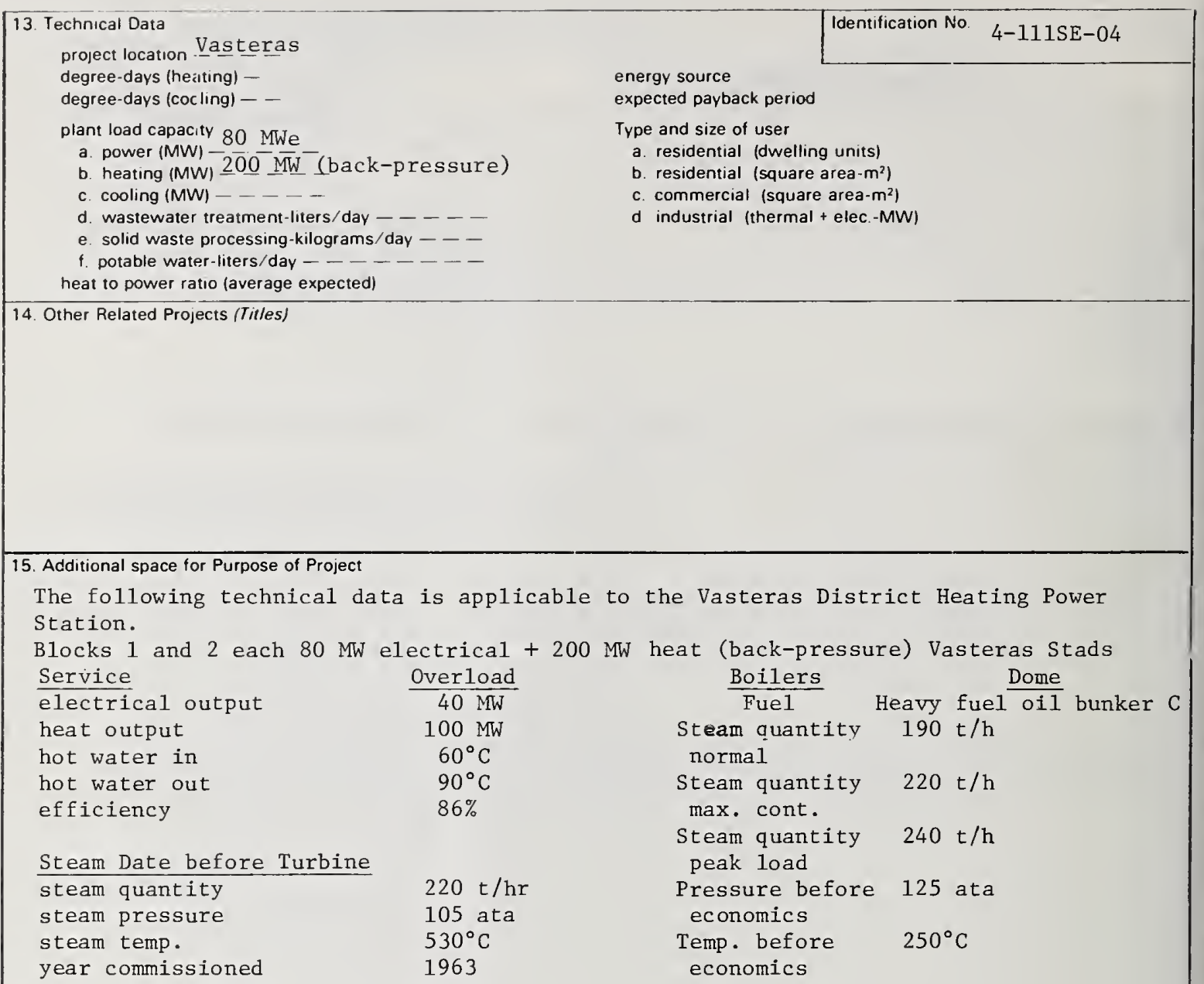




\begin{tabular}{|c|c|c|}
\hline \multicolumn{2}{|c|}{$\begin{array}{l}\text { U.S. DEPARTMENT OF COMMERCE } \\
\text { NATIONAL BUREAU OF STANDARDS } \\
\text { PROJECT SUMMARY FORM }\end{array}$} & \multirow{2}{*}{\begin{tabular}{|l}
$\begin{array}{l}\text { Identification No. } \\
\text { (Secretariat Use On/y) } \\
4-111 \mathrm{SE}-05\end{array}$ \\
2. Date (Form Completed) \\
$5 / 23 / 77$
\end{tabular}} \\
\hline $\begin{array}{l}\text { 1. Title of Project (Otficial Tit/e) } \\
\text { The Varta Power Station }\end{array}$ & & \\
\hline $\begin{array}{l}3 \text { Performing Organization (Complete Mailing Address) } \\
\text { Sweden }\end{array}$ & \multicolumn{2}{|c|}{4 Principal Investigator (Name and Complete Mailing Address) } \\
\hline \multirow[t]{2}{*}{$\begin{array}{l}\text { 5. Supporting Organization (Complete Mailing Address and Name of } \\
\text { Contact) }\end{array}$} & \multicolumn{2}{|c|}{$\begin{array}{l}\text { 6. Duration of Investigation (Beginning and ending) } \\
\text { N/A }\end{array}$} \\
\hline & \multicolumn{2}{|c|}{$\begin{array}{l}7 \text { Estimated Funding and Manpower (Monies and Manvears) } \\
\text { N/A }\end{array}$} \\
\hline
\end{tabular}

8. Purpose of Project (Jbjectives. Motivations, Approach, Plans and Expected Results)

The Varta power station is situated about $3 \mathrm{~km}$ from the centre of Stockholm in the Hjorthagen district on the Baltic. The plant dates from 1903, when two generators driven by reciprocating steam engines supplied a total of 3 MW mainly for lighting purposes in Stockholm. The plant has been gradually extended by generators driven by steam turbines, and a11 that is left of the older part of the works are three condensing steam turbines of a total rating of $60 \mathrm{MW}$ and six steam boilers.

Construction of a district heating system in the 0stermalm and Gardet districts of Stockholm was started at the beginning of the sixties. Heat was temporarily generated by means of heat exchangers from the steam boilers, but in 1969 two hot water boilers were installed for district heating purposes. Two steam boilers, which will also be capable of supplying steam to the -condensing turbines and replacing the old steam boilers, will be delivered by the autumn of 1973 to serve the district heating system being constructed in central Stockholm.

A gas turbine rated at $54 \mathrm{MW}$ electric power was installed in 1969 to cater for peak loads and to serve as standby plant.

Use Box No. 15 if additional space is needed

9. Status and Results

Condensing Plant: 6 steam boilers, steam pressure 22 at.g., steam temperature $390^{\circ} \mathrm{C}$, total steam supplied 235 tons/hr.

Fuel: low-sulphur Eo 4. Heat exchanger for district heating.

Feed water pumps: 3 No, one of which is driven by steam turbine, 1 by electric motor and 1 by electricity and steam.

Condensing steam turbines: G 12, De Lava1, 25 MW, G 13 STAL LAVAL, 25 MW and G 14, De Laval $10 \mathrm{MW}$.

GAS TURBINE: G3, supplier STAL LAVAL Type GT 120, 54 MW industrial mode1, open system This project is: $\square$ planned $\square$ in-progress $\square$ completed

wastewater treatment

solid waste processing

$\square$ potable water

Use Box No. 16 if additional space is needed

12. Exchange of data

$$
\text { public } \quad \square \text { private }
$$

cooperatıve 


\begin{tabular}{|c|c|}
\hline $\begin{array}{l}\text { 13. Technical Data } \\
\text { project location }-----\end{array}$ & Identification No. $4-111 \mathrm{SE}-05$ \\
\hline $\begin{array}{l}\text { degree-days (heating) }- \\
\text { degree-days (cocling) }--\end{array}$ & $\begin{array}{l}\text { energy source } \\
\text { expected payback period }\end{array}$ \\
\hline 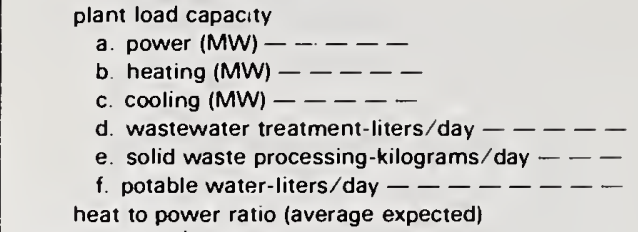 & 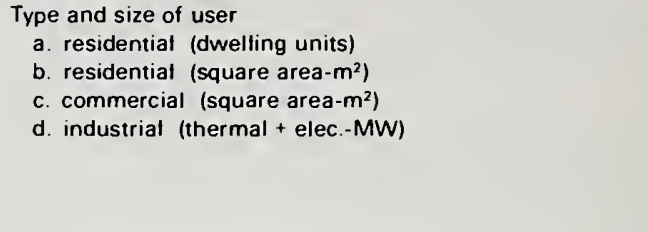 \\
\hline
\end{tabular}

14. Other Related Projects (Titles)

15. Additional space for Purpose of Project

A back pressure plant with a rated electric power of $210 / 250 \mathrm{MW}$ and district heating power of 330 MW will be delivered by $1976 / 77$.

16. Additional space for Status and Results

with intercooling. Fuel : Eo 1.

Heating Plant I: Boilers Nos 11 and 12, hot water boilers 2 x 125 MW heat, supplier Gotaverken, pressure $10 \mathrm{at.g.,} \mathrm{water} \mathrm{temperature} 150^{\circ} \mathrm{C}$, directly connected to the district heating system. The boilers are forced draught fired and have no flue gas fan Precipitators of multicyclone type. Fuel: low-sulphur Eo4-5.

Heating Plant II: Boilers Nos 13 and 14, steam boilers 2 x 160 MW heat, supplier Svenska Maskinverken. Pressure 42 at.g., steam temperature $400^{\circ} \mathrm{C}$, steam supp 1 ied 220 tons/h. Heat exchanger for district heating production and steam pipe 1ine to condensing steam turbines G12-G14. Precipitators of multicyclone type and steam turbine driven fans, feed pumps and heating system circulation pumps. Fuel: 1ow-sulphur Eo 4-5. 


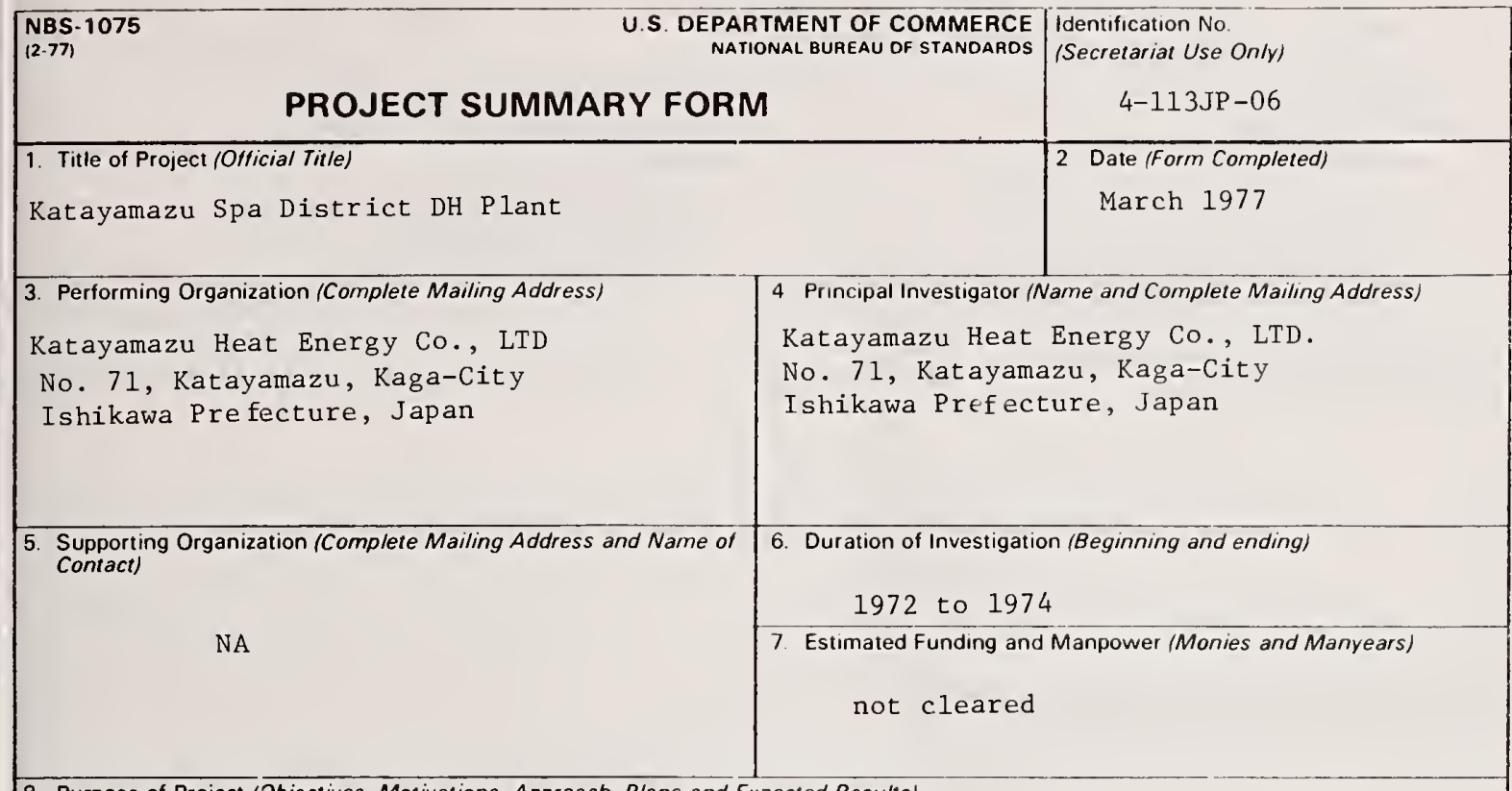

8. Purpose of Project (Objectives, Motivations. Approach. Plans and Expected Results)

(1) Effective use of energy

(2) Prevention of public-nuisance especially for air pollution

9. Status and Results

Use Box No. 15 if additional space is needed

Services started from Nov. 1975.

This project is: $\square$ planned $\square$ in-progress completed 
13. Technical Data

project location -- Ka tayama $z u$

degree-days (heating) - 1980

degree-days (cocling) - -

plant load capacity

a. power $(\mathrm{MW})-28.5$ (33 $\mathrm{Gca} 1 / \mathrm{H})$

c. cooling $(\mathrm{MW})$ -

d. wastewater treatment-liters/day $-\ldots-\ldots$

e. solid waste processing-kilograms/day $-\ldots$

$f$ potable water-liters/day $---\ldots---$

heat to power ratio (average expected)

14. Other Related Projects /Titles)

\author{
Identification No \\ energy source Heavy $0 i 1$ \\ expected payback period not known \\ Type and size of user
a. residential (dwelling units)
b. residential (square area-m²) 400,000
c. commercial (square area- $\mathrm{m}^{2}$ )
d. Industrial (thermal + elec.-MW)

4-113JP-06

15. Additional space for Purpose of Project

16. Additional space for Status and Results 


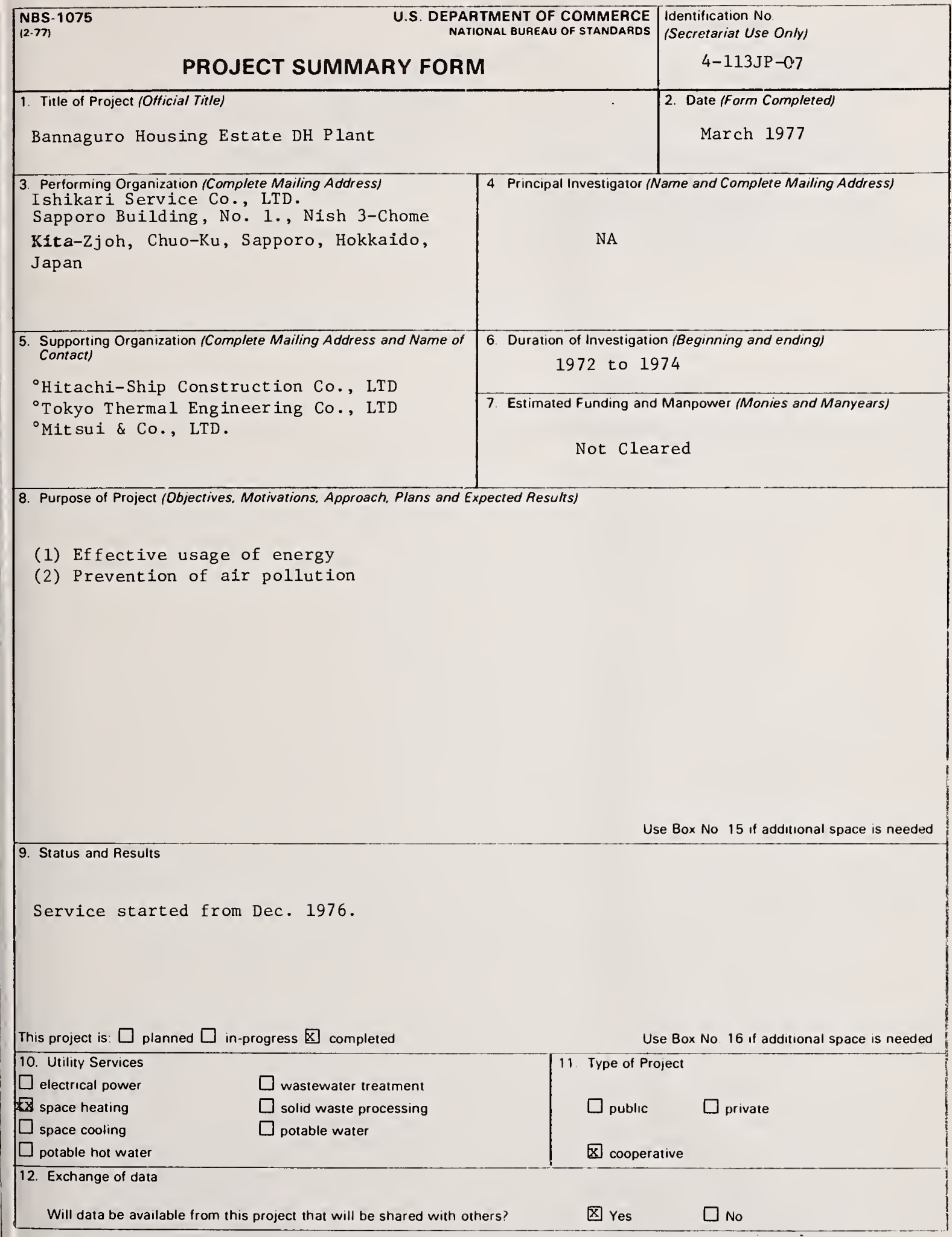




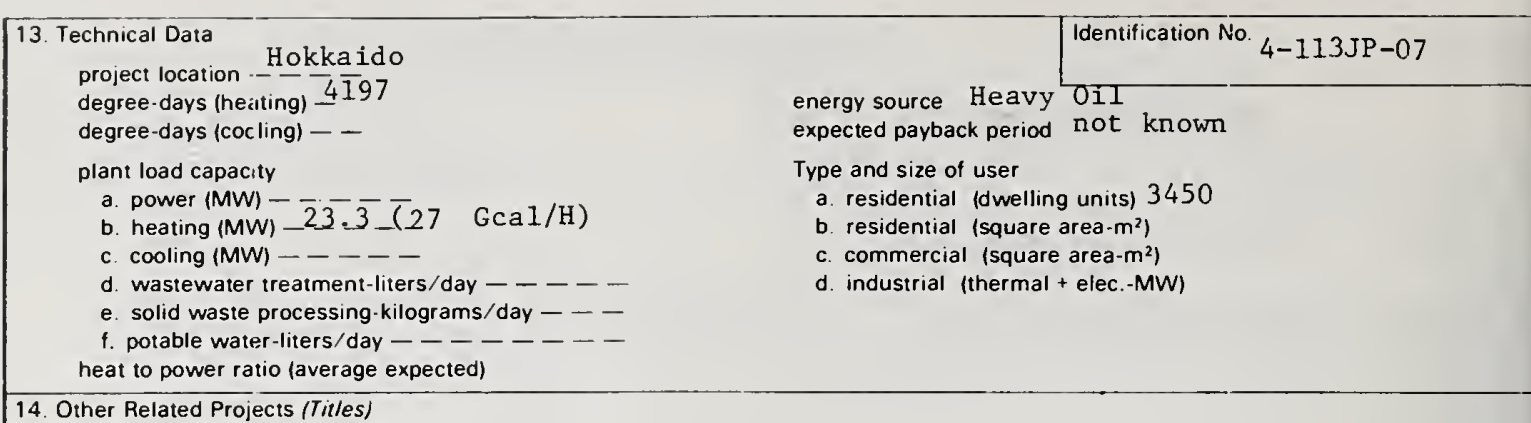

14. Other Related Projects (Titles)

15. Additional space for Purpose of Project

16. Additional space for Status and Results 


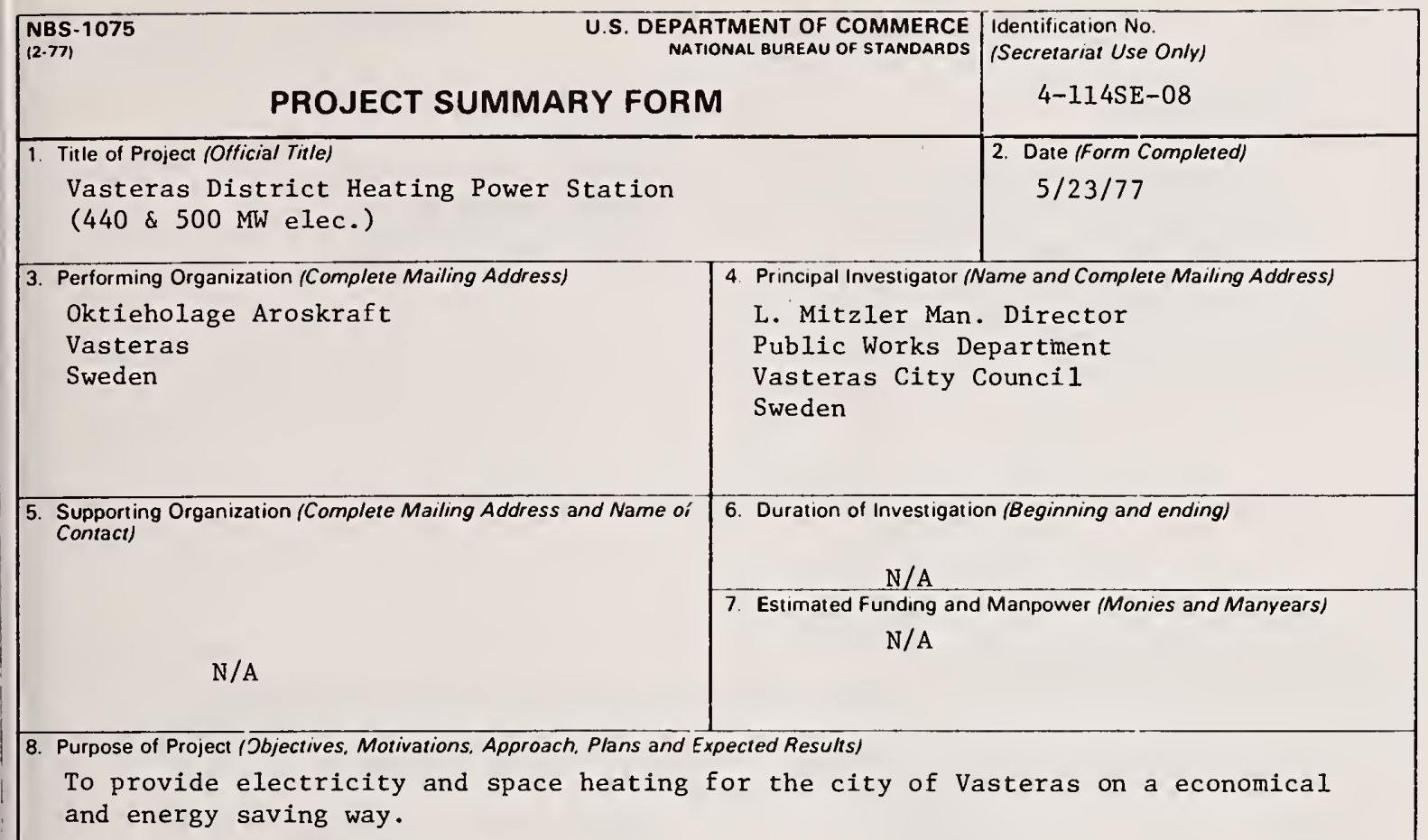

Use Box No. 15 if additional space is needed

9. Status and Results

The back pressure turbine was commissioned in 1969 .

The condensing turbine was commissioned in 1973.

(See blocks 15 and 16 on reverse side for technical data.)

This project is: $\square$ planned $\square$ in-progress $\otimes x$ completed

Use Box No. 16 if additional space is needed

10. Utility Services

wastewater treatment

$\square$ solid waste processing

$\square$ potable water

[x] road heating

Project

$\square$ potable hot water

2. Exchange of data

Contact 4

Will data be available from this project that will be shared with others?

$\square$ Yes $\square$ No $[\mathrm{x}]$ unknown


project location - - - -

degree-days (heating) -

degree-days (coc.ling) - -
plant load capactty $440 \& 500 \mathrm{MW}$ back pr. and
b. heating (MW) $-130-$ condensing back
c. cooling (MW) - - - pressure
d. wastewater treatment-liters/day - - - -
e. solid waste processing-kilograms/day - - -
f. potable water-liters/day $--\ldots---$
heat to power ratio (average expected)

Identification No.

4-114SE-08

energy source expected payback period

Type and size of user
a. residential (dwelling units)
b. residential (square area- $\mathrm{m}^{2}$ )
c. commercial (square area- $\mathbf{m}^{2}$ )
d. industrial (thermal + elec.-MW)

14. Other Related Projects (Titles)

\section{Additional space for Purpose of Project}

The following technical data is applicable to the Vasteras District Heating Power Station.

Blocks 3 and 4 each, 440 MW electrical + 730 MW heat (back-pressure) or 500 MW electrical (condensing) Aktiebolaget Aroskraft

\section{Service}

electrical output

heat output

hot water in

hot water out

efficiency

Steam data before turbine

steàm quantity

steam pressure

steam temp.

year commissioned

\section{Max. Cont.}

$365 \mathrm{MW}$

$585 \mathrm{MW}$

$60^{\circ} \mathrm{C}$

$90^{\circ} \mathrm{C}$

$89.5 \%$

$825 \mathrm{t} / \mathrm{h}$

181 ata

$535^{\circ} \mathrm{C}$

$1969 \& 1973$
Boilers

Fue1

Steam quantity

normal

Steam quantity

max. cont.

Steam quantity

peak load

Pressure before economiser

Temp. before economiser
Monotube

Heavy fuel oil bunker C $750 \mathrm{t} / \mathrm{h}$

$820 \mathrm{t} / \mathrm{h}$

$890 \mathrm{t} / \mathrm{h}$

250 ata max. sliding pressure

16. Additional space for Status and Results 


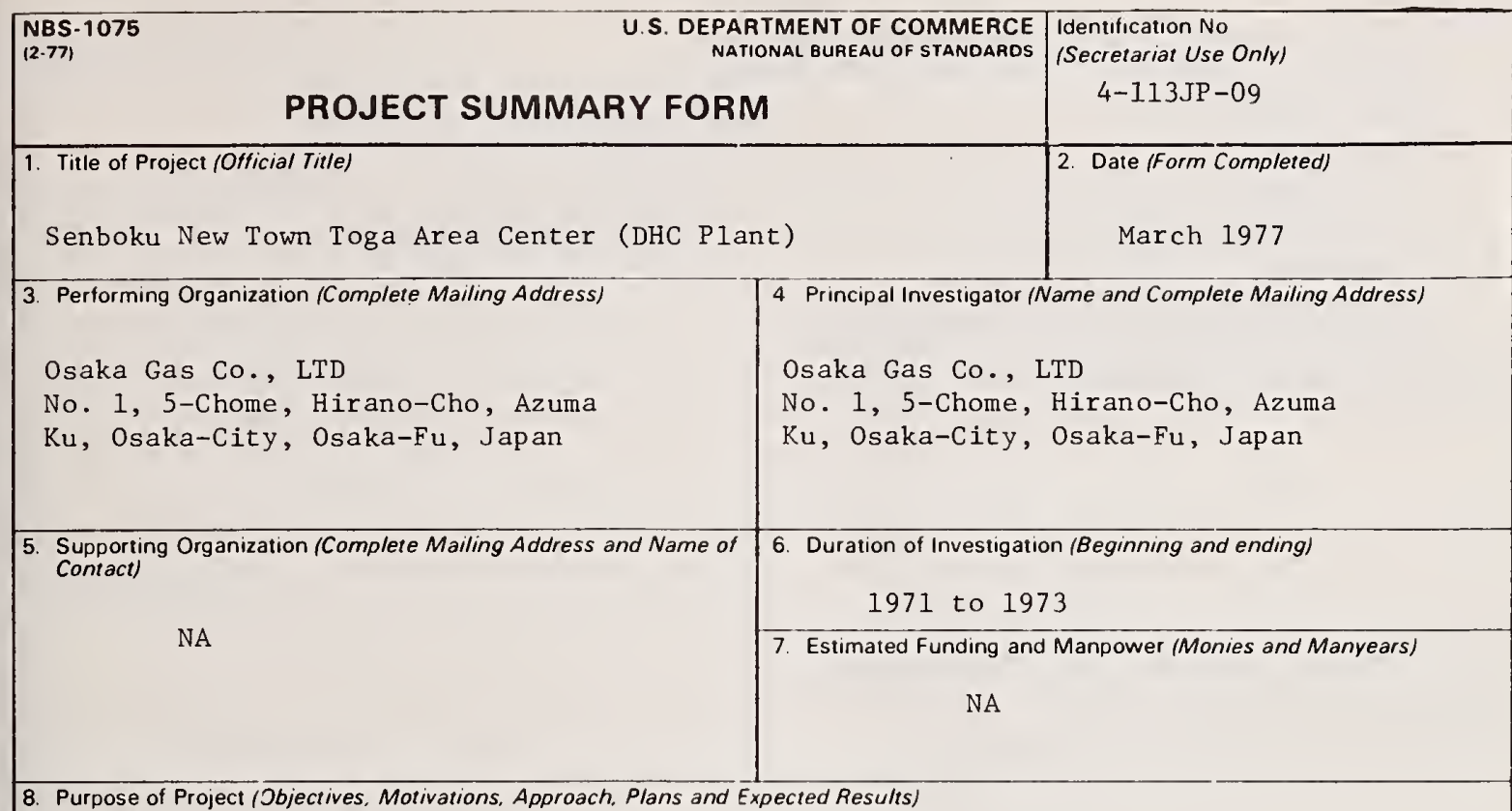

8. Purpose of Project (Jbjectives. Motivations, Approach, Plans and Expected Results)

(1) Effective usage of energy

9. Status and Results

Service starced from Aug. 1976

This project is: $\square$ planned $\square$ in-progress $\square$ completed 10. Utility Services $\square$ electrical power $\checkmark$ space heating space cooling $\square$ potable hot water 12. Exchange of data
Use Box No 16 if additional space is needed 11 Type of Project

public $\quad$ private

cooperative 


\section{Technical Data}

project location - Osaka

degree-days (heating) 1,737

degree-days (cocling) - -

plant load capacity

a. power $(\mathrm{MW})-\ldots$

b. heating $(\mathrm{MW}) \overline{6} . \overline{5}(\overline{7} . \overline{6} \mathrm{Gca} 1 / \mathrm{H})$

d. wastewater treatment-liters/day - _ - -

e. solid waste processing-kilograms/day - - -

f. potable water-liters/day $-\ldots-\ldots-\ldots$

heat to power ratio (average expected)

14. Other Related Projects (Titles)

\begin{tabular}{l|l} 
energy source Town Gas & $\begin{array}{c}\text { Identication No } \\
4-113 \mathrm{JP}-09\end{array}$ \\
expected payback period not known
\end{tabular}

Type and size of user

a. residential (dwelling units) 13,000

b. residential (square area- $\mathrm{m}^{2}$ )

c. commercial (square area- $\mathrm{m}^{2}$ )

d. Industrial (thermal + elec $-\mathrm{MW}$ )

15. Additional space for Purpose of Project

16. Additional space for Status and Results 


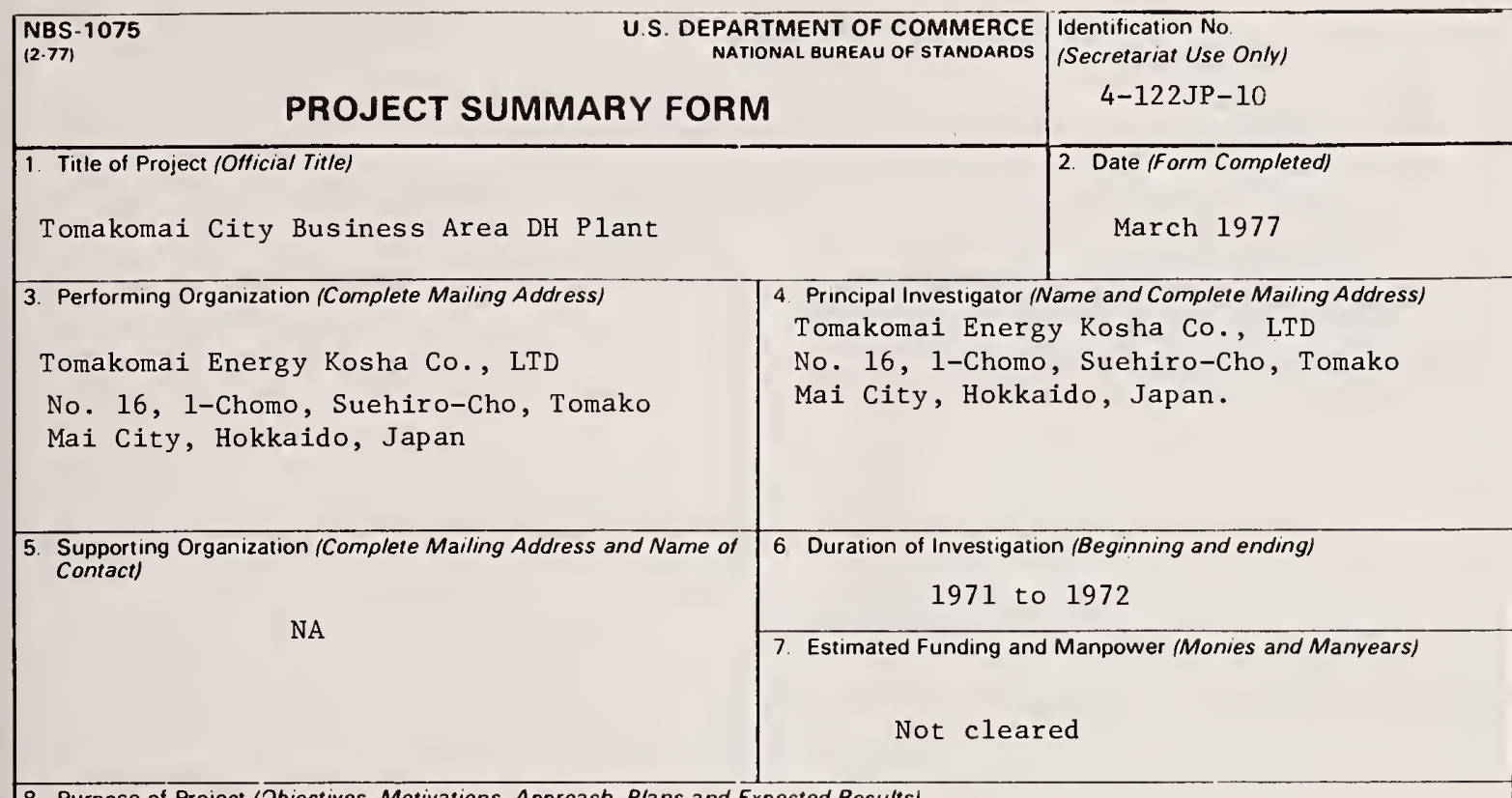

8. Purpose of Project (Jbjectives, Motivations, Approach, Plans and Expected Results)

(1) Effective usage of energy

Use Box No. 15 if additional space is needed

9. Status and Results

Service started from Nov. 1974

This project is: $\square$ planned $\square$ in-progress completed

Use Box No. 16 if additional space is needed

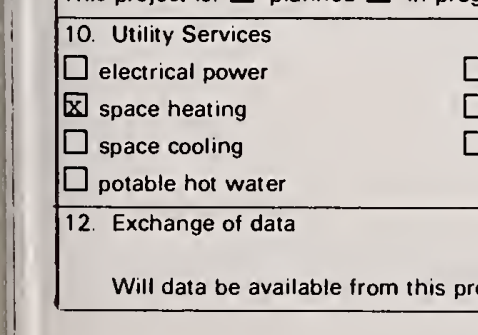

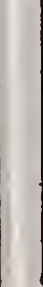$$
\text { data }
$$ 
13. Technical Data

project location -_ Hokkaido

degree-days (heating)

degree-days (cocling) - -

plant load capacity

a. power $(\mathrm{MW})-\overline{25.7}-(30 \mathrm{Gca} 1 / \mathrm{H})$

c. cooling (MW) - - -

d. wastewater treatment-liters/day $-\ldots-\ldots$

e. solid waste processıng-kilograms/day --

f potable water-liters/day $-----\ldots$ heat to power ratio (average expected)

14. Other Related Projects (Titles)
Identification No

$4-122 \mathrm{JP}-10$

energy source Town Gas expected payback period not known

Type and size of user

a. residential (dwelling units)

b. residential (square area- $\mathrm{m}^{2}$ )

c. commercial (square area- $\mathrm{m}^{2}$ )

d industrial (thermal + elec. - MW)

15. Additional space for Purpose of Project

16. Additional space for Status and Results 


\begin{tabular}{|c|c|c|}
\hline $\begin{array}{r}\text { US. DEPAI } \\
\text { PROJECT SUMMARY FORP }\end{array}$ & $\begin{array}{l}\text { TMENT OF COMMERCE } \\
\text { ONAL BUREAU OF STANDARDS } \\
\mathbf{1}\end{array}$ & $\begin{array}{l}\text { Identification No. } \\
\text { (Secretariat Use Only) } \\
\quad 4-122 \mathrm{JP}-11\end{array}$ \\
\hline $\begin{array}{l}\text { 1. Title of Project (Official Tille) } \\
\text { 2nd Morinomiya Housing Estate of Japan } \\
\text { Housing Corporation DHC Plant }\end{array}$ & & $\begin{array}{l}\text { 2. Date (Form Completed) } \\
\text { March } 1977\end{array}$ \\
\hline $\begin{array}{l}\text { 3. Performing Organization (Complete Mailing Address) } \\
\text { Osaka Gas Co., LTD } \\
\text { No. 1, 5-Chome, Hirano-Cho. Azuma-Ku } \\
\text { Ohasaka-City, Ohsaka-fu, Jap an }\end{array}$ & $\begin{array}{l}4 \text { Principal Investıgator } \\
\text { Ohsaka Gas Co. } \\
\text { No. 1, 5-Chome } \\
\text { Ohasaka-City, }\end{array}$ & $\begin{array}{l}\text { Vame and Complete Mailing Address) } \\
\text { LTD. } \\
\text { Ohirano-Cho. Azuma-Ku } \\
\text { Ohsaka-fu, Japan }\end{array}$ \\
\hline $\begin{array}{l}\text { 5. Supporting Organization (Complele Mailing Address and Name of } \\
\text { Contact) } \\
\text { NA }\end{array}$ & $\begin{array}{l}\text { 6. Duration of Investigatic } \\
1972 \text { to } 1974 \\
\text { 7. Estimated Funding and }\end{array}$ & $\begin{array}{l}\text { I (Beginning and ending) } \\
\text { NA }\end{array}$ \\
\hline
\end{tabular}

8. Purpose of Project (Jbjectives, Motivations. Approach. Plans and Expected Results)

1) Effective usage of energy.

9. Status and Results

Services started from May 1976.

This project is: $\square$ planned $\square$ in-progress $\square$ ]

Use Box No 16 if additional space is needed

10. Utility Services

$\square$ electrical power

잔 space heatıng

space cooling

$\square$ wastewater treatment

$\square$ potable hot water

a jolid waste processing

$\square$ potable water

public $\mathrm{X}$ private

12. Exchange of data 


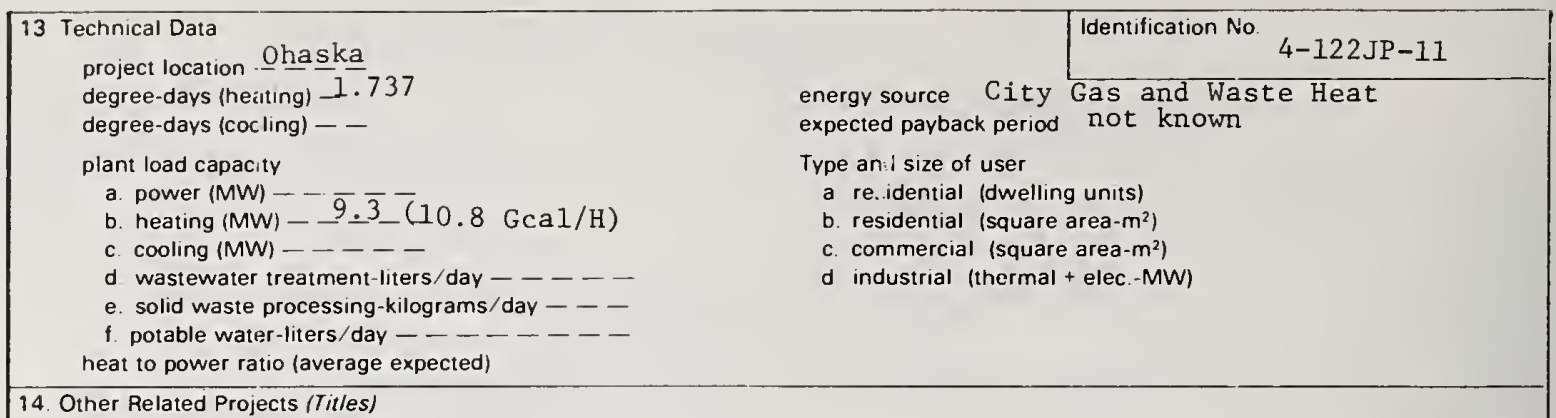

15. Additional space for Purpose of Project

16. Additional space for Status and Results 


\begin{tabular}{|c|c|c|}
\hline PROJECT SUMMARY FOR & $\begin{array}{l}\text { RTMENT OF COMMERCE } \\
\text { IONAL BUREAU OF STANDARDS } \\
\text { M }\end{array}$ & $\begin{array}{l}\text { Identification No } \\
\text { (Secretariat Use Only) } \\
4-123 \mathrm{JP}-12\end{array}$ \\
\hline $\begin{array}{l}\text { 1. Title of Project (Otficial Title) } \\
\text { Chiba Kaihin New Town (Kemigawa Area) }\end{array}$ & Plant & $\begin{array}{l}\text { 2. Date (Form Completed) } \\
\text { March } 1977\end{array}$ \\
\hline $\begin{array}{l}\text { 3. rerforming Organization (Complete Mailing Address) } \\
\text { Keiyo Toshi Service Co., LTD. } \\
\text { No. 1, 4-Chome Masuna Chiba-City } \\
\text { Chiba Prefecture, Japan }\end{array}$ & $\begin{array}{l}4 \text { Principal Investigator } / 1 \\
\text { Keiyo Toshi Sel } \\
\text { No. 1. 4-Chome } \\
\text { Chiba Prefectur }\end{array}$ & $\begin{array}{l}\text { Vame and Complete Mailing Address) } \\
\text { rvice Co., LTD. } \\
\text { Masuna Chiba-City. } \\
\text { re, Japan }\end{array}$ \\
\hline $\begin{array}{l}\text { 5. Supporting Organization (Complete Mailing Address and Name of } \\
\text { Contact) }\end{array}$ & $\begin{array}{l}\text { 6. Duration of Investigatic } \\
1972 \text { to }\end{array}$ & $\begin{array}{l}\text { on (Beginning and ending) } \\
1973\end{array}$ \\
\hline Mistui \& Co., LTD. & $\begin{array}{l}\text { 7. Estimated Funding and } \\
\text { NA }\end{array}$ & Manpower (Monies and Manyears) \\
\hline
\end{tabular}

1) Effective usage of energy

9. Status and Results

Service started from April 1974.

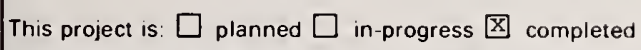
Use Box No 16 if additional space is needed

10. Utility Services

$\square$ electrical power

space heatıng

$\square$ space cooling

$\square$ potable hot water

12. Exchange of data

wastewater treatment

solid waste processing

$\square$ potable water 


\section{Technical Data}

project location -- Chiba City

degree-days (heating) $-1,971$

degree-days (cocling) - -

plant load capacity
a. power (MW) - I 8.0 ( $21 \mathrm{Gca} 1 / \mathrm{H})$
c. cooling (MW) - .....
d. wastewater treatment-liters/day - $-\ldots$
e. solid waste processıng-kilograms/day - -
f. potable water-liters/day $-\ldots \ldots \ldots$
heat to power ratio (average expected)

14. Other Related Projects (Titles)

15. Additional space for Purpose of Project

16. Additional space for Status and Results 


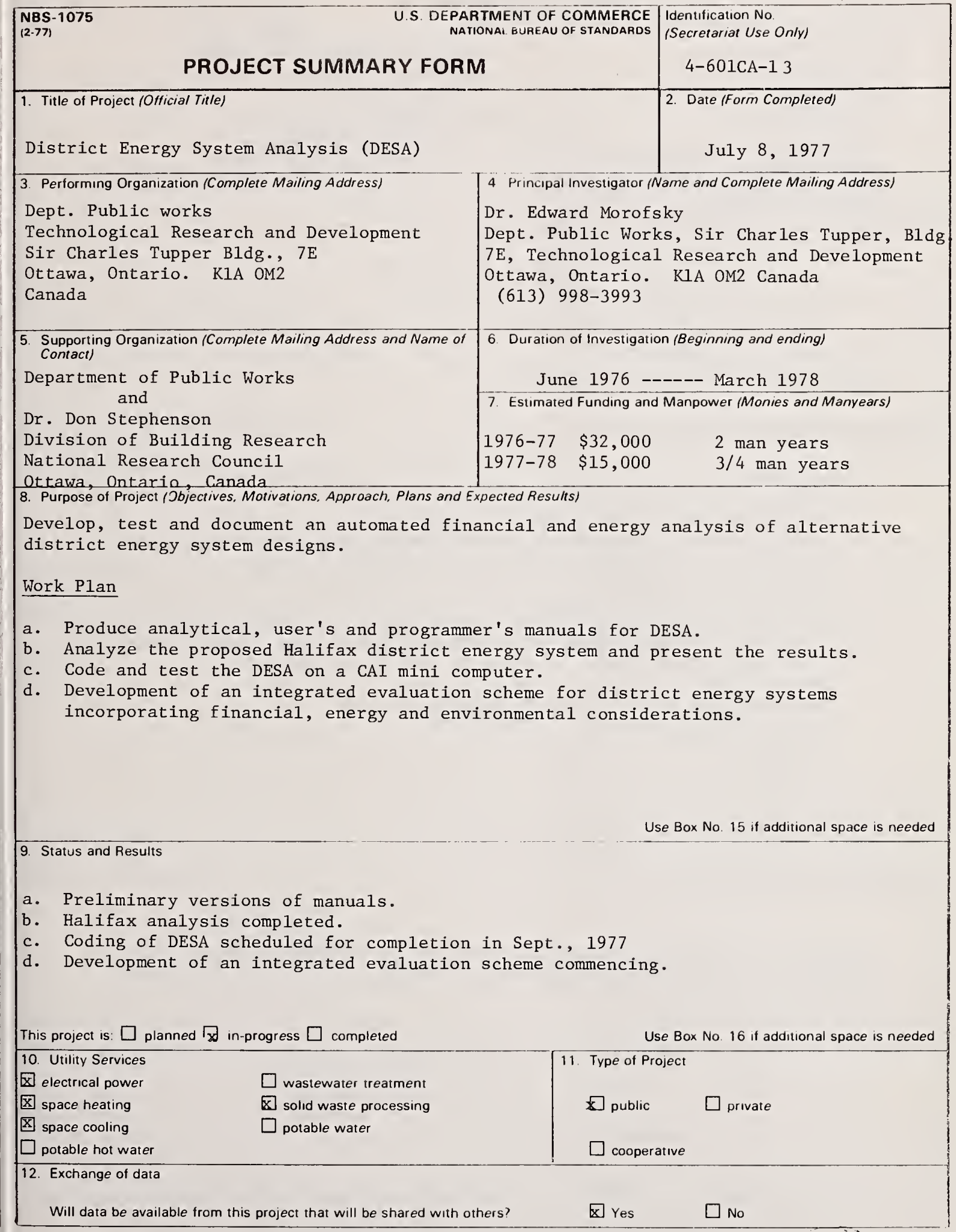




\begin{tabular}{|l|l|}
\hline 13 Technical Data & Identification No. \\
project location \\
degree-days (heatıng) \\
degree-days (cocling) -
\end{tabular}

14. Other Related Projects (Titles)

Halifax District Heating Study

Ottawa Master Plan Simulation Model

15. Additional space for Purpose of Project

\section{Publications}

a) Morofsky, E.L. (1976) A basis for a general distric energy system analysis (DESA) for Canadian cities, TR\&D Report, Aug.

b) Morofsky, E.L. (1976) An ecological framework for evaluating the urban impact of district energy systems, TR\&D Report, Oct.

c) Morofsky, E.L. (1977) Evaluating Distinct Energy Systems, 7 th CIB Congress, Edinburgh, Scotland, Sept.

d) Morofsky, E.L. (1977) District Energy Options and Urban Impacts, Economic Commission of Europe, Seminar on the Impact of Energy Considerations on the Planning and Development of Human Settlements, Ottawa, Oct.

e) DESA Analytical Manual

DESA User's Manual

DESA Programer's Manual

preliminary drafts

Spring 1977

f) Financial and energy evaluation of the proposed Halifax District Heating System.

Publications a-d are available from the author - a limited number of e and $f$ will be available in the autumn of 1977 .

16. Additional space for Status and Results

Principal investigator would appreciate receiving technical and financial information on other urban related energy projects and is willing to supply details of his own projects. 


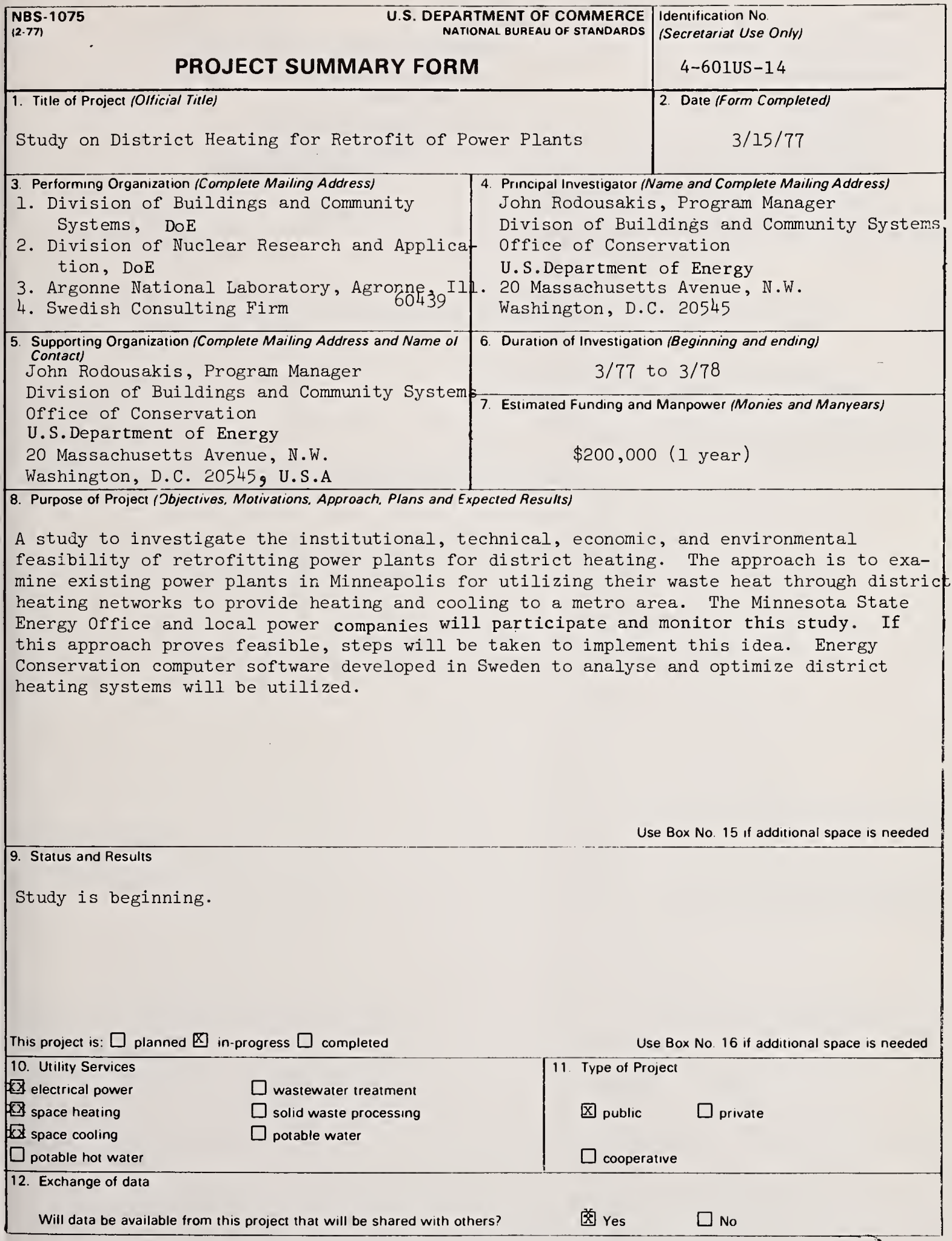




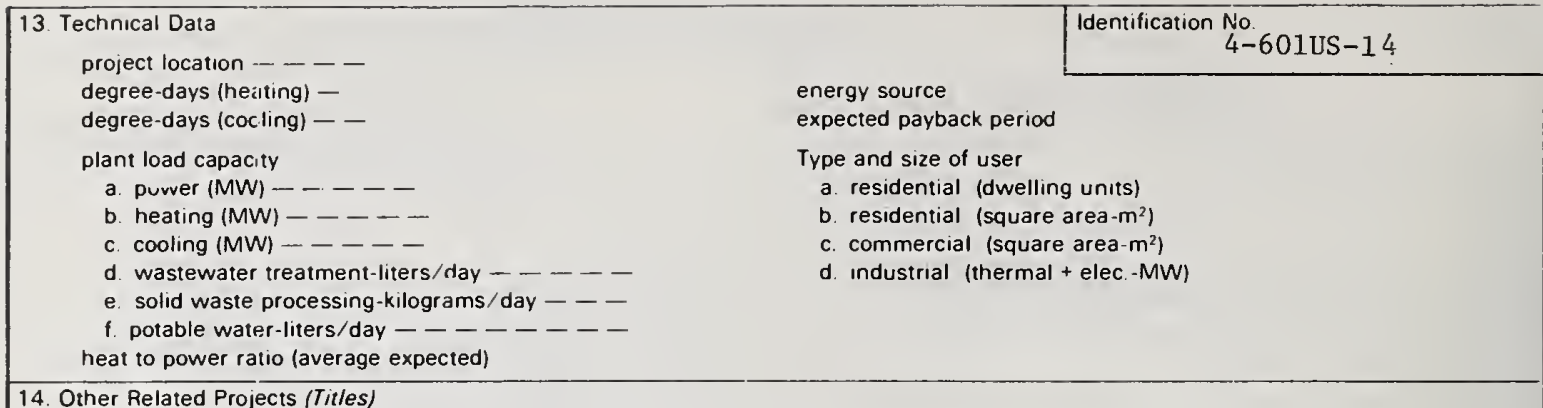

14. Other Related Projects (Tit/es)

15. Additional space for Purpose of Project 


NBS-1075 U.S. DEPARTMENT OF COMMERCE
(2-77)

PROJECT SUMMARY FORM

1. Title of Project (Official Title)

Performance of District Heating Schemes (907)
Identification No

(Secretariat Use Only)

\section{4-602GB-1 5}

2 Date (Form Completed)

$3 / 15 / 77$
3. Performing Organization (Complete Mailing Address)

Heating and Ventilation Research Association

Old Bracknell Lane

Bracknel1, Berks

England

5. Supporting Organization (Complete Mailing Address and Name of Contact)

Building Research Establishment

Bucknells Lane

Garston

Watford WD27JR,

England

8. Purpose of Project (Objectives, Motivations, Approach, Plans and Expected Results)
4 Principal Investigator (Name and Complete Mailing Address)

P. Jackman

Heating and Ventilation Restarch

Association

Old Brackne11 Lane

Bracknell, Berks

England

6. Duration of Investigation (Beginning and ending)

NA

7. Estimated Funding and Manpower (Monies and Manyears)

A field study of selected district heating schemes with the aim of comparing the predicted and actual demand for heat.

9. Status and Results

This project is: $\square$ planned $\square$ in-progress $\square$ completed

\section{Utility Services}

$\square$ electrical power

\$ space heating

$\square$ space cooling

$\square$ potable hot water

12. Exchange of data $\square$ wastewater treatment

$\square$ solid waste processing

$\square$ potable water

Use Box No. 16 if additional space is needed

11. Type of Project

国 public $\square$ private

cooperative 


\begin{tabular}{|c|c|}
\hline $\begin{array}{l}13 \text { Technical Data } \\
\text { project location }\end{array}$ & $\begin{array}{l}\text { Identification No. } \\
4-602 \mathrm{~GB}-15\end{array}$ \\
\hline $\begin{array}{l}\text { degree-days (heating) - } \\
\text { degree-days (cocling) - }\end{array}$ & $\begin{array}{l}\text { energy source } \\
\text { expected payback perıod }\end{array}$ \\
\hline $\begin{array}{l}\text { plant load capacity } \\
\text { a. power (MW) }- \\
\text { b. heatıng (MW) } \\
\text { c. cooling (MW) }- \\
\text { d. wastewater treatment-liters/day }-- \\
\text { e. solid waste processing-kilograms/day }- \\
\text { f. potable water-liters/day }-- \\
\text { heat to power ratio (average expected) }\end{array}$ & 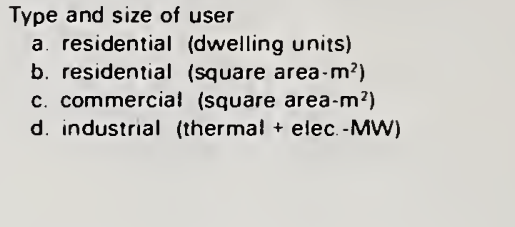 \\
\hline
\end{tabular}

14. Other Related Projects (Titles)

15. Additional space for Purpose of Project

16. Additional space for Status and Results 


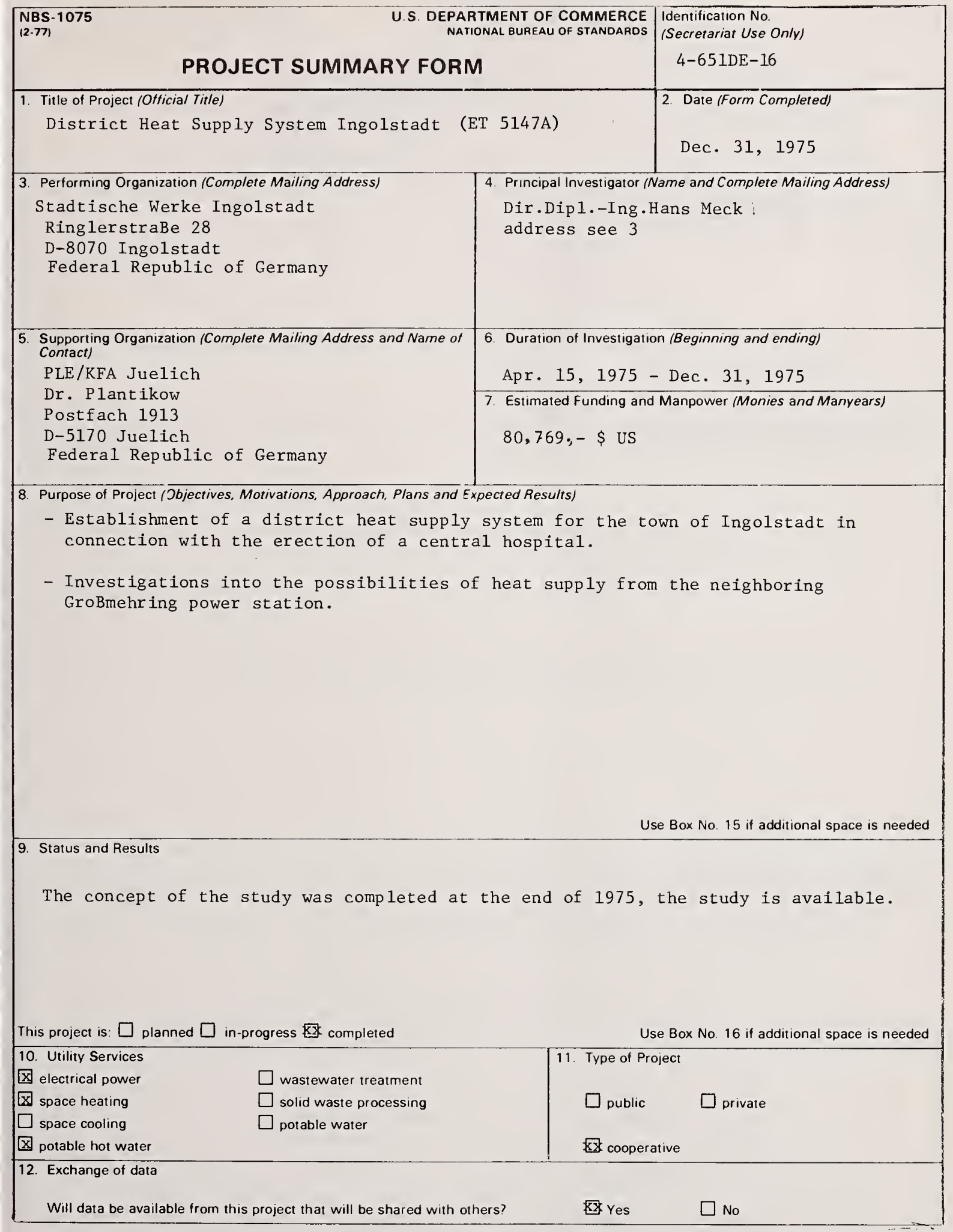




\begin{tabular}{|c|c|}
\hline $\begin{array}{l}13 \text { Technical Data } \\
\text { project location }-\ldots---\end{array}$ & Identification No. $4-651$ DE- 16 \\
\hline $\begin{array}{l}\text { degree-days (heitting) - } \\
\text { degree-days (cocling) - - }\end{array}$ & $\begin{array}{l}\text { energy source } \\
\text { expected payback period }\end{array}$ \\
\hline 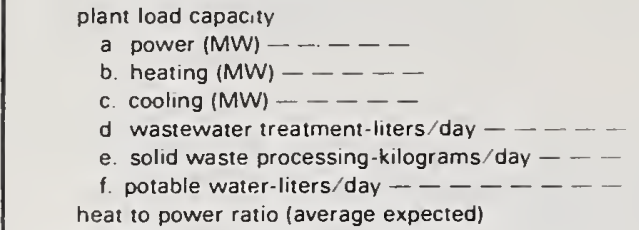 & $\begin{array}{l}\text { Type and size of user } \\
\text { a. residential (dwelling unıts) } \\
\text { b. residentıal (square area-m²) } \\
\text { c. commercial (square area-m²) } \\
\text { d. Industrial (thermal + elec.-MW) }\end{array}$ \\
\hline
\end{tabular}

14. Other Related Projects (Titles)

15. Additional space for Purpose of Project 


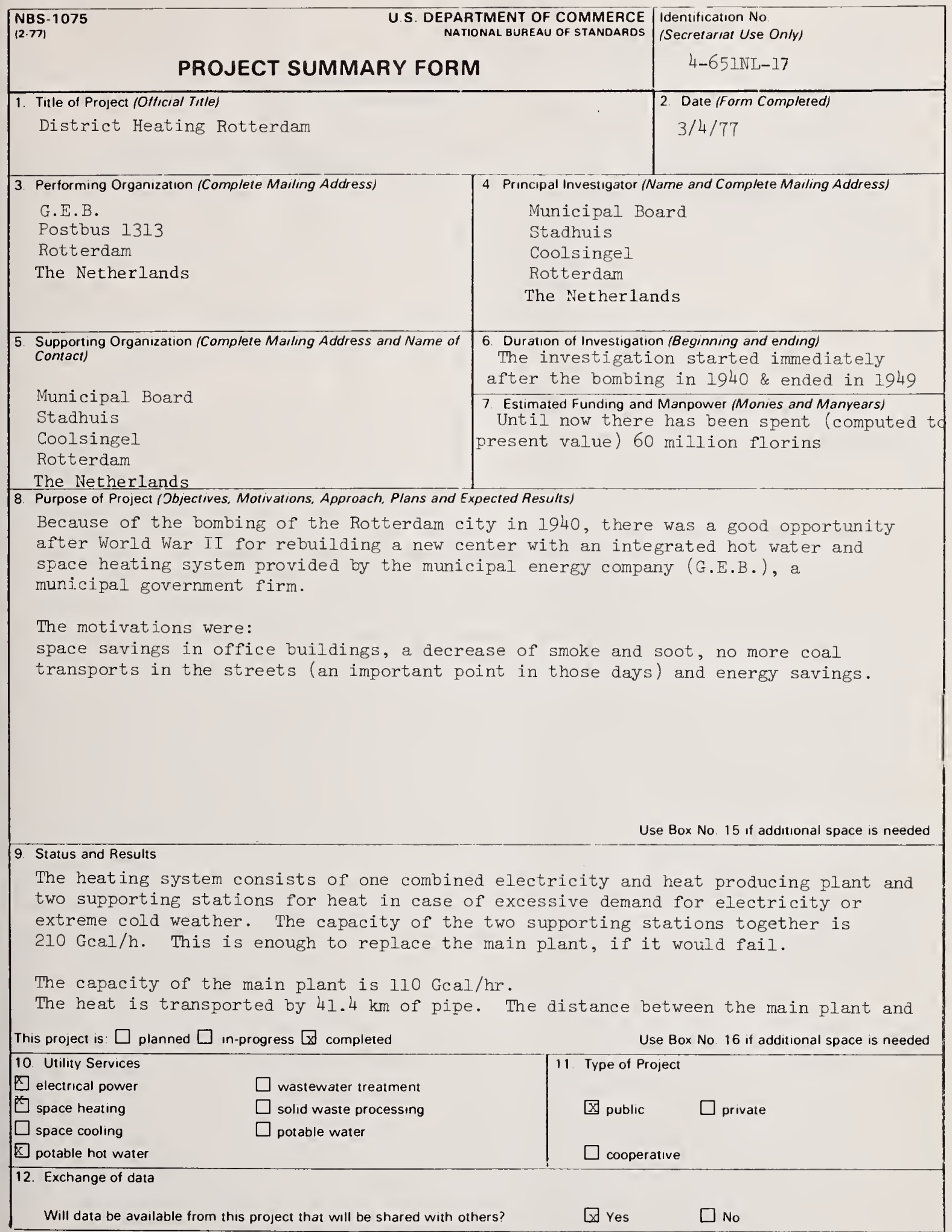


13 Technical Data

project location -- -
degree-days (heating)
degree-days (cocling)

Schiehaven Rotterdam $2786 *$

plant load capacity

a. power (MW) - 189 (main plant only)

b. heating (MW) -550 (a)1 together)

c. cooling (MW) -

f. potable water-liters/day $-\ldots-\ldots-\ldots$ heat to power ratio (average expected) *Refer to note 2 , table 2-9. dentification No.

\section{4-65INL-17}

energy source

expected payback period

Type and size of user $161,040 \mathrm{GJ}$

a. residential (dwelling units) 2941

b. residential (square area- $\mathrm{m}^{2}$ )

c. commercial (square area- $m^{2}$ )

d. industrial (thermal + elec.-MW) $1,349,0670$ GJ

14. Other Related Projects (Titles)

15. Additional space for Purpose of Project

16. Additional space for Status and Results

the consumers area is variating from $2.5 \mathrm{~km}$ to $5.5 \mathrm{~km}$. The water temperature can change between $105^{\circ} \mathrm{C}$ to $140^{\circ} \mathrm{C}$. 


\begin{tabular}{|c|c|c|}
\hline $\begin{array}{r}\text { U.S. DEPAI } \\
\text { PROT } \\
\text { PROJECT SUMMARY FORI }\end{array}$ & $\begin{array}{l}\text { TMENT OF COMMERCE } \\
\text { ONAL BUREAU OF STANDARDS } \\
\mathbf{n}\end{array}$ & $\begin{array}{l}\text { Identification No } \\
\text { (Secretariat Use Only) } \\
4-672 \mathrm{NL}-18\end{array}$ \\
\hline $\begin{array}{l}\text { 1. Title of Project (Official Tit/e) } \\
\text { District heating of the city of Utrecht }\end{array}$ & olland) & $\begin{array}{c}2 \text { Date (Form Completed) } \\
3 / 15 / 77\end{array}$ \\
\hline $\begin{array}{l}\text { 3. Performing Organization (Complete Mailing Address) } \\
\text { N.V.PEGUS } \\
\text { Keulsekade } 189 \\
\text { Utrecht } \\
\text { Holland }\end{array}$ & $\begin{array}{l}4 \text { Principal Investigator } \\
\text { Ir. J.C.Resing } \\
\text { N.V.PEGUS } \\
\text { Keulsekade } 189 \\
\text { Utrecht } \\
\text { Holland }\end{array}$ & 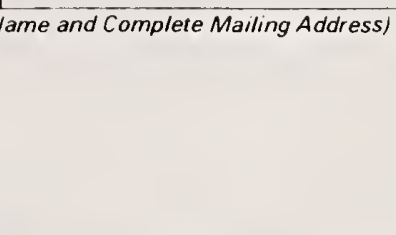 \\
\hline $\begin{array}{l}\text { 5. Supporting Organization (Complete Mailing Address and Name of } \\
\text { Contact) } \\
\text { Ir. J.C.Resing } \\
\text { N.V.PEGUS } \\
\text { Keulsekade } 189 \\
\text { Utrecht } \\
\text { Holland }\end{array}$ & $\begin{array}{l}\text { 6. Duration of Investigati } \\
\text { January } 1923 \text { - } \\
\text { 7. Estımated Funding anc } \\
\text { Not determ }\end{array}$ & $\begin{array}{l}\text { inknown } \\
\text { Manpower (Monies and Manyears) } \\
\text { ined }\end{array}$ \\
\hline
\end{tabular}

The district heating of the PEGUS at Utrecht originally started in the year of 1923 with a low-pressure steamnetwork ( $3 \mathrm{ata}$ ). All expansions after the year 1927 have been made in accordance with the low-pressure (maximum 6 ata) and low-temperature (maximum $100^{\circ} \mathrm{C}$ ) water-system. The basic principle of the Pegus-district heating is the operation of conventional (fossil-fuelled) steam turbines for combined electricity and heat production and the primary energy saving by combined production of both electricity and heat by one production plant. The combined production of both electricity and heat takes place with back pressure turbines in the power station "Nicolaas Beets-straat", where the main purpose is heat production, and electricity production is a by-product and in the power stations "Merwedekanaal" and "Lage Weide" by means of condensing turbines with district heating extraction, where the main product is electricity and heat is a by-product. More over there are 4 auxiliary stations with simple warm water boilers installed in the centre or the outskirt of the two supply-areas for regulation of the production during the peakload of the heat-supply. As the peakload of the heat-supply only takes place during a few hours in the heating season, ust will pot be economical to install the whole heat production capacity.

9. Status and Results

The status and the results for the heating season 1974/75 (September up to and including May) are as follows:

1. Connected heat load

2. Maximum heat load

3. Heat production in

a. Power and heat supply stations

b. Auxiliary heat supply stations

This project is: $\square$ planned $\square$ in-progress $\square$ completed 


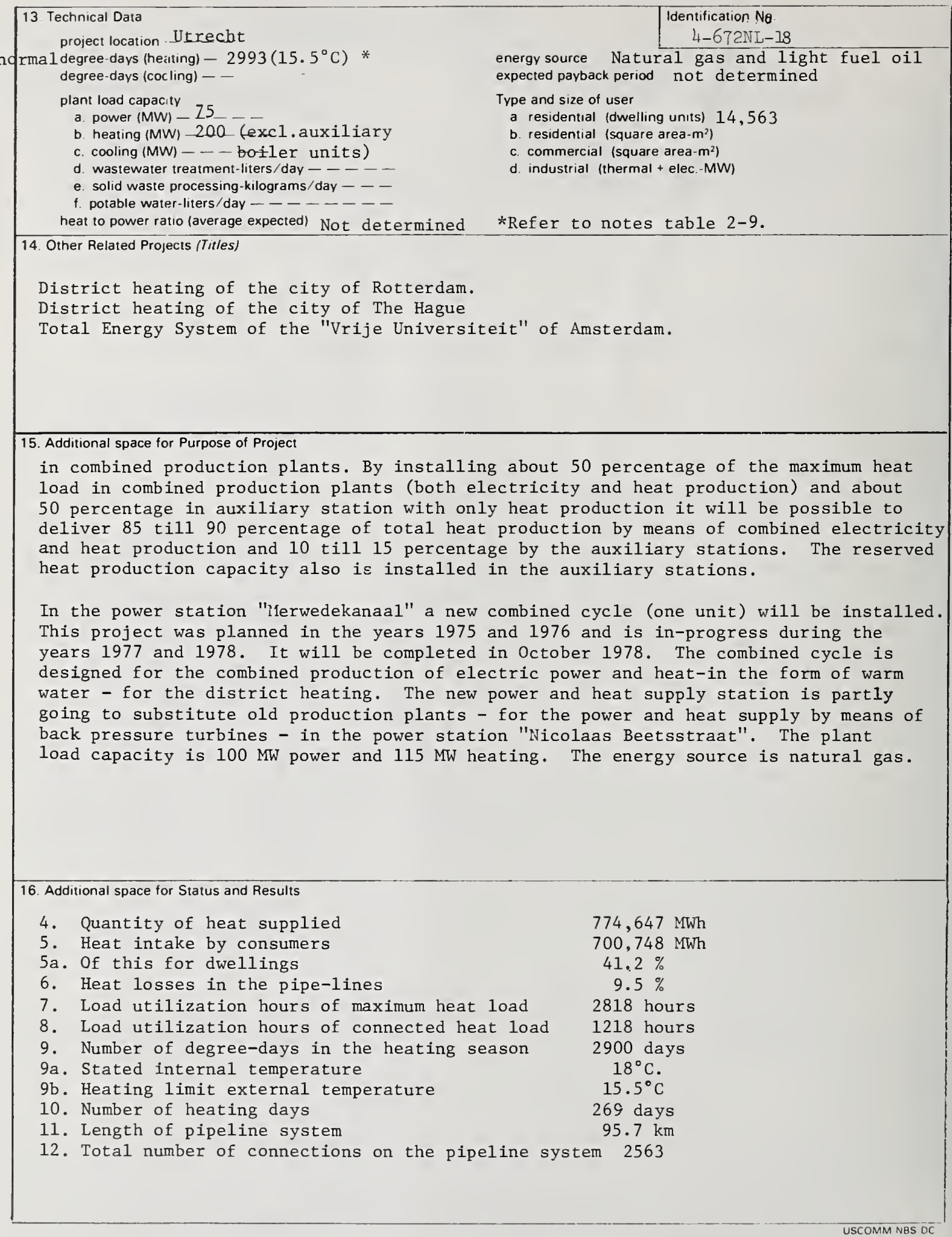


U.S. DEPARTMENT OF COMMERCE Identification No

\section{PROJECT SUMMARY FORM}

1. Title of Project (Official Title)

Installation of a heat-pump plant for the production of heat and warm water for residential bldgs. (ET 5084)

3. Performing Organization (Complete Mailing Address)

Vereinigte Esslinger

Wohnungsunternehmer $\mathrm{GmbH}$

Postfach 822

4300 Esslingen

Federal Republic of Germany
5. Supporting Organization (Complete Mailing Address and Name of Contact)

PLE/KFA Juelich

Dr. Plantikow

Postfach 1913

D-5170 Juelich

Federal Republic of Germany
4 Principal Investigator (Name and Complete Mailing Address) E. Arnold (BMFT)

8. Purpose of Project (Jbjectives. Motivations, Approach, Plans and Expected Results)

Gaining of practical experience in heating of residential complexes with new heating systems and use of heat pumps.

The measurement and evaluation program of the Forschungsstelle fur Energiewirtschaft, Munich, will be extended. It is planned that the extra energy requirements (electricify, water, heat) for the residences and commercial premises in the area will be satisfied.

Use Box No. 15 if additional space is needed

\section{Status and Results}

With the exception of the setting up of the measuring equipment (extension to the original program), work on the heat-pump plant has been completed by the Energiewirtschaft, Munich. The heat-pump plant was set in operation in April, 1976, and the measuring program was begun in October 1976.

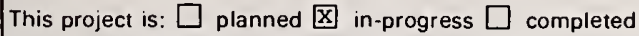
Use Box No. 16 if additional space is needed

10. Utility Services

$\square$ electrical power

WX space heatıng

wastewater treatment

$\square$ space cooling

$\square$ solid waste processing

$\square$ potable water

$\square$ potable hot water

12. Exchange of data 
project location -. - -

degree-days (heatting)

energy source

degree-days (coclıng) - -

expected payback period

plant load capactty

a. power (MW) - $\ldots$

Type and size of user

b. heating (MW) ----

c. cooling (MW) -

a. residential (dwelling units)

b. residential (square area- $\mathrm{m}^{2}$ )

d. wastewater treatment-liters/day - - - -

e. solid waste processing-kilograms/day _ - -

c. commercial (square area- $\mathrm{m}^{2}$ )

d. industrial (thermal + elec. $-\mathrm{MW}$ )

f. potable water-liters/day - - - - - heat to power ratio (average expected)

14. Other Related Projects (Titles)

15. Additional space for Purpose of Project

16. Additional space for Status and Results 
$\begin{aligned} & \text { NBS-1075 } \\ & (2-77)\end{aligned}$
U.S. DEPARTMENT OF COMMERCE
NATIONAL BUREAU OF STANDARDS

\section{PROJECT SUMMARY FORM}

1. Title of Project (Official Title)

Extraction of Heat from River by Heat Fump - Esslingen
Identification No.

(Secretariat Use Only)
3. Performing Organization (Complete Mailing Address)

Bundesministerium fur Forschung und Technologie

Stresemannstrasse 10

5300 Bonn-Bad Godesberg

Federal Republic of Germany
5-101US-02

2. Date (Form Completed)

\section{$3 / 15 / 77$}

4. Principal Investigator (Name and Complete Mailing Address) NA

5. Supporting Organization (Complete Mailing Address and Name of Contact)

1. Bundesministerium fur Forschung und Technologie

2. U.S.Department of Energy Washington, D.C. U.S.A. Mr. Steve Cavros

6. Duration of Investigation (Beginning and ending) 9/76 to $9 / 77$ approx.

7. Estimated Funding and Manpower (Monies and Manvears)

NA

8. Purpose of Project (Objectives, Motivations, Approach, Plans and Expected Results)

This project is testing the extraction of heat from a river near Esslingen using water-to-water heat pumps to supply heating to 2 high rise buildings. Heat is obtained from upstream power plants. There are three types of heating system in the high-rise building being examined, a radiator system, a floor type of radiator system, and an air system.

Use Box No. 15 if additional space is needed

9. Status and Results

A report will be available $9 / 76$

This project is: $\square$ planned $\mathrm{X}$ in-progress $\square$ completed Use Box No 16 if additional space is needed

$\begin{array}{ll}\text { 10. Utility Services } & \square \text { wastewater treatment } \\ \square \text { electrical power } & \square \text { solid waste processing } \\ \square \text { space heating } & \square \text { potable water } \\ \square \text { space coolıng } & \\ \square \text { potable hot water } & \end{array}$

Dotable hor water

12. Exchange of data

Will data be available from this project that will be shared with others?

X Yes $\square$ No 


\begin{tabular}{|c|c|c|}
\hline $\begin{array}{l}\text { 13. Technical Data } \\
\text { project location } \ldots \ldots \ldots\end{array}$ & Identification No. & $5-101 U S-02$ \\
\hline $\begin{array}{l}\text { degree-days (heating) - } \\
\text { degree-days (cocling) - - }\end{array}$ & $\begin{array}{l}\text { energy source } \\
\text { expected payback period }\end{array}$ & \\
\hline 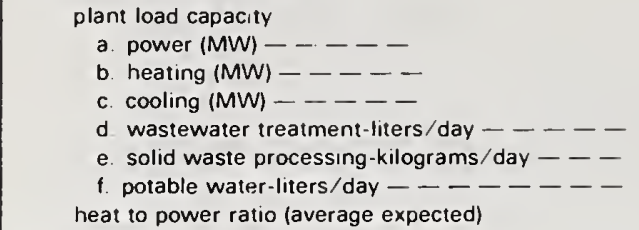 & $\begin{array}{l}\text { Type and size of user } \\
\text { a. residential (dwelling units) } \\
\text { b. residential (square area }-\mathrm{m}^{2} \text { ) } \\
\text { c. commercial (square area- } \mathrm{m}^{2} \text { ) } \\
\text { d. industrial (thermal + elec.-MW) }\end{array}$ & \\
\hline
\end{tabular}

14. Other Related Projects (Titles)

15. Additional space for Purpose of Project

16. Additional space for Status and Results 


\begin{tabular}{|c|c|c|c|}
\hline \multicolumn{3}{|l|}{$\begin{array}{l}\text { NBS-1075 } \\
(2-77)\end{array}$} & $\begin{array}{l}\text { Identification No. } \\
\text { (Secretariat Use On(y) } \\
5-102 \mathrm{FR}-03\end{array}$ \\
\hline $\begin{array}{l}\text { 3. Performing Organization (Complete Mailing Address) } \\
\text { TECHNIP } \\
232 \text {, Avenue Napoleon Bonaparte } \\
92500 \text { - Rueil-Malmaison } \\
\text { France }\end{array}$ & \multicolumn{3}{|c|}{$\begin{array}{l}\text { 4. Principal Investigator (Name and Complete Mailing Address) } \\
\text { J.M. Bourguet, Manager } \\
\text { TECHNIP Power Division } \\
\text { TECHNIP } \\
232 \text {, Avenue Napoleon Bonaparte } \\
92500 \text { - Rueil-Malmaison } \\
\text { France }\end{array}$} \\
\hline \multicolumn{4}{|c|}{$\begin{array}{l}\text { sults) } \\
\text { Use Box No. } 15 \text { if additional space is needed }\end{array}$} \\
\hline \multicolumn{4}{|c|}{$\begin{array}{l}\text { 9. Status and Results } \\
\text { Realized modification: hot water system and preheater of combustion air. } \\
\text { Pay-out of hot water system: } 2 \text { years } \\
\text { Pay-out of furnaces modification: } 8 \text { years } \\
\text { This project is: } \square \text { planned } \square \text { in-progress } \square \text { completed }\end{array}$} \\
\hline $\begin{array}{l}10 . \text { Utility Services } \\
\square \text { electrical power } \\
\otimes \text { space heating } \\
\square \text { space cooling } \\
\square \text { potable hot water }\end{array}$ & & 11. Type of Pro & $\mathbb{X}$ private \\
\hline 12. Exchange of data & & & \\
\hline
\end{tabular}


13. Technical Data

project location -

degree-days (heating) -

degree-days (cocling) - -

plant load capacity

a. power (MW) - - - -

b. heating $(M W)-\ldots$

c. cooling (MW) $-\ldots$

d. wastewater treatment-liters/day $--\ldots$

e. solid waste processing-kilograms/day - - -

f. potable water-liters/day -------

heat to power ratıo (average expected)

14. Other Related Projects (Titles)

15. Additional space for Purpose of Project
Identification No

5-102FR-03

energy source

expected payback period

Type and size of user

a. residential (dwelling units)

b. residential (square area- $m^{2}$ )

c. commercial (square area- $\mathrm{m}^{2}$ )

d. Industrial (thermal + elec.-MW)

16. Additional space for Status and Results 


\begin{tabular}{|c|c|c|}
\hline \multicolumn{2}{|l|}{$\begin{array}{l}\text { NBS-1075 } \\
(2-77)\end{array}$} & $\begin{array}{l}\text { Identification No. } \\
\text { (Secretariat Use On/y) } \\
5-102 \mathrm{FR}-04\end{array}$ \\
\hline $\begin{array}{l}\text { 8. Purpose of Project (Objectives, Motivations, Approach, Plans and } \\
\text { Heating system for a surface of buildings } \\
\text { for the whole buildings (11,200 m2). } \\
\text { Estimated surface of solar cells: } 262 \mathrm{~m} 2 \\
\text { Hot water storage: } 20 \mathrm{~m} 3 \\
\text { Yearly saving: } 93280 \mathrm{kWh} \\
\text { Insolator: COULET type } \\
\text { General design: TECHNIP Power Division }\end{array}$ & of $800 \mathrm{~m} 2$, and sa & Box 15 if additional space is needed \\
\hline This project is: $\square$ planned $\square$ in-progress $\square$ completed & & se Box No. 16 if additional space is needed \\
\hline $\begin{array}{ll}10 . & \text { Utility Services } \\
\square \text { electrical power } & \square \text { wastewater treatment } \\
\square] \text { space heating } & \square \text { solid waste processing } \\
\square \text { space cooling } & \square \text { potable water } \\
\mathbf{D} \text { potable hot water } & \end{array}$ & $\begin{array}{l}\text { 11. Type of Pre } \\
\square \text { public } \\
\square \text { cooper }\end{array}$ & Q private \\
\hline Will data be available from this project that will be shared witt & $\square$ Yes & No \\
\hline
\end{tabular}


project location - - - -

degree-days (heating) -

degree-days (cocling) - -

plant load capacity

a. power (MW) - - - -

b. heating (MW) - .... -

c cooling (MW) - $-\ldots$

d. wastewater treatment-liters/day _ _ _ -

e. solid waste processing-kilograms/day - -

f potable water-liters/day $-\ldots \ldots \ldots-\ldots$

heat to power ratio (average expected) energy source

expected payback period

Type and size of user

a. residential (dwelling units)

b. residential (square area $-\mathrm{m}^{2}$ )

c. commercial (square area $-\mathrm{m}^{2}$ )

d. industrial (thermal + elec.-MW)

14. Other Related Projects (Titles)

15. Additional space for Purpose of Project

16 Additional space for Status and Results 


\begin{tabular}{|c|c|c|}
\hline \multicolumn{2}{|l|}{ PROJECT SUMMARY FORM } & $\begin{array}{l}\text { Identification No } \\
\text { (Secretariat Use Only) } \\
5-102 \mathrm{~GB}-05\end{array}$ \\
\hline $\begin{array}{l}\text { 8. Purpose of Project / Objectives, Motivations, Approach, Plans and } \\
\text { Following encouraging tests on a } 4 \mathrm{~km} \mathrm{lo} \\
\text { it is proposed to inject polymer into a } \\
\text { flow. The sewer, which serves Stockwood } \\
\text { of the golf course. Further development } \\
\text { necessitate a sewer duplication, which w } \\
\text { polymer dosing is successful. }\end{array}$ & $\begin{array}{l}200 \mathrm{~mm} \text { sludge } \\
\text { wer at Knowle } \mathrm{G} \\
\text { surcharges and } \\
200 \text { houses) is } \\
1 \text { be avoided, or }\end{array}$ & $\begin{array}{l}\text { mping main at Avonmouth, } \\
\text { f Course at times of peak } \\
\text { uses foul water flooding } \\
\text { minent, and would normally } \\
\text { at least deferred, if }\end{array}$ \\
\hline
\end{tabular}

Use Box No. 15 if additional space is needed

9. Status and Results

This project is: $\square$ planned $\square$ in-progress completed

Use Box No. 16 if additional space is needed

10. Utility Services

$\square$ electrical power

space heatıng

space cooling

potable hot water

12. Exchange of data
X wastewater treatment

$\square$ solıd waste processing

$\square$ potable water

Will data be avallable from this project that will be shared with others?

Yes

No $[\mathrm{x}]$ Unknown 
13. Technical Data

project location

degree-days (cocling)

plant load capacity

a. power $(\mathrm{MW})-\ldots \ldots$

b. heating (MW) $-\ldots-\ldots$

c. cooling (MW) - - - -

d. wastewater treatment-liters/day - _ - - -

e. solid waste processing-kilograms/day - - -

f. potable water-liters/day _ _ _ _ - _ heat to power ratıo (average expected)

14. Other Related Projects (Tirles)

15. Additional space for Purpose of Project

energy source

expected payback period

Type and size of user

a. residential (dwelling units)

b. residential (square area $-\mathrm{m}^{2}$ )

c. commercial (square area $-\mathrm{m}^{2}$ )

d. industrial (thermal + elec.-MW) 


$\begin{aligned} & \text { NBS-1075 } \\ & (2-77)\end{aligned}$
US DEPARTMENT OF COMMERCE
NATIONAL BUREAU OF STANDARDS

PROJECT SUMMARY FORM

1. Title of Project (Official Tit/e)

Alternative Sources of Energy for Buildings (922)

4. Principal Investigator (Name and Complete Mailing Address)

3. Performing Organization (Complete Mailing Address)

Plymouth Polytechnic

Construction Studies Group

Drake Circus, Plymouth, Devon

England

\section{Supporting Organization (Complete Mailing Address and Name of Contact)}

Plymouth Polytechnic

Construction Studies Group

Drake Circus, Plymouth, Devon

England

8. Purpose of Project ( Objectives. Motivations. Approach, Plans and Expected Resu/ts)

To investigate the viability of alternative sources of energy for spaces and water heating. Projects are looking at the use of solar energy in a domestic, community and industrial situation. A study is also made of the hydro-electric potential of the streams on Dartmoor.

9. Status and Results

Metherall

Rendel

Polytechnic

Construction Studies Group

Drake Circus, Plymouth, Devon, England

6. Duration of Investigation (Beginning and ending)

$$
10 / 75 \text { to } 10 / 78
$$

$$
5,000
$$


13. Technical Data

project location ... - - -

degree-days (heäıng) -

energy source

degree-days (cocling)

expected payback period

Jlant load capacity

a. power $(\mathrm{MW})-\ldots$

Type and size of user

b. heating (MW) $-\ldots-\ldots$

c. cooling (MW) $-\ldots-\ldots$

d. wastewater treatment-liters/day _ - - -

e. solid waste processing-kilograms/day _ -

f. potable water-liters/day - - - - - heat to power ratio (average expected)

14. Other Related Projects (Tit/es)

15. Additional space for Purpose of Project

a residential (dwelling units)

b. residential (square area- $\mathrm{m}^{2}$ )

c. commercial (square area- $\mathrm{m}^{2}$ )

d Industrial (thermal + elec.-MW)

16. Additional space for Status and Results 
Identification No.

(Secretariat Use Only)

PROJECT SUMMARY FORM 5-103DE-07

1. Title of Project (Officral Title)

2. Date (Form Completed)

System study "Electric Bulk Power Transmission"

(ET 4042A)

Dec. 31, 1975

3. Performing Organization (Complete Mailing Address)

4 Principal Investigator (Name and Complete Mailing Address)

Forschungsgemeinschaft fur Hochspannungs und Hochstromtechnik e.V.

68 Mannheim-Rheinau

Federal Republic of Germany

5. Supporting Organization (Complete Mailing Address and Name of Contact)

PLE/KFA Juelich

Dr. Plantikow

Postfach 1913

D-517 Juelich

Federal Republic of Germany

8. Purpose of Project (Objectives, Motivations, Approach, Plans and Expected Resu/ts)

Dip1.-Ing.E.Rumpf

address see 3

6. Duration of Investigation (Beginning and ending)

Aug. 26, 1973 - Dec. 31, 1975

7. Estimated Funding and Manpower (Monies and Manyears)

847,294 . \$ US

Starting from the present state of technology, the possibilities of electric power supply in densely populated areas are to be investigated up to the year 2000 and means for a solution are to be worked out.

9. Status and Results

Data available in July 1977

This project is: $\square$ planned $\forall$ in-progress $\square$ completed

Utility Services

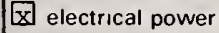

$\square$ space heating

$\square$ space cooling

$\square$ potable hot water

12. Exchange of data

Will data be available from this project that will be shared with others? wast ewater treatment

solid waste processing

potable water
Use Box No 16 if additional space is needed 11. Type of Project
$\square$ public
private

Ex cooperative
Y Yes No 
project location - - - -

degree-days (heating) -

degree-days (cocling) - -

plant load capacity

a. power (MW) - - - -

b. heating (MW) - - -

c. cooling (MW) - - - -

d. wastewater treatment-liters/day - - - -

e. solid waste processing-kilograms/day _ - -

$f$ potable water-liters/day $-\ldots-\ldots-\ldots$

heat to power ratio (average expected)

14. Other Related Projects (Tit/es) energy source

expected payback perıod

Type and size of user

a. residential (dwelling units)

b. residential (square area- $\mathbf{m}^{2}$ )

c. commercial (square area- $\mathrm{m}^{2}$ )

d industrial (thermat + elec.-MW)

15. Additional space for Purpose of Project

6. Additional space for Status and Results 


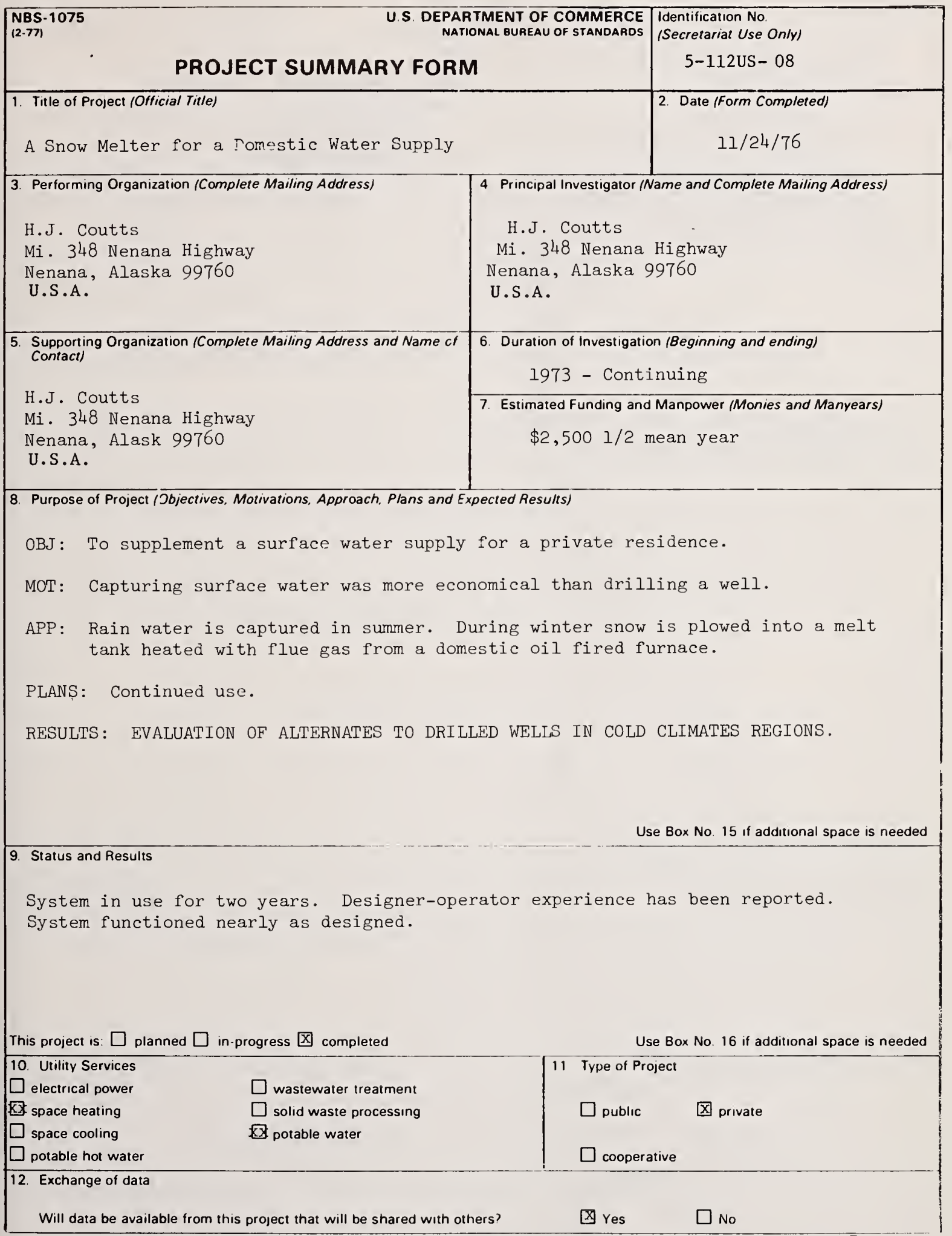


degree-days (cocling) - 0

plant load capacity

a. power (MW) - heating (MW) $-\overline{100,}, \overline{000} \mathrm{Btu} / \mathrm{hr}$.

c. cooling (MW) - - -

d wastewater treatment-liters/day - $-\ldots$

e. solid waste processing-kilograms/day $60-$

f. potable water-liters/day ---160 heat to power ratio (average expected)

14. Other Related Projects (Titles)

\section{None}

energy source

expected payback period

Type and size of user

a. residential (dwelling units)

b. residential (square area- $m^{2}$ ) 45

c. commercial (square area- $\mathrm{m}^{2}$ )

d industrial (thermal + elec. -MW)

15. Additional space for Purpose of Project

16. Additional space for Status and Results 


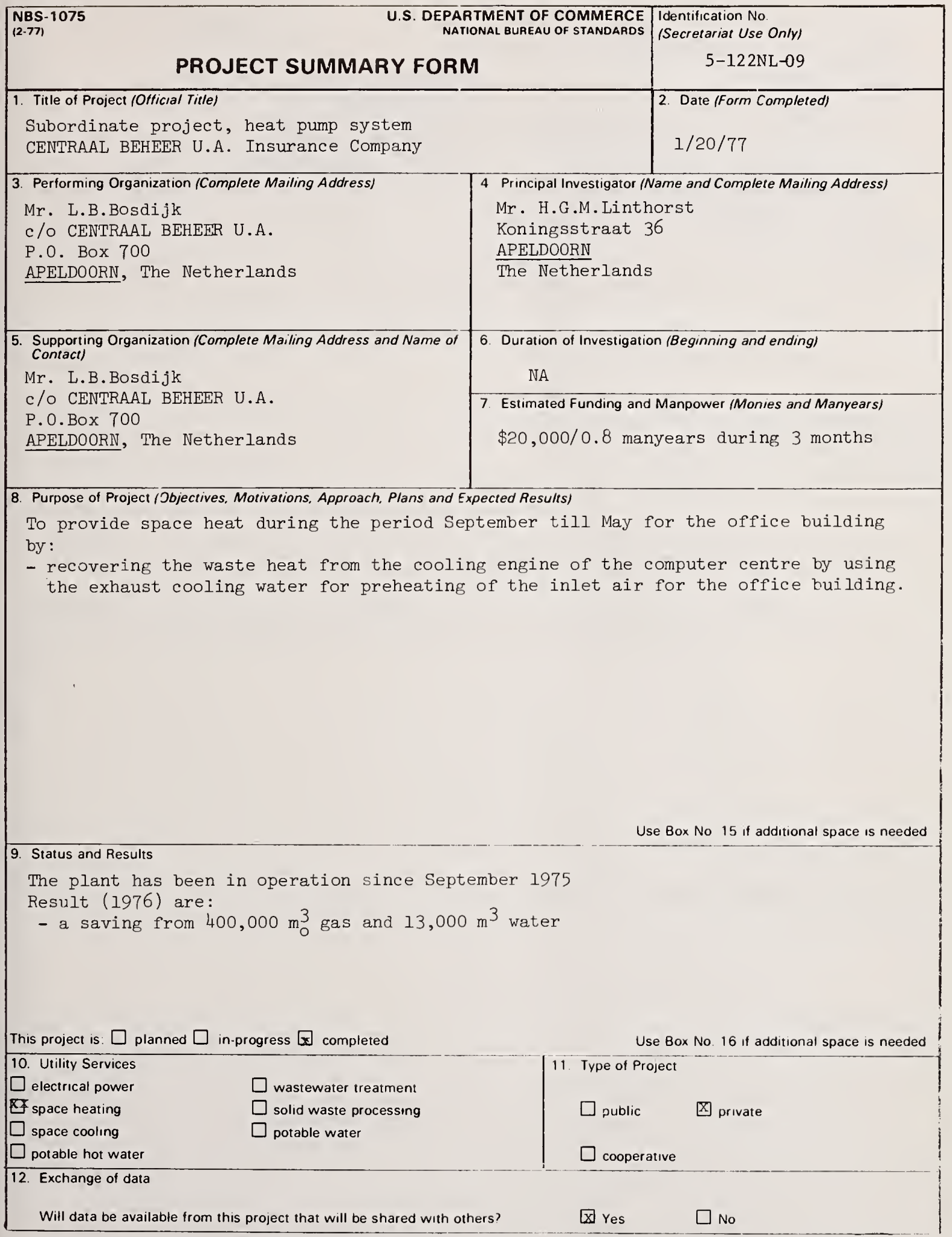


13. Technical Data

project location .

degree-days (heatting)

Apeldoorn

degree-days (cocling) - 125.6 days*

plant load capacity

a. power (MW) - . _ - $65 \mathrm{~kW}$

b. heating (MW) - - - $223,250 \mathrm{kcal} / \mathrm{h}$

c. cooling $(\mathrm{MW})-\ldots-\ldots 235,000 \mathrm{kcal} / \mathrm{h}$

d. wastewater treatment-liters/day _ _ _ _

e. solid waste processing-kilograms/day $-\ldots$

f. potable water-liters/day ------heat to power ratio (average expected)

14. Other Related Projects (Titles)

Note: This is a subordinate project of 2-122NL-11. dentification No

5-122NL-09

energy source

expected payback period 2 years

Type and size of user

a. residential (dwelling units)

b. residential (square area- $\mathrm{m}^{2}$ )

c. commercial (square area- $\mathrm{m}^{2}$ )

d. Industrial (thermal + elec-MW)

*Refer to note 2 , table $2-9$.

15. Additional space for Purpose of Project

16. Additional space for Status and Results 


UBS-1075 U.S. DEPARTMENT OF COMMERCE
$(2-77)$
NATIONAL BUREAU OF STANDARDS

PROJECT SUMMARY FORM

1. Title of Project /Official Title/ Technical Assessment of Air Pollution Control for $\mathrm{SO}_{\mathrm{X}}, \mathrm{NO}_{\mathrm{X}}$, and other Air Emissions at the Baltimore Demonstration Gas Pyrolysis Facility

3. Performing Organization (Complete Mailing Address)

TRW Systems Group

TRW, Inc.

One Space Park

Redondo Beach, California 90278
Identification No.

(Secretariat Use Only)

5-131US-10

2 Date (Form Completed)

$5 / 12 / 77$

\title{
5. Supporting Organization (Complete Mailing Address and Name of
} Contact)

Walter W. Liberick, Jr.

U.S. EPA

ORD, IERL

Cincinnati, Ohio 45268

\author{
4 Principal Investigator (Name and Complete Mailing Address) \\ Tony E. Eggleston \\ TRW, Inc. \\ One Space Park \\ Redondo Beach, California 90278
}

6. Duration of Investigation (Beginning and ending)

$$
4 / 76 \text { to } 1 / 77
$$

7 Estimated Funding and Manpower (Monies and Manyears)

$$
\$ 27,474 \text { FY76 }
$$

\section{Purpose of Project (Jbjectives, Motivations, Approach, Plans and Expected Results)}

Objective: The overall objective of this task is to assess $\mathrm{SO}_{\mathrm{X}}$, $\mathrm{NO}_{\mathrm{X}}$, and other air emissions from Baltimore, Maryland, Demonstration Gas Pyrolysis Facility.

Approach: Contractor will develop the sample plan for all constitutents, collect required samples, perform required analysis, interpret the data and provide a written report of results.

Use Box No. 15 if additional space is needed

\section{Status and Results}

Contractor has collected samples from the Baltimore Plant, analyzed then, and provided EPA with a draft report of their findings.

This project is: $\square$ planned $\square$ in-progress $\square$ completed Use Box No. 16 if additional space is needed

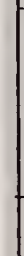

10. Utility Services $\square$ electrical power $\square$ space heating

public $\square$ private

cooperative 


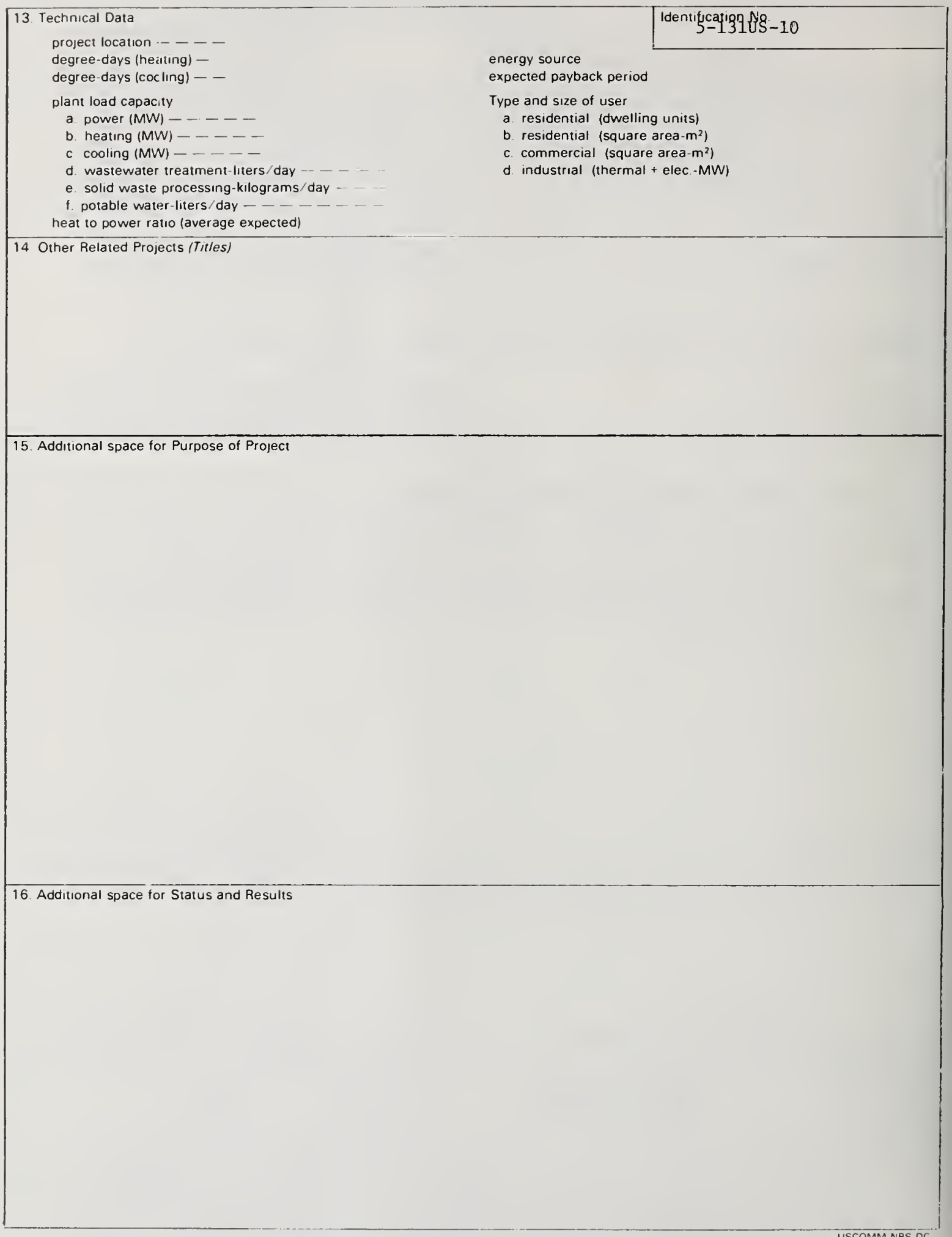




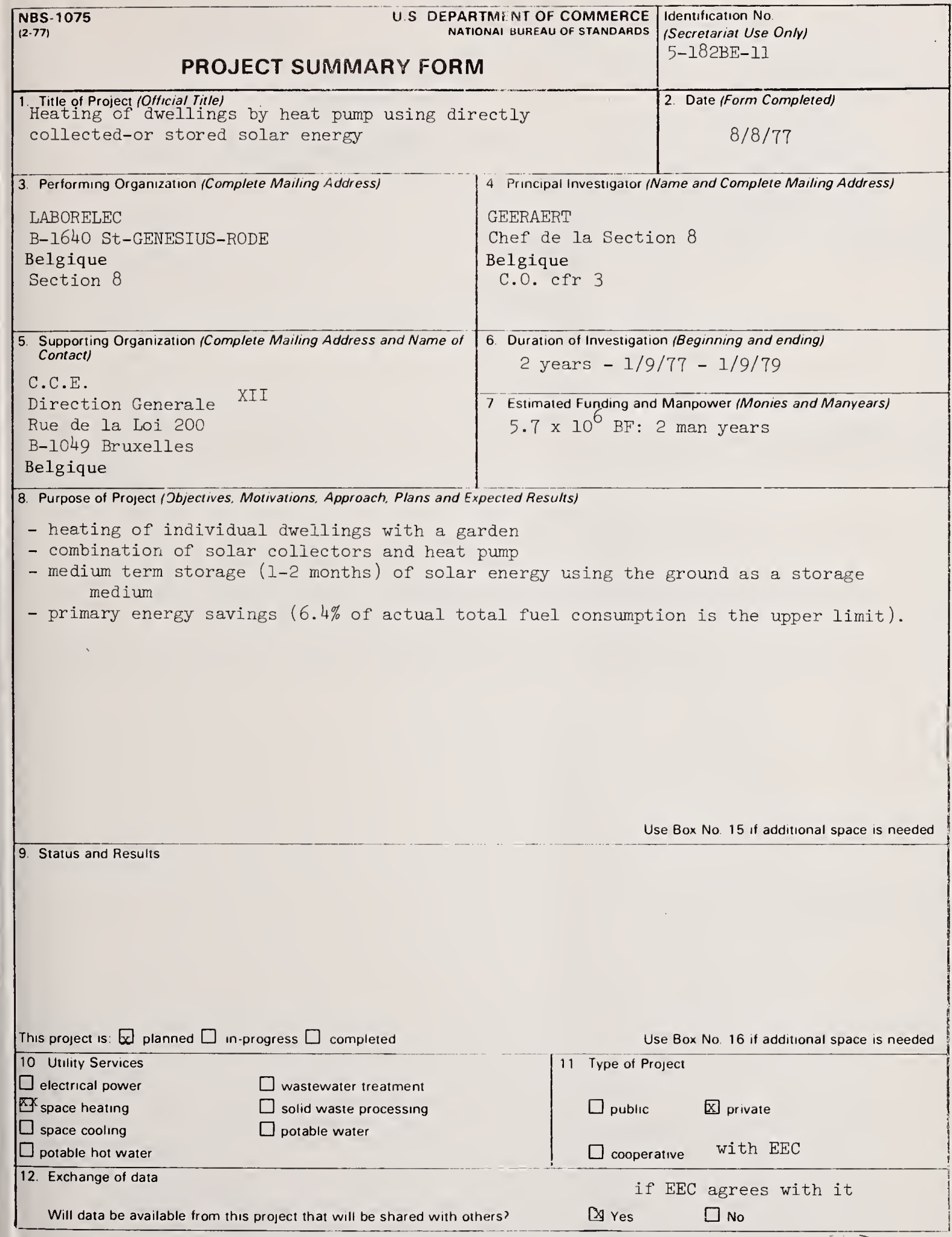




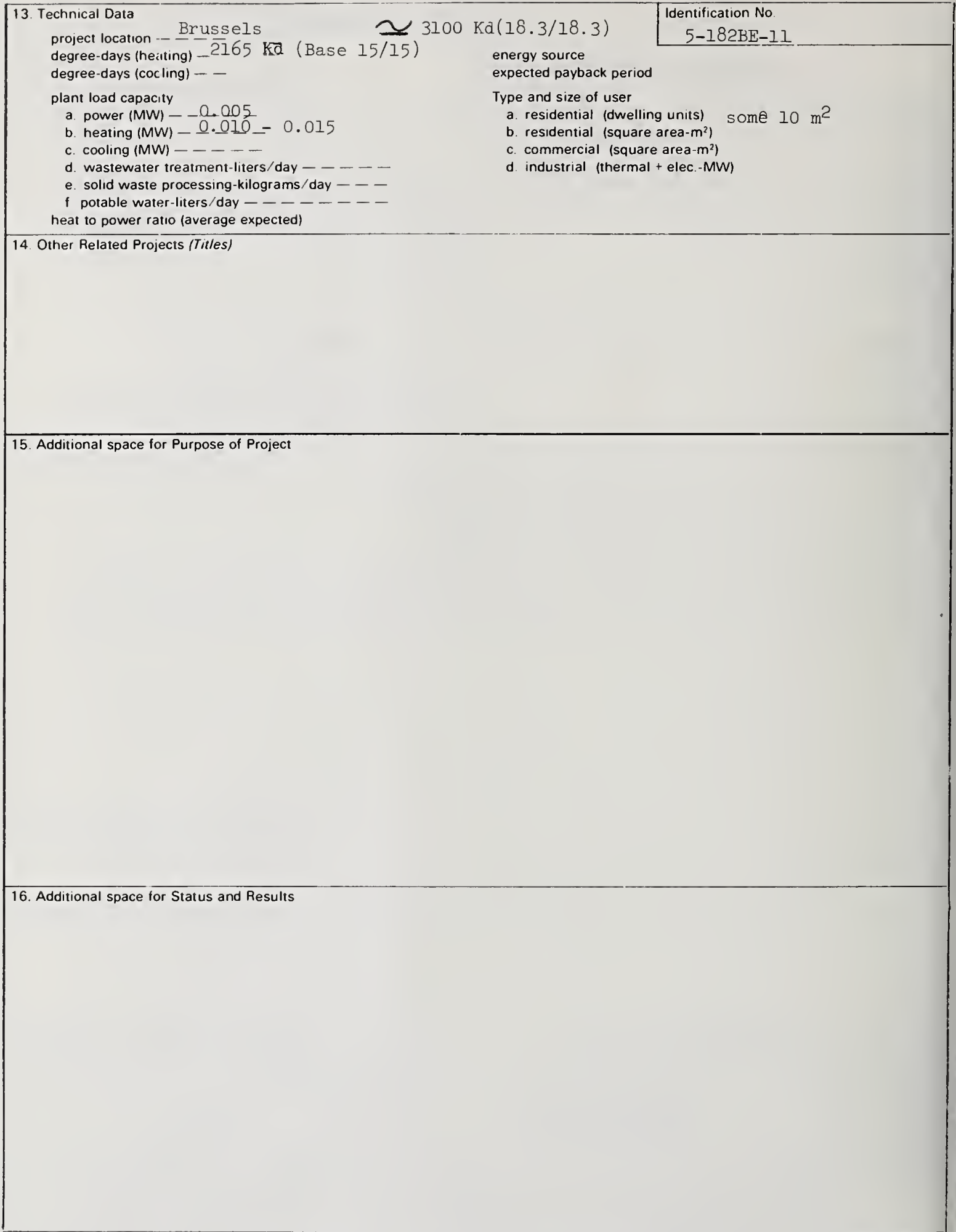




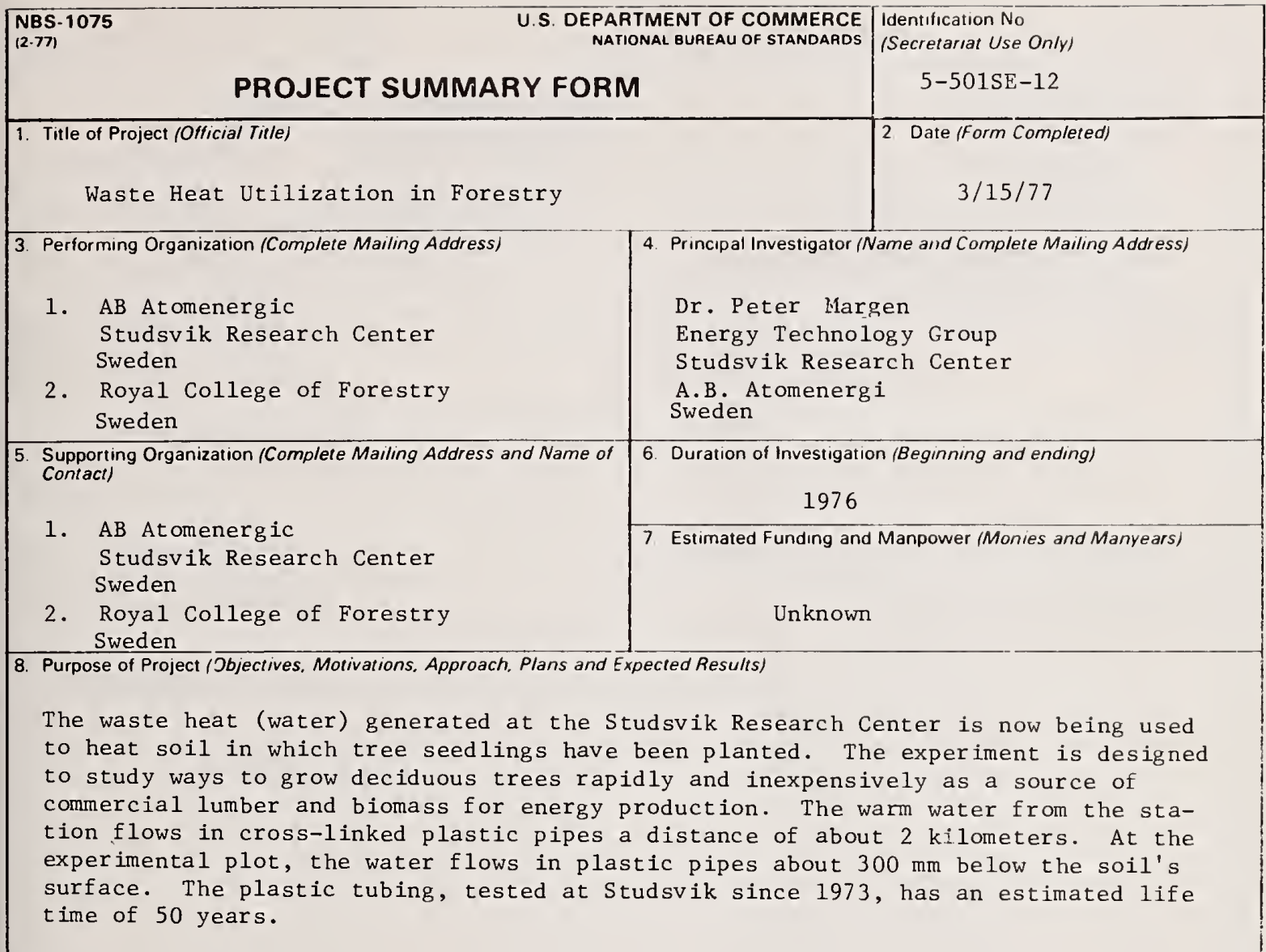

Use Box No. 15 if additional space is needed

9. Status and Results

planned $\square$ in-progress $\square$ completed Use Box No 16 if additional space is needed

electrical power $\quad \square$ wastewater treatment

space heating $\square$ solid waste processing

space cooling $\square$ potable water

potable hot water

2. Exchange of data

Will data be available from this project that will be shared with others?

$\square$ Yes

No $[\mathrm{x}]$ Unknown 


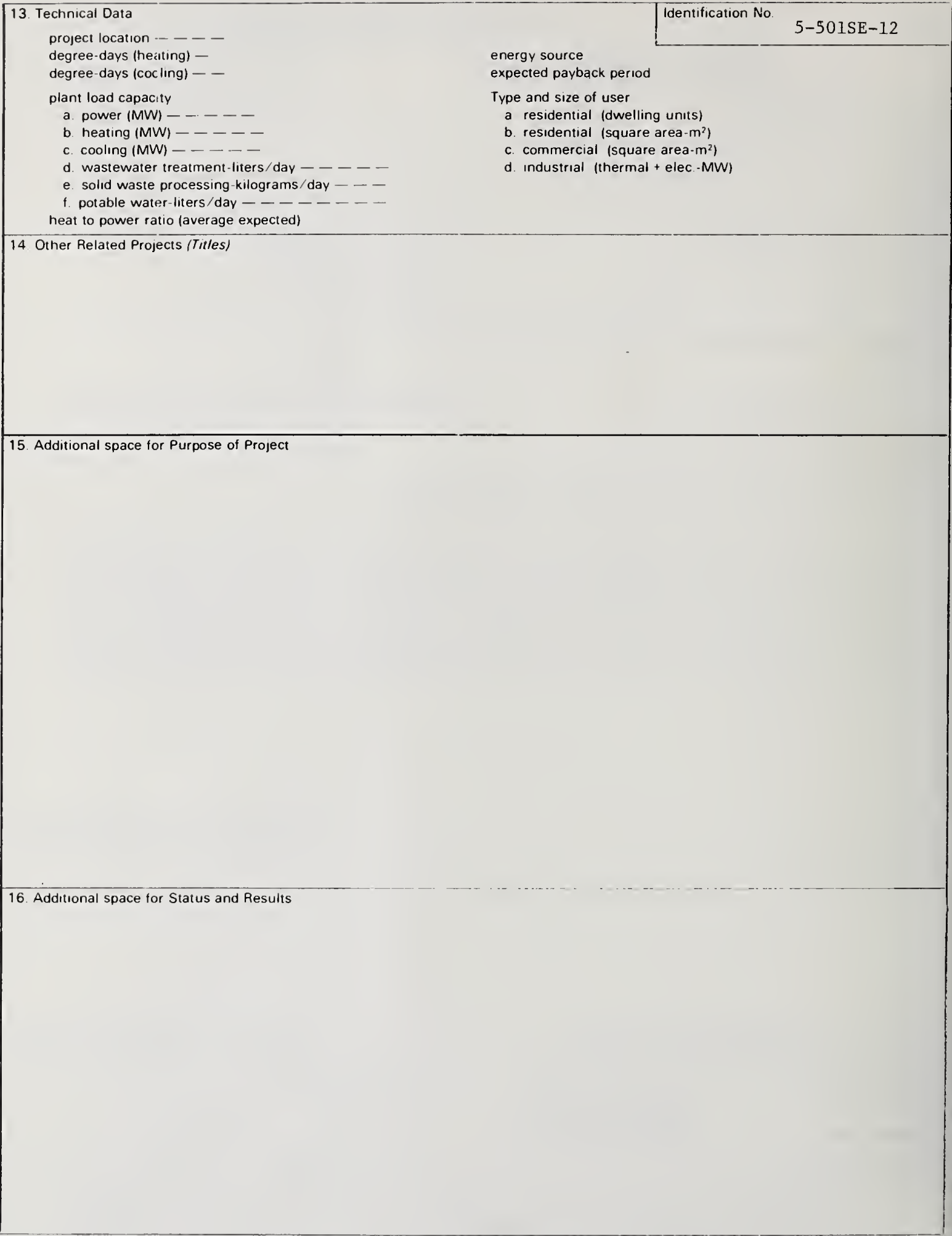




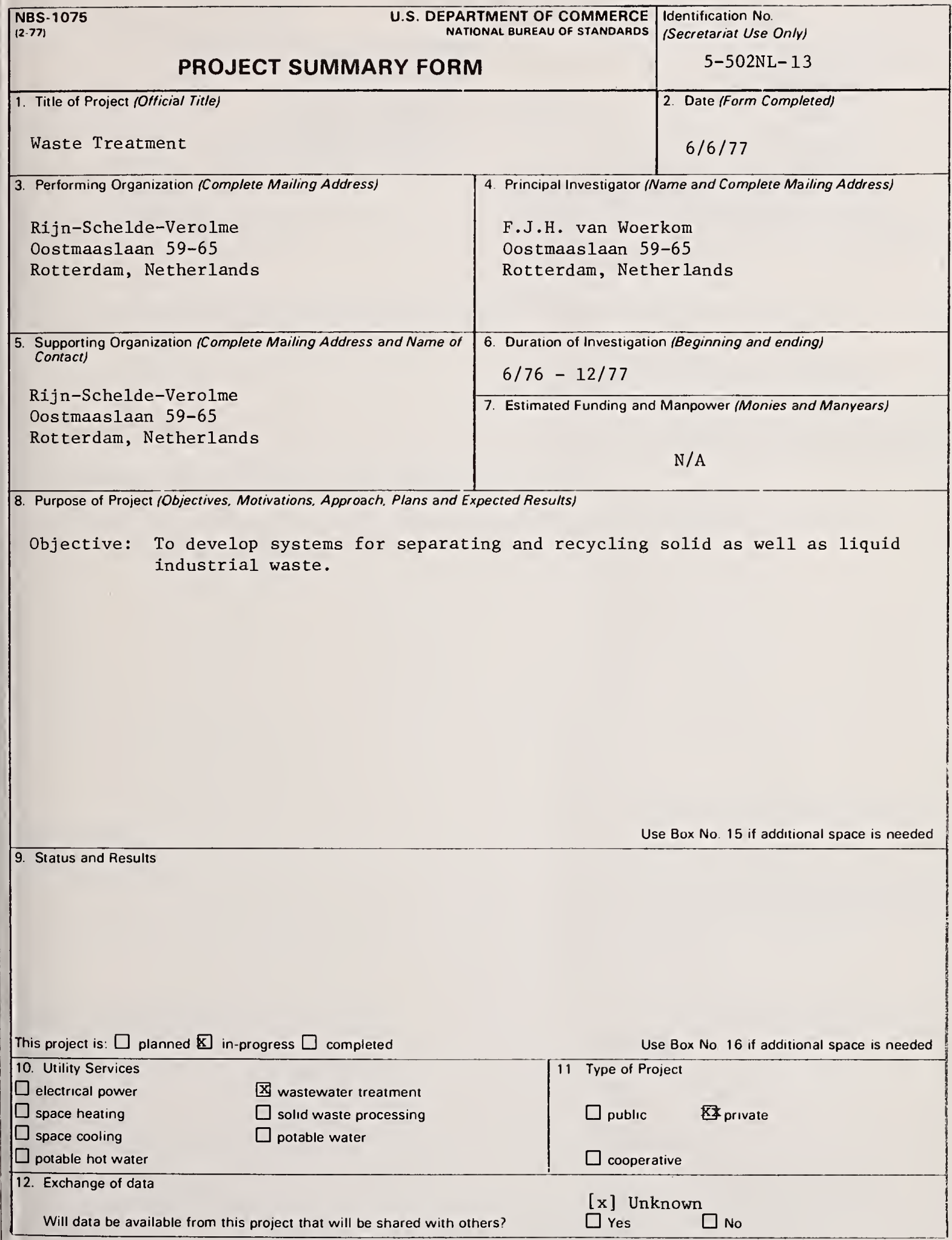


13. Technical Data

Identification $\mathrm{N}$

$5-502 \mathrm{NL}-13$

degree-days (heating) -

degree-days (cocling) - -

energy source

expected payback period

plant load capacity

a. power (MW) - - - -

b. heatıng ( $M W$ ) - - - -

c. cooling (MW) $-\ldots-\ldots$

d. wastewater treatment-liters/day $-\ldots-\ldots$

e. solid waste processing-kilograms/day - - -

$f$ potable water-liters/day $-\ldots \ldots-\ldots$ heat to power ratio (average expected)

14. Other Related Projects (Titles)

15. Additional space for Purpose of Project

16. Additional space for Status and Results

Type and size of user

a. residential (dwelling units)

b. residential (square area $-\mathrm{m}^{2}$ )

c. commercial (square area- $\mathrm{m}^{2}$ )

d. industrial (thermal + elec.-MW) 


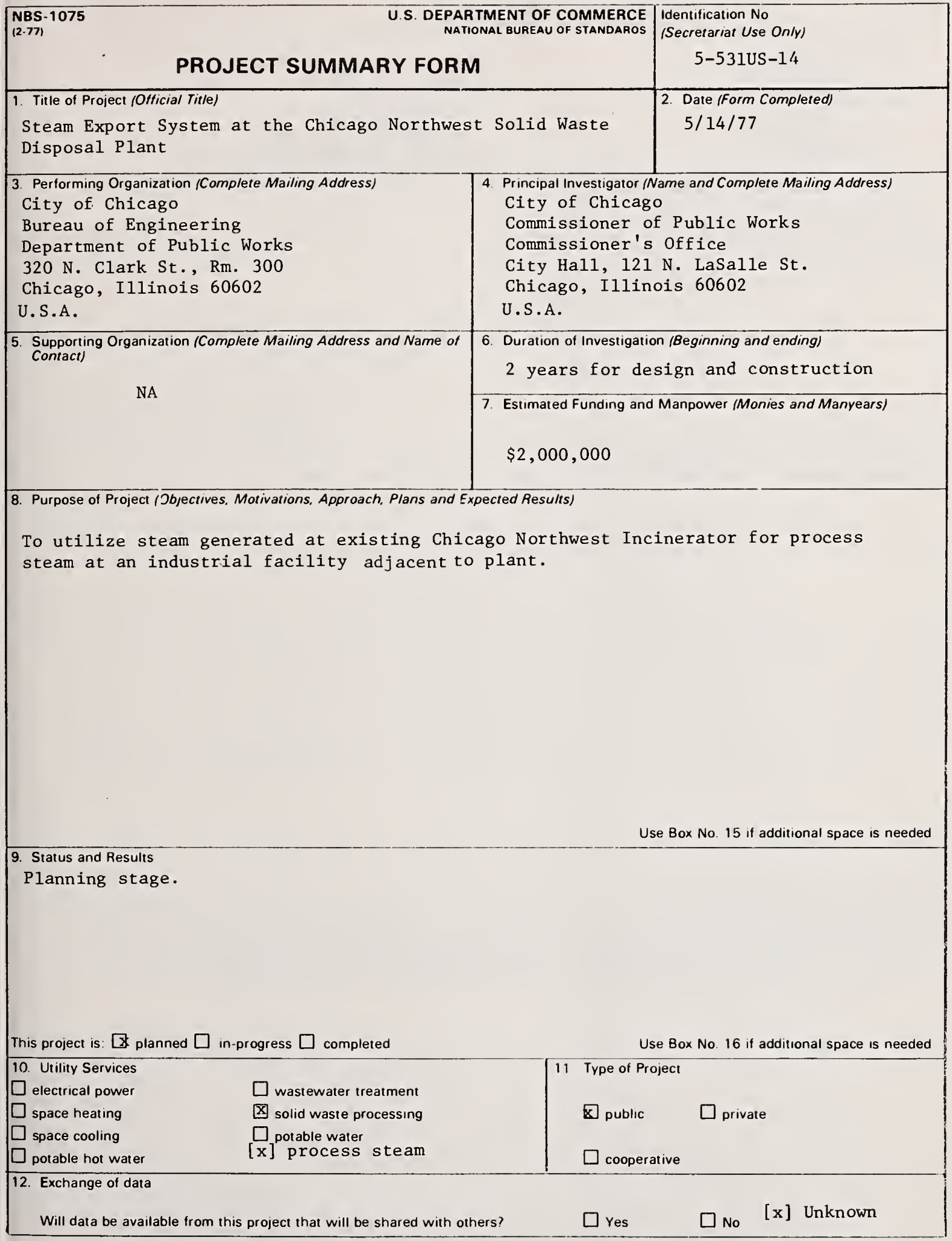


13. Technical Data 700 Nort project location - - - -
degree-days (heating) -

degree-days (cocling) - -

plant load capacity

a. power $(\mathrm{MW})-\overline{30}---$

$\mathrm{x}$ b. heating $(\mathrm{MW}) 30$

c. cooling $(\mathrm{MW})----$

d. wastewater treatment-liters/day - $\mathrm{x}-\overline{1}, \overline{45}, 000 \mathrm{Kg} / \mathrm{D}=600 \mathrm{~d}$ shtrial (thermal + elec.-MW)

e. solid waste processing-kilograms/day $1,455,000 \mathrm{Kg} / \mathrm{D}=600 \mathrm{sh}$. tpd.

f. potable water-liters/day $-\ldots-\ldots---$

heat to power ratio (average expected)

14. Other Related Projects (Titles)

\section{RESOURCE RECOVERY FERROUS METAL}

15. Additional space for Purpose of Project

Energy recovery from existing solid waste incineration plant.

16. Additional space for Status and Results

The Chicago N.W. Incinerator Plant is presently in full operation. The energy at a rate of $440,000 \mathrm{Lbs} / \mathrm{Hr}$ steam at $250 \mathrm{psig}$ saturated $=200,000 \mathrm{Kg} / \mathrm{H}$ at $1720 \mathrm{kPa}$ saturated is presently condensed in an air cooled condensing system. 
NBS-1075

(2.77)
U.S. DEPARTMENT OF COMMERCE IIdentification No.

NATIONAL BUREAU OF STANDARDS

(Secretariat Use On/y)

\section{PROJECT SUMMARY FORM}

1. Title of Project (Official Title)

$5-533 U S-15$

2. Date (Form Completed)

Firing Densified Refuse Derived Fuel In a Stoker Boiler

$11 / 24 / 76$

3. Performing Organization (Complete Mailing Address)

Systems Technology Corporation

245 North Valley Road

Xenia, Ohio 45385

U.S.A.
4 Principal Investigator (Name and Complete Mailing Address)

Dr. Greg Rigo

Systems Technology Corporation

245 North Valley Road

Xenia, Ohio 45385

U.S.A.

6. Duration of Investigation (Beginning and ending)

$$
6 / 76 \text { to } 6 / 77
$$

7. Estımated Fundıng and Manpower (Monies and Manyears) Office of Research and Development 26 West St. Clair Street Cincinnati, Ohil 45268, U.S.A. ATTN: Carlton C. Wiles

$\$ 294,000$

8. Purpose of Project (Objectives, Motivations, Approach, Plans and Expected Resu/ts)

The objective of this program is to demonstrate the use of densified Refuse Derived Fuel (d-RDF) as a coal supplement in stoker equipped boilers and to assess the environmental impact of wide spread implementation of the concept.

The approach will include burning pelletized, cubetted and bricquetted d-RDF and coal in spreader stoker equipped boilers. The coal/d-RDF ratio will be varied to establish the impact of substitution ratio on boiler performance and the environment. After initial testing is complete, a demonstration burn will occur to assess the impact of sustained firing. Each fuel-boiler combination will be approached in a three step sequence: (1) A field trail will establish the processability of the fuel by the boiler and the maximum substitution ratios usable without boiler problems; (2) A field test will quantify environmental, energy and boiler impacts of the fuel system over a range of boiler conditions; (3) A demonstration will be performed.

Use Box No. 15 if additıonal space is needed

\section{Status and Results}

Detailed burn tests of $1 / 2$ in. pellets are scheduled to being December 6 at a boiler facility near Hagerstown, Maryland. Equipment installation, boiler modifications, and other arrangements have been completed. Cold and hot flow tests are scheduled for December 1, 2, and 3 to test the system prior to start of detailed tests.

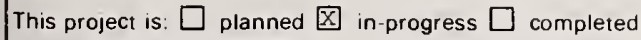
Use Box No 16 if additional space is needed 10. Utility Services

electrical power

$\square$ space heating

$\square$ space cooling

$\square$ potable hot water

11 Type of Project

国 public $\square$ private

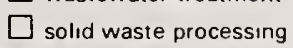

$\square$ potable water

12. Exchange of data

Will data be available from this project that will be shared with others?
Yes $\square$ No 
13. Technical Data

project location -- - -

degree-days (heating) -

degree-days (cocling) - -

plant load capacity

a. power $(\mathrm{MW})-\ldots--$

b. heating ( $M W)----$

c. cooling $(\mathrm{MW})-\ldots-\ldots$

d. wastewater treatment-liters/day $--\ldots-$

e. solid waste processing-kilograms/day - - -

f. potable water-liters/day $---\ldots-\ldots$ heat to power ratio (average expected)

14. Other Related Projects (Titles)

Preparation of Densified Refuse Derived Fuel for Stoker Boilers energy source

expected payback period

Type and size of user

a. residential (dwelling units)

b. residential (square area- $\mathbf{m}^{2}$ )

c. commercial (square area- $\mathrm{m}^{2}$ )

d. Industrial (thermal + elec.-MW)

15. Additional space for Purpose of Project

16. Additional space for Status and Results 
1. Title of Project (Officia/ Tit/e)

2. Date (Form Completed)

Preparation of Densified Refuse Derived Fuel for Stoker $11 / 24 / 76$ Boilers

3. Performing Organization (Complete Mailing Address)

National Central for Resource Recovery 1211 Connecticut Avenue, N.W. Washington, D.C. 20036 U.S.A.
4. Principal Investigator (Name and Complete Mailing Address)

Dr. Harvey Alter

National Central for Resource Recovery 1211 Connecticut Avenue, N.W. Washington, D.C. 20036

U.S.A.

6. Duration of Investigation (Beginning and ending)

$$
9 / 75 \text { to } 9 / 77
$$

7. Estimated Funding and Manpower (Monies and Manyears)

$\$ 271,000$ Cincinnati, Ohio 45268 , U.S.A. ATTN: Carlton C. Wiles

8. Purpose of Project (Jbjectives, Motivations, Approach. Plans and Expected Results)

DESCRIPTION: This study is investigating the technical and economic aspects of preparing and using densified forms of municipal solid waste (d-RDF) as supplementary fuel in industrial and institutional coal fired stoker boilers. This project will produce the d-RDF for use in combustion studies to determine the environmental and technical aspects of combusting d-RDF (densified refuse derived fuel) with coal. Equipment operational requirements, power requirements, refuse processing, die wear, and similar factors will be determined for production of a specification d-RDF acceptable for storage, transportation and combustion.

Use Box No. 15 if additional space is needed

\section{Status and Results}

Installation of equipment has been completed. Two dies are available for producing $1 / 2$ in. and 1 in. diameter pellets. Limited quantities of $1 / 2$ in. diameter pellets have been produced during equipment shakedowns and operations are progressing for production runs to provide pellets for the combustion tests.

This project is: $\square$ planned $\varangle$ in-progress $\square$ completed

Use Box No 16 if additional space is needed

$$
\text { ए }
$$
10. Utility Services $\square$ electrical power $\square$ space heating $\square$ space cooling $\square$ potable hot water wastewater treatment E solid waste processing $\square$ potable water 12. Exchange of data 
13 Technical Data

project location :- _ - -

degree-days (he itıng) -

degree-days (coclıng) -

plant load capacity

a power (MW) - . - - -

b. heatıng (MW) - - - -

c. cooling (MW) $-\ldots \ldots$

d wastewater treatment-liters/day _ _ _ - -

e. solid waste processing-kilograms/day - - -

f. potable water-liters/day $-\ldots-\ldots$ heat to power ratio (average expected)

14. Other Related Projects (Titles)

Firing Densified Refuse Derived Fuel in a Stoker Boiler
Identification No.

5-533US- 16

\section{energy source}

expected payback period

Type and size of user

a. residential (dwelling units)

b. residential (square area- $\mathrm{m}^{2}$ )

c. commercial (square area- $\mathrm{m}^{2}$ )

d. industrial (thermal + elec.-MW)

15. Additional space for Purpose of Project

16. Additional space for Status and Results 
NBS-1075

(2.77)
U S DEPARTMENT OF COMMERCE NATIONAI BUFEAU OF STANDARDS

PROJECT SUMMARY FORM

1 Title of Project (Official Tit/e)

Biogas plant for pig slurry treatment - Reggio Emilia
Identification No

(Secretariat Use Only)
$5-543 \mathrm{IE}-17$

2. Date (Form Completed)
3. Performing Organization (Complete Mailing Address)

Centro Ricerche Produzioni Animali

via Crispi, 3 - 42100 - Reggio FmiliaITALIA

5. Supporting Organization (Complete Mailing Address and Name of Contact)

Dr. L. Degen

Snamprogetti

c.p. 15

00015 Monterotondo (ROMA)

ITALIA

4 Principal Investigator (Name and Complete Mailing Address)

Dr. Walter Ganapini

Centro Ricerche Produzioni Animali

Via Crispi, 3

42100 Reggio Emilia

ITALIA

6. Duration of Investigation (Beginning and ending)

September 1977 - September 1978

7 Estimated Funding and Manpower (Monies and Manyears)

$$
\$ 80,000
$$

8. Purpose of Project (Jbjectives, Motivations, Approach, Plans and Expected Results)

Objective: To provide an effective way of pig slurry exploitation before agronomical use.

Motivation: To improve the biogas production from pig slurry; to study its use on farms.

Approach: ---

Expected Results: The production from $4000 \mathrm{pigs}$, of $380,000 \mathrm{~N} \mathrm{~m}^{3} \mathrm{CH}_{4} / \mathrm{y}$.

Use Box No. 15 if additional space is needed

9. Status and Results

The plant will be placed in operation September 1977.

This project is: $\square$ planned $\triangle$ in-progress $\square$ completed

Use Box No. 16 if additional space is needed

.

$$
\begin{aligned}
& \square \\
& \square \\
& \square \\
& \hline 12 \\
& \hline
\end{aligned}
$$

10. Utility Services
$\square$ electrical power
$\square$ space heating
space cooling
12. Exchable hot water
Will data be avallable from this prota


plant load capacity
a power $(\mathrm{MW})-\ldots$
b. heating $(\mathrm{MW})----$
c. cooling (MW)
e. solid waste processing-kilograms/day _ - -
f. potable water-liters/day $-\ldots-\ldots-\ldots$ heat to power ratio (average expected)

14. Other Related Projects (Titles)

15. Additional space for Purpose of Project

Identification No

5-543IE -17

Type and size of user
a. residential (dwelling units)
b. residential (square area $-\mathrm{m}^{2}$ )
c. commercial (square area $-m^{2}$ )
d. industrial (thermal + elec.-MW) 


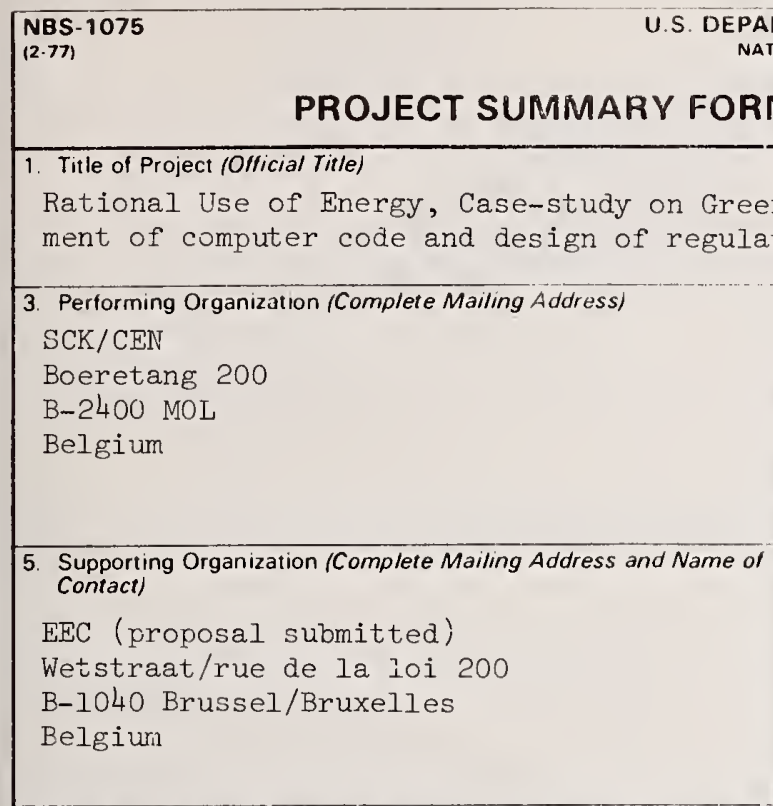

PARTMENT OF COMMERCE

NATIONAI BUREAU OF STANDARDS

Identification No

(Secretariat Use On/y)

8. Purpose of Project (Objectives, Motivations, Approach, Plans and Expected Results)

- As a function of meteo data, construct a computer code and a regulation cevice for optimal energy housekeeping

- SCK/CEN study on greenhouses: extrapolation to other cases

- It is expected to include advanced systems such as solar collectors and heat pumps

\section{Status and Results}

Use Bux No. 15 if additional space is needed

Program submitted to EIC

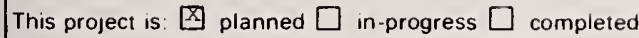

\begin{tabular}{ll}
\hline 10. Utility Services & $\square$ wastewater treatment \\
$\square$ electrical power & $\square$ solid waste processing \\
$\square$ space heating & $\square$ potable water \\
$\square$ space cooling &
\end{tabular}

12. Exchange of data

Will data be available from this project that will be shared with others?
4 Principal Investigator (Name and Complete Mailing Address)

\section{G. COCQUYT}

6 Duration of Investigation (Beginning and ending) $1 / 1 / 78-7 / 1 / 79$

7 Estimated Funding and Manpower (Monies and Manyears) $\$ 300,000 ; 1.5 \mathrm{mar} /$ year 


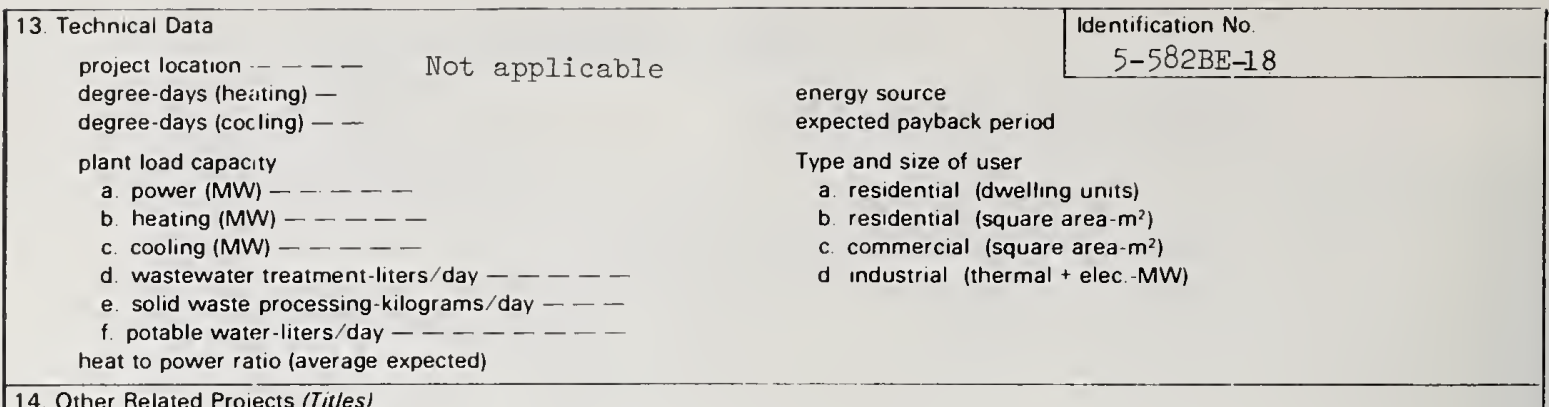

14. Other Related Projects (Titles)

Data bank maragement for air pollution control

15. Additional space for Purpose of Project

16. Additional space for Status and Results 
\begin{tabular}{|lr|}
\hline $\begin{array}{l}\text { NBS-1075 } \\
(2.77)\end{array}$ & U.S. DEPARTMENT OF COMMERCE \\
NATIONAL BUREAU OF STANDARDS
\end{tabular}

PROJECT SUMMARY FORM

1. Title of Project (Official Title)

Program Study "Heat Dispersion" (ET 5004)

\section{Performing Organization (Complete Mailing Address)}

Battelle-Institut e.V.

Am Romerhof 35

6000 Frankfurt/Main 90

Federal Republic of Germany
Identification No

(Secretariat Use Only)

\section{5-601DE- 19}

2. Date (Form Completed)

$$
3-15-77
$$

4. Principal Investigator (Name and Complete Mailing Address)

Ing. (grad) F. Gruning

Battelle-Institut e.V.

Am Romerhof 35

6000 Frankfurt/Main 90

Federal Republic of Germany 5. Supporting Organization (Complete Mailing Address and Name of
Contact)

Bundesministerium fur Forschung und

Technologie

Stresemannstrasse 10

5300 Bonn-Bad Godesberg

Federal Republic of Germany

8. Purpose of Project (Jbjectives, Motivations, Approach. Plans and Expected Results)

1. Objective: It is planned to critically analyze existing long distance heat distribution systems in countries possessing highly technical standards. It is further planned to invest how similar problems are solved in other branches of industry, and which of these solutions can be utilized for long distance heat distribution systems.

2. Work Program: The investigation consists of six main points:

a. Development of a multi-dimensional classification system scheme for the purposeful arrangement of the data to be gathered.

b. Compilation of international experience of existing long-distance heat dispersion systems and those in the process of being built.

c. Evaluation of published claims and actual values.

d. Deduction of development trends for future long distance heat dispersion networks, especially taking into consideration the anticipated costs.

e. Drafting of proposals for the technology of long distance heat distribution networks to be built and for improvements of those already existing. (cont.)

9. Status and Results

The survey has been completed.

This project is: $\square$ planned $\square$ in-progress $\square$ completed Use Box No. 16 if additional space is needed

10. Utility Services

$\square$ electrical power

space heating

$\square$ space cooling

$\square$ potable hot water Use Box No. 15 if additional space is needed

12. Exchange of data 


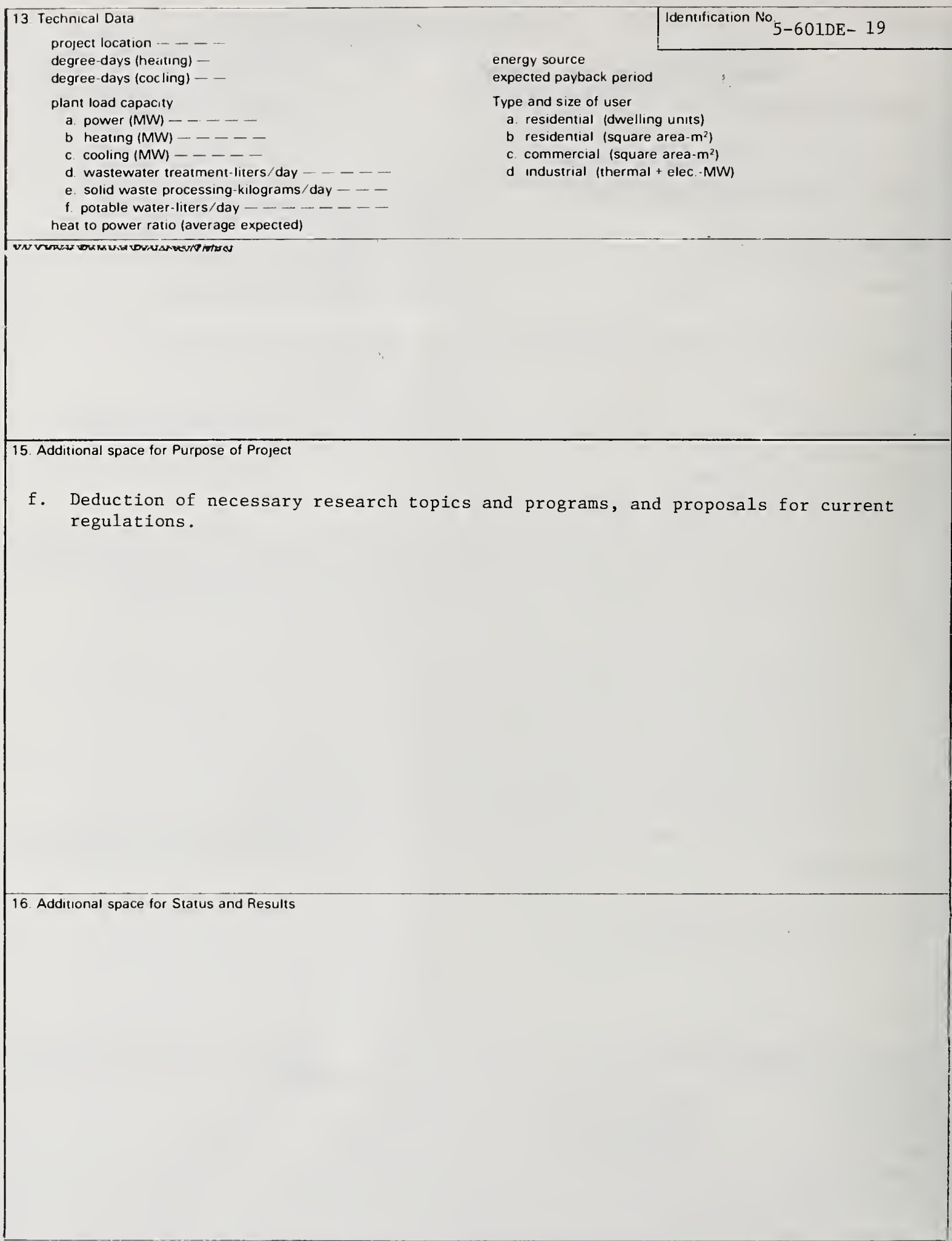




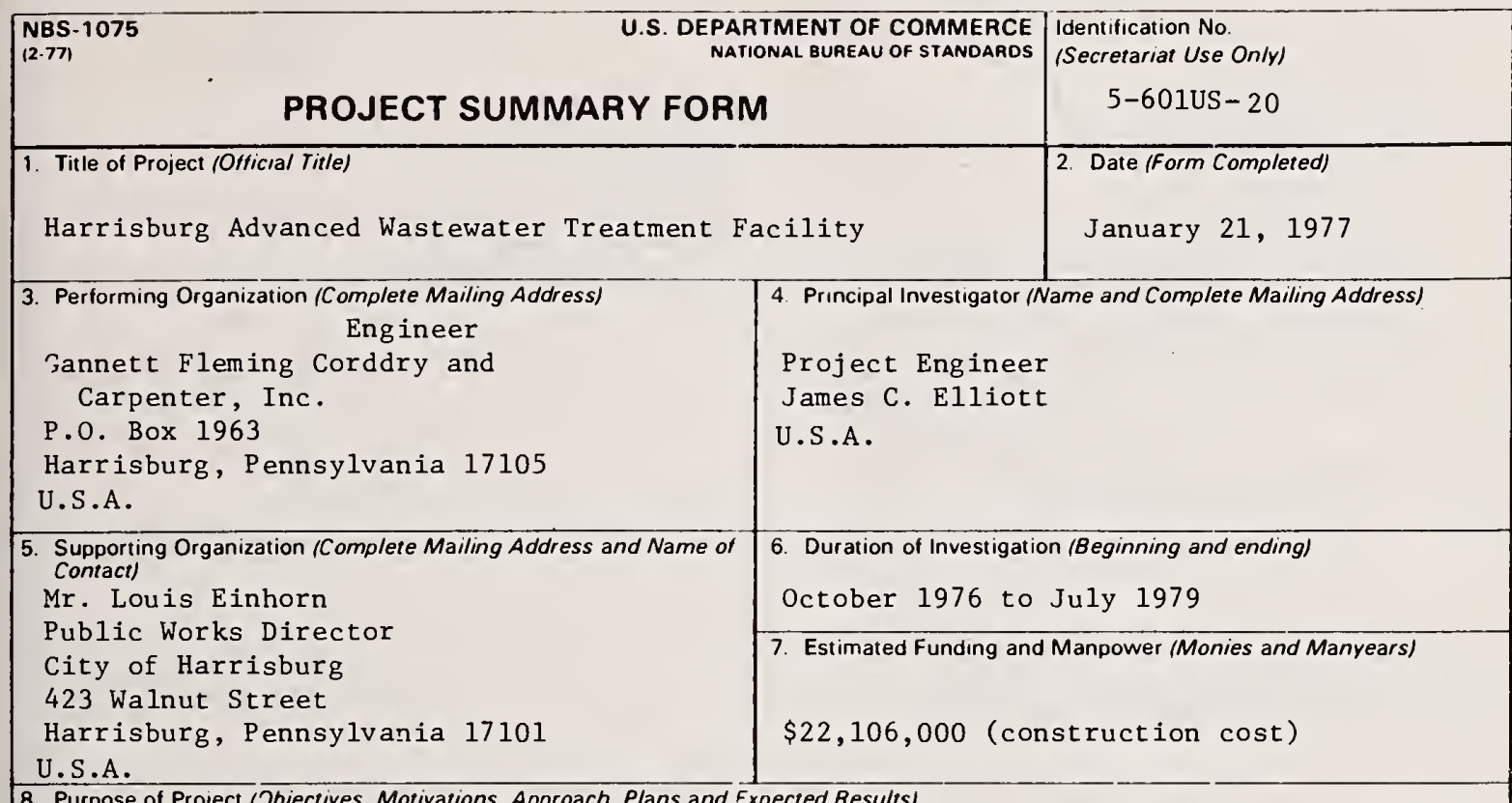

8. Purpose of Project (Objectives, Motivations. Approach, Plans and Expected Results)

Sludge from the City's wastewater treatment process will be dewatered using steam produced by the City's refuse incinerator. The dewatered sludge will then be charged into the incinerator, thereby producing steam and resulting in a practically self-sustaining sludge disposal operation.

Use $80 \times$ No. 15 if additional space is needed

9. Status and Results

The project is currently under construction.

Expected completion date is July 1979.

This project is: $\square$ planned $\otimes$ in-progress $\square$ completed

Use Box No. 16 if additional space is needed

\section{Utility Services}

$\square$ electrical power

$\square$ space heating

$\square$ space cooling

$\square$ potable hot water

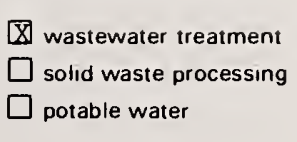

Wastewater treatment

$\square$ potable water

12. Exchange of data

Will data be available from this project that will be shared with others?

Yes

No 
13 Technical Data See below

project location .....

degree-days (heating) -

degree-days (cocling) - -

plant load capacity

a. power (MW) - - - -

b heating $(\mathrm{MW})-\ldots$

c. cooling (MW) -

d. wastewater treatment-liters/day $-\ldots \ldots$

e. solid waste processing-kilograms/day - - -

1. potable water-liters/day _ _ _ _ _ _ -

heat to power ratio (average expected)

14. Other Related Projects (Tit/es)

(LP) Harrisburg Refuse Incinerator

(SP) Harrisburg Steam Main
Identification $\mathrm{No}$

$5-601$ US -20

energy source

expected payback perıod

Type and size of user

a. residential (dwelling units)

b. residential (square area- $m^{2}$ )

c. commercial (square area- $m^{2}$ )

d. Industriat (thermal + elec-MW)

15. Additional space for Purpose of Project

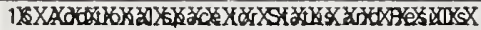

13. Technical Data

Wastewater Treatment $-30.9 \mathrm{mgd}$ (maximum)

Sludge to Incinerator - 4,070 pounds/hour

Steam required for dewatering - 20,450 pounds/hour

Steam produced by incinerating sludge - 13,550 pounds/hour 


\begin{tabular}{|c|c|c|}
\hline PROJECT SUMMARY FOPAI & $\begin{array}{l}\text { TMENT OF COMMERCE } \\
\text { ONAL BUREAU OF STANDARDS } \\
1\end{array}$ & $\begin{array}{l}\text { Identification No. } \\
\text { (Secretariat Use On/y) } \\
5-602 \mathrm{NL}-21\end{array}$ \\
\hline
\end{tabular}

8. Purpose of Project (Jbjectives, Motivations, Approach, Plans and Expected Results)

Objective: To develop a combined cycle power generation system in order to improve overall efficiency.

9. Status and Results

This project is: $\square$ planned $\square$ in-progress $\square$ completed

Use Box No 16 if additional space is needed

10. Utility Services

X electrical power

wastewater treatment

$\square$ space heating

wastewater treatment

$\square$ space cooling

$\square$ solıd waste processing

$\square$ potable hot water

$\square$ potable water

11. Type of Project

$\square$ public $\quad \forall x$ private

cooperative

12. Exchange of data

Yes

No 


\section{Technical Data}

project location -- - -

degree-days (heating) -

degree-days (cocling) - -

plant load capacity
a. power (MW)
b. heating (MW) ----
c. cooling (MW) - - - -
d. wastewater treatment-liters/day $-\ldots$
e. solid waste processing-kilograms/day - -
f. potable water-liters/day -------
heat to power ratio (average expected)

14. Other Related Projects (Titles)
Identification No

$5-602 N L-21$

energy source

expected payback period

Type and size of user

a. residential (dwelling units)

b. residential (square area $-\mathrm{m}^{2}$ )

c. commercial (square area- $\mathrm{m}^{2}$ )

d. Industrial (thermal + elec - MW)

15. Additional space for Purpose of Project

16. Additional space for Status and Results 
PROJECT SUMMARY FORM

1. Title of Project (Official Tit/e)

entification No

(Secretariat Use On/y)

(2.77)

5-631NL-22

2. Date (Form Completed)

Several projects concerning thermal disposal methods of municipal waste and sewage sludge.

$6 / 10 / 77$

3. Performing Organization (Complete Mailing Address)

CTI-TNO

Apeldoorn The Netherlands

Technical High Schools

Enschede-Eindhoven The Netherlands

5. Supporting Organization (Complete Mailing Address and Name of Contact)

Institute for Waste Disposal

P.0. Box 184

Amersfoort

The Netherlands

4. Principal Investigator (Name and Complete Mailing Address)

Ir. B.G. Kreiter/Kr. F. van Veen

Institute for Waste Disposal

P.O. Box 184

Amersfoort

The Nether lands

6. Duration of Investigation (Beginning and ending)

Continuously

7. Estimated Funding and Manpower (Monies and Manyears)

Projects are of evaluating nature

8. Purpose of Project (Objectives, Motivations, Approach, Plans and Expected Results)

Evaluating possibilities of incineration, pyrolysis, gasification, fluid-bed incineration of municipal waste, chemical waste and sewage sludge. Research in coperation with the Dutch Research Institute CTI-TNO, the Technical Highschools and the plants in operation.

Use Box No. 15 if additional space is needed

9. Status and Results

This project is: $\square$ planned $\mathrm{X}$ in-progress $\square$ completed

\begin{tabular}{ll}
\hline 10. Utility Services & $\square$ wastewater treatment \\
$\square$ electrical power & $\square$ solid waste processing \\
$\square$ space heating & $\square$ potable water \\
$\square$ space cooling &
\end{tabular}

Use Box No. 16 if additional space is needed 11. Type of Project

: public

private

cooperative

12. Exchange of data

Will data be available from this project that will be shared with others?

Yes

No 


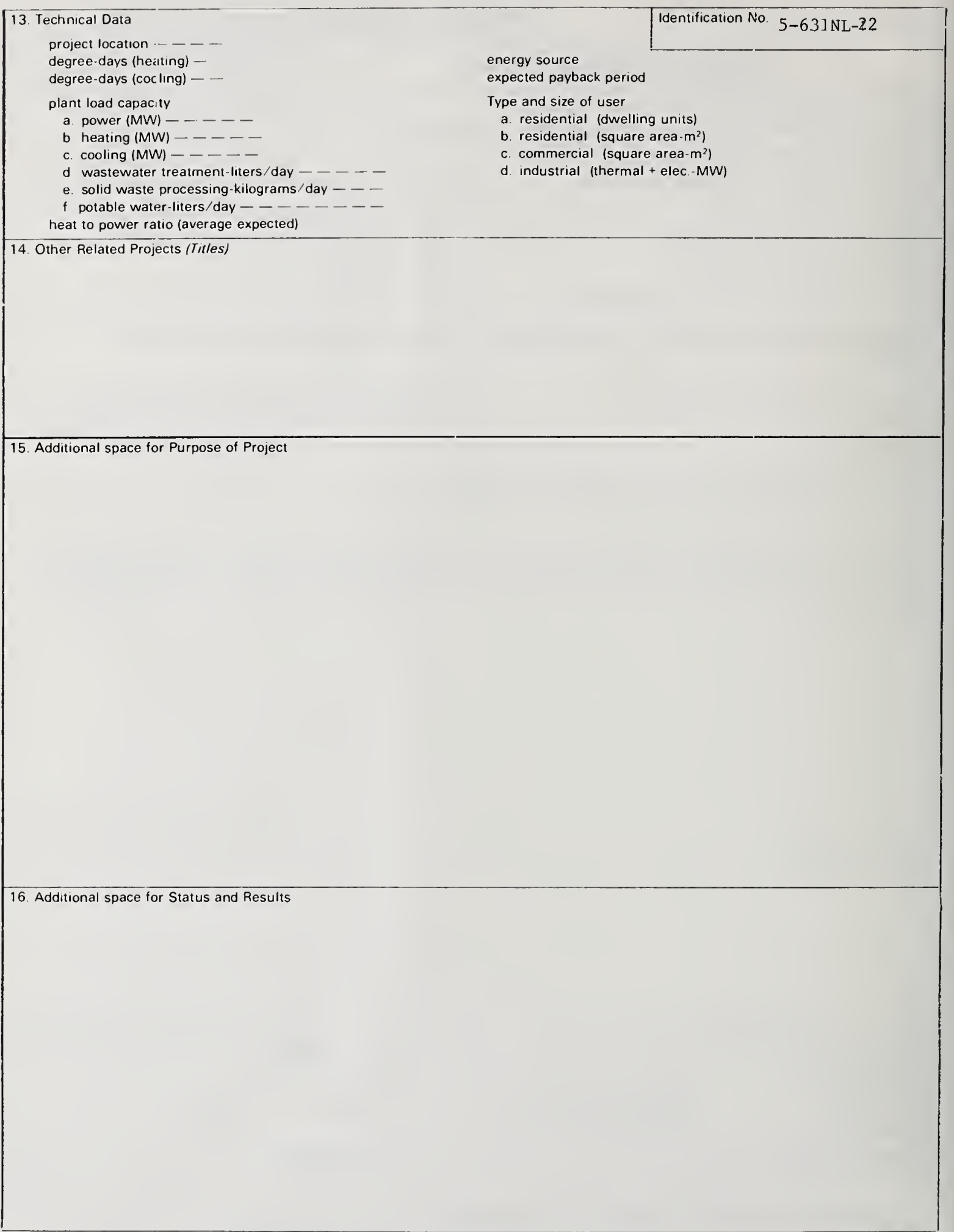


NBS-1075

(2.77)
U.S. DEPARTMENT OF COMMERCE

NATIONAL BUREAU OF STANDAROS

PROJECT SUMMARY FORM

1. Title of Project (Official Tit/e)

Recycle Energy System

3 Performing Organization (Complete Mailing Address)

City of Akron

166 S. High Street

Akron, Ohio 44308

U.S.A.
4 Principal Investıgator (Name and Complete Mailing Address)

James Alkire, Director

Department of Planning \& Urban

166 S. High Street \# 401 Renewal

Akron, Ohio 44308

U.S.A.

5. Supporting Organization (Complete Mailing Address and Name of Contact)

Department of Planning \& Urban

Renewal

6 Duration of Investigation (Beginning and ending)

1968 to present

7 Estimated Funding and Manpower (Monies and Manyears)

$\$ 46,000,000$ to present

8. Purpose of Project (Jbjectives, Motivations, Approach, Plans and Expected Results)

Provide long term solution for solid waste and to provide energy for the Central Business District

9. Status and Results

Construction has just started

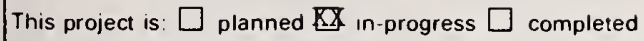
Use Box No. 16 if additional space is needed

$\begin{array}{ll}10 . \text { Utility Services } & \square \text { wastewater treatment } \\ \square \text { electrical power } & \square \text { solid waste processing } \\ \square \text { space heating } & \square \text { potable water } \\ \square \text { space cooling } & \end{array}$
11. Type of Project

12. Exchange of data 


\begin{tabular}{|c|c|c|}
\hline $\begin{array}{l}\text { 13. Technical Data Akron, Ohio } \\
\text { project location }\end{array}$ & 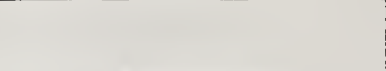 & Identification No. 5-631US-23 \\
\hline $\begin{array}{l}\text { degree-days (heating) - } \\
\text { degree-days (cocling) }--\end{array}$ & $\begin{array}{l}\text { energy source } \\
\text { expected payback perıod }\end{array}$ & \\
\hline $\begin{array}{l}\text { plant load capacity } \\
\text { a. power (MW) } \\
\text { b. heating (MW) -Energy-300,000 lbs/hr } \\
\text { c. cooling (MW) }-\ldots \\
\text { d. wastewater treatment-liters/day }-\ldots \\
\text { e. solid waste processing-kilograms/day } \\
\text { f. potable water-liters/day }-\ldots-\ldots \\
\text { heat to power ratio (average expected) }\end{array}$ & $\begin{array}{l}\text { Type and size of user } \\
\mathrm{xX} \text { a residential (dwellin } \\
\text { steam } \quad \text { b. residential (square } \\
\mathrm{xx} \text { c. commercial (square } \\
\mathrm{xx} \text { d industrial (thermal }\end{array}$ & $\begin{array}{l}\text { units) } \\
\text { area }-m^{2} \text { ) } \\
\text { area }-m^{2} \text { ) } \\
\text { elec. }-M W \text { ) }\end{array}$ \\
\hline
\end{tabular}

14. Other Related Projects (Titles)

15. Additional space for Purpose of Project

16. Additional space for Status and Results 


\section{PROJECT SUMMARY FORM}

1. Title of Project (Official Tit/e)

Technical and Economic Evaluation of the EPA Resource

Recovery Demonstration Facility in San Diego, California

\section{5-631US -24}

2. Date (Form Completed)

$5 / 12 / 77$
3. Performing Organization (Complete Mailing Address)

Acres American Incorporated

Liberty Bank Building, Main at Court

Buffalo, New York 14202

U.S.A.
4. Principal Investigator (Name and Complete Mailing Address)

Gera.ld Nugent

Acres American Incorporated

Liberty Bank Building, Main at Court

Buffalo, New York 14202

U.S.A.
5. Supporting Organization (Complete Mailing Address and Name of Contact)

Yvonne Garbe, U.S. EPA Washington,D.C. and Walter W. Liberick Jr.

U.S.EPA

ORD/and IERL, R\&D OSWMP

Cincinnati, ohio 45268

U.S.A.

8. Purpose of Project (Jbjectives, Motivations, Approach, Plans and Expected Results)

1. Objectives - To produce a published report which describes and assesses

comprehensively and in detail the environmental, technical, and economic feasibility of the San Diego County resource recovery plant which includes a 200-ton per day

Occidental Research Corporation pyrolysis process, plus steel, aluminum and gliss

recovery systems.

2. Approach - The contractor shall conduct a 12-month sampling program at the San Diego County plant beginning in mid-1977 for the purpose of collecting process information to facilitate the subsequent technical, environmental, and economic assessment of the Occidental Research Corporation pyrolysis and material recovery processes. The contractor shall have full access to the San Diego County plant and to related Occidental Research Corporation proprietary information for the conduct of the assessments.

3. Current Plans - (a) Develop Evaluation Plan - 3 months

(b) Data collection on-site at San Diego County Facility - 12 months

(c) Analyses of Data including technical evaluation, economic

evaluation and supplemental evaluation - 6 monthsuse Box No. 15 if additional space is needed

9. Status and Results

Plan (a) above has been completed and the on-site data collection is about to begin.

This project is: $\square$ planned $\mathrm{X}$ in-progress $\square$ completed Use Box No 16 if additional space is needed

10. Utility Services

$\square$ electrical power

$\square$ space heating

wastewater treatment

$\square$ space cooling

$\square$ solid waste processing

$\square$ potable water

$\square$ potable hot water

12. Exchange of data

Wilt data be available from this project that will be shared with others?

Yes

No 


\begin{tabular}{|c|c|c|}
\hline $\begin{array}{l}\text { 13. Technical Data } \\
\text { project location } \ldots \ldots-\ldots\end{array}$ & Identification No. & $5-631$ US -24 \\
\hline $\begin{array}{l}\text { degree-days (heating) - } \\
\text { degree-days (cocling) }--\end{array}$ & $\begin{array}{l}\text { energy source } \\
\text { expected payback period }\end{array}$ & \\
\hline 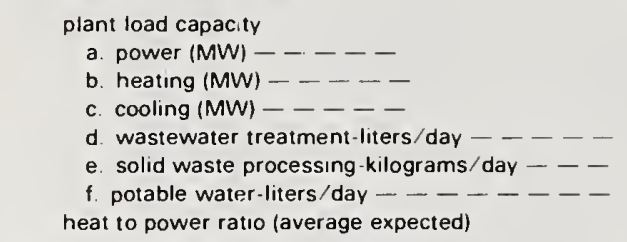 & $\begin{array}{l}\text { Type and size of user } \\
\text { a residential (dwelling units) } \\
\text { b. residential (square area- } m^{2} \text { ) } \\
\text { c. commercial (square area }-m^{2} \text { ) } \\
\text { d. Industrial (thermal + elec. }-M W \text { ) }\end{array}$ & \\
\hline
\end{tabular}

14. Other Related Projects (Titles)

15. Additional space for Purpose of Project

16. Additional space for Status and Results 
$\begin{array}{lr}\begin{array}{l}\text { NBS-1075 } \\ (2-77)\end{array} & \text { U.S. DEPARTMENT OF COMMERCE } \\ \text { NATIONAL BUREAU OF STANDARDS }\end{array}$

PROJECT SUMMARY FORM

1. Title of Project (Official Title)

Environmental Assessment of Waste-to-Energy Processes
Identification No.

(Secretariat Use On/y)

\section{5-631US- 25}

2. Date (Form Completed)

$5 / 12 / 77$

3. Performing Organization (Complete Mailing Address)

Midwest Research Institute

425 Volker Boulevard

Kansas City, Missouri 64110

U.S.A.

4. Principal Investigator (Name and Complete Mailing Address) M.P.Schrag

Midwest Research Institute

425 Volker Boulevard

Kansas City, Missouri 64110

U.S.A.

5. Supporting Organization (Complete Mailing Address and Name of Contact)

H.M.Freeman

U.S.EPA

ORD, IERL

Cincinnati, Ohio 45268

U.S.A.
6. Duration of Investigation (Beginning and ending)

$$
8 / 76 \text { to } 7 / 79
$$

7. Estimated Funding and Manpower (Monies and Manyears) $\$ 400,000$ FY75

717,000 FY76

330,000 FY77

8. Purpose of Project (Jbjectives, Motivations, Approach, Plans and Expected Resu/ts)

The objective of this project is to characterize the liquid, gaseous, and solid emissions from various waste-to-energy systems. The characterization will be based on actual data obtained from on-site sampling operations. The first report from this project will be distributed in July 1977. This is a three year project.

Use Box No. 15 if additional space is needed

9. Status and Results

A Work Plan has been generated, as has a draft, preliminary Source Assessment Document. One site has been tested and negotiations are underway to environmentally test several other waste-as-fuel facilities.

This project is: $\square$ planned $\square$ in-progress $\square$ completed

$\begin{array}{ll}\text { 10. Utility Services } & \\ \square \text { electrical power } & \square \text { wastewater treatment } \\ \square \text { space heating } & \square \text { solid waste processing } \\ \square \text { space cooling } & \square \text { potable water } \\ \square \text { potable hot water } & \end{array}$
Use Box No. 16 if additional space is needed

12. Exchange of data 


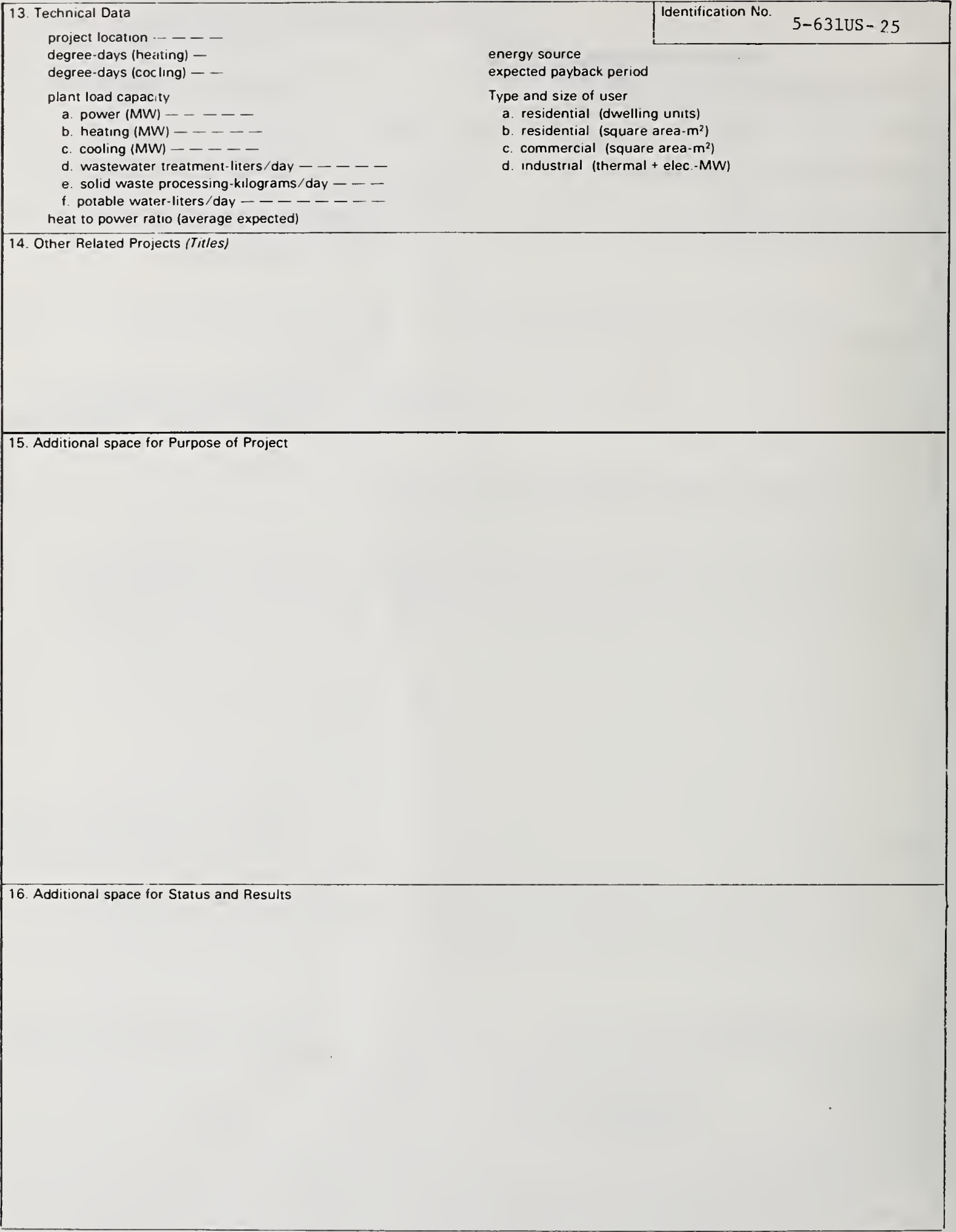




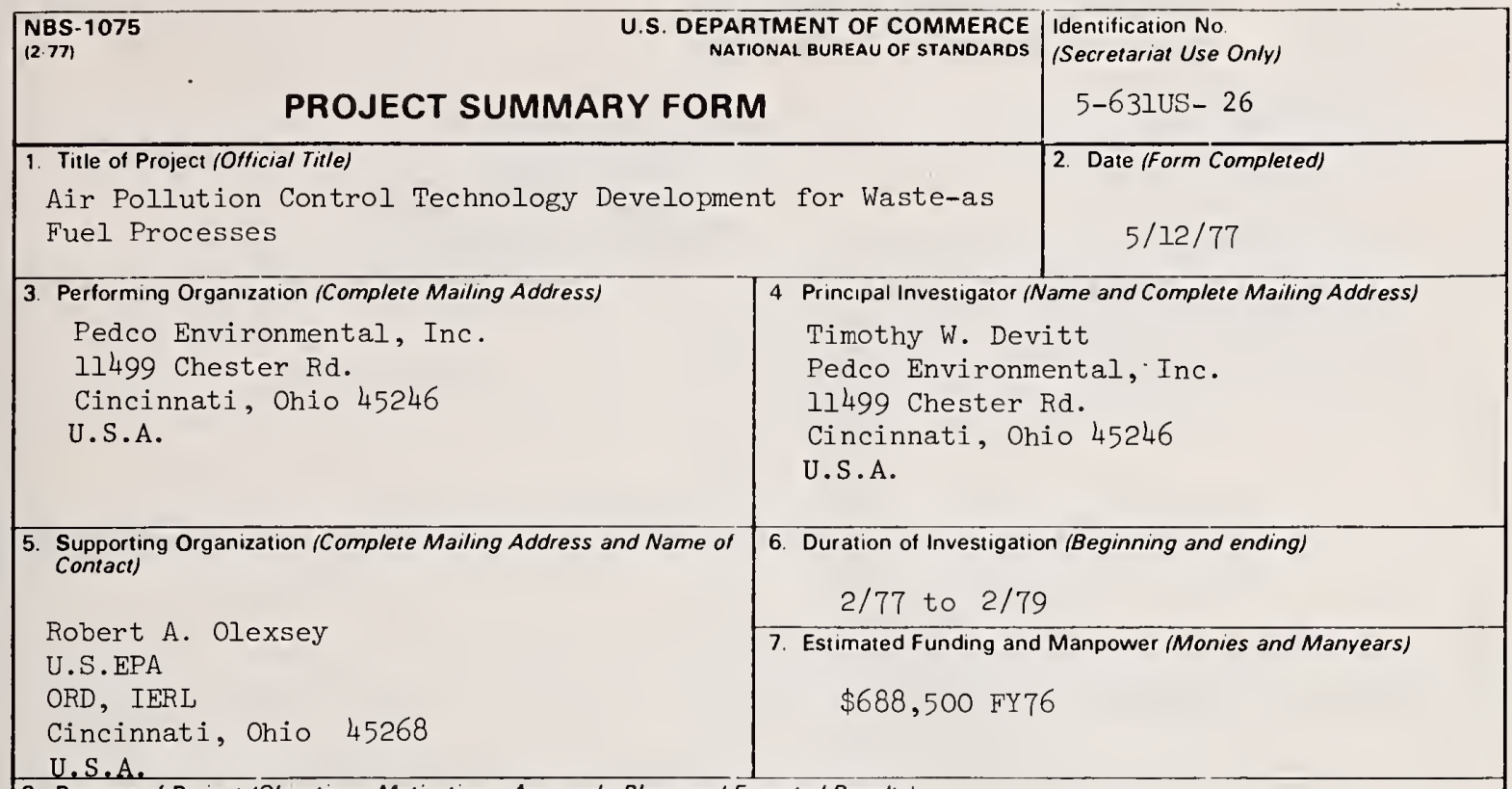

8. Purpose of Project (Jbjectives, Motivations, Approach, Plans and Expected Results)

The objective of this project is to develop techniques for controlling air emissions from wastes-to-energy systems. Inputs to the effort will come from an ongoing project on pollutant characterization, literature, and testing from pilot and full scale waste-to-fuel facilities. For this project, the contractor will survey emissions from active facilities, will analyze potential control technologies and then will design and fabricate slipstream (3000 cfm) pilot plant air pollution control units. The pilot plant units will be installed at 2 to 4 existing waste-as-fuel facilities. Data obtained on the effectiveness of such devices as high energy scrubbers, electrostatic precipitators and bag filters will aid engineers in design of future facilities and in correcting problems at existing plants.

Use Box No. 15 if additional space is needed

9. Status and Results

A work plan has beey generated by the contractor and work on Phase 1 and 2 of the program has begun.

This project is: $\square$ planned $\otimes$ in-progress $\square$ completed Use Box No. 16 if additional space is needed

$\begin{array}{ll}10 . \text { Utility Services } & \square \text { wastewater treatment } \\ \square \text { electrical power } & \square \text { solid waste processing } \\ \square \text { space heatıng } & \square \text { potable water } \\ \square \text { space cooling } & \\ \square \text { potable hot water } & \end{array}$

12. Exchange of data 


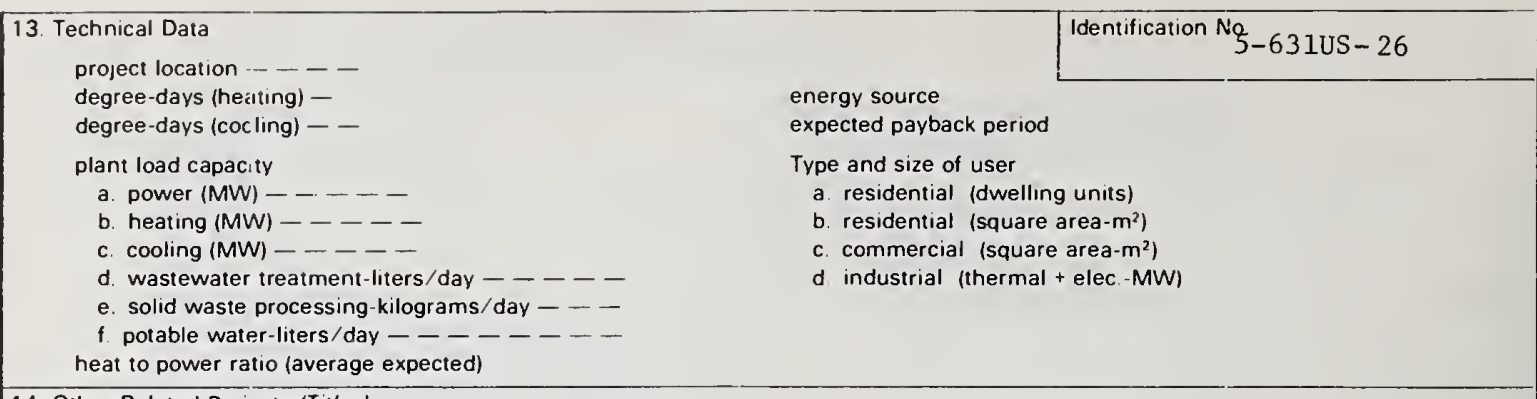

14. Other Related Projects (Titles)

15. Additional space for Purpose of Project

16. Additional space for Status and Results 


\begin{tabular}{|c|c|c|}
\hline \multicolumn{2}{|l|}{$\begin{array}{l}\text { NBS-1075 } \\
(2-77)\end{array}$} & \multirow{2}{*}{$\begin{array}{l}\begin{array}{l}\text { Identification No } \\
\text { (Secretariat Use Only) } \\
5-631 \mathrm{US}-27 \\
\text { 2. Date (Form Completed) } \\
5 / 12 / 77\end{array}\end{array}$} \\
\hline \multicolumn{2}{|l|}{$\begin{array}{l}\text { 1. Title of Project (Official Title) } \\
\text { Conversion of Solid Waste to Polymer Gasoline }\end{array}$} & \\
\hline \multicolumn{3}{|c|}{ 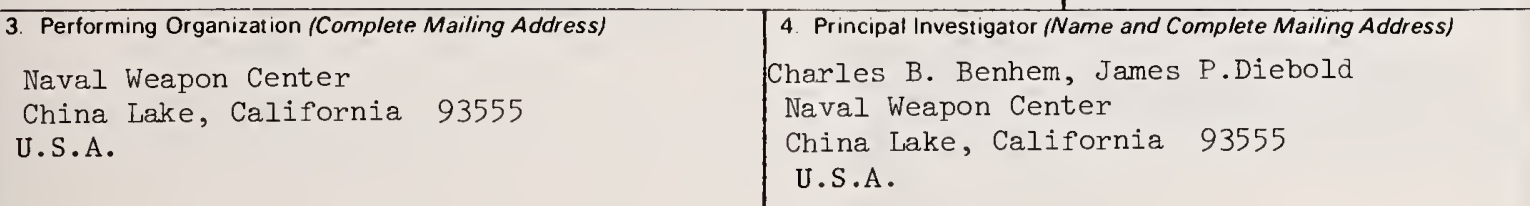 } \\
\hline $\begin{array}{l}\text { 5. Supporting Organization (Complete Mailing Address and Name of } \\
\text { Contact) } \\
\text { Walter W. Liberick, Jr. } \\
\text { U.S. EPA } \\
\text { ORD, IERL } \\
\text { Cincinnati, Ohio } 45268 \\
\text { U.S.A. }\end{array}$ & $\begin{array}{l}\text { 6. Duration of Investigatio } \\
6 / 75 \text { to } \\
\text { 7. Estimated Funding and } \\
\$ 100,000 \text { FY7 } \\
135,000 \text { FY7 } \\
110,500 \text { FY7 }\end{array}$ & \\
\hline \multicolumn{3}{|c|}{ 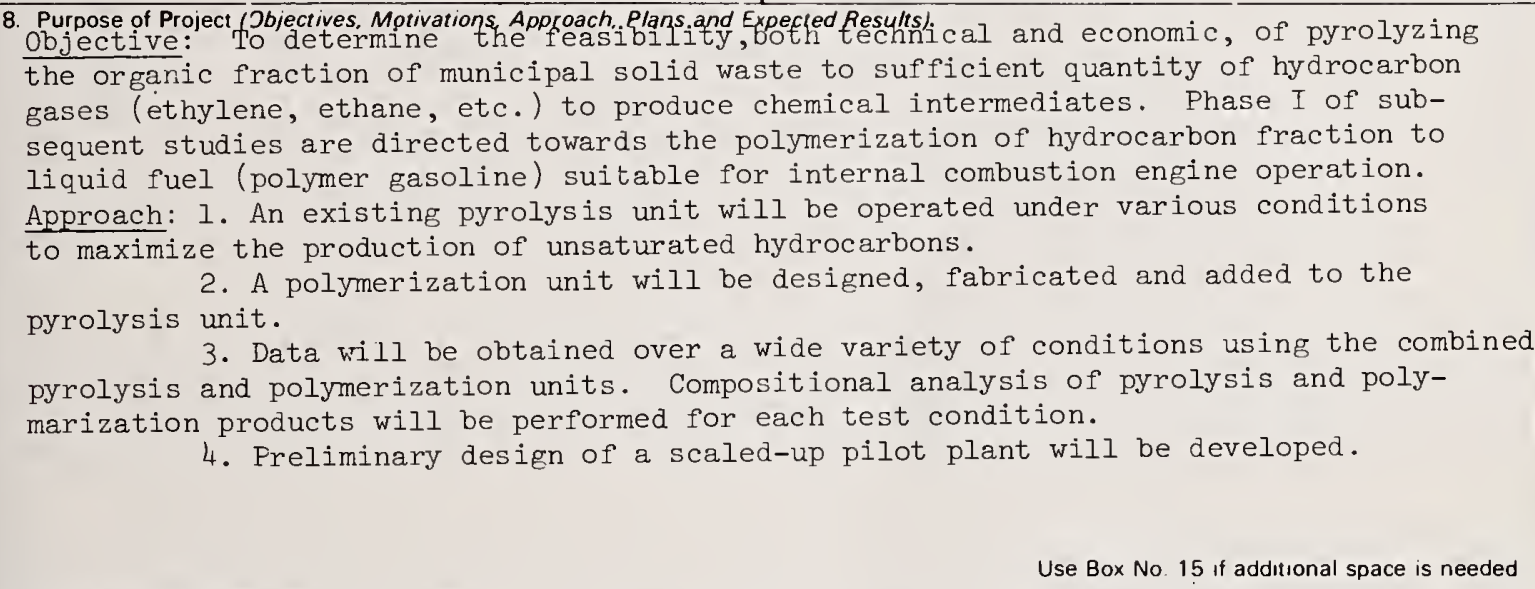 } \\
\hline \multicolumn{3}{|c|}{ 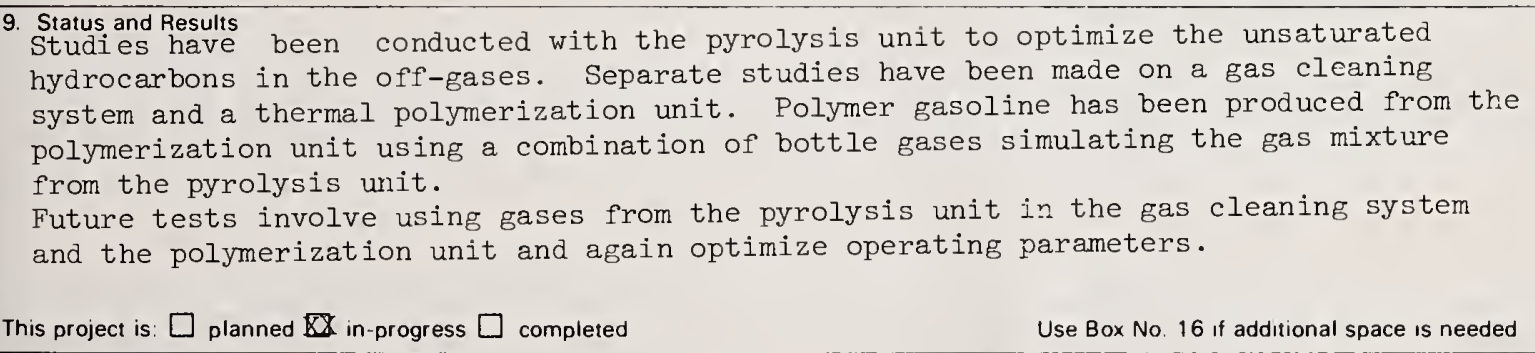 } \\
\hline \multicolumn{3}{|c|}{\begin{tabular}{ll|l} 
10. Utility Services & 11 Type of Project \\
$\square$ electrical power & $\square$ wastewater treatment \\
$\square$ space heating & $\square$ solıd waste processing \\
$\square$ space coolıng & $\square$ potable water & $\square$ public \\
$\square$ potable hot water & $\square$ cooperatıve
\end{tabular}} \\
\hline 12. Exchange of data & & \\
\hline
\end{tabular}




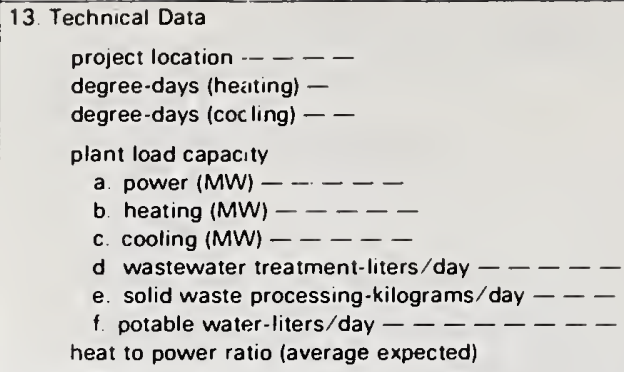

14. Other Related Projects (Tit/es)
Identification No

5-631US- 27

energy source expected payback period

Type and size of user
a. residential (dwelling units)
b. residential (square area- $\mathrm{m}^{2}$ )
c. commercial (square area- $\mathrm{m}^{2}$ )
d. Industrial (thermal + elec-MW)

15. Additional space for Purpose of Project 
NBS-1075

(2-77)
U.S. DEPARTMENT OF COMMERCE $/$ Identification No.

NATIONAL GUREAU OF STANDARDS (Secretariat Use Only)

5-631US- 28
PROJECT SUMMARY FORM

1. Title of Project (Official Title)

Pilot Scale Pyrolytic Conversion of Mixed Waste to Fuel
2. Date (Form Completed)

$5 / 12 / 77$

\section{Performing Organization (Complete Mailing Address)}

Energy Resources Co. , Inc. 185 Alewife Brook Parkway

Cambridge, MA 02138

U.S.A.
4. Principal investigator (Name and Complete Mailing Address)

Dr. John Howard, Mr. Richard H.Stephens

Energy Resources Co., Inc.

185 Alewife Brook Parkway

Cambridge, MA 02138

U.S.A.
5. Supporting Organization (Complete Mailing Address and Name of Contact)

Walter W. Liberick, Jr.

U.S.EPA

ORD, IERL

U.S.A.
6. Duration of Investigation (Beginning and ending) $7 / 75$ to $12 / 77$

7. Estimated Funding and Manpower (Monies and Manyears) $\$ 300,000$ FY75 265,000 FY76 100,000 FY77

8. Purpose of Project (Objectives, Motivations, Approach, Plans and Expected Results)

Objectives: To develop models relating fraction of fuel products (gas, liquid, solid) produced in pyrolysis of various types of solid wastes as function of pyrolyzed conditions. Solid wastes include mixed municipal, agricultural, and industrial wastes. An investigation of chemical conversions including steam gasification, partial oxidation, and catalytic effects of bed materials, as well as detailed analysis and characterization of pyrolysis products including char and oil will be conducted.

Approach: Experimental study using small batch pyrolyzer and pilot size ( $200 \mathrm{~kg} / \mathrm{hr}$ ) fluidized bed pyrolyzer to produce data for model development and verification. Statistical and semi-empirical models will be examined for the normal fluidized bed pyrolytic reaction as well as for steam gasification and partial oxidation. Several char and oil samples will be analyzed in detail to evaluate the acceptability of fuel products.

Use Box No. 15 if additional space is needed

\section{Status and Results}

Fabrication of the test units is completed. Test runs are under way to accumulate data for model verification.

This project is: $\square$ planned $\mathrm{X}$ in-progress $\square$ completed

$$
\text { י }
$$


13 Technical Data

Identification No

project location

5-631US- 28

degree-days (heaııng) -

degree-days (cocling) - -

energy source

expected payback period

plant load capacıty

a. power (MW) - - - - -

b. heating (MW) - $\ldots$

c cooling (MW) - $-\ldots$

d wastewater treatment-liters/day _ _ _ -

e. solid waste processing-kilograms/day $-\ldots$

f potable water-hiters/day - $-\ldots$

heat to power ratio (average expected)

14. Other Related Projecis (Titles)

15. Additional space for Purpose of Project

16. Additional space for Status and Results 
NBS-1075

(2.77)
U.S. DEPARTMENT OF COMMERCE

NATIONAL BUREAU OF STANDARDS

\section{PROJECT SUMMARY FORM}

Identification No.

(Secretariat Use On/y)

1. Title of Project (Officral Title) 5-633US- 29

2. Date (Form Completed)

PUROX System

$2 / 4 / 77$

3 Performing Organization (Complete Mailing Address)

Union Carbide Corporation

Linde Division

270 Park Avenue, 8th Floor

New York, NY 10017

U.S.A.

4 Principal Investigator (Name and Complete Mailing Address)

Mr. R.S. Paul

Union Carbide Corporation

Linde Division

270 Park Avenue, 8th Floor

New York, NY 10017

U.S.A.

5 Supporting Organization (Complete Mailing Address and Name of Contact)

The entire project to date has been funded by the Union Carbide Corp. Forthcoming tests on municipal sludges will be funded in part by the USEPA.

6. Duration of Investigation (Beginning and ending)

1970 to present

7. Estimated Funding and Manpower (Monies and Manyears)

In excess of $\$ 10,000,000$

In excess of 150 my

8. Purpose of Project (Jbjectives, Motivations, Approach, Plans and Expected Results)

The Union Carbide PUROX system is a process for the high temperature combustion and pyrolysis of all types of solid waste to produce a compact, inert residue and useful fuel within the constraints of national and local air and water emission standards. In addition it provides for the separation and recovery of valuable resources contained in refuse.

Use Box No 15 if additional space is needed

9. Status and Results

The project has progressed to a 200 ton/day demonstration plant in South Charleston, W.Va. that has successfully processed municipal refuse from the city of Charleston,

W.Va. and surrounding communities as well as assorted commercial solid waste.

This project is $\square$ planned $\bigotimes$ in-progress $\square$ completed

\begin{tabular}{ll}
\hline 10. Utility Services & $\square$ wastewater treatment \\
$\square$ electrical power & $\square$ solid waste processing \\
$\square$ space heatıng & $\square$ potable water \\
$\square$ space cooling & \\
$\square$ potable hot water &
\end{tabular}

2. Exchange of data
Use Box No. 16 if additional space is needed

\begin{tabular}{|ll}
11 Type of Project & \\
$\square$ public & $\square$ private \\
$\square$ cooperative & \\
$\square$ Yes & $\square$ No
\end{tabular}


13. Technical Data

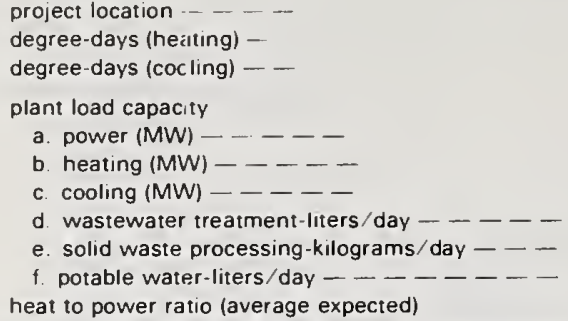

14. Other Related Projects (Titles)

\section{energy source}

expected payback period

Type and size of user

a. residential (dwellıng units)

b. residential (square area $-\mathrm{m}^{2}$ )

c. commercial (square area- $\mathrm{m}^{2}$ )

d. industrial (thermal + elec.-MW)

16. Additional space for Status and Results 


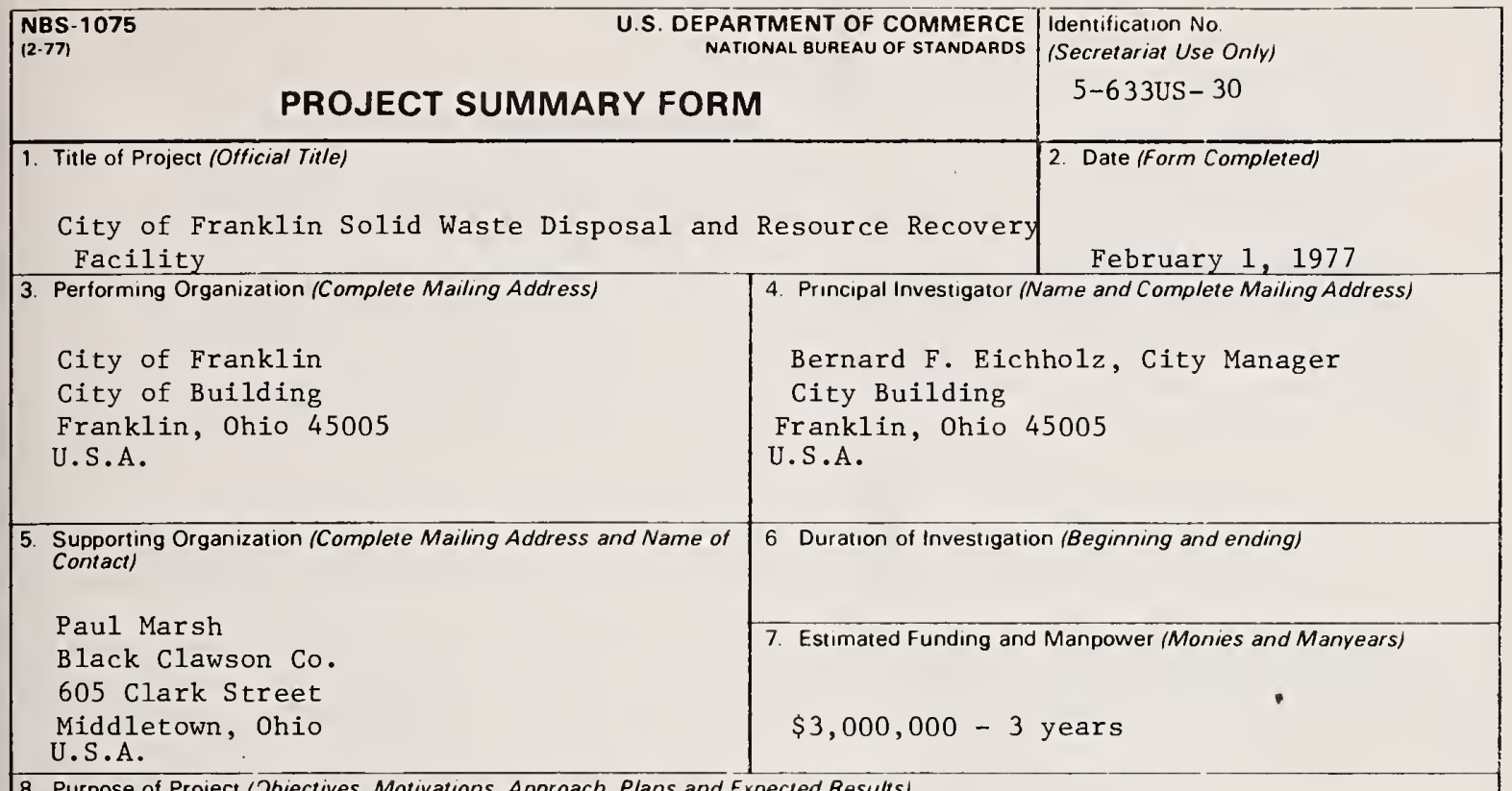

8. Purpose of Project (Jbjectives, Motivations, Approach, Plans and Expected Results)

To inoffensively to the environment dispose of solid waste material, after reclaiming for refuse, glass, metals and paper fibers. Has been successfully operating since May 15, 1971.

9. Status and Results

Use Box No. 15 if additional space is needed Much larger copies are being built in Hempstead, N.Y. and Dade County, Florida.

This project is: $\square$ planned $\square$ in-progress $\square$ completed 10. Utility Services $\square$ electrical power $\square$ space heating $\square$ space cooling $\square$ potable hot water 12. Exchange of data

Will data be available from this project that will be shared with others? $\square$ wastewater treatment

$\boldsymbol{\nabla}$ solid waste processing

$\square$ potable water

Use Box No. 16 if additional space is needed 11 Type of Project

$\square$ public $\quad \square$ private

cooperative 
13. Technical Data

project location.

degree-days (heatting) -

degree-days (cocling) - -

plant load capacity

a. power $(\mathrm{MW})-\ldots$

b. heating (MW) $-\cdots$

c. cooling (MW) $-\ldots-\ldots$

d. wastewater ireatment-liters/day _ _ _ _ -

e. solid waste processing-kilograms/day - -

f. potable water-liters/day -

heat to power ratio (average expected)

14 Other Related Projects (Titles) energy source

expected payback perıod

Type and size of user

a. residential (dwelling units)

b. residential (square area- $m^{2}$ )

c. commercial (square area- $\mathrm{m}^{2}$ )

d. industrial (thermal + elec. MW)

15. Additional space for Purpose of Project

16. Additional space for Status and Results 
\begin{tabular}{|l}
$\begin{array}{l}\text { NBS-1075 } \\
(2-77)\end{array}$ \\
U.S. DEPARTMENT OF COMMERCE \\
NATIONAL BUREAU OF STANDARDS
\end{tabular}

PROJECT SUMMARY FORM

1 Title of Project (Ofricial Title)

Palmer Solid Waste Resource Recovery Project
Identification No

(Secretariat Use On/y)

$$
\text { 5-633US- } 31
$$

2. Date (Form Completed)

December 7, 1976
3. Performing Organization (Complete Mailing Address)

Pa. D.E.R.

Div. of Solid Waste Management

Fulton Building

Harrisburg, $\mathrm{Pa} .17120$

U.S.A.
4. Principal Investigator (Name and Complete Mailing Address)

Mr. William Bucciare11i

5. Supporting Organization /Complete Mailing Address and Name of Contact)

Board of Supervisors

H.Robert Daws, Chairman

Township of Palmer

3245 Freemansburg Ave.

P.O. Easton, Pa. 18042

U.S.A.

8. Purpose of Project (Jbjectives, Motivations, Approach, Plans and Expected Resu/ts)

To demonstrate the economic and technical feasibility of an inter-municipal solid waste-resource recovery generation plant, and the use of 70 plus per cent of the waste as a supplemental fuel for use with coal in the manufacture of cement.

Use Box No. 15 if additional space is needed

9. Status and Results

Funding incomplete, construction phase pending.

This project is: planned $\square$ in-progress $\square$ completed

Use Box No. 16 if additional space is needed 10. Utility Services

$\square$ electrical power

$\square$ space heating

$\square$ space cooling

6. Duration of Investigation (Beginning and ending)

2 years - following construction

7. Estımated Funding and Manpower (Monies and Manyears)

$\$ 4 \mathrm{M}, 15$ man years

$\square$ potable hot water

12. Exchange of data

Yes

No 
13. Technical Data

project location -- - - -

degree-days (heiting) -

degree-days (cocling) - -

plant load capacity

a. power $(\mathrm{MW})----$

b. heating (MW) - . -

c. cooling (MW) $--\ldots$

d. wastewater treatment-liters/day - - - -

e. solid waste processing-kilograms/day _ -

f. potable water-liters/day $-\ldots-\ldots$

heat to power ratio (average expected)

14. Other Related Projects (Titles)
Identification No

5-633us- 31

energy source

expected payback period

Type and size of user

a residentıal (dwellıng units)

b. residential (square area- $m^{2}$ )

c. commercial (square area- $\mathrm{m}^{2}$ )

d industrial (thermal + elec.-MW)

15. Additional space for Purpose of Project

16. Additional space for Status and Results 


$\begin{aligned} & \text { NBS-1075 } \\ & (2.77)\end{aligned}$
U.S. DEPARTMENT OF COMMERCE
NATIONAL BUREAU OF STANDARDS

\section{PROJECT SUMMARY FORM}

1. Title of Project (Official Tit/e)

Evaluation of Ames' Waste Process - An Energy Recovery System

3. Performing Organization (Complete Mailing Address)

1. City of Ames, Iowa 50010

2. Midwest Research Institute

3. Iowa State University
Subcontractors

\section{Supporting Organization (Complete Mailing Address and Name of} Contact)

C. Wiles, R. Olexsey

U.S.EPA

ORD, MERL/IERL

Cincinnati, Ohio 45268 U.S.A.
4. Principal Investigator (Name and Complete Mailing Address)

A. O. Chantland, Project Mgr. Public Works Div. (Ames)

Dr. L.J.Shannon, Midwest Research Institute

Dr. A.W.Joensen, Iowa State University

Dr. E.R.Bauman, Director, ERI, Iowa State University

8. Purpose of Project (Jbjectives, Motivations. Approach. Plans and Expected Results)

The study will assess the effects of using municipal solid waste (MSW) as a supplementary fuel. Co-firing of MSW with coal in stoker and tangentially-fired boilers will be conducted and since one boiler is the same type as at St. Louis, studies will permit confirmation, and comparison of selected St. Louis results. Assessments will be made of the technical and environmental aspects of these co-firing techniques. In addition, technical and economic tests and evaluations will be conducted on the second generation MSW processing facility associated with supplying the refuse derived fuel.

Use Box No. 15 if additional space is needed

\section{Status and Results}

A full year of operation, complete with detailed data taking has been Eccomplished. A draft annual report has been provided to EPA on the results of these experiments.

This project is: $\square$ planned $区 \mathrm{x}_{\text {in-progress }} \square$ completed

Use Box No. 16 if additional space is needed

10. Utility Services

$\square$ electrical power

$\square$ space heating

$\square$ wastewater treatment

$\square$ space cooling

$\square$ solid waste processing

$\square$ potable water

$\square$ potable hot water

11. Type of Project

public $\square$ private

cooperative

XXY Y 
13. Technical Data

project location -

degree-days (heating) -

degree-days (cocling) - -

plant load capacity

a power $(\mathrm{MW})-\ldots$

b. heating (MW) - - - -

c. cooling (MW) $--\ldots-$

d. wastewater treatment-liters/day _ - _ - -

e. solid waste processing-kilograms/day _ - -

f. potable water-liters/day ------heat to power ratio (average expected)

14. Other Related Projects (Titles) energy source

expected payback period

Type and size of user

a. residential (dwelling units)

b. residential (square area- $\mathrm{m}^{2}$ )

c. commercial (square area- $\mathrm{m}^{2}$ )

d. industrial (thermal + elec.-MW)

15. Additional space for Purpose of Project

16. Additional space for Status and Results 


\begin{tabular}{|c|c|c|}
\hline \multicolumn{2}{|l|}{$\begin{array}{l}\text { NBS-1075 } \\
(2-77)\end{array}$} & $\mid \begin{array}{c}\text { Identification No } \\
\text { (S-661US- } 33\end{array}$ \\
\hline \multicolumn{2}{|c|}{$\begin{array}{l}\text { 1. Title of Project (Official Title) } \\
\text { Prepáration, Use and Cost of d-RDF as a Supplementary Fuel } \\
\text { in Stoker Fired Boilers }\end{array}$} & \\
\hline $\begin{array}{l}\text { 3. Performing Organization (Complete Mailing Address) } \\
\text { National Center for Resource Recovery, Inc } \\
1211 \text { Connecticut Avenue NW } \\
\text { Washington, D. C. } 20036 \\
\text { U.S.A. }\end{array}$ & \multicolumn{2}{|c|}{$\begin{array}{l}\text { 4. Principal Investigator (Name and Complete Mailing Address) } \\
\text { Dr. Harvey Alter, Mr. Stu Natof } \\
\text { National Center for Resource Recovery, Inc. } \\
\text { l2ll Connecticut Avenue NW } \\
\text { Washington, D. C.20036 }\end{array}$} \\
\hline $\begin{array}{l}\text { 5. Supporting Organization (Complete Mailing Address and Name of } \\
\text { Contact) } \\
\text { C.Wiles } \\
\text { R.Olexsey } \\
\text { U.S.EPA } \\
\text { ORD, MERL/IERL } \\
\text { Cincinnati, Ohio } 45268 \\
\text { U.S.A. }\end{array}$ & \multicolumn{2}{|c|}{$\begin{array}{l}\text { 7. Estimated Funding and Manpower (Monies and Manyears) } \\
\$ 270,464 \text { FY75 }\end{array}$} \\
\hline \multicolumn{3}{|c|}{$\begin{array}{l}\text { This Research Grant involves the study of the technical and economic aspects of } \\
\text { preparing and using densified forms of municipal solid waste as a supplementary fuel } \\
\text { in industrial and institutional stoker coal-fired boilers. Investigations will be } \\
\text { conducted to establish methodology for preparing densified refuse derived fuel (d-RDF). } \\
\text { Process and product characterizations will be developed to enable establishment of } \\
\text { specifications for d-RDF. Densification forms will include pellets, briquettes, and } \\
\text { cubettes. Independent boiler burn tests and operations will be conducted in conjunctio } \\
\text { with this research to fully characterize the concept. }\end{array}$} \\
\hline
\end{tabular}

Use Box No. 15 if additional space is needed

\section{Status and Results}

Densified forms of solid waste have been produced in quantity. Combustion and environmental tests of the d-RDF have been accomplished by the Systems Technology Corporation at the Hagerstown Correctional Institute under contract to the EPA.

This project is: $\square$ planned $\square$ in-progress $\square$ completed

Use Box No. 16 if additional space is needed

10. Utility Services

$\square$ electrical power

$\square$ space heatıng

$\square$ wastewater treatment

$\square$ space cooling

solid waste processing

$\square$ potable water

$\square$ potable hot water

12. Exchange of data

Will data be available from this project that will be shared with others?

Yes

No 
13. Technical Data

project location

degree-days (heating) -

degree-days (cocling) - -

plant load capacity

a. power $(M W)-\ldots$

b. heating (MW) $-\ldots$

c. cooling (MW) $-\ldots-\ldots$

d wastewater treatment-liters/day - - - -

e. solid waste processıng-kilograms/day - - -

f. potable water-liters/day $-\ldots-\ldots-\ldots-$

heat to power ratio (average expected)

14. Other Related Projects (Titles)

15. Additional space for Purpose of Project

Identification No.

5-661US-33

energy source

expected payback period

Type and size of user

a. residential (dwelling units)

b residential (square area- $\mathrm{m}^{2}$ )

c. commercial (square area- $\mathrm{m}^{2}$ )

d. industrial (thermal + elec.-MW)

16. Additional space for Status and Results 
NBS-1075

(2.77)
U.S. DEPARTMENT OF COMMERCE NATIONAL BUREAU OF STANDARDS

\section{PROJECT SUMMARY FORM}

1. Title of Project /Official Title)

Effects of Burning Densified Forms of Municipal Solid Wastes Derived Fuels in Industrial, Utility and Institutional

Stocker-Fired Boilers

3. Performing Organization (Complete Mailing Address)

Systems Technology Corporation

245 North Valley Road

Xenia, Ohio 45385
U.S.A. 5. Supporting Organization (Complete Mailing Address and Name of
Contact)

C.Wiles, R.Olexsey

U.S.EPA

ORD, MERL/IERL

Cincinnati, Ohio 45268

U.S.A.

8. Purpose of Project (Jbjectives, Motivations, Approach, Plans and Expected Results)

The objective of this program is to demonstrate the use of densified Refuse Derived Fuel (d-RDF) as a coal supplement in stoker-equipped boilers and to assess the environmental impact of widespread implementation of the concept.

The questions are to be answered by burning pelletized, cubetted and briquetted d-RDF and coal in spreader stoker-equipped boilers. The coal d-RDF ratio will be varied to establish the impact of substitution ratio on boiler performance and the environment After initial testing is complete, a demonstration burn will occur to assess the impact of sustained firing. Each fuel-boiler combination will be approached in a three step sequence: (1) a field trial will establish the processability of the fuel by the boiler and the maximum substitution ratios usable without boiler problems; (2) a field test will quantify environmental, energy and boiler impacts of the fuel system over a range of boiler conditions; (3) a demonstration will be performed. The program schedule calls for initiation of testing in september 1976 and completion in July 1977 with the draft report complete in October 1977.

Use Box No. 15 if additional space is needed

\section{Status and Results}

Several field tests have been accomplished utilizing a stoker boiler at the Hagerstown Correctional Institute; additional testing will be accomplished.

This project is: $\square$ planned in-progress $\square$ completed

Use Box No. 16 if additional space is needed

$$
\text { 口 }
$$
$\square$. Unices space heating space cooling $\square$ potable hot water

$\square$ wastewater treatment Qxsolid waste processing $\square$ potable water 12. Exchange of data 


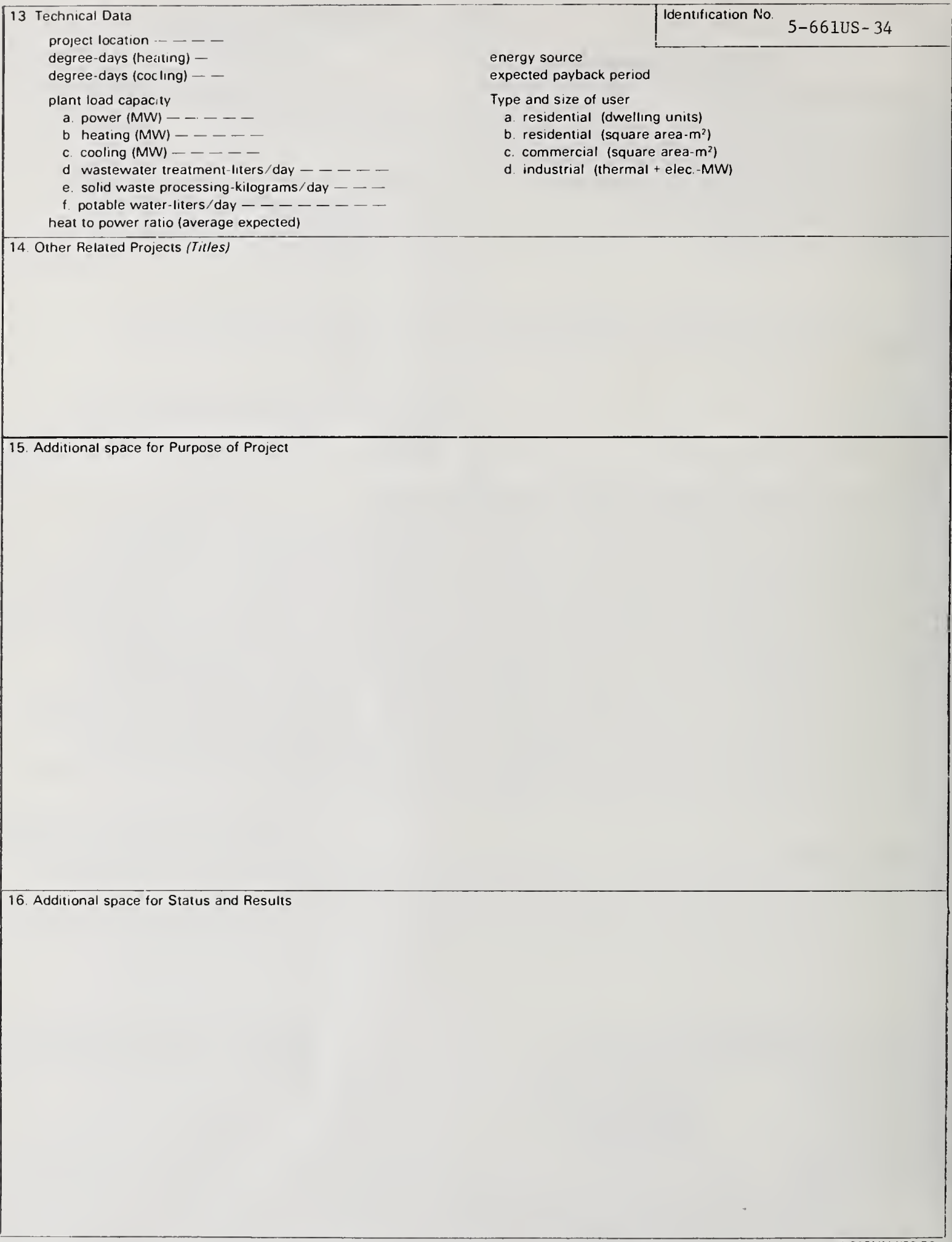


NBS-1075

(2.77)
U.S. DEPARTMENT OF COMMERCE

NATIONAL BUREAU OF STANDARDS

PROJECT SUMMARY FORM

1. Title of Project (Official Tit/e)

Wood Waste as a Power Plant Fuel in the Ozarks
3 Performing Organization (Complete Mailing Address)

University of Missouri - Rolla

Rolla, Missouri 65401

U.S.A.
4 Principal Investigator (Name and Complete Mailing Address) Virgil J.Flanigan, Assoc. Prof. of Mech. Eng. Dept. of Mech. and Aerospace Engr. University of Missouri - Rolla Rolla, Missouri 65401 U.S.A.

6. Duration of Investigation (Beginning and ending)

$$
10 / 76 \text { to } 9 / 77
$$

7. Estimated Funding and Manpower (Monies and Manyears) $\$ 50,000$ FY76

H.M.Freeman

U.S.EPA

ORD, IFRL

Cincinnati, Ohio 45268

U.S.A.

8. Purpose of Project (Objectives, Motivations, Approach, Plans and Expected Results)

It is proposed that part of the large reserves and part of the production of oak wood waste in the Ozark region be used as a boiler fuel. The waste is to be blended with coal to take advantage of existing furnace design. The blend is to be optimized for stack conditions, ash content, amount of fuel, boiler efficiency, and economics.

The objectives of the project are to assist the wood products industry with its problems in using and disposing of wood waste and to examine the environmental consequences of co-firing wood waste with coal.

Use Box No. 15 if additional space is needed

9. Status and Results

Tests are underway. Separate environmental testing was accomplished by the Midwest Research Institute (under contract to the EPA) during the first quarter of 1977.

$\begin{array}{ll}\text { Utility Services } & \\ \text { electrical power } & \square \text { wastewater treatment } \\ \text { space heatıng } & \square \text { solıd waste processing } \\ \text { space cooling } & \square \text { potable water } \\ \text { potable hot water } & \end{array}$

11 Type of Project

Will data be available from this project that will be shared with others?

Ges

No 
days (heating) -

degree-days (cocling) -

energy source

plant load capacity

a. power $(\mathrm{MW})-\cdots$

b. heating (MW) ----

c. cooling (MW) ----

d. wastewater treatment-liters/day - - - -

e. solid waste processing-kilograms/day - - -

f. potable water-liters/day _ _ _ _ _ -

heat to power ratio (average expected)

14. Other Related Projects (Titles)

15. Additional space for Purpose of Project

expected payback period

Type and size of user
a. residential (dwelling units)
b. residential (square area $-\mathrm{m}^{2}$ )
c. commercial (square area- $\mathrm{m}^{2}$ )
d. industrial (thermal + elec. - MW)

16. Additional space for Status and Results 


$\begin{aligned} & \text { NBS-1075 } \\ & (2-77)\end{aligned}$
U.S. DEPARTMENT OF COMMERCE
NATIONAL BUREAU OF STANDARDS

PROJECT SUMMARY FORM

1. Title of Project (Official Title)

Salvage Fuel Boiler Plant

3. Performing Organization (Complete Mailing Address)

Navy Public Works Center

Norfolk, Virginia 23511

U.S.A.
Identification No

(Secretariat Use Only)

5-731US- -36

2. Date (Form Completed)

Feb. 7, 1977
5. Supporting Organization (Complete Mailing Address and Name of Contact)

Naval Facilities Engineering Command Alexandria, Virginia 22332

U.S.A.
4 Principal Investigator (Name and Complete Mailing Address)

N/A

6. Duration of Investigation (Beginning and ending)

\section{$\mathrm{N} / \mathrm{A}$}

7. Estimated Funding and Manpower (Monies and Manyears)

$\$ 2,220,000$

8. Purpose of Project / Objectives, Motivations, Approach, Plans and Expected Resu/ts)

After a thorough analysis of the quantity and nature of the refuse produced by ships and activities in the complex, construction of a combination refuse incinerator and boiler plant was proposed to accommodate future disposal requirements and also, to provide for projected requirements for additional steam generating capacity on the station. A plant consisting of two (2) 180-ton per day incinerator furnaces, each with waterwalls and steam boiler capable of producing 50,000 pounds of steam per hour was built.

Use Box No. 15 if additional space is needed

9. Status and Results

Steam production averages about 35,000 pounds per hour and is used to supplement other primary sources on the station. Presently, a constant steam supply from this plant is not absolutely necessary and the operation is primarily oriented to the incineration of available refuse while producing as much steam as possible. The normal operating schedule is 5 days per week, 24 hours per day, with one unit in service.

This project is: $\square$ planned $\square$ in-progress $X \mathbb{X}$ completed

Use Box No. 16 if additional space is needed 10. Utility Services

$\square$ electrical power

$\square$ space heating

$\square$ space cooling

$\square$ potable hot water

$\square$ wastewater treatment
$\square$ solid waste processing
$\square$ potable water
X Steam
11 Type of Project

QX public $\square$ private

cooperative

12. Exchange of data 
13. Technical Data

project location Norfolk, Virginia

degree-days (heating) -

degree-days (cocling) - -

plant load capacity

a. power (MW) - - - - -

b. heating (MW) $-\ldots-\ldots$

c. cooling (MW) - $\ldots \ldots$

d. wastewater treatment-liters/day - - - -

e. solid waste processing-kilograms/day - - -

f. potable water-liters/day - - - - - heat to power ratio (average expected)

14. Other Related Projects (Tit/es)

\begin{tabular}{|c|c|c|}
\hline & Identification No. & $5-731$ US -36 \\
\hline $\begin{array}{l}\text { energy source } \\
\text { expected payback period }\end{array}$ & Solid Waste & $\begin{array}{l}\text { - Residual Fuel } \\
\text { Oil }\end{array}$ \\
\hline $\begin{array}{l}\text { Type and size of user } \\
\text { a. residential Idwellın } \\
\text { b. residential Isquare } \\
\text { c. commercial Isquare } \\
\text { d. Industrial (thermal }\end{array}$ & $\begin{array}{l}\text { g units) } \\
\text { area- } m^{2} \text { ) } \\
\text { area- }-m^{2} \text { ) } \\
+ \text { elec. }-M W \text { ) }\end{array}$ & \\
\hline
\end{tabular}

15. Additional space for Purpose of Project

16. Additional space for Status and Results 
$\begin{aligned} & \text { NBS-1075 } \\ & (2-77)\end{aligned}$
U.S. DEPARTMENT OF COMMERCE
NATIONAL BUREAU OF STANDARDS

PROJECT SUMMARY FORM

1. Title of Project (Official Tit/e)

Instrumentation of Sewage Sludge Processing Operations

Including Anaerobic Digestion \& Vacuum Filtration
Identification No

(Secretariat Use On/v)

5-801US- 37
2. Date (Form Completed)

$11 / 23 / 76$

\section{Performing Organization (Complete Mailing Address)}

Metropolitan Waste Control Commission

350 Metro Square Bldg.

St. Paul, MN 55101

U.S.A.

4. Principal Investigator (Name and Complete Mailing Address)

Dr. Robert Polta

Metropolitan Waste Control Commission 350 Metro Square Bldg.

St. Paul, MN 55101
U.S.A. 5. Supporting Organization (Complete Mailing Address and Name of
Contact)

6. Duration of Investigation (Beginning and ending)

$$
5 / 12 / 75-5 / 11 / 80
$$

7. Estimated Funding and Manpower (Monies and Manyears)

$\$ 500,000$ and 8 man years

8. Purpose of Project (Objectives, Motivations. Approach. Plans and Expected Results)

The initial work is being done on automation of the sludge thickening, sludge conditioning, vacuum filtration, incineration and anaerobic digestion processes. The automation of sludge thickening is now being demonstrated. Key parameters for automating the sludge conditioning, vacuum filtration and incineration of processes are to be studied by February 1977 with the intent of demonstrating the automation of these processes. A mathematical model for the anaerobic digester has been completed for the purpose of evaluating control strategies. Successful control strategies will then be piloted and demonstrated. It is anticipated that automation of these sludge handling process will improve process reliability, reduce operating costs and conserve energy. For example, substantial energy will be saved by providing a consistent low moisture sludge feed to the incinerator.

Use Box No. 15 if additional space is needed

\section{Status and Results}

The project is now ongoing. A report has been drafted describing the instrumentation at the Metro plant. The report includes problem areas and recommend solutions. Equipment has been ordered and installed for the demonstration of sludge thickening. Specifications are now being drawn for the equipment for the automation and monitoring of sludge conditioning, vacuum filtration and incineration. This equipment should be installed by Jan. 1977 after which time a monitoring program will be initiated to determined key parameters and their effect on the process.

This project is: $\square$ planned $\mathbb{6}$ in-progress $\square$ completed

Use Box No. 16 if additional space is needed

electrical power

space heating

[ wastewater treatment

$\square$ solid waste processıng

$\square$ potable water

11. Type of Project

space cooling

potable hot water

2. Exchange of data

Will data be available from this project that will be shared with others?

XYes

No 


\section{Technical Data}

project location -- _ -

degree-days (heating) -

energy source

degree-days (cocling) - -

expected payback perıod

plant load capacity

a power $(\mathrm{MW}) \ldots$

b. heating (MW) - - - -

Type and size of user

a. residential (dwelling units)

b. residential (square area $-m^{2}$ )

c. cooting (MW) $---\ldots$

d. wastewater treatment-liters/day - - - -

c. commercial (square area $-\mathrm{m}^{2}$ )

e. solıd waste processing-kilograms/day - - -

f. potable water-liters/day $-\ldots-\ldots-\ldots-$

d. Industrial (thermal + elec-MW)

heat to power ratio (average expected)

14. Other Related Projects (Titles)

15. Additional space for Purpose of Project

16. Additional space for Status and Results 


\begin{tabular}{|c|c|c|}
\hline \multicolumn{2}{|c|}{$\begin{array}{l}\text { U.S. DEPARTMENT OF COMMERCE } \\
\text { NATIONAL BUREAU OF STANDARDS }\end{array}$} & $\begin{array}{l}\text { Identification No. } \\
\text { (Secretariat Use Only) } \\
\qquad 5-802 \mathrm{~GB}-38\end{array}$ \\
\hline $\begin{array}{l}\text { 1. Title of Project (Official Title) } \\
\text { Effect of Load and Flow Variability on Sev } \\
\text { Performance ( } 975)\end{array}$ & vage Works & $\begin{array}{l}\text { 2. Date (Form Completed) } \\
\qquad 3 / 15 / 77\end{array}$ \\
\hline $\begin{array}{l}\text { 3. Performing Organization (Complete Mailing Address) } \\
\text { Southampton University } \\
\text { Department of Civil Engineering } \\
\text { Institute of Sound and Vibration Research } \\
\text { Southampton, Hampshire S095NH } \\
\text { England }\end{array}$ & $\begin{array}{l}\text { 4. Principal Investigator }(\mathrm{A} \\
\text { Dr. P.R. Helliz } \\
\text { R.J.R. Reed } \\
\text { S.R. Kothair } \\
\text { Southampton Uni } \\
\text { Department of }\end{array}$ & $\begin{array}{l}\text { (ame and Complete Mailing Address) } \\
\text { well } \\
\text { versity } \\
\text { ivil Eng ineering }\end{array}$ \\
\hline $\begin{array}{l}\text { 5. Supporting Organization (Complete Mailing Address and Name of } \\
\text { Contact) } \\
\text { Science Research Council }\end{array}$ & 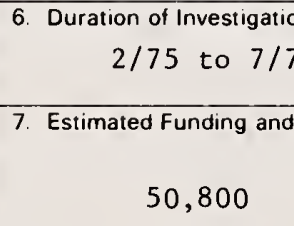 & $\begin{array}{l}\text { (Beginning and ending) } \\
7 \\
\text { Manpower (Monies and Manyears) }\end{array}$ \\
\hline
\end{tabular}

8. Purpose of Project (Dbjectives, Motivations, Approach, Plans and Expected Resufts)

The effect of balancing the organic load of urban foul sewage on treatment plant performance will be examined in a pilot plant treating $50 \mathrm{~m}^{3} / \mathrm{day}$. An on-line quality monitor and a magnetic flow meter will provide input signals to a control system system which will regulate flow to and from a stirred balance tank. Otherwise the treatment will be conventional, using diffused air activated sludge.

12. Exchange of data 
project location - - - -

degree-days (heating) -

degree-days (cocling) - -

plant load capacity

a. power $(\mathrm{MW})--\ldots$

b. heating $(\mathrm{MW})----$

c. cooling $(\mathrm{MW})----$

d. wastewater treatment-liters/day - - - -

e. solid waste processing-kilograms/day _ -

f. potable water-liters/day $-\ldots-\ldots-\ldots$ heat to power ratio (average expected)

14. Other Related Projects (Tit/es)

15. Additional space for Purpose of Project

16. Additional space for Status and Results

energy source

expected payback period

Type and size of user

a. residential (dwelling units)

b. residential (square area $-\mathrm{m}^{2}$ )

c. commercial (square area- $m^{2}$ )

d. industrial (thermal + elec.-MW) 


$\begin{array}{lr}\begin{array}{l}\text { NBS-1075 } \\ (2.77)\end{array} & \text { U.S. DEPARTMENT OF COMMERCE } \\ \text { NATIONAL BUAEAU OF STANDARDS }\end{array}$

PROJECT SUMIMARY FORM

1. Title of Project (O/ficial Title)

Investigate Heat Treatment of Sludge \& Processing of Supernatant to Reduce BOD \& COD

3. Performing Organization (Complete Mailing Address)

Hydroscience Assocs., Inc.

363 old Hook Road

Westwood, N.J. 07675

U.S.A.
4 Principal Investigator (Name and Complete Mailing Address)

Stanley C. Kmietz

Hydroscience Assocs., Inc.

363 Old Hook Road

Westwood, N.J. 07675

U.S.A.

6. Duration of Investıgation (Beginning and ending)

$$
9 / 76 \text { to } 8 / 78
$$

7. Estimated Funding and Manpower (Monies and Manyears)

$$
\$ 197,0002 \text { man years }
$$

Cincinnati, Ohio 45268

U.S.A.

8. Purpose of Project (Jbjectives, Motivations, Approach, Plans and Expected Results)

To demonstrate that the anaerobic filter process is an efficient and technically viable method for treating heat conditioned sludge liquor.

9. Status and Results

The pilot scale work is now beginning.

This project is: $⿴$ planned $\square$ in-progress $\square$ completed

Use Box No 16 if additional space is needed

\begin{tabular}{ll}
\hline 10. Utility Services & $\square$ wastewater treatment \\
$\square$ electrical power & $\square$ solid waste processing \\
$\square$ space heating & $\square$ potable water \\
$\square$ space cooling &
\end{tabular}

$\square$ potable hot water

12. Exchange of data 
13. Technical Data

project location -- - -

degree-days (heating) -

degree-days (cocling) - -

energy source

expected payback period

plant load capacity

a. power (MW) - - - -

Type and size of user

b. heating ( $\mathrm{MW}$ ) ----

a residential (dwelling units)

b. residential (square area- $\mathrm{m}^{2}$ )

d. wastewater treatment-liters/day $-\ldots-\ldots$

e. solid waste processing-kilograms/day - - -

c. commercial (square area- $\mathrm{m}^{2}$ )

d. industrial (thermal + elec. -MW)

f. potable water-liters/day $-----\ldots-$ heat to power ratio (average expected)

14. Other Related Projects (Titles)

15. Additional space for Purpose of Project

16. Additional space for Status and Results 
1. Title of Project (Official Title)

Fuel conservation in (conventional) hot water heating

2. Date (Form Completed)

systems by gas-operated heat pumps (ET5164A thru ET5167A)

3. Performing Organization (Complete Mailing Address)

Ruhrgas AG, 4270 Dorsten

AUDI-NSU AG, F.-Wankel-Str.,

7107 Nec Karsulm

H-NordhoffstraBe, 3180 Wolfsburg

4. Principal Investigator (Name and Complete Mailing Address)

June 30,1978

Federal Republic of Germany

5. Supporting Organization (Complete Mailing Address and Name of Contact)

PLE/KFA Juelich

Dr. Plantikow

Postfach 1913

D-5170 Juelich

Federal Republic of Germany

Mr. Rostek, Ruhrgas AG

Dr. Wilmers, AUDI-NSU

Mr. Pohle, VW AG

Federal Republic of Germany

8. Purpose of Project (Dbjectives, Motivations, Approach, Plans and Expected Resu/ts)

The energy consumption of hot water heating systems is to be reduced by $50 \%$ by the use of gas-operated heat pumps.

The prime movers of the compressors will be mass-progines converted to gas operation. In addition, compact units are to be developed from the above-mentioned car engines; the compact units will perform both the prime mover and the compressor functions. On the basis of these drive units, gas-fuelled heat pump systems suitable for the recoverey of heat from the atmosphere will be designed and constructed.

Use Box No 15 if additional space is needed

9. Status and Results

The results of the tests of the first pilot gas-fueled heat pump system consisting of commercial components were consistent with the theoretical computed data values. The tests are being continued. Modifications to increase the life of natural gasfueled rotary and reciprocating car engines were successful. The test results, so far, show that the preliminary targets of 10,000 full-load operating hours at a speed of 3,000 min under natural gas operation can be reached.

This project is: $\square$ planned in-progress $\square$ completed Use Box No. 16 if additional space is needed

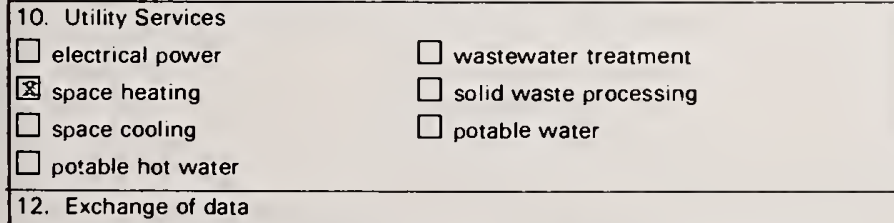
11 Type of Project

$\square$ public $\square$ private

Rx cooperative 
13. Technical Data

project location - - - -

degree-days (heatıing) -

degree-days (cocling) - -

plant load capacity

a power (MW) - - - - -

b heating $(\mathrm{MW})--\ldots$

c. cooling $(\mathrm{MW})---$

d wastewater treatment-liters/day - - - - -

e. solid waste processing-kilograms/day - -

f. potable water-liters/day -------

heat to power ratio (average expected)

14. Other Related Projects (Tit/es)

15. Additional space for Purpose of Project

16. Additional space for Status and Results

energy source

expected payback period

Type and size of user
a. residential (dwellıng units)
b. residential (square area-m²)
c. commercial (square area- $\mathrm{m}^{2}$ )
d. Industrial (thermal + elec.-MW) 


NBS-1075 U.S. DEPARTMENT OF COMMERCE
(2.77)

\section{PROJECT SUMMARY FORM}

1. Title of Project /Otficial Tit/e)

Gasification of municipal and industrial waste
Identification No.

(Secretariat Use Only)
3. Performing Organization (Complete Mailing Address)

Saarberg-Fernwarme GmbH

Postfach 238

D-66 Saarbrucken

Federal Republic of Germany

5. Supporting Organization (Complete Mailing Address and Name of Contact)

PLE/KFA Juelich

Dr. Plantikow

Postfach 1913

D-517 Juelich

Federal Republic of Germany
4 Principal Investigator (Name and Complete Mailing Address)

Dr. Huck

address see 3

\section{Purpose of Project (Jbjectives, Motivations, Approach. Plans and Expected Results)}

A process for conversion of municipal and industrial waste into a heating gas with a high BTU value without increase of pollution will be developed to tile commercial stage. The waste material wiil be gasified by means of partial oxidation. The resulting gas is purified of harmful components after removal of heavier fractions by means of condensation.

10. Utility Services

$\square$ electrical power

国 space heating

wastewater treatment

$\square$ space cooling

solid waste processing

$\square$ potable hot water

$\square$ potable water

6. Duration of Investigation (Beginning and ending)

May 23, 1974 - Dec. 31, 1977

$245,745 .-\$ U S$

12. Exchange of data 


\begin{tabular}{|c|c|c|}
\hline $\begin{array}{l}\text { 13. Technical Data } \\
\text { project location }-\ldots \ldots\end{array}$ & & Identification No. ${ }_{5-82.41 \mathrm{DE}-41}$ \\
\hline $\begin{array}{l}\text { degree-days (heating) - } \\
\text { degree-days (cocling) - - }\end{array}$ & \multicolumn{2}{|l|}{$\begin{array}{l}\text { energy source } \\
\text { expected payback period }\end{array}$} \\
\hline 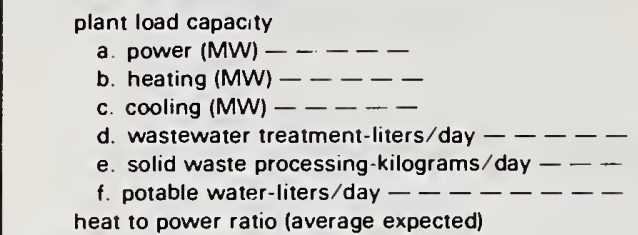 & \multicolumn{2}{|c|}{$\begin{array}{l}\text { Type and size of user } \\
\text { a. residential (dwelling units) } \\
\text { b. residential (square area- } \mathrm{m}^{2} \text { ) } \\
\text { c. commercial (square area- } \mathbf{m}^{2} \text { ) } \\
\text { d. industrial (thermal + elec.-MW) }\end{array}$} \\
\hline
\end{tabular}

14. Other Related Projects (Tit/es)

15. Additional space for Purpose of Project

16. Additional space for Status and Results 
NBS-1075

(2-77)
U.S. DEPARTMENT OF COMMERCE |Identification No.

NATIONAL BUREAU OF STANDARDS

(Secretariat Use On/y)

PROJECT SUMMARY FORM

1. Title of Project (Official Tit/e) $5-83$ IUS -42

Conceptual Design \& Cost Estimation for Heating an Anaerobic Digester by Solar Energy

3. Performing Organization (Complete Mailing Address)

Environmental System, Inc.

150 South Street

Annapolis, MD 21401

U.S.A.

\section{Supporting Organization (Complete Mailing Address and Name of Contact)}

R.V. Villiers

U.S. EPA, MERL, WRD

Cincinnati, OH 45268

U.S.A.

\section{Purpose of Project (Objectives, Motivations, Approach, Plans and Expected Resu/ts)}

4 Principal Investıgator (Name and Complete Mailing Address)

Jess W. Malcolm

Environmental Systems, Inc.

150 South Street

Annapolis, MD 21401

U.S.A.

6. Duration of investigation (Beginning and ending)

$$
11 / 75 \text { to } 8 / 76
$$

7. Estimated Funding and Manpower (Mories and Manyears) $\$ 30,0001$ man year

Feasibility study of the concept of heating an anaerobic digester by means of low energy solar energy so that the methane gas produced during anaerobic digestion of sludge can be used for a high energy application. Study will consist of detailing specifications for the equipment required for the solar energy system and of preparing a research plan for demonstrating the advantages of using solar energy as compared to methods presently used.

\section{Status and Results}

Use Box No. 15 if additional space is needed

Results of the study show that it is technologically and economically feasible to heat an anerobic digester with solar energy. Information is presented which shows that for maintaining a digester in the temperature range of $32^{\circ}-38^{\circ} \mathrm{C}$ year around for weather cordition similar to those at Annapolis, Maryland, the lowest cost method of heating the digester is to supply about 90 percent of the annual heat load with solar energy. The study also details specifications for a complete solar energy system for heating an anaerobic digester.

This project is: $\square$ planned $\square$ in-progress ${ }^{3}$ completed

Use Box No. 16 if additional space is needed

\begin{tabular}{ll}
\hline 10. Utility Services & \\
$\square$ electrical power & $\square$ wastewater treatment \\
$\square$ space heatıng & $\square$ solid waste processing \\
$\square$ space cooling & $\square$ potable water
\end{tabular}

$\square$ potable hot water

12. Exchange of data 
project location -_ - -

degree-days (heating) -

degree-days (cocling) - -

energy source

expected payback period

plani load capacity

a. power $(\mathrm{MW})-\ldots$

Type and size of user

b. heating (MW) ----

a. residential (dwelling units)

b. residential (square area- $m^{2}$ )

c. commercial (square area- $m^{2}$ )

d. wastewater treatment-liters/day $-\ldots-\ldots$

d. industrial (thermal + elec.-MW)

e. solid waste processing-kilograms/day - -

f. potable water-liters/day _ _ _ _ _ _ -

heat to power ratio (average expected)

14. Other Related Projects (Titles)

15. Additional space for Purpose of Project

16. Additional space for Status and Results 
$\begin{aligned} & \text { NBS-1075 } \\ & (2-77)\end{aligned}$
U.S. DEPARTMENT OF COMMERCE
NATIONAL BUREAU OF STANDARDS

PROJECT SUMMARY FORM

1. Title of Project (Official Title)

Evaluate Cost of Heat Treatment of Sludge Including Cost of Treating Side Streams

3. Performing Organization (Complete Mailing Address)

Culp-Wesner-Culp

P.O. Box 40

El Dorado Hills, California 95630

U.S.A.

5. Supporting Organization (Complete Mailing Address and Name of Contact)

R.V. Villiers

U.S. EPA, MERL, WRD

Cincinnati, Ohio 45268

U.S.A.

8. Purpose of Project (Jbjectives, Motivations, Approach, Plans and Expected Resu/ts)

The objective of this research is to determine the total costs of thermal conditioning of sludge. The study will include the impact of handling and diposing of the liquid process streams from the heat treatment of sludge on treatment plant costs.

Use Box No. 15 if additional space is needed

9. Status and Results

Results of the study give a general review of heat treatment processes and identify the various process side streams and present methods of dealing with them. Actual operating history of 28 heat treatment plants is given and the experience of these plants collectively is summarized. Based principally on actual cost information, all costs including those associated with the handling and treating of side streams are developed for heat treatment plants of various capacities. Summary report has been published. Final report is in preparation.

This project is: $\square$ planned $\square$ in-progress $\square$ completed

$\begin{array}{ll}10 . \text { Utility Services } & \square \text { wastewater treatment } \\ \square \text { electrical power } & \square \text { solid waste processing } \\ \square \text { space heating } & \square \text { potable water } \\ \square \text { space cooling } & \end{array}$

Use Box No. 16 if additional space is needed

12. Exchange

Will data be available from this project that will be shared with others?

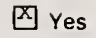

$\square$ No 


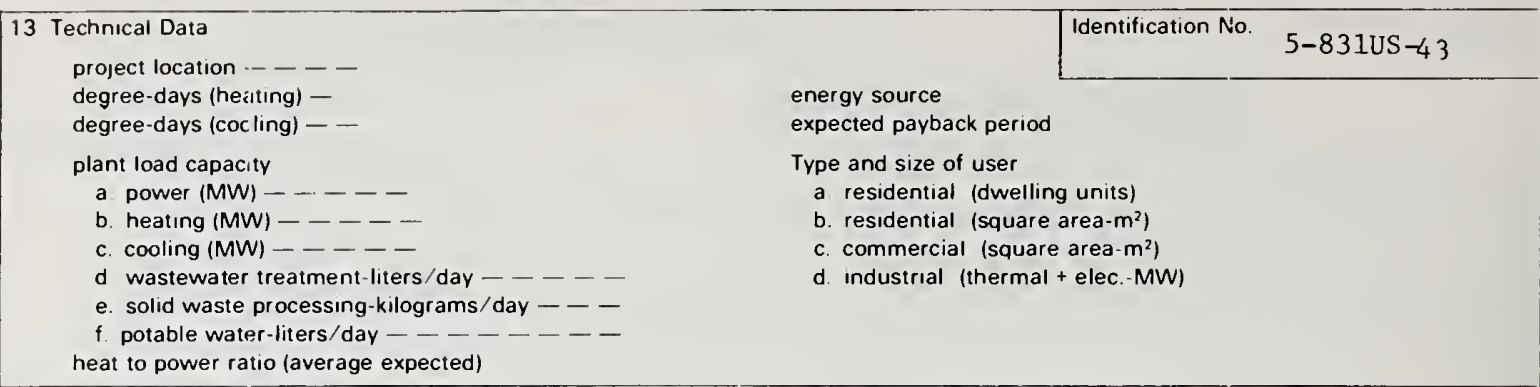

14. Other Related Projects (Titles)

15. Additional space for Purpose of Project

16. Additional space for Status and Results 


\begin{tabular}{|l}
$\begin{array}{l}\text { NBS-1075 } \\
(2.77)\end{array}$ \\
U.S. DEPARTMENT OF COMMERCE \\
NATIONAL BUREAU DF STANDARDS
\end{tabular}

PROJECT SUMMARY FORM

1. Title of Project (Official Tit/e)

Evaluation of Waste-to-Energy Processes

3. Performing Organization (Complete Mailing Address)

Ralph M. Parsons Company

$100 \mathrm{~W}$. Walnut Street

Pasadena, California 91124

U.S.A.

5. Supporting Organization (Complete Mailing Address and Name of Contact)

H.M.Freeman

U.S.EPA

ORD, IERL

Cincinnati, Ohio 45268

U.S.A.
Identification No

(Secretariat Use Only)

$$
5-831 \text { US }-44
$$

2. Date (Form Completed)

$5 / 12 / 77$

4. Principal Investigator (Name and Complete Mailing Address)

E.M.Wilson

Ralph M. Parsons Company

$100 \mathrm{~W}$. Walnut Street

Pasadena, California 91124

U.S.A.

6. Duration of Investigation (Beginning and ending)

$$
6 / 75 \text { to } 2 / 77
$$

7. Estimated Funding and Manpower (Monies and Manyears)

$$
\begin{array}{r}
\$ 225,000 \text { FY75 } \\
44,640 \text { FY76 } \\
54,000 \text { FY77 }
\end{array}
$$

8. Purpose of Project (Jbjectives, Motivations, Approach, Plans and Expected Results)

The objective of this project is to provide an objective third-party engineering evaluation of emerging waste-to-energy processes. The evaluation is to include cost figures and potential technical problems for the most prominent of the current and developing processes. A final report from this work will be available during the third quarter of 1977

Use Box No. 15 if additional space is needed

9. Status and Results

The work is completed and the draft final report is currently being revised.

The final report will be available in late 1977.

This project is: $\square$ planned $\square$ in-progress $\square$ completed

Use Box No. 16 if additional space is needed

$\begin{array}{ll}\text { 10. Utility Services } & \square \text { wastewater treatment } \\ \square \text { electrical power } & \square \text { solıd waste processing } \\ \square \text { space heating } & \square \text { potable water } \\ \square \text { space cooling } & \\ \square \text { potable hot water } & \end{array}$

12. Exchange of data

Will data be available from this project that will be shared with others?

\ Yes

$\square$ No 
plant load capacity

a. power (MW) - - - -

b. heating (MW) ----

c. cooling (MW) - - - -

d. wastewater treatment-liters/day - - - -

e. solid waste processing-kilograms/day - - -

f. potable water-liters/day - - - - - heat to power ratio (average expected)

14. Other Related Projects (Titles)

15. Additional space for Purpose of Project

16. Additional space for Status and Results 


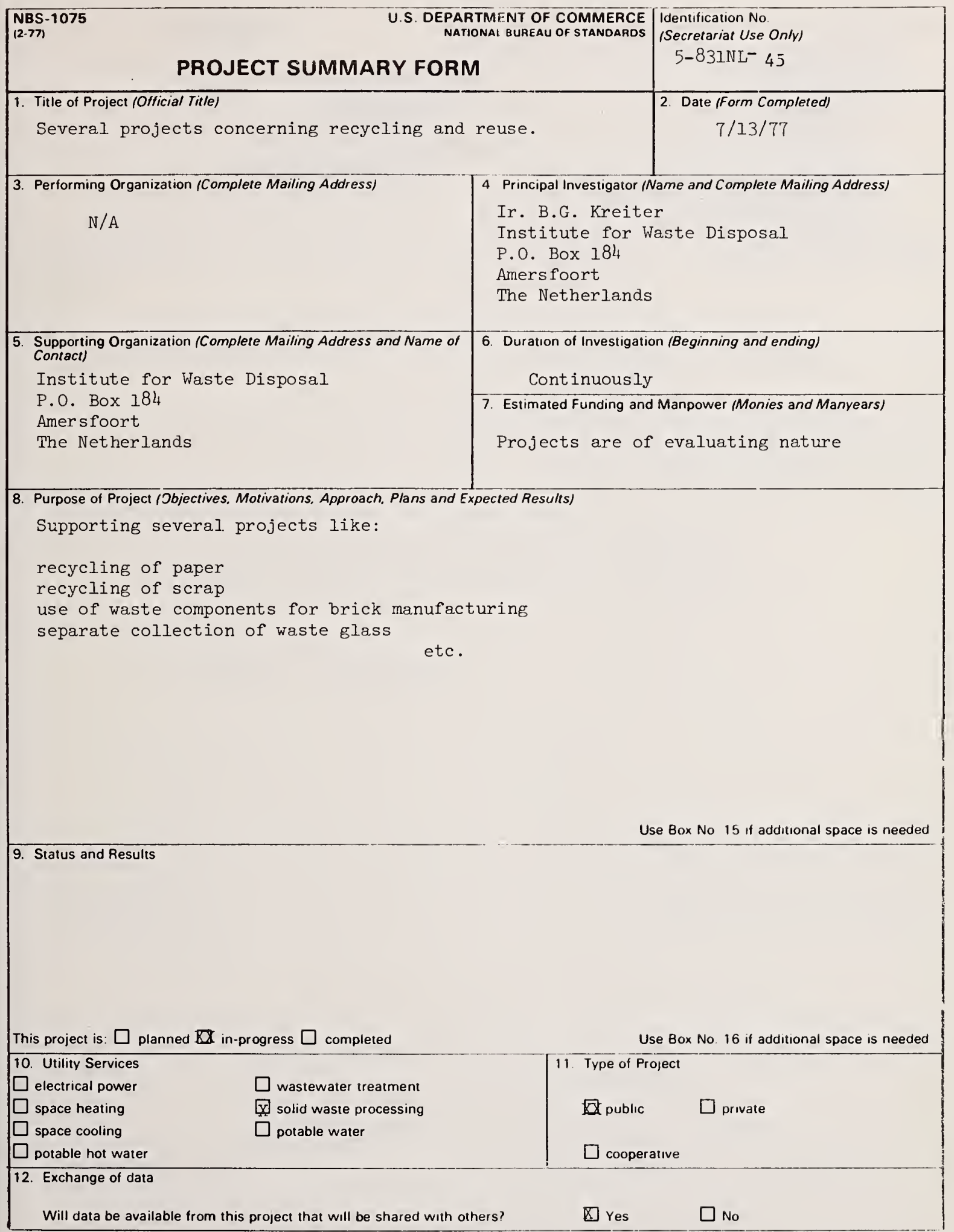


13. Technical Data Identification No

project location -- - - -

degree-days (heating) -

degree-days (cocling) - -

plant load capacity

a. power (MW) - - - -

b. heating (MW) $--\ldots-\cdots$

c. cooling (MW) - - - -

d. wastewater treatment-liters/day $-\ldots-\ldots$

e. solid waste processing-kilograms/day - - -

f. potable water-liters/day $-\ldots-\ldots-\ldots$ heat to power ratio (average expected)

14. Other Related Projects (Titles)

15. Additional space for Purpose of Project

\begin{tabular}{l} 
Additiona! space for Status and Results \\
\hline 16. Additional space for Purpose or Project
\end{tabular}

energy source

expected payback period

Type and size of user

a residential (dwelling units)

b. residential (square area- $m^{2}$ )

c. commercial (square area- $\mathrm{m}^{2}$ )

d. Industrial (thermal + elec.-MW)

14. Orher Relater 


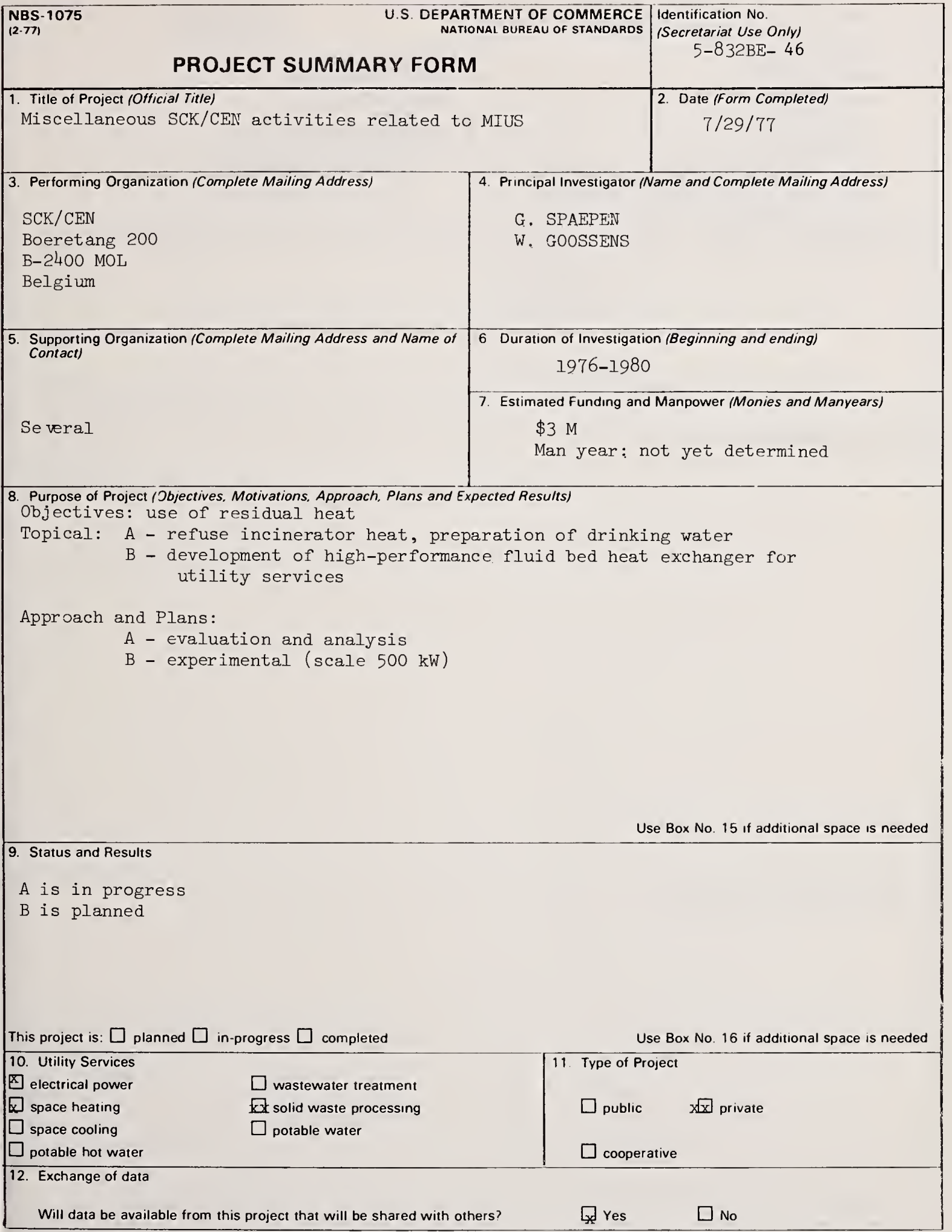




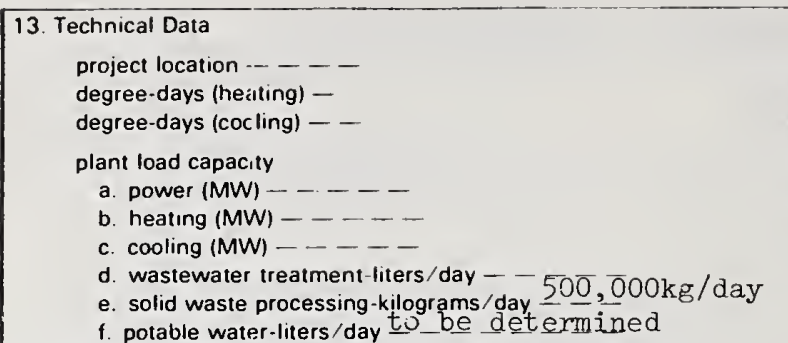

\section{energy source}

expected payback period

Type and size of user
a. residential (dwelling units)
b. residential (square area- $\mathrm{m}^{2}$ )
c. commercial (square area- $\mathrm{m}^{2}$ )
d industrial (thermal + elec. MW)
B/NOT YET DETERMINED

14 Other Related Projects (Tit/es)

15. Additional space for Purpose of Project

16. Additional space for Status and Results 


$\begin{array}{lr}\begin{array}{l}\text { NBS-1075 } \\ 12.77)\end{array} & \text { U.S. DEPART } \\ & \text { PRATIONAL } \\ & \text { PRECT SUMMARY FORM }\end{array}$

1. Title of Project /Official Tit/e)

Energy Conservation via the $\mathrm{CN}$ Heat Generator (891)

\section{Identification No}

(Secretariat Use On/y)

6-002GB-01

2. Date (Form Completed)

\section{$3 / 15 / 77$}

4 Principal Investigator (Name and Complete Mailing Address)

George Applegate

David Applegate

Westcraft Works, Alfred St., Wesbury, Wilts BA13 3DZ

England

6. Duration of Investigation (Beginning and ending)

Present (1976)

7. Estimated Funding and Manpower (Monies and Manyears)

NA

BA13 3DZ

England

8. Purpose of Project (Jbjectives, Motivations, Approach, Plans and Expected Resu/ts)

To develop and test $\mathrm{CN}$ heat generator and other heat recovery and energy conservation equipment.

9. Status and Results

This project is: $\square$ planned 78 in-progress $\square$ completed

[

$\square$ space cooling

$\square$ potable hot water

12. Exchange of data

Use Box No. 16 if additional space is needed

Will data be available from this project that will be shared with others?

$\square$ Yes

[x] Unknown
11. Type of Project

$\square$ public $\quad 8$ private

cooperative $\square$ wastewater treatment

$\square$ solid waste processing

$\square$ potable water 
13. Technical Data

project location -. - .

degree-days (heating) -

degree-days (cocling) -

plant load capacity

a. power $(\mathrm{MW})-\ldots$

b. heating $(\mathrm{MW})$

c. cooling $(\mathrm{MW})----$

d. wastewater treatment-liters/day - - - -

e. solid waste processing-kilograms/day _ -

f. potable water-liters/day _. heat to power ratio (average expected)

14. Other Related Projects (Titles)
Identification No.

6-002GB-01

energy source

expected payback period

Type and size of user

a. residential (dwelling units)

b. residential (square area- $m^{2}$ )

c. commercial (square area- $m^{2}$ )

d. industrial (thermal + elec.-MW)

15. Additional space for Purpose of Project

16. Additional space for Status and Results 


\begin{tabular}{l}
$\begin{array}{l}\text { NBS-1075 } \\
(2.77)\end{array}$ \\
PROJECT SUMMARY FORM \\
\hline NATIONAL BUREAU OF STANDAROS
\end{tabular}

1. Title of Project (Official Title)

Total Heat Systems - Stirling Engine and other Prime Movers for use as Heat Pumps and Circulators. (925)

3. Performing Organization (Complete Mailing Address)

Reading University

Department of Engineering and Cybernetics

Whitenights, Reading, Berks RG6 2BU

England
5. Supporting Organization (Complete Mailing Address and Name of Contact)

Science Research Council
4. Principal Investigator (Name and Complete Mailing Address) P.D. Dunn

G. Rice

Reading University

Department of Engineering and Cybernetics Whitenights, Reading, Berks RG6 2BU England

6. Duration of Investigation (Beginning and ending)

$$
5 / 70 \text { to } 4 / 75
$$

7. Estimated Funding and Manpower (Monies and Manyears) 13,000

8. Purpose of Project (Objectives, Motivations, Approach, Plans and Expected Resu/ts)

The Stirling engine programme covers all aspects of Stirling engine design and development. Particular features include the development of fluidized bed heat source the use of heat pipe for heat transmission, and the development of a number of new engine geometric.

In addition, consideration is given to the application of the Stirling engine cycle to buildings.

9. Status and Results

This project is: planned $\square$ in-progress $\square \times$ completed Use Box No. 16 if additional space is needed 10. Utility Services $\square$ electrical power space heating $\square$ space cooling $\square$ potable hot water 12. Exchange of data 
13. Technical Data

project location -

degree-days (heating) -

degree-days (cocling) - -

plant load capacity

a. power (MW) - - - -

b. heating (MW) ----

c. cooling (MW) $-\ldots-\ldots$

d. wastewater treatment-liters/day $-\ldots$

e. solid waste processing-kilograms/day - - -

f. potable water-liters/day --------

heat to power ratio (average expected)
Ientification No.

$6-002 \mathrm{~GB}-02$

energy source

expected payback period

Type and size of user

a. residential (dwelling units)

b. residential (square area- $\mathrm{m}^{2}$ )

c. commercial (square area- $m^{2}$ )

d. industrial (thermal + elec.-MW)

14. Other Related Projects (Tit/es)

15. Additional space for Purpose of Project

16. Additional space for Status and Results 
$\begin{aligned} & \text { NBS-1075 } \\ & (2.77)\end{aligned}$
U.S. DEPARTMENT OF COMMERCE
NATIONAL BUREAU OF STANDARDS

\section{PROJECT SUMMARY FORM}

1. Title of Project (Official Tit/e)

Utilization of Low Grade Heat Energy (936)
Identification No

(Secretariat Use Only)

6-002GB-03

2. Date (Form Completed)

$3 / 15 / 77$

3. Performing Organization (Complete Mailing Address)

South Bank Polytechnic

Faculty of Environmental Science and Technology

Borough Road, London, SE10AA

England

5. Supporting Organization /Complete Mailing Address and Name of Contact)

South Bank Polytechnic

Faculty of Environmental Science and

Technology

Borough Road, London, SE10AA, England

4. Principal Investigator (Name and Comp/ete Mailing Address) R.C.Blood

Dr. D.R. Scott

Dr. S.N. Salvja

R.W.James

South Bank Polytechnic

Faculty of Environmental Science and Technology

6. Duration of Investigation (Beginning and ending)

NA

7. Estimated Funding and Manpower (Monies and Manyears)

NA

8. Purpose of Project (Jbjectives, Motivations, Approach, Plans and Expected Results)

To study the performance of a heat pump using the subsurface soil as a source. The nature of the sub-soil varies with location and this affects the performance of the pump. Methods are being evolved for measuring significant properties. An electrical analogue will be used to simulate the heat pump system and to determine optimum values of the design parameters. The optimum heat pump system appropriate to a particular location will be constructed and its performance studied under year round conditions.

Use Box No 15 if additional space is needed

9. Status and Results $\square$ planned $\square$ in-progress $\square$ completed Use Box No 16 if additional space is needed Utility Services electrical power space heating space cooling potable hot water $\square$ wastewater treatment $\square$ solid waste processing $\square$ potable water private 12. Exchange of data Will dat a be available from this project that will be shared with others?

$\square$ Yes $\square$ No [x] Unknown 
13 Technical Data

Identification No

project location

6-002GB-03

degree-days (heating) -

energy source

degree-days (cocling) - -

expected payback period

plant load capacity
a. power (MW) - - -
b. heatıng (MW) $-\ldots-\cdots$
c. cooling $(\mathrm{MW})-\ldots$
d. wastewater treatment-liters/day - - - -
e. solid waste processing-kilograms/day _ -
f. potable water-liters/day _ _ $\ldots \ldots$ heat to power ratio (average expected)

14. Other Related Projects (Tit/es)

15. Additional space for Purpose of Project

Trpe and size of user

a. residential (dwelling units)

b. residential (square area- $\mathrm{m}^{2}$ )

c. commercial (square area- $\mathrm{m}^{2}$ )

d. industrial (thermal + elec.-MW)

16. Additional space for Status and Results 
NBS-1075

Identification No

(Secretariat Use Only)

PROJECT SUMMARY FORM

1. Title of Project (Official Title) 6-101GB-04

Heat Pumps (885)

2. Date (Form Completed)

$3 / 15 / 77$

3. Performing Organization (Complete Mailing Address)

Building Research Establishment Bucknells Lane

Garston, Watford Herts WD2-7JR

England

Principal Investıgator (Name and Complete Mailing Address)

K. Seymour- Walker

Building Research Establishment

Bucknells Lane

Garston, Watford Herts WD2-7JR

England

5. Supporting Organization /Complete Mailing Address and Name of Contact)

Building Research Establishment

Bucknells Lane

Garston, Watford Herts WD2-7JR

England

6. Duration of Investigation (Beginning and ending)

Present (1976)

7. Estimated Funding and Manpower (Monies and Manyears)

NA

8. Purpose of Project (Jbjectives, Motivations, Approach, Plans and Expected Resuits)

The evaluation and development of heat pump systems, for existing buildings and

future designs.

Particular attention will be paid to heat pumps for individual houses.

Several comnerically available machnies will be studied experimentally. Studies of less conventional machines, and boosting techniques, will be made and some experimental units developed. The consequences for building design will be examined, both for simple heat pumps and for machines forming parts of complete building environment systems.

Use Box No. 15 if additional space is needed

9. Status and Results

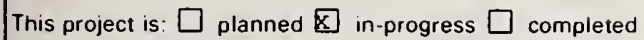

Use Box No. 16 if additional space is needed

10. Utility Services

$\square$ electrical power

wastewater treatment

a space heatıng

$\square$ wastewater treatment

$\square$ solıd waste processing

$\square$ potable water

$\square$ space cooling

$\square$ potable hot water

12. Exchange of data

Will data be available from this project that will be shared with others?

[x] Unknown

11 Type of Project

Yes

No

Qxublic $\quad \square$ private

cooperative 


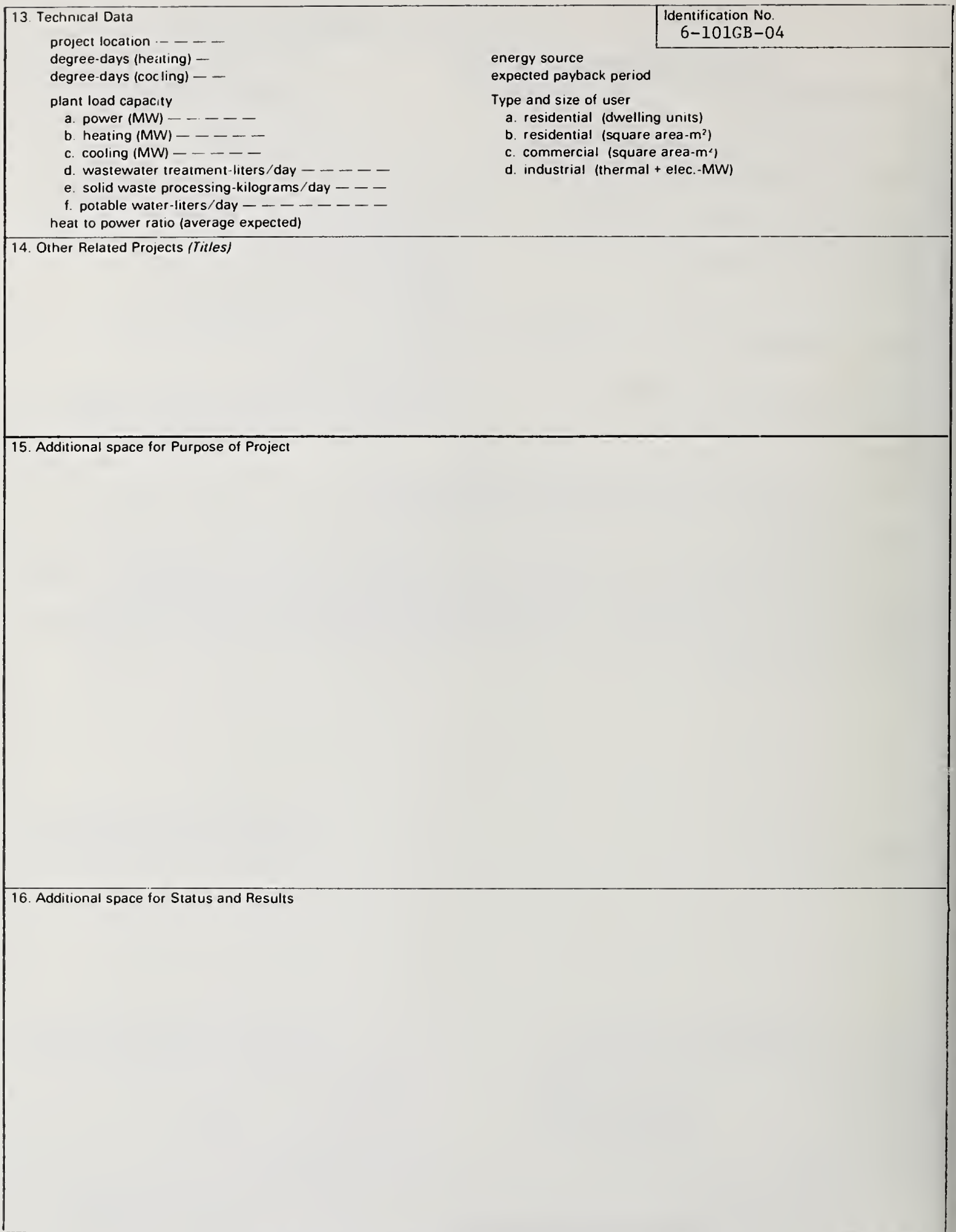




\section{PROJECT SUMMARY FORM}

1. Title of Project (Official Tit/e)

Solar Heat System for Indoor Swimning Facility

Identification No.

(Secretariat Use On/y)

$$
\text { 6-101US-05 }
$$

2. Date (Form Completed)

February 14, 1977

\section{Performing Organization (Complete Mailing Address)}

Bureau of Bridges and Public Buildings City of Milwaukee

Room 311 Municipal Building

841 North Broadway"

Milwaukee, Wisconsin 53202

U.S.A.

\section{Supporting Organization (Complete Mailing Address and Name of Contact)}

Application to be submitted to ERDA for financial support of the solar heat system.
4. Principal Investigator (Name and Complete Mailing Address) Mr. Henry J. Balconi, Superintendent Bureau of Bridges and Public Buildings Room 311 Municipal Building 841 North Broadway

Milwaukee, Wisconsin 53202 U.S.A.

6. Duratıon of Investigation (Beginning and ending) (Apply \& receive February, 1977 - June, 1977 ERDA Grant)

7. Estimated Funding and Manpower (Monies and Manvears)

Solar Heat System - $\$ 250,000.00$

Indoor Swimming Facility $\$ 1,475,000.00$

8. Purpose of Project (Jbjectives, Motivations, Approach, Plans and Expected Results

Due to the scaricity and high cost of existing energy sources, we are exploring the possibility of using solar energy for heating purposes on our proposed indoor Swimming Facility. An application will be submitted to the Federal Energy Research Development Administration for a grant to fund the additional cost of incorporating a solar heat system to our proposed Indoor Swimming facility. The purpose of the grant will be two fold: 1) Reduce energy requirement from existing energy sources and 2) to develop technical data for the advancement of solar energy. Expected energy savings would be approximately $\$ 7,500.00$ per year based on today's energy costs.

Use Box No. 15 if addıtıonal space is needed

9. Status and Results

Contracts have been awarded to construct the Swimming facility. Construction is expected to begin March 7, 1977. The initial design of the facility has incorporated those structural elements necessary to accommodate the future installation of a solar heating system.

This project is: $\square$ planned $\square$ in-progress $\square$ completed Use Box No. 16 if additional space is needed 10. Utility Services 区Kelectrical power space heating wastewater treatment $\square$ space cooling $\square$ solid waste processing Dotable water potable hot water

12. Exchange of data 
13 Technical Data

project location ...... Milwaukee

degree-days (heatting) $-7,635$

degree-days (cocling) - -

plant load capacity

a. power $(\mathrm{MW})-125 \mathrm{KW}$

b. heating $(\mathrm{MW}) 2700 \mathrm{MBH}$

c. cooling $(\mathrm{MW})+\mathrm{H} \sigma \mathrm{t}$ applicable

d. wastewater treatment-liters/day - - Not applicable

e solid waste processing-kilograms/day Not applicable

f. potable water-liters/day $-\ldots \ldots \ldots \ldots-50,000$ heat to power ratio (average expected) 19

e. recreational $-22,000 \mathrm{ft} .^{2}$

14. Other Related Projects (Titles)

None

15. Additional space for Purpose of Project

16. Additional space for Status and Results 
dentification No

(2.77)

PROJECT SUMMARY FORM

1. Title of Project (O/ficial Tit/e)

Applications of Heat Pumps, Heat Pipes and Similar

Devices for Heat Recovery and Energy Conservation (908)

(Secretariat Use On/y)

$$
6-102 \mathrm{~GB}-06
$$

2. Date (Form Completed)

$3 / 15 / 77$

3. Performing Organization (Complete Mailing Address)

International Research and Development

Company LTD.

Fossway, Newcastle-upon-Tyne NE62YD

England

5. Supporting Organization (Complete Mailing Address and Name of Contact)

Vickers LTD, \& Reyrolle Parsons LTD

(joint owners of IRD)

4. Principal Investigator (Name and Complete Mailing Address)

\section{D.A.Reay}

Fossway, Newcastle-upon-Tyne NE62YD

England

6. Duration of Investigation (Beginning and ending)

$$
3 / 74 \text { to } 3 / 76
$$

7. Estimated Funding and Manpower (Monies and Manyears)

$$
10,000-25,000
$$

\section{Purpose of Project (Jbjectives, Motivations, Approach, Plans and Expected Results)}

Review of current state of art and economics for domestic and industrial heat pumps. Use of heat pipes for heat exchange in heat recovery system, involving practical design and development of prototype system. A prototype heat exchanger has been constructed and is being tested.

9. Status and Results

This project is: $\square$ planned $\square$ in-progress $\square$ completed

Use Box No. 16 if additional space is needed

\begin{tabular}{ll}
\hline 10. Utility Services & $\square$ wastewater treatment \\
$\square$ electrical power & $\square$ solid waste processing \\
$\square$ space heating & $\square$ potable water \\
$\square$ space cooling & \\
$\square$ potable hot water &
\end{tabular}

potable hot water

12. Exchange of data 
13 Technical Data

project location

degree-days (heating) -

degree-days (cocling) - - -

energy source

plant load capacity

a. power (MW) - - - - -

b. heating (MW) - $\ldots$ expected payback period

c. cooling (MW) _ _ _ -

rype and size of user

a. residential (dwelling units)

b. residential (square area- $\mathrm{m}^{2}$ )

c. commercial (square area $-\mathrm{m}^{2}$ )

d. wastewater treatment-liters/day - $\ldots$

e. solid waste processing-kilograms/day - -

f. potable water-liters/day _ _ _ _ - -

d. industrial (thermal + elec.-MW)

heat to power ratio (average expected)

14. Other Related Projects (Titles)

15. Additional space for Purpose of Project

16. Additional space for Status and Results 


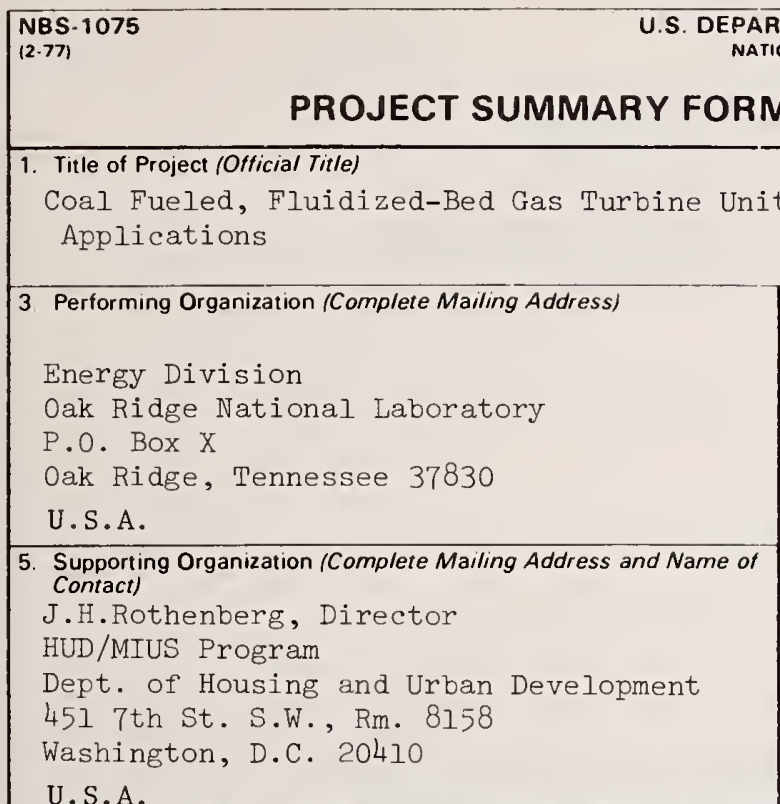

Ientification No. (Secretariat Use On/y) 6-151US-07

2. Date (form Completed)

Coal Fueled, Fluidized-Bed Gas Turbine Unit for MIUS Applications

$11 / 15 / 76$

\section{Purpose of Project (Jbjectives, Motivations, Approach, Plans and Expected Results)}

The objective of this project, jointly sponsored by HUD and ERDA/Fossil Energy, is to develop a Modular Integrated Utility System (MIUS) test unit, using coal or coal-derive fuels, to provide electricity, space heating and cooling, water heating, and solid waste combustion for residential-commercial developments. The shortages of gas and oil in 1973 led to the realization that viability of the MIUS concept would be greatly enhanced if gas- or oil-fueled engine-generators could be replaced by units using coal, especially the high sulphur coal that constitutes about $90 \%$ of the Northeast United States coal reserves. This project was initiated in four phases: I - Conceptual Preliminary Evaluation; II - Conceptual Design; III - Detailed Design and Construction; and IV - Performance and Endurance Testing. Phase I included a comprehensive investigation and evaluation of the various ways in which coal and coal-derived fuels might be used for MIUS application and the potential performance and development problems of power conversion units (in the size range of about 300-1000 KWe). Direct combustion of coal in a fluidized-bed furnace coupled to a closed-cycle gas turbine was recommended as the most promising concept. Phase II - IV were directed towards a (continued)

9. Status and Results

To date, Phase I and II of the project have been completed and detailed design and equipment specification activities of Phase III are well underway. In the context of design criteria estarlished by the intended MIUS application. Phase I efforts led to the conclusion that the coal-fueled fluidized-bed combustion system coupled to a closedcycle gas turbine appears to have outstanding advantages over any other coal-using system. Analyses indicated that this concept would convert about $30 \%$ of fuel energy into electricity and about 50\% into heat that could be used for space heating and (continued)

This project is: $\square$ planned $\mathrm{Kx}$ in-progress $\square$ completed

10. Utility Services

electrical power

space heatıng

xpace coolıng

$\mathrm{X}$ potable hot water
Use Box No. 16 if additional space is needed 11. Type of Project

$\square$ wastewater treatment

[ solid waste processing

$\square$ potable water

12. Exchange of data 


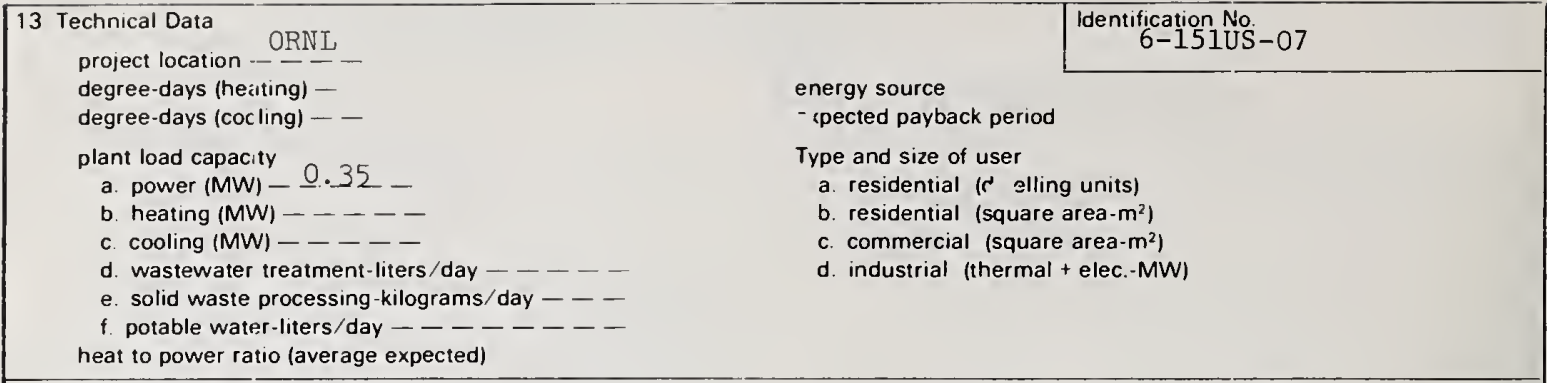

14 Other Related Projects (Titles)

15. Additional space for Purpose of Project

more detailed analysis and design of the concept, and actual construction and testing of a small test unit. The test unit represents one module of a multi-unit MIUS installation and will include the furnace and turbine-generator system, coal feed and metering systems, a recuperator, and various other heat exchangers for the recovery of waste heat.

16. Additional space for Status and Results

cooling and potable water heating. By burning coal in a fluidized-bed of limestone, sulphur emissions are reduced to the point that high-sulphur coal can be used within the residential sector without violating air quality standards. In Phase II, an effort was made to explore a wide variety of concepts for the geometry of the fluidized-bed as well as for various heat exchangers, duct arrangements, and provisions for instrumentation and control. Other aspects examined included furnace design, the modification of an available turbine, pulsation and heat tromsfer within the fluidized-bed, materials of construction, flow diagrams, and the coal feed and metering systems. Detailed design (Phase III) of a $350 \mathrm{KWe}$ test unit is in progress. The potential for also using this concept in the commercial/industrial market, with possible scale-up of unit size, is currently undergoing review. 


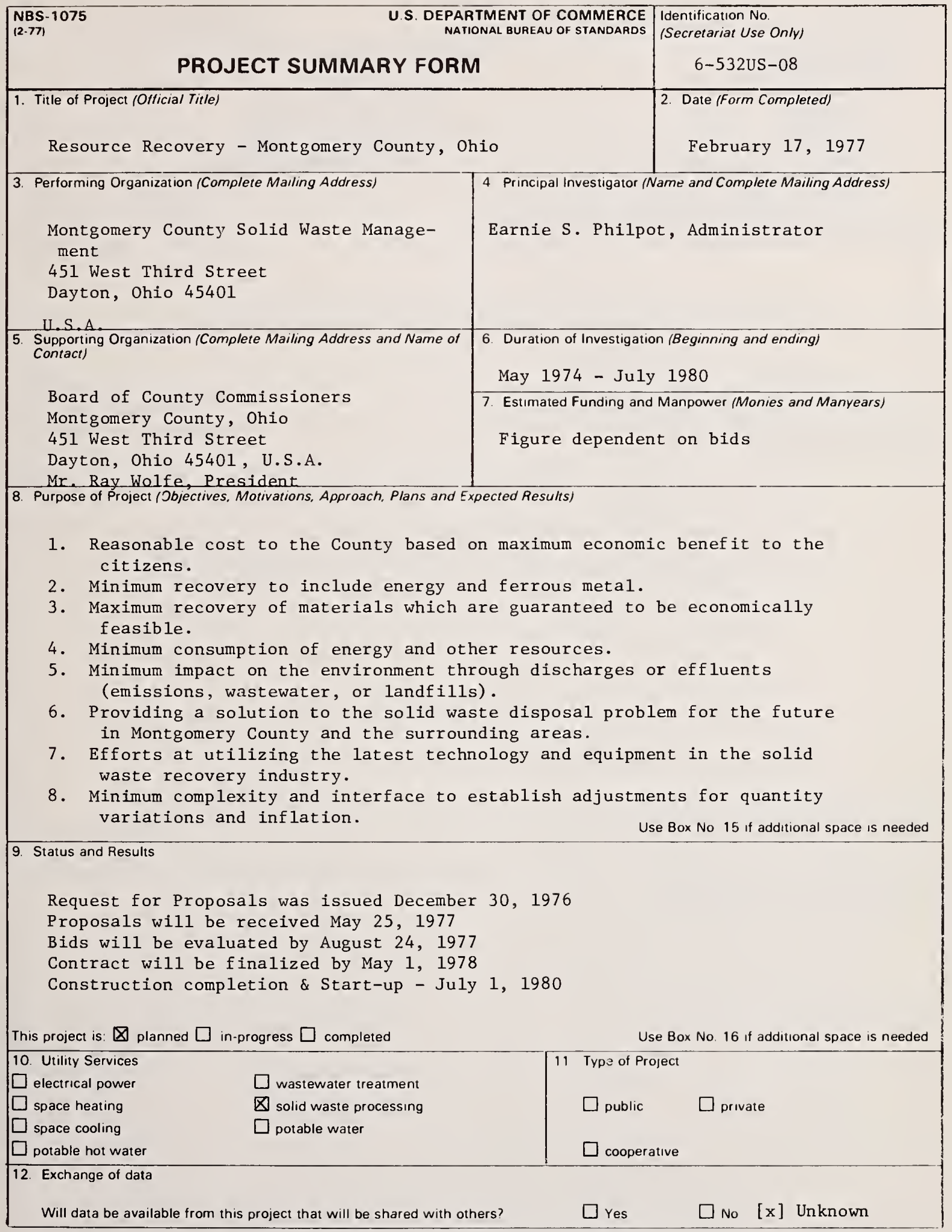


project location -- - - -

identification No

energy source

degree-days (cocling) - -

expected payback period

plant load capacity

a power (MW) - - - -

b. heating $(\mathrm{MW})----$

c. cooling (MW) - - - -

d. wastewater ireatment-liters/day _ _ _ -

e. solid waste processing-kilograms/day _ - -

f. potable water-liters/day

Type and size of user
a. residential (dwelling units)
b. residential (square area- $\mathrm{m}^{2}$ )
c. commercial (square area- $m^{2}$ )
d Industrial (thermal + elec. MW)

heat to power ratio (average expected)

14. Other Related Projects (Tit/es)

15. Additional space for Purpose of Project

16. Additional space for Status and Results 


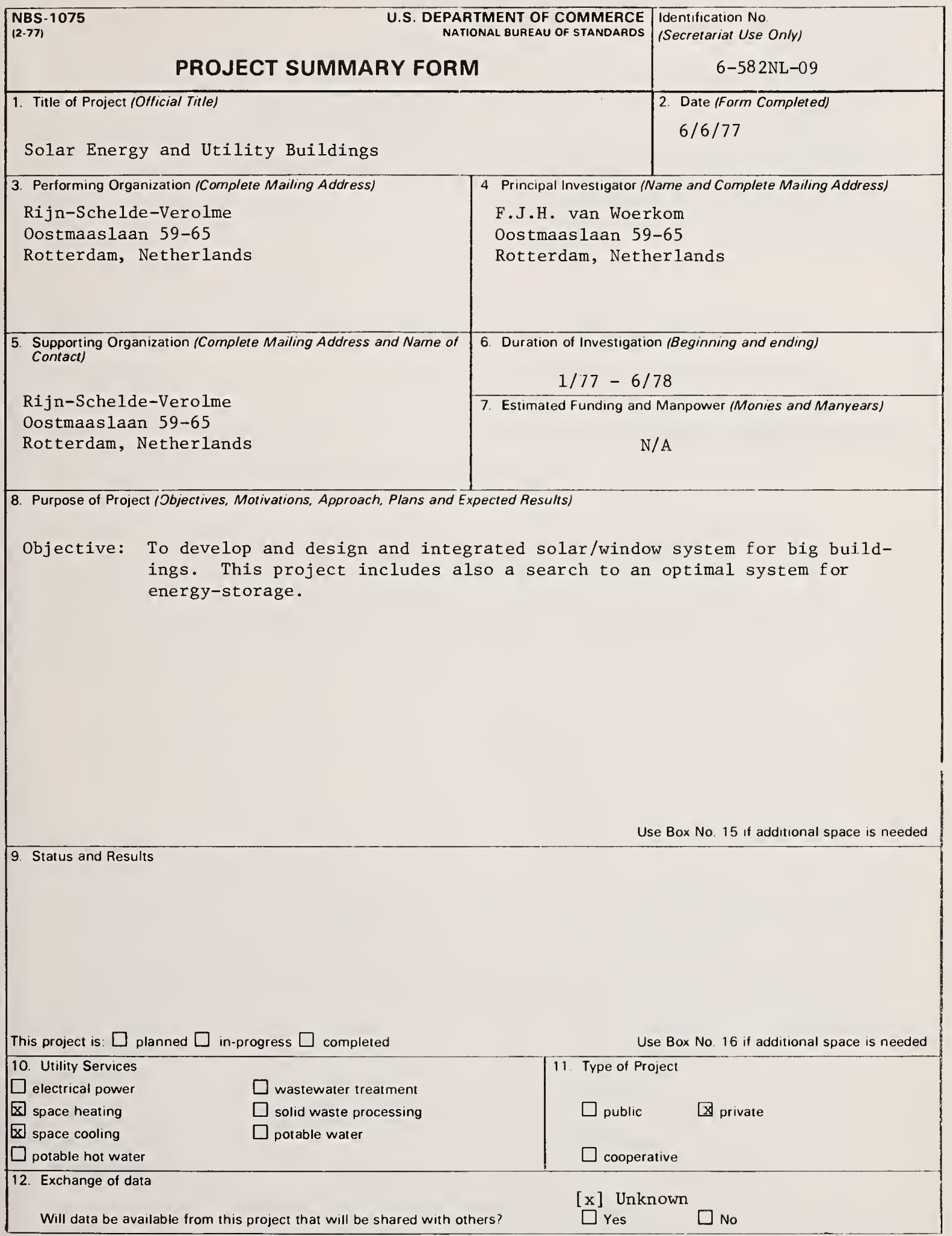


13 Technical Data

project location

degree-days (heating) -

degree-days (cooling) - -

plant load capacity

a power (MW) - - - -

b. heating $(\mathrm{MW})-\ldots-\ldots$

c. cooling (MW)

d. wastewater treatment-liters/day _ _ -

e. solid waste processing-kilograms/day _...

f. potable water-liters/day $--\ldots--\ldots$

heat to power ratio (average expected)
Identification No

6-582NL-09

energy source

expected payback period

Type and size of user

a. residential (dwelling units)

b. residential (square area- $\mathrm{m}^{2}$ )

c commercial (square area- $\mathrm{m}^{2}$ )

d. industrial (thermal + elec.-MW)

15. Additional space for Purpose of Project

16. Additional space for Status and Results

USCOMM NBS. DC

CCMS Rational Use of Energy PIlot Study. CCMS-MIUS Project. $9 \cdot 20 \cdot 76$ 
$\begin{aligned} & \text { NBS-1075 } \\ & (2-77)\end{aligned}$
U.S. DEPARTMENT OF COMMERCE
NATIONAL BUREAU OF STANDARDS

PROJECT SUMMARY FORM

1. Title of Project (Otficial Tirle)

Study concerning seasonal thermal storage devices for low temperatures (ET 4048)

3. Performing Organization (Complete Mailing Address)

Messer schmitt-Bolkow-Blohm

GMBH

Postfach 801169

D-8000 Munchen

Federal Republic of Germany

5. Supporting Organization (Complere Mailing Address and Name of Contact)

PLE/KFA Julich

Dr. Plantikow

Postfach 1913

D-517 Julich

Federal Republic of Germany

8. Purpose of Project (Jbjectives, Motivations, Approach, Plans and Expected Results

The aim is to investigate the possibility of storage waste heat by introducing it into the ground, aquifiers in lakes. Low-temperature heat could be stored in this way during the warmer seasons to be extracted for heating purposes in the winter. Exploitation of the waste heat from power stations and a more economic use of primary energy are the aims here. At the same time, this is associated with reduced emissions in congested regions in the winter peak and less waste heat from power stations in summer.

Use Box No. 15 if additional space is needed

9. Status and Results

The study was finished in 1976.

The following topics have been dealt with:

- Investigations of the geological prerequisites for establishing storage devices in the congested regions of the FRG.

- Concepts for storage devices in aquifiers and in mainly artifical lakes (storage devices near the surface and at greater depths, displacement storage devices, storage devices in caverns, tube-system ground storage devices, among others).

This project is: $\square$ planned $\square$ in-progress $\square$ completed

Use Box No. 16 if additional space is needed

10. Utility Services

$\checkmark$ electrical power

space heating

wastewater treatment

$\square$ space cooling

$\square$ solid waste processing

[8 potable hot water

$\square$ potable water

12. Exchange of data

Will data be available from this project that will be shared with others?

Yes

No 


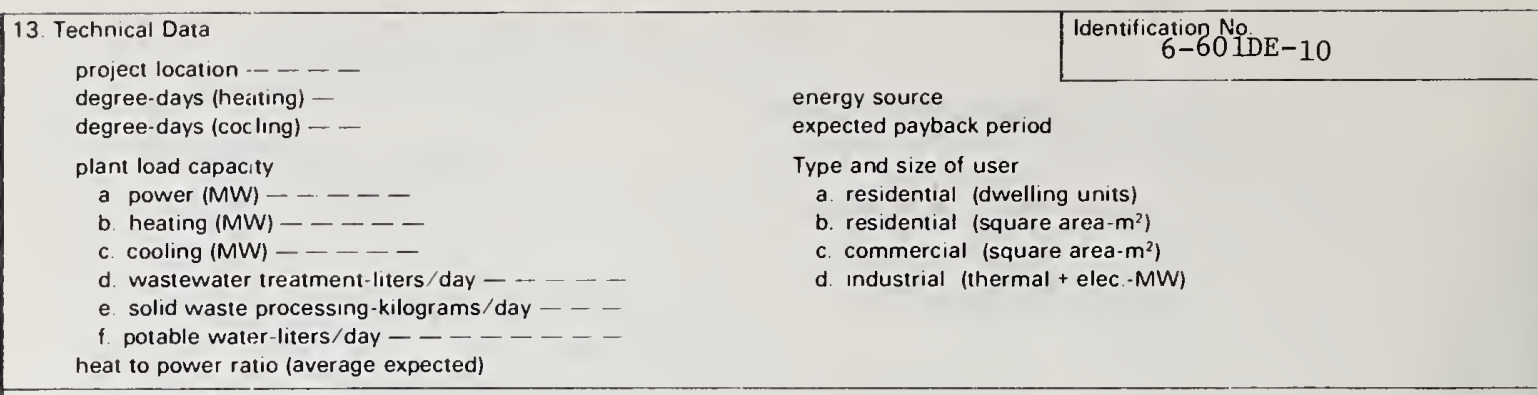

14. Other Related Projects (Titles)

15. Additional space for Purpose of Project

16. Additional space for Status and Results

- Component investigations for water retention and drainage, insulation, extraction and distribution, safety concept and approval potential. 


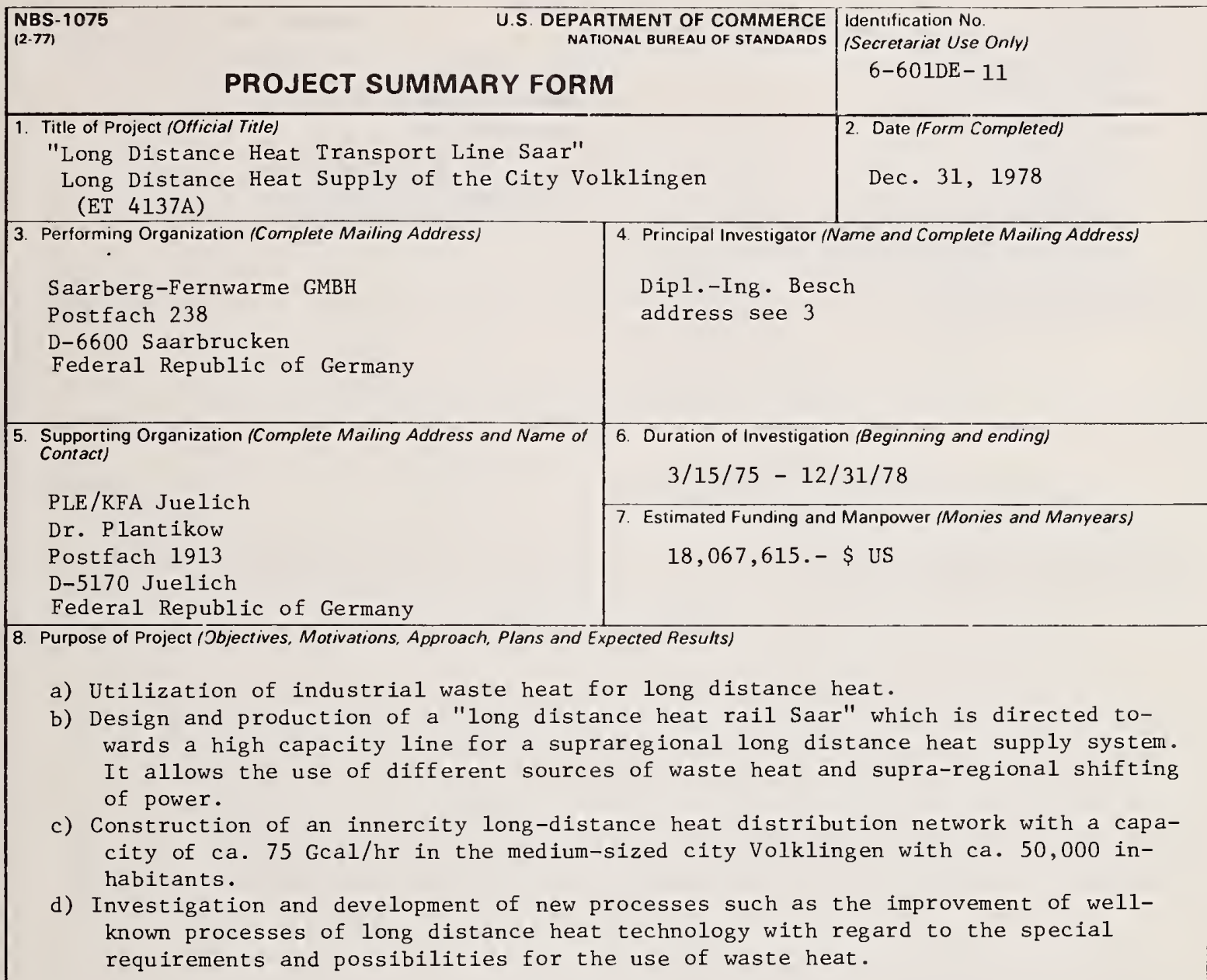

Use Box No. 15 if additional space is needed

9. Status and Results

The development of new long range heating pipe networks, in particular the testing of innovatory pipe material and the consequent methods of installation is still at the planning stage. By the end of January an experimental program will have been evolved. The use of a gas-fired heat absorption pump will also be investigated, which - as currently envisaged - would, among other things, transfer the residual heat of the coke gas to the long distance heating network so that cooling by river water would become to a very large degree unnecessary (contribution to the protection of the

This project is: $\square$ planned in-progress $\square$ completed Use Box No. 16 if additional space is needed

10. Utility Services

Q electrical power

space heating

$\square$ space cooling

$\square$ wastewater treatment

$\square$ solid waste processing

$\square$ potable water

$\checkmark$ potable hot water

$\begin{array}{cc}\text { 11. Type of Project } & \\ \square \text { public } \square \text { private }\end{array}$

12. Exchange of data

区 cooperative

Will data be available from this project that will be shared with others?

Q Yes

No 
13. Technical Data

project location -- ---

degree-days (heasting) -

degree-days (cocling) - -

plant load capacity

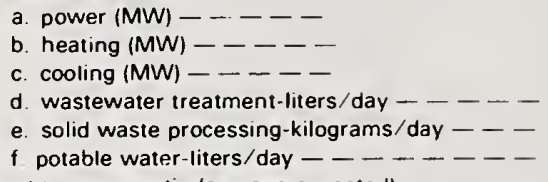
heat to power ratio (average expected)

\section{Identification No. 6-601DE- 11}

energy source

expected payback period

Type and size of user

a residential (dwelling units)

b. residential (square area- $m^{2}$ )

c. commercial (square area $-\mathrm{m}^{2}$ )

d. Industrial (thermal + elec.-MW)

14. Other Related Projects (Titles)

15. Additional space for Purpose of Project

16. Additional space for Status and Results

environment) and submitted to the Steering Committee for approval.

a) Negotiations with the city of Volklingen concerning their cooperation as well as compulsory connections and use are almost completed.

b) The necessary measures will be started in September 1976 . 
1. Title of Project /OHicia/ Tine)

Long-distance heat rail Ruhr: Middle Section (ET 4145)

STEAG AG

4300 Essen

Federal Republic of Germany
4 Principal Investigator (Name and Complete Mailing Address)

Dr. H. Volcker

STEAG AG

4300 Essen

Federal Republic of Germany
5. Supporting Organization (Complete Mailing Address and Name of Contact)

Bundesministerium fur Forschung und

Technologie

Stresemannstrasse 10

5300 Bonn-Bad Godesberg

(60 percent) Federa1 Republic of Germany
6. Duration of Investigation (Beginning and ending)

$$
1 / 7 / 75 \text { to } 6 / 30 / 78
$$

7. Estimated Funding and Manpower (Monies and Manyears)

$9910000 .--D M$

8. Purpose of Project (Jojectives, Motivations, Approach, Plans and Expected Resuits)

1. Objective:

A first section of a heat rail to be constructed in order to ensure the connection of existing local heat distribution networks including a heat power-station and other heat sources. The installation is to provide proof of feasibility of the total system concept. It is to be laid out in such a way as to enable it to be integrated into a large system at a later time. The project should provide information as to what extent transition to a connected system makes better use of existing power stations, whereby the storage capabilities of the network are to be made use of. Inform tion will be available as to how to use existing fuels most efficiently. Questions related to ensuring supply will be taken account of.

2. Work Program:

a) Test of different types of compensations to accommodate the expansion due to heat, taking special account of the anchorage-point stress occuring during one sided depletion.

(cont.) Use Box No. 15 if additional space is needed

9. Status and Results

Building of the delivery stations has begun.

In the region of Gelsenkirchen and Essen several tracks have been laid.

The first partial operation will begin the end of 1976.

This project is: $\square$ planned $\square$ in-progress $\square$ completed Use Box No. 16 if additional space is needed

\section{.

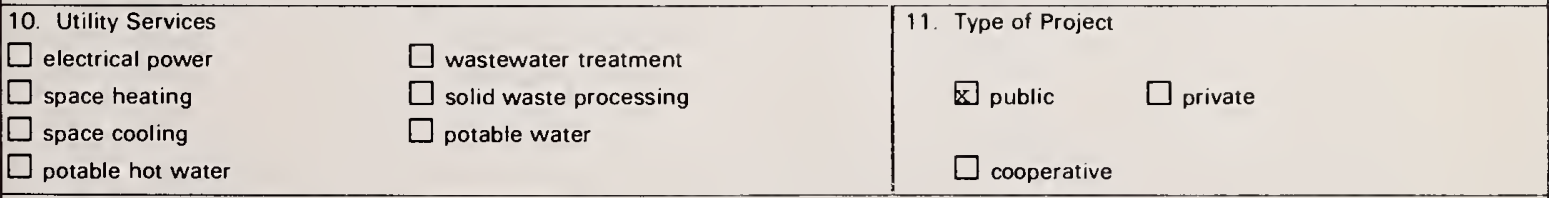

12. Exchange of data

Will data be available from this project that will be shared with others?

Yes No 
13. Technical Data

project location ...- -

degree-days (heáting) -

degree-days (cocling) -

plant load capacity

a power $(\mathrm{MW})-\ldots .--$

b. heatıng $(M W)-\ldots$

c. cooling (MW) - - - -

d. wastewater treatment-liters/day $-\ldots-\ldots$

e. solid waste processing-kilograms/day - - -

f. potable water-liters/day $--\ldots-\ldots-\ldots$

heat to power ratio (average expected)
Identification No

$6-601 D E-12$

energy source

expected payback period

Type and size of user

a residential (dwelling units)

b. residential (square area- $\mathrm{m}^{2}$ )

c. commercial (square area- $\mathrm{m}^{2}$ )

d. industrial (thermal + elec.-MW)

14. Other Related Projects (Titles)

15. Additional space for Purpose of Project (cont.)

b) Test of depletion systems.

c) Development and operation of ventilation and de-venting systems suitable for winter operations.

d) Test of different shut-off mountings and their respective drive mechanisms for the existing pressure and temperature situation.

e) Development and test of dynamic pressure reduction mechanisms in case of trouble.

f) Test of circuit and mode of operation of the return pumps.

g) Development of a trouble event management.

h) Test of circuits to directly connect the heat rail with local networks varying nominal pressures.

i) Building and test of a load distribution for the supra-regional connective system.

Optimizing of fuel input (grand load. peak load).

Use of storage capabilities of the complete network systems.

Considerations for electricity need.

j) Test of a reliable control system for power, temperature and pressure.

16. Additional space for Status and Results 
NBS-1075

(2.77)
U.S. DEPARTMENT OF COMMERCE

NATIONAL BUREAU OF STANOARDS

\section{PROJECT SUMMARY FORM}

1. Title of Project (Official Title)

Study of energy storages in systems of heat-power coupling (ET 4197A)

3. Performing Organization (Complete Mailing Address)

Messerschmitt-Bolkow-Blohm

$\mathrm{GmbH}$

Posttach 801169

D-8000 Munchen 80

Federa1 Republic of Germany

5. Supporting Organization /Complete Mailing Address and Name of Contact)

PLE/KFA Juelich

Dr. Plantikow

Postfach 1913

D-517 Juelich

Federal Republic of Germany

8. Purpose of Project (Jbjectives, Motivations, Approach. Plans and Expected Results)

Supply systems with storage of heat and electricity are to be designed, analysed, evaluated with respect to their economic, ecological consequences and their effects on the national economy.
4 Principal Investigator (Name and Complete Mailing Address) Dip 1.-Ing.G.Pulkert address see 3
6. Duration of Investigation (Beginning and ending)

Nov . 30, 1976

7 Estimated Funding and Manpower (Monies and Manyears)

Apr. 2, 1975 - Nov. 30, 1976

9. Status and Results

This project is: $\square$ planned $\otimes$ in-progress $\square$ completed

$\begin{array}{ll}10 . \text { Utility Services } & \square \text { wastewater treatment } \\ \square \text { Kelectrical power } & \square \text { solid waste processing } \\ \square \text { space heating } & \square \text { potable water } \\ \square \text { space cooling } & \end{array}$

12. Exchange of data

Use Box No. 15 if additıonal space is needed

Yes

$\square$ No

Use Box No. 16 if additional space is needed

11. Type of Project

$\square$ public $\square$ private

cooperative No 
13 Technical Data

project location -- - -

degree-days (heating) -

degree-days (cocling) - -

plant load capacity

a. power (MW) -----

b. heating (MW) - $-\ldots$

c. cooling (MW) - - - -

d. wastewater treatment-fiters/day _ - _ - -

e. solid waste processing-kilograms/day - - -

f. potable water-liters/day _ _.. _ - -

heat to power ratio (average expected)

14. Other Related Projects (Titles)

$$
\text { 3-691DE-39 to } 43
$$

15. Additional space for Purpose of Project
Identification No

6-601DE- 13

energy source

expected payback period

Type and size of user

a. residential (dwelling units)

b. residential (square area $-\mathrm{m}^{2}$ )

c. commercial (square area- $\mathrm{m}^{2}$ )

d. Industrial (thermal + elec.-MW)

16. Additional space for Status and Results

Study available from:

Projektleitung Energieforschung

Kernforschungsan lage

D-5170 Juelich

Postfach 19 13, Germany 


$\begin{aligned} & \text { NBS-1075 } \\ & \text { (2-77) }\end{aligned}$
P.S. DEPARTMENT OF COMMERCE
NATIONAL BUREAU OF STANDARDS

Thermal Storage of Energy

3. Performing Organization (Complete Mailing Address)

Electricite De France

Direction Des Etudes et Recherches

Paris, France

5. Supporting Organization /Complete Mailing Address and Name of Contact)

Electricite De France

Direction Des Etudes et Recherches

Paris, France

8. Purpose of Project (Jbjectives, Motivations, Approach, Plans and Expected Results)

Show the benefits of an energy storage system used for simultaneously providing steam and electricity. Test the system's fluids and components.

Use Box No. 15 if additional space is needed

9. Status and Results

This project is: $\square$ planned $\square$ in-progress $\square$ completed

\begin{tabular}{ll}
\hline 10. Utility Services & $\square$ wastewater treatment \\
⿴囗大 electrical power & $\square$ solid waste processing \\
$\square$ space heating & $\square$ potable water
\end{tabular}

$\square$ potable hot water

12. Exchange of data

Will data be available from this project that will be shared with others?
Identification No

(Secretarlat Use Only)
2. Date (Form Completed)

$3 / 15 / 77$
6. Duration of investigation (Beginning and ending)

\section{NA}

7. Estimated Funding and Manpower (Monies and Manyears)

NA 


\section{Technical Data}

project location - - - - -

degree-days (heating) -

dentıfication No.

degree-days (cocling) - -

$6-601 F R-14$

plant load capacity
a. power (MW) - - - -
b. heatıng (MW) $---\ldots$
c. cooling (MW) $-\ldots-\ldots$
d. wastewater treatment-liters/day _ _ _ -
e. solid waste processing-kilograms/day - - -
f. potable water-liters/day _ _ _ _ _ _
heat to power ratio (average expected)

energy source

expected payback period

Type and size of user

a. residential (dwelling units)

b. residential (square area- $\mathrm{m}^{2}$ )

c. commercial (square area- $\mathrm{m}^{2}$ )

d. Industrial (thermal + elec.-MW)

14. Other Related Projects (Titles)

15. Additional space for Purpose of Project

16. Additional space for Status and Results 


\begin{tabular}{|c|c|c|}
\hline \multicolumn{2}{|l|}{$\begin{array}{l}\text { NBS-1075 } \\
(2-77)\end{array}$} & $\begin{array}{l}\begin{array}{r}\text { Identification No. } \\
\text { (Secretariat Use Only) } \\
6-602 \mathrm{NL}-15 \\
\text { 2. Date (Form Completed) } \\
6 / 6 / 77\end{array}\end{array}$ \\
\hline $\begin{array}{l}\text { 5. Supporting Organization (Complete Mailing Address and Name of } \\
\text { Contact) } \\
\text { Rijn-Schelde-Verolme } \\
\text { Oostmaaslaan 59-65 } \\
\text { Rotterdam, Netherlands }\end{array}$ & $\begin{array}{l}\text { 6. Duration of Investigatic } \\
6 / 75- \\
\text { 7. Estimated Funding and }\end{array}$ & $\begin{array}{l}\text { on (Beginning and ending) } \\
12 / 77 \\
\text { Manpower (Monies and Manyears) }\end{array}$ \\
\hline \multicolumn{3}{|c|}{$\begin{array}{l}\text { 8. Purpose of Project (Jbjectives, Motivations, Approach, Plans and Expected Results) } \\
\text { for enertive: To develop a new type (pipes instead of plates) gas/gas regenerator } \\
\text { for enery in combination with a gas turbine. } \\
\text { Use Box No. } 15 \text { if additional space is needed }\end{array}$} \\
\hline \multicolumn{3}{|c|}{ 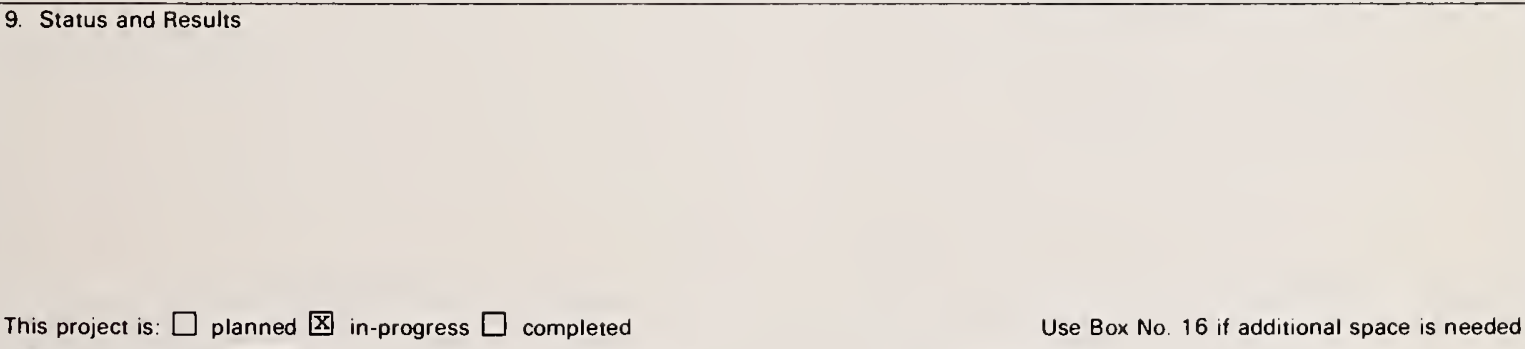 } \\
\hline $\begin{array}{l}\text { 10. Utility Services } \\
\square \text { electrical power } \\
\square \text { space heating } \\
\square \text { space cooling } \\
\square \text { potable hot water }\end{array}$ & $\begin{array}{l}\text { 11. Type of Pro } \\
\square \text { public } \\
\square \text { coopera }\end{array}$ & $\mathrm{X}$ private \\
\hline 12. Exchange of data & & \\
\hline
\end{tabular}


13 Technical Data

project location -. - - -

degree-days (heäting) -

degree-days (cocling) - -

plant load capacity

a. power $(\mathrm{MW})-\ldots .--$

b. heating (MW) -----

c. cooling (MW) ----

d wastewater treatment-liters/day _ _ _ -

e. solid waste processing-kilograms/day

f. potable water-liters/day $-\ldots-\ldots$

heat to power ratio (average expected)

14. Other Related Projects (Titles)
Identification No.

\section{$6-602 N L-15$}

energy source

expected payback period

Type and size of user

a. residential (dwelling units)

b. residential (square area- $\mathrm{m}^{2}$ )

c. commercial (square area- $\mathrm{m}^{2}$ )

d. Industrial (thermal + elec.-MW)

15. Additional space for Purpose of Project

16. Additional space for Status and Results 


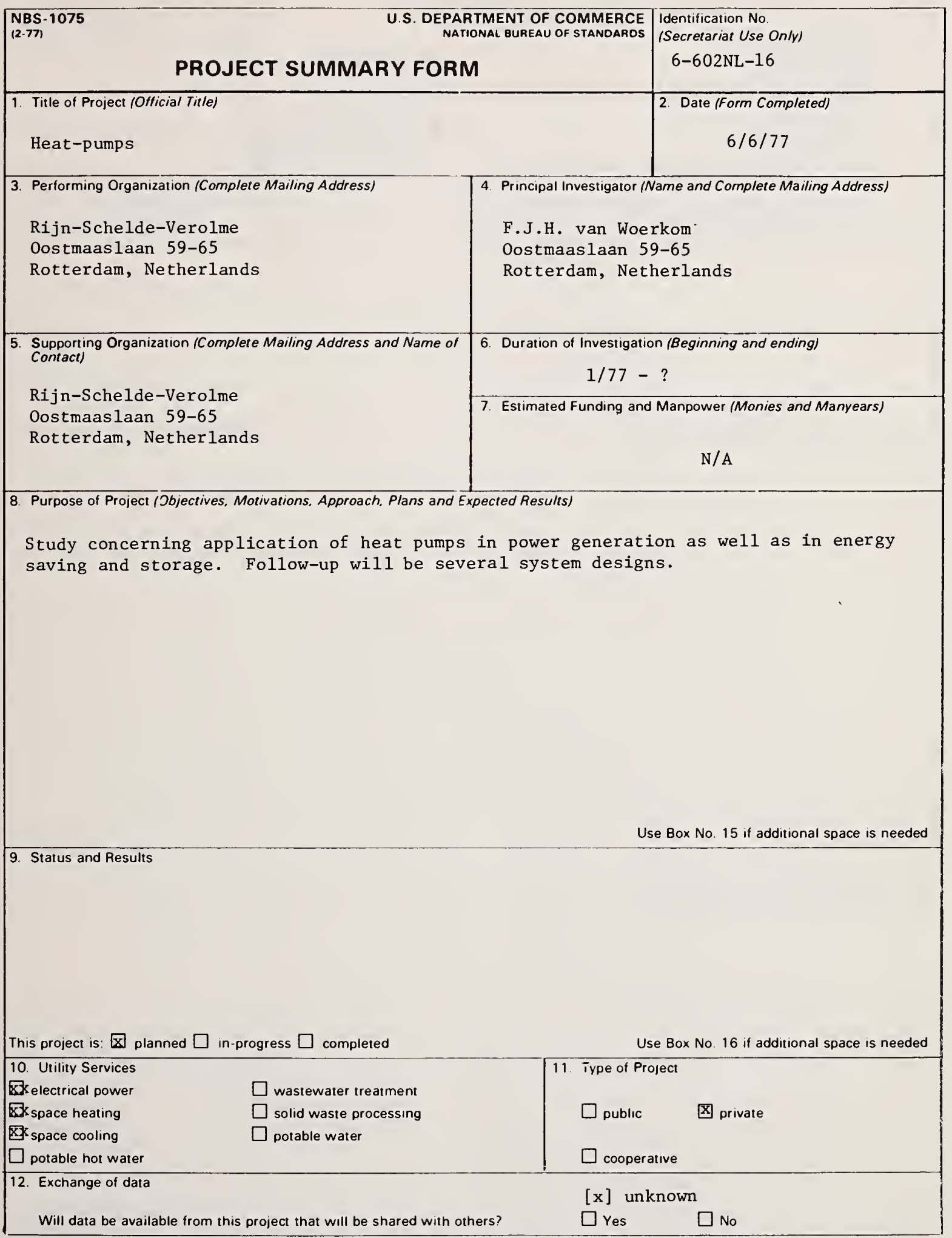


13. Technical Data

project location -... - -

degree-days (heating) -

degree-days (cocling) - -

energy source

expected payback period

plant load capacity
a. power (MW) - - - -
b. heating (MW) - - - -
c. cooling (MW) $--\ldots$
d. wastewater treatment-liters/day - - - -
e. Solid waste processing-kilograms/day - - -
f. potable water-liters/day - - - - - - - heat to power ratio (average expected)

14. Other Related Projects (Titles)

15. Additional space for Purpose of Project

Type and size of user

a. residential (dwelling units)

b. residential (square area- $\mathrm{m}^{2}$ )

c. commercial (square area- $\mathrm{m}^{2}$ )

d. Industrial (thermal + elec - MW)

16. Additional space for Status and Results 


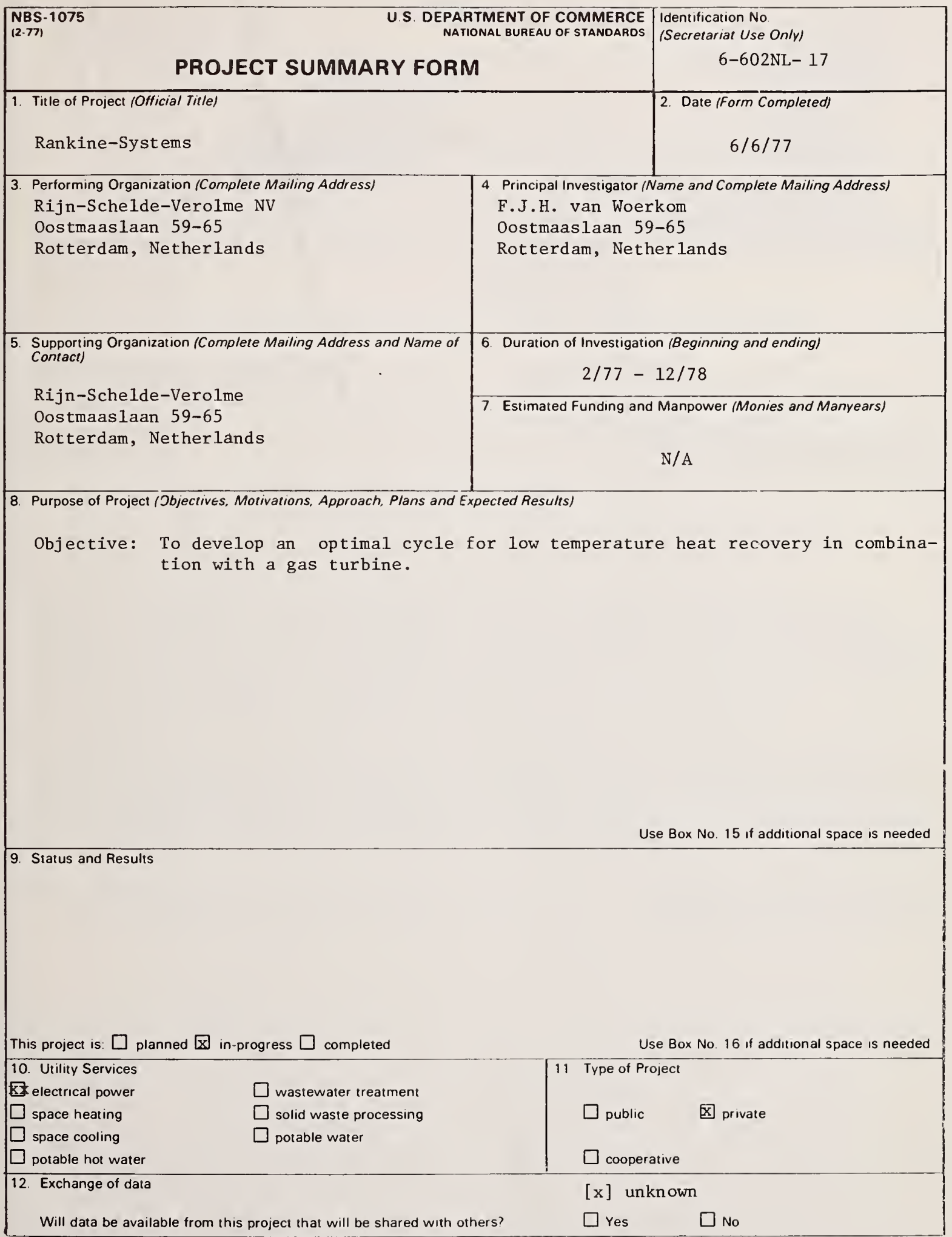


project location - - - -

degree-days (heating) -

degree-days (cocling) - -

plant load capacity

a. power $(\mathrm{MW})-\ldots--$

b. heating $(\mathrm{MW})-\ldots$

c. cooling (MW) - - - -

d. wastewater treatment-liters/day _. _ -

e. solid waste processing-kilograms/day _ _ -

f. potable water-liters/day $-\ldots \ldots$ heat to power ratio (average expected) energy source

expected payback period

Type and size of user

a residential (dwelling units)

b. residential (square area- $m^{2}$ )

c. commercial (square area- $\mathrm{m}^{2}$ )

d industrial (thermal + elec. $-\mathrm{MW}$ )

14. Other Related Projects (Titles) 
$\begin{aligned} & \text { NBS-1075 } \\ & (2-77)\end{aligned}$
U.S. DEPARTMENT OF COMMERCE
NATIONAL BUREAU OF STANDARDS

PROJECT SUMMARY FORM

1. Title of Project (Official Tinle)

Development of a Multi-Stage Flash/Fluidized Bed Evaporator (MSF/FBE)

3. Performing Organization (Complete Mailing Address)

Delft University of Technology

Laboratory for Thermal Power Engineering Rotterdamsweg $139 \mathrm{~A}$

Delft

The Netherlands
4 Principal Investigator (Name and Complete Mailing Address)

Ir. A.W. Veenman

Laboratory for Thermal Power Engineering

Rotterdamseweg 139A

Delft

The Netherlands

5. Supporting Organization (Complete Mailing Address and Name of Contact)

Delft University of Technology

Laboratory for Thermal Power Engineering

Rotterdamseweg 139A

Delft

The Netherlands

6. Duration of Investigation (Beginning and ending)

\section{1 til1 1979}

7. Estimated Funding and Manpower (Monies and Manyears) $\$ 2.10^{6}$ and 20 man years

8. Purpose of Project (Jbjectives, Mativations, Approach. Plans and Expected Results)

Development of a new type of Multi-Stage Flash Evaporator, a Multi-Stage FlashFluidized Bed Evaporator (MSF/FBE).

The MSF/FBE process in which a fluidized bed heat exchanger is used represents an attractive process for water distillation $f . i$. in combination with power generation. The main characteristics of the plant is its vertical concept with short flash chambers accommodating a large number of parallel heat exchanger tubes. Due to the fluidized bed in the heat exchanger the exchanger can be kept clean from fouling which results in a lower specific heat consumption than conventional evaporators.

The MSF/FBE can apply very small temperature differences over the stages, this makes it possible to design the MSF/FBE for a far greater number of stages and consequently for much lower specific heat consumption than the conventional Multi-Stage Evaporators Due to the superior process characteristics a higher loading of the evaporator volume can be achieved which results in a reduction of the invest 1 se Box No. 15 if additional space is needed

9. Status and Results

Pilot plant status is reached with good results.

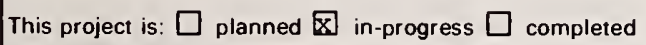
Use Box No. 16 if additional space is needed

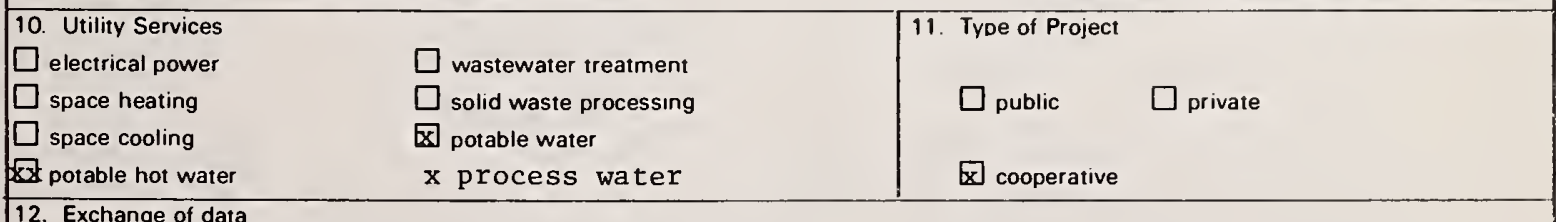

12. Exchange of data 


\section{Technical Data}

project location Delft_The Netherlands

degree-days (heilting) -

degree-days (cocling) - -

plant load capacity

a power (MW) - - . - .

$b$ heating $(M W)-\ldots-$

c. cooling (MW) - - -

d. wastewater treatment-liters/day _ _ _. -

e. solid waste processing-kilograms

f. potable water-liters/day -

heat to power ratio (average expected)
Identification No.

energy source

expected payback period

Type and size of user
a. residential (dwelling units)
b. residential (square area- $\mathrm{m}^{2}$ )
c. commercial (square area $-m^{2}$ )
d. industrial (thermal + elec-MW)

14. Other Related Projects (TIIles)

15. Additional space for Purpose of Project

ment costs.

16. Additional space for Status and Results 


\begin{tabular}{|c|c|c|}
\hline \multicolumn{2}{|l|}{ PROJECT SUMMARY FORM } & \multirow{2}{*}{$\begin{array}{l}\text { Identification No. } \\
\text { (Secretariat Use Only) } \\
6-612 \mathrm{NL}-19 \\
\text { 2. Date (Form Completed) } \\
3 / 15 / 77\end{array}$} \\
\hline \multicolumn{2}{|c|}{$\begin{array}{l}\text { 1. Title of Project (Official Tit/e) } \\
\text { Diesel Engine TM620 - An Uncommon1y Large Medium Speed } \\
\text { Diesel Engine for Power Generation }\end{array}$} & \\
\hline $\begin{array}{l}\text { 3. Performıng Organization (Complete Mailing Address) } \\
\text { Stork Werkspcor Diese1 } \\
\text { P.O. Box } 4196 \\
\text { Amsterdam, Nether lands }\end{array}$ & \multicolumn{2}{|c|}{$\begin{array}{l}4 \text { Principal Investigator (Name and Complete Marling Address) } \\
\text { Unknown } \\
\text { Stork Werkspcor Diesel } \\
\text { P.O. Box } 4196 \\
\text { Amsterdam, Netherlands }\end{array}$} \\
\hline \multirow[t]{2}{*}{$\begin{array}{l}\text { 5. Supporting Organization (Complete Mailing Address and Name of } \\
\text { Contact) }\end{array}$} & \multicolumn{2}{|c|}{$\begin{array}{l}\text { 6. Duration of Investigation (Beginning and ending) } \\
7 / 75 \text { to } 6 / 76\end{array}$} \\
\hline & \multicolumn{2}{|c|}{$\begin{array}{l}\text { 7. Estimated Funding and Manpower (Monies and Manyears) } \\
\text { Unknown }\end{array}$} \\
\hline
\end{tabular}

8. Purpose of Project (Jbjectives, Motivations, Approach, Plans and Expected Results)

A new engine, designation TM 620, of considerably larger capacity is under development. The unit power per cylinder is $1700 \mathrm{bhp}$, finally $2000 \mathrm{bhp} / \mathrm{cycl}$. at $428 \mathrm{rpm}$.

The TM 410 engine has been successfully applied for the generation of electricity. We expect that the TM 620 will meet the increasing requirements in this field.

In 197818 cylinder units will be available at 22.5 MW at generator terminals. (25 MW in 1980). The engine uses residual fuel oil and can easily be modified to use natural gas.

Economy comparison with steam plants shows advantage over 22.5 MW steam units at a11 load-schemes; at some load-schemes even over 4.5 MW steam-turbine units. This means, that this engine shifts the economical limit of diesel power stations to certain $1 \mathrm{y} 100$ MW, probably $200 \mathrm{MW}$, and could fit into decentralized power systems.

An environmental advantage is a reduction of thermal pollution, because only about $27 \%$ of the total fuel heat will be found in the cooling water. If wanted, thermal water pollution can be completely avoided by the use of air-cooling, as is already applied in desert climates.

9. Status and Results

Use Box No. 15 if additional space is needed

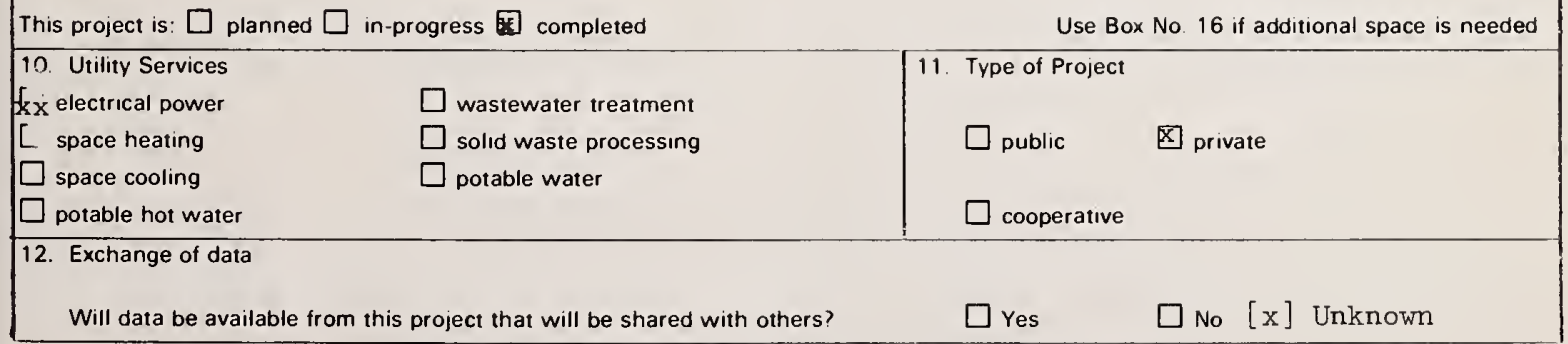




\begin{tabular}{|c|c|}
\hline $\begin{array}{l}13 \text { Technical Data } \\
\text { project location - } \ldots \ldots\end{array}$ & $\begin{array}{r}\text { Identification No. } \\
6-612 \mathrm{NL}-19\end{array}$ \\
\hline $\begin{array}{l}\text { degree-days (heatting) - } \\
\text { degree-days (cocling) }--\end{array}$ & $\begin{array}{l}\text { energy source } \\
\text { expected payback period }\end{array}$ \\
\hline $\begin{array}{l}\text { plant load capacity } \\
\text { a. power (MW) } \\
\text { b. heating (MW) } \\
\text { c. cooling (MW) } \\
\text { d. wastewater treatment-liters/day }-\ldots \\
\text { e. solid waste processing-kilograms/day } \\
\text { f. potable water-liters/day }-\ldots-\ldots \\
\text { heat to power ratio (average expected) }\end{array}$ & 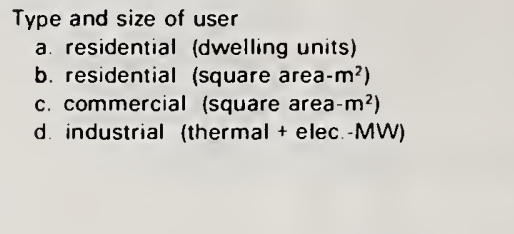 \\
\hline
\end{tabular}

14. Other Related Projects (Titles)

15. Additional space for Purpose of Project (cont.)

A further rise in total efficiency is possible by the use of waste heat in a steamboiler and steam turbine. An efficiency of $43 \%$ for pure electricity production is obtainable with safe conventional equipment. A feasibility study is on hand. of course a much higher efficiency is possible for the combined production of electricity and heat. (Total energy systems). 


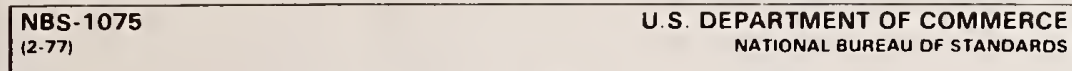

PROJECT SUMMARY FORM

1. Title of Project (Official Title)

Technical \& Economical Evaluation of Gas-fired Heat-pump Systems for Space-heating Purposes.

3. Performing Organization (Complete Mailing Address)

Organization for Industrial Research TNO

Institute for Mechanical Constructions

P.O. Box 29

Delft, Netherlands

5. Supporting Organization /Complete Mailing Address and Name of Contact)

-Org. for Industr. Research TNO

Netherlands

-VEG Gasinstituut

P.O. Box 137

Apeldoorn, Netherlands

8. Purpose of Project (Objectives, Motivations. Approach, Plans and Expected Results)

Determination of gas-fired heat-pump systems with the best potential for further development. The main investigated variables include the system capacity (degree of centralization) and the types of prime mover, heat pump(s) and heat transfer system inside the building. A computer program is written to perform the calculations. The results of the evaluation are to be used as a basis for continued evaluation and experimental investigation of selected configurations of heat-generating eqiupment.

Use Box No. 15 if additional space is needed

9. Status and Results

lst stage completed (use of yearly averaged performance values and simplified cost assumptions).

2nd stage planned (part-load operation accounted for in detail, use of more sophisticated costing procedures).

This project is: $\square$ planned in-progress $\square$ completed Use Box No. 16 if additional space is needed

\begin{tabular}{ll}
\hline 10. Utility Services & \\
$\square$ electrical power & $\square$ wastewater treatment \\
$\square$ space heating & $\square$ solid waste processing \\
$\square$ space cooling & $\square$ potable water \\
$\square$ potable hot water &
\end{tabular}

12. Exchange of data

Will data be available from this project that will be shared with others?

Restricted

$\square$ Yes No 
13. Technical Data

Identification No

project location -- - -

degree-days (heating) -

degree-days (cocling) - -

plant load capacity

a power (MW) - - - -

expected payback perıod

b. heatıng (MW) -----

c. cooling (MW) - - - -

d. wastewater treatment-liters/day - - - -

e. solid waste processing-kilograms/day

f. potable water-liters/day $-\ldots-\ldots-\ldots-$ heat to power ratio (average expected)

14. Other Related Projects (Tit/es)

15. Additional space for Purpose of Project

16. Additional space for Status and Results 
NBS-1075
$(2-77)$$\quad$ U.S. DEPARTMENT OF COMMERCE

PROJECT SUMMARY FORM

1. Title of Project (Official Title)

Harrisburg Steam Main

3. Performing Organization (Cerplg(te Mailing Address)

Gannett Fleming Cordry and Carpenter, Inc.

P.O. Box 1963

Harrisburg, Pennsylvania 17105

U.S.A.

5. Supporting Organization /Complete Mailing Address and Name of Contact)

Mr. Louis Einhorn

Public Works Director

City of Harrisburg

423 Walnut Street

Harrisburg, Pennsylvania 17101

U S A.

8. Purpose of Project (Objectives, Motivations, Approach, Plans and Expected Results)

The Harrisburg Steam Main will convey high pressure steam, produced by the incineration of solid waste in the City's Incinerator, to the Pennsylvania Power \& Light Company's

Steam Heat Plant. This steam will supplement the utility's steam supply to the

City's district heating system.

Use Box No 15 if additional space is needed

9. Status and Results

The project is expected to be advertised for bid during 1977 .

This project is: $[$ planned $\square$ in-progress $\square$ completed

Use Box No. 16 if additional space is needed

10. Utility Services

$\square$ electrical power

$\square$ space heating

$\square$ space cooling

$\square$ potable hot water

12. Exchange of data

Will data be available from this project that will be shared with others?

Yes

No
6-631US-21

Date (Form Completed)

January 21, 1977
4. Principal Investigator (Name and Complete Mailing Address)

Project Engineer

Paul W. Bricker
May 1977 to May 1978

7. Estimated Funding and Manpower (Monies and Manvears)

$\$ 2,506,700$ (construction cost) 


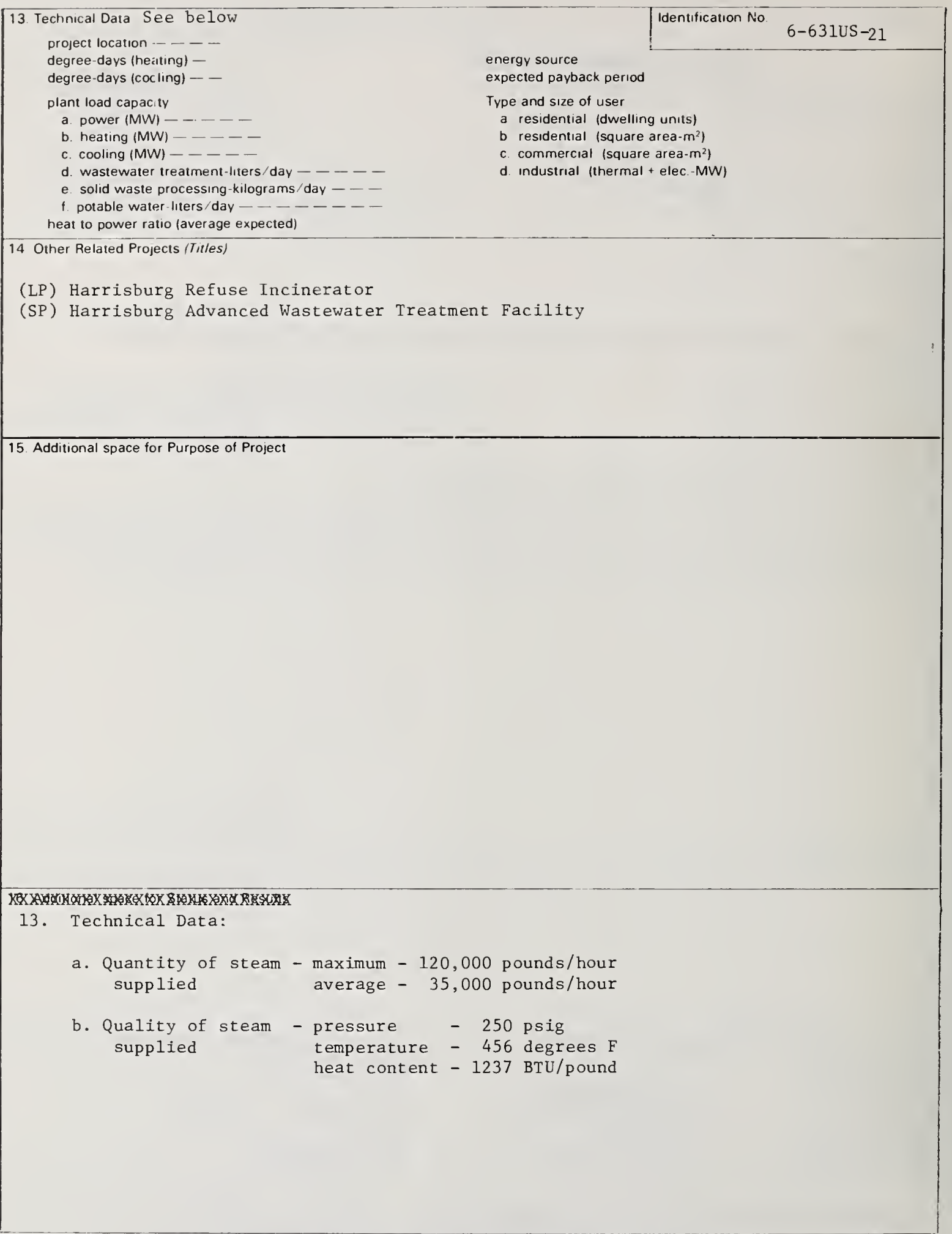

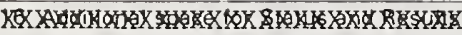

13. Technical Data:

a. Quantity of steam - maximum - 120,000 pounds/hour supplied average - 35,000 pounds/hour

b. Quality of steam - pressure - 250 psig supplied 


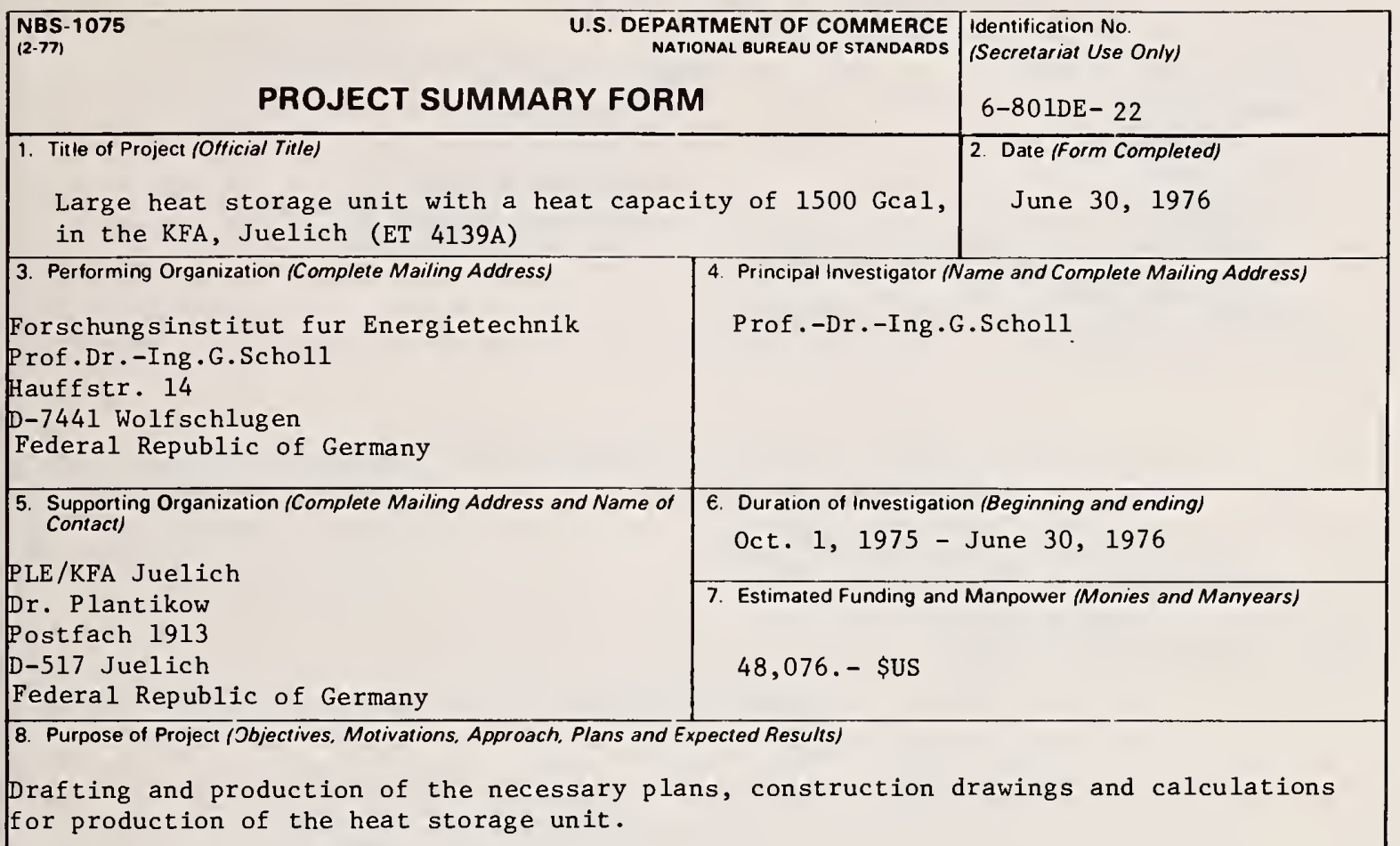

This project is: $\square$ planned $\square$ in-progress $\square$ completed 10. Utility Services 逐ectrical power 通 space heating $\square$ space cooling Expotable hot water 12. Exchange of data
Use Box No. 16 if additional space is needed 11. Type of Project
$\square$ public
private

Ex cooperative

X Yes $\square$ No 


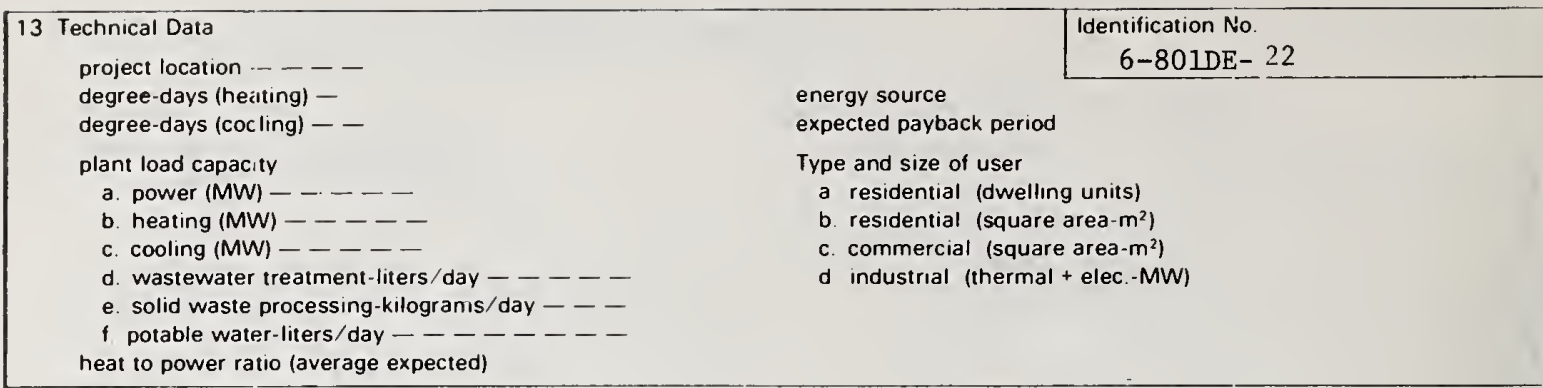

14. Other Related Projects (ritles)

15 Additional space for Purpose of Project 
NBS-1075

$(2-77)$
U.S. DEPARTMENT OF COMMERCE

NATIONAL BUREAU OF STANDARDS

\section{PROJECT SUMMARY FORM}

1. Title of Project (Official Title)

$\mathrm{H}_{2}$ - Production by Water Electrolysis

3. Performing Organization (Complete Mailing Address)

$\mathrm{SCK} / \mathrm{CEN}$

Bceretang 200

B-2400 MOL

Belgium
4 Principal Investigator (Name and Complete Mailing Address)

Project Leader

Dr. L.H.Baetsle
Identification No

(Secretariat Use On/y)

\section{$6-802 \mathrm{BE}-23$}

2. Date (Form Completed)

$7 / 29 / 77$

5. Supporting Organization (Complete Mailing Address and Name of Contact)

Buropean Economic Community

Wetstraat/rue de la Loi, 200

B-1040 Brussel/Bruxelles

Belgium
6. Duration of Investigation (Beginning and ending)

Beginning: 9/1/76 (2 \& 3 phase): 1985 Enåing (lst phase) $7 / 1 / 79$

7. Estimated Funding and Manpower (Monies and Manyears)

$$
\$ 2.5 \mathrm{M} 60 \text { man-year }
$$

8. Purpose of Project (Jbjectives, Motivations, Approach, Plans and Expected Results)

Objectives: Demonstrate a new type of electrolyser for energy storage in 3 phases $(1,50,150 \mathrm{~kW})$

Motivations: Belgium goes nuclear, hence $\mathrm{H}_{2}$ becomes important SCK/CEN possesses patents and know-how in this field

Approach: a new technology based on IME (Inorgaric Membrane Electrolyte) is used Plans and Expected Results:

a target is set of very low production costs of $\mathrm{H}_{2}$ at present off-peak electricity costs.

\section{Status and Results}

All testing equipment is in operation

Short-term cell tests have reached the desired performance

Long-term tests are prepared on stacks up to $1 \mathrm{~kW}$

This project is: $\square$ planned $\square$ in-progress $\square$ completed

Use Box No. 16 if additional space is needed

$\begin{array}{ll}10 . \text { Utility Services } & \square \text { wastewater treatment } \\ \text { tx electrical power } & \square \text { solid waste processing } \\ \square \text { space heating } & \square \text { potable water } \\ \square \text { space cooling } & \\ \square \text { potable hot water } & \end{array}$

12. Exchange of data

if EEC agrees with it

Will data be available from this project that will be shared with others?

XX Yes

$\square$ No 


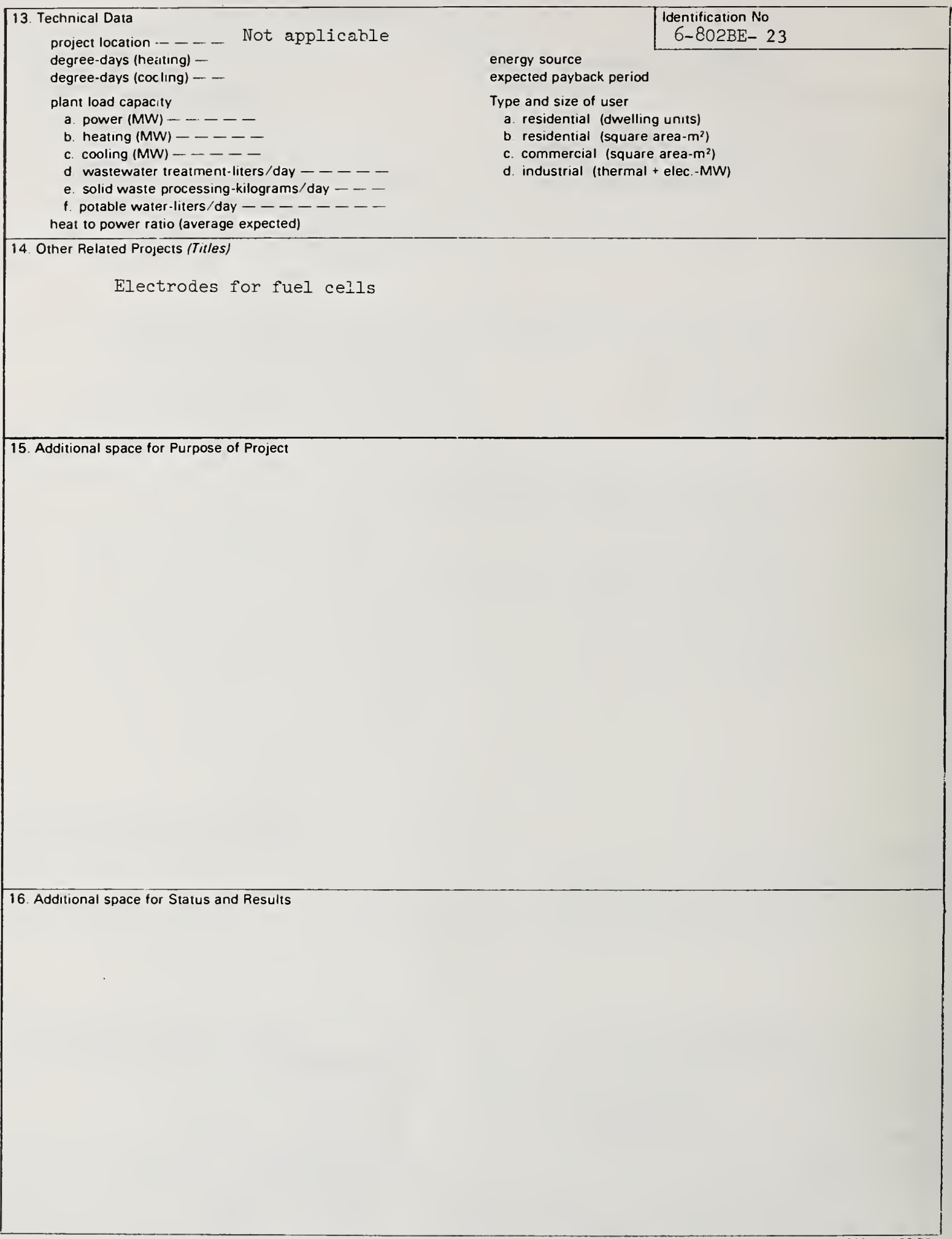


NBS-1075

(2-77)
U.S. DEPARTMENT OF COMMERCE NATIONAL BUREAU OF STANDARDS

\section{PROJECT SUMMARY FORM}

1. Title of Project (Olficial Tit/e)

ELECTRODES FOR FUEL CELLS

3. Performing Organization (Complete Mailing Address) SCK/CEN

Boeretang 200

B-2400 MOL

Belgi um
4. Principal Investigator (Name and Complete Mailing Address)

G.SPAEPEN

$\mathrm{SCK} / \mathrm{CEN}$

Boeretang 200

B-2400 MOL

Belgium
5. Supporting Organization (Complete Mailing Address and Name of Contact)

N.B. ELENCO

Manager $\mathrm{H}$. VAN DEN BROECK

p.a SCK/CEN

Boeretang 200

B-2400 MOL

Belgium
6. Duration of Investigation (Beginning and ending) Beginning 1969

Ending (present program) 1979

7. Estimated Funding and Manpower (Monies and Manyears) From 76-79

$\$ 500,000$ per year

9 man-year per year

8. Purpose of Project (Jbjectives, Motivations, Approach. Plans and Expected Resu/ts)

Objectives:

- Support to a large industrial fuel cell development program

- Improvement of electrode performance

- Long-lasting tests of electrodes, cells and stacks

- Demonstration of $2 \mathrm{x} 20 \mathrm{~kW}$ units

Motivations:

- Patents and know-how available on low-cost, high-performance electrodes

Approach and Plans:

- Cooperation with industrial firms for - series production of electrodes and stacks

- quality control

- development of production techniques

- market evaluation

- Use of very low concentration of noble metal catalysts in $\mathrm{H}_{2}$-air fuel cells

- First demonstration oriented towards motive application

Use Box No. 15 if additional space is needed

\section{Status and Results}

- All testing equipment in operation

- Life testing up to 14,000 h low density

$$
\text { 4,500 h high density }
$$

This project is: $\square$ planned $\square$ in-progress $\square$ completed

\begin{tabular}{ll}
\hline 10. Utility Services & $\square$ wastewater treatment \\
$\square$ electrical power & $\square$ solid waste processing \\
$\square$ space heating & $\square$ potable water \\
$\square$ space cooling &
\end{tabular}

$\square$ potable hot water

12. Exchange of data

Will data be available from this project that will be shared with others?

Y Yes

$\square$ No 


\begin{tabular}{|c|c|}
\hline $\begin{array}{l}\text { 13. Technical Data } \\
\text { project location }-----\end{array}$ & \begin{tabular}{l|l} 
Identification No. \\
$6-802 B E-24$
\end{tabular} \\
\hline $\begin{array}{l}\text { degree-days (heating) }- \\
\text { degree-days (cocling) - - }\end{array}$ & $\begin{array}{l}\text { energy source } \\
\text { expected payback period }\end{array}$ \\
\hline 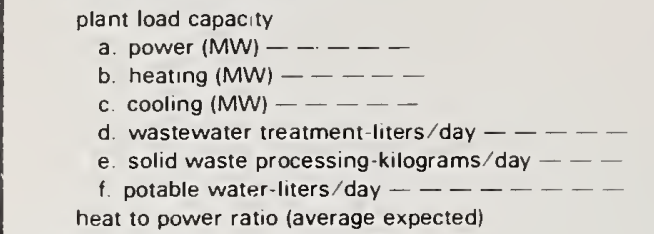 & $\begin{array}{l}\text { Type and size of user } \\
\text { a. residential (dwelling units) } \\
\text { b. residential (square area- } \mathrm{m}^{2} \text { ) } \\
\text { c. commercial (square area- } \mathrm{m}^{2} \text { ) } \\
\text { d. Industrial (thermal + elec-MW) }\end{array}$ \\
\hline
\end{tabular}

\section{Additional space for Purpose of Project}

Expected results:

- High-power density, low cost modules of up to $20 \mathrm{~kW}$

- Coupling to $\mathrm{H}_{2}$ - electrolysis unit as an energy-storage device

16. Additional space for Status and Results 
Identification No.

(Secretariat Use Only)

\section{PROJECT SUMMARY FORM}

1. Title of Project (Official Tit/e)

6-802BE- 25

Study and development of new alloys showing the shape memory effect, and their applications, i.a. in a "metal engine" or "solid state engine".

3 Performing Organization (Complete Mailing Address)

Katholieke Universiteit Leuven

Department Metaalkunde

de Croylaan 2

B-3030 Heverlee (Belgium)

2. Date (Form Completed)

\section{$8 / 8 / 77$}

\section{A. DERUYTTERE}

4 Principal Investıgator (Name and Complete Mailing Address)

5. Supporting Organization (Complete Mailing Address and Name of Contact)

Ministry of Scientific Policy
6 Duration of Investigation (Beginning and ending) 1976-1981

7. Estimated Funding and Manpower (Monies and Manyears)

50 million $B F-24$ man years

8. Purpose of Project (Jbjectives, Motivations, Approach Plans and Expected Results) the shape memory effect and related effects such as superelasticity and damping. The composition and the technology to prepare such alloys in a useable form has to be optimized. The properties, not only the special ones but also the normal design properties such as strength, ductility, fatique, corrosion have to be determined and improved. One possible application is their use in a novel type of engine in which the active element is not a fluidum like steam or gas or petrol but one of the alloys considered: cycling such an alloy between two temperatures causes a cycling between two crystal structures and therefore between two shapes. The change of shape allows forces to be exerted. So heat can be transformed into mechanical energy. The high temperature source (e.g. warm water from a utility service) need not be much warmer than the low temperature source (e.g. cold water from a utility service) (the temperature difference may be as $10 \mathrm{w}$ as $10^{\circ} \mathrm{C}$ ).

Use Box No. 15 if additional space is needed

\section{Status and Results}

A prototype engine has been built for demonstration purposes. Work is in progress on the thermodynamics of the system and on the improvement of the shape memory alloys and the geometry of the system.

This project is: $\square$ planned $\bar{U}$ in-progress $\square$ completed

Use Box No. 16 if additional space is needed

10 Utility Services

$\square$ electrical power

$\square$ space heating

$\square$ space cooling

$\square$ potable hot water

\section{$\square$ wastewater treatment}

solıd waste processing

$\square$ potable water

12. Exchange of data

Will data be available from this project that will be shared with others?

Q Yes

$\square$ No 


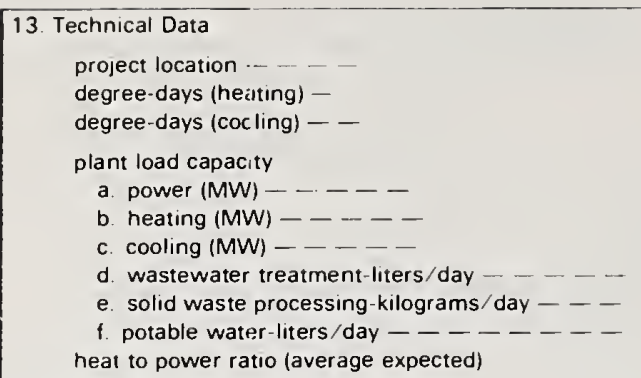

\begin{tabular}{l|c} 
Identification & $\begin{array}{c}\text { 6-802B } \\
\text { energy source primary so } \\
\text { expected payback period secon }\end{array}$ \\
Type and size of user \\
a residential (dwelling units) \\
b. residential (square area- $\mathrm{m}^{2}$ ) \\
c. commercial (square area- $\mathrm{m}^{2}$ ) \\
d. industrial (thermal + elec.-MW)
\end{tabular}

14. Other Related Projects (Titles)

15. Additional space for Purpose of Project

16. Additional space for Status and Results 


$\begin{aligned} & \text { NBS-1075 } \\ & \text { (2-77) }\end{aligned}$
PROJECT SUMMARY FORM
NATIONAL
1. Title of Project (Official Title)
Study of Modifications Required to Convert
Hearth Incinerator to Pyrolytic Operation
3. Performing Organization (Complete Mailing Address)
Interstate Sanitary Commission
10 Columbia Circle
New York, N.Y. 10019
(212) 582-0380
U.S.A.
5. Supporting Organization (Complete Mailing Address and Name of
Contact)
MERL, Wastewater Research Division
EPA
Cincinnati, Ohio 45268, U.S.A.
ATTN: Howard Wall

\section{Purpose of Project (Jbjectives, Motivations, Approach, Plans and Expected Resu/ts)}

The objective of the study is to develop a workable design for conversion of a plant scale multiple hearth sludge incinerator to the pyrolytic or limited air mode of operation.

\section{SPECIFIC OBJECTIVES ARE:}

1. To determine what physical modifications must be made to an existing multiple hearth system to convert that system to pyrolytic operation.

2. To determine the most appropriate methods for handling the products of pyrolysis from standpoints of energy efficiency and emissions control.

3. To develop an estimate of costs of conversion methods and of subsequent operations: what, if any, will be the advantages over heat recovery of multiple heart

incinerator.

Use Box No. 15 if additional space is needed

\section{Status and Results}

Project just started. Most of pilot plant equipment is set up for operation. Bench tests have been made on sludge and the plans for the first test of three have been completed.

This project is: $\square$ planned $\mathbb{Q}$ in-progress $\square$ completed

10. Utility Services

$\square$ electrical power

$\square$ space heating

$\square$ space cooling

$\square$ potable hot water $\square$ wastewater treatment

solid waste processing

$\square$ potable water

12. Exchange of data

Use Box No. 16 if additional space is needed 11. Type of Project

$\square$ public $\quad \square$ private

BX cooperative 
13. Technical Data

project location

degree-days (heating

degree-days (cocling) -

plant load capacity

a. power $(\mathrm{MW})-\ldots$

b. heating (MW) - . - -

c. cooling (MW) $-\ldots-\ldots$

d. wastewater treatment-liters/day - - - -

e. solid waste processıng-kilograms/day - - -

f. potable water-liters/day $-\ldots---\cdots$ heat to power ratio (average expected)
Identification No.

$6-833$ US -26

energy source

expected payback period

Type and size of user

a. residential (dwellıng units)

b. residential (square area- $\mathrm{m}^{2}$ )

c. commercial (square area- $\mathrm{m}^{2}$ )

d. Industrial (thermal + elec.-MW)

14. Other Related Projects (Tit/es)

15. Additional space for Purpose of Project

16. Additional space for Status and Results 


\begin{tabular}{|c|c|c|}
\hline \multicolumn{2}{|c|}{$\begin{array}{l}\text { NBS-1075 } \begin{array}{r}\text { U.S. DEPARTMENT OF COMMERCE } \\
\text { NATIONAL BUREAU OF STANDARDS }\end{array} \\
\text { PROJECT SUMMARY FORM }\end{array}$} & $\begin{array}{l}\text { Identification No } \\
\text { (Secretariat Use Only) } \\
6-833 \text { US- } 27\end{array}$ \\
\hline $\begin{array}{l}\text { 1. Title of Project (Official Tifle) } \\
\text { Optimization of Activation of Solid Wastes }\end{array}$ & & $\begin{array}{l}\text { 2. Date (Form Comp/eted) } \\
11 / 23 / 76\end{array}$ \\
\hline $\begin{array}{l}\text { 3. Performing Organization (Complete Mailing Address) } \\
\text { Stanford University } \\
\text { Department of Civil Engineering } \\
\text { Stanford, California } 94305 \\
\text { U.S.A. }\end{array}$ & \multicolumn{2}{|c|}{$\begin{array}{l}\text { 4. Principal Investıgator (Name and Complete Mailing Address) } \\
\text { Dr. J.O. Leckie } \\
\text { Stanford University } \\
\text { Department of Civil Engineering } \\
\text { Stanford, California } 94305 \\
\text { U.S.A. }\end{array}$} \\
\hline $\begin{array}{l}\text { 5. Supporting Organization (Complete Mailing Address and Name of } \\
\text { Contact) }\end{array}$ & $\begin{array}{r}\text { 6. Duration of Investigatic } \\
7 / 76 \text { to }\end{array}$ & $\begin{array}{l}\text { on (Beginning and ending) } \\
3 / 79\end{array}$ \\
\hline $\begin{array}{l}\text { Dr. R. Dobbs } \\
\text { U.S. EPA } \\
\text { OR\&D, MERL, WRD } \\
\text { Cincinnati, Ohio 45268, U.S.A. }\end{array}$ & $\begin{array}{l}\text { 7. Estimated Funding and } \\
\qquad 85,000 \text { ( } \mathrm{fi} \text {. }\end{array}$ & $\begin{array}{l}\text { Manpower (Monies and Manyears) } \\
\text { rst year) }\end{array}$ \\
\hline
\end{tabular}

To evaluate the optimum procedures to activate chars from municipal refuse and other solids waste sources. The activated char will be used as an adsorbent in wastewater treatment.

Use $80 \times$ No. 15 if additional space is needed

9. Status and Results

Preliminary data indicates activated solid waste char has at least the same capacity as commercial powdered activated carbon.

This project is: $\square$ planned $\otimes$ in-progress $\square$ completed

\begin{tabular}{|l|l|l|}
\hline 10. Utility Services & $\square$ wastewater treatment & $\begin{array}{c}11 . \text { Type of Project } \\
\square \text { electrical power }\end{array}$ \\
$\square$ space heating & $\square$ fublic \\
$\square$ space cooling & $\square$ polid waste processing & \\
$\square$ potable hot water & $\square$ cooperative \\
\hline
\end{tabular}

12. Exchange of data

Will data be available from this project that will be shared with others?

Yes

No 


\begin{tabular}{|c|c|c|}
\hline $\begin{array}{l}\text { 13. Technical Data } \\
\text { project location }---\ldots\end{array}$ & & Identification No. $6-833$ US - 27 \\
\hline $\begin{array}{l}\text { degree-days (heitting) - } \\
\text { degree-days (cocling) }--\end{array}$ & \multicolumn{2}{|l|}{$\begin{array}{l}\text { energy source } \\
\text { expected payback period }\end{array}$} \\
\hline $\begin{array}{l}\text { plant load capacity } \\
\text { a. power (MW) } \\
\text { b. heatıng (MW) } \\
\text { c. cooling (MW) } \\
\text { d. wastewater treatment-liters/day } \\
\text { e. solid waste processing-kilograms/day } \\
\text { f. potable water-liters/day } \\
\text { heat to power ratio (average expected) }\end{array}$ & \multicolumn{2}{|c|}{$\begin{array}{l}\text { Type and size of user } \\
\text { a. residential (dwelling units) } \\
\text { b. residential (square area- } \mathrm{m}^{2} \text { ) } \\
\text { c. commercial (square area- } \mathrm{m}^{2} \text { ) } \\
\text { d. Industrial (thermal + elec.-MW) }\end{array}$} \\
\hline
\end{tabular}

15. Additional space for Purpose of Project

16. Additional space for Status and Results 
NBS-114A (REV. 7-73)

US. DEPT. OF COMM. SHEET

4. TITLE AND SUBTITLE

International Project Catalog of

Modular Integrated Utility Systems

\begin{tabular}{l|l|}
$\begin{array}{l}\text { 1. PUBLICATION OR REPORT NO. } \\
\text { NBS SP- } 515\end{array}$ & $\begin{array}{l}\text { 2. Gov't Accession } \\
\text { No. }\end{array}$ \\
\hline
\end{tabular}

July 1978

6. Performing Organization Code

8. Performing Organ. Report No.

10. Project/Task/Work Unit No. 4654370

NATIONAL BUREAU OF STANDARDS

DEPARTMENT OF COMMERCE

WASHINGTON, D.C. 20234

11. Contract/Grant No.

12. Sponsoring Organization Name and Complete Address (Street, City, State, ZIP)

Division of Energy, Building Technology and Standards

Office of Policy Development and Research

U.S. Department of Housing and Urban Development

Washington, D.C. 20410

15. SUPPLEMENTARY NOTES

Library of Congress Catalog Card Number: 78-600056

16. ABSTRACT (A 200-word or less factual summary of most significant information. If document includes a significant bibliography or literature survey, mention it here.)

The International Project Catalog prepared for the Committee on the Challenges of Modern Society-Rational Use of Energy Pilot Study - Modular Integrated Utility Systems (CCMS-MIUS Project) is a compilation of project descriptions on more than 200 Modular Integrated Utility Systems (MIUS) type of projects being conducted in the participating countries. Each project description includes a description of each project, its status, the approach, expected results, some technical data, the principal investigator, an indication whether or not data is/or will be available and other miscellaneous project information. The catalog is useful to the experts in identifying the various projects being conducted and seeking further technical information on those particular projects in which they are interested.

The catalog is the first of a three level reporting system to report on MIUS type of projects. The second and third level reporting systems, which are expected to be improved and completed in future activities under another international organization, will provide information and guidelines for reporting progress and supplying data. The catalog consists of three parts: an Introduction, 1ist of Projects by Country, and Project Descriptions, one for each project reported.

17. KEY WORDS (six to twelve entries; alphabetical order; capitalize only the first letter of the first key word unless a proper name; separated by semicolons)

Catalog, CCMS-MIUS Project Catalog, International Project Catalog, Project Catalog, Project Summary Forms, Reporting System
18. AVAILABILITY
XXX Unlimited

[ For Official Distribution. Do Not Release to NTIS

X Order From Sup. of Doc., U.S. Government Printing Office Washington, D.C. 20402, SD Stock No. 003-003-

$\square$ Order From National Technical Information Sèrvice (NTIS) Springfield, Virginia 22151
19. SECURITY CLASS (THIS REPURT)

UNCL ASSIF IED

20. SECURITY CLASS (THIS PAGE)

UNCLASSIFIED
21. NO. OF PAGES

22. Price

$\$ 6.50$ 


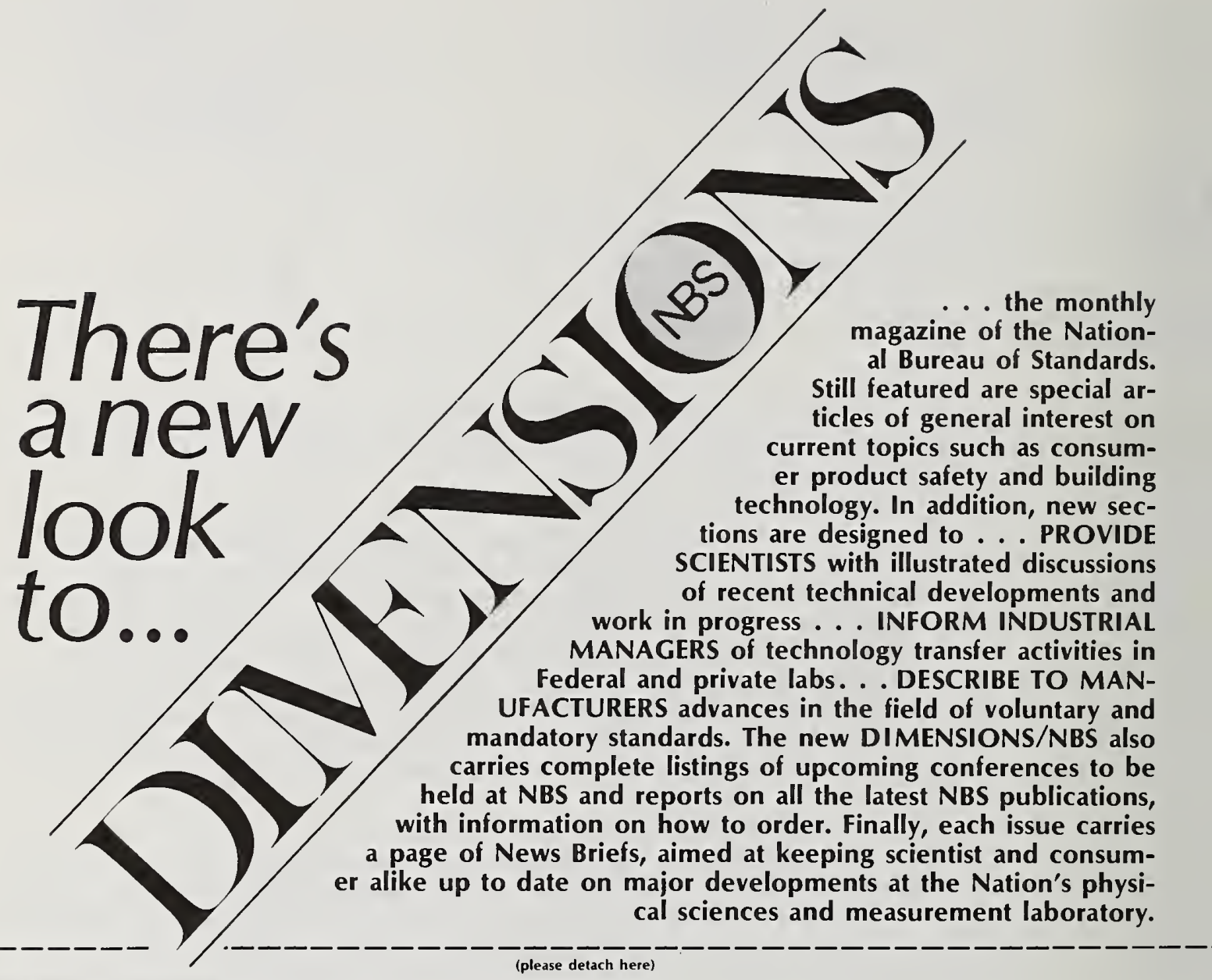

SUBSCRIPTION ORDER FORM

Enter my Subscription To DIMENSIONS/NBS at $\$ 12.50$. Add $\$ 3.15$ for foreign mailing. No additional postage is required for mailing within the United States or its possessions. Domestic remittances should be made either by postal money order, express money order, or check. Foreign remittances should be made either by international money order, draft on an American bank, or by UNESCO coupons.

Send Subscription to:

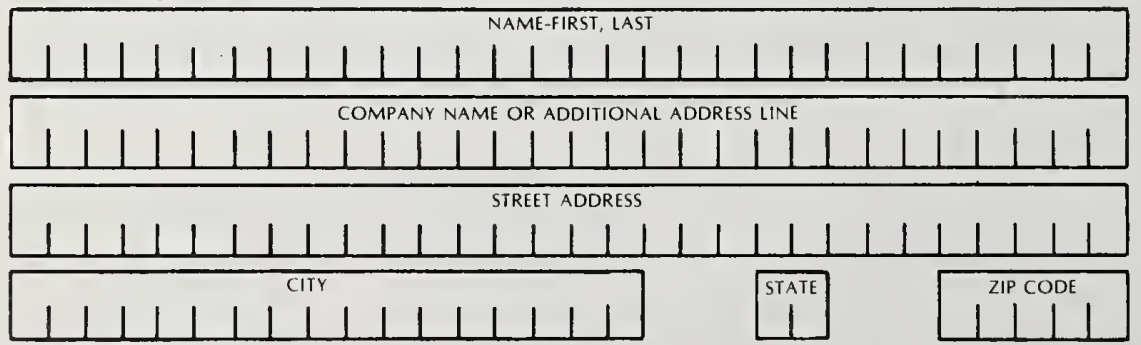

Remittance Enclosed (Make checks payable to Superintendent of Documents)

Charge to my Deposit Account No.

MAIL ORDER FORM TO:

Superintendent of Documents Government Printing Office Washington, D.C. 20402 


\section{PERIODICALS}

JOURNAL OF RESEARCH-The Journal of Research of the National Bureau of Standards reports NBS research and development in those disciplines of the physical and engineering sciences in which the Bureau is active. These include physics, chemistry, engineering, mathematics, and computer sciences. Papers cover a broad range of subjects, with major emphasis on measurement methodology, and the basic technology underlying standardization. Also included from time to time are survey articles on topics closely related to the Bureau's technical and scientific programs. As a special service to subscribers each issue contains complete citations to all recent NBS publications in NBS and nonNBS media. Issued six times a year. Annual subscription: domestic $\$ 17.00$; foreign $\$ 21.25$. Single copy, $\$ 3.00$ domestic; $\$ 3.75$ foreign.

Note: The Journal was formerly published in two sections: Section A "Physics and Chemistry" and Section B "Mathematical Sciences."

\section{DIMENSIONS/NBS}

This monthly magazine is published to inform scientists, engineers, businessmen, industry, teachers, students, and consumers of the latest advances in science and technology, with primary emphasis on the work at NBS. The magazine highlights and reviews such issues as energy research, fire protection, building technology, metric conversion, pollution abatement, health and safety, and consumer product performance. In addition, it reports the results of Bureau programs in measurement standards and techniques, properties of matter and materials, engineering standards and services, instrumentation, and automatic data processing.

Annual subscription: Domestic, \$12.50; Foreign \$15.65.

\section{NONPERIODICALS}

Monographs-Major contributions to the technical literature on various subjects related to the Bureau's scientific and technical activities.

Handbooks-Recommended codes of engineering and industrial practice (including safety codes) developed in cooperation with interested industries, professional organizations, and regulatory bodies.

Special Publications-Include proceedings of conferences sponsored by NBS, NBS annual reports, and other special publications appropriate to this grouping such as wall charts, pocket cards, and bibliographies.

Applied Mathematics Series-Mathematical tables, manuals, and studies of special interest to physicists, engineers, chemists, biologists, mathematicians, computer programmers, and others engaged in scientific and technical work.

National Standard Reference Data Series-Provides quantitative data on the physical and chemical properties of materials, compiled from the world's literature and critically evaluated. Developed under a world-wide program coordinated by NBS. Program under authority of National Standard Data Act (Public Law 90-396).
NOTE: At present the principal publication outlet for these data is the Journal of Physical and Chemical Reference Data (JPC'RD) published quarterly for NBS by the American Chemical Society (ACS) and the American Institute of Physics (AIP). Subscriptions, reprints, and supplements available from ACS, 1155 Sixteenth St. N.W., Wash., D.C. 20056.

Building Science Series-Disseminates technical information developed at the Bureau on building materials, components, systems, and whole structures. The series presents research results, test methods, and performance criteria related to the structural and environmental functions and the durability and safety characteristics of building elements and systems. Technical Notes-Studies or reports which are complete in themselves but restrictive in their treatment of a subject. Analogous to monographs but not so comprehensive in scope or definitive in treatment of the subject area. Often serve as a vehicle for final reports of work performed at NBS under the sponsorship of other government agencies.

Voluntary Product Standards-Developed under procedures published by the Department of Commerce in Part 10, Title 15, of the Code of Federal Regulations. The purpose of the standards is to establish nationally recognized requirements for products, and to provide all concerned interests with a basis for common understanding of the characteristics of the products. NBS administers this program as a supplement to the activities of the private sector standardizing organizations.

Consumer Information Series-Practical information, based on NBS research and experience, covering areas of interest to the consumer. Easily understandable language and illustrations provide useful background knowledge for shopping in today's technological marketplace.

Order above NBS publications from: Superintendent of Documents, Government Printing Office, Washington, D.C. 20402.

Order following NBS publications-NBSIR's and FIPS from the National Technical Information Services, Springfield, Va. 22161.

Federal Information Processing Standards Publications (FIPS PUB)-Publications in this series collectively constitute the Federal Information Processing Standards Register. Register serves as the official source of information in the Federal Government regarding standards issued by NBS pursuant to the Federal Property and Administrative Services Act of 1949 as amended, Public Law 89-306 (79 Stat. 1127), and as implemented by Executive Order 11717 (38 FR 12315, dated May 11, 1973) and Part 6 of Title 15 CFR (Code of Federal Regulations).

NBS Interagency Reports (NBSIR)-A special series of interim or final reports on work performed by NBS for outside sponsors (both government and non-government). In general, initial distribution is handled by the sponsor; public distribution is by the National Technical Information Services (Springfield, Va. 22161) in paper copy or microfiche form.

\section{BIBLIOGRAPHIC SUBSCRIPTION SERVICES}

The following current-awareness and literature-survey bibliographies are issued periodically by the Bureau:

Cryogenic Data Center Current Awareness Service. A literature survey issued biweekly. Annual subscription: Domestic, $\$ 25.00$; Foreign, $\$ 30.00$.

Liquified Natural Gas. A literature survey issued quarterly. Annual subscription: $\$ 20.00$.
Superconducting Devices and Materials. A literature survey issued quarterly. Annual subscription: $\$ 30.00$. Send subscription orders and remittances for the preceding bibliographic services to National Bureau of Standards, Cryogenic Data Center (275.02) Boulder, Colorado 80302. 
